Argonne National L aboratory, with facilities in the states of Illinois and Idaho, is owned by the United States government, and operated by The University of Chicago under the provisions of a contract with the Department of Energy.

DISC L A IM E R
This report was prepared as an account of work sponsored by an agency of the
United States Government. Neither the United States Government nor any agency
thereof, nor any of their employees, makes any warranty, express or implied, or
assumes any legal liability or responsibility for the accuracy, completeness, or
usefulness of any information, apparatus, product, or process disclosed, or
represents that its use would not infringe privately owned rights. Reference herein
to any specific commercial product, process, or service by trade name, trademark,
manufacturer, or otherwise, does not necessarily constitute or imply its
endorsement, recommendation, or favoring by the United States Government or
any agency thereof. The views and opinions of authors expressed herein do not
necessarily state or reflect those of the United States Government or any agency
thereof.

Reproduced from the best available copy.

A vailable to $D O E$ and $D O E$ contractors from the

Office of Scientific and Technical Information

P.O. Box 62

Oak Ridge, TN 37831

Prices available from (423) 576-8401

A vailable to the public from the National Technical Information Service

U.S. Department of Commerce

5285 Port Royal Road

Springfield, VA 22161 


\title{
ARGONNE NATIONAL LABORATORY-EAST SITE ENVIRONMENTAL REPORT FOR CALENDAR YEAR 1997
}

\author{
by \\ N.W. Golchert and R.G. Kolzow \\ Environmental Management Operations
}

September 1998

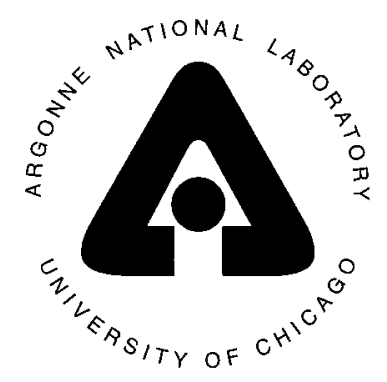
ARGONNE NATIONAL LABORATORY 9700 South Cass Avenue Argonne, Illinois 60439

Preceding Report in This Series: ANL-97/6 


\title{
PREFACE
}

This Site Environmental Report (SER) was prepared by Environmental Management Operations (EM O) at A rgonne N ational Laboratory-East (ANL-E) for the U.S. Department of Energy. The results of the environmental monitoring program and an assessment of the impact of site operations on the environment and the public are presented in this publication. This SER and those for recent years are available on the Internet at http://www.emo. anl gov/annrep.

Sample collection and field measurements were conducted under the direction of Ronald Kolzow of the EM O M onitoring and Surveillance Group by:

\author{
M ichael Cole \\ Noel Feeney \\ Rob Piorkowski
}

M ost of the figures and tables were prepared by the EM O Data M anagement Team of:

Dolores Ray

Jennifer Tucker

The analytical separations and measurements were conducted by the A nalytical Services Group of the Environment, Safety and Health Division by:

Donald N elson

Theresa Davis

A lan Demkovich

Bill Keenan

Emo Redey

Howard Svoboda
Emmer Thompson

Christos Stamoudis

Gary Griffin

Richard Kasper

Jim Riha 
The following staff made informational contributions to this report:

Greg Barrett

Al Carbaugh

$M$ ary Goodkind

M ark Gowdy

Chris Grandy

Gary Griffin

Beth Harvey

Richard Hart

John Herman

J im Huggins
Mark Kamiya

Gregg Kulma

Julie $M$ athiesen

Larry M oos

Geoff Pierce

Bob Swale

Keith Trychta

Bob Utesch

Support to prepare this report was provided by Rita M. Beaver (EMO). Editorial and document preparation services were provided by Nancy Erdmann, Pat H ollopeter, Cathy Kaicher, and L ouise Kickels of ANL-E's Information and Publishing Division. 
PREFACE

ACRONYMS

ABSTRACT

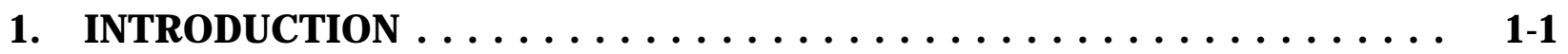

1.1. General ........................... 1-3

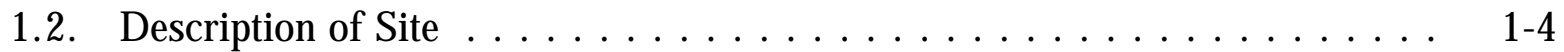

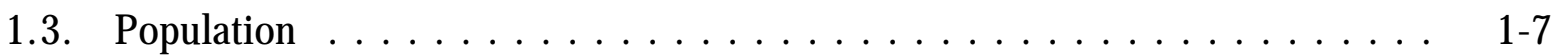

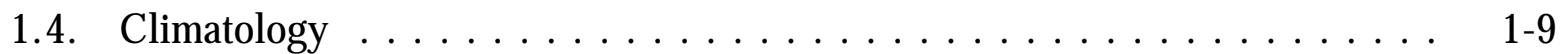

1.5. Geology ........................... 1-11

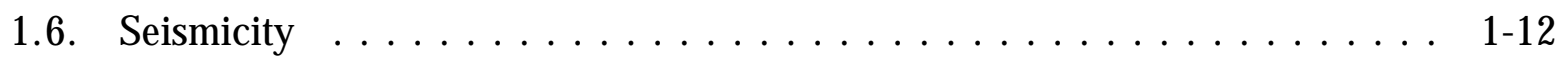

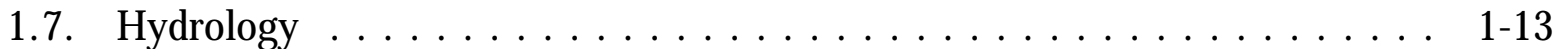

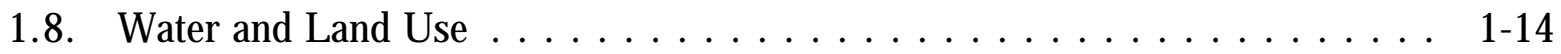

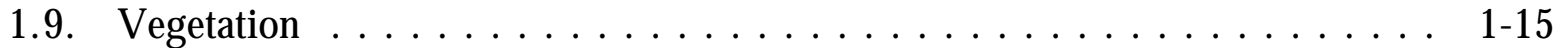

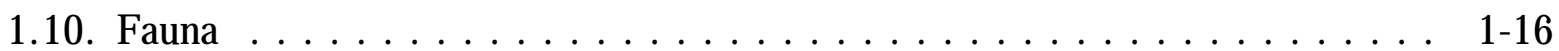

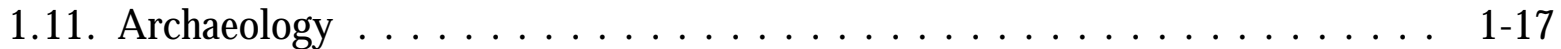

1.12. Endangered Species . . . . . . . . . . . . . . . . . . . 1-18

2. COMPLIANCE SUMMARY .................... 2-1

2.1. Clean Air Act ....................... 2-3

2.1.1. National Emission Standards for Hazardous A ir Pollutants ...................... 2-5

2.1.1.1. A sbestos Emissions . . . . . . . . . . . . . 2 2-5

2.1.1.2. Radionuclide Emissions . . . . . . . . . . . . 2-6 
2.1.2. Conventional Air Pollutants ................. 2-8

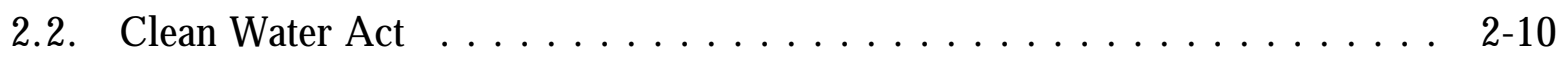

2.2.1. Liquid Effluent Discharge Permit . . . . . . . . . . . 2-12

2.2.1.1. Effluent $M$ onitoring Results and Compliance Issues . . . . . . . . . . . . . . . . 2-14

2.2.1.2. A dditional NPDES M onitoring . . . . . . . . . 2-16

2.2.2. Storm $W$ ater Regulations . . . . . . . . . . . . . . 2-17

2.2.3. N PDES Inspections and Audits ................. 2-19

2.2.4. General Effluent and Stream Quality Standards . . . . . . . . . . 2-19

2.2.5. Spill Prevention Control and

Countermeasures Plan . . . . . . . . . . . . . . . . . . . . . 2-19

2.3. Resource Conservation and Recovery Act . . . . . . . . . . 2-19

2.3.1. Hazardous W aste Treatment and Disposal . . . . . . . . 2-20

2.3.2. Permit Status . . . . . . . . . . . . . . . . . . . 2-24

2.3.3. Hazardous Waste Generation, Storage, Treatment, and Disposal . . 2 2-26

2.3.4. Mixed Waste Handling . . . . . . . . . . . . . . . 2-26

2.3.5. Federal Facility Compliance Act Activities $\ldots \ldots \ldots \ldots \ldots$

2.3.6. RCRA Inspections: Hazardous W aste $\ldots \ldots \ldots \ldots \ldots \ldots . . \ldots 2-30$

2.3.7. Underground Storage Tanks . . . . . . . . . . . . . . . . . 2-30

2.3.8. Corrective Action for Solid Waste

$M$ anagement $U$ nits . . . . . . . . . . . . . . . . . . 2-31

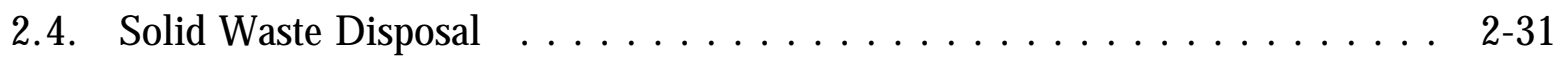

2.5. N ational Environmental Policy Act . . . . . . . . . . . . . . . . . 2-33

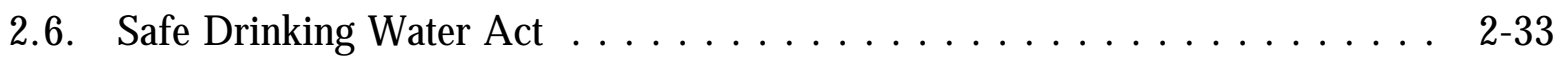

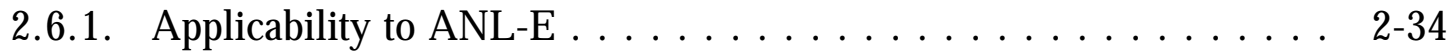

2.6.2. Water Supply M onitoring $\ldots \ldots \ldots \ldots \ldots \ldots \ldots \ldots . \ldots \ldots$

2.7. Federal Insecticide, Fungicide, and Rodenticide Act . . . . . . . . . 2 2-34 
2.8. Comprehensive Environmental Response, Compensation

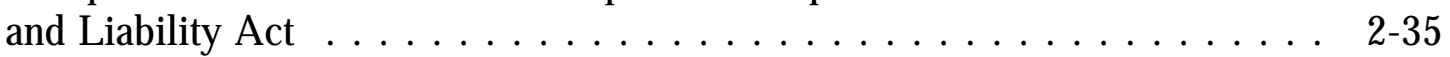

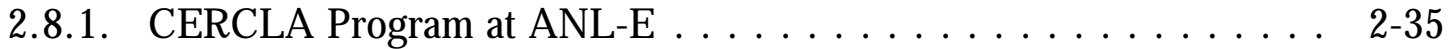

2.8.2. CERCLA Remedial Actions ................ 2-36

2.8.3. Emergency Planning and Community Right to Know Act and Superfund A mendments and Reauthorization Act, Title III . . . . . . . . . . . . . 2-37

2.9. Toxic Substances Control Act . . . . . . . . . . . . . . . . . . . . . 2-39

2.9.1. $P C B s$ in $U$ se at $A N L-E \ldots \ldots \ldots \ldots \ldots . \ldots \ldots . \ldots \ldots$

2.9.2. Disposal of PCBs .................. 2-40

2.9.3. Storage of Radioactive PCB-C ontaminated M aterial . . . . . . . 2-40

2. 10. Endangered Species Act . . . . . . . . . . . . . . . . . . . . 2-40

2.11. N ational Historic Preservation Act . . . . . . . . . . . . . . . . . . 2-43

2.12. Floodplain $M$ anagement . . . . . . . . . . . . . . . . . . . . 2-44

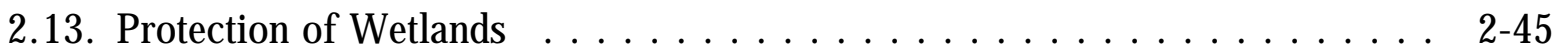

2.13.1. Sitewide $W$ etlands $M$ anagement $\ldots \ldots \ldots \ldots \ldots \ldots \ldots \ldots$

2.13.2. U.S. A rmy Corp of Engineers Review . . . . . . . . . . 2-46

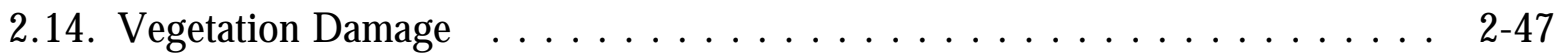

2.14.1. Data Collection . . . . . . . . . . . . . . . . . 2 2-47

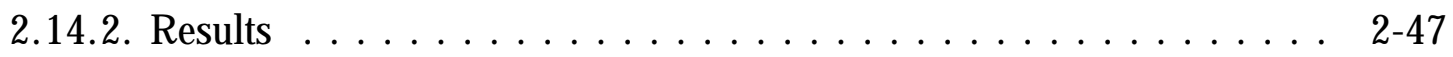

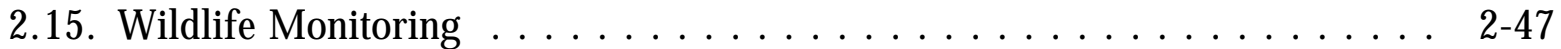

2.15.1. Deer Population M onitoring . . . . . . . . . . . . . . 2-47

2.15.2. Deer Health M onitoring $\ldots \ldots \ldots \ldots \ldots \ldots \ldots \ldots \ldots$

2.15.3. Deer Tissue M onitoring $\ldots \ldots \ldots \ldots \ldots \ldots \ldots \ldots . \ldots \ldots$

2.16. Current Issues and A ctions . . . . . . . . . . . . . . . . 2-49

2.16.1. M ajor Compliance Issues . . . . . . . . . . . . . . . . 2-49

2.16.1.1. Clean Water Act - N PDES . . . . . . . . . . . 2-50

2.16.1.2. RCRA - 800 A rea $L$ andfill . . . . . . . . . . . . 2-50 
2.16.1.3. RCRA - Underground Storage Tanks . . . . . . . . 2-51

2.16.1.4. DOE Hazardous $M$ aterials $M$ anagement Review .... . . 2-52

2.16.2. Regulatory A gency Interactions . . . . . . . . . . . . 2-52

2.16.3. ANL-E Environmental Reviews . . . . . . . . . . . 2-53

2.16.3.1. Environmental Vulnerability A ssessment . . . . . . . 2-53

2.16.3.2. Chemical Vulnerability A ssessment . . . . . . . . 2 2-53

2.17. Environmental Permits . . . . . . . . . . . . . . . 2-53

3. ENVIRONMENTAL PROGRAM INFORMATION $\ldots \ldots \ldots \ldots \ldots \ldots$ 3-1

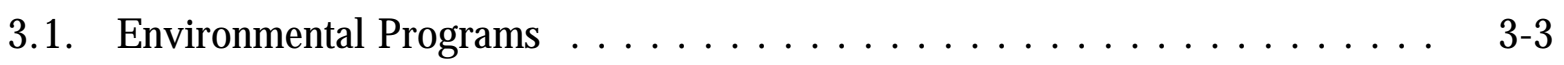

3.1.1. Environmental $M$ anagement Programs ............ 3-3

3.1.1.1. Waste $M$ anagement $D$ epartment . . . . . . . . . . 3-4

3.1.1.2. Environmental Protection Department . . . . . . . . 3-5

3.1.2. Remedial A ctions Progress in $1997 \ldots \ldots \ldots \ldots$. $3-6$

3.2. Environmental Support Programs . . . . . . . . . . . . . . . 3-7

3.2.1. Self-A ssessment $\ldots \ldots \ldots \ldots \ldots \ldots \ldots \ldots \ldots \ldots$ 3-7

3.2.2. Environmental Training Programs $\ldots \ldots \ldots \ldots \ldots \ldots \ldots$ 3-7

3.2.3. Waste M inimization and Pollution Prevention ........... 3-8

3.2.4. Site Environmental Performance $M$ easures Program $\ldots \ldots \ldots$ 3-11

3.2.5. Environmental M anagement System . . . . . . . . . . . . . . 3-12

3.3. Environmental M onitoring Program Description . . . . . . . . . . 3-13

3.3.1. Air Sampling . . . . . . . . . . . . . . . . . . 3-13

3.3.2. Water Sampling $\ldots \ldots \ldots \ldots \ldots \ldots \ldots \ldots \ldots \ldots \ldots \ldots . \ldots \ldots$

3.3.3. Bottom Sediment . . . . . . . . . . . . . . . . . 3-16

3.3.4. Soil $\ldots \ldots \ldots \ldots \ldots \ldots \ldots \ldots \ldots \ldots \ldots \ldots \ldots . \ldots \ldots$. $3-17$

3.3.5. Vegetation $\ldots \ldots \ldots \ldots \ldots \ldots \ldots \ldots \ldots \ldots \ldots \ldots \ldots \ldots \ldots$

3.3.6. External Penetrating Radiation $\ldots \ldots \ldots \ldots \ldots \ldots \ldots \ldots$ 3-18

3.3.7. Data Management .................... 3-19 
3.4. Compliance with D OE Order $5820.2 A \ldots \ldots \ldots$. $\ldots \ldots \ldots$

4. ENVIRONMENTAL RADIOLOGICAL PROGRAM INFORMATION .... 4-1

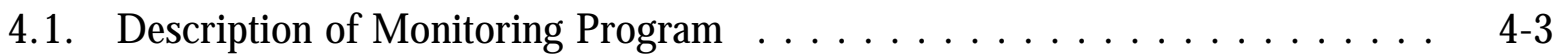

4.2. Air ............................. 4-4

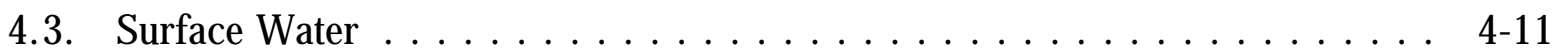

4.4. Soil, Grass, and Bottom Sediment . . . . . . . . . . . . . . . . . . . . . 4 4-19

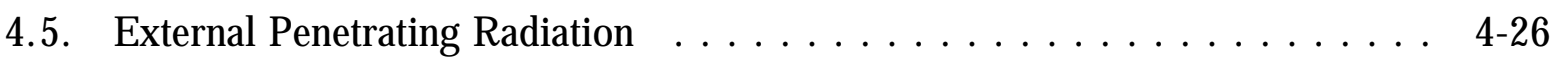

4.6. Estimates of Potential Radiation Doses . . . . . . . . . . . . . . . 4-30

4.6.1. A irborne Pathway ... . . . . . . . . . . . . . . . 4-30

4.6.2. Water Pathway .................... 4-46

4.6.3. External Direct Radiation Pathway . . . . . . . . . . . . . . . . 4 4-50

4.6.4. Dose Summary . . . . . . . . . . . . . . . . . . . . . . . 4-51

5. ENVIRONMENTAL NONRADIOLOGICAL PROGRAM

INFORMATION . . . . . . . . . . . . . . . . . . . . . . . 5 5-1

5.1. National Pollutant Discharge Elimination System

M onitoring Results ..................... $5-3$

5.1.1. Laboratory W astewater Treatment Plant Renovations . . . . . . . 5-6

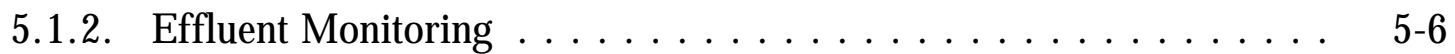

5.1.2.1. Sample Collection .................. 5-7

5.1.2.2. Sample A nalysis - NPDES . . . . . . . . . . 5-7

5.1.2.3. Results . . . . . . . . . . . . . . . . 5 5

5.1.2.4. Outfalls .................... 5-10

5.2. A dditional Effluent M onitoring $\ldots \ldots \ldots \ldots \ldots \ldots \ldots \ldots \ldots \ldots$ 5-34

5.2.1. Sample Collection ..................... 5-34

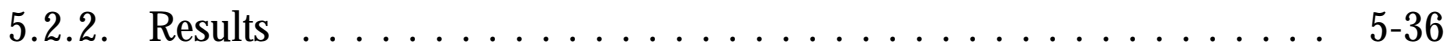


5.3. Sawmill Creek . . . . . . . . . . . . . . . . . . . . . . . . . . . 5-36

5.3.1. Sample Collection ................... 5-36

5.3.2. Results ...................... 5-38

6. GROUNDWATER PROTECTION $\ldots \ldots \ldots \ldots \ldots \ldots \ldots \ldots \ldots$ 6-1

6.1. Potable W ater System . . . . . . . . . . . . . . . . . . . . 6 6-3

6.1.1. Regulatory Required M onitoring ............. 6-3

6.1.2. Informational M onitoring $\ldots \ldots \ldots \ldots \ldots \ldots \ldots . \ldots \ldots$

6. 2. Groundwater $M$ onitoring at $W$ aste $M$ anagement Sites . . . . . . . . . . 6-6

6.2.1. 317 and 319 A reas . . . . . . . . . . . . . . . . 6-16

6.2.2. Groundwater M onitoring at the 317 and 319 A reas . . . . . . . 6-19

6.2.2.1. Sample Collection ................... 6-19

6.2.2.2. Sample A nalyses - 317 and 319 A reas . . . . . . . . 6 6-22

6.2.2.3. Results of A nalyses . . . . . . . . . . . . . 6-23

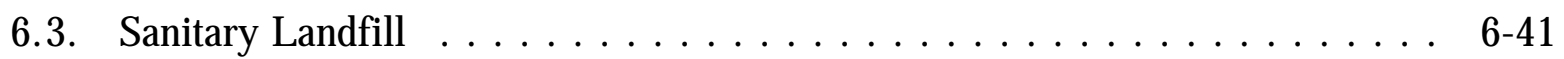

6.3.1. French Drain . . . . . . . . . . . . . . . . 6 6-42

6.3.2. M onitoring Studies . . . . . . . . . . . . . . . . 6-42

6.3.2.1. Sample Collection . . . . . . . . . . . . . . . 6-42

6.3.2.2. Sample A nalyses - 800 A rea . . . . . . . . . . . . 6-44

6.3.2.3. Results of A nalyses . . . . . . . . . . . . . . . 6-45

6.4. CP-5 Reactor A rea . . . . . . . . . . . . . . . . . . . 6-68

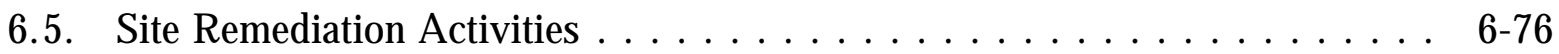

6.5.1. 317/319/E NE A rea Characterization . . . . . . . . . . 6 6-76

6.5.1.1. RCRA Facility Investigation ............ 6-76

6.5.1.2. Sealing of the East $V$ aults Footing D rain . . . . . . 6-78

6.5.1.3. 318 Area ... . . . . . . . . . . . . . 6-78

6.5.1.4. 317 A rea Groundwater Seep Interim Action . . . . . . . 6-79

6.5.1.5. 317 A rea French Drain Soil Treatment . . . . . . . . . . 6-79 
6.5.1.6. 319 A rea Landfill Interim Action . . . . . . . . . . . 6-79

6.5.2. 800 A rea Characterization . . . . . . . . . . . . . . . . $6-80$

6.5.3. Sitewide Hydrogeological Characterization Project . . . . . . . 6 6-81

7. QUALITY ASSURANCE $\ldots \ldots \ldots \ldots \ldots \ldots \ldots \ldots \ldots \ldots$ 7-1

7.1. Sample Collection .................... 7-3

7.2. Radiochemical A nalysis and Radioactivity M easurements . . . . . . . . . 7-4

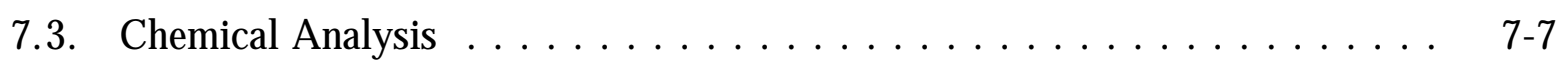

7.4. NPDES A nalytical Quality A ssurance $\ldots \ldots \ldots \ldots \ldots \ldots$ 7-7

8. APPENDIX $\ldots \ldots \ldots \ldots \ldots \ldots \ldots \ldots \ldots \ldots \ldots \ldots \ldots \ldots \ldots \ldots \ldots$ 8-1

8.1. References ........................ 8-3

8.2. Distribution for $98 / 2 \ldots \ldots \ldots \ldots \ldots \ldots \ldots \ldots \ldots \ldots \ldots$ 


\section{LIST OF FIGURES}

No.

1.1 Sampling Locations at A rgonne $N$ ational Laboratory-E ast . . . . . . . . . . . 1-5

1.2 Sampling L ocations near A rgonne National Laboratory-East . . . . . . . . . . . . 1-6

1.3 Monthly and A nnual Wind Roses at A rgonne National Laboratory-East, $1997 \ldots \ldots$. . . . . . . . . . . . . . . . . . . . 1-10

2.1 NPDES Permit Locations . . . . . . . . . . . . . . . . . . . . . . . . . 2-15

2.2 Total Number of NPDES Exceedances, 1990 to $1997 \ldots \ldots$. . . . . . . . . . . 2-16

2.3 Major Treatment, Storage, and/or Disposal A reas at A NL-E . . . . . . . . . . . 2-25

4.1 Comparison of Total Alpha and Beta A ctivities in Perimeter Air Filter Samples . . . . . . . . . . . . . . . . . . . . . . 4-8

4.2 Comparison of Gamma-Ray A ctivity in Air Filter Samples . . . . . . . . . . . . 4 4-9

4.3 Selected A irborne Radionuclide Emissions . . . . . . . . . . . . . . . . . . 4-13

4.4 Penetrating Radiation M easurements at the A N L-E Site, $1997 \ldots$. . . . . . . . . . 4-29

4.5 Individual and Perimeter Doses from Airborne Radioactive Emissions . . . . . . . . . . . . . . . . . . . . . . . . 4-45

4.6 Population Dose from A irborne Radioactive E missions . . . . . . . . . . . . . 4-47

4.7 Comparison of Dose Estimate from Ingestion of Sawmill Creek Water . . . . . . . . . . . . . . . . . . . . . . . . . . . . . 4-50

5.1 A NL-E W Wastewater Treatment Plant . . . . . . . . . . . . . . . . . 5-5

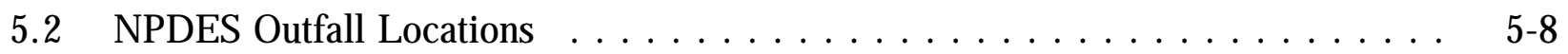

5.3 A verage A cetone L evels in Laboratory Wastewater, 1992 to 1997 . . . . . . . . . . 5-14

5.4 A verage M ethylene Chloride L evels in Laboratory W astewater, 1992 to 1997 . . 5-14

5.5 A verage Chloroform L evels in Laboratory W astewater, 1992 to 1997 . . . . . . 5-15

5.6 Total Dissolved Solids and Chloride in Outfall 001 Water, 1996 to 1997 . . . . 5-17

5.7 Total Dissolved Solids NPDES Outfall $001 \ldots \ldots \ldots$. . . . . . . . . . . . . . . .

5.8 NPDES Outfall 001 30-D ay A verage Copper Results, 1996 to 1997 . . . . . . . 5-19

5.9 NPDES Outfall 001 30-Day A verage A mmonia - Nitrogen Results, 1996 to $1997 \ldots \ldots \ldots \ldots$. . . . . . . . . . . . . . . . . . . . . .

6.1 Locations of Components within the $317 / 319 /$ ENE A rea $\ldots \ldots \ldots$. . . . . . . 6-17 
No.

6.2 A ctive M onitoring and Characterization W ells in the 317 and 319 A reas, 1997

6.3 Concentrations of 1,1-Dichloroethane and 1,1,1-T richloroethane in W ell $317021 \ldots \ldots \ldots \ldots$. . . . . . . . . . . . . . .

6.4 Trends of Selected Organics in 317 A rea M anholes, $1997 \ldots$. . . . . . . . . . 6-40

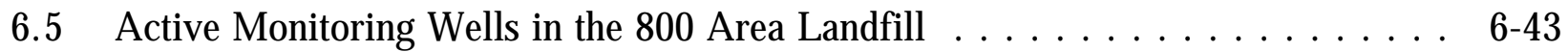

6.6 W ell 800161 Manganese Results . . . . . . . . . . . . . . . . . . . . . 6-59

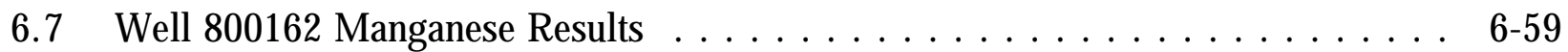

6.8 W ell 800163D Chloride Results . . . . . . . . . . . . . . . . . . . . . 6-60

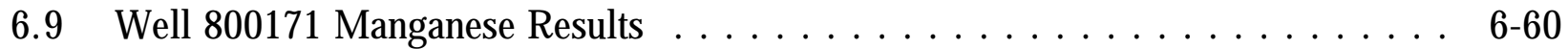

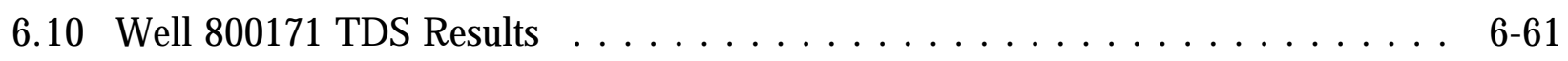

6.11 W ell 800173D Chloride Results . . . . . . . . . . . . . . . . . . 6 6-61

6.12 W ell $800181 \mathrm{M}$ anganese Results . . . . . . . . . . . . . . . . . . 6-62

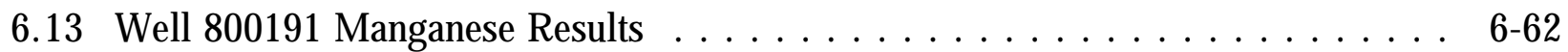

6.14 W ell 800191 Chloride Results . . . . . . . . . . . . . . . . . . . . . . . 6-63

6.15 Well 800191 TDS Results ... . . . . . . . . . . . . . . . . . . . 6 6-63

6.16 W ell 800192 M anganese Results . . . . . . . . . . . . . . . . . . 6 6-64

6.17 W ell 800192 Iron Results . . . . . . . . . . . . . . . . . . . . . . . . . . . 6. 6-64

6.18 W ell $800201 \mathrm{M}$ anganese Results . . . . . . . . . . . . . . . . . . . . . 6-65

6.19 W ell 800202 M anganese Results . . . . . . . . . . . . . . . . . . . . . 6-65

6.20 A ctive M onitoring W ells in the CP-5 Reactor A rea . . . . . . . . . . . 6 6-75

6.21 Hydrogen-3 Results in the CP-5 M onitoring W ells . . . . . . . . . . . 6-77 
No.

1.1 Population Distribution in the Vicinity of ANL-E, $1995 \ldots \ldots \ldots \ldots$ 1-8

1.2 A NL-E Weather Summary, $1997 \ldots \ldots \ldots \ldots$. . . . . . . . . . . . . . .

2.1 A sbestos A batement Projects: IE PA Notification, $1997 \ldots \ldots \ldots \ldots$. . . . . .

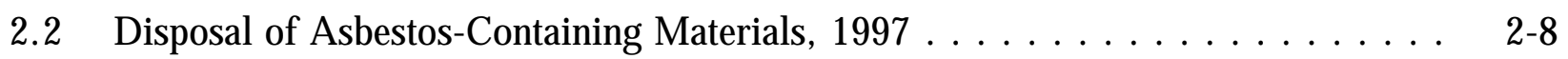

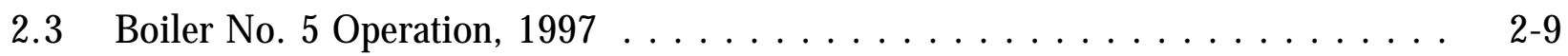

2.41997 A nnual Emissions Report: Emissions Summary . . . . . . . . . . . . . . 2-11

2.5 Characterization of N PDES Outfalls at ANL-E, $1997 \ldots \ldots \ldots \ldots \ldots$. . . . . . . .

2.6 Permitted Hazardous W aste Treatment and Storage Facilities, $1997 \ldots \ldots$. . . 2-21

2.7 Hazardous Waste Treatment, Storage, and Disposal, $1997 \ldots \ldots$. . . . . . 2-27

2.8 M ixed W aste Treatment, Storage, and Disposal, $1997 \ldots \ldots \ldots \ldots$. . . . . . . .

2.9 Generation and Disposal of Special and Nonspecial Waste, $1997 \ldots \ldots$. . . . . 2

2.10 List of Inactive Waste Disposal Sites at A N L-E Described in Various CERCLA Reports ................ 2-36

2.11 Compounds Reported under SARA Title III, $1997 \ldots \ldots \ldots \ldots$ 2-38

2.12 M ean Percent H orizontal V egetation Density at A NL -E and Herrick Lake Forest Preserve, DuPage County,

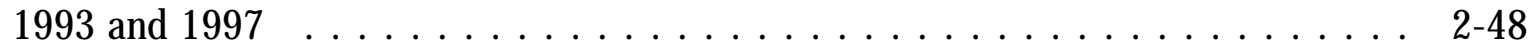

2.13 Tree Species $\geq 0.5 \mathrm{~m}$ in Height and $\leq 2.54 \mathrm{~cm}$ in Diameter Observed in M icroplots Randomly Located at A NL-E and HLFP, DuPage County, 1993 and $1997 \ldots \ldots \ldots \ldots \ldots \ldots \ldots$ 2-48

2.14 ANL-E Environmental Permits in Effect December 31, $1997 \ldots \ldots \ldots \ldots$. . . . . .

3.1 Environmental $M$ anagement Projects $\ldots \ldots \ldots \ldots \ldots$. $3-4$

4.1 Total A lpha and Beta A ctivities in A ir-Filter Samples, $1997 \ldots \ldots$. . . . . . . 4-6

4.2 Gamma-Ray A ctivity in A ir-Filter Samples, $1997 \ldots \ldots$. . . . . . . . . . 4

4.3 Strontium, Thorium, U ranium, and Plutonium Concentrations in Air Filter Samples, 1997

4.4 Summary of M onitored A irborne Radioactive E missions from ANL-E Facilities, $1997 \ldots \ldots \ldots \ldots$. . . . . . . . . . . . . . . . . .

4.5 Radionuclides in Sawmill Creek Water, $1997 \ldots \ldots$. . . . . . . . . . . . . . 4-15

4.6 Total Radioactivity Released to Sawmill Creek, $1997 \ldots \ldots$. . . . . . . . . . 4-16

4.7 Radionuclides in Storm Water Outfalls, $1997 \ldots \ldots \ldots \ldots$. . . . . . . . . . . . 
4.8 Radionuclides in Des Plaines River Water, $1997 \ldots \ldots \ldots \ldots$. . . . . . . . . . 4 4

4.9 Radionuclides in Illinois River Water, $1997 \ldots \ldots$. . . . . . . . . . . . . . 4-20

4.10 Gamma-Ray-Emitting Radionuclides in Soil, $1997 \ldots \ldots$. . . . . . . . . . . . 4-22

4.11 Transuranics in Soil, $1997 \ldots \ldots \ldots \ldots$. . . . . . . . . . . . . . . . . . . .

4.12 Radionuclides in Grass, $1997 \ldots \ldots \ldots \ldots$. . . . . . . . . . . . . . . . . . . .

4.13 Radionuclides in Bottom Sediment, $1997 \ldots \ldots$. . . . . . . . . . . . . . 4-25

4.14 External Penetrating Radiation at Off-Site

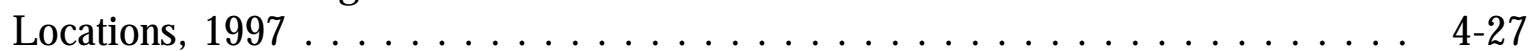

4.15 External Penetrating Radiation at A NL-E, $1997 \ldots \ldots \ldots$. . . . . . . . . . . .

4.16 Radiological A irborne Releases from Building 200, $1997 \ldots \ldots$. . . . . . . . 4 4-32

4.17 Maximum Perimeter and Individual Doses from Building 200

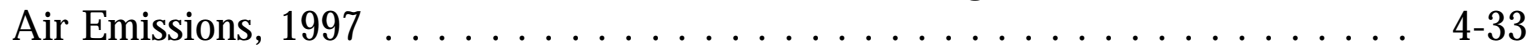

4.18 Radiological A irborne Releases from Building 205, $1997 \ldots \ldots$. . . . . . . 4-34

4.19 M aximum Perimeter and Individual Doses from Building 205 Air Emissions, $1997 \ldots \ldots \ldots \ldots$. . . . . . . . . . . . . . . . . . . 4-35

4.20 Radiological A irborne Releases from Building 212, $1997 \ldots \ldots$. . . . . . . 4-36

4.21 M aximum Perimeter and Individual Doses from Building 212 Air Emissions, $1997 \ldots \ldots \ldots \ldots \ldots$. . . . . . . . . . . . . . . . . . . . . .

4.22 Radiological Airborne Releases from Building 350, $1997 \ldots \ldots \ldots$. . . . . . 4-38

4.23 Maximum Perimeter and Individual Doses from Building 350 Air Emissions, $1997 \ldots \ldots \ldots \ldots$. . . . . . . . . . . . . . . . . . 49

4.24 Radiological Airborne Releases from Building 375, $1997 \ldots \ldots$. . . . . . . 4 4-40

4.25 Maximum Perimeter and Individual Doses from Building 375 Air Emissions, $1997 \ldots \ldots \ldots \ldots \ldots \ldots$. . . . . . . . . . . . . . . 41

4.26 Radiological A irborne Releases from Building 411/415, $1997 \ldots \ldots$. . . . . 4 4-42

4.27 Maximum Perimeter and Individual Doses from Building 411/415

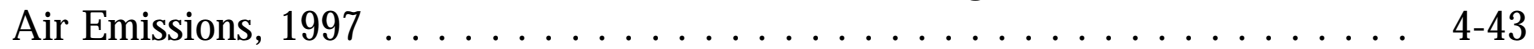

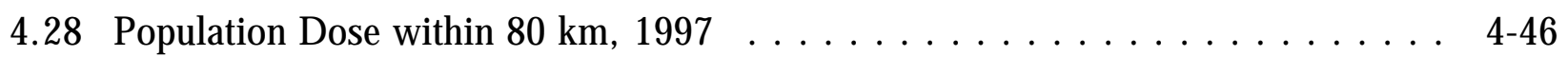

$4.2950-Y$ ear Committed Effective D ose Equivalent Factors . . . . . . . . . . . . . 4 4-48

4.30 Radionuclide Concentrations and Dose Estimates for Sawmill Creek W ater, 1997 
No.

4.31 Summary of the Estimated Dose to the Public, $1997 \ldots \ldots \ldots$. . . . . . . . 42

4.32 A nnual A verage Dose Equivalent in the U.S. Population . . . . . . . . . . . 4-53

5.1 N PDES Permit Limit Exceedances, $1997 \ldots \ldots \ldots \ldots$. . . . . . . . . . . .

5.2 Outfall 001A Effluent Limits and M onitoring Results, $1997 \ldots \ldots$. . . . . . 5-10

5.3 Outfall 001B Priority Pollutant M onitoring Results, $1997 \ldots \ldots \ldots$ 5-12

5.4 V olatile Organic Compounds in Laboratory Wastewater, $1997 \ldots \ldots$. . . . . 5-13

5.5 Outfall 001 M onitoring Results and Effluent Limits, $1997 \ldots \ldots$. . . . . . . 5

5.6 Outfall 001 A quatic Toxicity Test Results, $1997 \ldots \ldots$. . . . . . . . . . 5 . 20

5.7 Outfall 001 A quatic Toxicity Test Results, 1991 to $1997 \ldots \ldots$. . . . . . . . . 5-21

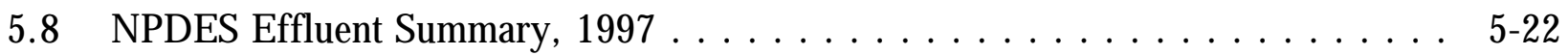

5.9 A cute Toxicity Results: F athead M innow, $1997 \ldots \ldots \ldots$. . . . . . . . . . 5

5.10 A cute Toxicity Results: Ceriodaphnia, $1997 \ldots \ldots$. . . . . . . . . . . . 5-27

5.11 Chemical Constituents in Effluents from the ANL-E Wastewater Treatment Plant, $1997 \ldots \ldots \ldots \ldots \ldots$. . . . . . . . . . . . . . . . 5-35

5.12 Chemical Constituents in Sawmill Creek, Location 7M, $1997 \ldots \ldots$. . . . . . . 5-37

6.1 A LL-E Former Water Supply Wells . . . . . . . . . . . . . . . . . 6. 6

6.2 Radioactivity in A NL-E F ormer W ater Supply W ells, $1997 \ldots \ldots \ldots$ 6.5 . . . .

6.3 Volatile Organic Compounds in Former Water Supply W ell Samples Collected M arch 11, $1997 \ldots \ldots$. . . . . . . . . . . . . . . . . . . 6-7

6.4 Volatile Organic Compounds in Former Water Supply W ell Samples Collected M ay 6, $1997 \ldots \ldots$. . . . . . . . . . . . . . . . . . . . . . . .

6.5 Volatile Organic Compounds in Former Water Supply W ell Samples Collected A ugust 4, 1997 .

6.6 V olatile Organic Compounds in Former Water Supply W ell Samples Collected December 1, 1997.

6.7 Copper and Lead Samples Collected Sitewide, M ay 15 and September 25, 1997

6.8 Groundwater M onitoring W ells: 317 and 319 A reas . . . . . . . . . . . 6-21

6.9 Groundwater M onitoring Results, 300 A rea W ell 317021, 1997 . . . . . . . . 6 6-24

6.10 Groundwater M onitoring Results, 300 A rea W ell 317052, $1997 \ldots \ldots$. . . . . . 6 
6.11 Groundwater M onitoring Results, 300 A rea W ell 317061, $1997 \ldots \ldots$. . . 6 6 6

6.12 Groundwater M onitoring Results, 300 A rea W ell 317101, $1997 \ldots \ldots$. . . . 6 6

6.13 Groundwater M onitoring Results, 300 A rea W ell 317111, 1997 . . . . . . . . 6 6-28

6.14 Groundwater M onitoring Results, 300 A rea W ell 317121D, $1997 \ldots \ldots$. . . . 6-29

6.15 Groundwater M onitoring Results, 300 A rea W ell 319011, $1997 \ldots \ldots$. . . . . 6 6

6.16 Groundwater M onitoring Results, 300 A rea W ell 319031, 1997 . . . . . . . . 6 6-31

6.17 Groundwater M onitoring Results, 300 A rea W ell 319032, $1997 \ldots \ldots$. . . . 6.32

6.18 Groundwater M onitoring Results, 300 A rea W ell 319131D, $1997 \ldots \ldots$. . . 6-33

6.19 Illinois Class I Groundwater Quality Standards: Inorganics . . . . . . . . . . . 6-34

6.20 Illinois Class I Groundwater Quality Standards: Organics . . . . . . . . . 6. 6-35

6.21 V olatile Organic Compounds in 317 A rea: Manholes E1 and E2, $1997 \ldots \ldots \ldots \ldots \ldots \ldots \ldots$. . . . . . . . . . . . . . . .

6.22 Groundwater M onitoring Wells: 800 A rea $L$ andfill . . . . . . . . . . . . . 6-44

6.23 Groundwater M onitoring Results, Sanitary Landfill Well 800161, $1997 \ldots \ldots \ldots \ldots \ldots \ldots$. . . . . . . . . . . . . . . . . .

6.24 Groundwater M onitoring Results, Sanitary Landfill

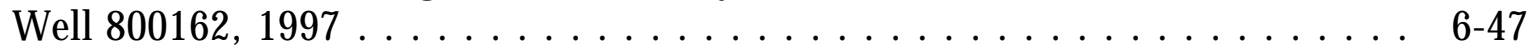

6.25 Groundwater M onitoring Results, Sanitary L andfill

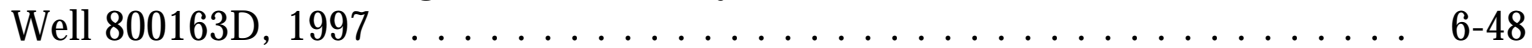

6.26 Groundwater M onitoring Results, Sanitary L andfill

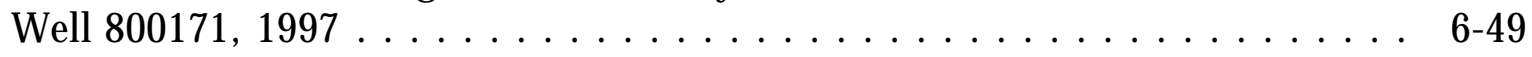

6.27 Groundwater M onitoring Results, Sanitary L andfill

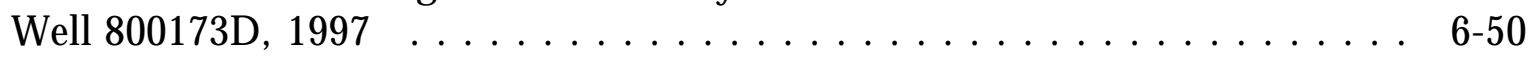

6.28 Groundwater M onitoring Results, Sanitary Landfill Well 800181, $1997 \ldots \ldots \ldots \ldots \ldots \ldots \ldots$. . . . . . . . . . . . . . . 6 6-51

6.29 Groundwater M onitoring Results, Sanitary Landfill W ell 800183D, 1997

6.30 Groundwater M onitoring Results, Sanitary L andfill Well 800191, $1997 \ldots \ldots \ldots \ldots \ldots \ldots \ldots \ldots \ldots \ldots \ldots \ldots$

6.31 Groundwater M onitoring Results, Sanitary L andfill Well 800192, 1997 


\section{LIST OF TABLES}

No.

6.32 Groundwater M onitoring Results, Sanitary L andfill

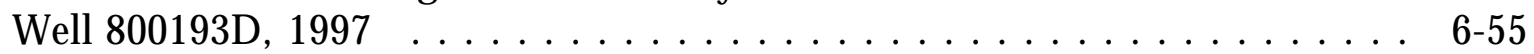

6.33 Groundwater M onitoring Results, Sanitary L andfill W ell 800201, $1997 \ldots \ldots \ldots \ldots \ldots$. . . . . . . . . . . . . . . . . . . . . 6-56

6.34 Groundwater M onitoring Results, Sanitary Landfill W ell 800202, $1997 \ldots \ldots$. . . . . . . . . . . . . . . . . . . . . . . . . . . 6-57

6.35 Groundwater M onitoring Results, Sanitary L andfill Well 800203D, 1997

6.36 Groundwater M onitoring Results, 330 A rea W ell 330011, 1997 . . . . . . . . 6-70

6.37 Groundwater M onitoring Results, 330 A rea W ell 330021, 1997 . . . . . . . . 6 6-71

6.38 Groundwater M onitoring Results, 330 A rea W ell 330031, 1997 . . . . . . . . 6 6-72

6.39 Groundwater M onitoring Results, 330 A rea W ell 330012D, $1997 \ldots \ldots$. . . 6-73

6.40 Groundwater M onitoring W ells: 330 A rea/CP-5 . . . . . . . . . . . . . . . 6-74

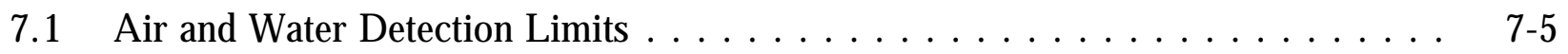

7.2 Summary of DOE-EML-QAP Samples, $1997 \ldots \ldots \ldots \ldots \ldots$ 7-6

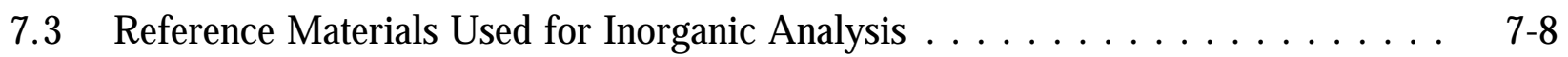

7.4 Detection $L$ imit for $M$ etals A nalysis, $1997 \ldots \ldots \ldots$. . . . . . . . . . . .

7.5 Quality Check Sample Results: Volatile A nalyses, $1997 \ldots \ldots$. . . . . . . 7-10

7.6 Quality Check Sample Results: Semivolatile A nalyses, $1997 \ldots \ldots$. . . . . 7-11 
ACM

ANL-E

AMSL

APS

BAT

BGS

BOD

CAA

CAAPP

CEDE

CERCLA

CFR

COD

COE

CP-5

CRMP

CWA

CY

D\&D

DCG

DMR

DOE

DPCHD

EA

EBWR

EIS

EML

EMS

ENE

EPA

EPCRA

ERAP

ESH

E SH-ASC L

ESH-ASR C

A sbestos-C ontaining $M$ aterial

A rgonne N ational L aboratory-E ast

A bove M ean Sea L evel

A dvanced Photon Source

Best A vailable Technology

Below Ground Surface

Biochemical Oxygen Demand

Clean A ir A ct

Clean A ir A ct Permit Program

Committed Effective Dose Equivalent

Comprehensive Environmental Response, Compensation

and Liability Act

Code of Federal Regulations

Chemical Oxygen Demand

U.S. A rmy Corps of Engineers

Chicago Pile-Five

Cultural Resources M anagement Plan

Clean Water Act

Calendar $Y$ ear

Decontamination and Decommissioning

Derived Concentration Guide

Discharge M onitoring Report

U.S. D epartment of Energy

DuPage C ounty Health Department

Environmental A ssessment

Experimental Boiling W ater Reactor

Environmental Impact Statement

Environmental M easurements L aboratory

Environmental Protection Data M anagement System

East-N ortheast

U.S. Environmental Protection A gency

Emergency Planning and Community Right to Know Act

A NL-E Remedial A ctions Project

Environment, Safety and Health

Environment, Safety and Health/A nalytical Services, Control Laboratory

Environment, Safety and Health/A nalytical Services,

Radiochemistry L aboratory

FFCA

Federal Facility Compliance A greement

FWS

HSW A

U.S. Fish and W ildlife Service

IAC

ICRP

Hazardous and Solid W aste A mendments

Illinois Administrative Code

International Commission on Radiological Protection

IEPA

Illinois Environmental Protection A gency 


$\begin{array}{ll}\text { IPNS } & \text { Intense Pulsed N eutron Source } \\ \text { LLW } & \text { Low-L evel Radioactive Waste } \\ \text { M SL } & \text { M ean Sea L evel } \\ \text { NBL } & \text { New Brunswick Laboratory } \\ \text { NE PA } & \text { National Environmental Policy Act } \\ \text { NE SHAP } & \text { National E mission Standards for Hazardous A ir Pollutants } \\ \text { NHPA } & \text { National Historic Preservation Act } \\ \text { NM OC } & \text { Nonmethane Organic Compounds } \\ \text { NPDES } & \text { National Pollutant Discharge Elimination System } \\ \text { NPL } & \text { National Priority List } \\ \text { NRHP } & \text { National Register of Historical Places } \\ \text { OSH A } & \text { Occupational Safety and Health A dministration } \\ \text { PA } & \text { Preliminary A ssessment } \\ \text { PCB } & \text { Polychlorinated Biphenyl } \\ \text { PFS } & \text { Plant Facilities and Services } \\ \text { PQL } & \text { practical quantification limit } \\ \text { PSTP } & \text { Proposed Site Treatment Plan } \\ \text { QA } & \text { Quality A ssurance } \\ \text { QAP } & \text { Quality A ssurance Program } \\ \text { RCRA } & \text { Resource Conservation and Recovery Act } \\ \text { RFI } & \text { RCRA Facility Investigation } \\ \text { SDWA } & \text { Safe D rinking Water Act } \\ \text { SOP } & \text { Standard Operating Procedure } \\ \text { SVOC } & \text { Semivolatile Organic Compound } \\ \text { SWM U } & \text { Solid Waste M anagement U nit } \\ \text { TDS } & \text { Total Dissolved Solids } \\ \text { TLD } & \text { Thermoluminescent Dosimeter } \\ \text { TOC } & \text { Total Organic Carbon } \\ \text { TOX } & \text { Total Organic Halogen } \\ \text { TSCA } & \text { Toxic Substances Control Act } \\ \text { TSS } & \text { Total Suspended Solids } \\ \text { UST } & \text { Underground Storage Tank } \\ \text { VOC } & \text { Volatile Organic Compound } \\ \text { WM } & \text { Waste M anagement } \\ \text { WM \& PP } & \text { Waste M inimization and Pollution Prevention } \\ \text { WQS } & \text { Water Quality Standard } \\ \text { WTP } & \text { Wastewater Treatment Plant } \\ & \end{array}$


This report discusses the results of the environmental protection program at A rgonne National Laboratory-East (ANL-E) for 1997. To evaluate the effects of ANL-E operations on the environment, samples of environmental media collected on the site, at the site boundary, and off the ANL-E site were analyzed and compared with applicable guidelines and standards. A variety of radionuclides were measured in air, surface water, on-site groundwater, soil, grass, and bottom sediment samples. In addition, chemical constituents in surface water, groundwater, and ANL-E effluent water were analyzed. External penetrating radiation doses were measured, and the potential for radiation exposure to off-site population groups was estimated. Results are interpreted in terms of the origin of the radioactive and chemical substances (i.e., natural, fallout, ANL-E, and other) and are compared with applicable environmental quality standards. A U.S. Department of Energy dose calculation methodology, based on International Commission on Radiological Protection recommendations and the CA P-88 version of the EPA-AIRDOSE/RADRISK computer code, was used in preparing this report. The status of ANL-E environmental protection activities with respect to the various laws and regulations that govern waste handling and disposal is discussed, along with the progress of environmental corrective actions and restoration projects. 
This report summarizes the ongoing environmental protection program conducted by A rgonne National Laboratory-East (ANL-E) in 1997. It includes descriptions of the site, the ANL-E missions and programs, the status of compliance with environmental regulations, environmental protection and restoration activities, and the environmental surveillance program. The surveillance program conducts regular monitoring for radiation, radioactive materials, and nonradiological constituents on the ANL-E site and in the surrounding region. These activities document compliance with appropriate standards and permit limits, identify trends, provide information to the public, and contribute to a better understanding of ANL-E's impact on the environment. The surveillance program supports the ANL-E policy of protecting the public, employees, and the environment from harm that could be caused by ANL-E activities and of reducing environmental impacts to the greatest degree practicable.

\section{Compliance Summary}

Radionuclide emissions, the disposal of asbestos, and conventional air pollutants from ANL-E facilities are regulated under the Clean Air Act. A number of airborne radiological emission points at ANL-E are subject to National Emission Standards for Hazardous A ir Pollutants (NESHAP) regulations for radionuclide releases from U.S. Department of Energy (DOE) facilities (Code of Federal Regulations, Title 40, Part 61 [40 CFR 61], Subpart H). All such air emission sources were evaluated to ensure that these requirements are being properly addressed. The ANL-E individual off-site dose required to be reported by U.S. Environmental Protection A gency (EPA) regulations (40 CFR 61, Subpart $H$ ) in 1997 was $0.018 \mathrm{mrem} / \mathrm{yr}$. This is $0.18 \%$ of the $10 \mathrm{mrem} / \mathrm{yr}$ standard. This dose does not include contributions from radon-220 and radon-222 emissions as required by the regulations.

At ANL-E, asbestos-containing material is frequently encountered during maintenance or renovation of existing facilities and equipment. A sbestos is removed and disposed of in strict accordance with NESHAP, Toxic Substances Control Act (TSCA), and Occupational Safety and Health A dministration worker protection standards. Other applicable authorities include (1) the accreditation program of the EPA M odel Accreditation Plan implementing the A sbestos School Hazard A batement Reauthorization Act of 1990, which amends the TSCA asbestos provisions, 
and (2) the registration and licensing requirements of the Illinois Commercial and Public Building A sbestos A batement A ct, effective J uly 14, 1995. A pproximately $150 \mathrm{~m}^{3}\left(5,295 \mathrm{ft}^{3}\right)$ of asbestoscontaining materials was removed and disposed of at off-site landfills in Illinois during 1997.

The ANL -E site contains several sources of conventional air pollutants. The steam plant and fuel dispensing facilities operate continuously and are the only significant sources of continuous air pollutants. The emergency generators at the Advanced Photon Source (APS) are also significant sources, when operational. The operating air pollution control permit for the steam plant requires continuous opacity and sulfur dioxide monitoring of the smoke stack from Boiler No. 5, the only boiler equipped to burn coal. Low-sulfur coal was burned as the fuel for the steam plant for six months during 1997, whereas natural gas was used as the fuel for the other six months of the year. During the period coal was burned, which occurred during colder weather to supplement the gas-fired boilers, one exceedance for opacity was observed.

The principal regulatory mechanism designed to achieve the goals of the Clean Water Act is the National Pollutant Discharge Elimination System (NPDES). The authority to implement the NPDES program has been delegated to the State of Illinois. The renewal of the ANL-E NPDES permit, which became effective October 30, 1994, increased the number of monitored discharge points from 9 to 28. The permit was modified on August 24, 1995, to increase temporarily some limits and to include a three-year compliance schedule to achieve final limits. During 1997, only 3 exceedances of the NPDES permit limits were reported out of approximately 1,600 measurements.

ANL-E was granted interim status under the Resource Conservation and Recovery Act (RCRA) upon submitting a Part A permit application in 1980. In 1990, a Part B permit application was submitted to the Illinois Environmental Protection A gency (IEPA). The IEPA issued the RCRA Part B permit on September 30, 1997. It became effective on N ovember 4, 1997. The permit addresses 22 hazardous waste treatment and storage facilities and establishes corrective action procedures and requirements for 49 Solid W aste $M$ anagement $U$ nits and 3 A reas of Concern. 
ANL-E has prepared and implemented a sitewide underground storage tank (UST) compliance plan. Thirty-four tanks have been removed over the past several years, and 24 tanks were replaced or upgraded. Of the locations from which tanks were removed or replaced, 17 were found to have some degree of contamination from leaks, spills, or overfills.

The only TSCA compounds in significant quantities at ANL-E are polychlorinated biphenyls (PCBs) contained in electrical capacitors, power suppliers, and small transformers. All polemounted transformers and circuit breakers containing PCBs were replaced or retrofilled with non$P C B$ oil. All removal and disposal activities were conducted by licensed contractors specializing in such operations. PCB-contaminated sludge from the ANL-E wastewater treatment plant was characterized, containerized, and stored during 1994. The ANL-E PCB Item Inventory Program was initiated in 1995 to identify all suspect PCB-containing items.

DOE implementation of National Environmental Policy Act (NEPA) requirements has undergone significant changes since 1992. In 1997, most NEPA project reviews sent to DOE for review and approval were determined to be categorical exclusions. One Environmental A ssessment addressing environmental remediation at ANL-E was prepared during 1997. Currently, there are no active projects at ANL-E requiring an Environmental Impact Statement.

The ANL-E Environmental M anagement Plan requests funds for on-site rehabilitation projects, environmental restoration projects, and waste management activities. The rehabilitation projects concentrate on upgrading or replacing existing treatment facilities. ANL-E environmental restoration activities consist of projects that assess and clean up inactive waste sites. These include two inactive landfills, three French drains (dry wells used to dispose of liquid chemicals), two inactive wastewater treatment facilities, and a number of areas that may have been contaminated with small amounts of hazardous chemicals. The majority of the $W$ aste $M$ anagement Department's projects involve improvements to existing treatment or storage facilities.

On-going compliance issues at ANL-E during 1997 were the ability to meet final effluent limits for total dissolved solids (TDS), copper, and ammonia nitrogen; the APS wetlands remediation; elevated levels of some routine indicator parameters in the groundwater at the 
sanitary landfill; and cleanup of environmental contamination caused by previous activities on the ANL-E site.

\section{Environmental Surveillance Program}

A irborne emissions of radioactive materials from ANL-E were monitored during 1977. The effective dose equivalents were estimated at the site perimeter and to the maximally exposed member of the public with the CAP-88 version of the EPA/AIRDOSE-RADRISK code. The estimated maximum perimeter dose was $0.24 \mathrm{mrem} / \mathrm{yr}$ in the southwest direction, while the estimated maximum dose to a member of the public was $0.033 \mathrm{mrem} / \mathrm{yr}$. This is $0.033 \%$ of the DOE radiation protection standard of $100 \mathrm{mrem} / \mathrm{yr}$ for all pathways. A pproximately $45 \%$ of this estimated dose is due to the release of $287 \mathrm{Ci}$ of radon-220 in 1997. If the contribution of radon-220 is excluded from reporting, as required in $40 \mathrm{CFR} 61$, Subpart $H$, the estimated dose to the maximally exposed individual would be $0.018 \mathrm{mrem} / \mathrm{yr}$. The estimated population dose from all releases to the approximately eight million people living within $80 \mathrm{~km}(50 \mathrm{mi})$ of the site was 1.77 man-rem.

Air monitoring also was conducted at ANL-E for total alpha activity, total beta activity, strontium-90, isotopic thorium, isotopic uranium, and plutonium-239. No statistically significant difference was identified between samples collected at the ANL-E perimeter and samples collected off site. M onitoring was not conducted for hazardous chemical constituents in ambient air.

The only source of radionuclides and chemical pollutants in surface water due to ANL-E releases was in Sawmill Creek below the wastewater discharge point. At various times, measurable levels of hydrogen-3, strontium-90, plutonium-239, and americium-241 were detected. Of these radionuclides, the maximum annual release was $0.72 \mathrm{Ci}$ of hydrogen-3. The hydrogen-3 was added to the wastewater as part of normal ANL-E operations. The dose to a hypothetical individual using water from Sawmill Creek as his or her sole source of drinking water would be $0.0347 \mathrm{mrem} / \mathrm{yr}$. However, no one uses this water for drinking, and dilution by the Des Plaines River reduces the concentrations of the measured radionuclides to levels below their respective detection limits downstream from ANL-E at Lemont. Sawmill Creek also is monitored for 
nonradiological constituents to demonstrate compliance with State of Illinois water quality standards. Iron, copper, and zinc occasionally were detected above the standards.

Sediment samples were collected from Sawmill Creek, above, at, and below the point of wastewater discharge. For comparative purposes, samples also were collected from the beds of 10 off-site streams and ponds. The analysis of the off-site samples for selected radionuclides established their current ambient levels. Elevated levels of plutonium-238 (up to $0.020 \mathrm{pCi} / \mathrm{g}$ ), plutonium-239 (up to $0.060 \mathrm{pCi} / \mathrm{g}$ ), and americium-241 (up to $0.288 \mathrm{pCi} / \mathrm{g}$ ) were detected in the sediment below the outfall and are attributed to past ANL-E releases.

Surface soil and grass samples were collected at 10 perimeter and 10 off-site locations during 1997. The purpose of the sampling was to detect the possible buildup of radionuclides from the deposition of airborne emissions. The results indicate no statistically significant difference between the perimeter and off-site concentrations of potassium-40, cesium-137, radium-226, thorium-228, thorium-232, plutonium-238, plutonium-239, and americium-241.

D ose rates from penetrating radiation (gamma-rays) were measured at 14 perimeter and on-site locations and at five off-site locations in 1997 using thermoluminescent dosimeters. The off-site results averaged $82 \pm 4 \mathrm{mrem} / \mathrm{yr}$, which is consistent with the long-term average. A bovebackground doses occurred at one perimeter location and were due to ANL-E operations. At the south fence, radiation from a temporary storage facility for radioactive waste resulted in an average dose of $100 \pm 8 \mathrm{mrem} / \mathrm{yr}$ for 1997 . The estimated dose from penetrating radiation to the nearest resident south of the site was $<0.01 \mathrm{mrem} / \mathrm{yr}$.

The potential radiation doses to members of the public from A N L-E operations during 1997 were estimated by combining the exposure from inhalation, ingestion, and direct radiation pathways. The inhalation pathway dominates. The highest estimated dose was approximately $0.08 \mathrm{mrem} / \mathrm{yr}$ to individuals living $500 \mathrm{~m}(1,640 \mathrm{ft})$ north of the site if they were outdoors at that location during the entire year. Doses from other pathways were calculated and were small at this location. The magnitude of the doses from ANL-E operations are well within all applicable standards and are insignificant when compared to doses received by the public from natural 
radiation $(\approx 300 \mathrm{mrem} / \mathrm{yr})$ or other sources, for example, medical $\mathrm{x}$-rays and consumer products ( $\approx 60 \mathrm{mrem} / \mathrm{yr})$.

Radiological and chemical constituents in the groundwater were monitored in several areas of the ANL-E site in 1997. The former ANL-E domestic water supply is monitored by collecting quarterly samples from the four supply wells and a treated water tap. All results were less than the limits established by the Safe Drinking Water Act except for elevated levels of TDS.

Ten monitoring wells screened in the glacial till and two in the dolomite were sampled quarterly at the 317 and 319 A reas and analyzed for radiological, volatile organic, semivolatile, $P C B$, and pesticide and herbicide constituents. The major organic contaminants detected were trichloroethene, 1,1,1-trichloroethane, 1,1-dichloroethane, carbon tetrachloride, tetrachloroethene, and chloroform. Measurable levels of hydrogen-3, strontium-90, and cesium-137 were present in several of the wells. Remediation continued in this area. In situ treatment of soil in the 317 A rea, coupled with thermally enhanced vapor extraction, was initiated in 1997 to control offsite releases of contamination.

Thirteen monitoring wells at the 800 A rea sanitary landfill were sampled on a quarterly basis and analyzed for metals, cyanide, phenols, total organic carbon, total organic halogens, volatile organic compounds, semivolatiles, PCBs, pesticides and herbicides, and hydrogen-3. Levels above Illinois Class I Ground W ater Quality Standards for chloride, iron, manganese, and TDS were found in some wells. A bove-background levels of hydrogen-3 were detected in several of the wells. Trichlorofluoromethane was noted in one well during one quarter.

An extensive quality assurance program is maintained to cover all aspects of the environmental surveillance sampling and analysis programs. A pproved documents are in place along with supporting standard operating procedures. N ewly collected data were compared with recent results and historical data to ensure that deviations from previous conditions were identified and promptly evaluated. Samples at all locations were collected using well-established and documented procedures to ensure consistency. Samples were analyzed by documented standard analytical procedures. Data quality was verified by a continuing program of analytical laboratory 
quality control, participation in interlaboratory cross-checks, and replicate sampling and analysis. Data were managed and tracked by a dedicated computerized data management system that assigns unique sample numbers, schedules collection and analysis, checks status, and prepares tables and information for the annual report.

ANL-E maintains a documented environmental management system that identifies responsibilities for environmental activities. ANL-E is committed to implementing that system in accordance with environmental policy. 


\section{INTRODUCTION}

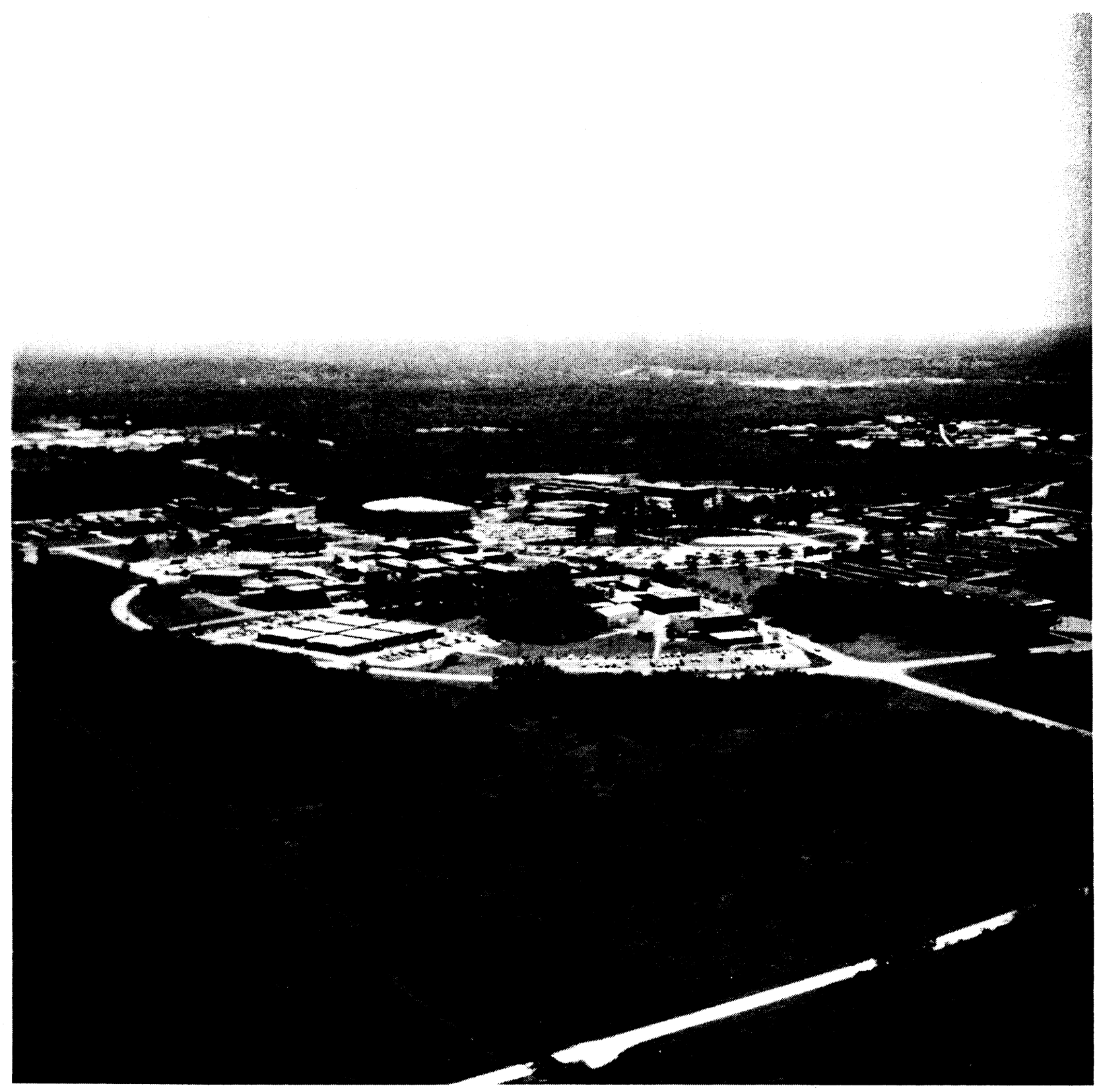




\subsection{General}

This annual report for 1997 on the Argonne National Laboratory-East (ANL-E) environmental protection program was prepared to inform the U.S. Department of Energy (DOE), environmental agencies, and the public about the levels of radioactive and chemical pollutants in the vicinity of ANL-E and the amounts, if any, added to the environment by ANL-E operations. It also summarizes the compliance of ANL-E operations with applicable environmental laws and regulations and highlights significant accomplishments and problems related to environmental protection. The report was prepared in accordance with the guidelines of DOE Orders $5400.1^{1}$ and $231.1^{2}$ and supplemental DOE guidance.

ANL-E conducts a continuous environmental surveillance program on and near the site to determine the identity, magnitude, and origin of radioactive and chemical substances in the environment. The detection of any releases of such materials to the environment from ANL-E operations is of special interest because one important function of this program is verification of the adequacy of the site's pollution control systems.

ANL-E is a DOE energy research and development laboratory with several principal objectives. It conducts a broad program of research in the basic energy and related sciences (i.e., physical, chemical, material, computer, nuclear, biomedical, and environmental) and serves as an important engineering center for the study of nuclear and nonnuclear energy sources. Energyrelated research projects conducted during 1997 included safety studies for light-water and breeder reactors; superconductivity advances and applications; improvements in the use of coal for power production (particularly high-sulfur coal); synchrotron radiation accelerator design; development of electrochemical energy sources, including fuel cells and batteries for vehicles and for energy storage; and evaluation of heat exchangers for the recovery of waste heat from engines.

Other areas of research are the use of superconducting magnets for improved nuclear particle accelerators, fundamental coal chemistry studies, the immobilization of radioactive waste products for safe disposal, medical radioisotope technology, carcinogenesis, and the biological effects of small amounts of radiation. Environmental research studies include the biological 


\section{INTRODUCTION}

activity of energy-related mutagens and carcinogens; characterization and monitoring of energyrelated pollutants; and the effects of acid rain on vegetation, soil, and surface water quality. A significant number of these laboratory studies require the controlled use of radioactive and chemically toxic substances.

The principal nuclear facilities at ANL-E are the Advanced Photon Source (APS); a superconducting heavy-ion linear accelerator (A rgonne Tandem Linac Accelerating System [ATLAS]); a 22-M eV pulsed electron Linac; several other charged-particle accelerators (principally of the $V$ an de Graaff and Dynamitron types); a large fast neutron source (Intense Pulsed N eutron Source [IPNS]) in which high-energy protons strike a uranium target to produce neutrons; chemical and metallurgical laboratories; and several hot cells and laboratories designed for work with multicurie quantities of the actinide elements and with irradiated reactor fuel materials. The DOE New Brunswick Laboratory (NBL), a safeguards plutonium and uranium measurements and analytical chemistry laboratory, is located on the A NL-E site.

The principal nonnuclear activities at ANL-E in 1997 that could have measurable impacts on the environment include the use of a coal-fired boiler ( $\mathrm{No} .5)$ and studies of the closed-loop heat exchanger for waste heat recovery. The closed-loop heat exchanger studies involved the use of moderately large quantities of toxic or flammable organic compounds such as toluene, Freon, biphenyl oxides, methyl pyridine, and trifluoroethanol. The chemical vulnerability assessment identified the storage of approximately $6,000 \mathrm{~L}(1,600$ gal) of sodium on site that could pose a significant chemical hazard and potential environmental impact. The major potential for environmental impact from these materials would be associated with any accidental releases caused by equipment malfunction. However, no such releases have occurred.

\subsection{Description of Site}

A NL-E occupies the central 607 ha (1,500 acres) of a 1,514-ha (3,740-acre) tract in DuPage County. The site is $43 \mathrm{~km}$ (27 mi) southwest of downtown Chicago and $39 \mathrm{~km}(24 \mathrm{mi})$ west of Lake Michigan. It is north of the Des Plaines River Valley, south of Interstate Highway 55 (I-55), and west of Illinois Highway 83. Figures 1.1 and 1.2 are maps of the site, the surrounding 


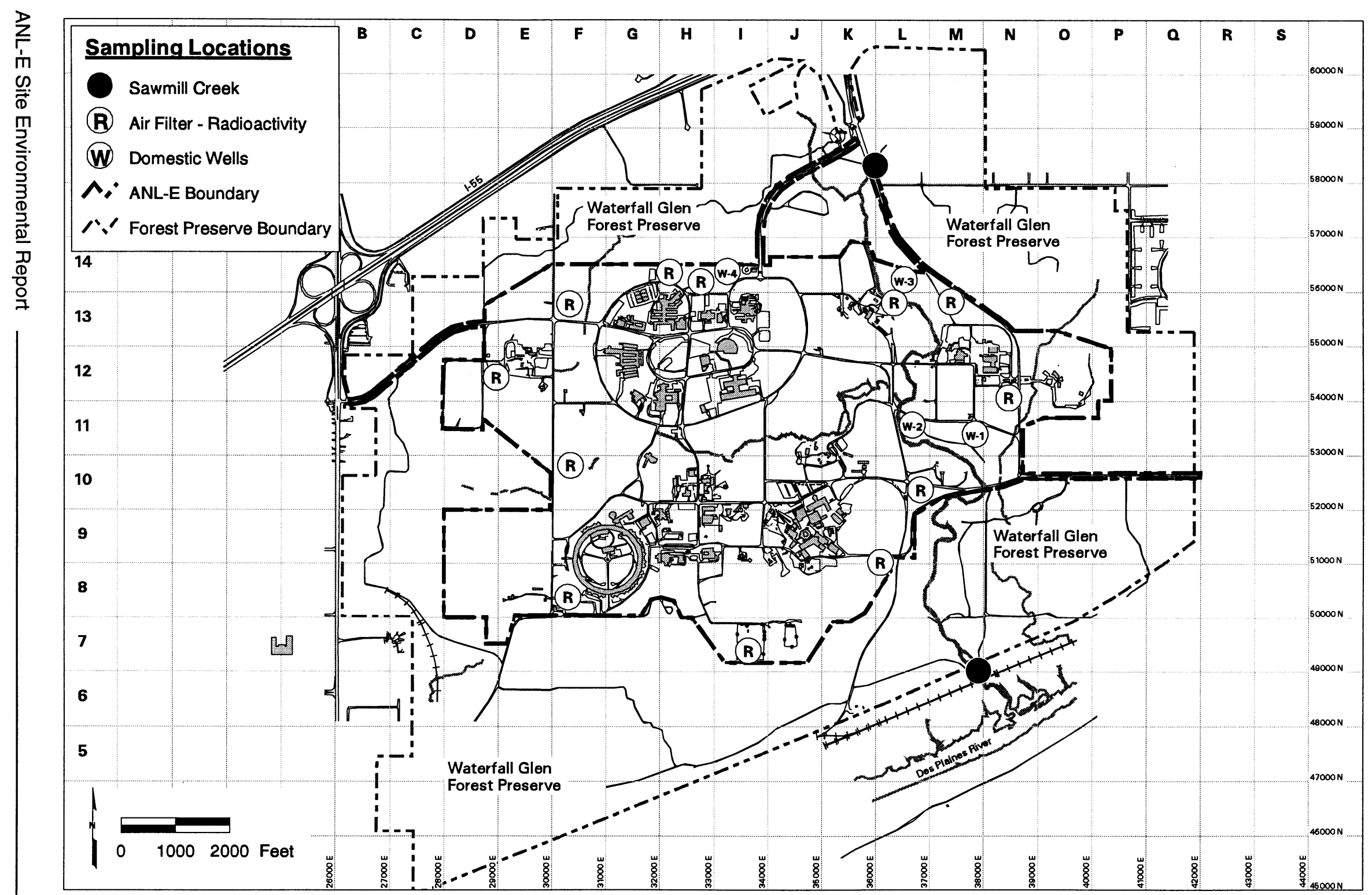

Figure 1.1 Sampling Locations at Argonne National Laboratory-East 


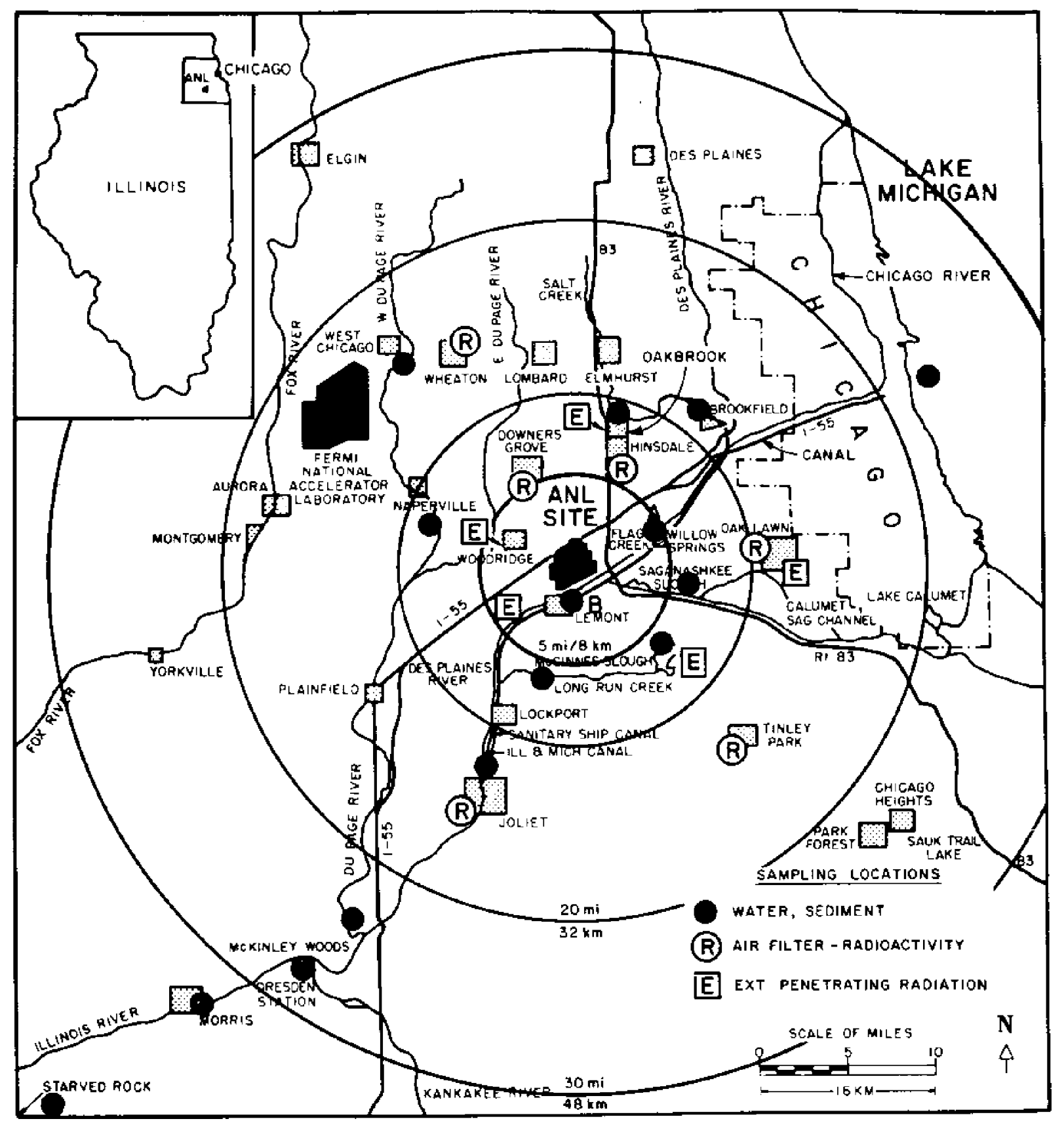

Figure 1.2 Sampling Locations near A rgonne National L aboratory-East 
area, and sampling locations of the monitoring program. The 907-ha (2,240-acre) W aterfall Glen Forest Preserve surrounding the site is mostly former ANL-E property that was deeded to the DuPage County Forest Preserve District in 1973 for use as a public recreational area, nature preserve, and demonstration forest. In this report, facilities are identified by the alpha-numeric designations in Figure 1.1 to facilitate their location.

The terrain of ANL-E is gently rolling, partially wooded, former prairie, and farmland. The grounds contain a number of small ponds and streams. The principal stream is Sawmill Creek, which runs through the site in a southerly direction and enters the Des Plaines River about $2.1 \mathrm{~km}$ (1.3 mi) southeast of the center of the site. The land is drained primarily by Sawmill Creek, although the extreme southern portion drains directly into the Des Plaines River, which flows along the southern boundary of the forest preserve. This river flows southwest until it joins the K ankakee River about $48 \mathrm{~km}$ (30 mi) southwest of A N L-E to form the Illinois River.

The largest topographical feature of the area is the Des Plaines River valley, which is about $1.6 \mathrm{~km}$ (1 mi) wide. This valley contains the river, the Chicago Sanitary and Ship Canal, and the Illinois and Michigan Canal. The elevation of the channel surface of these waterways is $180 \mathrm{~m}$ (578 ft) above sea level. The bluffs that form the southern border of the site rise from the river channel at slope angles of 15 to $60^{\circ}$ and reach an average elevation of $200 \mathrm{~m}(650 \mathrm{ft}$ ) above sea level at the top. The land then slopes gradually upward and reaches the average site elevation of $220 \mathrm{~m}$ (725 ft) above sea level at $915 \mathrm{~m}$ (3,000 ft) from the bluffs. Several large ravines oriented in a north-south direction are located in the southern portion of the site. The bluffs and ravines generally are forested with mature deciduous trees. The remaining portion of the site changes in elevation by no more than $7.6 \mathrm{~m}(25 \mathrm{ft})$ in a horizontal distance of $150 \mathrm{~m}(500 \mathrm{ft})$. The Chicago District Pipe Line Co. and the Burlington Northern Santa Fe Railroad have rights-of-way in the southern portion of the forest preserve.

\subsection{Population}

The area around ANL-E has experienced a large population growth in the past 30 years. Large areas of farmland have been converted into housing. Table 1.1 gives the directional and 
TABLE $1 \mathbf{1}$

Population Distribution in the Vicinity of ANL-E, 1995

\begin{tabular}{|c|c|c|c|c|c|c|c|c|c|c|}
\hline \multirow[b]{2}{*}{ Direction } & \multicolumn{5}{|c|}{ Population (individuals) at 0-5 Miles } & \multicolumn{5}{|c|}{ Population (thousands) at 5-50 Miles } \\
\hline & $0-1$ & $1-2$ & $2-3$ & $3-4$ & $4-5$ & $5-10$ & $10-20$ & $20-30$ & $30-40$ & $40-50$ \\
\hline $\mathrm{N}$ & 0 & 722 & 4,584 & 6,116 & 9,589 & 48.8 & 187.8 & 338.8 & 203.3 & 245.3 \\
\hline NNE & 0 & 24 & 4,022 & 6,469 & 5,773 & 41.3 & 305.8 & 488.8 & 92.6 & 0 \\
\hline NE & 0 & 805 & 2,504 & 2,654 & 1,808 & 41.3 & 678.6 & 871.7 & 0 & 0 \\
\hline ENE & 0 & 1,219 & 2,724 & 1,574 & 1,496 & 33.7 & 602.4 & 180.0 & 0 & 0 \\
\hline E & 0 & 18 & 11 & 1 & 42 & 41.1 & 469.9 & 201.4 & 13.2 & 28.1 \\
\hline ESE & 0 & 0 & 56 & 333 & 308 & 22.5 & 187.3 & 284.9 & 248.6 & 86.7 \\
\hline SE & 0 & 2 & 220 & 428 & 199 & 20.1 & 104.6 & 119.1 & 29.6 & 12.4 \\
\hline SSE & 0 & 75 & 404 & 222 & 1,945 & 13.6 & 25.3 & 8.9 & 11.8 & 17.8 \\
\hline$S$ & 0 & 108 & 2,313 & 927 & 957 & 4.3 & 27.1 & 2.3 & 37.6 & 37.1 \\
\hline SSW & 0 & 34 & 3,526 & 1,237 & 805 & 17.0 & 103.9 & 12.4 & 19.7 & 7.6 \\
\hline SW & 0 & 87 & 20 & 94 & 91 & 13.4 & 42.5 & 10.5 & 17.6 & 9.6 \\
\hline WSW & 0 & 235 & 95 & 717 & 1,904 & 5.6 & 8.8 & 4.3 & 8.5 & 7.4 \\
\hline W & 0 & 851 & 1,417 & 9,646 & 10,477 & 30.2 & 76.4 & 21.8 & 16.1 & 7.1 \\
\hline WNW & 0 & 277 & 253 & 6,642 & 4,945 & 48.5 & 117.2 & 23.5 & 7.2 & 56.6 \\
\hline NW & 0 & 603 & 2,841 & 7,620 & 7,401 & 45.4 & 75.7 & 108.0 & 20.7 & 19.2 \\
\hline NNW & 0 & 537 & 3,029 & 4,936 & 10,252 & 36.5 & 118.5 & 232.4 & 152.6 & 117.1 \\
\hline Total & 0 & 5,597 & 28,019 & 49,616 & 57,992 & 463.2 & $3,131.7$ & $2,908.7$ & 879.1 & 652.1 \\
\hline Cumulative total $^{\text {b }}$ & 0 & 5,597 & 33,616 & 83,232 & 141,224 & 604.5 & $3,736.2$ & $6,644.9$ & $7,524.0$ & $8,176.2$ \\
\hline
\end{tabular}

a To convert from miles to kilometers, multiply by 1.6 .

b Cumulative total $=$ total of this sector plus totals of all previous sectors. 
annular $80-\mathrm{km}(50-\mathrm{mi})$ population distribution for the area, which was used to derive the population dose calculations presented later in this report. The population distribution, centered on the Chicago Pile-5 (CP-5) reactor (Location 9G in Figure 1.1), was prepared by the Risk Assessment and Safety Evaluation Group of the Environmental A ssessment Division at ANL-E and represents projections to 1995 , on the basis of 1990 census data.

\subsection{Climatology}

The climate of the area is representative of the upper M ississippi V alley, as moderated by Lake M ichigan. Summaries of the meteorological data collected on the site from 1950 to 1964 are available ${ }^{3}$ and provide a historical sample of the climatic conditions. The most important meteorological parameters for the purposes of this report are wind direction, wind speed, temperature, and precipitation. The wind data are used to select air sampling locations and distances from sources and to calculate radiation doses from air emissions. Temperature and precipitation data are useful in interpreting some of the monitoring results. The 1997 data were obtained from the on-site A NL-E meteorological station. The 1997 average monthly and annual wind rose at the $60-\mathrm{m}(200-\mathrm{ft})$ level is shown in Figure 1.3. The wind rose is a polar coordinate plot in which the lengths of the radii represent the percentage frequency of wind speeds in classes of $2.01-6 \mathrm{~m} / \mathrm{s}(4.5-13.4 \mathrm{mph}), 6.01-10 \mathrm{~m} / \mathrm{s}(13.4-22.4 \mathrm{mph})$, and greater than $10.01 \mathrm{~m} / \mathrm{s}$ $(22.4 \mathrm{mph})$. The number in the center of the wind rose represents the percentage of observations of wind speed less than $2 \mathrm{~m} / \mathrm{s}(4.5 \mathrm{mph})$ in all directions. The direction of the radii from the center represents the direction from which the wind blows. Sixteen radii are shown on each plot at $22.5^{\circ}$ intervals; each radius represents the average wind speed for the direction covering $11.25^{\circ}$ on either side of the radius.

The annual average wind rose for 1997 is consistent with the long-term average wind direction, which usually varies from the west to south, but with a significant northeast component. Table 1.2 gives 1997 precipitation and temperature data. The monthly precipitation data for 1997 showed some differences from the average. For example, February, July, and A ugust are above the average, while March, April, and June are below the average. The annual total is 


\section{INTRODUCTION}
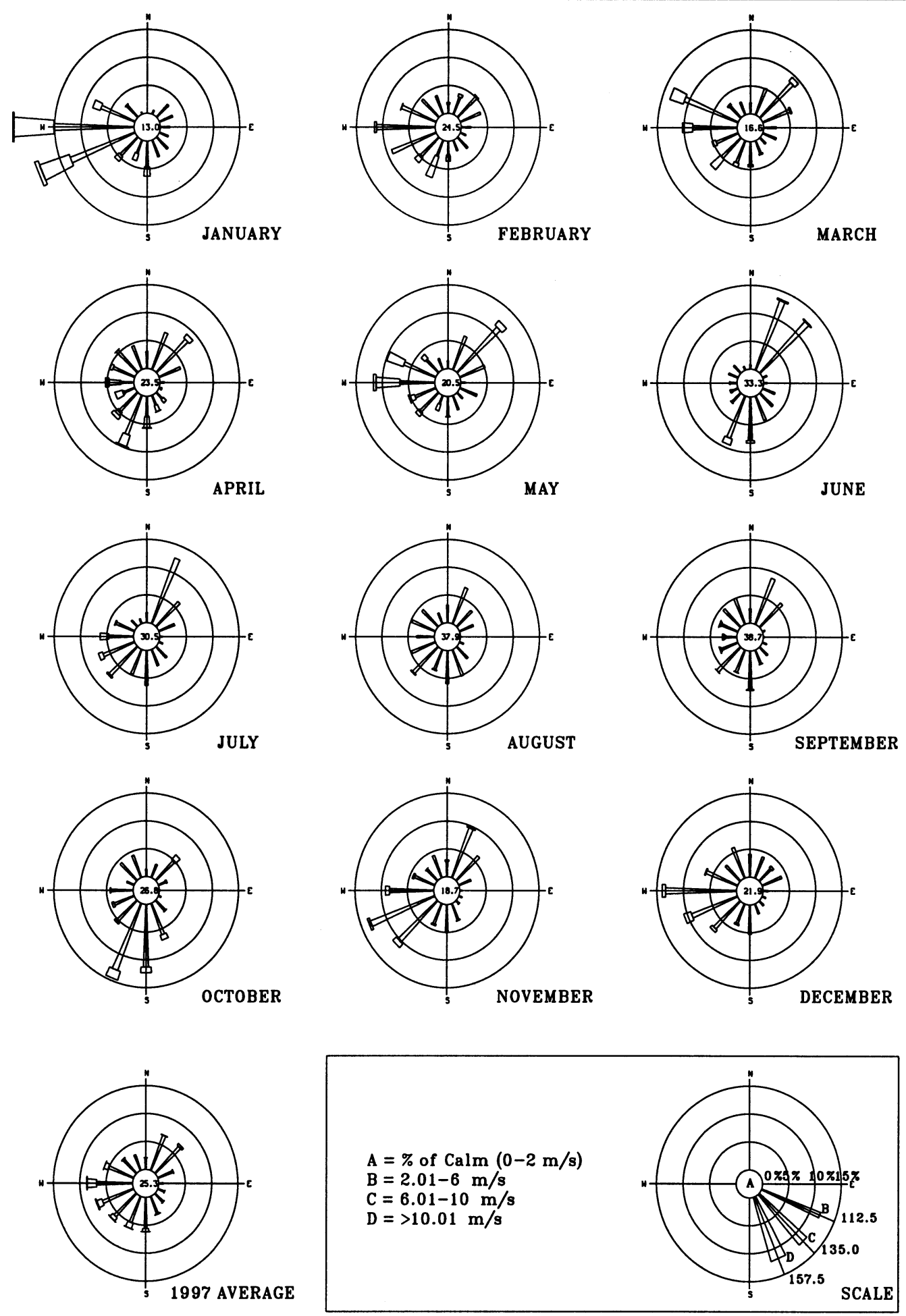

Figure 1.3 Monthly and Annual Wind Roses at Argonne National Laboratory-East, 1997 
TABLE 1.2

A N L-E W eather Summary, 1997

\begin{tabular}{|c|c|c|c|c|c|c|}
\hline \multirow[b]{2}{*}{ M onth } & \multicolumn{3}{|c|}{ A verage Precipitation $(\mathrm{cm})$} & \multicolumn{3}{|c|}{ A verage Temperature $\left({ }^{\circ} \mathrm{C}\right)$} \\
\hline & $\begin{array}{c}\text { A NL-E } \\
1997\end{array}$ & $\begin{array}{c}\text { ANL-E } \\
\text { Historical }^{\text {a }}\end{array}$ & Historical ${ }^{b}$ & $\begin{array}{c}\text { A N L-E } \\
1997\end{array}$ & $\begin{array}{c}\text { ANL-E } \\
\text { Historical }^{a}\end{array}$ & Historical ${ }^{b}$ \\
\hline January & 3.91 & 3.61 & 4.06 & -7.3 & -5.9 & -5.9 \\
\hline February & 15.82 & 3.38 & 3.33 & -4.2 & -3.7 & -3.3 \\
\hline M arch & 2.92 & 5.56 & 6.58 & 3.4 & 0.6 & 2.2 \\
\hline A pril & 4.43 & 9.14 & 9.30 & 7.6 & 8.3 & 9.3 \\
\hline M ay & 5.67 & 7.82 & 8.00 & 12.3 & 14.5 & 15.1 \\
\hline June & 5.96 & 9.47 & 10.36 & 20.6 & 19.7 & 20.3 \\
\hline July & 17.14 & 10.97 & 9.22 & 22.7 & 21.7 & 22.8 \\
\hline August & 12.09 & 8.71 & 8.97 & 20.4 & 20.9 & 22.2 \\
\hline September & 4.14 & 7.14 & 8.51 & 17.9 & 16.8 & 18.2 \\
\hline October & 5.47 & 6.58 & 5.79 & 12.0 & 11.4 & 11.9 \\
\hline November & 3.63 & 4.37 & 5.23 & 2.4 & 2.9 & 4.3 \\
\hline December & 3.78 & 3.20 & 5.33 & -3.7 & -4.2 & -2.4 \\
\hline Total & 84.96 & 79.95 & 84.68 & & & \\
\hline
\end{tabular}

a ANL-E data obtained from Reference 3.

b Data obtained from the $\mathrm{N}$ ational Oceanic and A tmospheric Administration for the weather station at $\mathrm{O}^{\prime} \mathrm{H}$ are International A irport. The average is for the years 1951-1980.

approximately $5 \%$ above the long-term average. The temperatures are similar to the long-term averages.

\subsection{Geology}

The geology of the ANL-E area consists of about $30 \mathrm{~m}(100 \mathrm{ft})$ of glacial till on top of bedrock, which is Niagaran and A lexandrian dolomite, underlain by shale and older dolomites and sandstones of Ordovician and Cambrian age. The beds are nearly horizontal. Niagaran and

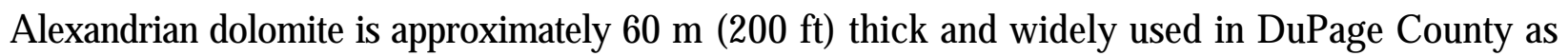
a source of groundwater. The shale separating the upper dolomite aquifer from the underlying sandstone and dolomite aquifers retards the hydraulic connection between them. The lower 


\section{INTRODUCTION}

aquifer has a much lower piezometric level and does not appear to be affected by pumpage from the overlying bedrock.

The southern boundary of A NL-E follows the escarpment of a broad valley, which is now occupied by the Des Plaines River and the Chicago Sanitary and Ship Canal. This valley was carved by waters flowing out of the glacial Lake M ichigan about 11,000 to 14,000 years ago. The soils on the site were derived from glacial till over the past 12,000 years and are primarily of the M orley series, that is, moderately well-drained upland soils with a slope ranging from 2 to $20 \%$.

The surface layer is a dark grayish-brown silt loam, the subsoil is a brown silty clay, and the underlying material is a silty clay loam glacial till. M orley soils have a relatively low organic content in the surface layer, moderately slow subsoil permeability, and a large water capacity. These soils are well suited to growing crops if good erosion control practices are used. The remaining soils along creeks, intermittent streams, bottomlands, and a few small upland areas are of the Sawmill, A shkum, Peotone, and Beecher series, which are generally poorly drained. They have a black to dark gray or brown silty clay loam surface layer, high organic-matter content, and a large water capacity.

\subsection{Seismicity}

No tectonic features within $135 \mathrm{~km}$ (62 mi) of ANL-E are known to be seismically active. The longest of these features is the Sandwich Fault. Smaller local features are the Des Plaines disturbance, a few faults in the Chicago area, and a fault of apparently Cambrian age.

Although a few minor earthquakes have occurred in northern Illinois, none has been positively associated with particular tectonic features. M ost of the recent local seismic activity is believed to be caused by isostatic adjustments of the earth's crust in response to glacial loading and unloading, rather than by motion along crustal plate boundaries.

Several areas of considerable seismic activity are located at moderate distances (hundreds of kilometers) from ANL-E. These areas include the N ew M adrid F ault zone (southeast M issouri) 
in the St. L ouis area, the Wabash V alley F ault zone along the southern Illinois-Indiana border, and the Anna region of western Ohio. Although high-intensity earthquakes have occurred along the $\mathrm{N}$ ew $\mathrm{M}$ adrid Fault zone, their relationship to plate motions remains speculative at this time.

According to estimates, ground motions induced by near and distant seismic sources in northern Illinois are expected to be minimal. However, peak accelerations in the ANL-E area may exceed $10 \%$ of gravity (approximate threshold of major damage) once in approximately 600 years, with an error range of -250 to +450 years.

\subsection{Hydrology}

Up until 1997, most groundwater supplies in the ANL-E area were derived from the Niagaran, and to some extent, the Alexandrian dolomite bedrock. Dolomite well yields are variable, but many approach 3,028 L/min (800 gal/min). In DuPage County, groundwater pumpage over the past 100 years has led to severe overdraft; in northeastern Illinois, the piezometric surface has been lowered in areas of heavy pumping. Delivery of Lake Michigan water to the major suburban areas is expected to relieve this problem. Because the cones of depression of ANL-E wells do not extend beyond the site and adjacent forest preserve, ANL-E water use does not affect neighboring communities. With the acquisition of $L$ ake $M$ ichigan water in 1997, the recovery of the dolomite water table is being measured.

Two principal aquifers are used as water supplies in the vicinity of ANL-E. The upper aquifer is the Niagaran and A lexandrian dolomite, which is approximately $60 \mathrm{~m}$ (200 ft) thick in the ANL-E area and has a piezometric surface between 15 and $30 \mathrm{~m} \mathrm{(50} \mathrm{and} 100 \mathrm{ft}$ ) below the ground surface for much of the site. The lower aquifer is Galesville sandstone, which lies between 150 and $450 \mathrm{~m}$ (500 and 1,500 ft) below the surface. M aquoketa shale separates the upper dolomite aquifer from the underlying sandstone aquifer. This shale retards the hydraulic connection between the two aquifers. 


\section{INTRODUCTION}

\subsection{Water and Land Use}

Sawmill Creek flows through the eastern portion of the site. This stream originates north of the site, flows through the property in a southerly direction, and discharges into the Des Plaines River. Two small streams originate on site and combine to form F reund Brook, which discharges into Saw mill Creek. Along the southern margin of the property, the terrain slopes abruptly downward forming forested bluffs. These bluffs are dissected by ravines containing intermittent streams that discharge some site drainage into the Des Plaines River. In addition to the streams, various ponds and cattail marshes are present on the site. A network of ditches and culverts transport surface runoff toward the smaller streams.

The greater portion of the ANL-E site is drained by Freund Brook. Two intermittent branches of Freund Brook flow from west to east, drain the interior portion of the site, and ultimately discharge into Sawmill Creek. The larger, south branch originates in a marsh adjacent to the western boundary line of the site. It traverses wooded terrain for a distance of about $2 \mathrm{~km}$ (1.5 mi) before discharging into the Lower Freund Pond. The upper Freund Brook branch discharges into the M iddle Freund Pond.

Sawmill Creek carried effluent water continuously from a sewage treatment plant ( $M$ arion Brook Treatment Plant) located a few kilometers north of the site until October 27, 1986, when the plant was closed. Residential and commercial development in the area have resulted in the collection and channeling of runoff water into Sawmill Creek. Treated sanitary and laboratory wastewater from ANL-E are combined and discharged into Sawmill Creek at location 7M in Figure 1.1. In 1997, this effluent averaged 2.6 million L ( 0.71 million gal)/day, which is similar to the averages for the last few years. The combined ANL -E effluent consisted of 51\% laboratory wastewater and $49 \%$ sanitary wastewater. The water flow in Sawmill Creek upstream of the wastewater outfall averaged about 21 million L (5.8 million gal)/day during 1997 .

Saw mill Creek and the Des Plaines River above J oliet, about $21 \mathrm{~km}$ (13 mi) southwest of $A N L-E$, receive very little recreational or industrial use. A few people fish in these waters downstream of ANL-E, and some duck hunting takes place on the Des Plaines River. Water from 
the Chicago Sanitary and Ship Canal is used by ANL-E for cooling towers and by others for industrial purposes, such as hydroelectric generators and condensers, and for irrigation at the state prison near Joliet. ANL-E usage is approximately 1.1 million $L(290,000$ gal $) /$ day. The canal, which receives Chicago Metropolitan Sanitary District effluent water, is used for industrial transportation and some recreational boating. N ear J oliet, the river and canal combine into one waterway, which continues until it joins the Kankakee River to form the Illinois River about $48 \mathrm{~km}$ (30 mi) southwest of ANL-E. The D resden Nuclear Power Station complex is located at the confluence of the Kankakee, Des Plaines, and Illinois Rivers. This station uses water from the Kankakee River for cooling and discharges the water into the Illinois River. The first downstream location where water is used as a community water supply system is at Peoria, on the Illinois River about $240 \mathrm{~km}$ (150 mi) downstream of ANL-E. In the vicinity of ANL-E, only subsurface water (from both shallow and deep aquifers) and Lake M ichigan water are used for drinking purposes.

The principal recreational area near ANL-E is the Waterfall Glen Forest Preserve, which surrounds the site (see Section 1.2 and Figure 1.1). The area is used for hiking, skiing, and equestrian sports. Sawmill Creek flows south through the eastern portion of the preserve on its way to the Des Plaines River. Several large forest preserves of the Forest Preserve District of Cook County are located east and southeast of ANL-E and the Des Plaines River. The preserves include the MCGinnis and Saganashkee Sloughs (shown in Figure 1.2), as well as other, smaller lakes. These areas are used for picnicking, boating, fishing, and hiking. A small park located in the eastern portion of the ANL-E site (Location 12-0 in Figure 1.1) is for the use of ANL-E and DOE employees. A local municipality has use of the park for athletic events.

\subsection{Vegetation}

A N L-E lies within the Prairie Peninsula of the Oak-Hickory Forest Region. The Prairie Peninsula is a mosaic of oak forest, oak openings, and tall-grass prairie occurring in glaciated portions of Illinois, northwest Indiana, southern Wisconsin, and sections of other states. M uch of the natural vegetation of this area has been modified by clearing and tillage. Forests in the ANL-E region, which are predominantly oak and hickory, are somewhat limited to slopes of 


\section{INTRODUCTION}

shallow, ill-defined ravines or low morainal ridges. Gently rolling to flat intervening areas between ridges and ravines were predominantly occupied by prairie before their use for agriculture. The prevailing successional trend on these areas, in the absence of cultivation, is toward oak-hickory forest. Forest dominated by sugar maple, red oak, and basswood may occupy more pronounced slopes. Poorly drained areas, streamside communities, and floodplains may support forests dominated by silver maple, elm, and cottonwood.

From early photographs of the site, it appears that most of the land that ANL-E now occupies was actively farmed. A bout $75 \%$ was plowed field and $25 \%$ was pasture, open oak woodlots, and oak forests. Starting in 1953 and continuing for three seasons, some of the formerly cultivated fields were planted with jack, white, and red pine trees. Other fields are dominated by bluegrass.

The deciduous forests on the remainder of the site are dominated by various species of oak, generally as large, old, widely spaced trees, often not forming a complete canopy. Their large low branches indicate that they probably matured in the open, rather than in a dense forest. Other upland tree species include hickory, hawthorn, cherry, and ash.

\subsection{Fauna}

Terrestrial vertebrates that are commonly observed or likely to occur on the site include about 5 species of amphibians, 7 of reptiles, 40 of summer resident birds, and 25 of mammals. $M$ ore than a hundred other bird species can be found in the area during migration or winter, but they do not nest on the site or in the surrounding region. An unusual species on the ANL-E site is the fallow deer, a European species that was introduced to the area by a private landowner prior to government acquisition of the property in 1947. A population of native white-tailed deer also inhabit the ANL-E site. The white-tailed and fallow deer populations are each maintained at a target density of $20 \mathrm{deer} / \mathrm{mi}^{2}$ under an ongoing deer management program. Terrestrial invertebrate species and plants also reside on the ANL-E site. 
Freund Brook crosses the center of the site but is impounded by a beaver dam in this area. The gradient of the stream is relatively steep, and riffle habitat predominates. The substrate is coarse rock and gravel on a firm mud base. Primary production in the stream is limited by shading, but diatoms and some filamentous algae are common. A quatic macrophytes include common arrowhead, pondweed, duckweed, and bulrush. Invertebrate fauna consist primarily of dipteran larvae, crayfish, caddisfly larvae, and midge larvae. Few fish are present because of low summer flows and high temperatures. Other aquatic habitats on the ANL-E site include additional beaver ponds, artificial ponds, ditches, and Sawmill Creek.

The biotic community of Sawmill Creek is relatively impoverished, which reflects the creek's high silt load, steep gradient, and historic release of sewage effluent from the $M$ arion Brook sewage treatment plant north of the site. The fauna consists primarily of blackflies, midges, isopods, flatworms, segmented worms, and creek chubs. A few other species of minnows, sunfishes, and catfish are also present. Clean water invertebrates, such as mayflies and stoneflies, are rare or absent. Fish species that have been recorded in A NL-E aquatic habitats include black bullhead, bluegill, creek shub, golden shiner, goldfish, green sunfish, largemouth bass, stoneroller, and orange-spotted sunfish.

The U.S. Fish and W ildlife Service (FWS) has rated the Des Plaines River system, including ANL-E streams, as "poor" in terms of the fish species present because of domestic and industrial pollution and stream modification.

\subsection{Archaeology}

ANL-E, which is located in the Illinois and M ichigan Canal National Heritage Corridor, is situated in an area known to have a long and complex cultural history. All periods listed in the cultural chronology of Illinois, with the exception of the earliest period (Paleo-Indian), have been documented in the ANL-E area either by professional cultural resource investigators or through interviews of local artifact collectors by ANL-E staff. A variety of site types, including mounds, quarries, lithis workshops, and habitation sites, have been reported by amateurs within a $25-\mathrm{km}$ (16-mi) radius. 


\section{INTRODUCTION}

The 46 recorded sites include prehistoric chert quarries, special purpose camps, base camps, and historical farmsteads. The range of human occupation spans several time periods (Early A rchaic through M ississippian Prehistoric to Historical). Three sites have been determined to be eligible for the National Register for Historic Places (NRHP), 20 sites have been determined to be ineligible, and 23 sites have not been evaluated for eligibility.

\subsection{Endangered Species}

No federally listed threatened or endangered species are known to occur on the ANL -E site, and no critical habitat of federally listed species exists on the site. Three federally listed endangered species are known to inhabit the Waterfall Glen Forest Preserve that surrounds the ANL-E property or to occur in the area.

The Hine's emerald dragonfly (Somatochlora hineana), federally and state listed as endangered, occurs in locations with calcaerous seeps and wetlands along the Des Plaines River floodplain. Leafy prairie clover (Dalea foliosa), which is federally listed as endangered, is associated with dolomite prairie remnants of the Des Plaines River valley; two planted populations of this species occur in Waterfall Glen Forest Preserve. A n unconfirmed capture of Indiana bat (M yotis sodalis), which is federally listed as endangered, indicates that this species may occur in the area. A dditional state-listed species that occur in the area include the following:

- Early fen sedge (C arex crawei), threatened

- White lady's slipper (Cypripedium candidum), endangered

- Slender sandwort (Arenaria patula), endangered

- M arsh speedwell (Veronica scutellata), threatened

- Rough marsh cress (Rorippa islandica var. hispida), endangered

- Kirtland's snake (Clonophis kirtlandi), threatened

- Pied-billed grebe (Podilymbus podiceps), endangered

- Great egret (C asmerodius alba), endangered

- Black-crowned night heron (Nycticorax nycticorax), endangered 
- Red-shouldered hawk (Buteo lineatus), endangered

- River otter (Lutra canadensis), endangered

Of these, rough marsh cress, Kirtland's snake, pied-billed grebe, great egret, black-crowned night heron, and red-shouldered hawk have been observed on A N L-E property. 


\section{COMPLIANCE SUMMARY}

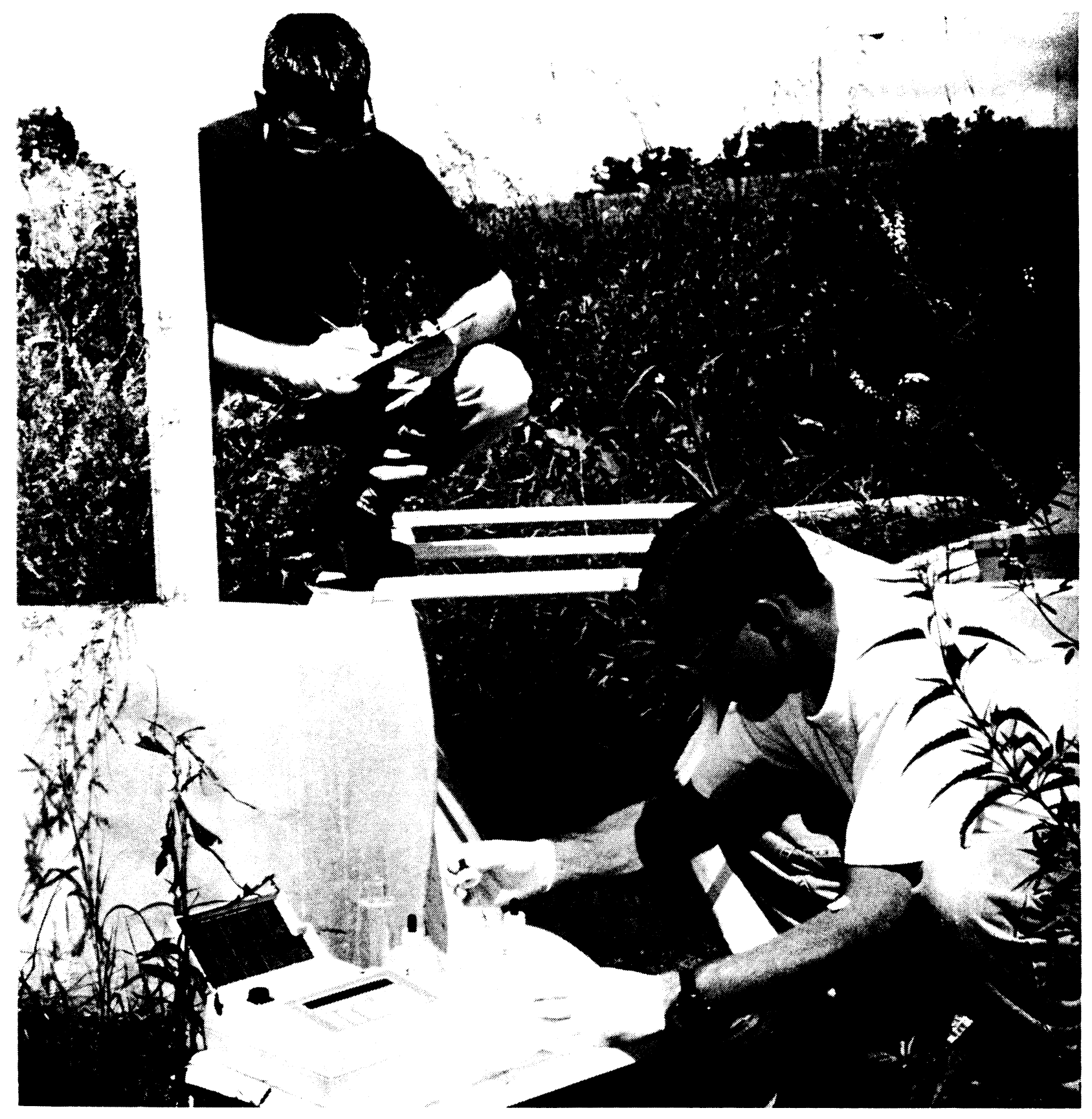




\section{COMPLIANCE SUMMARY}


ANL-E is a government-owned, contractor-operated (GOCO) nonproduction facility that is subject to environmental statutes and regulations administered by the U.S. Environmental Protection Agency (EPA), the Illinois Environmental Protection A gency (IEPA), the Illinois Department of Public Health (IDPH), and the State Fire Marshal, as well as numerous DOE Orders and Executive Orders. A detailed listing of applicable regulations is contained in DOE Order $5400.1,{ }^{1}$ which establishes DOE's policy concerning environmental compliance. The status of ANL-E during 1997 with regard to these authorities is discussed in this chapter.

To ensure compliance with both the letter and spirit of these requirements, ANL-E has made a commitment to comply with all applicable environmental requirements, as described in the following policy statement:

It is the policy of A rgonne $\mathrm{N}$ ational Laboratory that its activities will be conducted in such a manner that worker and public safety, including protection of the environment, is given the highest priority. The L aboratory will comply with all applicable federal and state environmental laws, regulations, and orders.

\subsection{Clean Air Act}

The Clean A ir A ct (CAA) is a federal statute that specifies National A mbient A ir Quality Standards, sets emission limits for air pollutants, and determines emission limits and operating criteria for a number of hazardous air pollutants. The program is implemented by individual states through a State Implementation Plan (SIP) that describes how that state will ensure compliance with the air quality standards for stationary sources.

A number of major changes to the CAA were made with the passage of the Clean Air Act A mendments of 1990. Under Title V of the Clean Air Act A mendments of 1990, ANL-E was required to submit a Clean Air Act Permit Program (CAAPP) application to the IEPA for a sitewide, federally-enforceable operating permit to cover emissions of all regulated air pollutants at the facility. This permit superseded the state air pollution control permits that were currently in effect. All facilities designated as major emission sources for regulated air pollutants are 


\section{COMPLIANCE SUMMARY}

subject to this requirement. ANL-E meets the definition of a major source because of potential emissions of oxides of nitrogen $\left(\mathrm{NO}_{\mathrm{x}}\right)$ in excess of 25 tons/yr and sulfur dioxide $\left(\mathrm{SO}_{2}\right)$ in excess of 100 tons/yr at the Building 108 Central Heating Plant.

Facilities subject to Title $\mathrm{V}$ must characterize emissions of all regulated air pollutants, not only those that qualify them as major sources. In addition to $\mathrm{NO}_{X}$ and $\mathrm{SO}_{2}, \mathrm{ANL}-\mathrm{E}$ also must evaluate emissions of carbon monoxide (CO), particulates, volatile organic compounds (VOCs), hazardous air pollutants (a list of 188 chemicals, including radionuclides), and ozone-depleting substances. The air pollution control permit program requires that facilities pay annual fees on the basis of the total amount of regulated air pollutants (except $\mathrm{CO}$ ) they will be allowed to emit.

When the IEPA acknowledges a CA A PP application as timely and complete, the applicant receives an application shield and is in compliance with the CAA. The ANL-E CAAPP application was submitted to the IEPA on September 19, 1995; the IEPA issued the N otice of Completeness on October 26, 1995. The Notice of Completeness also means that current air pollution control permits under which operations remain unchanged do not need to be renewed. A $n$ exception to this is the ANL-E Fire Department's open burning permit (used for fire training), which must be renewed annually.

The ANL-E CAAPP application has never been technically reviewed by the IEPA. In October 1997, the IEPA announced that it had reorganized its CAAPP unit in an effort to expedite the issuance of permits. Part of this reorganization included the assignment of a new permit writer to the ANL-E CAAPP application. The IEPA plans to conduct the technical review of the application during 1998. Following a major revision of the application in 1996, a second application revision was submitted to the IEPA on January 13, 1997; a third revision was submitted on J une 25, 1997. A fourth revision will be submitted in J anuary 1998 to certify that A NL-E is not subject to the Emission Reduction M arket System program designed to reduce volatile organic emissions in the Chicago nonattainment area. At the IEPA's request, no additional revisions will be submitted in 1998 until the technical review of the application has been initiated. 
The ANL -E site contains a large number of air emission point sources. The vast majority are laboratory ventilation systems that are exempt from state permitting requirements, except for those systems emitting radionuclides. By the end of 1997, a total of 44 air pollution control permits were in place covering all known emission points. Section 2.17 contains a list (Table 2.14) of the air pollution control permits in effect at ANL-E. The IEPA conducted an air emissions inspection on September 5, 1997; no significant issues were identified.

\subsubsection{National Emission Standards for Hazardous Air Pollutants}

The National Emission Standards for Hazardous A ir Pollutants (NESHAP) constitute a body of federal regulations that set forth emission limits and other requirements, such as monitoring, record keeping, and operational requirements, for activities generating emissions of certain hazardous air pollutants. The only standards affecting A N L-E operations are those for asbestos, radionuclides, and halogenated solvent cleaning. The IEPA has issued a total of 24 air pollution control permits for NESHAP sources to ANL-E. In 1997, a new NESHAP construction/operating permit was issued for the 317 A rea French Drain Soil M ixing/Vapor Extraction project; one NESHAP air pollution control permit was modified to increase the number of Waste $M$ anagement (WM ) portable High-Efficiency Particulate Air (HEPA) filter systems from two to four; one NESHA P air pollution control construction permit (Radon Remediation Demonstration) expired and was not renewed because of project inactivity.

\subsubsection{Asbestos Emissions}

M any buildings on the ANL-E site contain large amounts of asbestos-containing material (ACM ) such as thermal system insulation around pipes and tanks, spray-applied surfacing material for fireproofing, floor tile, and asbestos-cement panels. This material is removed as necessary during renovations or maintenance of equipment and facilities. The removal and disposal of this material are governed by the asbestos NESHAP.

ANL-E maintains an asbestos abatement program designed to ensure compliance with these and other regulatory requirements. In general, $\mathrm{ACM}$ is removed from buildings either by 


\section{COMPLIANCE SUMMARY}

specially trained ANL-E crews (for small-scale, short-duration projects) or by outside contractors (for large-scale insulation removal projects lasting a day or longer). All removal work is performed in strict compliance with both NESHAP and Occupational Safety and Health Administration $(\mathrm{OSHA})$ requirements governing worker safety at $\mathrm{ACM}$ removal sites.

A pproximately $150 \mathrm{~m}^{3}\left(5,295 \mathrm{ft}^{3}\right)$ of ACM was removed from ANL-E buildings during 1997. A total of 80 small removal projects that were completed generated $51 \mathrm{~m}^{3}\left(1,800 \mathrm{ft}^{3}\right)$ of ACM waste; the remaining $99 \mathrm{~m}^{3}\left(3,495 \mathrm{ft}^{3}\right)$ generated resulted from large removal projects. A sbestos abatement project information is provided in Table 2.1. The IEPA was notified during December 1997 that no more than $100 \mathrm{~m}^{3}\left(3,500 \mathrm{ft}^{3}\right)$ of $\mathrm{ACM}$ waste will be generated during 1998.

A separate portion of the standards contains requirements for waste disposal sites used for disposing of ACM. Off-site shipments are to be accompanied by completed shipping manifests. A sbestos disposal information is provided in Table 2.2. Until closure of the ANL-E landfill in September 1992, asbestos from small-scale projects was disposed of on site in a designated area of the landfill.

\subsubsection{Radionuclide Emissions}

The NESHAP standard for radionuclide emissions from DOE facilities (C ode of Federal Regulations, Title 40, Part 61 [40 CFR 61], Subpart H) establishes the emission limits for the release of radionuclides other than radon to the air and the requirements for monitoring, reporting, and record keeping. A number of emission points at ANL-E are subject to these requirements. These points include ventilation systems for hot cell facilities for storage and handling of radioactive materials (Buildings 200, 205, and 212), ventilation systems for particle accelerators (Building 375, IPNS facility, and the Building 411 APS Linac), and several ventilation systems associated with the Building $350 \mathrm{NBL}$. In addition, many small ventilation systems and fume hoods are used occasionally for processing small quantities of radioactive materials. 
TABLE 2.1

A sbestos A batement Projects: IEPA N otification, 1997

\begin{tabular}{|c|c|c|c|c|c|c|c|}
\hline $\begin{array}{l}\text { Completion } \\
\text { D ate }\end{array}$ & $\begin{array}{l}\text { A sbestos } \\
\text { A batement } \\
\text { Contractor }\end{array}$ & \multicolumn{2}{|c|}{$\begin{array}{l}\text { Notification } \\
\text { Quantity }\end{array}$} & M aterial & \multicolumn{3}{|c|}{$\begin{array}{l}\text { Disposal } \\
\text { Quantity }\end{array}$} \\
\hline 03/14/97 & A ction W recking & 18 & 3,761 & $\begin{array}{l}\text { Pipe insulation, transite wall } \\
\text { panels, floor tile }\end{array}$ & $\begin{array}{l}33 \\
481 \\
481 A \\
825 \\
828\end{array}$ & 960 & County ${ }^{a}$ \\
\hline 06/04/97 & $\begin{array}{l}\text { SECO } \\
\text { Environmental }\end{array}$ & 800 & 400 & Pipe insulation, duct jacket & 202 & 510 & County \\
\hline 06/11/97 & A ction W recking & $N A^{b}$ & 300 & Floor tile, nonfriable & 108 & 25 & County \\
\hline \multirow[t]{2}{*}{ 09/30/97 } & $\begin{array}{l}\text { ANL-E } \\
\text { EMO-WM d }\end{array}$ & NA & 16,000 & Ceiling tile & 362 & 2,000 & Streator ${ }^{c}$ \\
\hline & & & & & Total & 3,495 & \\
\hline
\end{tabular}

a County Environmental Livingston L andfill, Pontiac, IL.

b $\mathrm{NA}=$ not applicable.

c Streator A rea L andfill, Streator, IL.

d A N L-E Environmental M anagement O perations-W aste $M$ anagement. 


\section{COMPLIANCE SUMMARY}

TABLE 2.2

\begin{tabular}{|c|c|c|c|}
\hline Project Size & L andfill & $\begin{array}{l}\text { Quantity } \\
\left(\mathrm{ft}^{3}\right)\end{array}$ & $\begin{array}{c}\text { Total Quantity } \\
\left(\mathrm{ft}^{3}\right)\end{array}$ \\
\hline \multirow[t]{2}{*}{ Small-scale } & County ${ }^{a}$ & 910 & \\
\hline & Streator ${ }^{b}$ & 890 & 1,800 \\
\hline \multirow[t]{3}{*}{ Large } & County & 1,495 & \\
\hline & Streator & 2,000 & 3,495 \\
\hline & & & 5,295 \\
\hline
\end{tabular}

a County Environmental Livingston L andfill, Pontiac, IL.

b Streator A rea L andfill, Streator, IL.

The amount of radioactive material released to the atmosphere from ANL-E emission sources is extremely small. The maximum off-site dose to a member of the general public for 1997 was $0.018 \mathrm{mrem}$, which, excluding radon-220, is $0.18 \%$ of the $10 \mathrm{mrem} / \mathrm{yr}$ EPA standard. Section 4.6.1. contains a more detailed discussion of these emission points and compliance with the standard.

\subsubsection{Conventional Air Pollutants}

The ANL -E site contains a number of sources of conventional air pollutants, including a steam plant; gasoline, methanol/gasoline blend, and ethanol/gasoline blend fuel-dispensing facilities; two alkali metal reaction booths; bulk chemical tanks; a dust collection system; a medical equipment sterilization unit; and fire training activities. Table 2.14 gives the emission sources that have been granted operating air pollution control permits by the IEPA. During 1997, one new air pollution control permit was issued by the IEPA (see Table 2.14) to conduct prescribed vegetation burning at A N L-E as part of the site landscape management plan. 
The operating air pollution control permit for the steam plant requires continuous opacity and $\mathrm{SO}_{2}$ monitoring of the smoke stack from Boiler $\mathrm{No}$. 5, the only one of the five boilers equipped to burn coal. The permit requires submission of a quarterly report listing any exceedances beyond emission limits for this boiler [30\% opacity averaged over 6 minutes and $0.82 \mathrm{~kg}(1.8 \mathrm{lb}) \mathrm{SO}_{2}$ per million Btu averaged over a 1-hour period]. Table 2.3 gives the hours that Boiler N o. 5 operated on low-sulfur coal during 1997, as well as the amount of low-sulfur coal burned. One exceedance for opacity at Boiler No. 5, because of mechanical failure of a damper, was reported to the IEPA during 1997. The IEPA conducted an air emission compliance inspection of the steam plant on September 5, 1997; no significant issues were identified.

The ANL-E 800 A rea L andfill, which was closed in 1992, was not subject to air pollution control permitting requirements during its operation. It is not subject to 40 CFR 60, Subpart WW W (Standards of Performance for M unicipal Solid Waste L andfills), or Subpart CC (E mission Guidelines and Compliance Times for M unicipal Solid Waste Landfills), because it

\section{TABLE 2.3}

Boiler No. 5 Operation, 1997

\begin{tabular}{lcc}
\hline M onth & $\begin{array}{c}\text { Low-Sulfur } \\
\text { Coal (H ours) }\end{array}$ & $\begin{array}{c}\text { Low-Sulfur } \\
\text { Coal Burned } \\
\text { (Tons) }\end{array}$ \\
\hline J anuary & 615.75 & $2,021.6$ \\
February & 672.0 & $2,116.4$ \\
M arch & 744.0 & $2,478.6$ \\
A pril & 386.0 & $1,070.5$ \\
M ay & 0 & 0 \\
June & 0 & 0 \\
July & 0 & 0 \\
A ugust & 0 & 0 \\
September & 0 & 0 \\
October & 0 & 0 \\
November & 241.0 & 727.4 \\
December & 744.0 & $2,848.3$ \\
\cline { 2 - 3 } Total & $3,402.75$ & $11,262.8$ \\
\hline
\end{tabular}




\section{COMPLIANCE SUMMARY}

does not meet the definition of a municipal solid waste landfill. Because closed landfills are sources of emissions, in 1997, the EPA Landfill Gas Emissions M odel (L andGEM $)^{4}$ was used to determine levels of methane $\left(\mathrm{CH}_{4}\right)$ and $\mathrm{N}$ onmethane Organic Compounds ( $\mathrm{N} \mathrm{OC}$ ) for inclusion in the ANL-E CAAPP application and emissions inventory. For 1997, the model calculated $\mathrm{CH}_{4}$ emissions of approximately 70 tons/yr and NMOC emissions (from analysis of samples from gas monitoring wells) of approximately 0.02 ton/yr. E missions of these parameters are expected to decline on the basis of initial refuse placement and closure of the landfill.

Fuel-dispensing facilities include a commercial service station and the Building 46 Grounds and Transportation facility. Except for methanol and ethanol vapors from alternate fuel usage, these facilities have VOC emissions typical of any commercial gasoline service station. Stage II vapor recovery systems were installed at both facilities by November 1, 1994. Pursuant to Illinois Administrative Code, Title 35, Part 254 (35 IA C 254), A N L-E submits an emissions summary to the IEPA each M ay 1 for the previous calendar year. The summary for 1997 is presented in Table 2.4 .

\subsection{Clean Water Act}

The Clean Water Act (CWA) was established in 1977 as a major amendment to the Federal Water Pollution Control Act of 1972 and was modified substantially by the Water Quality A ct of 1987. Section 101 of the CWA provides for the restoration and maintenance of water quality in all waters throughout the country, with the ultimate goal of "fishable and swimmable" water quality. The act established the National Pollutant Discharge Elimination System (NPDES) permitting system, which is the regulatory mechanism designed to achieve this goal. The authority to implement the NPDES program has been delegated to those states, including Illinois, that have developed a program substantially the same and at least as stringent as the federal NPDES program.

The 1987 amendments to the CWA significantly changed the thrust of enforcement activities. Greater emphasis is placed on monitoring and control of toxic constituents in 


\section{COMPLIANCE SUMMARY}

TABLE 2.4

1997 A nnual Emissions Report: Emissions Summary

\begin{tabular}{|c|c|c|c|c|c|c|}
\hline Building No. and Source & $\mathrm{CO}$ & $\mathrm{NO}_{\mathrm{x}}$ & $\begin{array}{c}\text { Particulat } \\
\mathrm{e}\end{array}$ & $\mathrm{SO}_{2}$ & $\operatorname{VOM}^{\mathrm{a}}$ & Lead \\
\hline 108 Boiler 1 & 1,729 & 77,044 & 798 & 479 & 372 & 0 \\
\hline 108 Boiler 2 & 1 & 3,100 & 30 & 24 & 14 & 0 \\
\hline 108 Boiler 3 & 37 & 36,205 & 365 & 511 & 170 & 0 \\
\hline 108 Boiler 4 & 207 & 43,974 & 444 & 118 & 207 & 0 \\
\hline 108 Boiler 5 (gas-fired) & 406 & 1,240 & 18 & 6 & 18 & 0 \\
\hline 108 Boiler 5 (coal-fired) & 58,010 & 313,498 & 878 & 244,237 & 410 & 0 \\
\hline 400 A PS Generator Caterpillar (1 unit) & 406 & 2,115 & 75 & 175 & 57 & 0 \\
\hline 400 A PS Generator Kohler (2 units) & 2,374 & 3,204 & 125 & 658 & 114 & 0 \\
\hline 370 Alkali Reaction Booth ${ }^{b}$ & 0 & 0 & $-c$ & 0 & 0 & 0 \\
\hline 308 A lkali Reaction Booth ${ }^{\mathrm{b}}$ & 0 & 0 & - & 0 & 0 & 0 \\
\hline 206 A lkali Reaction Booth $(R)^{d}$ & 0 & 0 & 8 & 0 & 0 & 0 \\
\hline 363 Central Shop Dust Collector ${ }^{b}$ & 0 & 0 & - & 0 & 0 & 0 \\
\hline 201 Ethylene Oxide Sterilizer & 0 & 0 & 0 & 0 & 31.5 & 0 \\
\hline 212 Building Exhausts ${ }^{b}$ & 0 & 0 & - & 0 & 0 & 0 \\
\hline 366 Grieve Oven ${ }^{b}$ & 0 & 0 & - & 0 & 0 & 0 \\
\hline 368 W oodshop Dust Collector ${ }^{b}$ & 0 & 0 & - & 0 & 0 & 0 \\
\hline 306 Bulking Sheds & 0 & 0 & $<1$ & 0 & 29.6 & 0 \\
\hline 306 Building V ents ( $\mathrm{R}$ ) & 0 & 0 & $<1$ & 0 & 0 & 0 \\
\hline 306 Vial Crusher & 0 & 0 & 0 & 0 & 15.6 & 0 \\
\hline 46 M ethanol/Gasoline & 0 & 0 & 0 & 0 & 2.3 & 0 \\
\hline 46 Ethanol/Gasoline & 0 & 0 & 0 & 0 & 26.3 & 0 \\
\hline 46 10,000 Gal Gasoline & 0 & 0 & 0 & 0 & 347 & 0 \\
\hline 300 10,000 Gal Gasoline & 0 & 0 & 0 & 0 & 247 & 0 \\
\hline 300 8,000 Gal Gasoline & 0 & 0 & 0 & 0 & 843 & 0 \\
\hline 300 6,000 Gal Gasoline & 0 & 0 & 0 & 0 & 224 & 0 \\
\hline 108 Sulfuric A cid Tank ${ }^{b}$ & 0 & 0 & - & 0 & 0 & 0 \\
\hline 400 A PS F acility (R) & 0 & 61.5 & 0 & 0 & 0 & 0 \\
\hline WM Portable HEPA - (4) (R) & 0 & 0 & $<1$ & 0 & 0 & 0 \\
\hline 317 L ead Brick Cleaning (R) & 0 & 0 & $<1$ & 0 & 0 & $<1$ \\
\hline Torch Cut L ead-Based Paint ${ }^{b}$ & 0 & 0 & - & 0 & 0 & 0 \\
\hline 595 L ab W astewater Plant (R) & 0 & 0 & 771 & 0 & 30 & 0 \\
\hline PCB Tank Cleanout & 0 & 0 & 0 & 0 & 0 & 0 \\
\hline 315 M ACE Project (R) & 100 & 0 & $<1$ & 0 & 0 & 0 \\
\hline Transportation Research F acility & 345 & 721 & 51 & 48 & 67 & 0 \\
\hline 317 A rea French Drain Remediation & 0 & 0 & 182 & 0 & 132 & 0 \\
\hline Total (Ib/yr) & 63,615 & 481,162 & 3,745 & 246,256 & 3,357 & 0 \\
\hline Total (ton/yr) & 31.8078 & 240.5805 & 1.8724 & 123.1278 & 1.6786 & 0 \\
\hline CAAPP Limit (ton/yr) - Typical & 152.08 & 680.30 & 29.98 & 462.62 & 14.15 & 0.11 \\
\hline CAAPP Limit (ton/yr) - Alt 1 & 236.10 & 1685.10 & 38.82 & 800.83 & 18.15 & 0.11 \\
\hline CAAPP Limit (ton/yr) - Alt 2 & 300.10 & 1393.10 & 58.82 & 990.00 & 18.15 & 0.11 \\
\hline \multirow{3}{*}{\multicolumn{7}{|c|}{$\begin{array}{l}\text { a } \mathrm{VOM}=\text { volatile organic material. } \\
\text { b These sources have been designated as insignificant in the Clean Air Act Permit Program (CAAPP) application. }\end{array}$}} \\
\hline & & & & & & \\
\hline & & & & & & \\
\hline \multicolumn{7}{|c|}{$d \quad(R)=$ radionuclide source regulated by NESHAP (40 CFR 61 Subpart $H$ ). } \\
\hline
\end{tabular}




\section{COMPLIANCE SUMMARY}

wastewater, the permitting of outfalls composed entirely of storm water, and the imposition of regulations governing sewage sludge disposal. These changes in the NPDES program resulted in much stricter discharge limits and greatly expanded the number of chemical constituents monitored in the effluent. The ANL-E sanitary wastewater treatment facility was upgraded in 1996 to replace aging components. The ANL-E laboratory wastewater treatment facility was upgraded in 1997 to improve treatment capabilities.

\subsubsection{Liquid Effluent Discharge Permit}

The NPDES permitting process administered by the IEPA is the primary tool for enforcing the requirements of the NPDES program. Before wastewater can be discharged to any receiving stream, each wastewater discharge point (outfall) must be characterized and described in a permit application. The IEPA then issues a permit that, for each outfall, contains numeric limits on certain pollutants likely to be present and sets forth a number of additional specific and general requirements, including sampling and analysis schedules and reporting and record keeping requirements. Wastewater discharge activities at ANL-E are covered by NPDES Permit No. IL 0034592. This permit was renewed during 1994, effective October 30, 1994. For reasons discussed below, the permit was modified during 1995, effective August 24, 1995. The modification incorporates interim limits and a compliance schedule for achieving final effluent limits at Outfall 001.

Wastewater at ANL-E is generated by a number of activities and consists of sanitary wastewater (from restrooms, cafeteria sinks and sinks in certain buildings and laboratories, and steam boiler blowdown), laboratory wastewater (from laboratory sinks and floor drains in most buildings), and storm water. Water softener regenerant is discharged to the DuPage County sewer system. Cooling water and cooling tower blowdown are discharged into storm water ditches that are monitored as part of the NPDES permit. The current permit authorizes the release of wastewater from 40 separate outfalls, most of which discharge directly or indirectly into Sawmill Creek. Two of the outfalls are internal sampling points that combine to form the main wastewater outfall, O utfall 001. Table 2.5 lists these outfalls; Figure 2.1 shows their locations. 
TABLE 2.5

Characterization of N PDES Outfalls at A NL-E, 1997

\begin{tabular}{|c|c|c|}
\hline Outfall & Description & Flow $^{\mathrm{a}}$ \\
\hline $001 \mathrm{~A}$ & Sanitary T reatment Plant & 0.35 \\
\hline 001B & Laboratory Treatment Plant & 0.36 \\
\hline 001 & Combined Outfall & 0.71 \\
\hline 003A & Swimming Pool & 0.0 \\
\hline 003B & 300 A rea (Condensate) & 0.049 \\
\hline 003C & Building 205 Footing Tile D rainage & 0.025 \\
\hline $003 D \& E$ & Steam Trench Drainage (Condensate) & $<0.01$ \\
\hline 003F & Building 201 Fire Pond Overflow Storm W ater & 0.013 \\
\hline 003G & North Building 201 Storm Sewer (Condensate) & 0.032 \\
\hline 003H & Building 212 Cooling Tower Blowdown & 0.019 \\
\hline 0031 & Buildings 200 and 211 Cooling Tower Blowdown & 0.014 \\
\hline 003] & $\begin{array}{l}\text { Building } 213 \text { and Building } 213 \text { Parking L ot } \\
\text { Storm W ater }\end{array}$ & 0.027 \\
\hline 004 & $\begin{array}{l}\text { Building } 203 \text { Cooling Tower and Building } 221 \text { Footing } \\
\text { Drainage and Storm Water }\end{array}$ & 0.028 \\
\hline 005A & W estgate R oad Storm W ater & Storm Water Only \\
\hline 005B & 800 A rea E ast Storm W ater & Storm Water Only \\
\hline $005 \mathrm{C}$ & Building 200 West & $<0.01$ \\
\hline 005D & Storm Water & Storm Water Only \\
\hline 005E & Building 203 W est F ooting Drainage and Condensate & 0.024 \\
\hline 006 & Cooling Tower Blowdown and Storm Water & 0.042 \\
\hline 007 & $\begin{array}{l}\text { Domestic Cooling Water for Compressor and Storm } \\
\text { W ater }\end{array}$ & 0.011 \\
\hline 008 & Transportation and Grounds Storm W ater & $<0.01$ \\
\hline 010 & Coal Pile Runoff Emergency Overflow & Storm Water Only \\
\hline 101 & N orth Fence Line M arsh Storm Discharge & Storm Water Only \\
\hline 102 & 100 A rea Storm Water Discharge & Storm Water Only \\
\hline 103 & Southeast 100 A rea Storm W ater & Storm Water Only \\
\hline 104 & N orthern East A rea Storm W ater D ischarge & Storm Water Only \\
\hline $105 A \& B$ & Building 40 Storm Water Discharge & Storm Water Only \\
\hline $106 \mathrm{~A} \& \mathrm{~B}$ & Southern East A rea Storm W ater D ischarge & Storm Water Only \\
\hline 108 & Eastern 300 A rea Storm W ater and Cooling W ater & 0.034 \\
\hline 110 & Shooting Range Storm W ater Discharge & Storm Water Only \\
\hline 111 & 319 Landfill and N ortheast 317 A rea & Storm Water Only \\
\hline $112 A \& B$ & Southern and W estern 317 A rea & Storm Water Only \\
\hline
\end{tabular}




\section{COMPLIANCE SUMMARY}

TABLE 2.5 (C ont.)

\begin{tabular}{|c|c|c|}
\hline Outfall & Description & Flow \\
\hline 113 & $\begin{array}{l}\text { Southern and Eastern } 800 \text { A rea L andfill Storm W ater } \\
\text { Runoff }\end{array}$ & 0.013 \\
\hline 114 & $\begin{array}{l}\text { N orthern and W estern } 800 \text { A rea L andfill Storm Water } \\
\text { Runoff }\end{array}$ & $<0.01$ \\
\hline 115 & $\begin{array}{l}\text { 314, 315, and } 316 \text { Cooling W ater, E astern and } \\
\text { Southern APS A rea }\end{array}$ & $<0.01$ \\
\hline 116 & W ater T reatment Plant and Storm W ater & $<0.01$ \\
\hline
\end{tabular}

a Flow is measured in million gallons per day, except for outfalls with storm water only.

\subsubsection{Effluent Monitoring Results and Compliance Issues}

Results of the routine monitoring required by the N PDES permit are submitted monthly to the IEPA in a Discharge M onitoring Report (DMR). As required by the permit, any exceedance of permit limits or conditions is reported by telephone to the IEPA within 24 hours, and a written explanation of the exceedance is submitted with each DMR. During 1997, there were 3 exceedances of NPDES permit limits out of approximately 1,600 measurements. This result represents greater than a $99 \%$ compliance rate, similar to the 1996 compliance rate. The total suspended solids (TSS) limit was exceeded at Outfall 004 in September. This exceedance was probably caused by excessive algae and precipitation that resulted in increased runoff from construction activities in the area. The loading and concentration limits for mercury were exceeded at Outfall 001B in September. These exceedances may have been caused by residual mercury in the laboratory sewer system.

The IEPA issued an NPDES permit modification to ANL-E, effective A ugust 24, 1995. The permit modification gave ANL-E a provisional variance from the existing limits for ammonianitrogen, copper, and total dissolved solids (TDS) and included a compliance schedule that would address bringing these discharges under their respective limits. The compliance schedule required 


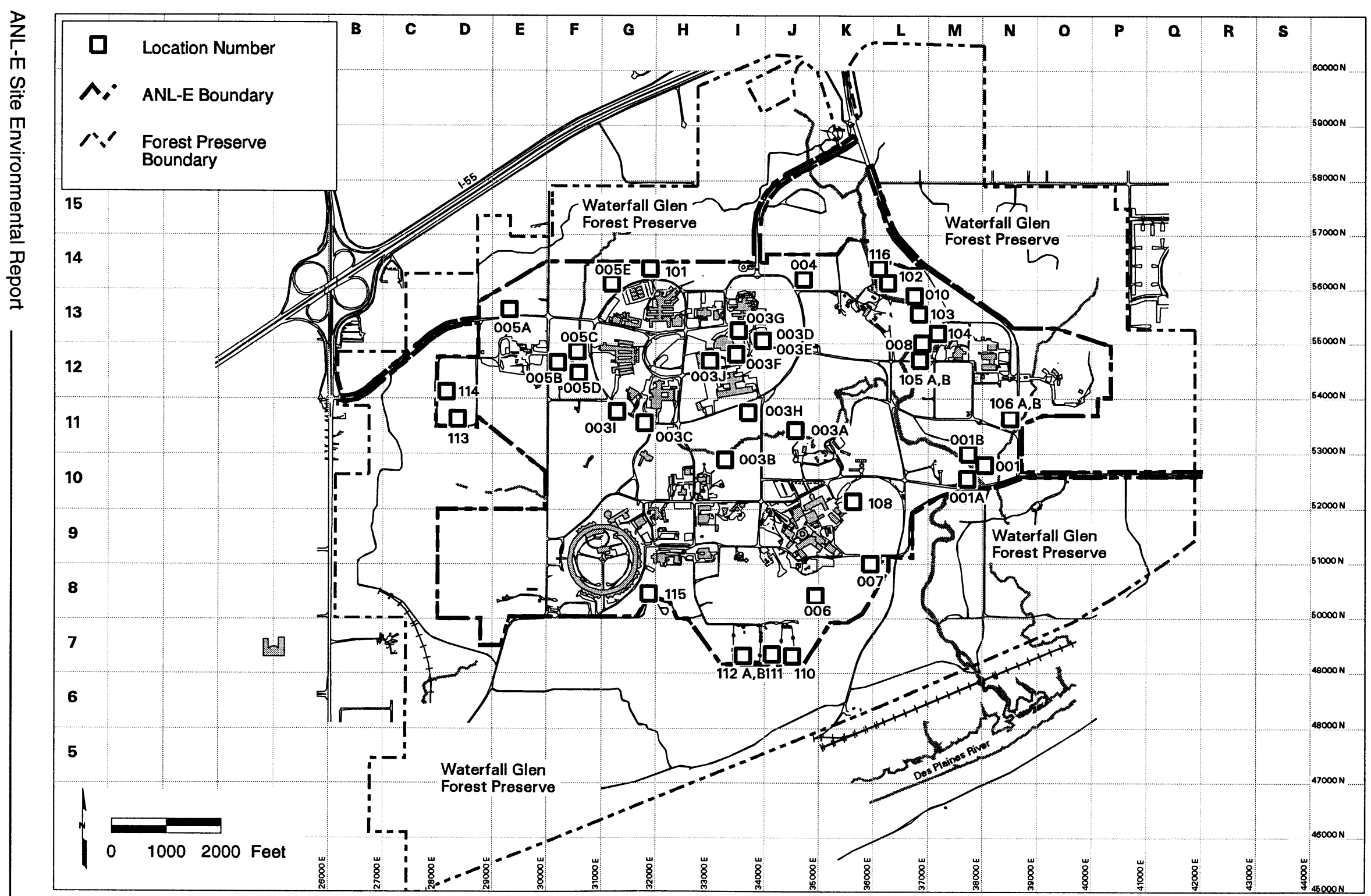




\section{COMPLIANCE SUMMARY}

ANL-E to meet the permit limits for these discharges by July 1, 1998. Efforts undertaken to achieve these specific discharge limits have included the upgrade of the ANL-E sanitary wastewater treatment facility, which was completed during 1996, the upgrade of the laboratory wastewater treatment facility, which was completed during 1997, and the incorporation of Lake Michigan water as the ANL-E source water, which was completed in J anuary 1997.

Figure 2.2 presents the data for the total number of each type of exceedance over the past eight years. In general, since 1990, the total number of exceedances per year has been reduced. Although the number of exceedances increased in 1995 (49), that can be attributed to the renewal of the N PDES Permit, effective October 30,1994, which placed more restrictive limits on A N L-E discharges and increased the number of analyses required each year by approximately 600 . The more restrictive limits for copper, TDS, and ammonia-nitrogen resulted in a substantial increase of exceedances during 1995 prior to issuance of the modified permit. Since the effective date of the modified permit, August 24, 1995, no NPDES exceedances have occurred for these parameters.

\subsubsection{Additional NPDES Monitoring}

The current permit requires semiannual testing of Outfall 001B, the laboratory Wastewater Treatment Plant (WTP) outfall, and for all the priority pollutants (a list of 124 metals and organic

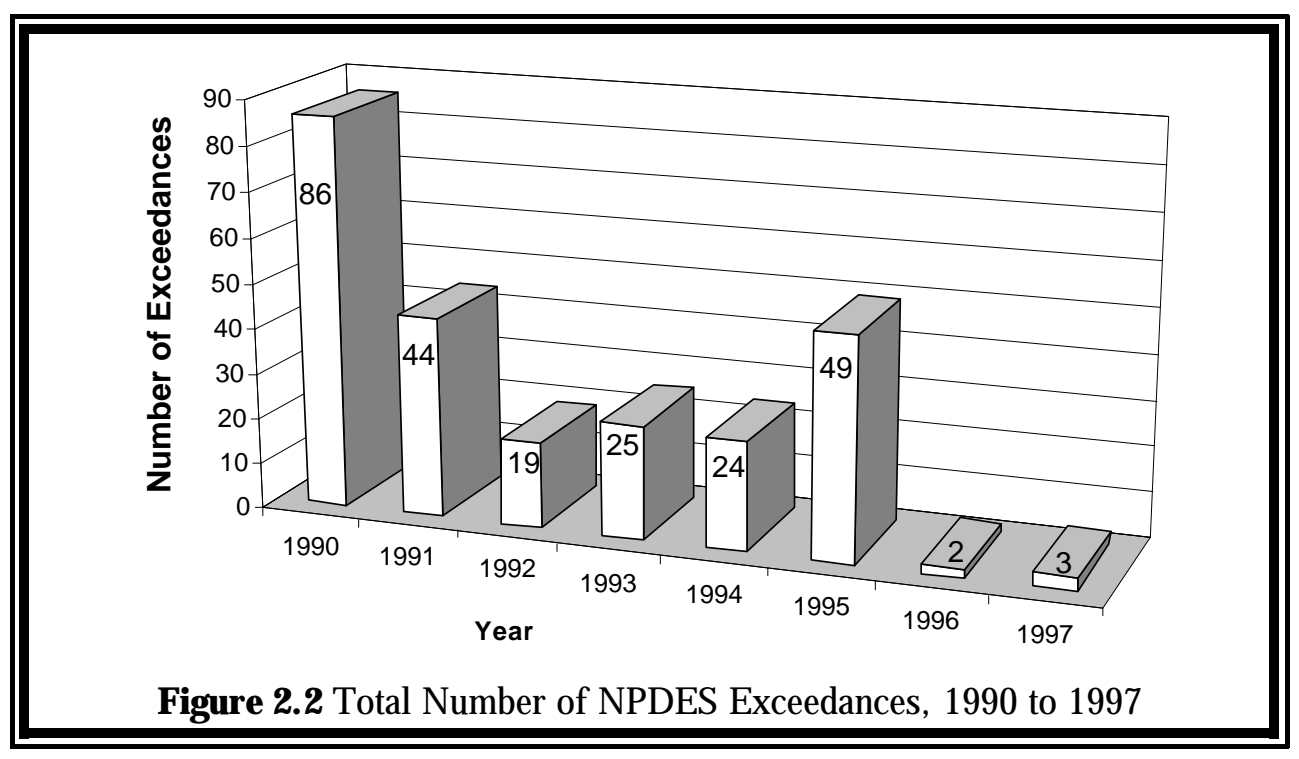


compounds identified by the IEPA as being of particular concern). During 1997, this sampling was conducted in June and December. Chloroform ( $5 \mu \mathrm{g} / \mathrm{L}$ and $1 \mu \mathrm{g} / \mathrm{L})$, dibromochloromethane $(6 \mu \mathrm{g} / \mathrm{L}$ and $1 \mu \mathrm{g} / \mathrm{L})$, and methylene chloride $(8 \mu \mathrm{g} / \mathrm{L}$ and $4 \mu \mathrm{g} / \mathrm{L})$ were detected at low concentrations in both the June and December samples. Bromoform $(8 \mu \mathrm{g} / \mathrm{L}$ ), bromodichloromethane (3 $\mu \mathrm{g} / \mathrm{L})$, and 1,1,2-trichloroethane $(2 \mu \mathrm{g} / \mathrm{L})$ were noted in the June sample. The sources of chloroform, dibromochloromethane, bromoform, and bromodichloromethane are suspected to result from the contact of chlorinated water with organic chemicals in the site laboratory performing the analysis, as well as the discharge of small amounts of chemicals from various research and support operations. All semivolatile concentrations were below the detection limits. Low concentrations of arsenic $(0.002 \mathrm{mg} / \mathrm{L})$, copper $(0.09 \mathrm{mg} / \mathrm{L})$, cadmium $(0.0003 \mathrm{mg} / \mathrm{L})$, lead $(0.005 \mathrm{mg} / \mathrm{L})$, silver $(0.001 \mathrm{mg} / \mathrm{L})$, and phenols $(0.020 \mathrm{mg} / \mathrm{L})$ were detected. Zinc was noted at an elevated level $(9.6 \mathrm{mg} / \mathrm{L})$ in the J une sample. These findings are discussed further in Chapter 5.

In addition to the priority pollutant analysis, the permit requires annual biological toxicity testing of the combined effluent stream, Outfall 001 . This was conducted June 23 through June 27, 1997. The data indicate that the effluent was not acutely toxic to either the fathead minnow or the water flea. Data from the past four years seem to indicate that cessation of chlorination of ANL-E's effluent correlates to a beneficial effect on aquatic life in the receiving streams.

A cute toxicity testing is required at Outfalls 003H, 0031, 003J, 004, 006, and 115 twice a year, during the months of July and A ugust. Samples were collected July 21 through 25, 1997, and A ugust 19 through 22, 1997. The samples were tested on the fathead minnow and the water flea. No toxicity was detected at these outfalls for either the fathead minnow or the water flea.

\subsubsection{Storm Water Regulations}

In N ovember 1990, the EPA promulgated new regulations governing the permitting and discharge of storm water from industrial sites. The A NL-E site contains a large number of smallscale operations that are considered industrial activities by these regulations and are thus subject 


\section{COMPLIANCE SUMMARY}

to these requirements. An extensive storm water characterization program was initiated in 1991, and a storm water permit application identifying 15 storm water outfalls was submitted to the IEPA during 1992.

The NPDES permit issued in October 1994 includes these 15 outfalls. In addition, the permit breaks up the watersheds for Outfalls 003 and 005 into smaller components and requires that their corresponding point source discharges be analyzed and characterized for submission of a permit application. The permit application required the characterization to include both industrial wastewater and storm water runoff discharged from these point sources. Since 1994, three additional storm water outfall locations requiring characterization have been identified. Wastewater and storm water characterizations were completed in 1996 in the 18 outfalls identified within the subdivided watersheds. The characterization data include quantitative data; flow measurements; analyses for certain specified pollutants; and dates, durations, and precipitation volumes for monitored storm events. The resulting permit application was completed and submitted to the IEPA on September 18, 1996.

The NPDES permit contains two special conditions requiring Storm Water Pollution Prevention Plans (SWPPPS) for both the APS construction site (Special Condition N o. 12) and the remainder of the ANL-E site (Special Condition No. 11). Both of these plans were completed by the mandated date, $M$ ay 1, 1995, which was 180 days after the effective date of the permit. The special conditions also require implementation of the plans by 365 days after the effective date of the permit; this was accomplished on November 1, 1995.

The same special conditions require A NL-E to inspect and report on the effectiveness of the SWPPP annually. The inspection was completed on November 21, 1997. The permit requires that the report resulting from the annual inspection be submitted to the IEPA within 60 days after the one-year period following the previous year's inspection; for the initial inspection, this was accomplished on J anuary 20,1998. Changes to the plan will be required throughout the life of the permit and through any subsequent permits reissued. 


\subsubsection{NPDES Inspections and Audits}

The IEPA did not conduct an N PDES Compliance Sampling Inspection during 1997.

\subsubsection{General Effluent and Stream Quality Standards}

In addition to specific NPDES permit conditions, ANL-E discharges are required to comply with general effluent limits contained in 35 IAC, Subtitle C, Chapter I, Part 304. Also, wastewater discharges must be of sufficient quality to ensure that Sawmill Creek complies with IEPA General Use W ater Quality Standards found in 35 IAC, Subtitle C, Chapter I, Part 302, Subpart B. Chapter 5 of this report, which presents the results of the routine environmental monitoring program, also describes the general effluent limits and water quality standards applicable to the outfalls and discusses compliance with these standards.

\subsubsection{Spill Prevention Control and Countermeasures Plan}

A NL-E maintains a Spill Prevention Control and Countermeasures (SPCC) plan as required by the CWA and EPA regulations in 40 CFR 112. This plan describes the actions to be taken in case of oil or oil product releases to navigable waters of the U nited States. Persons with specific duties and responsibilities in such situations are identified, as are reporting and record keeping requirements mandated by the regulations. Effective use of this plan is ensured by regular training. This plan was updated and provided to DOE in June 1997. No reportable spills occurred during 1997.

\subsection{Resource Conservation and Recovery Act}

The Resource Conservation and Recovery Act (RCRA) and its implementing regulations are intended to ensure that facilities that treat, store, or dispose of hazardous waste do so in a way that protects human health and the environment. The Hazardous and Solid W aste A mendments of 1984 (HSWA) created a set of restrictions on land disposal of hazardous waste. In addition, the HSWA also require that releases of hazardous waste or hazardous constituents from any Solid 


\section{COMPLIANCE SUMMARY}

W aste M anagement U nit (SW M U) at a RCRA-permitted facility be cleaned up, regardless of when the waste was placed in the unit or whether the unit was originally intended as a waste disposal unit. The RCRA program includes regulations governing management of underground storage tanks (USTS) containing hazardous materials or petroleum products. The IEPA has been authorized to administer most aspects of the RCRA program in Illinois. The IEPA issued the RCRA Part B Permit on September 30, 1997. The permit became effective on November 4, 1997.

\subsubsection{Hazardous Waste Treatment and Disposal}

Because of the nature of the research activities conducted at ANL-E, small quantities of a large number of waste chemicals are generated. Many of these materials are classified as hazardous waste under RCRA. A small amount of these wastes also exhibit radioactivity, thereby making them "mixed waste." The hazardous component of mixed waste is subject to RCRA regulation by the IEPA, while the radioactive component is subject to $D O E$ regulation under the A tomic Energy Act of 1954 (AEA). H azardous waste is collected by the ANL-E WM Department from individual on-site generators and shipped off site for treatment and disposal at approved hazardous waste treatment and disposal facilities. During 1997, reactive hazardous wastes and mixed wastes were treated on site (see Tables 2.7 and 2.8, respectively). Off-site treatment options for mixed waste are extremely limited (see Section 2.3.4). ANL-E operates several RCRA-permitted storage and treatment facilities. These facilities, designed and operated in compliance with RCRA requirements, allow for accumulation and storage of waste pending offsite disposal.

A NL -E has 22 Hazardous W aste M anagement U nits (HW M Us), consisting of 14 container storage units, 4 miscellaneous treatment units, 1 tank storage unit, and 3 tank chemical treatment units. Table 2.6 provides descriptions of all of the units. No RCRA closures were conducted in 1997.

Six treatability studies were conducted at ANL-E during 1997. A description of each study, as well as the amount of waste treated, follows. 
TABLE 26

Permitted Hazardous Waste Treatment and Storage Facilities, 1997

\begin{tabular}{|c|c|c|}
\hline Description & Location & Purpose \\
\hline \multicolumn{3}{|l|}{ Permitted Facilities } \\
\hline \multirow[t]{5}{*}{ Waste and Storage } & Building 306 - Storage Room A-142 & $\begin{array}{l}\text { Storage of ignitable radioactive mixed waste } \\
(\mathrm{RMW})\end{array}$ \\
\hline & Building 306 - Storage Room A-150 & Storage of solid and liquid RMW \\
\hline & Building 306 - Storage Room C-131 & $\begin{array}{l}\text { Storage of ignitable, corrosive, and reactive } \\
\text { hazardous waste }\end{array}$ \\
\hline & Building 306 - Storage Room C-157 & Storage of corrosive and oxidizer RMW \\
\hline & Building 306 - Storage Room D-001 & $\begin{array}{l}\text { Storage of solid RMW containing toxic metal } \\
\text { constituents }\end{array}$ \\
\hline Tank Storage & Building 306 & $\begin{array}{l}\text { Storage of corrosive and toxic mixed waste and } \\
\text { radiological liquid wastes ( } 4,000 \text { gal })\end{array}$ \\
\hline \multirow[t]{2}{*}{ Portable Storage Units } & Building 306 & $\begin{array}{l}\text { Storage of hazardous, radiological, or RMW } \\
\text { (3 units) }\end{array}$ \\
\hline & & $\begin{array}{l}\text { Bulking operations to consol idate and reduce the } \\
\text { volume of lab-packed waste in contai ners ( } 1 \text { unit) }\end{array}$ \\
\hline \multirow[t]{4}{*}{ Contai ner Storage Area } & Building 325C, East & $\begin{array}{l}\text { Storage of liquid and solid bulk or lab-packed } \\
\text { flammable and reactive hazardous waste and solid } \\
\text { and liquid bulk polychlorinated bi phenyls (PCBS) } \\
\text { and miscellaneous PCB units }\end{array}$ \\
\hline & Building 325C, West & $\begin{array}{l}\text { Storage of bulk and lab-packed liquid flammable } \\
\text { hazardous waste }\end{array}$ \\
\hline & $\begin{array}{l}\text { Building } 303 \text { Mixed Waste Storage } \\
\text { Facility }\end{array}$ & $\begin{array}{l}\text { Storage of contai ners of ignitable, corrosive, } \\
\text { oxidizing, reactive, and solid hazardous, } \\
\text { radiological, or RWM }\end{array}$ \\
\hline & $\begin{array}{l}\text { Building } 307 \text { Hazardous Waste } \\
\text { Storage Facility }\end{array}$ & (To be constructed) \\
\hline
\end{tabular}




\begin{tabular}{|c|c|c|}
\hline Description & Location & Purpose \\
\hline Contai ner Storage Area (Cont) & $\begin{array}{l}\text { Buil ding } 331 \text { Radi oactive Waste } \\
\text { Storage Facility }\end{array}$ & $\begin{array}{l}\text { Storage of containers of flammable, toxic, } \\
\text { corrosive, and oxidizing hazardous, } \\
\text { radiological , and RMW }\end{array}$ \\
\hline Dry Mixed Waste Storage Area & Building 374A & $\begin{array}{l}\text { Storage of solid RMW and radioactively } \\
\text { contaminated lead bricks }\end{array}$ \\
\hline Mixed Waste Container Storage & Building 329 & $\begin{array}{l}\text { Storage of containers of bulk and lab-packed } \\
\text { ignitable mixed waste or compatible waste }\end{array}$ \\
\hline Concrete Storage Pad & 317 Area & $\begin{array}{l}\text { Storage of solid radioactive waste and solid } \\
\text { RMW in the form of steel-encased lead } \\
\text { shied ding containers and containerized solid } \\
\text { RMW }\end{array}$ \\
\hline Alkali Metal Passivation Booth & Building 308 & Destruction of water reactive al kali metals \\
\hline Alkali Metal Passivation Booth & Building 206 & $\begin{array}{l}\text { Destruction of water reactive al kali metals } \\
\text { possibly contaminated with radionuclides }\end{array}$ \\
\hline $\begin{array}{l}\text { Low-Leve Waste (LLW) } \\
\text { Neutralization/Precipitation } \\
\text { System }\end{array}$ & Building 306 & $\begin{array}{l}\text { Treatment of aqueous, corrosive LLW, some } \\
\text { of which is contaminated with heavy metals }\end{array}$ \\
\hline Chemical/Photo-Oxidation Unit & Building 306 & $\begin{array}{l}\text { Treatment of ignitable liquid RMW } \\
\text { containing organic contaminants }\end{array}$ \\
\hline $\begin{array}{l}\text { TRU Neutral ization } \\
\text { Precipitation Treatment Unit }\end{array}$ & Building 306 & $\begin{array}{l}\text { Treatment of corrosive, aqueous RMW } \\
\text { containing transuranic radionuclides and } \\
\text { RCRA metals }\end{array}$ \\
\hline $\begin{array}{l}\text { Mixed Waste Immobilization/ } \\
\text { Macroencapsul ation Unit }\end{array}$ & Building 306 & $\begin{array}{l}\text { Treatment of solid, semisolid, and organic } \\
\text { liquid RMW containing RCRA metals }\end{array}$ \\
\hline $\begin{array}{l}\text { Dry Ice Pellet Decontamination } \\
\text { Unit }\end{array}$ & 317 Area & $\begin{array}{l}\text { Treatment of solid RMW having radionuclide } \\
\text { and/or RCRA metal surface contamination }\end{array}$ \\
\hline
\end{tabular}


The Neutralization and Solidification of Transuranic (TRU) M ixed Waste Streams Study consists of treating corrosive TRU mixed waste by using magnesium hydroxide. This study was conducted from August through December 1997; a total of $271 \mathrm{~kg}(597 \mathrm{lb})$ was treated. Treatment residues are being managed as TRU waste to be disposed of at the DOE Waste Isolation Pilot Plant (WIPP). This study will be continued in 1998.

The A malgamation of Radioactive Elemental M ercury Waste Stream Study consists of combining mercury with various powdered metals to determine the most suitable amal gamation method for ANL-E's mercury waste stream. Zinc, tin, and copper are being evaluated for the amalgams. This study was conducted from A ugust through September 1997; a total of $25 \mathrm{~kg}$ (55 lb) was treated. Treatment residues are being managed as low-level radioactive waste ( $L L W)$. This study will be continued in 1998.

The RCRA M etal Precipitation and Filtration for N on-TRU M ixed A queous Waste Study consists of a precipitation process to concentrate hazardous heavy metals separated from low-level mixed (LLMW) aqueous waste. The process uses precipitation and $\mathrm{pH}$ adjustment with sodium hydroxide, followed by precipitation with sodium sulfide. This study was conducted from January 2 to $M$ arch 5, 1997; a total of $30 \mathrm{~kg}(66 \mathrm{lb})$ was treated. This unit is now permitted under ANL-E'S RCRA Part B Permit.

The M ixed W aste Immobilization/E ncapsulation T reatability Study uses soil contaminated with RCRA metals and radioactive wastewater. The process uses magnesium oxide, potassium hydrophosphate, and potassium sulfide to bind and stabilize RCRA metals in an agglomerate matrix. This study was conducted from January 2 to March 5, 1997; approximately $150 \mathrm{~kg}$ (331 lb) of soil was treated. The treatment residues as well as the untreated soil will be disposed of off site. This study will be continued in 1998.

The Solvent Recovery treatment process uses distillation and filtration of waste solvents to recover high-purity solvents for reuse. This study was conducted from January through September 1997; a total of $191 \mathrm{~kg}(421 \mathrm{lb})$ of an ethanol waste solution was treated. The recovered solvent was returned to the generator for reuse. The residual wastewater was 


\section{COMPLIANCE SUMMARY}

discharged to a wastewater treatment system permitted under a NPDES permit. This study will be continued during 1998.

The Chemically Bonded Phosphate Ceramic Waste Forms Study involves mixing uranium mill tailings containing hazardous constituents (metals) with magnesium oxide, monopotassium dihydrogen phosphate, and water. Prior to conducting the study on actual waste, ANL-E prepared nonhazardous and nonradioactive surrogate wastes to simulate the actual wastes and conducted optimization studies. The optimization studies considered the waste loading and corresponding structural and physical properties. The optimization study was conducted from October through November 1997; however, no actual waste was treated in 1997. The Chemically Bonded Phosphate Ceramic Waste Forms Study will be conducted in 1998; approximately $5 \mathrm{~kg}(11 \mathrm{lb})$ of waste is expected to be treated.

Figure 2.3 shows the locations of the major hazardous and nonhazardous waste treatment, storage, and disposal areas at ANL-E.

\subsubsection{Permit Status}

ANL-E was granted interim status under RCRA on A pril 30, 1982, after submitting a notification of Waste Handling Activities and a Part A application on November 3, 1980. On December 20, 1990, a new Part B permit application (one had been submitted to the EPA on December 19, 1985, but not acted upon) was submitted to the IEPA, which had been granted authority to administer most of the RCRA program. Revisions to the permit application were submitted on June 17, 1991, and September 24, 1991, in response to IEPA and EPA comments.

The RCRA Part B Permit application was revised and updated in 1993. Revision I was submitted to the IEPA on November 11, 1993, and included information on four new portable hazardous waste storage units and a mixed waste storage tank. In addition, ANL-E responded to the EPA's notice of deficiency comments regarding the alkali metal passivation booths in Buildings 308 and 206 and incorporated the response into the revised application. Revision II of the Part B application was submitted on M ay 26, 1995, and included a new hazardous waste 


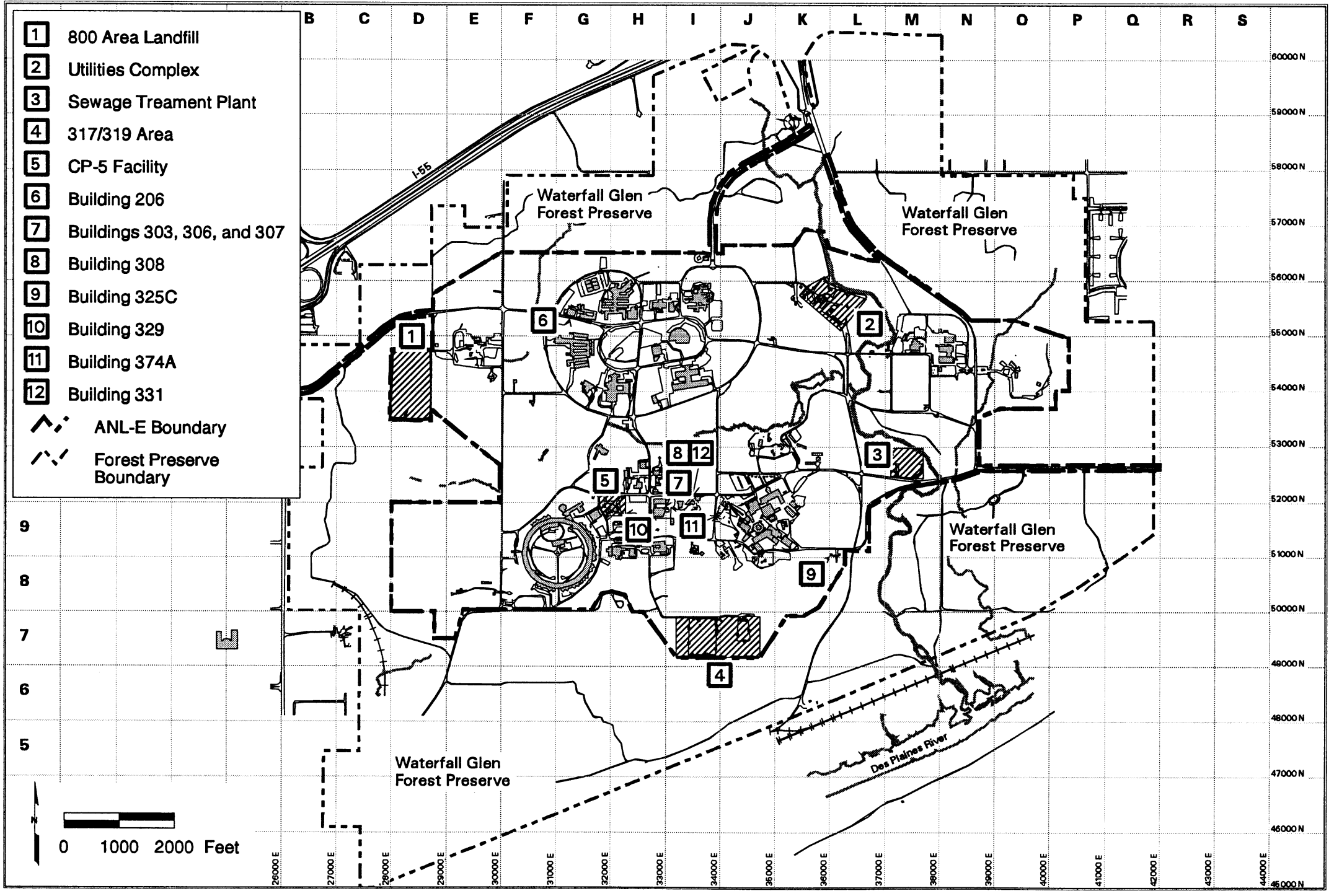

Figure 2.3 Major Treatment, Storage, and/or Disposal Areas at ANL-E 


\section{COMPLIANCE SUMMARY}

storage facility, a new mixed waste storage facility, and a new radioactive waste storage facility. In response to the IEPA's technical review of the Part B permit application, a final application was prepared and submitted on A ugust 26, 1996. The IEPA issued the RCRA Part B Permit on September 30, 1997. The permit became effective on N ovember 4, 1997.

\subsubsection{Hazardous Waste Generation, Storage, Treatment, and Disposal}

ANL-E typically generates a wide variety of hazardous and mixed wastes each year. Hazardous and mixed wastes generated, treated, and stored during 1997 are described in Tables 2.7 and 2.8, respectively. Hazardous wastes are managed in 15 storage units and 7 treatment units before they are transported off site for any necessary further treatment and disposal. All hazardous wastes shipped off site go to IEPA-permitted hazardous waste disposal facilities. Both hazardous and mixed wastes are treated on site.

\subsubsection{Mixed Waste Handling}

The hazardous component of mixed waste is governed by RCRA regulations, while the radioactive component is subject to regulation under the $A E A$ as implemented by $D O E$ Orders. Accordingly, facilities storing or disposing of mixed waste must comply with both $D O E$ requirements and RCRA permitting and facility standards. ANL-E generates several types of mixed waste, including acids, solvents, and sludges contaminated with radionuclides. Reactive alkali metals, primarily elemental sodium contaminated with uranium, have been treated in the Building 206 Alkali M etal Passivation Booth. The RCRA Part B permit provides for on-site treatment in five new mixed waste treatment systems. These systems include neutralization of low-level and transuranic corrosive aqueous wastes and the stabilization of sludge and soil. An off-site commercial treatment facility was used to treat $786 \mathrm{~L}$ (208 gal) of organic solvent waste.

\subsubsection{Federal Facility Compliance Act Activities}

The Federal Facility Compliance Act of 1992 (FFCA) amended RCRA to clarify the application of requirements and sanctions to federal facilities. The FFCA also requires that DOE 
TABLE 2.7

H azardous W aste Treatment, Storage, and Disposal, 1997

\begin{tabular}{|c|c|c|}
\hline W aste & $\begin{array}{l}\text { Volume } \\
\text { (gal) }\end{array}$ & $\begin{array}{l}\text { W eight } \\
\text { (lb) }\end{array}$ \\
\hline \multicolumn{3}{|l|}{ Generated and Disposed of } \\
\hline A erosol cans & 180 & 900 \\
\hline Alkaline solutions with lead & 110 & 913 \\
\hline A ntifreeze contaminated with Freon & 55 & 495 \\
\hline Brake cleaner fluid & 14 & 120 \\
\hline Compressed gases & 73 & 329 \\
\hline D ebris contaminated with lead & 660 & 2,640 \\
\hline Dilute ethanol solution with silver & 165 & 1,370 \\
\hline Filter contaminated with chromium & 55 & 220 \\
\hline H azardous debris, with flammables & 140 & 840 \\
\hline Hazardous paint wastes & 215 & 1,760 \\
\hline Hazardous waste oils & 550 & 3,850 \\
\hline Immersion cleaner fluid & 12 & 95 \\
\hline Labpacks of liquid chemicals & 2,211 & 17,688 \\
\hline L abpacks of solid chemicals & 1,438 & 5,752 \\
\hline L aboratory solvents, bulked & 165 & 1,155 \\
\hline L ead acid batteries & 55 & 667 \\
\hline M etal scrap containing cadmium & 715 & 5,720 \\
\hline Petroleum distillates & 207 & 1,550 \\
\hline Plating wastes containing lead & 550 & 4,950 \\
\hline W aste perchloroethylene and rinsate & 715 & 7,650 \\
\hline \multicolumn{3}{|l|}{ Treated } \\
\hline Alkali metals & 2 & 14 \\
\hline E thanol solvents with silver & 50 & 418 \\
\hline L aboratory acids & 60 & 595 \\
\hline
\end{tabular}


TABLE 2.8

M ixed W aste Treatment, Storage, and Disposal, 1997

\begin{tabular}{|c|c|c|}
\hline W aste & $\begin{array}{l}\text { Volume } \\
\text { (gal) }\end{array}$ & $\begin{array}{l}\text { W eight } \\
\text { (Ib) }\end{array}$ \\
\hline \multicolumn{3}{|l|}{ Generated } \\
\hline Acidic solutions & 243 & 2,187 \\
\hline Acidic solutions with heavy metals & 70 & 630 \\
\hline Alkali metals & 345 & 2,760 \\
\hline A queous solutions with heavy metals & 420 & 3,486 \\
\hline Caustic effluents & 7,700 & 69,300 \\
\hline Elemental mercury & 0.1 & 5 \\
\hline Flammable liquids & 164 & 1,148 \\
\hline M etal scrap with cadmium & 1,692 & 33,840 \\
\hline M ill tailings waste & 6 & 110 \\
\hline RM W debris with heavy metals & 969 & 3,876 \\
\hline RM W debris with volatile organics & 66 & 264 \\
\hline RM W lead articles & 4,979 & 448,110 \\
\hline RM W soil with heavy metals & 18 & 166 \\
\hline TRU acids & 13 & 119 \\
\hline TRU sludges with heavy metals & 478 & 4,775 \\
\hline U ranyl nitrate & 42 & 844 \\
\hline \multicolumn{3}{|l|}{ Treated } \\
\hline A cidic solutions with heavy metals (neutralized) & 300 & 2,700 \\
\hline Alkali metals (passivation) & 145 & 1,160 \\
\hline $\begin{array}{l}\text { A queous solutions with heavy metals } \\
\text { (neutralized) }\end{array}$ & 500 & 4,150 \\
\hline Caustic effluents (neutralized) & 7,700 & 69,300 \\
\hline Elemental mercury (amalgamated) & 0.5 & 25 \\
\hline M ill tailings waste (encapsulated) & 6 & 110 \\
\hline RM W acidic solutions (neutralized) & 742 & 6,678 \\
\hline $\begin{array}{l}\text { RM W sludges with heavy metals } \\
\text { (immobilized) }\end{array}$ & 1,135 & 11,350 \\
\hline
\end{tabular}


TABLE 2.8 (C ont.)

\begin{tabular}{|c|c|c|}
\hline W aste & $\begin{array}{c}\text { (Volume } \\
\text { (gal) }\end{array}$ & $\begin{array}{l}\text { W eight } \\
\text { (Ib) }\end{array}$ \\
\hline \multicolumn{3}{|l|}{ Treated (cont.) } \\
\hline $\begin{array}{l}\text { RM W soil with heavy metals } \\
\text { (immobilized) }\end{array}$ & 264 & 2,429 \\
\hline TRU acids (neutralized) & 186 & 1,670 \\
\hline \multicolumn{3}{|l|}{ Shipped } \\
\hline Flammable liquids & 208 & 1,456 \\
\hline \multicolumn{3}{|l|}{ In Storage } \\
\hline Acidic solutions & 60 & 540 \\
\hline A cidic solutions with heavy metals & 426 & 3,834 \\
\hline Alkali metals & 223 & 1,784 \\
\hline A queous solutions with heavy metals & 18 & 149 \\
\hline A queous solutions with organics & 19 & 158 \\
\hline Cyanide solution & 11 & 92 \\
\hline Elemental mercury & 4 & 200 \\
\hline Flammable liquids & 177 & 1,240 \\
\hline M etal scrap with cadmium & 3,526 & 70,520 \\
\hline M etal scrap with heavy metals & 135 & 4,050 \\
\hline RM W debris with chromium & 3 & 75 \\
\hline RM W debris with heavy metals & 814 & 3,256 \\
\hline RM W debris with volatile organics & 121 & 484 \\
\hline RM W lead articles & 11,850 & $1,066,500$ \\
\hline RM W sludges with heavy metals & 266 & 2,660 \\
\hline RM W soil with heavy metals & 95 & 874 \\
\hline TRU acids & 90 & 810 \\
\hline TRU cadmium & 130 & 3,250 \\
\hline TRU lead & 155 & 15,345 \\
\hline TRU sludge & 478 & 4,780 \\
\hline U ranyl nitrate & 162 & 3,240 \\
\hline
\end{tabular}




\section{COMPLIANCE SUMMARY}

prepare mixed waste treatment plans for DOE facilities that store or generate mixed waste. The Proposed Site Treatment Plan (PSTP) for mixed waste generated at A NL-E was submitted to the IEPA and the Illinois Department of Nuclear Safety in M arch 1995. M ixed waste at ANL-E has been managed in accordance with the PSTP as of October 1995. During 1997, A NL-E received the site RCRA Part B Permit, which provides for on-site treatment of certain mixed waste as required by the PSTP.

\subsubsection{RCRA Inspections: Hazardous Waste}

A RCRA Compliance Inspection was conducted by the EPA on M ay 29 and 30, 1997. No significant issues were identified.

\subsubsection{Underground Storage Tanks}

In response to UST regulations, A NL-E prepared a Sitewide Underground Tank Compliance Plan. The ANL-E site currently contains 24 existing, upgraded, replaced, or new USTs; 34 tanks have been removed over the last several years. The majority of these tanks are being used, or were used in the past, for storage of fuel oil for emergency generators or space heaters. The onsite vehicle maintenance facilities use underground gasoline and methanol/gasoline blend tanks. The ethanol/gasoline blend is stored in an aboveground tank. The compliance plan requires that a program be established for replacing or upgrading tanks that must remain in use. Currently, all tanks remaining in use are being monitored under a new record keeping program initiated by ANL-E. One 22,712-L (6,000-gal) UST used for fuel oil storage and located near former Building 825 was removed, along with contaminated soil, in September 1997. At the same time, contaminated soil from an adjacent UST, which had been removed in 1995, was removed. A UST completion report was approved by the IEPA, which indicated that no further remediation was required. 


\subsubsection{Corrective Action for Solid Waste Management Units}

As mentioned previously, the HSWA requires that any RCRA Part B permit issued must include provisions for corrective action to address major releases of hazardous constituents from any SWMU at the site, regardless of when waste was placed in the unit. The Part B permit contains procedures and requirements that govern the corrective action of such units. The Part $B$ permit identifies 49 SWM U S and 3 A reas of Concern (AOCS), both active and inactive. The majority of these sites are believed to contain little or no residual contamination; however, a number may be required to undergo some type of corrective action. Prior to issuance of the permit, ANL-E had been working proactively and on a voluntary basis to characterize, investigate, and remediate its SWM Us, with emphasis on the 800 and 317 A reas. This remediation program will continue under the authority of the Part B permit. The process of conducting detailed characterization studies to determine whether hazardous materials have been released from these units was begun in 1989. A summary of the preliminary results of these investigations can be found in Chapter 3. M ore extensive characterization and remediation are currently underway at a number of the SWMUs in accordance with IEPA-approved corrective action work plans, as discussed in Chapter 6.

\subsection{Solid Waste Disposal}

In September 1992, ANL-E ceased operation of its sanitary landfill, which had begun operating in 1966. The original operating permit was issued by the IEPA in 1981 in accordance with 35 IAC 807. Supplemental permits addressing final elevations, a groundwater monitoring program, and closure/postclosure requirements such as gas monitoring were issued by the IEPA on A pril 24, 1992, and revised on September 15, 1992, January 11, 1995, and November 20, 1997.

A NL-E generates a large volume and variety of nonhazardous special wastes. Some special waste, such as sanitary sewage sludge, is certified by ANL-E as "nonspecial waste" pursuant to IEPA regulations. Table 2.9 gives the nonhazardous special and nonspecial wastes generated and disposed of during 1997. All nonhazardous special and nonspecial wastes generated at ANL-E 
TABLE 2.9

Generation and Disposal of Special and N onspecial Waste, 1997

\begin{tabular}{|c|c|c|}
\hline W aste & Volume & W eight (lb) \\
\hline \multicolumn{3}{|l|}{ Nonhazardous Special } \\
\hline A ntifreeze & 880 gal & 7,900 \\
\hline $\begin{array}{l}\text { Contaminated water ( } 800 \text { A rea leaking } \\
\text { UST s) }\end{array}$ & $7,700 \mathrm{gal}$ & 64,400 \\
\hline $\begin{array}{l}\text { Contaminated soil (800 A rea leaking } \\
\text { UST s) }\end{array}$ & $1,785 \mathrm{yd}^{3}$ & $3,570,000$ \\
\hline Fly ash (boiler house) & $2,480 \mathrm{yd}^{3}$ & $2,480,000$ \\
\hline Fuel oil (800 A rea leaking UST) & $1,220 \mathrm{gal}$ & 8,600 \\
\hline Investigation-derived waste & $60 \mathrm{yd}^{3}$ & 60,000 \\
\hline M edical waste & $195 \mathrm{ft}^{3}$ & 720 \\
\hline Nonhazardous liquid chemicals & $2,696 \mathrm{gal}$ & 19,976 \\
\hline Nonhazardous solid chemicals & $5,050 \mathrm{gal}$ & 23,678 \\
\hline Petroleum naphtha & $1,235 \mathrm{gal}$ & 8,276 \\
\hline Sanitary sewage sludge & $96 \mathrm{yd}^{3}$ & 192,000 \\
\hline Soap rinses & 220 gal & 1,900 \\
\hline U sed oil & $3,090 \mathrm{gal}$ & 22,260 \\
\hline Oily water & 905 gal & 7,538 \\
\hline \multicolumn{3}{|l|}{ Certified Nonspecial } \\
\hline Sanitary sewage sludge & $5 \mathrm{yd}^{3}$ & 10,000 \\
\hline Drained capacitors & $20 \mathrm{yd}^{3}$ & 20,000 \\
\hline \multicolumn{3}{|l|}{ TSCA Special } \\
\hline A sbestos & $243 y d^{3}$ & 243,000 \\
\hline PCBs & $1,255 \mathrm{gal}$ & 7,425 \\
\hline
\end{tabular}


were disposed of at permitted off-site special waste landfills. The IE PA began requiring annual nonhazardous special waste reporting in 1991. The report is submitted by February 1 of each year and describes the activity of the previous year. It is a summation of all manifested nonhazardous and PCB wastes.

\subsection{National Environmental Policy Act}

The National Environmental Policy Act of 1969 (NEPA) established a national environmental policy that promotes consideration of environmental factors in federal or federally sponsored projects. NEPA requires that the environmental impacts of proposed actions with potentially significant impacts be considered in an Environmental Assessment (EA) or Environmental Impact Statement (EIS). DOE has promulgated regulations in 10 CFR 1021 that list classes of actions that ordinarily require those levels of documentation or that are categorically excluded from further NEPA review. No EISs were prepared during 1997. One EA that addressed environmental remediation at ANL-E was completed in 1997. An EA is being prepared for the decontamination and disassembly of the A rgonne Thermal Source Reactor in 1998.

\subsection{Safe Drinking Water Act}

The Safe D rinking Water Act of 1974 (SDW A) established a program to ensure that public drinking water supplies are free of potentially harmful materials. This mandate is carried out through the institution of national drinking water quality standards, such as Maximum Contaminant Levels (MCLs) and M aximum Contaminant Level Goals (MCLGs), as well as through the imposition of well head protection requirements, monitoring requirements, treatment standards, and regulation of underground injection activities. The regulations implementing the SDWA in 40 CFR 141-143 establish Primary and Secondary National Drinking Water Regulations that set forth requirements to protect human health (primary standards) and provide aesthetically acceptable water (secondary standards). 


\section{COMPLIANCE SUMMARY}

\subsubsection{Applicability to ANL-E}

In January 1997, A NL-E incorporated Lake M ichigan water as its domestic source water. The water is purchased from the DuPage County Water Commission. As such, ANL-E is now a customer rather than a supplier of water. The DuPage County Health Department (DPCHD) notified DOE on J anuary 23,1997 , that the federal and state monitoring requirements applicable to a "non-transient, non-community" public water supply no longer are applicable to ANL-E. In addition, sampling, analysis, and reporting of the drinking water data to the DPCHD and the Illinois Department of Public Health (IDPH) are no longer required.

\subsubsection{Water Supply Monitoring}

During 1997, ANL-E continued an informational monitoring program at the previously used dolomite domestic wells; quarterly samples were analyzed for radionuclides and VOCS. Semiannual copper and lead monitoring throughout the current domestic drinking water distribution system also continued on a voluntary basis in 1997. The copper action level was exceeded two times in the spring sample set and in the fall sample set (see Table 6.7). The availability of information on lead and copper concentrations throughout the domestic drinking water distribution system is valuable to individual consumers such as the $\mathrm{C}$ hild $\mathrm{C}$ are $\mathrm{C}$ enter. In addition, the continuation of the copper and lead monitoring allowed ANL-E to study the effect of $L$ ake $M$ ichigan water on the leaching of copper from distribution piping and the subsequent copper concentrations in the effluent wastewater.

\subsection{Federal Insecticide, Fungicide, and Rodenticide Act}

During 1997, all exterior pesticides and herbicides were applied by licensed contractors who provide the chemical used and remove any unused portions. ANL-E ensures that the chemical is EPA-approved, that it is used properly, and that any residue is disposed of in accordance with applicable regulations. These activities are carried out by oversight inspections and maintenance of records. Routine applications of pesticides are performed within buildings, as needed. Indoor pesticide applications are provided by IDPH-licensed contractors under the direction of Plant 
Facilities and Services (PFS)-Custodial Services and Marriott M anagement. None of these applications involves EPA "Restricted U se" products. Between May and November 1997, approximately $28,515 \mathrm{~L}$ (7,504 gal) of commercial-grade herbicide and 1,349 L (355 gal) of pesticide were applied throughout the ANL-E site. Fertilizer with weed control is included in the above quantity of herbicide.

\subsection{Comprehensive Environmental Response, Compensation and Liability Act}

The Comprehensive Environmental Response, Compensation and Liability Act (CERCLA) addresses the cleanup of hazardous waste disposal sites and the response to hazardous substance spills. Under CERCLA, the EPA collects site data regarding sites subject to CERCLA action through generation of a Preliminary A ssessment (PA) report, followed up by a Site Investigation (SI). Sites are then ranked, on the basis of the data collected, according to their potential for affecting human health or causing environmental damage. The sites with the highest rankings are placed on the National Priority List (NPL) and are subject to mandatory cleanup actions. No ANL-E sites are included in the NPL.

\subsubsection{CERCLA Program at ANL-E}

In early 1990, the EPA requested that DOE submit Site Screening Investigation (SSI) reports for 6 of 13 ANL-E sites for which PA reports previously had been submitted. Upon further discussions between the EPA and DOE, one of the six sites was eliminated from consideration, and three adjacent units (317/319/E ast-N ortheast [ENE]) were treated as a single site. As a result, three SSI reports were submitted to the EPA in January 1991. Table 2.10 lists the sites for which a PA report was submitted.

Inquiries into waste disposal practices during the 1950s and 1960s have identified a number of smaller waste disposal sites, some of which could contain hazardous materials. These sites are under investigation; however, their potential to affect groundwater is thought to be minimal. 


\section{COMPLIANCE SUMMARY}

\subsubsection{CERCLA Remedial Actions}

Remedial actions to clean up any release of hazardous materials from these sites could occur in a number of different ways. All but one of the CERCLA sites (see Table 2.10) are on the ANL-E site and were included as SWM U s in the RCRA Part B permit application. The RCRA Part B Permit, effective November 4, 1997, contains procedures and requirements that govern the corrective action of these sites. However, several of these SWMUS also contain radiological contamination that is not regulated under RCRA. Therefore, the SWMUs that are both

\section{TABLE 2.10}

List of Inactive Waste Disposal Sites at A NL-E

Described in Various CERCLA Reports

\begin{tabular}{|c|}
\hline Site N ame \\
\hline On Current ANL-E Property \\
\hline 800 A rea L andfill and French Drain ${ }^{a}$ \\
\hline 319 A rea L andfill and French Drain ${ }^{a}$ \\
\hline L andfill E ast-N ortheast of the $319 \mathrm{Area}^{\mathrm{a}}$ \\
\hline $\begin{array}{l}\text { Compressed Gas Cylinder Disposal A rea, } \\
318 \text { A rea }^{\mathrm{a}}\end{array}$ \\
\hline French Drain, 317 Area $^{a}$ \\
\hline M ixed W aste Storage V aults, 317 A rea $^{a}$ \\
\hline Shock Treatment Facility, 317 A rea $^{a}$ \\
\hline $\begin{array}{l}\text { Wastewater Holding Basin, Sewage } \\
\text { Treatment Plant }\end{array}$ \\
\hline Liquid W aste Treatment Facility, Building 34 \\
\hline Decommissioned Reactor CP-5, Building $330^{\mathrm{a}}$ \\
\hline Gasoline Spill, Gasoline Station \\
\hline 810 A rea Paint Shop \\
\hline $\begin{array}{l}\text { On Former ANL-E Property, } \\
\text { Currently Waterfall G len Forest Preserve }\end{array}$ \\
\hline Reactive W aste Disposal, Underwriters Pond \\
\hline
\end{tabular}

a SSI report submitted to the EPA in 1991. 
radiologically and chemically contaminated could be cleaned up under other authorities and RCRA, as appropriate.

\subsubsection{Emergency Planning and Community Right to Know Act and Superfund Amendments and Reauthorization Act, Title III}

Title III of the 1986 Superfund A mendments and Reauthorization (SA RA) amendments to CERCLA created the Emergency Planning and Community Right to Know Act (EPCRA) as a free-standing provision for response to emergency situations involving hazardous materials and for making known to federal, state, and local emergency planning authorities information regarding the presence and storage of hazardous substances and their planned and unplanned environmental releases. Under EPCRA, ANL-E may be required to submit reports pursuant to Sections 302, 304, 311, 312, and 313.

! EPCRA 302: Planning Notification

Required

- EPCRA 304: Extremely Hazardous Substances Release Required Notification

- EPCRA 311-312: M aterial Data Safety Sheet/Chemical Required

- EPCRA 313: TRI Reporting

Required

Section 302 of SARA Title III requires notification to the State Emergency Response Commission when an extremely hazardous substance is present at a facility in excess of the threshold planning quantity.

Section 304 of SARA Title III requires that the Local Emergency Planning Committee (LEPC) and state emergency planning agencies be notified of accidental or unplanned releases of Section 302 hazardous substances to the environment. The procedures for notification are described in the A rgonne Comprehensive Emergency M anagement Plan. No incidents occurred during 1997 that required notification of the LEPC and Illinois E mergency M anagement A gency.

Under EPCRA Sections 311, ANL-E is required to provide applicable emergency response agencies with M aterial Safety Data Sheets (MSDSs), or a list of MSDSs, for each hazardous 


\section{COMPLIANCE SUMMARY}

chemical stored on site. In addition, pursuant to EPCRA Section 312, ANL-E is required to report certain information regarding inventories and the locations of hazardous chemicals to state and local emergency authorities upon request. Petroleum products need to be reported. However, chemicals used in research laboratories under the direct supervision of a technically qualified individual are exempt from reporting. This report was updated and provided to DOE on February 2, 1997. Table 2.11 lists the hazardous chemicals reported.

Section 313 of EPCRA requires facilities to prepare an annual report entitled "Toxic Chemical Release Inventory, Form R" if annual usage quantities of listed toxic chemicals exceed certain thresholds. ANL -E is not within the range of Standard Industrial Codes specified in the statute. ANL-E reports this information, however, because DOE, which is subject to Executive Order 12856 and participates in the EPA 33/50 program, directs ANL-E to do so. Threshold

TABLE 2.11

Compounds Reported under SARA Title III, 1997

\begin{tabular}{|c|c|c|c|c|c|}
\hline \multirow[b]{2}{*}{ Compound } & \multicolumn{5}{|c|}{ Hazard Class } \\
\hline & Fire & $\begin{array}{c}\text { Sudden } \\
\text { Release of } \\
\text { Pressure }\end{array}$ & Reactive & $\begin{array}{l}\text { A cute } \\
\text { H ealth } \\
\text { H azard }\end{array}$ & $\begin{array}{c}\text { Chronic } \\
\text { Health } \\
\text { H azard }\end{array}$ \\
\hline Aluminum sulfate & $-a$ & - & - & $x$ & - \\
\hline Diesel fuel/heating oil & $x$ & - & - & - & - \\
\hline Gasoline & $x$ & - & - & - & - \\
\hline M ethanol/gasoline & $x$ & - & - & - & - \\
\hline Chlorofluorocarbon 11 & - & $x$ & - & - & - \\
\hline Sulfuric acid & - & - & - & $x$ & - \\
\hline Calcium oxide & - & - & - & $x$ & - \\
\hline Oils containing PCBs & - & - & - & - & $X$ \\
\hline L ubricating oils & $x$ & - & - & - & - \\
\hline $\begin{array}{l}\text { NALCO } 356 \text { amine } \\
\text { corrosion inhibitor }\end{array}$ & $x$ & - & - & $x$ & - \\
\hline Pyrofoam & - & - & - & - & $x$ \\
\hline
\end{tabular}

a A hyphen indicates that the compound does not fall within the particular hazard class. 
quantities for chemical usage are 4,536 $\mathrm{kg}(10,000 \mathrm{lb})$ for listed chemicals and $11,340 \mathrm{~kg}$ $(25,000 \mathrm{lb})$ for chemicals manufactured or processed. ANL-E was required to file one Form $\mathrm{R}$ in calendar year 1997 for usage in 1996 that exceeded reporting thresholds. A report was filed for chlorodifluoromethane (Freon 22) on the basis of usage over 4,536 kg $(10,000 \mathrm{lb})$, which indicates a total annual release (e. g., fugitive or nonpoint air emissions) of 2,903 kg $(6,400 \mathrm{lb})$. M ost of this release occurred during the charging of a new chiller system at the APS facility. The initial charging of this large system and a number of leaks resulted in the significant release level.

The removal of another listed chemical (ethylene glycol), which exceeded the threshold level, was not reportable, because the EPA ruled that this activity did not constitute "usage" as defined under Section 313. No chemicals subject to reporting were identified for calendar year (CY) 1997.

\subsection{Toxic Substances Control Act}

The Toxic Substances Control A ct (TSCA) (U nited States Code, V olume 15, Section 2601 [15 U.S.C. § 2601] et seq.) was enacted to require chemical manufacturers and processors to develop adequate data on the health and environmental effects of their chemical substances. The EPA has promulgated regulations to implement the provisions of TSCA. These regulations are found in CFR Title 40, Protection of the Environment, Chapter I: Environmental Protection A gency, Subchapter R - Toxic Substances Control Act. These regulations provide specific authorizations and prohibitions on the manufacturing, processing, and distribution in commerce of designated chemicals. Of these specially regulated substances, only asbestos and polychlorinated biphenyls (PCBS) are found at the ANL-E site. The ANL-E safety training program addresses asbestos handling. Suspect PCB-containing items are identified through the PCB Item Inventory Program. 


\section{COMPLIANCE SUMMARY}

\subsubsection{PCBs in Use at ANL-E}

The PCB Item Inventory Program was initiated in 1995 to identify all suspect PCBcontaining items. Considerable effort was expended in 1997 to complete the physical inventory and to verify PCB-containing items. Positively identified PCB items were appropriately labeled and identified with a unique number for inventory and tracking purposes. These items are included in the required PCB annual report, which describes the location, quantity of PCBS, manufacturer, and unique identification number. M ost of the PCBs in use at ANL-E are contained in capacitors, power supplies, and small transformers. The regulations governing the use and disposal of PCBs are located in 40 CFR 761.

\subsubsection{Disposal of PCBs}

Disposal of PCBs from ANL-E operations includes materials lab-packed and bulked and aggregated solids shipped off site through WM. Table 2.9 gives the amounts of PCBs and PCB-contaminated materials shipped by A NL-E during 1997.

\subsubsection{Storage of Radioactive PCB-Contaminated Material}

Contamination from historical PCB spills has resulted in the generation of sludge from the building retention tanks and holding tanks at the laboratory wastewater treatment plant that is contaminated by both PCBs and low-level radioactivity. Because a disposal option does not presently exist for this mixture, it is stored for future disposal. A total of $18,710 \mathrm{~L}$ (4,992 gal) of sludge and debris contaminated with PCBs is being so kept in permitted storage.

\subsection{Endangered Species Act}

The Endangered Species Act of 1973 (ESA) is designed to protect plant and animal resources from the adverse effects of development. U nder the act, the Secretaries of the Interior and Commerce are directed to establish programs to ensure the conservation of endangered or 


\section{COMPLIANCE SUMMARY}

threatened species and the critical habitat of such species. The FWS has been delegated authority to conduct these consultations and enforce the ESA.

To comply with the ESA, federal agencies are required to assess the proposed project area to determine whether any threatened or endangered species or critical habitat of these species exist. If no such species or habitat are present, this fact is to be documented in a letter to the FWS. If such species or habitat are found to exist, the FWS is to be notified, and a series of consultations and studies then will be carried out to determine the extent of impact and any special actions that must be taken to minimize this impact.

At ANL-E, the provisions of the ESA are implemented through the NEPA project review process. All proposed projects must provide a statement describing the potential impact to threatened or endangered species and critical habitat. This statement is included in the general Environmental Evaluation N otification Form. If the potential exists for an adverse impact, this impact will be assessed further and evaluated through the preparation of a more detailed NEPA document, such as an EA or EIS.

No federally listed threatened or endangered species are known to occur on the A NL-E site, and no critical habitat of federally listed species exists on the site. Three federally listed endangered species are known to inhabit the Waterfall Glen Forest Preserve that surrounds the ANL-E property or to occur in the area.

The Hine's emerald dragonfly (Somatochlora hineana), federally and state listed as endangered, occurs in locations with calcaerous seeps and wetlands along the Des Plaines River floodplain. Leafy prairie clover (Dalea foliosa), which is federally listed as endangered, is associated with dolomite prairie remnants of the Des Plaines River valley; two planted populations of this species occur in Waterfall Glen Forest Preserve. A n unconfirmed capture of Indiana bat 


\section{COMPLIANCE SUMMARY}

(M yotis sodalis), which is federally listed as endangered, indicates that this species may occur in the area. A dditional state-listed species that occur in the area include:

- Early fen sedge (Carex crawei), threatened

- White lady's slipper (Cypripedium candidum), endangered

- Slender sandwort (Arenaria patula), endangered

- M arsh speedwell (Veronica scutellata), threatened

- Rough marsh cress (Rorippa islandica var. hispida), endangered

- Kirtland's snake (Clonophis kirtlandi), threatened

- Pied-billed grebe (Podilymbus podiceps), endangered

- Great egret (C asmerodius alba), endangered

- Black-crowned night heron (Nycticorax nycticorax), endangered

- Red-shouldered hawk (Buteo lineatus), endangered

- River otter (Lutra canadensis), endangered

Of these, rough marsh cress, Kirtland's snake, pied-billed grebe, great egret, black-crowned night heron, and red-shouldered hawk have been observed on A NL-E property. I mpacts to these species also would be assessed during the NEPA process. No project at A NL-E has ever had to be stopped, delayed, or modified as a result of a potential impact to an endangered species. In February 1997, the FWS concluded that a groundwater remediation project in the 800 and 317/319 A reas would most likely not affect the hydrology of the breeding area of the Hine's emerald dragonfly, Somatochlora hineana. To confirm that a seep in the surrounding Waterfall Glen Forest Preserve had not been contaminated by some other activity at the ANL-E site, or by a third party, the FW S requested that A N L-E take water quality and sediment samples from the seep, a potential breeding area for the Hine's emerald dragonfly. In December 1997, a project was initiated to sample this specific location to ensure that hazardous materials are not being released to the area either as the result of ANL-E activities or by a third party. 


\subsection{National Historic Preservation Act}

The National Historic Preservation Act (NHPA) requires federal agencies to assess the impact of proposed projects on historic or culturally important sites, structures, or objects within the site of the proposed projects. It further requires federal agencies to assess all sites, buildings, and objects on the site to determine whether any qualify for inclusion in the NRHP. The Act also requires federal agencies to consult with the Illinois Historic Preservation A gency (IHPA) and the Advisory Council on Historic Preservation, as appropriate, when proposed actions would adversely affect properties that are eligible for listing on the NRHP.

The NHPA is implemented at ANL-E through the NEPA review process, as well as through the ANL-E digging permit process. All proposed actions must consider the potential impact to historic or culturally important artifacts and document this consideration on the Environmental Evaluation N otification Form. If the proposed site has not been surveyed for the presence of such artifacts, a cultural resources survey is conducted, and any artifacts found are carefully documented and removed. Prior to disturbing the soil, an ANL-E digging permit must be obtained from the PFS Division. Prior to digging, this permit must be signed by an individual who is familiar with the location of archaeological sites at ANL-E to document the fact that no significant cultural resources will be affected. DOE consults with the IHPA and the Advisory Council on Historic Preservation, as appropriate, when proposed actions would adversely affect properties eligible for listing on the NRHP.

The CP-5, Experimental Boiling W ater Reactor (EBWR), and the A rgonne Thermal Source Reactor facilities are under evaluation for NRHP eligibility. The IHPA provided notification that DOE needs to develop a historic context within which its role in the development of nuclear research, experimentation, and technology in Illinois and the United States is addressed. DOE will need to develop a plan for reviewing all structures on site and for identifying those that have contributed to ANL-E activities of historic significance. 


\section{COMPLIANCE SUMMARY}

A draft Cultural Resources M anagement Plan (CRM P) has been prepared to fulfill DOE's responsibilities under the NHPA. This draft CRMP describes the management of cultural resources at ANL-E pursuant to the NHPA and identifies a strategy toward good faith stewardship of cultural resources. M anagement goals for cultural resources at ANL-E reflect current issues, interests, and problems identified through internal assessment. They include protecting and preserving significant resources, establishing outreach programs, and continuing the integrity of the Cultural Resource Program.

Cultural resources include historic structures and properties. Much of the focus at A NL-E has been on evaluating properties rather than structures. Phase I archaeological surveys have been completed for the entire ANL-E facility, and 46 archaeological sites have been recorded. Of these, 23 sites have been tested to determine eligibility for inclusion on the NRHP. Three of the 23 sites tested are potentially eligible for the NRHP. The remainder of the 46 recorded sites have not been formally evaluated to determine whether they are eligible for inclusion under the NRH P. A comprehensive inventory of historic structures at ANL-E has not been completed. During 1997, artifacts previously recovered from A N L-E archaeological investigations and excavations were transferred to the Illinois State M useum for curation.

\subsection{Floodplain Management}

Federal policy on managing floodplains is contained in Executive Order 11988 ( $M$ ay 24, 1977). In addition, 10 CFR 1022 describes DOE's implementation of this Executive Order. This Executive Order requires federal facilities to avoid, to the extent possible, adverse impacts associated with the occupancy and modifications of floodplains. To construct a project in a floodplain, DOE must demonstrate that there is no reasonable alternative to the floodplain location.

The ANL-E site is located approximately $46 \mathrm{~m}(150 \mathrm{ft})$ above the nearest large body of water (Des Plaines River) and thus is not subject to major flooding. A number of small areas, associated with Sawmill Creek and other small streams or low-lying areas, are subject to local flood conditions following extremely heavy precipitation. To ensure that these areas are not 
adversely affected, new facility construction is not permitted within these areas, unless there is no practical alternative. Any impacts to floodplains are fully assessed in a floodplain assessment, and, as appropriate, documented in the NEPA documents prepared for a proposed project. There were no significant floodplain management issues during 1997.

\subsection{Protection of Wetlands}

Federal policy on wetland protection is contained in Executive Order 11990. In addition, 10 CFR 1022 describes DOE's implementation of this Executive Order. This Order requires federal agencies to identify potential impacts to wetlands resulting from proposed activities and to minimize these impacts. Where impacts cannot be avoided, action must be taken to mitigate the damage by repairing the damage or replacing the wetlands with an equal or greater amount of a man-made wetland as much like the original wetland as possible. The current federal policy is for no net decrease in the amount of wetlands as the result of federal activities.

Because of its topography and the nature of the soil at ANL-E, the site contains a significant number of natural and man-made wetlands. These range from small storm water ditches overgrown with cattails to natural depressions, beaver ponds, and man-made ponds. Potential impacts to those areas from proposed actions are assessed in wetlands assessments and NEPA documentation as appropriate.

\subsubsection{Sitewide Wetlands Management}

During 1993, an ANL-E sitewide wetlands delineation was completed. A survey was conducted to identify and delineate all jurisdictional wetlands present on site in accordance with the 1987 U.S. Army Corps of Engineers Wetlands Delineation Manual. ${ }^{5}$ The results of the survey were delineated on a site map that indicates the aerial extent of all wetlands present at ANL-E down to $500 \mathrm{~m}^{2}$ (1/8th acre). The findings are documented in an accompanying report that describes in detail the soil, vegetation, and hydrology of each wetland area delineated on the map. Thirty-five individual wetland areas were identified; their total area is approximately 18 ha (45 acres). The wetland areas also were digitized onto a computer-aided design file to provide 


\section{COMPLIANCE SUMMARY}

ANL-E engineers with scale maps for planning and designing projects. This delineation also will be useful for determining project impacts under NEPA review. In 1998, a plan will be developed to address the enhancement and management of existing wetlands, wetland restoration activities, and related regulatory issues. Also, the site wetlands map will be updated, because much of the fieldwork for the wetlands delineation was performed in 1992, and wetland boundaries can change significantly in five years.

\subsubsection{U.S. Army Corps of Engineers Review}

In F ebruary 1989, the U.S. A rmy Corps of Engineers (COE) issued a permit to DOE under Section 404 of the CW A addressing the construction of the APS facility at ANL-E. The permit was required because construction of the APS involved the filling of three small wetland areas, known as Wetlands $A, B$, and $E$, which totaled 0.7 ha (1.8 acres) in size. Issuance of the permit had been contingent upon approval of a mitigation plan submitted to the COE by DOE. The plan outlined procedures for the construction of a new wetland area, W etland R, and also identified actions to be taken to avoid a fourth wetland, W etland C, during APS construction activities. In addition, DOE committed to monitoring the progress of $W$ etlands $C$ and $R$ for a period of five years. The monitoring period was initiated in 1992.

During October 1996, the COE conducted a compliance inspection to assess compliance with conditions of the 1989 permit; this inspection resulted in COE's contending that the state of the APS wetlands reflected a lack of compliance with an unspecified provision of the permit. A management plan for Wetland R was submitted to the COE in January 1997; the plan was verbally approved two months later. An assessment for the cause of a water deficit was conducted at W etland $C$. The assessment concluded that the hydrology of Wetland $C$ did not change significantly during the five-year monitoring period, and that the water deficit at the wetland could not be attributed to any single cause. 


\subsection{Vegetation Damage}

V egetation monitoring was conducted in 1993 and 1997 to determine the effects of browsing by deer on woody vegetation. These data were collected to meet conditions of Deer Population Control Permits issued by the Illinois Department of $\mathrm{Natural}$ Resources and to provide input to wildlife management decisions. Horizontal vegetation densities at ANL-E were compared with previous A N L-E data and with data from Herrick Lake Forest Preserve, which has a lower density of deer than ANL-E. Vegetation monitoring will be conducted biennially in the future.

\subsubsection{Data Collection}

Horizontal vegetation densities are determined for five, half-meter strata in 20 randomly located circular wooded plots. Numbers and species of trees taller than $0.5 \mathrm{~m}(1.6 \mathrm{ft})$ and with a diameter less than $2.54 \mathrm{~cm}(1 \mathrm{in}$.$) at 0.5 \mathrm{~m}(1.6 \mathrm{ft})$ are also recorded.

\subsubsection{Results}

Tables 2.12 and 2.13 present the results of the vegetation monitoring. As indicated in the tables, more damage was evident in 1997 than in 1993. However, the high deer population in 1993 continued to increase until a deer management program was initiated in 1995. The general site condition and specific data collected on horizontal vegetation density and tree species present indicate that deer have caused very heavy or extremely heavy damage to the vegetation at ANL-E.

\subsection{Wildlife Monitoring}

\subsubsection{Deer Population Monitoring}

The size of the deer population is monitored periodically by spotlight surveys to meet the requirements of deer removal permits and to provide input into wildlife management decisions. The second year of the deer management program began in N ovember 1996. In the fall of 1996, calculations based on spotlight surveys indicated that the white-tailed deer population was 
TABLE 2.12

M ean Percent H orizontal V egetation Density at A NL-E $(N=20)$ and

Herrick Lake Forest Preserve (HLFP) $(\mathrm{N}=20)$,

DuPage County, 1993 and 1997

\begin{tabular}{|c|c|c|c|c|c|c|c|c|}
\hline \multirow{2}{*}{$\begin{array}{l}\text { Strata } \\
(\mathrm{m})\end{array}$} & \multicolumn{2}{|c|}{ ANL-E 1993} & \multicolumn{2}{|c|}{ HLFP 1993} & \multicolumn{2}{|c|}{ ANL-E 1997} & \multicolumn{2}{|c|}{ HLFP 1997} \\
\hline & $\ddot{O}^{a}$ & $S D^{b}$ & 0 & SD & $0 ̈$ & SD & 0 & SD \\
\hline $0-0.5$ & 52.2 & 29.8 & 97.1 & 4.7 & 87.7 & 24.9 & 98.6 & 3.9 \\
\hline $0.5-1.0$ & 35.6 & 31.5 & 91.9 & 10.2 & 30.9 & 41.3 & 86.7 & 21.17 \\
\hline $1.0-1.5$ & 13.9 & 16.2 & 71.1 & 33.8 & 2.2 & 4.9 & 64.8 & 38.4 \\
\hline $1.5-2.0$ & 50.1 & 31.8 & 75.1 & 34.5 & 11.2 & 24.9 & 55.0 & 41.9 \\
\hline $2.0-2.5$ & 48.9 & 33.6 & 61.2 & 37.2 & 37.5 & 39.4 & 51.8 & 40.7 \\
\hline
\end{tabular}

TABLE 2.13

Tree Species $\geq 0.5 \mathrm{~m}$ in Height and $\leq 2.54 \mathrm{~cm}$ in Diameter Observed in M icroplots Randomly Located at A NL-E and HLFP, DuPage County, 1993 and 1997

\begin{tabular}{|c|c|c|c|c|}
\hline \multirow[b]{2}{*}{ Woody Tree Species } & \multicolumn{2}{|c|}{1993} & \multicolumn{2}{|c|}{1997} \\
\hline & ANL-E & HLFP & $A N L-E$ & HLFP \\
\hline Prunus spp. & $x$ & $x$ & & $x$ \\
\hline Crataegus spp. & $x$ & $x$ & & $x$ \\
\hline Rhamnus cathartica & $x$ & $x$ & $x$ & $x$ \\
\hline Fraxinus americana & $x$ & $x$ & & $x$ \\
\hline Cornus spp. & $x$ & $x$ & & \\
\hline Carya spp. & $x$ & $x$ & $x$ & $x$ \\
\hline Ulmus americana & $x$ & $x$ & & $x$ \\
\hline Viburnum rafinesquianum & & $x$ & & $x$ \\
\hline Tilia american & & $x$ & & \\
\hline Quercus spp. & & $x$ & & \\
\hline
\end{tabular}


approximately 95 deer (51 deer $/ \mathrm{mi}^{2}$ ). Fifty-seven white-tailed deer were removed to achieve a target density of 20 deer $/ \mathrm{mi}^{2}$. A smaller number of fallow deer were removed to achieve a target density of $20 \mathrm{deer} / \mathrm{mi}^{2}$ for that species as well.

\subsubsection{Deer Health Monitoring}

The physical condition of all white-tailed deer removed was evaluated by a modified Kistner Scoring System for evaluating fat stored in several body sites and by evaluating mean live and dressed weights. Overall Kistner scores were slightly better in November 1996 than in N ovember 1995. M ean live and dressed weights also indicated that white-tailed deer were in better physical condition in November 1996 than in N ovember 1995.

\subsubsection{Deer Tissue Monitoring}

M uscle samples from white-tailed and fallow deer are analyzed periodically for radionuclides to verify that deer meat donated to charity does not pose a radiological health hazard. Samples sent to the Illinois Department of N uclear Safety's radiochemistry laboratory in December 1997 were analyzed for gamma-ray-emitting radionuclides and hydrogen-3. Naturally occurring potassium-40 was the only gamma-ray-emitting radionuclide identified above detection limits. No hydrogen-3 was observed above the detection limit in any muscle sample.

\subsection{Current Issues and Actions}

The purpose of this section is to summarize the most important issues related to environmental protection encountered during 1997.

\subsubsection{Major Compliance Issues}

A number of significant outstanding compliance issues were addressed by ANL-E during 1997. 


\section{COMPLIANCE SUMMARY}

\subsubsection{Clean Water Act - NPDES}

The revised NPDES permit became effective October 30, 1994. The new permit included a number of changes to sampling parameters for various outfalls, and ANL-E was not consistently able to meet the permit limits for TDS and copper. It also was anticipated that ANL-E would have difficulty consistently meeting the new permit limits for ammonia nitrogen. In M arch 1995, A NL-E requested a modification to the NPDES permit, to relax the permit limits on the above parameters in the interim, while establishing a compliance schedule to meet the new permit limits. A modified permit was issued in A ugust 1995, which provided interim limits for TDS, copper, and ammonia nitrogen at Outfall 001 . The modified permit provided a schedule for performing certain actions as a means of attaining the final effluent limits. ANL -E must be able to meet the final effluent limits at Outfall 001 by July 1, 1998. ANL-E was able to meet all of the milestones identified for 1997 and has made progress toward meeting the final effluent limits. A continuing issue for 1998 will be the ability to meet these effluent limits.

\subsubsection{RCRA - 800 Area Landfill}

The IEPA issued a Compliance Inquiry L etter on J une 17, 1994, for failure to modify the property deed to note that the landfill had been used for the disposal of ACM, thereby making that disposal part of the public record and subject to discovery during title search of the property. DOE responded to the IEPA on July 8,1994 , and indicated that steps would be taken to modify the deed. DOE has conducted a survey to obtain an accurate legal description of the ANL-E boundary.

Landfill gas monitoring to determine levels of methane and nonmethane organic compounds will continue. Emissions of these parameters are expected to decline.

The IEPA -approved sanitary landfill groundwater monitoring program continues to indicate that the Groundwater Quality Standards of some routine indicator parameters such as iron, manganese, and TDS, are consistently being exceeded. Contamination in this area will be addressed under the RCRA Corrective A ction Program (see Section 2.3.8). 


\subsubsection{RCRA - Underground Storage Tanks}

During the removal of a number of USTs in October 1995, four of the tanks were found to have been leaking. These USTs were reported to the IEPA in two separate incidents and received UST incident numbers 952081 and 952114. A Corrective A ction Completion Report addressing both incidents was submitted to the IEPA in December 1995. In a letter dated A pril 5, 1996, the IEPA rejected the Corrective Action Completion Report, citing several technical points. On M ay 9, 1996, ANL-E submitted additional information to the IEPA to supplement the original report. The IEPA again rejected the report on September 10, 1996.

The IEPA had determined that the corrective actions taken for Incident N o. 952114 were insufficient because adequate sampling was not conducted following removal of the tank (UST 21) involved in that incident. Only one sample had been collected from the excavation, rather than the required five samples. In the $M$ ay 9, 1996, supplemental information, it was explained that the proximity of another tank, UST 20, near the excavation for UST 21, prevented the collection of all required samples. This information also indicated that UST 20 recently had been taken out of service and would be removed in the near future, in accordance with UST regulations. ANL-E committed to collecting additional samples from the UST 21 excavation at the time UST 20 was removed.

UST 20 was removed in September 1997. No contamination from UST 20 was encountered during its removal. However, additional contamination from UST 21 was encountered. Immediately following the removal of UST 20 , contaminated soil was removed from the vicinity of USTs 20 and 21 and along the north face of the excavation. Two concrete pads underlying the USTs were also removed. The residual contamination from UST 21 was verbally reported to the IEPA. A written update of the situation was submitted to the IEPA in October 1997. The final closure report for the removal of UST 21 was submitted to the IEPA on February 19, 1998. 


\section{COMPLIANCE SUMMARY}

\subsubsection{DOE Hazardous Materials Management Review}

DOE conducted a review of ANL-E's Hazardous M aterials $M$ anagement program during July 1996. The final report was issued on February 6, 1997. Two findings were identified: (1) The Chemical M anagement System/Chemical Tracking System is not implemented consistently across the site, and Environment, Safety and Health (ESH) guidance on use of the system is not well defined; and (2) The M ultiprogram Energy Laboratories - Facilities Support-funded orphan waste project and general funding responsibilities for characterizing wastes are not well defined. It also is not clear how ANL-E is managing potential regulatory, safety, and environmental risks of uncharacterized wastes. These issues remain open.

\subsubsection{Regulatory Agency Interactions}

In A ugust 1994, ANL-E waste oil contaminated with PCBs inadvertently was shipped to an off-site recycling facility. The EPA and the IEPA were informed of the incident, and both agencies conducted investigations at A N L-E relating to the incident. On November 14, 1994, the IEPA issued a Compliance Inquiry L etter (CIL) that stated that ANL-E was in apparent violation of 35 IAC Parts 808 and 809 (Special Waste Regulations). The CIL requested information on the reasons for the apparent violations and a description of the steps taken to address them. DOE responded to the CIL on December 14, 1994. On January 10, 1995, the IEPA responded that ANL-E had returned to compliance.

The EPA conducted two follow-up investigations on N ovember 10, 1994, and J anuary 13, 1995. In a letter dated March 19, 1996, the EPA transmitted a Complaint and Notice of Opportunity for Hearing to the U niversity of Chicago (operator of $A N L-E$ ) regarding the above incident and alleged violations of TSCA. The U niversity of Chicago and the EPA have entered into a Consent A greement. 


\subsubsection{ANL-E Environmental Reviews}

Two major reviews were initiated and conducted by ANL-E during 1997 - the Environmental V ulnerability A ssessment and the Chemical V ulnerability A ssessment.

\subsubsection{Environmental Vulnerability Assessment}

In M ay 1997, ANL-E initiated the Argonne Environmental Vulnerability A ssessment to review the status of environmental activities. The purpose of the assessment was to maintain a positive environmental posture to ensure that ANL-E remains aggressive and proactive in addressing open issues in the environmental arena. The initial tasks were to (1) develop a consolidated historical record; (2) validate the subsurface geology; (3) audit and validate selected facilities; (4) compile a historical ESH record; and (5) review the completion rate for corrective actions. These first five tasks were completed by the end of June. On the basis of this information, a gap analysis was performed to identify missing information that may lead to potential environmental problems. This analysis was completed by the end of September. ANL-E is currently addressing the identified issues.

\subsubsection{Chemical Vulnerability Assessment}

A comprehensive review of chemical vulnerabilities at ANL-E was completed. No significant vulnerabilities were identified; however, the review served to focus attention on several minor and easily eliminated classes of vulnerabilities. The biggest benefit of the review was that it led to a major reduction in holdings of old and inactive chemical stores in the various laboratories across the site.

\subsection{Environmental Permits}

Table 2.14 lists all the environmental permits in effect at the end of 1997. Other portions of this chapter discuss special requirements of these permits and compliance with those 


\section{COMPLIANCE SUMMARY}

requirements. The monitoring results required by these permits are discussed in those sections, as well as in Chapters 5 and 6. 
TABLE 2.14

A N L -E Environmental Permits in Effect December 31, 1997

\begin{tabular}{|c|c|c|c|c|}
\hline Type & Source & Building & Issued & $\begin{array}{c}\text { Expiration } \\
\text { Date }\end{array}$ \\
\hline Air & A lkali M etal Reaction Booth ${ }^{b}$ & 308 & $02 / 15 / 89$ & $11 / 18 / 98$ \\
\hline Air & A rgonne Service Station & 300 & $01 / 09 / 91$ & $10 / 04 / 00$ \\
\hline Air & Sulfuric A cid Storage Tank ${ }^{b}$ & 108 & $01 / 17 / 91$ & $12 / 01 / 99$ \\
\hline Air & Central Shops Dust Collectorb & 363 & $03 / 12 / 91$ & $01 / 08 / 01$ \\
\hline Air & Ethylene Oxide Sterilizer & 201 & $03 / 27 / 91$ & $01 / 08 / 01$ \\
\hline Air & Grieve Oven ${ }^{b, c}$ & 366 & 08/08/91 & $08 / 06 / 96$ \\
\hline Air & M ethanol/Gasoline Storage Tank & 46 & $09 / 24 / 91$ & $09 / 23 / 96$ \\
\hline Air & ALEX A Ikali M etal Scrubber ${ }^{b}$ & 370 & $12 / 05 / 91$ & $12 / 03 / 96$ \\
\hline Air & Gasoline Dispensing F acility ${ }^{d}$ & 46 & $02 / 01 / 93$ & $05 / 22 / 00$ \\
\hline Air & Wood Shop D ust Collectorb & 809 & $12 / 16 / 93$ & $10 / 17 / 96$ \\
\hline Air & Central Heating Plant & 108 & $12 / 28 / 93$ & $12 / 28 / 98$ \\
\hline Air & A PS Emergency Generators (3) & 400 & $05 / 16 / 94$ & $03 / 15 / 99$ \\
\hline Air & Waste Bulking Sheds ${ }^{\mathrm{e}}$ & 306 & $06 / 14 / 94$ & $07 / 25 / 96$ \\
\hline Air & Hazardous W aste Storage F acility ${ }^{c}$ & 307 & $05 / 24 / 95$ & $04 / 26 / 00$ \\
\hline Air & Paint Spray Boothc, f & 306 & $07 / 03 / 95$ & $06 / 27 / 00$ \\
\hline Air & Torch Cutting (W elding) Fumes ${ }^{b}$ & Sitewide & 07/20/95 & $07 / 20 / 00$ \\
\hline Air & Boiler No. 5 Low NO $_{x}$ Gas Burnerg & 108 & $06 / 21 / 96$ & $12 / 28 / 98$ \\
\hline Air & Transportation R esearch F acility & 376 & $07 / 25 / 96$ & $07 / 25 / 01$ \\
\hline Air & Open-Burning Permit - Fire Dept. ${ }^{b}$ & 333 & $01 / 14 / 97$ & $04 / 16 / 98$ \\
\hline Air & Open Burning - Vegetation & Sitewide & $3 / 24 / 97$ & $3 / 23 / 98$ \\
\hline H azardous W aste & RCRA Part B & Sitewide & $09 / 30 / 97$ & $11 / 4 / 07$ \\
\hline M iscellaneous & Deer Population Control Permit & Sitewide & $11 / 01 / 96$ & $01 / 29 / 97$ \\
\hline M iscellaneous & Nuisance W ildlife Control & Sitewide & $02 / 5 / 97$ & $01 / 31 / 98$ \\
\hline
\end{tabular}


TABLE 2.14 (C ont.)

\begin{tabular}{|c|c|c|c|c|}
\hline Type & Source & Building & Issued & $\begin{array}{c}\text { Expiration } \\
\text { Date }^{\mathrm{a}}\end{array}$ \\
\hline NESHAP & A Ipha Gamma Hot Cell Facility & 212 & 03/25/91 & $08 / 09 / 00$ \\
\hline NESHAP & Intense Pulsed N eutron Source & 375 & $03 / 25 / 91$ & $08 / 09 / 00$ \\
\hline NESHAP & M-Wing Hot Cells & 200 & $03 / 25 / 91$ & $08 / 09 / 00$ \\
\hline NESHAP & New Brunswick Lab Hoods & 350 & 04/25/91 & $04 / 19 / 96$ \\
\hline NESHAP & Continuous W ave Deuterium Demonstration ${ }^{C}$ & 369 & 05/09/91 & $12 / 28 / 99$ \\
\hline NESHAP & CP-5 D\&D Project & 330 & 05/10/91 & $12 / 08 / 96$ \\
\hline NESHAP & Cyclotron ${ }^{c}$ & 211 & 05/10/91 & $12 / 01 / 99$ \\
\hline NESHAP & Building Exhausts ${ }^{b, h}$ & 212 & 07/30/91 & $07 / 23 / 96$ \\
\hline NESHAP & Building Vents & 306 & 08/06/91 & $07 / 25 / 96$ \\
\hline NESHAP & Rad Hoods & Sitewide & 07/09/92 & 07/09/97 \\
\hline NESHAP & A lkali M etal Reaction Booth & 206 & 06/09/93 & $06 / 09 / 97$ \\
\hline NESHAP & A dvanced Photon Source & 400 & $12 / 21 / 93$ & $07 / 26 / 98$ \\
\hline NESHAP & $D \& D$ HEPA Filter System ${ }^{c}$ & 317 & 05/10/94 & 05/10/99 \\
\hline NESHAP & W M HEPA Filter Systems (4) & Sitewide & 09/28/94 & $09 / 28 / 99$ \\
\hline NESHAP & Building Rehab - Phase $1^{\mathrm{e}}$ & 306 & 03/13/95 & $07 / 25 / 96$ \\
\hline NESHAP & Rad (TRU) W aste Storage F acility & 331 & 05/18/95 & $04 / 26 / 00$ \\
\hline NESHAP & M ixed W aste Storage F acility & 303 & 05/18/95 & $04 / 26 / 00$ \\
\hline NESHAP & Lead Brick Cleaning $\left(\mathrm{CO}_{2}\right)$ & $200 / 317$ & $06 / 20 / 95$ & $06 / 19 / 00$ \\
\hline NESHAP & PCB Tank Cleanout ${ }^{i}$ & Sitewide & 08/16/95 & $09 / 28 / 99$ \\
\hline NESHAP & L ab W astewater Treatment Plant & 575 & 08/29/95 & $08 / 29 / 00$ \\
\hline NESHAP & M elt A ttack/Coolability Experiment & 315 & $03 / 22 / 96$ & $03 / 22 / 01$ \\
\hline NESHAP & Janus D \& D Project ${ }^{c}$ & 202 & 06/12/96 & $06 / 12 / 01$ \\
\hline NESHAP & French Drain Soil Vapor Extraction & 317 A rea & $5 / 8 / 97$ & $5 / 8 / 02$ \\
\hline NESHAP & W M Portable HEPA Filters ${ }^{\mathrm{i}}$ & 306 & $6 / 4 / 97$ & $-j$ \\
\hline
\end{tabular}


TABLE 2.14 (C ont.)

\begin{tabular}{|c|c|c|c|c|}
\hline Type & Source & Building & Issued & $\begin{array}{c}\text { Expiration } \\
\text { Date }\end{array}$ \\
\hline Solid Waste & L andfill & 800 A rea & $03 / 31 / 82$ & - \\
\hline Solid Waste & L andfill & 800 A rea & $03 / 30 / 89$ & - \\
\hline Solid W aste & L andfill & 800 A rea & $04 / 12 / 89$ & - \\
\hline Solid W aste & L andfill L eachate T est W ells & 800 A rea & $08 / 31 / 90$ & - \\
\hline Solid Waste & L andfill Groundwater A ssessment & 800 A rea & $09 / 30 / 91$ & - \\
\hline Solid Waste & L andfill L eachate Characterization & 800 A rea & 09/30/91 & - \\
\hline Solid Waste & Landfill Revised Closure Plan & 800 A rea & $04 / 24 / 92^{k}$ & - \\
\hline Solid Waste & L andfill Supplemental Closure Plan & 800 A rea & 09/15/92 & - \\
\hline Solid Waste & Landfill Supplemental Permit Groundwater & 800 A rea & $04 / 19 / 94$ & - \\
\hline Solid W aste & Landfill Supplemental Permit Groundwater & 800 A rea & $01 / 11 / 95$ & - \\
\hline Solid Waste & L andfill Supplemental Permit Groundwater & 800 A rea & $11 / 20 / 97$ & - \\
\hline W ater & A PS W etland & 400 A rea & $02 / 02 / 89$ & - \\
\hline W ater & L andfill W etlands & 800 A rea & $05 / 20 / 81$ & - \\
\hline W ater & Lime Sludge A pplication - L and A pplication & Sitewide & $01 / 12 / 94$ & $12 / 31 / 98$ \\
\hline W ater & NPDES Permitted Outfalls & Sitewide & $10 / 31 / 94$ & 07/01/99 \\
\hline W ater & NPDES Storm Water Outfalls & Sitewide & $10 / 31 / 94$ & $07 / 01 / 99$ \\
\hline & Title V (CAAPP) & Sitewide & Pending & \\
\hline
\end{tabular}


a The expiration dates on NESHAP and air pollution permits are no longer valid (except for open burning) since the Notice of Completeness for the CA A PP application was received (see Section 2.1).

b These units have been designated as insignificant sources in the A NL-E Title V permit application.

c Inactive.

d Includes ethanol/gasoline tank.

e Construction permit issued; operated under Building 306 permit.

$f$ Permit originally issued for Building 815.

$g$ Construction permit issued; operated under Central Heating Plant permit.

h Plasma spray booth added to permit 05/27/94.

i Construction permit issued; operated under WM HEPA permit.

j A hyphen indicates no expiration date.

k Revised September 15, 1992, and October 22, 1992. 


\section{ENVIRONMENTAL PROGRAM INFORMATION}

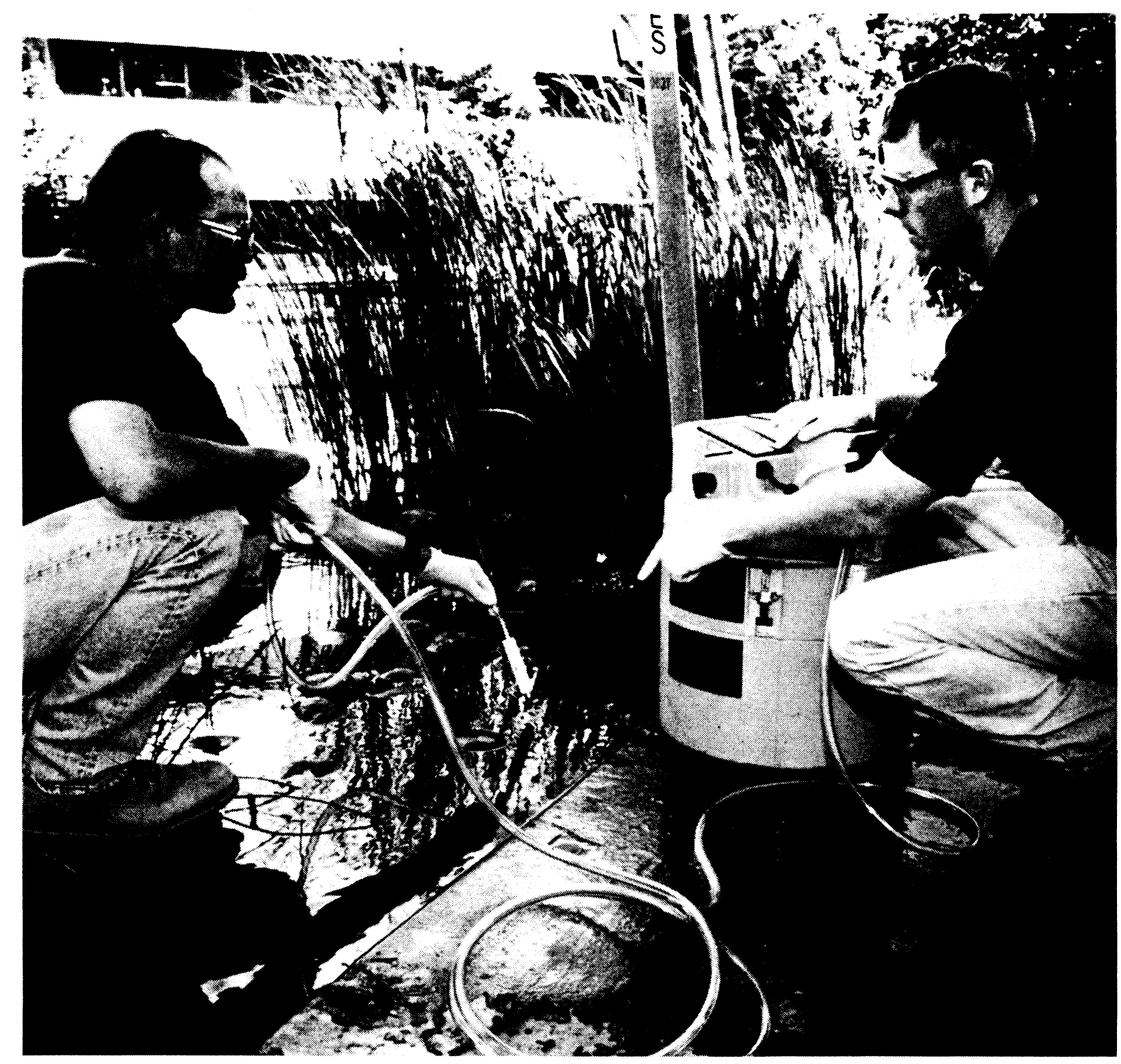




\section{ENVIRONMENTAL PROGRAM INFORMATION}

\subsection{Environmental Programs}

DOE and ANL-E policies require that all operations be conducted in compliance with applicable environmental statutes, regulations, and standards, and that environmental obligations be carried out consistently across all operations and organizations. Protection of the environment and human health and safety are always given the highest priority. A number of programs and organizations exist at ANL-E to ensure compliance with these authorities and to monitor and minimize the impact of ANL-E operations on the environment.

\subsubsection{Environmental Management Programs}

In 1989, DOE established the goal of achieving compliance with all applicable environmental authorities, assessing and cleaning up releases of hazardous materials from inactive waste sites, and returning all such sites to unrestricted use. To increase the likelihood of achieving this goal, DOE established the Environmental Restoration and W aste $M$ anagement Program, now called the Environmental M anagement Program (EM ). This program identifies specific needs and establishes a system for allocating funds to support ongoing activities and resolve various deficiencies. Each DOE facility has prepared a set of planning documents (A ctivity Data Sheets [ADSs]) describing those activities necessary to bring that specific site into compliance and to identify and clean up inactive waste sites. These planning documents are contained in a report, the Environmental M anagement Plan, which is updated and published annually. The 1997 plan contained information on 11 separate projects (see Table 3.1). The plan is a public document that is available from DOE upon request.

A NL-E management has designated Environmental M anagement Operations (EM O) as the lead environmental organization. EM O's mission is to proactively support A NL-E operations by conducting those activities that ensure compliance with applicable environmental statutes, regulations, DOE Orders, and ANL-E policies and procedures. These activities include restoration of the ANL-E site; proper collection, treatment, and disposal of radioactive, hazardous, and other regulated waste materials; and the conduct of the ANL-E environmental 


\section{ENVIRONMENTAL PROGRAM INFORMATION}

TABLE 3.1

Environmental M anagement Projects

\begin{tabular}{|c|c|}
\hline $\begin{array}{c}\text { ADS } \\
\text { N umber }\end{array}$ & Title \\
\hline $\mathrm{CH} 1301 \mathrm{~B}$ & F acility Operations and $\mathrm{M}$ aintenance - $\mathrm{N}$ ondefense Programs \\
\hline $\mathrm{CH} 1303$ & R ehabilitation of W aste $M$ anagement Building \\
\hline $\mathrm{CH} 1304$ & H azardous, Radioactive, and M ixed W aste Storage Facility \\
\hline $\mathrm{CH} 1306$ & Sanitary W astewater Treatment Plant I mprovements \\
\hline $\mathrm{CH} 1309$ & L aboratory W astewater Treatment Plant Improvements \\
\hline $\mathrm{CH} 1432$ & Implementation of RCRA Corrective A ction Strategy \\
\hline $\mathrm{CH} 1433$ & Remediation of Solid W aste Storage or Disposal Facilities \\
\hline $\mathrm{CH} 1434$ & Remediation of M ixed W aste Storage or Disposal Facilities \\
\hline $\mathrm{CH} 1437$ & Reactor Facilities $D \& D$ Projects \\
\hline $\mathrm{CH} 1438$ & Support Facilities $D \& D$ Projects \\
\hline CH 1439 & Program M anagement \\
\hline
\end{tabular}

protection program. These activities are carried out to minimize potential adverse effects on the health and safety of personnel at the ANL-E site and the general public, to property, and to the environment.

EMO is divided into three major operational units: Waste M anagement; Environmental Protection; and Administration. The principal function of EMO is to serve as the ANL-E focal point for implementation of the DOE Office of Environmental M anagement program.

\subsubsection{Waste Management Department}

The Waste M anagement Department (WM) supports the scientific mission of ANL-E by providing customer-defined quality products and services for the safe collection, treatment, storage, and disposal of all regulated waste generated at the Illinois site at minimal cost and burden to its customers. These products and services are delivered by WM professionals who operate in a customer-centered culture and who are committed to waste prevention, protection of the surrounding community and the environment, and continuous quality improvement. 


\section{ENVIRONMENTAL PROGRAM INFORMATION}

Several improvements to ANL-E waste management facilities were completed during 1997. First, minor modifications were made to the radioactive waste storage facility (converted from the former EBWR reactor shell). These modifications were required to satisfy DOE health and safety requirements. Second, significant improvements to Building 306, ANL-E's primary waste management facility, were completed. A new loading dock and storage facilities were constructed, and improvements to the fire alarm and sprinkler system were completed. Third, a major upgrade to the laboratory wastewater treatment facility was completed. These enhancements will improve significantly the effectiveness and safety of waste handling and storage facilities and pollution control systems.

In 1997, ANL-E shipped a substantial quantity of accumulated radioactive waste off site for disposal or storage, thereby significantly reducing the ANL-E inventory. WM personnel began operations in their newly rehabilitated waste storage facility in Building 306. The new area provides for the inspection, compaction, assay, and shipment of LLW in one area, thus streamlining these operations. Five new mixed waste treatment systems were installed to treat mixed wastes in accordance with the FFCA-proposed site treatment plan for ANL-E; these treatment systems are permitted by the RCRA Part B permit.

\subsubsection{Environmental Protection Department}

The Environmental Protection Department supports A N L-E operations, organizations, and DOE environmental missions by providing technical experts and services to address environmental issues. The Department is composed of the ANL-E Remedial Actions Project (ERAP), the Environmental Compliance Section, and the M onitoring and Surveillance Section. Environmental

protection activities are those sets of actions conducted at ANL-E to ensure the safety of the public; protection of the environment; and compliance with applicable federal, state, and local environmental regulations and DOE Orders. 


\section{ENVIRONMENTAL PROGRAM INFORMATION}

\subsubsection{Remedial Actions Progress in 1997}

In 1997, ANL-E began implementing a plan to complete site remediation efforts, both remedial actions and decontamination and decommissioning $(D \& D)$, by 2001. If funding continues at requested levels, A NL-E would be the first multiprogram laboratory to complete its environmental restoration. Remedial actions at ANL-E are being implemented in accordance with RCRA corrective action requirements. All such work is being conducted under a single project known as ERAP. The goal of ERAP is to complete all remedial actions by fiscal year (FY) 2001.

With respect to 1997 accomplishments, the 317 A rea RCRA Facility Investigation (RFI), which was begun in December 1994, was completed, and the final RFI report ${ }^{6}$ was submitted to the IEPA. A partially demolished underground drainage system, known as the East Vaults Footing Drain, was sealed to prevent migration of contaminated groundwater away from the 317 A rea French Drain. The drainage pipe was filled with grout, and the gravel bedding outside of the pipe was sealed by pressure-injecting grout into the backfill. A concrete cover was constructed over the 318 A rea, which is a small unit within the 317 A rea where inoperative compressed gas cylinders were buried in the 1970s. The cover prevents inadvertent disturbance of these cylinders. ANL-E accelerated the planned construction of a groundwater collected system south of the 317 A rea F rench D rain. This system was installed to intercept groundwater moving to the south, away from the 317 A rea F rench D rain. The groundwater in this area contains similar chemicals to those found in the French D rain. A soil treatment project was initiated in the 317 A rea French Drain. The treatment system uses an innovative soil mixing process to remove volatile organic materials from the soil. An interim action to contain a leachate seep and contaminated groundwater emanating from the inactive 319 A rea Landfill, which involved pumping groundwater and discharging the laboratory wastewater treatment plant, was completed in 1996, and pumping continued throughout 1997. The RFI for the 800 A rea also was completed, and the final report ${ }^{7}$ was submitted to the IEPA. An EA for remedial activities anticipated the ANL-E site was finalized. A Finding of No Significant Impact (FONSI) was issued by DOE. A dditional details are provided in Chapter 6 (Sections 6.2 and 6.5). 


\section{ENVIRONMENTAL PROGRAM INFORMATION}

\subsection{Environmental Support Programs}

\subsubsection{Self-Assessment}

The responsibility of internal self-assessment has been delegated from the central ESH/Quality A ssurance (QA) organization to line management. As a result, the process changed from a checklist format to a focus on the activities of individual organizations. At the beginning of each calendar year, each organization develops an agenda of activities to be reviewed that year. A schedule is prepared and assignments are made to manage the organization's self-assessment program. The plan is approved by the organization director and submitted to the Director for ESH/QA Oversight.

In 1997, independent assessments were conducted by technically qualified and knowledgeable persons independent of the line organization. The assessments focused on providing meaningful information regarding achievements of the organizational mission, meeting performance requirements and expectations, and advising the appropriate levels of management regarding actions that may promote quality improvement. A summary report was prepared that documents the self-assessment process, lessons learned, and any action plans developed on the basis of any discovered weaknesses.

\subsubsection{Environmental Training Programs}

ANL-E has a comprehensive environmental protection training program that includes mechanisms to identify, track, and document requirements for every employee. Environmental protection training for ANL-E personnel is provided primarily by the ESH Training Section, although ancillary training may be delivered by subject matter experts from other organizations. Personnel training requirements are provided to respond to DOE Orders, the U.S. Department of Transportation (DOT), the EPA, and OSHA regulations and are identified by a Job Hazards Checklist form that is completed by every employee and reviewed by each employee's supervisor. A positive answer to any one of a battery of specific questions triggers the training requirements 


\section{ENVIRONMENTAL PROGRAM INFORMATION}

specific to that question. Options also exist for division-required training, recommended training, and elective training.

A ctivities are managed through the Training $M$ anagement System, an on-line computerbased system that tracks the training status of each employee. Environmental protection training courses and course descriptions are listed in the Training Course $\mathrm{C}$ atalog available from divisional representatives, the ESH Training Section, or Human Resources.

\subsubsection{Waste Minimization and Pollution Prevention}

ANL-E possesses a formal Waste Minimization and Pollution Prevention (WM \& PP) Program. The program's long-term strategy is identified in the ANL -E WM \&PP Strategic Plan dated November 1995. In A pril 1997, ANL-E revised and finalized a Pollution Prevention Program Plan that identifies A N L-E's short-term (three-year cycle) pollution prevention goals and describes the strategies that will be employed to achieve those goals. The pollution prevention goals outlined in the ANL-E Pollution Prevention Program Plan are the same as the 1999 DOE Pollution Prevention Goals that were established in 1996 and that use CY 1993 as a baseline.

In the following paragraphs, the seven DOE Pollution Prevention Goals are presented, brief descriptions of ANL-E's progress toward each goal in 1997 are reported, and future strategies for achieving each goal are provided.

Goal 1. Reduce by $\mathbf{5 0 \%}$ the generation of radioactive waste.

Annual Radioactive Waste $\mathrm{G}$ eneration ( $\mathrm{ft}^{3}$ [thousands])

\begin{tabular}{llllllll}
\hline & 1993 & 1994 & 1995 & 1996 & 1997 & 1998 & 1999 \\
\hline $\begin{array}{l}\text { Generation } \\
\text { Goal }\end{array}$ & 10.5 & 16.9 & 19.5 & 12.3 & 9.1 & & \\
\hline
\end{tabular}


LLW generation has continued a downward trend and is approaching levels established by the 1999 DOE Pollution Prevention Goal. During 1997, $260 \mathrm{~m}^{3}\left(9,194 \mathrm{ff}^{3}\right)$ of LLW was generated at ANL-E. Depletion of archived waste, in conjunction with the implementation of waste reduction activities, will result in a $50 \%$ reduction in radioactive waste by December 31 , 1999.

G oal 2. Reduce by $50 \%$ the generation of radioactive mixed waste. Radioactive M ixed W aste $\mathrm{G}$ eneration ( $\mathrm{ft}^{3}$ [thousands])

\begin{tabular}{lccccccc}
\hline & 1993 & 1994 & 1995 & 1996 & 1997 & 1998 & 1999 \\
\hline $\begin{array}{l}\text { Generation } \\
\text { Goal }\end{array}$ & 5.0 & 0.67 & 0.71 & 0.16 & 0.3 & & \\
\hline
\end{tabular}

M ixed waste generation has continued a downward trend and remains at levels below the 1999 D OE Pollution Prevention Goal established from the 1993 baseline. The mixed waste goal has been achieved through a combination of treatment and source reduction. Current generation levels should be maintained through the continued execution and improvement of current waste reduction activities and the implementation of planned activities.

Goal 3. Reduce by $50 \%$ the generation of hazardous waste.

Annual Hazardous W aste Generation (metric tons)

\begin{tabular}{lrrrrrrr}
\hline & 1993 & 1994 & 1995 & 1996 & 1997 & 1998 & 1999 \\
\hline $\begin{array}{l}\text { Generation } \\
\text { Goal }\end{array}$ & 5,588 & 2,509 & 1,246 & 1,226 & 1,605 & & \\
\hline
\end{tabular}

Hazardous waste generation remains at levels below the 1999 DOE Pollution Prevention Goal established from the 1993 baseline. The hazardous waste goal will be achieved by successfully identifying and implementing alternative uses for the state-regulated (hazardous and special) waste streams, that is, sorbent lime sludge, fly ash, coal fines, etc., and taking advantage 


\section{ENVIRONMENTAL PROGRAM INFORMATION}

of the IEPA's new special waste regulations that allow ANL-E to certify some state-regulated wastes as "nonspecial."

In addition, ANL-E will reduce the volume of RCRA-related waste by implementing more efficient packaging procedures for waste chemicals, by developing and implementing treatment procedures for suitable waste chemicals, and by enhancing its Surplus Chemical Inventory Program that promotes the exchange and reuse of suitable chemicals that otherwise would require disposal.

Goal 4. Reduce by $33 \%$ the generation of sanitary waste.

Annual Sanitary Waste Generation (metric tons)

\begin{tabular}{lccccccc}
\hline & 1993 & 1994 & 1995 & 1996 & 1997 & 1998 & 1999 \\
\hline $\begin{array}{l}\text { Generation } \\
\text { Goal }\end{array}$ & 1,260 & 2,670 & 1,753 & 1,228 & 970 & & \\
\hline
\end{tabular}

During 1997, ANL-E continued the downward trend of reducing the amount of routine sanitary waste toward the 1999 DOE Pollution Prevention Goal established from the 1993 baseline. ANL-E has developed and is implementing aggressive recycling programs to achieve this goal. Through the continuous improvement of recycling programs and improved data management, ANL-E will achieve this goal.

Goal 5. Reduce by $\mathbf{5 0 \%}$ total releases and off-site transfers for treatment and disposal of toxic chemicals.

Annual Toxic R elease Inventory (metric tons)

\begin{tabular}{lccccccc}
\hline & 1993 & 1994 & 1995 & 1996 & 1997 & 1998 & 1999 \\
\hline $\begin{array}{l}\text { Treatment } \\
\text { or Disposal }\end{array}$ & 1.78 & 0 & 0 & 0 & 0 & & \\
Goal & & & & & & & \\
\hline
\end{tabular}




\section{ENVIRONMENTAL PROGRAM INFORMATION}

Since 1993, ANL-E has focused on eliminating all forms of toxic releases. From 1994 through 1996, ANL-E has maintained zero generation levels.

Goal 6. Recycle $33 \%$ of sanitary waste from all operations, including cleanup and stabilization activities.

During 1997, A NL-E generated a total of 16,276 metric tons (17,942 tons) of sanitary waste and materials from all operations (including cleanup and stabilization activities). ANL-E was able to recycle (reuse) 10,063 metric tons (11,093 tons) of these materials. This amounts to a $62 \%$ level of recycling of sanitary waste from all ANL-E operations. To improve this recycling level, ANL-E is developing and implementing a variety of additional recycling programs for sanitary waste and materials originating from environmental restoration, $D \& D$, and facility construction and demolition activities. Programs have already been successful in recycling fill material, roadway materials, and wood and scrap metal from routine and nonroutine activities. ANL-E will continue to work to develop, implement, and document waste stream diversion, material recycling, and other pollution prevention initiatives.

Goal 7. Affirmative Procurement: Increase procurement of E PA-designated, recycled products to $100 \%$, except where they are not commercially available competitively at a reasonable price or do not meet performance standards.

The Procurement Department estimates that in 1997, approximately $31 \%$ of ANL-E purchases of recyclable-content products were of the EPA-designated variety. Because of tracking inefficiencies, pricing, and lack of product demand, several of the EPA-designated product types were not purchased in 1997. ANL-E is working toward this goal through a combination of an Affirmative Procurement A wareness Program, the development of an upgraded procurement tracking system, and the development and execution of ANL-E recycled product procurement procedures.

\subsubsection{Site Environmental Performance Measures Program}

Effective J une 1, 1995, the contract between DOE and the University of Chicago made provisions for a performance fee based on performance of research and operations, including ESH 


\section{ENVIRONMENTAL PROGRAM INFORMATION}

performance. Performance objectives and supporting metrics have been developed to administer the contract and determine the performance fee. Each performance measure is weighted; at the end of the performance period, a rating (outstanding, excellent, good, marginal, or unsatisfactory) is assigned. The performance fee is based on these ratings.

For the period of the performance-based contract, October 1996 to September 1997, the environmental measures involved performance related to environmental remediation activities and the environmental portion of ESH activities. Performance measures and associated ratings for environmental remediation activities were scope and cost control (outstanding) and schedule compliance (excellent). The overall rating for environmental restoration activities was outstanding. The measures and grades for the environmental measures were permit conditions and milestones (outstanding), meeting environmental effluent limits (outstanding), pollution prevention (excellent), and NEPA process (excellent). The overall rating for environmental performance during this contract period was excellent.

\subsubsection{Environmental Management System}

It is ANL-E policy to conduct its operations in an environmentally safe and sound manner. Protection of the environment and the public are responsibilities of paramount importance and concern to ANL-E. To that end, ANL-E is firmly committed to ensuring the incorporation of national environmental protection goals in the formulation and implementation of ANL-E programs. It has an equal commitment to advance the goals of restoring and enhancing environmental quality and protecting public health. Accordingly, it is ANL-E policy to conduct its operations in compliance with the letter and spirit of applicable environmental statutes, regulations, and standards. To manage these commitments, ANL-E has structured its activities to focus on these goals. Line organizations have primary responsibility for environmental management, with professional staff support from the core ESH organizations. The ESH/QA organization provides oversight. However, ANL-E currently does not have a formally documented environmental management system in accordance with International Standards Organization (ISO)-14001 standards. 


\section{ENVIRONMENTAL PROGRAM INFORMATION}

\subsection{Environmental Monitoring Program Description}

As required by DOE Order $5400.1,{ }^{1} \mathrm{ANL}-\mathrm{E}$ conducts a routine environmental monitoring program. This program is designed to determine the effect ANL-E operations have on the environment surrounding the site. This section describes this monitoring program. In 1997, a total of 1,942 samples were collected and 21,141 analyses were performed. A general description of the techniques used to sample each environmental medium is provided. This is followed by the collection procedures, the sampling schedule, and the analytical techniques used. Greater detail is provided in the ANL -E Environmental M onitoring Plan.

\subsubsection{Air Sampling}

Continuously operating air samplers are used at ANL-E to collect samples for the measurement of concentrations of airborne particulate matter contaminated by radionuclides. Currently, nonradiological air contaminants in ambient air are not monitored. Particulate samplers are placed at 14 locations around the A N L-E perimeter and at 6 off-site locations, approximately $8 \mathrm{~km}(5 \mathrm{mi})$ from ANL-E, to determine the ambient or background concentrations.

A irborne particulate samples for measurement of total alpha, total beta, and gamma-ray emitters, are collected continuously at 12 perimeter locations and at 5 off-site locations on glass fiber filter media. A verage flow rates on the air samplers are about $70 \mathrm{~m}^{3} / \mathrm{h}\left(2,472 \mathrm{ft}^{3} / \mathrm{h}\right)$. Filters are changed weekly. The filters on perimeter samplers are changed by ANL-E staff, and the filters on off-site samplers are changed and mailed to ANL-E by cooperating local agencies. A dditional samples of particulate matter in air, used for radiochemical analysis of plutonium and other radionuclides, are collected at two perimeter locations and one off-site location. These samples are collected on special filter media that are changed every 10 days by ANL -E staff. The sampling units are serviced every six months, and the flow meters are recalibrated annually.

At the time of sample collection, the date and time when sampling was begun, the initial flow rate, the date and time when the sample was collected, and the final flow rate are recorded 


\section{ENVIRONMENTAL PROGRAM INFORMATION}

on a label attached to the sample container. The samples are then transported to ANL-E where this information is then transferred to the EM S.

Each air filter sample collected for alpha, beta, and gamma-ray analysis is cut in half. Half of each sample for any calendar week is combined with all the other perimeter samples from that week and packaged for gamma-ray spectrometry. A similar package is prepared for the off-site filters for each week. A 5-cm (2-in.) circle is cut from the other half of the filter, mounted in a 5-cm (2-in.) low-lip stainless-steel planchet, and counted to determine alpha and beta activity. The remainder of the filter is saved.

The air filter samples collected for radiochemical analysis are composited by location for each month. A fter the addition of appropriate tracers, the samples are ashed, then sequentially analyzed for plutonium, thorium, uranium, and strontium.

Stack monitoring is conducted continuously at those emission points that have a probability of releasing measurable radionuclides. The results of these measurements are used for estimating the annual off-site dose using the required CA P- 88 version ${ }^{8}$ of the EPA-AIRDOSE atmospheric dispersion computer code and dose conversion method.

\subsubsection{Water Sampling}

Water samples are collected to determine what, if any, radionuclides or selected hazardous chemicals used or generated at ANL-E enter the environment by the water pathway. Surface water samples are collected from Saw mill C reek below the point at which ANL-E discharges its treated wastewater. The results of radiological analysis of water samples at this location are compared to upstream and off-site results to determine the ANL-E contribution. The results of the chemical analyses are compared to the applicable IEPA stream quality standards to determine whether the site is degrading the quality of the creek. These results are discussed in more detail in Chapters 4 and 5. 


\section{ENVIRONMENTAL PROGRAM INFORMATION}

Surface water samples are collected from Saw mill Creek and combined into a single weekly composite sample. A continuous sampling device has been installed at this location to improve sample collection representativeness. To provide control samples, Sawmill Creek is sampled upstream of ANL-E once a month. The Des Plaines River is sampled twice a month below, and monthly above, the mouth of Sawmill Creek to determine whether radionuclides in the creek are detectable in the river. Water samples are collected from remote locations in the spring and fall to serve as additional control samples.

In addition to surface water, subsurface water samples are also collected at 31 locations. These samples are collected from monitoring wells located near areas that have the potential for adversely impacting groundwater. These areas are the 800 A rea Landfill, the 317/319 waste management area, and the site of the inactive CP-5 reactor. Samples from the four on-site wells that formerly provided domestic water are also collected and analyzed for hazardous and radioactive constituents.

Subsurface water samples are collected quarterly from the monitoring wells located in the 317/319 A rea, the 800 A rea Sanitary L andfill, and the CP-5 reactor. The monitoring wells are purged, and samples are collected from the recharged well water. These samples are analyzed for both chemical and radiological constituents, as discussed in Chapter 6. Samples are collected quarterly from the wellheads of the four A NL-E wells that formally provided the domestic water supply. The water is pumped to the surface and collected in appropriate containers, depending on the required analysis.

A the time of sample collection for radiological analysis, the sampling location, time, date, and collector identification number are recorded on a label attached to the sample container. U pon return to the laboratory, the information is transferred to the EMS system. Each sample is assigned a unique number that accompanies it through all analyses.

A fter the sample has been logged in, an aliquot is removed for tritium analysis, $20 \mathrm{~mL}$ (1 oz) of concentrated nitric acid $\left(\mathrm{HNO}_{3}\right)$ is added per gallon of water as a preservative, and the 


\section{ENVIRONMENTAL PROGRAM INFORMATION}

sample is filtered through Whatman No. 2 filter paper to remove any sediment present in the sample. A ppropriate aliquots are then taken, depending on the analysis.

For nonradiological analysis, samples are collected and preserved using EPA-prescribed procedures. Cooling is used for organic analysis, and nitric acid is used to preserve samples to be analyzed for metals. Specific collection procedures are used for other components, and EPA methods are used. All samples are analyzed within the required holding period, or noncompliance is documented. The quality control requirements of either $S W-846^{9}$ or the Contract L aboratory Program (CLP) must be met, or deviations are documented. All samples are assigned a unique number that serves as a reference source for each sample. When duplicate samples are obtained, unique numbers are assigned, and an indication that duplicates exist is entered in the data management system.

\subsubsection{Bottom Sediment}

Bottom sediment accumulates small amounts of radionuclides that may be present from time to time in a stream and, as a result, acts as an accumulator of the radionuclides that were present in the water. The sediment provides evidence of radionuclides in the surface water system. These samples are not routinely analyzed for chemical constituents.

Bottom sediment samples are collected annually from Sawmill Creek above, at, and several locations below the point at which ANL-E discharges its treated wastewater. Periodically, sediment samples are collected from several on-site ponds and lagoons. Ten off-site bottom sediment samples are collected each year, five in the spring and five in the fall, from remote locations to serve as controls. Sediment is collected from each location with a stainless-steel scoop and is transferred to a glass bottle.

At the time of sample collection, the date, time, and sample collector identification are recorded on sample labels affixed to the sample container. U pon return to the laboratory, the information is transferred to the EM S system. Each sample is assigned a unique number that accompanies it through the process. 


\section{ENVIRONMENTAL PROGRAM INFORMATION}

Each sample is dried for several days at $110^{\circ} \mathrm{C}\left(230^{\circ} \mathrm{F}\right)$, ball milled, and sieved through a N o. 70 mesh screen. The material that does not pass the N 0.70 screen is discarded. A 100-g portion is taken for gamma-ray spectrometric measurement, and other appropriate aliquots are used for specific radiochemical analyses. Off-site sediment sampling will be discontinued after 1997 (see Section 4.4).

\subsubsection{Soil}

Soil integrates small amounts of particulate matter and collects radioactive materials deposited from airborne releases. Although soil should not be used as the primary measurement system for air monitoring, in many cases, it may be the only available avenue if insufficient air sampling occurred at the time of an incident. The ANL-E program is designed to provide samples for analysis to determine whether any changes in concentrations have occurred over the year. No analysis for chemical constituents is carried out on these samples.

Each year soil is collected from 10 locations at the site perimeter (five spring and five fall) and from 10 remote locations (five spring and five fall). Sampling sites are selected in reasonably level areas that represent undisturbed soil. Two 1-m (3-ft) squares are marked off, and soil samples are collected from the corners and center of each square. Samples are collected with a 10.4- $\mathrm{cm}$ (4-in.) diameter coring tool to a depth of $5 \mathrm{~cm}(2 \mathrm{in}$.). All 10 cores are aggregated as a single sample. This procedure follows the A merican Society for Testing and M aterials (A STM) Standard M ethod for Sampling Surface Soil for Radionuclides, C-998.

A the time of sample collection, the date, time, and sample collector identification number are recorded on a preprinted sample label affixed to the sample container. On return to the laboratory, the information is transferred to the EM S system. Each sample is assigned a unique number that accompanies it through the process.

The entire sample is dried at $110^{\circ} \mathrm{C}\left(230^{\circ} \mathrm{F}\right)$ for several days, ball milled, and sieved through a No. 70 mesh screen. The material that does not pass the No. 70 mesh screen is discarded. A 100-g portion is taken for gamma-ray spectrometric measurement, and appropriate 


\section{ENVIRONMENTAL PROGRAM INFORMATION}

aliquots are taken for radiochemical analysis. Because a known area of surface soil was collected, results are calculated in terms of concentration and deposition per unit area. The soil sampling program will be discontinued after 1997 (see Section 4.4).

\subsubsection{Vegetation}

Grass samples are collected to determine the uptake of radionuclides from the soil by vegetation. This sampling is performed to monitor the vegetation part of the food chain pathway.

Grass samples are collected each year from 10 perimeter and 10 off-site locations at the same places as the soil samples. All vegetation within one of the 1-m (3-ft) plots used for soil sampling is cut just above the soil surface and collected.

At the time of sample collection, the date, time, and sample collector identification number are recorded on a preprinted sample label affixed to the sample container. U pon return to the laboratory, the information is transferred to the EM S system. Each sample is assigned a unique number that accompanies it through the process.

G rass samples are washed in water to remove surface dirt, dried at $110^{\circ} \mathrm{C}\left(230^{\circ} \mathrm{F}\right)$ for several days, and ground. A 100-g aliquot is measured by gamma-ray spectrometry, and appropriate aliquots are taken for radiochemical analysis. The vegetation sampling program will be discontinued after 1997 (see Section 4.4).

\subsubsection{External Penetrating Radiation}

M easurements of direct penetrating radiation emanating from several sources within A NL -E are taken by using aluminum oxide thermoluminescent dosimeters (TLDs) provided by a commercial vendor. Each measurement is the average of two chips exposed in the same packet. Dosimeters are exposed at 14 locations at the site perimeter and on site and at five off-site locations. All dosimeters are changed quarterly. At the time of dosimeter collection, the date, time, and collector identification number are recorded on a preprinted label affixed to the 


\section{ENVIRONMENTAL PROGRAM INFORMATION}

container. Each sample is assigned a unique number that accompanies it through the process. A fter completion of the exposure period, the TLDs are mailed to the vendor for reading. When the dose information is provided to the on-site laboratory by the vendor, it is entered into the EMS system.

\subsubsection{Data Management}

The management of the large amount of data assembled in the environmental monitoring program is handled by ANL -E in a very structured manner that allows a number of reports to be generated. Basic radiological data management, including sample record keeping, is implemented with the EM S computerized record keeping program. All sample and analytical data are kept in the EMS for eventual output in formats required for either regulatory compliance reports or for annual reports. In addition, reports are provided for trend analysis, statistical analysis, and tracking.

The ANL-E-developed EMS program is the basic data management tool; it generates sampling schedules, all other tracking and calculation routines, and the final analytical result tabulations. The EM S program is set up for the radiological portion of the monitoring program and for nonradiological monitoring for groundwater and NPDES surface water effluents.

The starting point for effluent monitoring and environmental surveillance is establishing a set of sampling locations and a sample schedule. On the basis of regulatory parameters, pathway analysis, or professional judgment, sample locations for the various media are identified and entered into the EMS. For each sample location, nine categories of data are entered into the EM S: geographic code, location description, sampling frequency, sample type (water, soil, plant, etc.), exact sampling position, last date sampled, sampling priority (same location with multiple samples), size of sample to collect, and analytes.

Once the data are entered, the EM S program is used to generate a sampling schedule. Every week a schedule for the next week is printed out, along with uniquely numbered, preprinted labels for the sample containers. These items are provided to the staff who conduct the sampling 


\section{ENVIRONMENTAL PROGRAM INFORMATION}

in the field. Field data are entered into the EM S system. At the time the samples are submitted to the analytical laboratory, chain of custody documents are generated. The EMS system distributes sample data electronically (via diskette) to the ESH data management system and accepts back the analytical data (via diskette or E-mail).

As the laboratory results are compiled, the data are entered into the EM S program. This permits up-to-date tracking of all samples currently in process. When the analysis for each sample is completed and the results electronically entered into the EMS, the completed final results sample card is retained in a file as an additional QA measure.

Complete data sets for all samples are maintained by the EM S program. When all results have been completed and entered into the EM S, a final result card is generated that lists all data related to each sample. The electronic files are backed up by the EM 0 computer network server. The printed final result card is filed after review, then ultimately put in DOE's archives in Chicago. Final results are thus available both on line via the network and in hard copy.

\subsection{Compliance with DOE Order 5820.2A}

DOE Order 5820.2A, "Radioactive Waste M anagement," Section III-3 $(k)^{10}$ requires that an environmental monitoring and surveillance program be conducted to determine any releases or migration from LLW treatment, storage, or disposal sites. Compliance with these requirements is an integral part of the ANL-E sitewide monitoring and surveillance program. Waste management operations in general are covered by relying on the perimeter air monitoring network and monitoring of the liquid effluent streams and Sawmill Creek. The analytical results are presented in Chapter 4 of this report.

Of particular interest is monitoring of the waste management activities conducted in the 317 A rea. These include air monitoring for total alpha, total beta, and gamma-ray emitters and radiochemical determinations of plutonium, uranium, thorium, and strontium-90; direct radiation measurements with TLDs; surface water discharges for tritium and gamma-ray emitters; perimeter soil and plant samples analyzed for gamma-ray emitters, plutonium, and americium; and 
subsurface water samples at all the monitoring wells with analyses for tritium, strontium-90, and gamma-ray emitters, plus selected monitoring for VOCs. The results are presented in Chapters 4 and 6 of this report. 


\section{ENVIRONMENTAL PROGRAM INFORMATION}




\section{ENVIRONMENTAL RADIOLOGICAL PROGRAM INFORMATION}

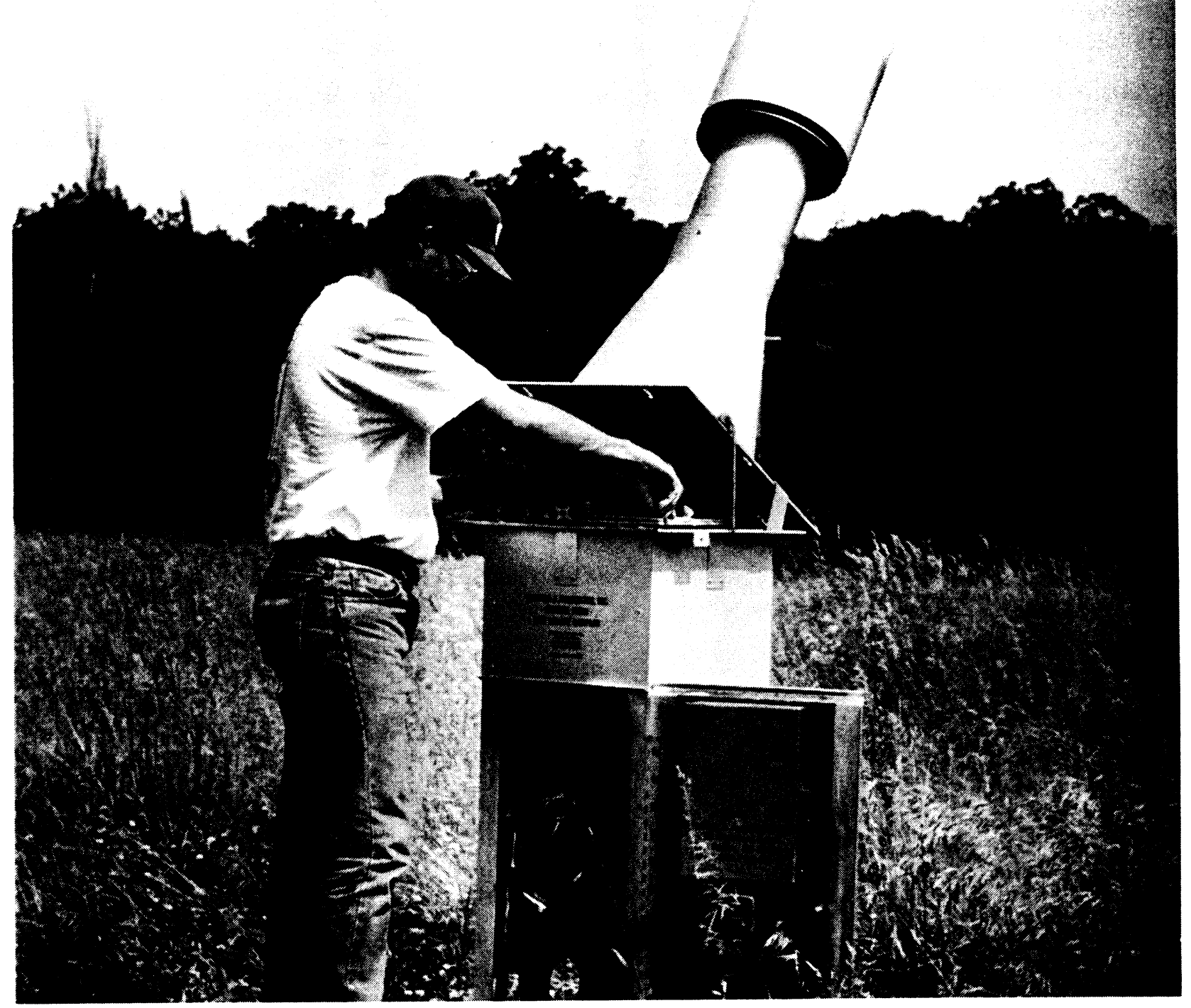




\section{ENVIRONMENTAL RADIOLOGICAL PROGRAM INFORMATION}

\subsection{Description of Monitoring Program}

The radioactivity of the environment around A N L-E in 1997 was determined by measuring radionuclide concentrations in naturally occurring materials and by measuring the external penetrating radiation dose. Sample collections and measurements were made at the site perimeter and off site for comparative purposes. Some on-site results are also reported when they are useful in interpreting perimeter and off-site results.

Because radioactivity is primarily transported by air and water, the sample collection program concentrates on these media. In addition, samples of soil, plants, and materials from the beds of lakes and streams also are analyzed. The program follows the guidance provided in the DOE Environmental Regulatory Guide. ${ }^{11}$ The results of radioactivity measurements are expressed in terms of $\mathrm{pCi} / \mathrm{L}$ for water; $\mathrm{fCi} / \mathrm{m}^{3}$ and $\mathrm{aCi} / \mathrm{m}^{3}$ for air; and $\mathrm{pCi} / \mathrm{g}, \mathrm{fCi} / \mathrm{g}$, and $/$ or $\mathrm{nCi} / \mathrm{m}^{2}$ for soil, bottom sediment, and vegetation. Penetrating radiation measurements are reported in units of $\mathrm{mrem} / \mathrm{yr}$, and population dose is reported in units of man-rems.

DOE has provided guidance ${ }^{12}$ for effective dose equival ent calculations for members of the public based on International Commission on Radiological Protection (ICRP) Publications 26 and $30 .{ }^{13,14}$ Those procedures have been used in preparing this report. The methodology requires that three components be calculated: (1) the committed effective dose equivalent (CEDE) from all sources of ingestion, (2) the CEDE from inhalation, and (3) the direct effective dose equivalent from external radiation. These three components were summed for comparison with the DOE effective dose equivalent limits for environmental exposure. The guidance requires that sufficient data on exposure to radionuclide sources be available to ensure that at least $90 \%$ of the total CEDE is accounted for. The primary radiation dose limit for members of the public is $100 \mathrm{mrem} / \mathrm{yr}$. The effective dose equivalents for members of the public from all routine DOE operations, natural background and medical exposures excluded, shall not exceed $100 \mathrm{mrem} / \mathrm{yr}$ and must adhere to the As L ow As Reasonably A chievable (A LARA) process or be as far below the limits as is practical, taking into account social, economic, technical, practical, and public policy considerations. Routine DOE operations are normally planned operations, which exclude actual or potential accidental or unplanned releases. 


\section{ENVIRONMENTAL RADIOLOGICAL PROGRAM INFORMATION}

The measured or calculated environmental radionuclide concentrations were converted to a 50-year CEDE with the use of the CEDE factors ${ }^{15}$ and were compared to the annual dose limits for uncontrolled areas. The CEDEs were calculated from the DOE Derived Concentration Guides $(D C G s)^{12}$ for members of the public on the basis of a radiation dose of $100 \mathrm{mrem} / \mathrm{yr}$. The numerical values of the CEDE factors used in this report are provided later in this chapter. A Ithough the CEDE factors apply only to concentrations above natural levels, for comparative purposes, the calculated dose is sometimes given in this report for radioactivities that are primarily of natural origin. Such values are enclosed in parentheses. Occasionally, other standards are used, and their sources are identified in the text.

\subsection{Air}

The radioactive content of particulate matter in the air was determined by collecting and analyzing air filter samples. The sampling locations are shown in Figures 1.1 and 1.2. Separate collections were made for specific radiochemical analyses and for gross alpha, gross beta, and gamma-ray spectrometry. The latter measurements were taken from samples collected continuously on laminated glass fiber filters (changed weekly) at 12 locations at the A NL-E site perimeter by using $\mathrm{PM}_{10}$ units (particulate matter less than 10 micrometers) and at 5 off-site locations.

Samples were collected at the site perimeter to determine whether a statistically significant difference exists between perimeter measurements and measurements taken from samples collected at various off-site locations. The off-site samples establish the local background concentrations of naturally occurring or ubiquitous man-made radionuclides, such as from nuclear weapons testing fallout. Higher levels of radioactivity in the air measured at the site perimeter may indicate radioactivity releases from $A N L-E$, provided that the perimeter samples are greater than the background samples by an amount greater than the relative error of the measurement. The relative error is a result of natural variation in background concentrations as well as sampling and measurement error. This relative error is typically 5 to $20 \%$ of the measurement value for most of the analyses, but approaches $100 \%$ at values near the detection limit of the instrument. 
Table 4.1 summarizes the total al pha and beta activities in the individual weekly samples. These measurements were made in low-background gas-flow proportional counters, and the counting efficiencies used to convert counting rates to disintegration rates were those measured for a $0.30-\mathrm{M} \mathrm{eV}$ beta and a $5.5-\mathrm{M} \mathrm{eV}$ alpha on filter paper. The results were obtained by measuring the samples four days after they were collected to avoid counting the natural activity due to shortlived radon and thoron decay products. This activity is normally present in air and disappears within four days by radioactive decay. The average concentrations of gamma-ray emitters, as determined by gamma-ray spectrometry performed on composite weekly samples, are given in Table 4.2. The gamma-ray detector is a shielded germanium diode calibrated for each gammaray-emitting nuclide measured.

The alpha activity, principally due to naturally occurring nuclides, averaged the same as in the past several years and was within its normal range. The perimeter beta activity averaged $29 \mathrm{fCi} / \mathrm{m}^{3}$, which is similar to the average value for the past five years. The elevated beta activity in the January and February off-site samples was identified as cesium-137, as determined by gamma-ray spectrometry. No environmental source of cesium-137 could be identified. It is speculated that the filters were somehow contaminated with very low levels of cesium-137 during sample preparation. The gamma-ray emitters listed in Table 4.2 are those that have been present in the air for the past few years and are of natural origin. The beryllium- 7 concentration increases in the spring, which indicates its stratospheric origin. The concentration of lead-210 in the air is due to the radioactive decay of gaseous radon-222 and is similar to the concentration last year.

The annual average al pha and beta activities since 1985 are displayed in Figure 4.1. The elevated beta activity in 1986 was due to fallout from the Chernobyl incident. If the radionuclides attributed to the Chernobyl incident are subtracted from the annual beta average of $40 \mathrm{fCi} / \mathrm{m}^{3}$, the net would be $27 \mathrm{fCi} / \mathrm{m}^{3}$, very similar to the averages of the other years. Figure 4.2 presents the annual average concentrations of the two major gamma-ray-emitting radionuclides in air. The annual average beryllium-7 concentrations have decreased regularly since 1987, reached a minimum in 1991, and are now increasing. The increase in the beryllium-7 air concentrations has 
TABLE 4.1

Total A Ipha and Beta A ctivities in A ir-Filter Samples, 1997 (concentrations in $\mathrm{fCi} / \mathrm{m}^{3}$ )

\begin{tabular}{|c|c|c|c|c|c|c|c|c|}
\hline \multirow[b]{2}{*}{ Month } & \multirow[b]{2}{*}{ Location } & \multirow{2}{*}{$\begin{array}{c}\text { No. of } \\
\text { Samples }\end{array}$} & \multicolumn{3}{|c|}{ Alpha A ctivity } & \multicolumn{3}{|c|}{ Beta A ctivity } \\
\hline & & & Avg. & Min. & Max. & Avg. & Min. & Max. \\
\hline J anuary & $\begin{array}{l}\text { Perimeter } \\
\text { Off site }\end{array}$ & $\begin{array}{l}27 \\
24\end{array}$ & $\begin{array}{l}2.0 \\
2.3\end{array}$ & $\begin{array}{l}1.1 \\
0.3\end{array}$ & $\begin{array}{l}2.8 \\
3.9\end{array}$ & $\begin{array}{l}36.7 \\
49.1\end{array}$ & $\begin{array}{c}23.7 \\
5.0\end{array}$ & $\begin{array}{r}49.3 \\
292.5\end{array}$ \\
\hline February & $\begin{array}{l}\text { Perimeter } \\
\text { Off site }\end{array}$ & $\begin{array}{l}23 \\
18\end{array}$ & $\begin{array}{l}1.2 \\
1.4\end{array}$ & $\begin{array}{l}0.9 \\
0.3\end{array}$ & $\begin{array}{l}1.9 \\
2.1\end{array}$ & $\begin{array}{l}29.5 \\
28.4\end{array}$ & $\begin{array}{c}21.8 \\
4.9\end{array}$ & $\begin{array}{l}38.0 \\
50.8\end{array}$ \\
\hline M arch & $\begin{array}{l}\text { Perimeter } \\
\text { off site }\end{array}$ & $\begin{array}{l}20 \\
16\end{array}$ & $\begin{array}{l}1.6 \\
1.7\end{array}$ & $\begin{array}{l}1.1 \\
0.8\end{array}$ & $\begin{array}{l}2.7 \\
2.4\end{array}$ & $\begin{array}{l}28.3 \\
27.8\end{array}$ & $\begin{array}{l}17.0 \\
15.0\end{array}$ & $\begin{array}{l}35.1 \\
36.9\end{array}$ \\
\hline A pril & $\begin{array}{l}\text { Perimeter } \\
\text { Off site }\end{array}$ & $\begin{array}{l}30 \\
21\end{array}$ & $\begin{array}{l}1.8 \\
1.9\end{array}$ & $\begin{array}{l}1.0 \\
0.4\end{array}$ & $\begin{array}{l}2.4 \\
3.3\end{array}$ & $\begin{array}{l}23.6 \\
22.4\end{array}$ & $\begin{array}{c}13.4 \\
9.3\end{array}$ & $\begin{array}{l}31.8 \\
34.6\end{array}$ \\
\hline M ay & $\begin{array}{l}\text { Perimeter } \\
\text { Off site }\end{array}$ & $\begin{array}{l}39 \\
16\end{array}$ & $\begin{array}{l}1.1 \\
1.3\end{array}$ & $\begin{array}{l}0.6 \\
0.7\end{array}$ & $\begin{array}{l}1.6 \\
2.4\end{array}$ & $\begin{array}{l}16.0 \\
15.9\end{array}$ & $\begin{array}{c}6.7 \\
10.4\end{array}$ & $\begin{array}{l}24.9 \\
24.6\end{array}$ \\
\hline J une & $\begin{array}{l}\text { Perimeter } \\
\text { Off site }\end{array}$ & $\begin{array}{l}45 \\
15\end{array}$ & $\begin{array}{l}1.2 \\
1.3\end{array}$ & $\begin{array}{l}0.5 \\
0.7\end{array}$ & $\begin{array}{l}2.2 \\
2.1\end{array}$ & $\begin{array}{l}19.9 \\
20.1\end{array}$ & $\begin{array}{l}7.7 \\
9.9\end{array}$ & $\begin{array}{l}27.1 \\
29.3\end{array}$ \\
\hline July & $\begin{array}{l}\text { Perimeter } \\
\text { Off site }\end{array}$ & $\begin{array}{l}59 \\
18\end{array}$ & $\begin{array}{l}1.3 \\
1.4\end{array}$ & $\begin{array}{l}0.4 \\
0.7\end{array}$ & $\begin{array}{l}2.0 \\
2.2\end{array}$ & $\begin{array}{l}24.2 \\
27.5\end{array}$ & $\begin{array}{c}8.7 \\
18.1\end{array}$ & $\begin{array}{l}34.7 \\
40.3\end{array}$ \\
\hline A ugust & $\begin{array}{l}\text { Perimeter } \\
\text { Off site }\end{array}$ & $\begin{array}{l}44 \\
19\end{array}$ & $\begin{array}{l}1.0 \\
1.2\end{array}$ & $\begin{array}{l}0.4 \\
0.6\end{array}$ & $\begin{array}{l}2.0 \\
2.1\end{array}$ & $\begin{array}{l}22.4 \\
27.4\end{array}$ & $\begin{array}{c}8.1 \\
14.5\end{array}$ & $\begin{array}{l}32.4 \\
37.7\end{array}$ \\
\hline September & $\begin{array}{l}\text { Perimeter } \\
\text { Off site }\end{array}$ & $\begin{array}{l}44 \\
14\end{array}$ & $\begin{array}{l}1.2 \\
1.4\end{array}$ & $\begin{array}{l}0.4 \\
0.9\end{array}$ & $\begin{array}{l}2.0 \\
1.9\end{array}$ & $\begin{array}{l}25.7 \\
29.8\end{array}$ & $\begin{array}{l}11.1 \\
19.3\end{array}$ & $\begin{array}{l}41.3 \\
45.5\end{array}$ \\
\hline October & $\begin{array}{l}\text { Perimeter } \\
\text { Off site }\end{array}$ & $\begin{array}{l}44 \\
18\end{array}$ & $\begin{array}{l}1.4 \\
1.8\end{array}$ & $\begin{array}{l}0.4 \\
1.1\end{array}$ & $\begin{array}{l}2.9 \\
2.9\end{array}$ & $\begin{array}{l}23.5 \\
31.2\end{array}$ & $\begin{array}{c}6.7 \\
16.4\end{array}$ & $\begin{array}{l}38.8 \\
50.7\end{array}$ \\
\hline November & $\begin{array}{l}\text { Perimeter } \\
\text { Off site }\end{array}$ & $\begin{array}{l}42 \\
15\end{array}$ & $\begin{array}{l}1.1 \\
1.7\end{array}$ & $\begin{array}{l}0.2 \\
0.5\end{array}$ & $\begin{array}{l}2.2 \\
3.1\end{array}$ & $\begin{array}{l}30.3 \\
36.2\end{array}$ & $\begin{array}{c}7.5 \\
17.5\end{array}$ & $\begin{array}{l}58.8 \\
59.2\end{array}$ \\
\hline December & $\begin{array}{l}\text { Perimeter } \\
\text { Off site }\end{array}$ & $\begin{array}{l}27 \\
15\end{array}$ & $\begin{array}{l}1.0 \\
1.6\end{array}$ & $\begin{array}{l}0.1 \\
0.4\end{array}$ & $\begin{array}{l}3.1 \\
3.5\end{array}$ & $\begin{array}{l}24.9 \\
31.7\end{array}$ & $\begin{array}{c}5.3 \\
10.7\end{array}$ & $\begin{array}{l}58.7 \\
56.0\end{array}$ \\
\hline $\begin{array}{l}\text { A nnual } \\
\text { summary }\end{array}$ & $\begin{array}{l}\text { Perimeter } \\
\text { off site }\end{array}$ & $\begin{array}{l}444 \\
209\end{array}$ & $\begin{array}{l}1.3 \pm 0.2 \\
1.6 \pm 0.2\end{array}$ & $\begin{array}{l}0.1 \\
0.3\end{array}$ & $\begin{array}{l}3.1 \\
3.9\end{array}$ & $\begin{array}{l}25.4 \pm 3.4 \\
29.0 \pm 5.3\end{array}$ & $\begin{array}{l}5.3 \\
4.9\end{array}$ & $\begin{array}{r}58.8 \\
292.5\end{array}$ \\
\hline
\end{tabular}


TABLE 4.2

Gamma-Ray A ctivity in A ir-Filter Samples, 1997

(Concentrations in $\mathrm{fCi} / \mathrm{m}^{3}$ )

\begin{tabular}{|c|c|c|c|}
\hline Month & Location & Beryllium-7 & L ead- 210 \\
\hline January & $\begin{array}{l}\text { Perimeter } \\
\text { Off site }\end{array}$ & $\begin{array}{r}105 \\
72\end{array}$ & $\begin{array}{l}30 \\
26\end{array}$ \\
\hline F ebruary & $\begin{array}{l}\text { Perimeter } \\
\text { Off site }\end{array}$ & $\begin{array}{l}85 \\
46\end{array}$ & $\begin{array}{l}26 \\
18\end{array}$ \\
\hline M arch & $\begin{array}{l}\text { Perimeter } \\
\text { Off site }\end{array}$ & $\begin{array}{l}140 \\
101\end{array}$ & $\begin{array}{l}23 \\
17\end{array}$ \\
\hline A pril & $\begin{array}{l}\text { Perimeter } \\
\text { Off site }\end{array}$ & $\begin{array}{l}175 \\
156\end{array}$ & $\begin{array}{l}15 \\
13\end{array}$ \\
\hline M ay & $\begin{array}{l}\text { Perimeter } \\
\text { Off site }\end{array}$ & $\begin{array}{l}131 \\
110\end{array}$ & $\begin{array}{c}10 \\
9\end{array}$ \\
\hline June & $\begin{array}{l}\text { Perimeter } \\
\text { Off site }\end{array}$ & $\begin{array}{r}121 \\
71\end{array}$ & $\begin{array}{l}13 \\
13\end{array}$ \\
\hline July & $\begin{array}{l}\text { Perimeter } \\
\text { Off site }\end{array}$ & $\begin{array}{l}135 \\
127\end{array}$ & $\begin{array}{l}16 \\
18\end{array}$ \\
\hline August & $\begin{array}{l}\text { Perimeter } \\
\text { Off site }\end{array}$ & $\begin{array}{l}111 \\
123\end{array}$ & $\begin{array}{l}16 \\
19\end{array}$ \\
\hline September & $\begin{array}{l}\text { Perimeter } \\
\text { Off site }\end{array}$ & $\begin{array}{r}98 \\
108\end{array}$ & $\begin{array}{l}18 \\
21\end{array}$ \\
\hline October & $\begin{array}{l}\text { Perimeter } \\
\text { Off site }\end{array}$ & $\begin{array}{r}99 \\
109\end{array}$ & $\begin{array}{l}20 \\
23\end{array}$ \\
\hline November & $\begin{array}{l}\text { Perimeter } \\
\text { Off site }\end{array}$ & $\begin{array}{l}83 \\
84\end{array}$ & $\begin{array}{l}31 \\
31\end{array}$ \\
\hline December & $\begin{array}{l}\text { Perimeter } \\
\text { Off site }\end{array}$ & $\begin{array}{l}59 \\
56\end{array}$ & $\begin{array}{l}26 \\
28\end{array}$ \\
\hline $\begin{array}{l}\text { A nnual } \\
\text { summary }\end{array}$ & $\begin{array}{l}\text { Perimeter } \\
\text { Off site }\end{array}$ & $\begin{array}{r}112 \pm 9 \\
97 \pm 20\end{array}$ & $\begin{array}{l}20 \pm 4 \\
20 \pm 4\end{array}$ \\
\hline D ose (mrem) & $\begin{array}{l}\text { Perimeter } \\
\text { Off site }\end{array}$ & $\begin{array}{l}(0.00028) \\
(0.00024)\end{array}$ & $\begin{array}{l}(2.31) \\
(2.25)\end{array}$ \\
\hline
\end{tabular}




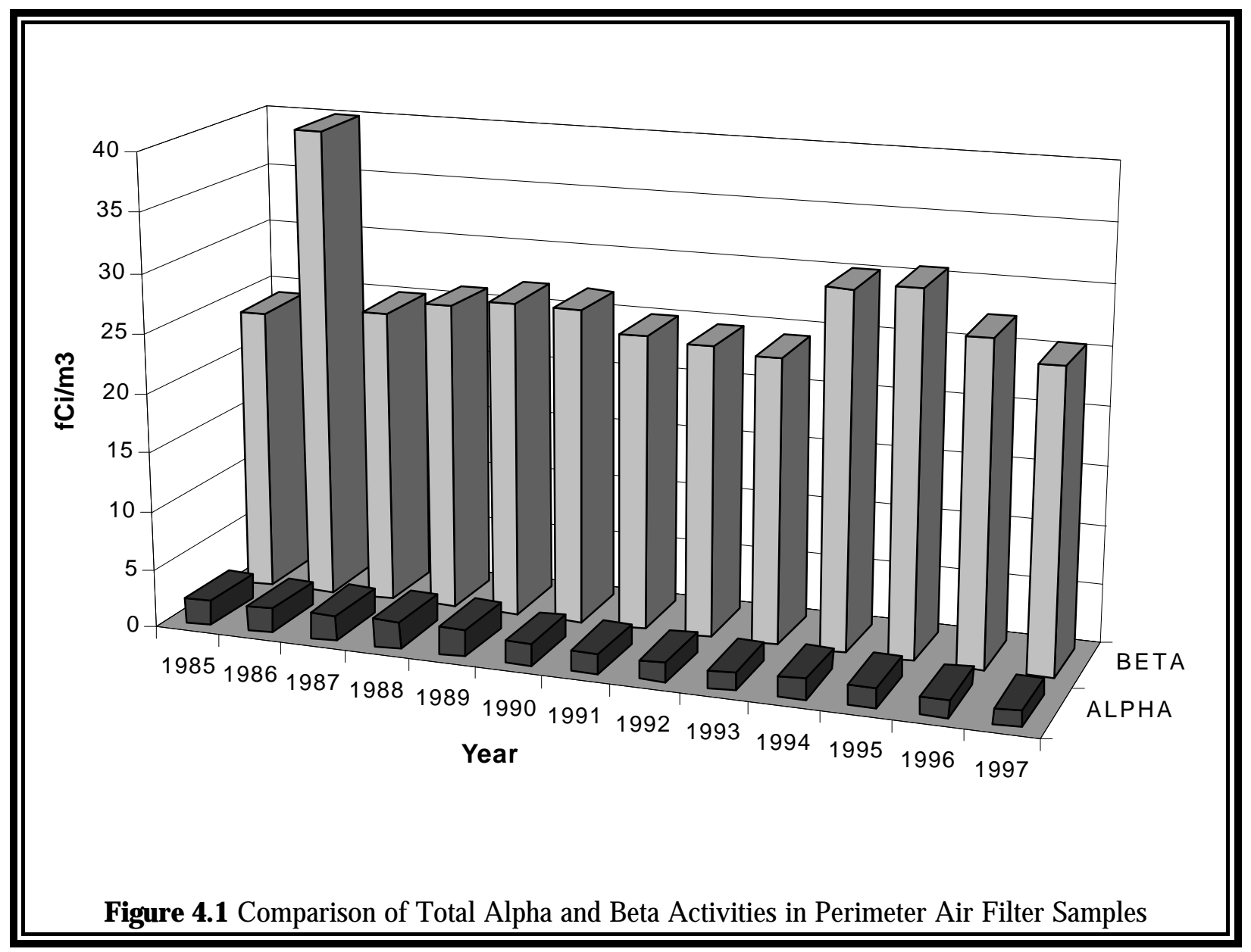

been observed worldwide by the DOE Environmental L aboratory's Surface A ir Sampling Program and is attributed to an increase in solar activity. ${ }^{16}$

Samples for radiochemical analyses were collected at perimeter locations $12 \mathrm{~N}$ and $7 \mathrm{I}$ (Figure 1.1) and off the site in Downers Grove (Figure 1.2). Collections were made on polystyrene filters. The total air volume filtered for the monthly samples was approximately $20,000 \mathrm{~m}^{3}\left(700,000 \mathrm{ft}^{3}\right)$. Samples were ignited at $600^{\circ} \mathrm{C}\left(1,100^{\circ} \mathrm{F}\right)$ to remove organic matter and were prepared for analysis by vigorous treatment with hot hydrochloric, hydrofluoric, and nitric acids. 


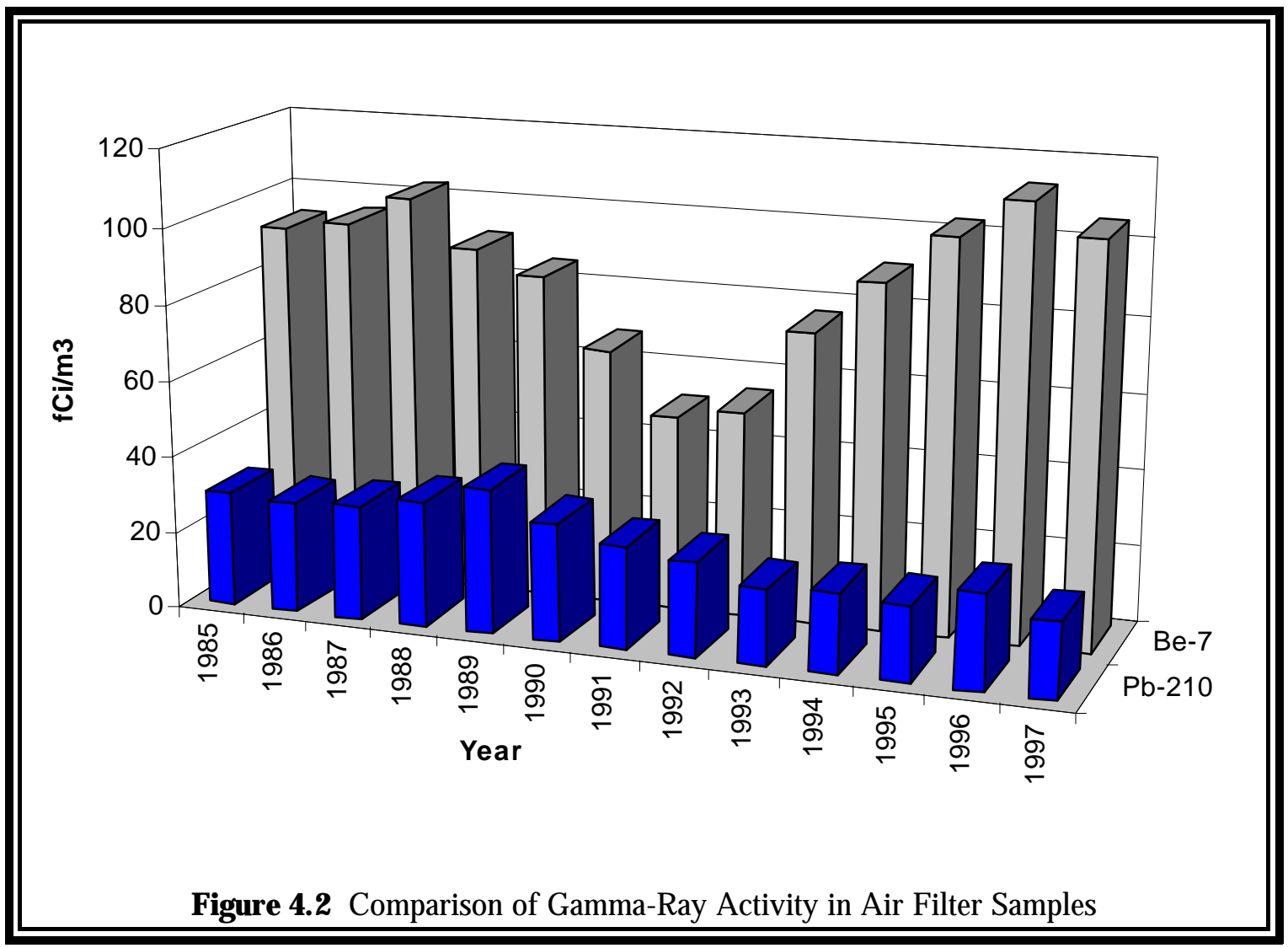

Plutonium and thorium were separated on an ion-exchange column, and the uranium was extracted from the column effluent. Following the extraction, the aqueous phase was analyzed for radiostrontium by a standard radiochemical procedure. The separated plutonium, thorium, and uranium fractions were electrodeposited and measured by alpha spectrometry. The chemical recoveries were monitored by adding known amounts of plutonium-242, thorium-229, and uranium-236 tracers prior to ignition. Because spectrometry cannot distinguish between plutonium-239 and plutonium-240, when plutonium-239 is mentioned in this report, the alpha activity due to the plutonium-240 isotope is also included. The results are given in Table 4.3.

The strontium-90 concentrations have decreased over the past several years; consequently, during 1997, all of the results were less than the detection limit of $10 \mathrm{aCi} / \mathrm{m}^{3}$. Strontium-89 was not observed above the detection limit of $100 \mathrm{aCi} / \mathrm{m}^{3}$. The plutonium- 239 concentrations at all locations were similar to those of the last few years. The thorium and uranium concentrations 


\section{ENVIRONMENTAL RADIOLOGICAL PROGRAM INFORMATION}

TABLE 4.3

Strontium, Thorium, U ranium, and Plutonium Concentrations

in A ir-Filter Samples, 1997

(Concentrations in $\mathrm{aCi} / \mathrm{m}^{3}$ )

\begin{tabular}{|c|c|c|c|c|c|c|c|c|}
\hline M onth & Location $^{a}$ & Strontium-90 & Thorium-228 & Thorium-230 & Thorium-232 & U ranium-234 & U ranium-238 & Plutonium-239 \\
\hline January & $\begin{array}{l}71 \\
12 \mathrm{~N} \\
\text { Off site }\end{array}$ & $\begin{array}{l}<10 \\
<10 \\
<10\end{array}$ & $\begin{array}{r}8 \pm 1 \\
15 \pm 3 \\
3 \pm 1\end{array}$ & $\begin{array}{r}10 \pm 1 \\
17 \pm 2 \\
5 \pm 1\end{array}$ & $\begin{array}{r}7 \pm 1 \\
10 \pm 2 \\
3 \pm 1\end{array}$ & $\begin{array}{r}8 \pm 1 \\
16 \pm 2 \\
6 \pm 1\end{array}$ & $\begin{array}{r}10 \pm 1 \\
17 \pm 2 \\
6 \pm 1\end{array}$ & $\begin{array}{l}1.1 \pm 0.3 \\
0.4 \pm 0.2 \\
1.5 \pm 0.3\end{array}$ \\
\hline February & $\begin{array}{l}71 \\
12 \mathrm{~N} \\
\text { Off site }\end{array}$ & $\begin{array}{l}<10 \\
<10 \\
<10\end{array}$ & $\begin{array}{l}2 \pm 1 \\
7 \pm 2 \\
2 \pm 1\end{array}$ & $\begin{array}{l}3 \pm 1 \\
8 \pm 2 \\
3 \pm 1\end{array}$ & $\begin{array}{l}2 \pm 1 \\
5 \pm 1 \\
<1\end{array}$ & $\begin{array}{l}4 \pm 1 \\
9 \pm 2 \\
2 \pm 1\end{array}$ & $\begin{array}{r}4 \pm 1 \\
10 \pm 2 \\
2 \pm 1\end{array}$ & $\begin{array}{c}<0.1 \\
0.6 \pm 0.4 \\
<0.1\end{array}$ \\
\hline March & $\begin{array}{l}71 \\
12 \mathrm{~N} \\
\text { Off site }\end{array}$ & $\begin{array}{l}<10 \\
<10 \\
<10\end{array}$ & $\begin{array}{r}4 \pm 1 \\
11 \pm 2 \\
2 \pm 1\end{array}$ & $\begin{array}{r}7 \pm 1 \\
15 \pm 2 \\
3 \pm 1\end{array}$ & $\begin{array}{l}3 \pm 1 \\
9 \pm 2 \\
2 \pm 1\end{array}$ & $\begin{array}{r}5 \pm 1 \\
14 \pm 2 \\
3 \pm 1\end{array}$ & $\begin{array}{r}8 \pm 1 \\
16 \pm 2 \\
3 \pm 1\end{array}$ & $\begin{array}{c}0.2 \pm 0.1 \\
0.9 \pm 0.4 \\
<0.1\end{array}$ \\
\hline A pril & $\begin{array}{l}71 \\
12 \mathrm{~N} \\
\text { Off site }\end{array}$ & $\begin{array}{l}<10 \\
<10 \\
<10\end{array}$ & $\begin{array}{r}3 \pm 1 \\
17 \pm 2 \\
6 \pm 1\end{array}$ & $\begin{array}{r}5 \pm 1 \\
22 \pm 2 \\
8 \pm 1\end{array}$ & $\begin{array}{r}2 \pm 1 \\
13 \pm 2 \\
5 \pm 1\end{array}$ & $\begin{array}{r}5 \pm 1 \\
18 \pm 2 \\
6 \pm 1\end{array}$ & $\begin{array}{r}5 \pm 1 \\
18 \pm 2 \\
7 \pm 1\end{array}$ & $\begin{array}{c}<0.1 \\
0.3 \pm 0.2 \\
0.4 \pm 0.2\end{array}$ \\
\hline M ay & $\begin{array}{l}71 \\
12 \mathrm{~N} \\
\text { Off site }\end{array}$ & $\begin{array}{l}<10 \\
<10 \\
<10\end{array}$ & $\begin{array}{r}8 \pm 2 \\
17 \pm 2 \\
2 \pm 1\end{array}$ & $\begin{array}{r}10 \pm 1 \\
22 \pm 2 \\
4 \pm 1\end{array}$ & $\begin{array}{r}7 \pm 1 \\
14 \pm 2 \\
2 \pm 1\end{array}$ & $\begin{array}{r}8 \pm 2 \\
19 \pm 2 \\
3 \pm 1\end{array}$ & $\begin{array}{r}9 \pm 2 \\
20 \pm 2 \\
4 \pm 1\end{array}$ & $\begin{array}{l}0.5 \pm 0.3 \\
0.2 \pm 0.2 \\
0.2 \pm 0.2\end{array}$ \\
\hline June & $\begin{array}{l}71 \\
12 \mathrm{~N} \\
\text { Off site }\end{array}$ & $\begin{array}{l}<10 \\
<10 \\
<10\end{array}$ & $\begin{array}{l}5 \pm 1 \\
7 \pm 3 \\
5 \pm 1\end{array}$ & $\begin{array}{r}6 \pm 1 \\
10 \pm 2 \\
4 \pm 1\end{array}$ & $\begin{array}{l}3 \pm 1 \\
5 \pm 2 \\
3 \pm 1\end{array}$ & $\begin{array}{l}6 \pm 1 \\
7 \pm 2 \\
4 \pm 1\end{array}$ & $\begin{array}{l}6 \pm 1 \\
7 \pm 2 \\
5 \pm 1\end{array}$ & $\begin{array}{c}<0.1 \\
1.2 \pm 0.6 \\
0.2 \pm 0.1\end{array}$ \\
\hline July & $\begin{array}{l}7 \mathrm{I} \\
12 \mathrm{~N} \\
\text { Off site }\end{array}$ & $\begin{array}{l}<10 \\
<10 \\
<10\end{array}$ & $\begin{array}{r}4 \pm 1 \\
16 \pm 2 \\
10 \pm 2\end{array}$ & $\begin{array}{r}5 \pm 1 \\
19 \pm 2 \\
12 \pm 1\end{array}$ & $\begin{array}{r}3 \pm 1 \\
13 \pm 1 \\
8 \pm 1\end{array}$ & $\begin{array}{r}5 \pm 1 \\
15 \pm 1 \\
12 \pm 1\end{array}$ & $\begin{array}{r}4 \pm 1 \\
17 \pm 2 \\
12 \pm 1\end{array}$ & $\begin{array}{l}0.3 \pm 0.2 \\
0.4 \pm 0.2 \\
0.4 \pm 0.2\end{array}$ \\
\hline A ugust & $\begin{array}{l}71 \\
12 \mathrm{~N} \\
\text { Off site }\end{array}$ & $\begin{array}{l}<10 \\
<10 \\
<10\end{array}$ & $\begin{array}{l}2 \pm 1 \\
6 \pm 2 \\
2 \pm 1\end{array}$ & $\begin{array}{l}4 \pm 1 \\
8 \pm 1 \\
2 \pm 1\end{array}$ & $\begin{array}{l}2 \pm 1 \\
6 \pm 1 \\
1 \pm 1\end{array}$ & $\begin{array}{l}4 \pm 1 \\
8 \pm 1 \\
3 \pm 1\end{array}$ & $\begin{array}{l}4 \pm 1 \\
9 \pm 1 \\
3 \pm 1\end{array}$ & $\begin{array}{l}0.9 \pm 0.5 \\
0.3 \pm 0.2 \\
0.2 \pm 0.2\end{array}$ \\
\hline September & $\begin{array}{l}71 \\
12 \mathrm{~N} \\
\text { Off site }\end{array}$ & $\begin{array}{l}<10 \\
<10 \\
<10\end{array}$ & $\begin{array}{l}3 \pm 2 \\
7 \pm 1 \\
3 \pm 1\end{array}$ & $\begin{array}{l}3 \pm 1 \\
9 \pm 1 \\
4 \pm 1\end{array}$ & $\begin{array}{l}2 \pm 1 \\
6 \pm 1 \\
2 \pm 1\end{array}$ & $\begin{array}{l}3 \pm 1 \\
9 \pm 2 \\
4 \pm 1\end{array}$ & $\begin{array}{l}4 \pm 1 \\
9 \pm 2 \\
3 \pm 1\end{array}$ & $\begin{array}{c}0.2 \pm 0.2 \\
<0.1 \\
0.3 \pm 0.2\end{array}$ \\
\hline October & $\begin{array}{l}7 \mathrm{l} \\
12 \mathrm{~N} \\
\text { Off site }\end{array}$ & $\begin{array}{l}<10 \\
<10 \\
<10\end{array}$ & $\begin{array}{r}3 \pm 1 \\
10 \pm 4 \\
3 \pm 2\end{array}$ & $\begin{array}{r}3 \pm 1 \\
14 \pm 3 \\
3 \pm 1\end{array}$ & $\begin{array}{r}2 \pm 1 \\
11 \pm 3 \\
2 \pm 1\end{array}$ & $\begin{array}{r}5 \pm 1 \\
16 \pm 3 \\
4 \pm 1\end{array}$ & $\begin{array}{r}5 \pm 1 \\
14 \pm 3 \\
3 \pm 1\end{array}$ & $\begin{array}{c}0.3 \pm 0.2 \\
0.3 \pm 0.2 \\
<0.1\end{array}$ \\
\hline November & $\begin{array}{l}71 \\
12 \mathrm{~N} \\
\text { Off site }\end{array}$ & $\begin{array}{l}<10 \\
<10 \\
<10\end{array}$ & $\begin{array}{l}3 \pm 2 \\
5 \pm 2 \\
2 \pm 2\end{array}$ & $\begin{array}{l}4 \pm 1 \\
7 \pm 2 \\
3 \pm 1\end{array}$ & $\begin{array}{l}3 \pm 1 \\
4 \pm 1 \\
2 \pm 1\end{array}$ & $\begin{array}{l}5 \pm 2 \\
8 \pm 2 \\
3 \pm 1\end{array}$ & $\begin{array}{l}5 \pm 2 \\
7 \pm 2 \\
4 \pm 1\end{array}$ & $\begin{array}{l}0.3 \pm 0.3 \\
0.3 \pm 0.2 \\
0.2 \pm 0.2\end{array}$ \\
\hline December & $\begin{array}{l}7 \mathrm{I} \\
12 \mathrm{~N} \\
\text { Off site }\end{array}$ & $\begin{array}{l}<10 \\
<10 \\
<10\end{array}$ & $\begin{array}{l}2 \pm 2 \\
4 \pm 2 \\
3 \pm 2\end{array}$ & $\begin{array}{l}2 \pm 1 \\
7 \pm 1 \\
5 \pm 1\end{array}$ & $\begin{array}{l}2 \pm 1 \\
4 \pm 1 \\
1 \pm 1\end{array}$ & $\begin{array}{l}4 \pm 1 \\
7 \pm 1 \\
5 \pm 1\end{array}$ & $\begin{array}{l}4 \pm 1 \\
6 \pm 1 \\
4 \pm 1\end{array}$ & $\begin{array}{c}0.2 \pm 0.2 \\
0.1 \pm 0.1 \\
<0.1\end{array}$ \\
\hline $\begin{array}{l}\text { A nnual } \\
\text { summary }\end{array}$ & $\begin{array}{l}71 \\
12 \mathrm{~N} \\
\text { Off site }\end{array}$ & $\begin{array}{l}<10 \\
<10 \\
<10\end{array}$ & $\begin{aligned} 4 & \pm 5 \\
10 & \pm 11 \\
3 & \pm 5\end{aligned}$ & $\begin{aligned} 5 & \pm 6 \\
13 & \pm 13 \\
5 & \pm 6\end{aligned}$ & $\begin{array}{l}3 \pm 4 \\
8 \pm 9 \\
3 \pm 4\end{array}$ & $\begin{aligned} 5 & \pm 4 \\
12 & \pm 10 \\
4 & \pm 6\end{aligned}$ & $\begin{aligned} 6 & \pm 5 \\
12 & \pm 11 \\
5 & \pm 6\end{aligned}$ & $\begin{array}{l}0.3 \pm 0.7 \\
0.4 \pm 0.7 \\
0.3 \pm 0.9\end{array}$ \\
\hline $\begin{array}{l}\text { Dose } \\
\quad \text { (mrem) }\end{array}$ & $\begin{array}{l}7 \mathrm{I} \\
12 \mathrm{~N} \\
\text { Off site }\end{array}$ & $\begin{array}{l}<(0.00011) \\
<(0.00011) \\
<(0.00011)\end{array}$ & $\begin{array}{l}(0.0095) \\
(0.0254) \\
(0.0087)\end{array}$ & $\begin{array}{l}(0.0097) \\
(0.0261) \\
(0.0092)\end{array}$ & $\begin{array}{l}(0.032) \\
(0.081) \\
(0.027)\end{array}$ & $\begin{array}{l}(0.00025) \\
(0.00060) \\
(0.00022)\end{array}$ & $\begin{array}{l}(0.00028) \\
(0.00061) \\
(0.00023)\end{array}$ & $\begin{array}{l}(0.0009) \\
(0.0011) \\
(0.0007)\end{array}$ \\
\hline
\end{tabular}

a Perimeter locations are given in terms of the grid coordinates in Figure 1.1. 
were in the same range as in the past and are considered to be of natural origin. The amounts of thorium and uranium in a sample were proportional to the mass of inorganic material collected on the filter paper. The presence of most of these airborne elements can be attributed to the resuspension of soil.

The major airborne effluents released at ANL-E during 1997 are listed by location in Table 4.4; Figure 4.3 shows the annual releases of the major sources since 1985. The radon-220 releases from Building 200, due to radioactive contamination from the "proof-of-breeding" program, have been eliminated. The remaining emissions are from nuclear medicine studies. The hydrogen-3 emitted from Building 212 is from tritium recovery studies, while short-lived activation products are emitted from the IPNS and APS. In addition to the radionuclides listed in Table 4.4, several other fission products also were released in millicurie or smaller amounts. The quantities listed in Table 4.4 were measured by on-line stack monitors in the exhaust systems of the buildings, except for those for Building 350 .

\subsection{Surface Water}

All surface water samples collected in the monitoring program were acidified to $0.1 \underline{\mathrm{N}}$ with $\mathrm{HNO}_{3}$ and filtered immediately after collection. Total nonvolatile al pha and beta activities were determined by counting the residue remaining after evaporation of the water and then applying counting efficiency corrections determined for plutonium-239 (for alpha activity) and thallium-204 (for beta activity) to obtain disintegration rates. Hydrogen-3 was measured from a separate aliquot; this activity does not appear in the results for total nonvolatile beta activity. A nalyses for the radionuclides were performed by specific radiochemical separations followed by appropriate counting. One-liter aliquots were used for all analyses except for hydrogen-3 and the transuranium nuclides. Hydrogen-3 analyses were performed by liquid scintillation counting of $9 \mathrm{~mL}(0.03 \mathrm{oz})$ of a distilled sample in a nonhazardous cocktail. A nalyses for transuranium nuclides were performed on 10-L (3-gal) samples with chemical separation methods followed by al pha spectrometry. Plutonium-236 was used to determine the yields of plutonium and neptunium, which were separated from the sample together. A group separation of a fraction containing the transplutonium elements was monitored for recovery with an americium-243 tracer. Isotopic 


\section{ENVIRONMENTAL RADIOLOGICAL PROGRAM INFORMATION}

TABLE 4.4

Summary of M onitored A irborne Radioactive Emissions from A N L-E F acilities, 1997

\begin{tabular}{|c|c|c|c|c|}
\hline Building & Nuclide & Half-Life & $\begin{array}{l}\text { A mount } \\
\text { Released } \\
\text { (Ci) }\end{array}$ & $\begin{array}{c}\text { A mount } \\
\text { Released }(\mathrm{Bq})\end{array}$ \\
\hline 200 & Radon-220 & $56 \mathrm{~s}$ & 286.6 & $1.1 \times 10^{13}$ \\
\hline 205 & $\begin{array}{l}\text { Hydrogen-3 (tritiated } \\
\text { water [HTO]) }\end{array}$ & $12.3 \mathrm{yr}$ & 0.84 & $3.1 \times 10^{10}$ \\
\hline \multirow[t]{4}{*}{212} & Hydrogen-3 (HTO) & $12.3 \mathrm{yr}$ & 11.95 & $4.4 \times 10^{11}$ \\
\hline & $\begin{array}{l}\text { Hydrogen-3 (tritiated } \\
\text { hydrogen gas }[\mathrm{HT}] \text { ) }\end{array}$ & $12.3 \mathrm{yr}$ & 123.40 & $4.6 \times 10^{12}$ \\
\hline & Krypton-85 & $10.7 \mathrm{yr}$ & 1.04 & $3.9 \times 10^{10}$ \\
\hline & Radon-220 & $56 \mathrm{~s}$ & 0.15 & $5.6 \times 10^{9}$ \\
\hline \multirow[t]{8}{*}{350 (NBL) } & U ranium-234 & $2.4 \times 10^{5} \mathrm{yr}$ & $5.2 \times 10^{-6}$ & $1.9 \times 10^{4}$ \\
\hline & U ranium-238 & $4.5 \times 10^{9} \mathrm{yr}$ & $5.2 \times 10^{-6}$ & $1.9 \times 10^{4}$ \\
\hline & Plutonium-238 & $87.7 \mathrm{yr}$ & $7.7 \times 10^{-7}$ & $2.8 \times 10^{4}$ \\
\hline & Plutonium-239 & $2.4 \times 10^{4} \mathrm{yr}$ & $2.7 \times 10^{-6}$ & $1.0 \times 10^{5}$ \\
\hline & Plutonium-240 & $6.6 \times 10^{4} \mathrm{yr}$ & $1.4 \times 10^{-6}$ & $5.2 \times 10^{4}$ \\
\hline & Plutonium-241 & $14.4 \mathrm{yr}$ & $7.2 \times 10^{-5}$ & $2.7 \times 10^{6}$ \\
\hline & Plutonium-242 & $3.76 \times 10^{5} \mathrm{yr}$ & $4.1 \times 10^{-9}$ & $1.5 \times 10^{2}$ \\
\hline & Plutonium-244 & $8.0 \times 10^{7} \mathrm{yr}$ & $1.7 \times 10^{-10}$ & $6.3 \times 10^{0}$ \\
\hline \multirow[t]{2}{*}{375 (IPNS) } & Carbon-11 & $20 \mathrm{~m}$ & 642.5 & $2.4 \times 10^{13}$ \\
\hline & A rgon-41 & $1.8 \mathrm{~h}$ & 9.9 & $3.7 \times 10^{11}$ \\
\hline \multirow[t]{3}{*}{ 411/415 (APS) } & Carbon-11 & $20 \mathrm{~m}$ & 0.14 & $5.2 \times 10^{9}$ \\
\hline & Nitrogen-13 & $10 \mathrm{~m}$ & 3.8 & $1.4 \times 10^{11}$ \\
\hline & Oxygen-15 & $122 \mathrm{~s}$ & 0.4 & $1.5 \times 10^{10}$ \\
\hline
\end{tabular}




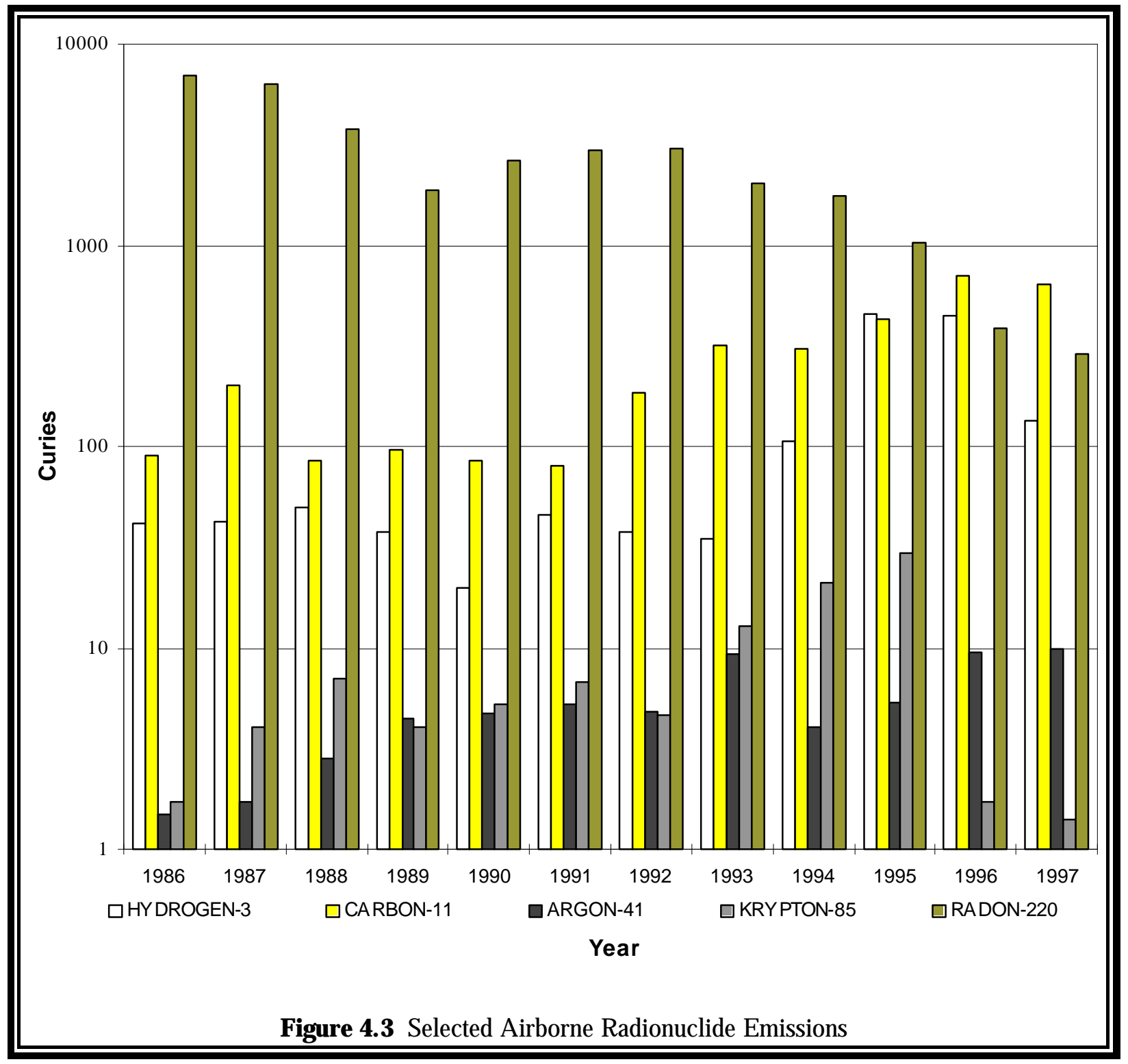

uranium concentrations were determined by alpha spectrometry by using uranium-236 as an isotopic tracer.

ANL-E wastewater is discharged into Sawmill Creek, which runs through the ANL-E grounds, drains surface water from much of the site, and flows into the Des Plaines River about $500 \mathrm{~m}$ (1,600 ft) downstream from the A N L-E wastewater outfall. Sawmill Creek was sampled upstream from the ANL-E site and downstream from the wastewater outfall to determine whether radioactivity was added to the stream by ANL-E wastewater or surface drainage. The sampling 


\section{ENVIRONMENTAL RADIOLOGICAL PROGRAM INFORMATION}

locations are shown in Figure 1.1. Below the wastewater outfall, daily samples were collected. Equal portions of the daily samples collected each week were combined and analyzed to obtain an average weekly concentration. U pstream of the site, samples were collected once a month and were analyzed for the same radionuclides measured in the below-outfall samples.

Table 4.5 gives the annual summaries of the results obtained for Sawmill Creek. Comparison of the results and $95 \%$ confidence levels of the averages for the two sampling locations shows that the following radionuclides found in the creek water can be attributed to ANL-E operations: hydrogen-3, strontium-90, plutonium-239, and americium-241; and occasionally neptunium-237, plutonium-238, and curium-244 and/or californium-249. The percentage of individual samples containing activity attributable to ANL-E was $36 \%$ for hydrogen-3, 100\% for strontium-90, 94\% for plutonium-239, and $80 \%$ for americium-241. The concentrations of all these nuclides are low and at a small fraction of DOE limits. If the concentrations of the radionuclides listed in Table 4.5 were increased by a factor of five, which approximates the effect of the dilution by Sawmill Creek on the ANL-E effluent water, the concentrations would still be well below the DOE limits. This demonstrates compliance with DOE Order $5400.5^{12}$ for use of the Best A vailable Technology (BAT) for release of liquid effluents.

During the early weeks in May, approximately 75,000 L (20,000 gal) of water was discharged from the Building 330 fuel storage pool as part of the $D \& D$ of the CP-5 reactor. A lthough no fuel had been stored in the pool for many years, the pool water contained elevated levels of hydrogen-3. Examination of the monitoring data in Sawmill Creek during this time period indicated measurable levels of hydrogen-3, up to $530 \mathrm{pCi} / \mathrm{L}$, and very low concentrations of cobalt-60, up to $1.7 \mathrm{pCi} / \mathrm{L}$. The total estimated hydrogen-3 discharge during this release was $0.11 \mathrm{Ci}$.

Liquid wastewater from buildings or facilities that use or process radioactive materials are collected in retention tanks. When a tank is full, it is sampled and analyzed for alpha and beta radioactivity. If the radioactivity exceeds the release limits, the tank is processed by evaporation and the residue is disposed of as solid LLW. If the radioactivity is below the release limits, the 
TABLE 4.5

Radionuclides in Sawmill Creek Water, 1997

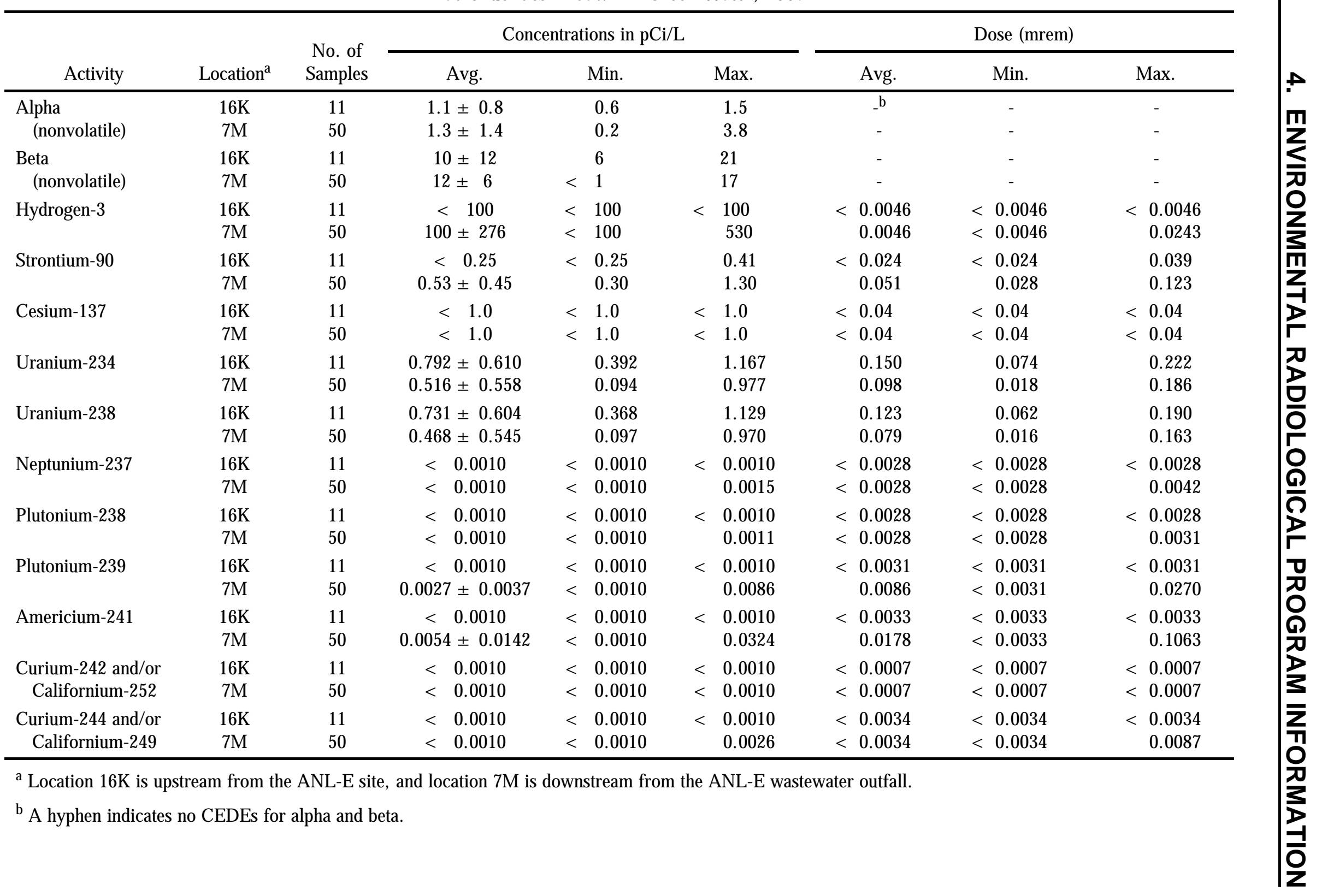


wastewater is conveyed to the laboratory WTP in dedicated pipes to waste storage tanks. The release limits are based on the $D C G s$ for plutonium-239 $(0.03 \mathrm{pCi} / \mathrm{mL})$ for alpha activity and for strontium-90 $(1.0 \mathrm{pCi} / \mathrm{mL})$ for beta activity. These radionuclides were selected because of their potential for release and their conservative allowable limits in the environment. The effluent monitoring program documents that no liquid releases above the DCGs have occurred and reinforces the demonstration of compliance with the use of BAT as required by DOE Order $5400.5 .^{12}$

At location $7 \mathrm{M}$, below the ANL-E outfall, the annual average concentrations of most measured radionuclides were similar to recent annual averages. All the annual averages were well below the applicable standards. The annual total radioactive effluent discharged to the creek in A NL-E wastewater can be estimated from the average net concentrations and the volume of water carried by the creek. These totals are presented in Table 4.6.

On the basis of the results of the Storm Water Characterization Study (see Section 2.2.2), two perimeter surface water locations were identified that contained measurable levels of radionuclides. They were south of the $319 \mathrm{~A}$ rea, Location 7J, and south of the $800 \mathrm{~A}$ rea L andfill, L ocation 11D (see Figure 1.1). Samples were scheduled to be collected quarterly and analyzed for hydrogen-3 and strontium-90 and by gamma-ray spectrometry. The results are presented in Table 4.7.

TABLE 4.6

Total Radioactivity Released to Sawmill Creek, 1997

\begin{tabular}{lcr}
\hline \multicolumn{1}{c}{ Radionuclide } & Released (Ci) & Percent \\
\hline Hydrogen-3 & 0.724 & 99.6 \\
Strontium-90 & 0.0026 & 0.4 \\
Plutonium-239 & 0.00002 & $<0.1$ \\
A mericium-241 & 0.00004 & $<0.1$ \\
Total & 0.727 & \\
\hline
\end{tabular}




\section{ENVIRONMENTAL RADIOLOGICAL PROGRAM INFORMATION}

TABLE 4.7

Radionuclides in Storm Water Outfalls, 1997

(Concentrations in $\mathrm{pCi} / \mathrm{L}$ )

\begin{tabular}{lcccc}
\hline Date Collected & $\begin{array}{c}\text { Location 7J } \\
\text { Hydrogen-3 }\end{array}$ & $\begin{array}{c}\text { Location 7J } \\
\text { Strontium-90 }\end{array}$ & $\begin{array}{c}\text { Location 7J } \\
\text { Cesium-137 }\end{array}$ & $\begin{array}{c}\text { Location 11D } \\
\text { Hydrogen-3 }\end{array}$ \\
\hline January 22, 1997 & 12,380 & 4.1 & $<1$ & $<100$ \\
A pril 1997 & Dry & Dry & Dry & Dry \\
A ugust 11, 1997 & $<100$ & 1.8 & $<1$ & $<100$ \\
December 22, 1997 & 486 & 5.6 & $<1$ & Dry \\
\hline
\end{tabular}

The source of the radionuclides at L ocation 7J appears to be leachate from the $319 \mathrm{~A}$ rea L andfill. A subsurface barrier wall and leachate collection system were constructed south of the 319 Landfill in November 1995 and became operational in 1996. The hydrogen-3 at Location 11D is probably also from the leachate; the decrease in the concentration from earlier years is due to the completion of the clay cap on the $800 \mathrm{~A}$ rea L andfill in the fall of 1993.

Because Sawmill Creek empties into the Des Plaines River, which in turn flows into the Illinois River, data on the radioactivity in the two rivers are important in assessing the contribution of ANL-E wastewater to environmental radioactivity. The Des Plaines River was sampled twice a month below, and once a month above, the mouth of Sawmill Creek to determine whether the radioactivity in the creek had any effect on the radioactivity in the river.

Table 4.8 presents annual summaries of the results obtained for these two locations. The average nonvolatile alpha, beta, and uranium concentrations in the river were very similar to past averages and remained in the normal range. Results were quite similar above and below the creek for all radionuclides, because the activity in Sawmill Creek was reduced by dilution to the point that it was not detectable in the Des Plaines River. The average nonvolatile alpha and beta activities, $1.0 \mathrm{pCi} / \mathrm{L}$ and $11.0 \mathrm{pCi} / \mathrm{L}$, respectively, of 22 off-site surface water samples collected in 1997, were similar to the levels found in previous years. The hydrogen-3 concentration in these surface water samples averaged $26 \mathrm{pCi} / \mathrm{L}$. 
TABLE 4.8

Radionuclides in Des Plaines River Water, 1997

\begin{tabular}{|c|c|c|c|c|c|c|c|c|c|}
\hline \multirow[b]{2}{*}{ A ctivity } & \multirow[b]{2}{*}{ Location $^{\mathrm{a}}$} & \multirow{2}{*}{$\begin{array}{l}\text { No. of } \\
\text { Samples }\end{array}$} & \multicolumn{4}{|c|}{ Concentrations in $\mathrm{pCi} / \mathrm{L}$} & \multicolumn{3}{|c|}{ Dose (mrem) } \\
\hline & & & Avg. & \multicolumn{2}{|r|}{ Min. } & Max. & Avg. & M in. & M ax. \\
\hline \multirow{2}{*}{$\begin{array}{l}\text { A lpha } \\
\quad \text { (nonvolatile) }\end{array}$} & $A$ & 12 & \multirow{2}{*}{$\begin{array}{l}1.2 \pm 1.0 \\
1.2 \pm 0.9\end{array}$} & \multirow{2}{*}{\multicolumn{2}{|c|}{$\begin{array}{l}0.5 \\
0.4\end{array}$}} & \multirow{2}{*}{$\begin{array}{l}1.9 \\
1.9\end{array}$} & $-b$ & - & - \\
\hline & B & 24 & & & & & - & - & - \\
\hline \multirow{2}{*}{$\begin{array}{l}\text { Beta } \\
\quad \text { (nonvolatile) }\end{array}$} & $A$ & 12 & \multirow{2}{*}{$\begin{array}{l}15 \pm 9 \\
16 \pm 9\end{array}$} & & 9 & \multirow{2}{*}{$\begin{array}{l}22 \\
24\end{array}$} & - & \multirow{2}{*}{ - } & \multirow{2}{*}{-} \\
\hline & B & 24 & & & 9 & & - & & \\
\hline \multirow[t]{2}{*}{ Hydrogen-3 } & $A$ & 12 & \multirow{2}{*}{$\begin{array}{l}<100 \\
<100\end{array}$} & & $<100$ & \multirow{2}{*}{$\begin{array}{l}<100 \\
<100\end{array}$} & $<0.0046$ & $<0.0046$ & $<0.0046$ \\
\hline & B & 24 & & & $<100$ & & $<0.0046$ & $<0.0046$ & $<0.0046$ \\
\hline \multirow[t]{2}{*}{ Strontium-90 } & $A$ & 12 & \multirow{2}{*}{$\begin{array}{l}0.30 \pm 0.12 \\
0.31 \pm 0.15\end{array}$} & $<$ & 0.25 & \multirow{2}{*}{$\begin{array}{l}0.38 \\
0.57\end{array}$} & 0.029 & $<0.024$ & 0.036 \\
\hline & B & 24 & & $<$ & 0.25 & & 0.030 & $<0.024$ & 0.054 \\
\hline \multirow[t]{2}{*}{ U ranium-234 } & $A$ & 12 & \multirow{2}{*}{$\begin{array}{l}0.557 \pm 0.338 \\
0.529 \pm 0.386\end{array}$} & & 0.285 & 0.836 & 0.106 & 0.054 & 0.159 \\
\hline & B & 24 & & & 0.204 & 0.854 & 0.101 & 0.039 & 0.162 \\
\hline U ranium-238 & $A$ & 12 & $0.466 \pm 0.303$ & & 0.239 & 0.756 & 0.078 & 0.040 & 0.127 \\
\hline & B & 24 & $0.451 \pm 0.354$ & & 0.163 & 0.871 & 0.076 & 0.027 & 0.146 \\
\hline N eptunium-237 & $A$ & 12 & $<0.0010$ & $<$ & 0.0010 & $<0.0010$ & $<0.0028$ & $<0.0028$ & $<0.0028$ \\
\hline & B & 12 & $<0.0010$ & $<$ & 0.0010 & $<0.0010$ & $<0.0028$ & $<0.0028$ & $<0.0028$ \\
\hline Plutonium-238 & $A$ & 12 & $<0.0010$ & $<$ & 0.0010 & $<0.0010$ & $<0.0028$ & $<0.0028$ & $<0.0028$ \\
\hline & B & 12 & $<0.0010$ & $<$ & 0.0010 & 0.0013 & $<0.0028$ & $<0.0028$ & 0.0035 \\
\hline Plutonium-239 & $A$ & 12 & $<0.0010$ & $<$ & 0.0010 & 0.0064 & $<0.0031$ & $<0.0031$ & 0.0199 \\
\hline & B & 12 & $<0.0010$ & $<$ & 0.0010 & 0.0011 & $<0.0031$ & $<0.0031$ & 0.0034 \\
\hline A mericium-241 & $A$ & 12 & $<0.0010$ & $<$ & 0.0010 & 0.0010 & $<0.0033$ & $<0.0033$ & $<0.0033$ \\
\hline & B & 12 & $<0.0010$ & $<$ & 0.0010 & $<0.0010$ & $<0.0033$ & $<0.0033$ & $<0.0033$ \\
\hline Curium-242 and/or & $A$ & 12 & $<0.0010$ & $<$ & 0.0010 & $<0.0010$ & $<0.0007$ & $<0.0007$ & $<0.0007$ \\
\hline Californium-252 & B & 12 & $<0.0010$ & $<$ & 0.0010 & $<0.0010$ & $<0.0007$ & $<0.0007$ & $<0.0007$ \\
\hline Curium-244 and/or & $A$ & 12 & $<0.0010$ & $<$ & 0.0010 & 0.0010 & $<0.0034$ & $<0.0034$ & $<0.0034$ \\
\hline Californium-249 & B & 12 & $<0.0010$ & $<$ & 0.0010 & 0.0010 & $<0.0034$ & $<0.0034$ & $<0.0034$ \\
\hline
\end{tabular}

a L ocation A near Willow Springs is upstream, and location B near Lemont is downstream from the mouth of Sawmill Creek. See Figure 1.2.

b A hyphen indicates no CEDEs for alpha and beta. 
The radioactivity levels in samples of Illinois River water, as shown in Table 4.9, were similar to those found previously at these same locations. No radioactivity originating at A NL-E could be detected in the Des Plaines or Illinois Rivers. The elevated hydrogen-3 levels appear to be due to discharges from the Dresden nuclear power station complex.

\subsection{Soil, Grass, and Bottom Sediment}

The radioactive content of soil, grass, and bottom sediment was measured at the site perimeter and off the site. The purpose of the off-site sampling was to measure deposition for comparison with perimeter samples and with results obtained by other organizations for samples collected at large distances from nuclear installations. Such comparisons are useful in determining whether the radioactivity of soil near ANL-E is normal. For this purpose, site-selection criteria and sample collection and sample preparation techniques recommended by the ASTM were used. ${ }^{17,18}$ Sites were selected in several directions and at various distances from ANL-E. Each site was selected on the basis that the soil appeared, or was known to have been, undisturbed for a number of years. A ttempts were made to select open, level, grassy areas that were mowed at reasonable intervals. Public parks were selected when available.

As part of the QA program, replicate samples were taken from $10 \%$ of the locations. The EMS data management system has been programmed to schedule the replicate samples on a rotating basis. The following tables show paired results from the same location. Comparison of the analytical data in these tables of pairs of samples collected at the same location provides a measure of the heterogeneity of the media, that is, soil, grass, or bottom sediment.

Each soil sample consisted of 10 cores, totaling $864 \mathrm{~cm}^{2}$ (134 in. ${ }^{2}$ ) in area by $5 \mathrm{~cm}(2 \mathrm{in}$.) deep. Through 1976, samples were collected down to $30 \mathrm{~cm}$ (12 in.) to measure total deposition. The results of five years of sample collection at this depth established the total deposition in the ANL-E environment. Reducing the sampling depth to $5 \mathrm{~cm}(2 \mathrm{in}$.) made the analysis more sensitive to changes in current deposition. The grass samples were obtained by collecting the grass from a $1-\mathrm{m}^{2}\left(10-\mathrm{ft}^{2}\right)$ area in the immediate vicinity of a soil sample. A grab sample technique was used to obtain bottom sediments from water bodies. After drying, grinding, and 
TABLE 4.9

Radionuclides in Illinois River Water, 1997

Concentrations in $\mathrm{PCi} / \mathrm{L}$

\begin{tabular}{|c|c|c|c|c|c|c|c|}
\hline $\begin{array}{c}\text { Date } \\
\text { Collected }\end{array}$ & Location & Alpha ${ }^{a}$ & Beta $^{a}$ & Hydrogen-3 & U ranium-234 & U ranium-238 & Plutonium-239a \\
\hline May 8 & M cK inley W oods Park, IL & $0.8 \pm 0.4$ & $13.8 \pm 0.4$ & $<100$ & $0.46 \pm 0.05$ & $0.38 \pm 0.04$ & $<0.001$ \\
\hline May 8 & Dresden L ock \& Dam, IL & $1.0 \pm 0.4$ & $11.0 \pm 0.4$ & $430 \pm 50$ & $0.53 \pm 0.05$ & $0.48 \pm 0.04$ & $<0.001$ \\
\hline May 8 & M orris, IL & $0.9 \pm 0.3$ & $9.2 \pm 0.3$ & $384 \pm 49$ & $0.59 \pm 0.11$ & $0.44 \pm 0.09$ & $-b$ \\
\hline May 8 & Starved Rock State Park, IL & $1.1 \pm 0.3$ & $7.3 \pm 0.3$ & $<100$ & $0.72 \pm 0.13$ & $0.54 \pm 0.10$ & - \\
\hline May 8 & Starved Rock State Park, IL & $1.3 \pm 0.4$ & $7.6 \pm 0.3$ & $<100$ & $0.61 \pm 0.12$ & $0.64 \pm 0.11$ & - \\
\hline September 30 & M cK inley Woods Park, IL & $1.1 \pm 0.3$ & $12.8 \pm 0.4$ & $<100$ & $0.17 \pm 0.07$ & $0.16 \pm 0.05$ & $<0.001$ \\
\hline September 30 & Dresden L ock \& Dam, IL & $0.6 \pm 0.3$ & $11.3 \pm 0.3$ & $<100$ & $0.32 \pm 0.08$ & $0.23 \pm 0.06$ & $<0.001$ \\
\hline September 30 & Dresden L ock \& Dam, IL & $0.6 \pm 0.3$ & $10.6 \pm 0.3$ & $<100$ & $0.23 \pm 0.07$ & $0.16 \pm 0.06$ & $<0.001$ \\
\hline September 30 & M orris, IL & $0.2 \pm 0.2$ & $9.6 \pm 0.3$ & $126 \pm 44$ & $0.28 \pm 0.08$ & $0.22 \pm 0.06$ & - \\
\hline September 30 & Starved Rock State Park, IL & $0.7 \pm 0.2$ & $8.2 \pm 0.3$ & $<100$ & $0.26 \pm 0.07$ & $0.27 \pm 0.06$ & - \\
\hline
\end{tabular}

a $N$ onvolatile activity.

${ }^{\mathrm{b}} \mathrm{A}$ hyphen indicates no analysis performed. 
mixing 100-g portions of each; soil, bottom sediment, and grass samples were analyzed by the same methods described in Section 4.2 for air filter residues. The plutonium and americium were separated from the same $10-\mathrm{g}$ aliquot of soil. Results are given in terms of the oven-dried $\left(110^{\circ} \mathrm{C}\right.$ $\left.\left[230^{\circ} \mathrm{F}\right]\right)$ weight.

The results for the gamma-ray-emitting nuclides in soil are presented in Table 4.10. Intermediate half-life fission products such as ruthenium-103, iodine-131, cesium-134, and barium-140, which were reported in 1986, have decayed to below their detection limits, and no evidence of Chernobyl fallout is apparent. The cesium-137 levels were similar to those found over the past several years and represent an accumulation from nuclear tests over a period of many years. The annual average concentrations for the perimeter and off-site samples were similar. The plutonium and americium concentrations are given in Table 4.11. The range and average concentrations of plutonium and americium in soil were similar at both the perimeter and off-site sampling points. For fallout americium-241 in soil, about $10 \%$ is due to direct deposition, while about $90 \%$ is due to the decay of previously deposited plutonium-241. The americium-241/ plutonium-239 ratio is consistent with the current estimated value of 0.35 for this ratio in falloutderived material. ${ }^{19}$

The lack of measurable radionuclides in years of soil sample results indicates that radionuclides in soil contribute a very small potential dose to the public. Therefore, effective January 1, 1998, soil sampling will be discontinued.

Table 4.12 gives the radionuclide concentrations measured in grass. The annual averages and concentration ranges were similar at the perimeter and off-site locations and were similar to those of previous years, which indicates that there is no contribution from ANL-E operations. In terms of deposition, the plutonium-239 concentration was a factor of about $10^{4}$ less in the grass than in the soil from the same location. For the same reasons that apply to soil, grass sampling will be discontinued effective January 1, 1998.

Table 4.13 gives the results of analyses of bottom sediment samples for gamma-ray emitters and transuranics. The annual off-site averages were in the same range found in off-site 
TABLE 4.10

Gamma-Ray-E mitting Radionuclides in Soil, 1997

(Concentrations in $\mathrm{pC} / \mathrm{g}$ )

\begin{tabular}{|c|c|c|c|c|c|c|}
\hline $\begin{array}{c}\text { Date } \\
\text { Collected }\end{array}$ & Location & Potassium-40 & Cesium-137 & Radium-226 & Thorium-228 & Thorium-232 \\
\hline & Perimeter ${ }^{a}$ & & & & & \\
\hline M ay 19 & $10 \mathrm{P}$ & $15.71 \pm 0.63$ & $0.60 \pm 0.03$ & $0.78 \pm 0.06$ & $0.81 \pm 0.04$ & $0.65 \pm 0.08$ \\
\hline M ay 19 & $14 \mathrm{E}$ & $17.62 \pm 0.65$ & $0.96 \pm 0.04$ & $0.92 \pm 0.06$ & $1.02 \pm 0.04$ & $0.68 \pm 0.09$ \\
\hline M ay 19 & $14 \mathrm{~N}$ & $19.03 \pm 0.68$ & $0.14 \pm 0.02$ & $1.16 \pm 0.06$ & $1.17 \pm 0.05$ & $0.92 \pm 0.09$ \\
\hline M ay 19 & $4 \mathrm{EF}$ & $17.71 \pm 0.66$ & $0.52 \pm 0.03$ & $0.96 \pm 0.06$ & $1.02 \pm 0.04$ & $0.89 \pm 0.09$ \\
\hline M ay 19 & $7 \mathrm{EF}$ & $19.69 \pm 0.68$ & $0.49 \pm 0.03$ & $1.01 \pm 0.06$ & $1.20 \pm 0.04$ & $0.79 \pm 0.09$ \\
\hline M ay 19 & $14 \mathrm{E}$ & $18.15 \pm 0.66$ & $0.85 \pm 0.04$ & $1.04 \pm 0.06$ & $0.96 \pm 0.04$ & $0.73 \pm 0.09$ \\
\hline October 3 & $13 D$ & $19.04 \pm 0.67$ & $0.53 \pm 0.03$ & $0.92 \pm 0.06$ & $1.12 \pm 0.04$ & $0.82 \pm 0.09$ \\
\hline October 3 & $13 \mathrm{~N}$ & $16.38 \pm 0.56$ & $1.14 \pm 0.04$ & $0.95 \pm 0.05$ & $0.82 \pm 0.04$ & $0.67 \pm 0.07$ \\
\hline October 3 & $15 \mathrm{H}$ & $16.52 \pm 0.64$ & $0.23 \pm 0.03$ & $1.11 \pm 0.06$ & $1.04 \pm 0.04$ & $0.77 \pm 0.09$ \\
\hline October 3 & $7 M$ & $17.57 \pm 0.64$ & $0.68 \pm 0.03$ & $1.14 \pm 0.06$ & $0.82 \pm 0.04$ & $0.64 \pm 0.08$ \\
\hline October 3 & $8 G$ & $21.21 \pm 0.70$ & $0.08 \pm 0.02$ & $1.12 \pm 0.06$ & $1.06 \pm 0.04$ & $0.87 \pm 0.09$ \\
\hline \multirow[t]{3}{*}{ October 3} & $7 \mathrm{M}$ & $14.88 \pm 0.60$ & $0.58 \pm 0.03$ & $0.74 \pm 0.05$ & $0.62 \pm 0.04$ & $0.63 \pm 0.08$ \\
\hline & A verage & $17.79 \pm 3.93$ & $0.57 \pm 0.70$ & $0.99 \pm 0.30$ & $0.97 \pm 0.38$ & $0.75 \pm 0.23$ \\
\hline & Off site & & & & & \\
\hline M ay 8 & Dresden L ock \& Dam, IL & $17.55 \pm 0.65$ & $0.55 \pm 0.03$ & $1.10 \pm 0.06$ & $1.03 \pm 0.04$ & $0.90 \pm 0.09$ \\
\hline M ay 8 & M cK inley W oods Park, IL & $15.42 \pm 0.63$ & $0.48 \pm 0.03$ & $0.87 \pm 0.06$ & $1.03 \pm 0.04$ & $0.87 \pm 0.09$ \\
\hline M ay 8 & Morris, IL & $13.79 \pm 0.60$ & $0.16 \pm 0.02$ & $0.73 \pm 0.06$ & $0.87 \pm 0.04$ & $0.74 \pm 0.08$ \\
\hline M ay 8 & Morris, IL & $15.15 \pm 0.62$ & $0.16 \pm 0.02$ & $0.84 \pm 0.06$ & $1.00 \pm 0.04$ & $0.81 \pm 0.09$ \\
\hline M ay 13 & M cCormick W oods, Brookfield, IL & $18.62 \pm 0.67$ & $0.22 \pm 0.03$ & $1.24 \pm 0.07$ & $1.02 \pm 0.04$ & $0.81 \pm 0.09$ \\
\hline M ay 13 & Bemis W oods, W estern Springs, IL & $22.21 \pm 0.72$ & $0.35 \pm 0.03$ & $1.66 \pm 0.07$ & $1.24 \pm 0.05$ & $0.83 \pm 0.09$ \\
\hline M ay 13 & M cCormick W oods, Brookfield, IL & $19.02 \pm 0.68$ & $0.28 \pm 0.03$ & $1.16 \pm 0.06$ & $1.08 \pm 0.04$ & $0.87 \pm 0.09$ \\
\hline September 29 & Orland Park, IL & $18.15 \pm 0.58$ & $0.58 \pm 0.03$ & $1.26 \pm 0.05$ & $0.93 \pm 0.04$ & $0.69 \pm 0.07$ \\
\hline September 29 & Palos Hills, IL & $18.27 \pm 0.65$ & $0.27 \pm 0.03$ & $1.07 \pm 0.06$ & $1.12 \pm 0.04$ & $0.81 \pm 0.09$ \\
\hline September 29 & Orland Park, IL & $18.72 \pm 0.66$ & $0.78 \pm 0.04$ & $1.15 \pm 0.06$ & $0.96 \pm 0.04$ & $0.72 \pm 0.09$ \\
\hline September 30 & Channahon, IL & $19.78 \pm 0.69$ & $0.26 \pm 0.03$ & $1.31 \pm 0.07$ & $1.36 \pm 0.05$ & $1.09 \pm 0.10$ \\
\hline September 30 & Starved Rock State Park, IL & $10.80 \pm 0.52$ & $0.19 \pm 0.02$ & $0.69 \pm 0.05$ & $0.59 \pm 0.04$ & $0.48 \pm 0.08$ \\
\hline \multirow[t]{2}{*}{ September 30} & Starved R ock State Park, IL & $7.61 \pm 0.38$ & $0.10 \pm 0.02$ & $0.47 \pm 0.04$ & $0.44 \pm 0.03$ & $0.33 \pm 0.06$ \\
\hline & A verage & $16.55 \pm 8.62$ & $0.34 \pm 0.44$ & $1.04 \pm 0.69$ & $0.98 \pm 0.53$ & $0.77 \pm 0.41$ \\
\hline
\end{tabular}

${ }^{a}$ The perimeter locations are given in terms of the grid coordinates in Figure 1.1. 
TABLE 4.11

Transuranics in Soil, 1997

\begin{tabular}{|c|c|c|c|c|c|c|c|c|c|}
\hline $\begin{array}{c}\text { Date } \\
\text { Collected }\end{array}$ & Location & $\begin{array}{l}\text { Plutonium-238 } \\
\text { (fCi/g) }\end{array}$ & $\begin{array}{l}\text { Plutonium-238 } \\
\qquad\left(\mathrm{nCi} / \mathrm{m}^{2}\right)\end{array}$ & $\begin{array}{l}\text { Plutonium-239 } \\
\text { (fCi/g) }\end{array}$ & $\begin{array}{l}\text { Plutonium-239 } \\
\qquad\left(\mathrm{nCi} / \mathrm{m}^{2}\right)\end{array}$ & $\begin{array}{l}\text { Pu-238/ } \\
\text { Pu-239 }\end{array}$ & $\begin{array}{l}\text { A mericium-241 } \\
(\mathrm{fCi} / \mathrm{g})\end{array}$ & $\begin{array}{l}\text { A mericium-241 } \\
\left(\mathrm{nCi} / \mathrm{m}^{2}\right)\end{array}$ & $\begin{array}{l}\text { A m-241/ } \\
\text { Pu-239 }\end{array}$ \\
\hline & Perimeter $^{a}$ & & & & & & & & \\
\hline M ay 19 & $10 P$ & $0.6 \pm 0.3$ & $0.026 \pm 0.011$ & $17.4 \pm 1.5$ & $0.706 \pm 0.063$ & 0.036 & $6.6 \pm 1.4$ & $0.269 \pm 0.057$ & 0.381 \\
\hline M ay 19 & $14 \mathrm{E}$ & $1.0 \pm 0.5$ & $0.035 \pm 0.015$ & $24.5 \pm 2.5$ & $0.822 \pm 0.085$ & 0.043 & $9.5 \pm 1.1$ & $0.319 \pm 0.039$ & 0.388 \\
\hline M ay 19 & $14 N$ & $0.1 \pm 0.1$ & $0.006 \pm 0.006$ & $4.0 \pm 0.7$ & $0.201 \pm 0.036$ & 0.031 & $1.4 \pm 0.6$ & $0.068 \pm 0.033$ & 0.338 \\
\hline M ay 19 & $4 \mathrm{EF}$ & $0.7 \pm 0.3$ & $0.019 \pm 0.010$ & $16.0 \pm 1.8$ & $0.472 \pm 0.054$ & 0.041 & $5.8 \pm 1.0$ & $0.170 \pm 0.030$ & 0.361 \\
\hline M ay 19 & $7 \mathrm{EF}$ & $0.8 \pm 0.4$ & $0.031 \pm 0.015$ & $12.0 \pm 1.6$ & $0.449 \pm 0.062$ & 0.069 & $3.3 \pm 0.8$ & $0.122 \pm 0.031$ & 0.273 \\
\hline M ay 19 & $14 \mathrm{E}$ & $1.0 \pm 0.3$ & $0.040 \pm 0.014$ & $24.5 \pm 1.9$ & $0.975 \pm 0.077$ & 0.042 & $9.2 \pm 1.6$ & $0.366 \pm 0.064$ & 0.375 \\
\hline October 3 & $13 D$ & $0.2 \pm 0.3$ & $0.006 \pm 0.009$ & $10.8 \pm 1.2$ & $0.368 \pm 0.042$ & 0.017 & $4.5 \pm 1.2$ & $0.155 \pm 0.041$ & 0.420 \\
\hline October 3 & $13 N$ & $0.9 \pm 0.4$ & $0.042 \pm 0.019$ & $27.4 \pm 2.6$ & $1.298 \pm 0.122$ & 0.032 & $9.6 \pm 1.4$ & $0.456 \pm 0.068$ & 0.351 \\
\hline October 3 & $15 \mathrm{H}$ & $0.3 \pm 0.3$ & $0.014 \pm 0.014$ & $6.3 \pm 1.2$ & $0.338 \pm 0.067$ & 0.040 & $2.7 \pm 0.7$ & $0.143 \pm 0.036$ & 0.421 \\
\hline October 3 & $7 \mathrm{M}$ & $0.6 \pm 0.3$ & $0.030 \pm 0.014$ & $16.0 \pm 1.5$ & $0.781 \pm 0.075$ & 0.039 & $5.9 \pm 1.0$ & $0.288 \pm 0.051$ & 0.369 \\
\hline October 3 & $8 \mathrm{G}$ & $0.3 \pm 0.2$ & $0.010 \pm 0.008$ & $2.5 \pm 0.6$ & $0.092 \pm 0.022$ & 0.105 & $1.0 \pm 0.6$ & $0.036 \pm 0.021$ & 0.395 \\
\hline \multirow[t]{3}{*}{ October 3} & $7 \mathrm{M}$ & $0.6 \pm 0.3$ & $0.027 \pm 0.016$ & $21.0 \pm 2.1$ & $1.013 \pm 0.101$ & 0.026 & $5.3 \pm 1.0$ & $0.253 \pm 0.050$ & 0.250 \\
\hline & A verage & $0.6 \pm 0.2$ & $0.024 \pm 0.008$ & $15.2 \pm 5.3$ & $0.626 \pm 0.232$ & 0.043 & $5.4 \pm 1.9$ & $0.220 \pm 0.080$ & 0.360 \\
\hline & Off site & & & & & & & & \\
\hline May 8 & Dresden Lock \& Dam, IL & $0.4 \pm 0.3$ & $0.022 \pm 0.017$ & $9.0 \pm 1.4$ & $0.498 \pm 0.080$ & 0.045 & $3.3 \pm 0.8$ & $0.185 \pm 0.044$ & 0.372 \\
\hline May 8 & M cK inley Woods Park, IL & $0.4 \pm 0.2$ & $0.015 \pm 0.008$ & $14.3 \pm 1.4$ & $0.507 \pm 0.050$ & 0.029 & $5.1 \pm 1.1$ & $0.182 \pm 0.040$ & 0.359 \\
\hline May 8 & Morris, IL & $0.2 \pm 0.3$ & $0.014 \pm 0.014$ & $4.2 \pm 1.0$ & $0.226 \pm 0.054$ & 0.060 & $1.3 \pm 0.4$ & $0.071 \pm 0.021$ & 0.313 \\
\hline May 8 & Morris, IL & $<0.1$ & $<0.001$ & $4.3 \pm 1.1$ & $0.154 \pm 0.039$ & 0.005 & $2.0 \pm 0.5$ & $0.074 \pm 0.020$ & 0.477 \\
\hline M ay 13 & $\begin{array}{l}\text { M cCormick Woods, } \\
\text { Brookfield, IL }\end{array}$ & $0.2 \pm 0.2$ & $0.007 \pm 0.007$ & $6.7 \pm 1.0$ & $0.279 \pm 0.040$ & 0.024 & $2.2 \pm 0.7$ & $0.090 \pm 0.029$ & 0.324 \\
\hline M ay 13 & $\begin{array}{l}\text { Bemis W oods, } \\
\text { W estern Springs, IL }\end{array}$ & $0.5 \pm 0.3$ & $0.018 \pm 0.013$ & $9.4 \pm 1.1$ & $0.373 \pm 0.044$ & 0.048 & $3.5 \pm 0.8$ & $0.140 \pm 0.030$ & 0.376 \\
\hline M ay 13 & $\begin{array}{l}\text { M cCormick Woods, } \\
\text { Brookfield, IL }\end{array}$ & $0.2 \pm 0.3$ & $0.011 \pm 0.015$ & $6.3 \pm 1.4$ & $0.281 \pm 0.061$ & 0.039 & $2.8 \pm 0.7$ & $0.127 \pm 0.030$ & 0.451 \\
\hline September 29 & Orland Park, IL & $0.8 \pm 0.3$ & $0.025 \pm 0.009$ & $27.0 \pm 2.0$ & $0.852 \pm 0.062$ & 0.030 & $5.3 \pm 1.1$ & $0.166 \pm 0.036$ & 0.195 \\
\hline September 29 & Palos Hills, IL & $0.3 \pm 0.2$ & $0.010 \pm 0.009$ & $6.6 \pm 1.3$ & $0.232 \pm 0.044$ & 0.041 & $2.4 \pm 0.7$ & $0.083 \pm 0.024$ & 0.358 \\
\hline September 29 & Orland Park, IL & $0.7 \pm 0.3$ & $0.021 \pm 0.009$ & $18.5 \pm 1.7$ & $0.578 \pm 0.055$ & 0.036 & $6.2 \pm 1.2$ & $0.194 \pm 0.037$ & 0.336 \\
\hline September 30 & Channahon, IL & $0.3 \pm 0.3$ & $0.020 \pm 0.017$ & $6.9 \pm 1.3$ & $0.397 \pm 0.076$ & 0.049 & $2.3 \pm 0.7$ & $0.135 \pm 0.041$ & 0.341 \\
\hline September 30 & Starved Rock State Park, IL & $<0.1$ & $0.004 \pm 0.005$ & $3.6 \pm 0.7$ & $0.150 \pm 0.030$ & 0.023 & $1.9 \pm 0.6$ & $0.080 \pm 0.026$ & 0.533 \\
\hline \multirow[t]{2}{*}{ September 30} & Starved Rock State Park, IL & $0.1 \pm 0.2$ & $0.005 \pm 0.007$ & $2.4 \pm 0.8$ & $0.095 \pm 0.031$ & 0.053 & $1.3 \pm 0.4$ & $0.053 \pm 0.016$ & 0.555 \\
\hline & A verage & $0.3 \pm 0.1$ & $0.013 \pm 0.005$ & $9.2 \pm 4.2$ & $0.355 \pm 0.128$ & 0.037 & $3.1 \pm 0.9$ & $0.122 \pm 0.030$ & 0.384 \\
\hline
\end{tabular}

a The perimeter locations are given in terms of grid coordinates in Figure 1.1. 


\section{ENVIRONMENTAL RADIOLOGICAL PROGRAM INFORMATION}

TABLE 4.12

Radionuclides in Grass, 1997

\begin{tabular}{|c|c|c|c|c|c|}
\hline $\begin{array}{c}\text { Date } \\
\text { Collected }\end{array}$ & Location & $\begin{array}{l}\text { Potassium-40 } \\
\quad(\mathrm{pCi} / \mathrm{g})\end{array}$ & $\begin{array}{l}\text { Cesium-137 } \\
\text { (fCi/g) }\end{array}$ & $\begin{array}{l}\text { Plutonium-239 } \\
\qquad(\mathrm{fC} \mathrm{i} / \mathrm{g})\end{array}$ & $\begin{array}{l}\text { Deposited } \\
\text { Plutonium-239 } \\
\left(\mathrm{pCi} / \mathrm{m}^{2}\right)\end{array}$ \\
\hline & Perimeter $^{a}$ & & & & \\
\hline M ay 19 & $10 \mathrm{P}$ & $33.93 \pm 0.66$ & $<10$ & $0.1 \pm 0.1$ & $0.01 \pm 0.01$ \\
\hline M ay 19 & $14 \mathrm{E}$ & $33.35 \pm 0.49$ & $12 \pm 9$ & $0.3 \pm 0.1$ & $0.04 \pm 0.01$ \\
\hline M ay 19 & $4 \mathrm{EF}$ & $39.16 \pm 0.71$ & $<10$ & $<0.1$ & $<0.01$ \\
\hline M ay 19 & $7 \mathrm{EF}$ & $22.10 \pm 0.42$ & $<10$ & $0.3 \pm 0.1$ & $0.04 \pm 0.01$ \\
\hline M ay 19 & $14 \mathrm{E}$ & $40.51 \pm 0.64$ & $13 \pm 16$ & $0.6 \pm 0.1$ & $0.08 \pm 0.01$ \\
\hline June 19 & $14 \mathrm{~N}$ & $31.86 \pm 0.48$ & $<10$ & $<0.1$ & $0.01 \pm 0.01$ \\
\hline October 3 & $13 \mathrm{D}$ & $9.30 \pm 0.40$ & $<10$ & $0.3 \pm 0.1$ & $0.03 \pm 0.01$ \\
\hline October 3 & $15 \mathrm{H}$ & $16.22 \pm 0.50$ & $17 \pm 17$ & $0.4 \pm 0.1$ & $0.04 \pm 0.01$ \\
\hline October 3 & $7 \mathrm{M}$ & $21.77 \pm 0.47$ & $<10$ & $<0.1$ & $0.01 \pm 0.01$ \\
\hline October 3 & $7 M$ & $18.38 \pm 0.40$ & $<10$ & $0.1 \pm 0.1$ & $0.02 \pm 0.01$ \\
\hline \multirow[t]{3}{*}{ October 3} & $13 \mathrm{~N}$ & $17.14 \pm 0.54$ & $17 \pm 14$ & $0.2 \pm 0.1$ & $0.02 \pm 0.01$ \\
\hline & A verage & $25.79 \pm 2.21$ & $<10$ & $0.2 \pm 0.1$ & $0.03 \pm 0.01$ \\
\hline & Off site & & & & \\
\hline May 8 & $\begin{array}{l}\text { M cCormick Woods, } \\
\text { Brookfield, IL }\end{array}$ & $13.33 \pm 0.53$ & $<10$ & $0.4 \pm 0.1$ & $0.02 \pm 0.01$ \\
\hline May 8 & Dresden Lock \& Dam, IL & $49.73 \pm 0.83$ & $32 \pm 16$ & $0.3 \pm 0.1$ & $0.03 \pm 0.01$ \\
\hline May 8 & M cKinley Woods Park, IL & $39.83 \pm 0.76$ & $<10$ & $<0.1$ & $<0.01$ \\
\hline May 8 & Morris, IL & $29.58 \pm 0.67$ & $<10$ & $0.1 \pm 0.1$ & $<0.01$ \\
\hline May 8 & $\begin{array}{l}\text { M cCormick Woods, } \\
\text { Brookfield, IL }\end{array}$ & $13.79 \pm 0.54$ & $11 \pm 17$ & $0.2 \pm 0.1$ & $0.01 \pm 0.01$ \\
\hline May 8 & Morris, IL & $27.25 \pm 0.62$ & $<10$ & $0.2 \pm 0.1$ & $0.01 \pm 0.01$ \\
\hline M ay 13 & $\begin{array}{l}\text { Bemis W oods, } \\
\text { W estern Springs, IL }\end{array}$ & $31.43 \pm 0.71$ & $<10$ & $<0.1$ & $<0.01$ \\
\hline September 29 & Orland Park, IL & $23.00 \pm 0.59$ & $<10$ & $<0.1$ & $<0.01$ \\
\hline September 29 & Palos Hills, IL & $31.05 \pm 0.54$ & $<10$ & $<0.1$ & $<0.01$ \\
\hline September 29 & Orland Park, IL & $16.70 \pm 0.50$ & $<10$ & $<0.1$ & $0.01 \pm 0.01$ \\
\hline September 30 & Channahon, IL & $23.34 \pm 0.61$ & $16 \pm 15$ & $0.2 \pm 0.1$ & $0.02 \pm 0.01$ \\
\hline September 30 & $\begin{array}{l}\text { Starved Rock State } \\
\text { Park, IL }\end{array}$ & $11.45 \pm 0.38$ & $<10$ & $<0.1$ & $<0.01$ \\
\hline \multirow[t]{2}{*}{ September 30} & $\begin{array}{l}\text { Starved Rock State } \\
\text { Park, IL }\end{array}$ & $13.59 \pm 0.45$ & $<10$ & $<0.1$ & $<0.01$ \\
\hline & Average & $24.93 \pm 2.01$ & $<10$ & $0.1 \pm 0.1$ & $0.01 \pm 0.01$ \\
\hline
\end{tabular}

a The perimeter locations are given in terms of the grid coordinates in Figure 1.1. 
TABLE 4.13

Radionuclides in Bottom Sediment, 1997

\begin{tabular}{|c|c|c|c|c|c|c|c|c|c|}
\hline \multirow{2}{*}{$\begin{array}{c}\text { Date } \\
\text { Collected }\end{array}$} & \multirow[b]{2}{*}{ Location } & \multicolumn{5}{|c|}{ Concentrations in $\mathrm{pCi} / \mathrm{g}$} & \multicolumn{3}{|c|}{ Concentrations in $\mathrm{fCi} / \mathrm{g}$} \\
\hline & & Potassium-40 & Cesium-137 & Radium-226 & Thorium-228 & Thorium-232 & Plutonium-238 & Plutonium-239 & A mericium-241 \\
\hline & Perimeter ${ }^{a}$ & & & & & & & & \\
\hline July 29 & $\begin{array}{l}\text { Sawmill Creek } \\
25 \mathrm{~m} \text { above outfall }\end{array}$ & $9.49 \pm 0.46$ & $0.06 \pm 0.02$ & $0.55 \pm 0.05$ & $0.48 \pm 0.04$ & $0.34 \pm 0.06$ & $0.3 \pm 0.3$ & $5.8 \pm 1.2$ & $1.0 \pm 0.5$ \\
\hline July 29 & $\begin{array}{l}\text { Sawmill Creek } \\
\text { at outfall }\end{array}$ & $6.29 \pm 0.41$ & $2.21 \pm 0.05$ & $0.53 \pm 0.05$ & $0.50 \pm 0.04$ & $0.37 \pm 0.07$ & $39.7 \pm 3.1$ & $60.4 \pm 60.4$ & $287.6 \pm 20.0$ \\
\hline July 29 & $\begin{array}{l}\text { Sawmill Creek } \\
50 \mathrm{~m} \text { below outfall }\end{array}$ & $8.83 \pm 0.52$ & $0.14 \pm 0.03$ & $0.51 \pm 0.06$ & $0.41 \pm 0.04$ & $0.27 \pm 0.08$ & $0.5 \pm 0.3$ & $5.4 \pm 0.9$ & $2.1 \pm 0.6$ \\
\hline July 29 & $\begin{array}{l}\text { Sawmill Creek } \\
100 \mathrm{~m} \text { below outfall }\end{array}$ & $7.81 \pm 0.51$ & $0.15 \pm 0.03$ & $0.43 \pm 0.05$ & $0.36 \pm 0.04$ & $0.29 \pm 0.08$ & $0.4 \pm 0.3$ & $11.4 \pm 1.8$ & $2.9 \pm 0.8$ \\
\hline \multirow[t]{2}{*}{ July 29} & $\begin{array}{l}\text { Sawmill Creek } \\
\text { at Des Plaines River }\end{array}$ & $7.16 \pm 0.49$ & $0.13 \pm 0.03$ & $0.39 \pm 0.05$ & $0.37 \pm 0.04$ & $0.26 \pm 0.07$ & $0.6 \pm 0.6$ & $10.1 \pm 1.9$ & $3.0 \pm 0.9$ \\
\hline & Off site & & & & & & & & \\
\hline M ay 8 & $\begin{array}{l}\text { Illinois River } \\
\text { Dresden L ock \& Dam, IL }\end{array}$ & $18.39 \pm 0.67$ & $0.04 \pm 0.03$ & $1.05 \pm 0.07$ & $1.10 \pm 0.05$ & $0.95 \pm 0.10$ & $0.1 \pm 0.2$ & $2.9 \pm 0.7$ & $1.1 \pm 0.7$ \\
\hline M ay 8 & $\begin{array}{l}\text { Illinois River } \\
\text { M cK inley W oods Park, IL }\end{array}$ & $16.32 \pm 0.62$ & $0.05 \pm 0.02$ & $0.63 \pm 0.05$ & $0.72 \pm 0.04$ & $0.54 \pm 0.08$ & $0.1 \pm 0.1$ & $1.5 \pm 0.5$ & $0.9 \pm 0.5$ \\
\hline M ay 8 & $\begin{array}{l}\text { Illinois River } \\
\text { M orris, IL }\end{array}$ & $9.79 \pm 0.53$ & $0.01 \pm 0.02$ & $0.27 \pm 0.05$ & $0.34 \pm 0.04$ & $0.31 \pm 0.08$ & $<0.1$ & $0.2 \pm 0.3$ & $0.5 \pm 0.3$ \\
\hline M ay 8 & $\begin{array}{l}\text { Illinois River } \\
\text { M orris, IL }\end{array}$ & $9.72 \pm 0.54$ & $0.01 \pm 0.02$ & $0.32 \pm 0.05$ & $0.36 \pm 0.04$ & $0.33 \pm 0.07$ & $<0.1$ & $1.0 \pm 0.4$ & $0.6 \pm 0.3$ \\
\hline M ay 13 & $\begin{array}{l}\text { Des Plaines River } \\
\text { M cCormick W oods, } \\
\text { Brookfield, IL }\end{array}$ & $18.62 \pm 0.68$ & $0.30 \pm 0.03$ & $1.30 \pm 0.07$ & $1.11 \pm 0.05$ & $0.84 \pm 0.09$ & $<0.1$ & $6.6 \pm 1.2$ & $2.6 \pm 0.9$ \\
\hline M ay 13 & $\begin{array}{l}\text { Salt Creek } \\
\text { Bemis W oods, } \\
\text { W estern Springs, IL }\end{array}$ & $20.38 \pm 0.69$ & $0.06 \pm 0.03$ & $1.49 \pm 0.07$ & $1.11 \pm 0.05$ & $0.83 \pm 0.10$ & $<0.1$ & $0.9 \pm 0.5$ & $1.1 \pm 0.4$ \\
\hline M ay 13 & $\begin{array}{l}\text { Des Plaines River } \\
\text { M cC ormick W oods, } \\
\text { Brookfield, IL }\end{array}$ & $18.40 \pm 0.66$ & $0.34 \pm 0.03$ & $1.36 \pm 0.07$ & $1.14 \pm 0.05$ & $0.82 \pm 0.09$ & $0.3 \pm 0.3$ & $7.2 \pm 1.3$ & $3.5 \pm 0.8$ \\
\hline September 29 & $\begin{array}{l}\text { McGinnis Slough } \\
\text { Orland Park, IL }\end{array}$ & $18.45 \pm 0.59$ & $0.05 \pm 0.02$ & $1.10 \pm 0.06$ & $0.83 \pm 0.04$ & $0.73 \pm 0.07$ & $0.2 \pm 0.2$ & $2.3 \pm 0.7$ & $0.8 \pm 0.3$ \\
\hline September 29 & $\begin{array}{l}\text { Saganashkee Slough } \\
\text { Palos Hills, IL }\end{array}$ & $16.89 \pm 0.65$ & $0.16 \pm 0.03$ & $1.81 \pm 0.08$ & $1.25 \pm 0.05$ & $0.85 \pm 0.10$ & $<0.1$ & $5.7 \pm 1.1$ & $2.3 \pm 0.6$ \\
\hline September 30 & $\begin{array}{l}\text { DuPage River } \\
\text { Channahon, IL }\end{array}$ & $14.92 \pm 0.62$ & $<0.01$ & $1.15 \pm 0.07$ & $0.97 \pm 0.05$ & $0.77 \pm 0.09$ & $<0.1$ & $0.3 \pm 0.3$ & $0.3 \pm 0.3$ \\
\hline September 30 & $\begin{array}{l}\text { Illinois River } \\
\text { Starved Rock State Park, IL }\end{array}$ & $9.09 \pm 0.49$ & $0.05 \pm 0.02$ & $0.69 \pm 0.06$ & $0.45 \pm 0.04$ & $0.42 \pm 0.08$ & $<0.1$ & $1.0 \pm 0.4$ & $0.9 \pm 0.4$ \\
\hline \multirow[t]{2}{*}{ September 30} & $\begin{array}{l}\text { DuPage River } \\
\text { Channahon, IL }\end{array}$ & $14.15 \pm 0.59$ & $0.01 \pm 0.02$ & $0.99 \pm 0.06$ & $0.89 \pm 0.04$ & $0.72 \pm 0.09$ & $<0.1$ & $0.3 \pm 0.2$ & $0.3 \pm 0.3$ \\
\hline & A verage & $15.43 \pm 8.68$ & $0.09 \pm 0.26$ & $1.01 \pm 1.03$ & $0.86 \pm 0.71$ & $0.68 \pm 0.49$ & $0.1 \pm 0.3$ & $2.5 \pm 5.7$ & $1.3 \pm 2.3$ \\
\hline
\end{tabular}

a The perimeter locations are given in terms of the grid coordinates in Figure 1.1. 


\section{ENVIRONMENTAL RADIOLOGICAL PROGRAM INFORMATION}

samples collected in previous years. Plutonium results varied widely among locations and were strongly dependent on the retentiveness of the bottom material. A set of sediment samples was collected on July 11, 1997, from the Sawmill Creek bed, above, at the outfall, and at several locations below the point at which ANL-E discharges its treated wastewater (location 7M in Figure 1.1). The results, as listed in Table 4.13, show that the concentrations in the samples collected above the 7M outfall are similar to those of the off-site samples. The plutonium, americium, and cesium-137 concentrations are elevated below the outfall, which indicates that their origin is in ANL-E wastewater. The changes in concentrations of these nuclides with time and location indicate the dynamic nature of the sediment material in this area. Because all the perimeter and off-site sediment samples have not indicated any contributions from ANL-E in the past, effective January 1, 1998, sampling at these locations will be discontinued.

\subsection{External Penetrating Radiation}

Levels of external penetrating radiation at and in the vicinity of the ANL-E site were measured with aluminum oxide TLD chips provided and read by a commercial vendor. Each measurement reported represents the average of two chips exposed in the same packet. Dosimeters were exposed at 14 locations at the site boundary and on the site. Readings were also taken at five off-site locations for comparative purposes. These locations are shown in Figure 1.2.

The results are summarized in Tables 4.14 and 4.15 , and the site boundary and on-site readings are shown in Figure 4.4. M easurements were taken during the four successive exposure periods shown in the tables, and the results were calculated in terms of annual dose for ease in comparing measurements made for different elapsed times. The uncertainty of the averages given in the tables is the $95 \%$ confidence limit calculated from the standard deviation of the average.

The off-site results averaged $82 \pm 2 \mathrm{mrem} / \mathrm{yr}$ and were slightly lower than last year's offsite average of $90 \pm 4 \mathrm{mrem} / \mathrm{yr} .{ }^{20}$ To compare boundary results for individual sampling periods, the standard deviation of the 20 individual off-site results is useful. This value is $9 \mathrm{mrem} / \mathrm{yr}$; thus, individual results in the range of $82 \pm 18 \mathrm{mrem} / \mathrm{yr}$ may be considered to be the average natural background with a $95 \%$ probability. 


\section{ENVIRONMENTAL RADIOLOGICAL PROGRAM INFORMATION}

TABLE 4.14

External Penetrating Radiation at Off-Site L ocations, 1997

\begin{tabular}{lccccc}
\hline & \multicolumn{5}{c}{$\begin{array}{c}\text { Dose Rate (mrem/yr) } \\
\text { Period of M easurement }\end{array}$} \\
\cline { 2 - 6 } \multicolumn{1}{c}{ Location } & $1 / 3-3 / 31$ & $3 / 31-7 / 1$ & $7 / 1-10 / 2$ & $10 / 2-1 / 7$ & A verage \\
\hline Lemont & 76 & 75 & 84 & 80 & $79 \pm 4$ \\
Oak Brook & 93 & 81 & 91 & 84 & $87 \pm 6$ \\
Orland Park & 74 & 88 & 77 & 85 & $81 \pm 6$ \\
W oodridge & 83 & 85 & 82 & 78 & $82 \pm 3$ \\
Willow Springs & 85 & 76 & 74 & 88 & $81 \pm 7$ \\
& & & & & $82 \pm 2$ \\
A verage & $82 \pm 7$ & $81 \pm 5$ & $82 \pm 6$ & $83 \pm 4$ & $82 \pm 2$ \\
\hline
\end{tabular}

In the past, two site boundary locations, 7I (south) and 14I (north), had dose rates consistently above the average background. At $7 \mathrm{l}$, this was the result of radiation from ANL-E'S 317 A rea in the northern half of grid 7l. Waste is packaged and temporarily kept in this area before removal for permanent disposal off site. In 1997, the dose at this perimeter fence location was approximately $100 \pm 8 \mathrm{mrem} / \mathrm{yr}$; in 1985, this value was $941 \mathrm{mrem} / \mathrm{yr}$. A pproximately 300 $\mathrm{m}$ (960 ft) south of the fence in grid 6l, the measured dose dropped to $91 \pm 3 \mathrm{mrem} / \mathrm{yr}$, which is within the normal background range.

Previously, an elevated dose had been measured in the perimeter area at Location 14I, at the north boundary. This dose was attributed to the use of cobalt-60 irradiation sources in Building 202. However, the irradiation program using the cobalt-60 source was terminated at the end of FY 1990 and has not been used since then. The perimeter dose at Location 14I, $84 \pm 17 \mathrm{mrem} / \mathrm{yr}$, was within the normal background range.

In the past, an elevated on-site dose had been measured at L ocation $9 \mathrm{H}$, next to the $\mathrm{CP}-5$ reactor, where irradiated hardware from the CP-5 was stored. During the past few years, considerable cleanup of the CP-5 yard has occurred as part of the CP-5 D\&D project. The dose at Location $9 \mathrm{H}$ decreased from about 1,200 mrem/yr in 1989 to $139 \mathrm{mrem} / \mathrm{yr}$ in 1997. The 
TABLE 4.15

External Penetrating Radiation at A N L-E, 1997

\begin{tabular}{|c|c|c|c|c|c|}
\hline \multirow[b]{2}{*}{ Location $^{\text {a }}$} & \multicolumn{5}{|c|}{$\begin{array}{l}\text { Dose Rate (mrem/yr) } \\
\text { Period of M easurement }\end{array}$} \\
\hline & $1 / 3-3 / 31$ & $3 / 31-7 / 1$ & $7 / 1-10 / 2$ & $10 / 2-1 / 7$ & A verage \\
\hline 14G - Boundary & 92 & 85 & 87 & 81 & $86 \pm 4$ \\
\hline 141 - Boundary & 109 & 75 & 76 & 74 & $84 \pm 17$ \\
\hline 14L - Boundary & 81 & 82 & 90 & 73 & $82 \pm 7$ \\
\hline $6 \mathrm{I}-200 \mathrm{~m} \mathrm{~N}$ of Quarry Road & 89 & 95 & 91 & 89 & $91 \pm 3$ \\
\hline $\begin{array}{l}\text { 71 - Center, W aste Storage A rea } \\
\text { Facility } 317\end{array}$ & 455 & 500 & 955 & 2,174 & $1,021 \pm 785$ \\
\hline 7I - Boundary & 107 & 93 & 100 & $-b$ & $100 \pm 8$ \\
\hline $8 \mathrm{H}$ - Boundary & 87 & 85 & 94 & 81 & $87 \pm 5$ \\
\hline $8 \mathrm{H}-65 \mathrm{~m} \mathrm{~S}$ of Building 316 & 82 & 78 & 84 & 82 & $82 \pm 2$ \\
\hline $\begin{array}{r}8 \mathrm{H}-200 \mathrm{~m} \mathrm{~N} \mathrm{~W} \text { of Waste } \\
\text { Storage A rea (H eliport) }\end{array}$ & 97 & 69 & 87 & 75 & $82 \pm 12$ \\
\hline $\begin{array}{l}\text { 8H - Boundary, Center, } \\
\text { St. Patrick Cemetery }\end{array}$ & 86 & 94 & 94 & - & $91 \pm 5$ \\
\hline $9 \mathrm{H}-50 \mathrm{~m}$ SE of CP-5 & 80 & 78 & 99 & 300 & $139 \pm 105$ \\
\hline $\begin{array}{c}91-65 \mathrm{~m} \mathrm{NE} \text { of Building } 350, \\
230 \mathrm{~m} \mathrm{NE} \text { of Building } 316\end{array}$ & 78 & 69 & 64 & 65 & $69 \pm 6$ \\
\hline 9/10 EF - Boundary & 93 & 72 & 88 & 81 & $84 \pm 9$ \\
\hline 10/11 K - Facilities & 87 & 65 & 77 & 70 & $75 \pm 9$ \\
\hline
\end{tabular}

a See Figure 1.1.

${ }^{\mathrm{b}}$ A hyphen indicates that the sample was lost. 


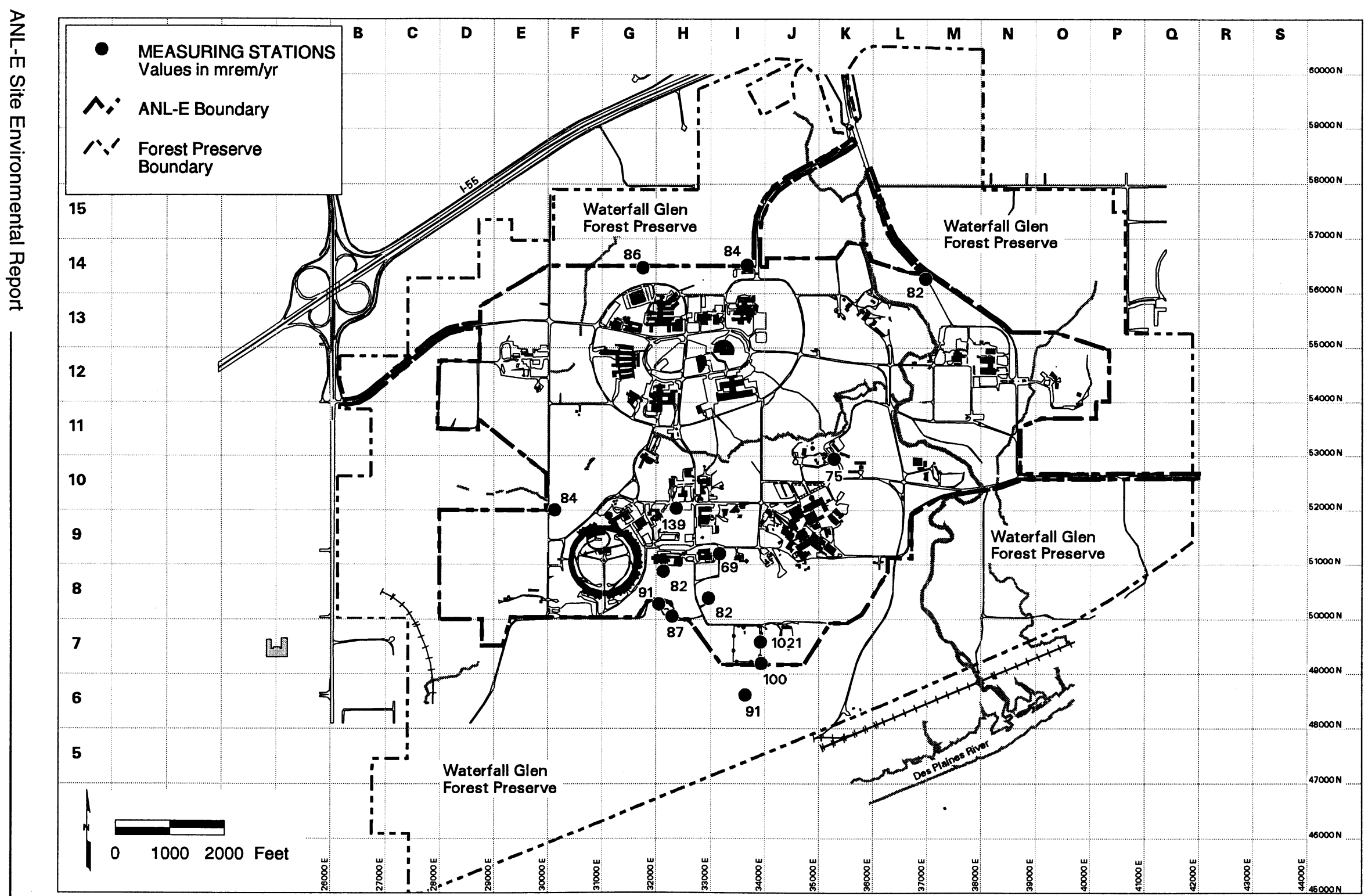




\section{ENVIRONMENTAL RADIOLOGICAL PROGRAM INFORMATION}

cleanup was completed in 1994; the residual dose is from sources in the building, which is currently undergoing $D \& D$. The elevated levels reported in the last quarter of 1997 can be attributed to the movement of high-activity waste from the building.

\subsection{Estimates of Potential Radiation Doses}

The radiation doses at the site boundary and off the site that could have been received by the public from radioactive materials and radiation leaving the site were calculated. Calculations were performed for three exposure pathways; airborne, water, and direct radiation from external sources.

\subsubsection{Airborne Pathway}

Guidance issued by $D O E^{12}$ stipulates that DOE facilities with airborne releases of radioactive materials are subject to 40 CFR Part 61, Subpart $H^{21}$ which requires the use of the CAP-88 version ${ }^{8}$ of the EPA-AIRDOSE/RADRISK code to calculate the dose for radionuclides released to the air and to demonstrate compliance with the regulation. The dose limit applicable for 1997 for the air pathway is a 10-mrem/yr effective dose equivalent. The EPAAIRDOSE/RADRISK computer code uses a modified Gaussian plume equation to estimate both horizontal and vertical dispersion of radionuclides released to the air from stacks or area sources. For 1997, doses were calculated for hydrogen-3, carbon-11, nitrogen-13, oxygen-15, argon-41, krypton-85, radon-220 plus daughters, and a number of actinide radionuclides. The annual release rates are those listed in Table 4.4; separate calculations were performed for each of the six release points. The wind speed and direction data shown in Figure 1.3 were used for these calculations. In the past, the wind stability classes had been determined by the temperature differences between the $10-\mathrm{m}(33-\mathrm{ft})$ and $60-\mathrm{m}$ (197-ft) levels. To improve the determination of stability levels, the categories were obtained from daytime measurements of solar radiation and nighttime measurements of the standard deviation of the horizontal wind speed. Doses were calculated for an area extending out to $80 \mathrm{~km}(50 \mathrm{mi})$ from $A N L-E$. The population distribution of the 16 compass segments and 10 distance increments given in Table 1.1 was used. The dose rate was 


\section{ENVIRONMENTAL RADIOLOGICAL PROGRAM INFORMATION}

calculated at the midpoint of each interval and integrated over the entire area to give the annual population cumulative dose.

Distances from the specific facilities that exhaust radiological airborne emissions (see Table 4.4) to the fence line (perimeter) and nearest resident were determined in the 16 compass segments. Calculations also were performed to evaluate the major airborne pathways: ingestion, inhalation, and immersion, both at the point of maximum perimeter exposure and to the maximally exposed resident. The perimeter and resident doses and the maximum doses are listed, respectively, for releases from Buildings 200 (Tables 4.16 and 4.17), Building 205 (Tables 4.18 and 4.19), Building 212 (Tables 4.20 and 4.21), Building 350 (Tables 4.22 and 4.23), Building 375 (Tables 4.24 and 4.25), and Building 411 (Tables 4.26 and 4.27). The doses given in these tables are the committed whole body effective dose equivalents.

During 1995, a significant $D \& D$ program was completed for the $M-W$ ing hot cells in Building 200, which constituted the source of the radon-220 emissions. Cleanup of the major source of the radon-220, cell $M-1$, was completed in 1995. This has resulted in a decrease of radon-220 emissions: 3,000 $\mathrm{Ci}$ in 1992; 2,023 $\mathrm{Ci}$ in 1993; 1,750 $\mathrm{Ci}$ in 1994; 1,033 $\mathrm{Ci}$ in 1995; $388 \mathrm{Ci}$ in 1996; and $286.6 \mathrm{Ci}$ in 1997. The present radon-220 emissions will continue because of the ongoing nuclear medical program that separates radium-224 from the thorium-228 parent.

In A ugust 1992, operation of the J anus reactor (Building 202) was terminated because of a lack of programmatic support. In early 1993, the fuel was removed and shipped to the Savannah River Plant for reprocessing. Likewise, the cyclotron in Building 211 ceased operation at the end of 1992 because of the lack of use. The facility was placed in standby status awaiting future $D \& D$. N either facility will produce radiological airborne emissions in the future.

In the past, the dominant emission source was radon-220 from Building 200. However, with the $D \& D$ of the $M-W$ ing hot cells, the residual emissions from Building 200 account for only $60 \%$ of the off-site dose, while the IPNS facility in Building 375 accounts for $35 \%$ of the dose. The remainder of the emissions account for the other $5 \%$. The highest perimeter dose was in the southwest direction with a maximum dose of $0.24 \mathrm{mrem} / \mathrm{yr}$ (location $7 \mathrm{H}$ in Figure 1.1). The 
TABLE 4.16

Radiological Airborne Releases from Building 200, 1997

Source Term: Radon-220 $=286.6 \mathrm{Ci}$ (plus daughters)

\begin{tabular}{lcccc}
\hline Direction & $\begin{array}{c}\text { Distance to } \\
\text { Perimeter }(\mathrm{m})\end{array}$ & $\begin{array}{c}\text { Dose } \\
(\mathrm{mrem} / \mathrm{yr})\end{array}$ & $\begin{array}{c}\text { Distance to Nearest } \\
\text { Resident }(\mathrm{m})\end{array}$ & $\begin{array}{c}\text { Dose } \\
(\mathrm{mrem} / \mathrm{yr})\end{array}$ \\
\hline N & 500 & $7.1 \times 10^{-2}$ & 1,000 & $1.8 \times 10^{-2}$ \\
N NE & 600 & $5.4 \times 10^{-2}$ & 1,100 & $1.6 \times 10^{-2}$ \\
NE & 750 & $3.1 \times 10^{-2}$ & 2,600 & $3.1 \times 10^{-3}$ \\
E NE & 1,700 & $6.1 \times 10^{-3}$ & 3,100 & $2.1 \times 10^{-3}$ \\
E & 2,400 & $4.3 \times 10^{-3}$ & 3,500 & $2.3 \times 10^{-3}$ \\
ESE & 2,200 & $3.6 \times 10^{-3}$ & 3,600 & $1.6 \times 10^{-3}$ \\
SE & 2,100 & $3.0 \times 10^{-3}$ & 4,000 & $1.0 \times 10^{-3}$ \\
SSE & 2,000 & $4.4 \times 10^{-3}$ & 4,000 & $1.4 \times 10^{-3}$ \\
S & 1,500 & $3.8 \times 10^{-3}$ & 4,000 & $7.5 \times 10^{-4}$ \\
SSW & 1,000 & $2.1 \times 10^{-2}$ & 2,500 & $4.1 \times 10^{-3}$ \\
SW & 800 & $4.7 \times 10^{-2}$ & 2,200 & $9.5 \times 10^{-3}$ \\
W SW & 1,100 & $1.3 \times 10^{-2}$ & 1,500 & $7.6 \times 10^{-3}$ \\
W & 750 & $2.7 \times 10^{-2}$ & 1,500 & $8.1 \times 10^{-3}$ \\
W NW & 800 & $1.7 \times 10^{-2}$ & 1,300 & $7.5 \times 10^{-3}$ \\
NW & 600 & $2.7 \times 10^{-2}$ & 1,100 & $9.1 \times 10^{-3}$ \\
N NW & 600 & $3.5 \times 10^{-2}$ & 800 & $2.0 \times 10^{-2}$ \\
\hline
\end{tabular}


TABLE 4.17

M aximum Perimeter and Individual Doses from

Building 200 A ir Emissions, 1997

Dose (mrem/yr)

\begin{tabular}{|c|c|c|}
\hline Pathway & $\begin{array}{l}\text { Perimeter } \\
(500 \mathrm{~m} \mathrm{~N})\end{array}$ & $\begin{array}{c}\text { Individual } \\
(800 \text { m N N W })\end{array}$ \\
\hline Ingestion & $1.0 \times 10^{-13}$ & $3.6 \times 10^{-14}$ \\
\hline Inhalation & $7.0 \times 10^{-2}$ & $2.0 \times 10^{-2}$ \\
\hline A ir immersion & $4.9 \times 10^{-4}$ & $1.2 \times 10^{-4}$ \\
\hline Ground surface & $3.4 \times 10^{-5}$ & $1.2 \times 10^{-5}$ \\
\hline Total & $7.1 \times 10^{-2}$ & $2.0 \times 10^{-2}$ \\
\hline \multicolumn{3}{|l|}{ Radionuclide } \\
\hline Thallium-208 & $4.2 \times 10^{-4}$ & $1.0 \times 10^{-4}$ \\
\hline Bismuth-212 & $8.4 \times 10^{-3}$ & $2.8 \times 10^{-3}$ \\
\hline L ead-212 & $4.2 \times 10^{-2}$ & $1.4 \times 10^{-2}$ \\
\hline Radon-220 & $2.0 \times 10^{-2}$ & $2.7 \times 10^{-3}$ \\
\hline Total & $7.1 \times 10^{-2}$ & $2.0 \times 10^{-2}$ \\
\hline
\end{tabular}


TABLE 4.18

Radiological A irborne Releases from Building 205, 1997

Source Term: Hydrogen-3 $=0.84 \mathrm{Ci}$

\begin{tabular}{lrccc}
\hline Direction & $\begin{array}{c}\text { Distance to } \\
\text { Perimeter }(\mathrm{m})\end{array}$ & $\begin{array}{c}\text { Dose } \\
(\mathrm{mrem} / \mathrm{yr})\end{array}$ & $\begin{array}{c}\text { Distance to } \\
\text { Nearest Resident }(\mathrm{m})\end{array}$ & $\begin{array}{c}\text { Dose } \\
\text { (mrem/yr) }\end{array}$ \\
\hline N & 850 & $3.5 \times 10^{-5}$ & 1,300 & $1.8 \times 10^{-5}$ \\
N NE & 1,000 & $2.8 \times 10^{-5}$ & 2,100 & $8.1 \times 10^{-6}$ \\
NE & 1,200 & $1.9 \times 10^{-5}$ & 2,700 & $4.9 \times 10^{-6}$ \\
E NE & 2,400 & $5.7 \times 10^{-6}$ & 3,000 & $3.9 \times 10^{-6}$ \\
E & 2,200 & $8.5 \times 10^{-6}$ & 2,400 & $4.2 \times 10^{-6}$ \\
ESE & 2,000 & $7.0 \times 10^{-6}$ & 3,500 & $2.8 \times 10^{-6}$ \\
SE & 1,800 & $6.6 \times 10^{-6}$ & 3,900 & $1.9 \times 10^{-6}$ \\
SSE & 1,500 & $1.2 \times 10^{-5}$ & 4,000 & $2.4 \times 10^{-6}$ \\
S & 1,300 & $7.8 \times 10^{-6}$ & 3,900 & $1.4 \times 10^{-6}$ \\
SSW & 1,100 & $2.7 \times 10^{-5}$ & 2,400 & $7.7 \times 10^{-6}$ \\
SW & 900 & $5.9 \times 10^{-5}$ & 2,100 & $1.9 \times 10^{-5}$ \\
W SW & 1,100 & $2.0 \times 10^{-5}$ & 1,800 & $9.2 \times 10^{-6}$ \\
W & 1,300 & $1.3 \times 10^{-5}$ & 1,800 & $1.0 \times 10^{-5}$ \\
W NW & 1,100 & $1.6 \times 10^{-5}$ & 1,700 & $8.1 \times 10^{-6}$ \\
NW & 1,100 & $1.4 \times 10^{-5}$ & 1,500 & $8.9 \times 10^{-6}$ \\
N NW & 900 & $2.3 \times 10^{-5}$ & 1,500 & $1.0 \times 10^{-5}$ \\
\hline
\end{tabular}




\section{ENVIRONMENTAL RADIOLOGICAL PROGRAM INFORMATION}

TABLE 4.19

M aximum Perimeter and Individual Doses from

Building 205 A ir E missions, 1997

Dose (mrem/yr)

\begin{tabular}{lcc}
\hline \multicolumn{1}{c}{ Pathway } & $\begin{array}{c}\text { Perimeter } \\
(900 \mathrm{~m} \mathrm{SW})\end{array}$ & $\begin{array}{c}\text { Individual } \\
(2,100 \mathrm{~m} \mathrm{SW})\end{array}$ \\
\hline $\begin{array}{l}\text { Ingestion } \\
\text { Inhalation }\end{array}$ & $\begin{array}{c}1.4 \times 10^{-5} \\
4.5 \times 10^{-5}\end{array}$ & $\begin{array}{c}4.5 \times 10^{-6} \\
1.4 \times 10^{-5}\end{array}$ \\
$\begin{array}{l}\text { Air immersion } \\
\text { Ground surface }\end{array}$ & $-{ }^{-}$ & - \\
Total & $-5.9 \times 10^{-5}$ & $1.9 \times 10^{-5}$ \\
Radionuclide & & \\
Hydrogen-3 & $5.9 \times 10^{-5}$ & $1.9 \times 10^{-5}$ \\
\hline
\end{tabular}

a A hyphen indicates no exposure by this pathway. 
TABLE 4.20

Radiological Airborne Releases from Building 212, 1997

Source Term: Hydrogen-3 $(\mathrm{HT})=11.95 \mathrm{Ci}$

$\mathrm{Hydrogen}-3(\mathrm{HTO})=123.40 \mathrm{Ci}$

Krypton-85 $=1.04 \mathrm{Ci}$

Radon-220 $\quad=0.15 \mathrm{Ci}$

\begin{tabular}{lcccc}
\hline Direction & $\begin{array}{c}\text { Distance to } \\
\text { Perimeter }(\mathrm{m})\end{array}$ & $\begin{array}{c}\text { Dose } \\
(\mathrm{mrem} / \mathrm{yr})\end{array}$ & $\begin{array}{c}\text { Distance to N earest } \\
\text { Resident }(\mathrm{m})\end{array}$ & $\begin{array}{c}\text { Dose } \\
\text { (mrem/yr) }\end{array}$ \\
\hline N & 800 & $6.4 \times 10^{-3}$ & 2,000 & $1.4 \times 10^{-3}$ \\
N NE & 1,000 & $4.5 \times 10^{-3}$ & 2,500 & $9.8 \times 10^{-4}$ \\
NE & 1,300 & $2.6 \times 10^{-3}$ & 2,000 & $1.3 \times 10^{-3}$ \\
ENE & 1,500 & $2.0 \times 10^{-3}$ & 2,500 & $8.6 \times 10^{-4}$ \\
E & 1,600 & $2.3 \times 10^{-3}$ & 2,800 & $9.2 \times 10^{-4}$ \\
ESE & 1,200 & $2.7 \times 10^{-3}$ & 2,500 & $7.8 \times 10^{-4}$ \\
SE & 1,400 & $1.6 \times 10^{-3}$ & 3,500 & $3.6 \times 10^{-4}$ \\
SSE & 1,400 & $2.2 \times 10^{-3}$ & 4,500 & $3.3 \times 10^{-4}$ \\
S & 1,500 & $1.0 \times 10^{-3}$ & 5,000 & $1.6 \times 10^{-4}$ \\
SSW & 1,600 & $2.4 \times 10^{-3}$ & 5,000 & $4.0 \times 10^{-4}$ \\
SW & 1,400 & $5.3 \times 10^{-3}$ & 2,400 & $2.5 \times 10^{-3}$ \\
W SW & 1,300 & $2.5 \times 10^{-3}$ & 2,300 & $9.9 \times 10^{-4}$ \\
W & 1,700 & $1.8 \times 10^{-3}$ & 2,200 & $1.2 \times 10^{-3}$ \\
W NW & 1,500 & $1.6 \times 10^{-3}$ & 2,000 & $1.0 \times 10^{-3}$ \\
NW & 1,300 & $1.8 \times 10^{-3}$ & 2,000 & $9.1 \times 10^{-4}$ \\
N NW & 1,000 & $3.1 \times 10^{-3}$ & 2,000 & $1.0 \times 10^{-3}$ \\
\hline
\end{tabular}


TABLE 4.21

$M$ aximum Perimeter and Individual Doses from Building 212 A ir Emissions, 1997

Dose (mrem/yr)

\begin{tabular}{|c|c|c|}
\hline Pathway & $\begin{array}{l}\text { Perimeter } \\
(800 \mathrm{~m} \mathrm{~N})\end{array}$ & $\begin{array}{c}\text { Individual } \\
(2,400 \mathrm{~m} \mathrm{SW})\end{array}$ \\
\hline Ingestion & $1.5 \times 10^{-3}$ & $6.0 \times 10^{-4}$ \\
\hline Inhalation & $4.9 \times 10^{-3}$ & $1.9 \times 10^{-3}$ \\
\hline Air immersion & $3.4 \times 10^{-6}$ & $4.4 \times 10^{-7}$ \\
\hline Ground surface & $3.8 \times 10^{-8}$ & $1.0 \times 10^{-8}$ \\
\hline Total & $6.4 \times 10^{-3}$ & $2.5 \times 10^{-3}$ \\
\hline \multicolumn{3}{|l|}{ Radionuclide } \\
\hline Hydrogen-3 & $6.3 \times 10^{-3}$ & $2.5 \times 10^{-3}$ \\
\hline Krypton-85 & $6.0 \times 10^{-7}$ & $2.4 \times 10^{-7}$ \\
\hline Radon-220 & $2.4 \times 10^{-6}$ & $1.8 \times 10^{-8}$ \\
\hline Total & $6.4 \times 10^{-3}$ & $2.5 \times 10^{-3}$ \\
\hline
\end{tabular}


TABLE 4.22

Radiological A irborne Releases from Building 350, 1997

Source Term: U ranium-234 $=5.2 \times 10^{-6} \mathrm{Ci}$

Uranium-238 $=5.2 \times 10^{-6} \mathrm{Ci}$

Plutonium-238 $=7.7 \times 10^{-7} \mathrm{Ci}$

Plutonium-239 $=2.7 \times 10^{-6} \mathrm{Ci}$

Plutonium-240 $=1.4 \times 10^{-6} \mathrm{Ci}$

Plutonium-241 $=7.2 \times 10^{-5} \mathrm{Ci}$

Plutonium-242 $=4.1 \times 10^{-9} \mathrm{Ci}$

Plutonium-244 $=1.7 \times 10^{-10} \mathrm{Ci}$

\begin{tabular}{lcccc}
\hline Direction & $\begin{array}{c}\text { Distance to } \\
\text { Perimeter }(\mathrm{m})\end{array}$ & $\begin{array}{c}\text { Dose } \\
(\mathrm{mrem} / \mathrm{yr})\end{array}$ & $\begin{array}{c}\text { Distance to N earest } \\
\text { Resident }(\mathrm{m})\end{array}$ & $\begin{array}{c}\text { Dose } \\
(\mathrm{mrem} / \mathrm{yr})\end{array}$ \\
\hline N & 1,700 & $2.4 \times 10^{-4}$ & 2,200 & $1.7 \times 10^{-4}$ \\
N NE & 1,800 & $2.3 \times 10^{-4}$ & 3,200 & $1.0 \times 10^{-4}$ \\
NE & 2,200 & $1.5 \times 10^{-4}$ & 3,100 & $9.3 \times 10^{-5}$ \\
E NE & 2,000 & $1.7 \times 10^{-4}$ & 3,100 & $8.9 \times 10^{-5}$ \\
E & 1,700 & $2.7 \times 10^{-4}$ & 2,500 & $1.6 \times 10^{-4}$ \\
ESE & 900 & $4.7 \times 10^{-4}$ & 3,000 & $8.9 \times 10^{-5}$ \\
SE & 900 & $3.2 \times 10^{-4}$ & 3,000 & $6.6 \times 10^{-5}$ \\
SSE & 700 & $6.3 \times 10^{-4}$ & 2,700 & $1.1 \times 10^{-4}$ \\
S & 600 & $2.3 \times 10^{-4}$ & 2,700 & $5.1 \times 10^{-5}$ \\
SSW & 400 & $8.6 \times 10^{-4}$ & 2,500 & $1.6 \times 10^{-4}$ \\
SW & 600 & $1.0 \times 10^{-3}$ & 2,700 & $2.0 \times 10^{-4}$ \\
W SW & 800 & $4.8 \times 10^{-4}$ & 2,100 & $1.5 \times 10^{-4}$ \\
W & 900 & $2.9 \times 10^{-4}$ & 2,200 & $1.2 \times 10^{-4}$ \\
W NW & 1,000 & $2.1 \times 10^{-4}$ & 2,100 & $9.5 \times 10^{-5}$ \\
NW & 1,900 & $1.1 \times 10^{-4}$ & 2,400 & $8.0 \times 10^{-5}$ \\
N NW & 1,900 & $1.5 \times 10^{-4}$ & 2,200 & $1.2 \times 10^{-4}$ \\
\hline
\end{tabular}


TABLE 4.23

M aximum Perimeter and Individual Doses from

Building 350 A ir Emissions, 1997

Dose (mrem/yr)

\begin{tabular}{lll}
\hline \multicolumn{1}{c}{ Pathway } & $\begin{array}{c}\text { Perimeter } \\
(600 \mathrm{~m} \mathrm{SW})\end{array}$ & $\begin{array}{c}\text { Individual } \\
(2,700 \mathrm{~m} \mathrm{SW})\end{array}$ \\
\hline $\begin{array}{l}\text { Ingestion } \\
\text { Inhalation }\end{array}$ & $\begin{array}{l}1.1 \times 10^{-5} \\
9.9 \times 10^{-4}\end{array}$ & $2.2 \times 10^{-6}$ \\
A ir immersion & $2.6 \times 10^{-13}$ & $5.2 \times 10^{-4}$ \\
Ground surface & $4.7 \times 10^{-8}$ & $9.7 \times 10^{-9}$ \\
& & \\
Total & $1.0 \times 10^{-3}$ & $2.0 \times 10^{-4}$ \\
Radionuclide & & \\
U ranium-234 & $1.9 \times 10^{-4}$ & $3.8 \times 10^{-5}$ \\
U ranium-238 & $1.7 \times 10^{-4}$ & $3.4 \times 10^{-5}$ \\
Plutonium-238 & $7.2 \times 10^{-5}$ & $1.4 \times 10^{-5}$ \\
Plutonium-239 & $2.8 \times 10^{-4}$ & $5.2 \times 10^{-5}$ \\
Plutonium-240 & $1.5 \times 10^{-4}$ & $3.0 \times 10^{-5}$ \\
Plutonium-241 & $1.4 \times 10^{-4}$ & $2.7 \times 10^{-5}$ \\
Plutonium-242 & $4.1 \times 10^{-7}$ & $8.2 \times 10^{-8}$ \\
Plutonium-244 & $1.7 \times 10^{-8}$ & $3.4 \times 10^{-9}$ \\
Total & & \\
\hline & $1.0 \times 10^{-3}$ & $2.0 \times 10^{-4}$ \\
\hline
\end{tabular}


TABLE 4.24

Radiological Airborne Releases from Building 375 (IPN S), 1997

Source Term: Carbon-11 $=642.5 \mathrm{Ci}$

Argon-41 $=9.9 \mathrm{Ci}$

\begin{tabular}{lcccc}
\hline Direction & $\begin{array}{c}\text { Distance to } \\
\text { Perimeter }(\mathrm{m})\end{array}$ & $\begin{array}{c}\text { Dose } \\
(\mathrm{mrem} / \mathrm{yr})\end{array}$ & $\begin{array}{c}\text { Distance to N earest } \\
\text { Resident }(\mathrm{m})\end{array}$ & $\begin{array}{c}\text { Dose } \\
(\mathrm{mrem} / \mathrm{yr})\end{array}$ \\
\hline N & 1,600 & $3.3 \times 10^{-2}$ & 3,200 & $8.8 \times 10^{-3}$ \\
N NE & 1,700 & $3.1 \times 10^{-2}$ & 3,100 & $9.9 \times 10^{-3}$ \\
NE & 1,700 & $2.8 \times 10^{-2}$ & 2,700 & $1.1 \times 10^{-2}$ \\
E NE & 1,500 & $3.2 \times 10^{-2}$ & 2,500 & $1.2 \times 10^{-2}$ \\
E & 600 & $2.1 \times 10^{-1}$ & 2,500 & $1.7 \times 10^{-2}$ \\
ESE & 600 & $1.6 \times 10^{-1}$ & 2,500 & $1.2 \times 10^{-2}$ \\
SE & 600 & $1.2 \times 10^{-1}$ & 2,500 & $8.7 \times 10^{-3}$ \\
SSE & 600 & $1.6 \times 10^{-1}$ & 3,000 & $8.2 \times 10^{-3}$ \\
S & 800 & $4.9 \times 10^{-2}$ & 3,000 & $4.3 \times 10^{-3}$ \\
SSW & 800 & $1.3 \times 10^{-1}$ & 3,500 & $8.1 \times 10^{-3}$ \\
SW & 800 & $1.8 \times 10^{-1}$ & 4,000 & $7.7 \times 10^{-3}$ \\
W SW & 1,500 & $3.3 \times 10^{-2}$ & 2,700 & $1.1 \times 10^{-2}$ \\
W & 2,200 & $1.9 \times 10^{-2}$ & 2,700 & $1.1 \times 10^{-2}$ \\
W N W & 1,500 & $2.5 \times 10^{-2}$ & 2,600 & $8.7 \times 10^{-3}$ \\
NW & 2,200 & $1.0 \times 10^{-2}$ & 2,500 & $8.1 \times 10^{-3}$ \\
N NW & 1,800 & $1.8 \times 10^{-2}$ & 2,200 & $1.2 \times 10^{-2}$ \\
\hline
\end{tabular}


TABLE 4.25

M aximum Perimeter and Individual Doses from

Building 375 (IPNS) Air Emissions, 1997

Dose (mrem/yr)

\begin{tabular}{|c|c|c|}
\hline Pathway & $\begin{array}{l}\text { Perimeter } \\
(600 \mathrm{~m} \mathrm{E})\end{array}$ & $\begin{array}{l}\text { Individual } \\
(2,400 \mathrm{~m} \mathrm{E})\end{array}$ \\
\hline Ingestion & $-a$ & - \\
\hline Inhalation & $9.2 \times 10^{-3}$ & $7.5 \times 10^{-4}$ \\
\hline Air immersion & $2.0 \times 10^{-1}$ & $1.6 \times 10^{-2}$ \\
\hline Ground surface & $7.6 \times 10^{-3}$ & $7.7 \times 10^{-4}$ \\
\hline Total & $2.1 \times 10^{-1}$ & $1.7 \times 10^{-2}$ \\
\hline \multicolumn{3}{|l|}{ Radionuclide } \\
\hline Carbon-11 & $2.1 \times 10^{-1}$ & $1.7 \times 10^{-2}$ \\
\hline Argon-41 & $4.1 \times 10^{-3}$ & $4.0 \times 10^{-4}$ \\
\hline Total & $2.1 \times 10^{-1}$ & $1.7 \times 10^{-2}$ \\
\hline
\end{tabular}

a A hyphen indicates no exposure by this pathway. 
TABLE 4.26

Radiological A irborne Releases from Building 411/415 (APS), 1997

Source Term: Carbon-11 $=0.14 \mathrm{Ci}$

Nitrogen-13 $=3.80 \mathrm{Ci}$

Oxygen-15 $=0.40 \mathrm{Ci}$

\begin{tabular}{lcccc}
\hline Direction & $\begin{array}{c}\text { Distance to } \\
\text { Perimeter }(\mathrm{m})\end{array}$ & $\begin{array}{c}\text { Dose } \\
(\mathrm{mrem} / \mathrm{yr})\end{array}$ & $\begin{array}{c}\text { Distance to } \\
\text { Nearest Resident }(\mathrm{m})\end{array}$ & $\begin{array}{c}\text { Dose } \\
(\mathrm{mrem} / \mathrm{yr})\end{array}$ \\
\hline N & 1,500 & $1.9 \times 10^{-4}$ & 2,000 & $8.2 \times 10^{-5}$ \\
N NE & 1,600 & $1.7 \times 10^{-4}$ & 2,100 & $8.0 \times 10^{-5}$ \\
NE & 2,200 & $8.0 \times 10^{-5}$ & 3,100 & $3.0 \times 10^{-5}$ \\
E NE & 2,500 & $5.5 \times 10^{-5}$ & 3,300 & $2.3 \times 10^{-5}$ \\
E & 1,600 & $1.9 \times 10^{-4}$ & 3,400 & $3.0 \times 10^{-5}$ \\
ESE & 1,500 & $1.6 \times 10^{-4}$ & 3,500 & $2.1 \times 10^{-5}$ \\
SE & 400 & $1.3 \times 10^{-3}$ & 3,000 & $2.0 \times 10^{-5}$ \\
SSE & 400 & $1.9 \times 10^{-3}$ & 3,000 & $2.7 \times 10^{-5}$ \\
S & 350 & $9.8 \times 10^{-4}$ & 2,500 & $2.1 \times 10^{-5}$ \\
SSW & 400 & $2.4 \times 10^{-3}$ & 2,800 & $4.1 \times 10^{-5}$ \\
SW & 550 & $1.8 \times 10^{-3}$ & 3,000 & $4.2 \times 10^{-5}$ \\
W SW & 800 & $5.5 \times 10^{-4}$ & 1,400 & $1.5 \times 10^{-4}$ \\
W & 800 & $5.4 \times 10^{-4}$ & 1,500 & $1.3 \times 10^{-4}$ \\
W NW & 500 & $8.1 \times 10^{-4}$ & 1,400 & $1.1 \times 10^{-4}$ \\
N W & 350 & $1.3 \times 10^{-3}$ & 1,600 & $7.2 \times 10^{-5}$ \\
N NW & 1,500 & $1.2 \times 10^{-4}$ & 2,000 & $5.4 \times 10^{-5}$ \\
\hline
\end{tabular}


TABLE 4.27

M aximum Perimeter and Individual Doses from

Building 411/415 A ir Emissions, 1997

Dose (mrem/yr)

\begin{tabular}{|c|c|c|}
\hline Pathway & $\begin{array}{c}\text { Perimeter } \\
(400 \text { m SSW })\end{array}$ & $\begin{array}{c}\text { Individual } \\
(1,400 \mathrm{~m} \text { W SW })\end{array}$ \\
\hline Ingestion & $-{ }^{a}$ & - \\
\hline Inhalation & $7.0 \times 10^{-5}$ & $4.5 \times 10^{-6}$ \\
\hline A ir immersion & $2.3 \times 10^{-3}$ & $1.4 \times 10^{-4}$ \\
\hline Ground surface & $4.2 \times 10^{-5}$ & $3.2 \times 10^{-6}$ \\
\hline Total & $2.4 \times 10^{-3}$ & $1.5 \times 10^{-4}$ \\
\hline \multicolumn{3}{|l|}{ Radionuclide } \\
\hline Carbon-11 & $8.8 \times 10^{-5}$ & $7.9 \times 10^{-6}$ \\
\hline Nitrogen-13 & $2.2 \times 10^{-3}$ & $1.4 \times 10^{-4}$ \\
\hline Oxygen-15 & $1.5 \times 10^{-4}$ & $5.5 \times 10^{-6}$ \\
\hline Total & $2.4 \times 10^{-3}$ & $1.5 \times 10^{-4}$ \\
\hline
\end{tabular}

a A hyphen indicates no exposure by this pathway. 


\section{ENVIRONMENTAL RADIOLOGICAL PROGRAM INFORMATION}

major component of this dose is air immersion of carbon-11 $(0.21 \mathrm{mrem} / \mathrm{yr})$. The completion of the $D \& D$ activities in Building 200 and the subsequent reduction in radon-220 emissions resulted in a shift of the maximum perimeter dose from the north to the south. The major contributors to this perimeter dose are emissions from the IPNS in Building 375.

The full-time resident who would receive the largest annual dose $(0.033 \mathrm{mrem} / \mathrm{yr})$ is located approximately $0.8 \mathrm{~km}(0.5 \mathrm{mi})$ north-northwest of the site boundary. The major contributor to the whole body dose is the inhalation dose from lead-212 $(0.014 \mathrm{mrem} / \mathrm{yr})$. If radon-220 plus daughters were excluded from the calculation, as required by NESHAP, ${ }^{21}$ the maximally exposed resident would receive a dose of $0.018 \mathrm{mrem} / \mathrm{yr}$, primarily carbon-11 from the IPNS facility (Building 375).

The individual doses to the maximally exposed member of the public and the maximum fence line dose are shown in Figure 4.5. The decrease in individual and population doses since 1988 are due in part to the decrease of radon-220 emissions as a result of the cleanup of the Building $200 \mathrm{M}$-Wing hot cells.

The population data in Table 1.1 were used to calculate the cumulative population dose from gaseous radioactive effluents from ANL-E operations. The results are given in Table 4.28, along with the natural external radiation dose. The natural radiation dose listed is the product of the $80-\mathrm{km}$ (50-mi) population and the natural radiation dose of $300 \mathrm{mrem} / \mathrm{yr}^{22}$ It is assumed that this dose is representative of the entire area within an $80-\mathrm{km}(50-\mathrm{mi})$ radius. The population dose resulting from ANL-E operations since 1987 is shown in Figure 4.6.

The potential radiation exposures by the inhalation pathways also were calculated by the methodology specified in DOE Order 5400.5. ${ }^{12}$ The total quantity for each radionuclide inhaled, in microcuries $(\mu \mathrm{Ci})$, is calculated by multiplying the annual average air concentrations by the general public breathing rate of $8,400 \mathrm{~m}^{3} / \mathrm{yr}$. ${ }^{23}$ This annual intake is then multiplied by the CEDE for the appropriate lung retention class. ${ }^{12}$ Because the CEDE factors are in units of $\mathrm{rem} / \mu \mathrm{Ci}$, this calculation gives the 50-year CEDE. Table 4.29 lists the applicable CEDE factors. 


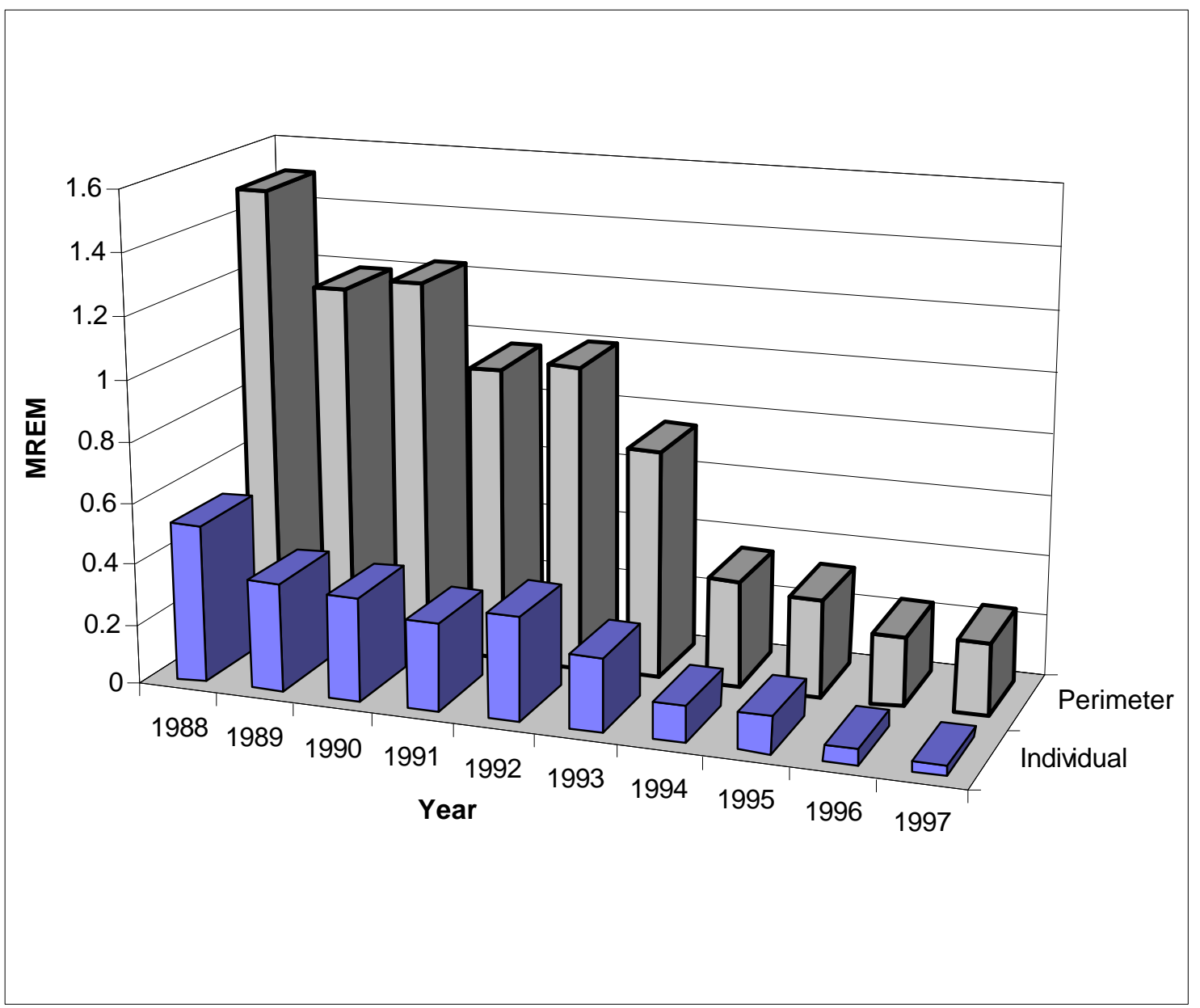

Figure 4.5 Individual and Perimeter Doses from A irborne Radioactive Emissions

The calculated doses in Tables 4.2 and 4.3 were derived by using this procedure. Because they are all essentially at perimeter locations, these doses represent the fence line values for those radionuclides measured. In most cases, these doses also are the same as the off-site measurements and represent the ambient dose for the area from these nuclides. No doses were calculated for the total alpha and total beta measurements because the guidance does not provide CEDE factors for such measurements. 
TABLE 4.28

\begin{tabular}{lr}
\multicolumn{1}{c}{ Population Dose within 80 km, 1997} \\
\hline \multicolumn{1}{c}{ Radionuclide } & M an-rem \\
\hline Hydrogen-3 & 0.22 \\
Carbon-11 & 0.77 \\
Nitrogen-13 & $<0.01$ \\
Oxygen-15 & $<0.01$ \\
Argon-41 & 0.06 \\
Krypton-85 & $<0.01$ \\
Thallium-208 & $<0.01$ \\
Lead-212 & 0.63 \\
Bismuth-212 & 0.06 \\
Radon-220 & $<0.01$ \\
Uranium-234 & $<0.01$ \\
Uranium-238 & $<0.01$ \\
Plutonium-238 & $<0.01$ \\
Plutonium-239 & 0.01 \\
Plutonium-240 & $<0.01$ \\
Plutonium-241 & $<0.01$ \\
Plutonium-242 & $<0.01$ \\
Plutonium-244 & $<0.01$ \\
Total & 1.77 \\
Natural & $2.5 \times 10^{6}$ \\
\hline &
\end{tabular}

\subsubsection{Water Pathway}

Following the methodology outlined in DOE Order $5400.5,{ }^{12}$ the annual intake of radionuclides (in $\mu \mathrm{Ci}$ ) ingested with water is obtained by multiplying the concentration of radionuclides in microcuries per milliliter $(\mu \mathrm{Ci} / \mathrm{mL})$ by the average annual water consumption of a member of the general public $\left(7.3 \times 10^{5} \mathrm{~mL}\right)$. This annual intake is then multiplied by the CEDE factor for ingestion (Table 4.29) to obtain the dose received in that year. This procedure was carried out for all radionuclides, and the individual results were summed to obtain the total ingestion dose. 


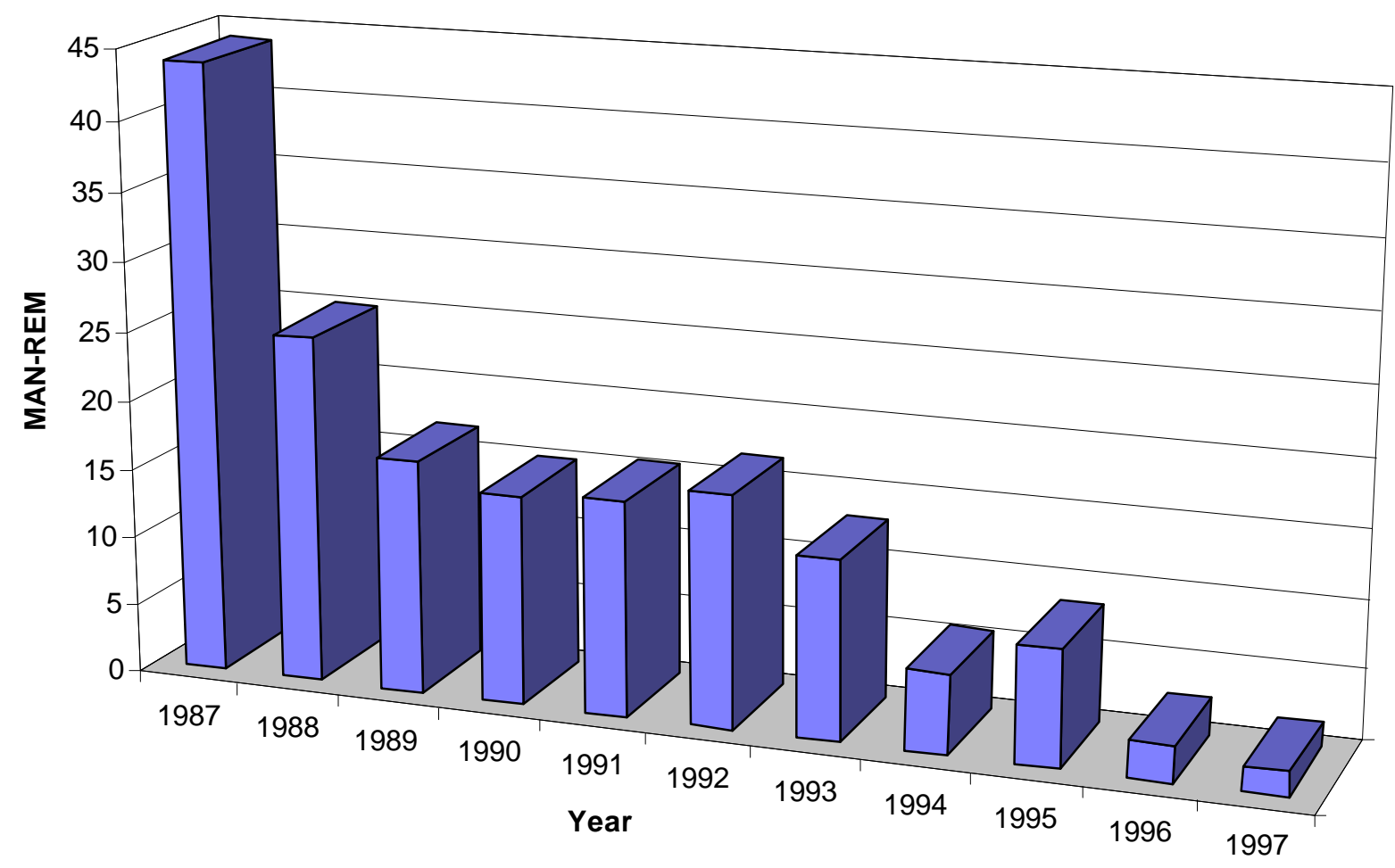

Figure 4.6 Population Dose from A irborne Radioactive Emissions

The only location where radionuclides attributable to A NL -E operations could be found in off-site water was Sawmill Creek below the wastewater outfall (see Table 4.5). Although this water is not used for drinking purposes, the 50-year effective dose equivalent was calculated for a hypothetical individual ingesting water at the radionuclide concentrations measured at that location. Those radionuclides added to Sawmill Creek by ANL-E wastewater, their net concentrations in the creek, and the corresponding dose rates (if water at these concentrations were used as the sole water supply by an individual) are given in Table 4.30. The dose rates were all well below the standards for the general population. It should be emphasized that Sawmill Creek is not used for drinking, swimming, or boating. Inspection of the area shows that there are fish in the stream; however, they do not constitute a significant source of food for any individual. Figure 4.7 is a plot of the estimated dose an individual would receive if ingesting Sawmill Creek water. 


\section{ENVIRONMENTAL RADIOLOGICAL PROGRAM INFORMATION}

TABLE 4.29

50-Y ear Committed E ffective D ose Equivalent

(CEDE) Factors

$(\mathrm{rem} / \mu \mathrm{Ci})$

\begin{tabular}{lcc}
\hline \multicolumn{1}{c}{ Nuclide } & Ingestion & Inhalation \\
\hline Hydrogen-3 & $6.3 \times 10^{-5}$ & $9.6 \times 10^{-5}$ \\
Beryllium-7 & - a & $2.7 \times 10^{-4}$ \\
Carbon-11 & - & $8.0 \times 10^{-6}$ \\
Strontium-90 & 0.13 & 1.32 \\
Cesium-137 & 0.05 & 0.032 \\
L ead-210 & - & 13.2 \\
Radium-226 & 1.1 & - \\
Thorium-228 & - & 310 \\
Thorium-230 & - & 260 \\
Thorium-232 & - & 1,100 \\
U ranium-234 & 0.26 & 130 \\
U ranium-235 & 0.25 & 120 \\
U ranium-238 & 0.23 & 120 \\
Neptunium-237 & 3.90 & - \\
Plutonium-238 & 3.80 & - \\
Plutonium-239 & 4.30 & 330 \\
A mericium-241 & 4.50 & - \\
Curium-242 & 0.11 & - \\
Curium-244 & 2.30 & - \\
Californium-249 & 4.60 & - \\
Californium-252 & 0.94 & - \\
\hline & &
\end{tabular}

a A hyphen indicates value not required.

As indicated in Table 4.5, occasional Sawmill Creek samples (fewer than 10\%) contained traces of cesium-137, plutonium-238, curium-242 and 244, or californium-249 and 252; however, the averages were only slightly greater than the detection limit. The annual dose to an individual consuming water at these concentrations can be calculated with the same method used for those radionuclides more commonly found in creek water; this method of averaging, however, probably overestimates the true concentration. A nnual doses range from $3 \times 10^{-3}$ to $6 \times 10^{-5} \mathrm{mrem} / \mathrm{yr}$ for these radionuclides. 
TABLE 4.30

Radionuclide Concentrations and D ose Estimates

for Saw mill Creek Water, 1997

\begin{tabular}{lccc}
\hline Radionuclide & $\begin{array}{c}\text { Total Released } \\
\text { (Ci) }\end{array}$ & $\begin{array}{c}\text { Net Avg. } \\
\text { Conc. (pCi/L) }\end{array}$ & $\begin{array}{c}\text { Dose } \\
(\mathrm{mrem})\end{array}$ \\
\hline Hydrogen-3 & 0.724 & 83 & 0.0038 \\
Strontium-90 & 0.0026 & 0.30 & 0.0285 \\
Plutonium-239 & 0.00002 & 0.0023 & 0.0007 \\
A mericium-241 & 0.00004 & 0.0053 & 0.0017 \\
Total & 0.727 & & 0.0347 \\
\hline
\end{tabular}

DOE Order $5400.5^{12}$ requires that an evaluation be made of the dose to aquatic organisms from liquid effluents. The dose limit is $1 \mathrm{rad} /$ day or $365 \mathrm{rad} / \mathrm{yr}$. The location that could result in the highest dose to aquatic organisms is in Sawmill Creek downstream of the point where ANL-E discharges its treated wastewater. Inspection of the creek at this location indicates the presence of small bluegill and carp (about $100 \mathrm{~g}$ each). A dose can be estimated by using the annual average concentrations of the radionuclides listed in Table 4.5. The sum of the exposure from these radionuclides is estimated to be about $5 \times 10^{-6} \mathrm{rad} / \mathrm{yr}$, which is well within the DOE standard. This value, therefore, demonstrates compliance with that portion of the order.

The EPA has established drinking water standards on the basis of a maximum dose of $4 \mathrm{mrem} / \mathrm{yr}$ for man-made beta particle and photon-emitting radionuclides. ${ }^{24}$ The EPA standard is $2 \times 10^{4} \mathrm{pCi} / \mathrm{L}$ for hydrogen-3 and $8 \mathrm{pCi} / \mathrm{L}$ for strontium-90. The net concentrations in Table 4.30 correspond to $0.42 \%$ (hydrogen-3) and $3.8 \%$ (strontium-90) of the EPA standards. No specific EPA standards exist for the transuranic nuclides.

Saw mill Creek flows into the Des Plaines River. The flow rate of Sawmill Creek (see Section 1.6) is about $0.28 \mathrm{~m}^{3} / \mathrm{s}\left(10 \mathrm{ft}^{3} / \mathrm{s}\right)$; the flow rate of the Des Plaines River in the vicinity of $A N L-E$ is about $25 \mathrm{~m}^{3} / \mathrm{s}\left(900 \mathrm{ft}^{3} / \mathrm{s}\right)$. A pplying this ratio to the concentration of radionuclides in Sawmill Creek listed in Table 4.30, the dose to a hypothetical individual ingesting water from 


\section{ENVIRONMENTAL RADIOLOGICAL PROGRAM INFORMATION}

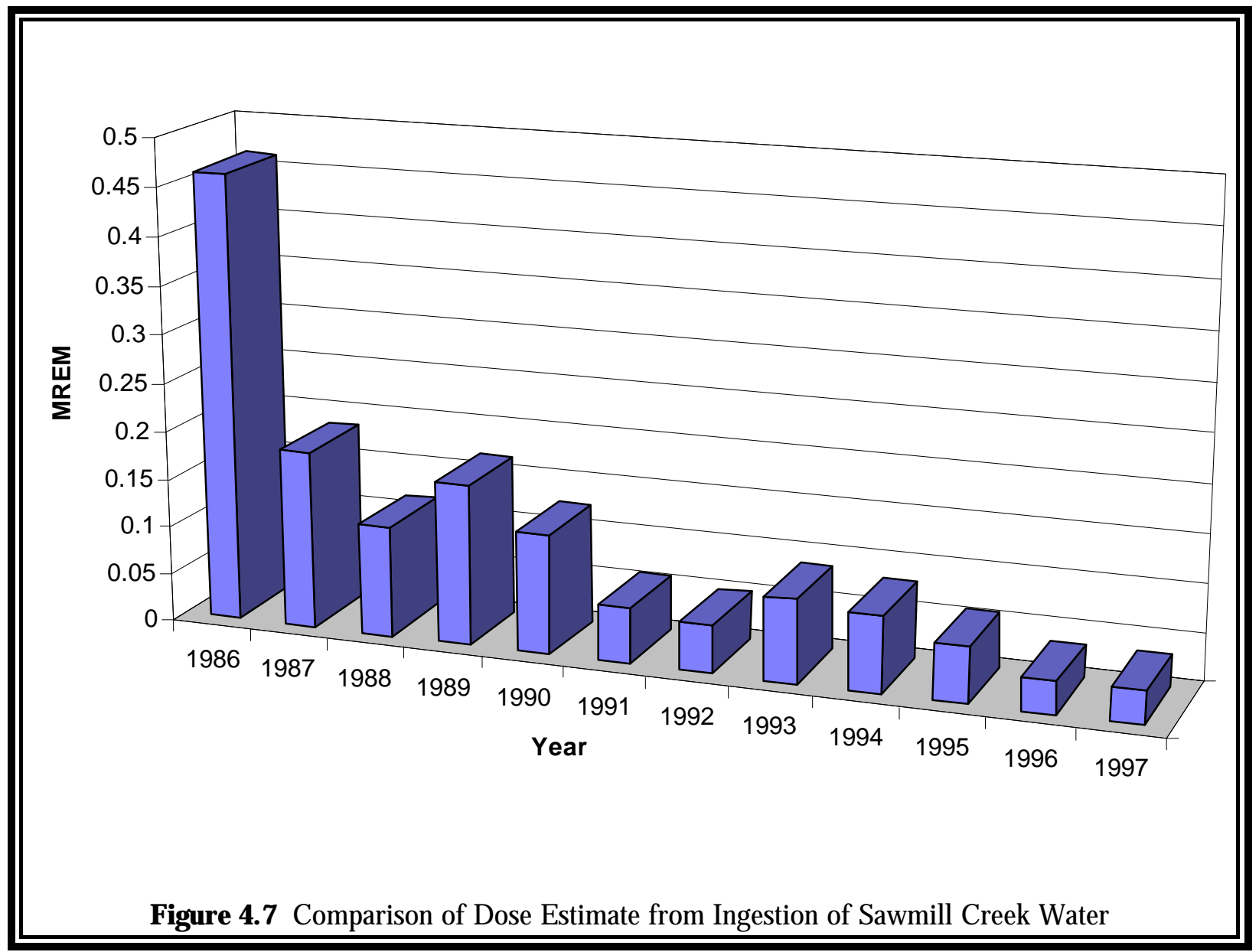

the Des Plaines River at L emont would be about $0.00004 \mathrm{mrem} / \mathrm{yr}$. Significant additional dilution occurs further downstream. Very few people, either directly or indirectly, use the Des Plaines River as a source of drinking water. If 100 people used Des Plaines River water at the hypothetical concentration at Lemont, the estimated population dose would be about $10^{-5}$ man-rem.

\subsubsection{External Direct Radiation Pathway}

The TLD measurements given in Section 4.5 were used to calculate the radiation dose from external sources. A bove-normal fence line doses attributable to ANL-E operations were found at the southern boundary near the Waste Storage F acility (L ocation 7I). 
At Location 7l, the fence line dose from ANL-E was approximately $100 \pm 8 \mathrm{mrem} / \mathrm{yr}$. Approximately $300 \mathrm{~m}(960 \mathrm{ft})$ south of the fence line (grid 6l), the measured dose was $91 \pm 3 \mathrm{mrem} / \mathrm{yr}$, slightly higher than the off-site average ( $82 \pm 2 \mathrm{mrem} / \mathrm{yr}$ ). No individuals live in this area. The closest residents are about $1.6 \mathrm{~km}(1 \mathrm{mi})$ south of the fence line. At this distance, the calculated dose rate from the Waste Storage Facility was $0.001 \mathrm{mrem} / \mathrm{yr}$, if the energy of the radiation were that of a $0.66-\mathrm{M} \mathrm{eV}$ cesium-137 gamma-ray, and approximately $0.003 \mathrm{mrem} / \mathrm{yr}$, if the energy were that of a 1.33-M eV cobalt-60 gamma-ray.

At the fence line, where higher doses were measured, the land is wooded and unoccupied. All of these dose calculations are based on full-time, outdoor exposure. Actual exposures to individuals would be substantially less because some of the individuals are indoors (which provides shielding) or away from their dwellings for part of the time.

In addition to the permanent resident in the area, occasionally visitors may conduct activities around ANL-E that could result in exposure to radiation from this site. Examples of these activities could be cross-country skiing, horseback riding, or running in the fire lane next to the perimeter fence. If the individual spent 10 minutes per week adjacent to the $317 \mathrm{~A} \mathrm{rea}$, the dose would be $0.02 \mathrm{mrem} / \mathrm{yr}$ at the 317 A rea fence (location $7 \mathrm{l}$ ).

\subsubsection{Dose Summary}

The total effective dose equivalent received by off-site residents during 1997 was a combination of the individual doses received through the separate pathways that contributed to exposure: hydrogen-3, carbon-11, nitrogen-13, oxygen-15, argon-41, krypton-85, radon-220 (plus daughters), and actinides through the airborne pathway. The highest dose was approximately $0.033 \mathrm{mrem} / \mathrm{yr}$ to individuals living north of the site if they were outdoors at that location during the entire year. The total annual population dose to the entire area within an $80-\mathrm{km}(50-\mathrm{mi})$ radius was 1.77 man-rem. The dose pathways are presented in Table 4.31 and compared with the applicable standards. 


\section{ENVIRONMENTAL RADIOLOGICAL PROGRAM INFORMATION}

TABLE 4.31

Summary of the Estimated Dose to the Public, 1997

(mrem/yr)

\begin{tabular}{lcc}
\hline \multicolumn{1}{c}{ Pathway } & ANL -E Estimate & A pplicable Standard \\
\hline Air (less radon) & 0.018 & 10 (EPA) \\
Air total & 0.033 & 100 (DOE) \\
Water & 0.035 & 100 (DOE) \\
Direct radiation & 0.010 & 100 (DOE) \\
M aximum public & 0.078 & 100 (DOE) \\
\hline
\end{tabular}

To receive the maximum public dose, an individual would need to live north of the site at the point of maximum air and direct radiation exposure and use only water from Saw mill Creek below the ANL-E wastewater outfall. This is a very conservative and unlikely situation. To put the maximum individual dose of $0.078 \mathrm{mrem} / \mathrm{yr}$ attributable to ANL-E operations into perspective, comparisons can be made to annual average doses received by the public from natural or accepted sources of radiation. These values are listed in Table 4.32. The magnitude of the doses received from ANL-E operations is insignificant compared with these sources. Therefore, the monitoring program results establish that the radioactive emissions from A NL-E are very low and do not endanger the health or safety of those living in the vicinity of the site. 
TABLE 4.32

A nnual A verage Dose Equivalent in the U.S. Population ${ }^{a}$

\begin{tabular}{lr}
\hline \multicolumn{1}{c}{ Source } & $\begin{array}{c}\text { Dose } \\
\text { (mrem) }\end{array}$ \\
\hline Natural & \\
Radon & 200 \\
Internal (potassium-40 and radium-226) & 39 \\
Cosmic & 28 \\
T errestrial & 28 \\
M edical & \\
Diagnostic X-rays & 39 \\
N uclear medicine & 14 \\
Consumer Products & 10 \\
D omestic water supplies, & \\
$\quad$ building materials, etc. & \\
Occupational (medical radiology, industrial & \\
radiography, research, etc.) & \\
Nuclear fuel cycle & $<1$ \\
Fallout & $<1$ \\
Other miscellaneous sources & $<1$ \\
$\quad$ Total & 360 \\
\hline a N ational Council on Radiation Protection and & \\
M easurements Report N 0. 93.22 & \\
\hline
\end{tabular}




\section{ENVIRONMENTAL NONRADIOLOGICAL PROGRAM INFORMATION}

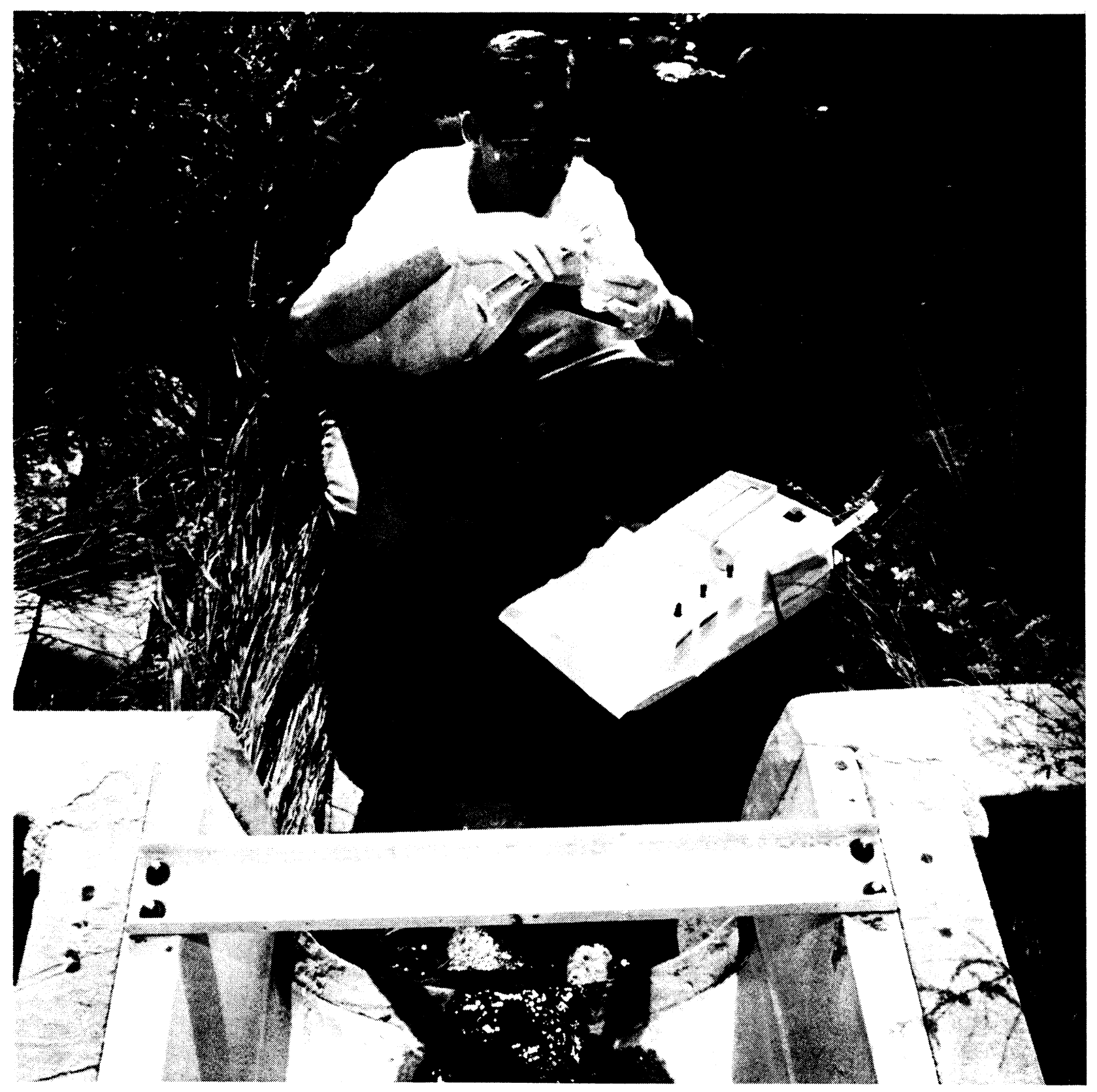




\section{ENVIRONMENTAL NONRADIOLOGICAL PROGRAM INFORMATION}




\section{ENVIRONMENTAL NONRADIOLOGICAL PROGRAM INFORMATION}

The nonradiological monitoring program involves the collection and analysis of surface water and groundwater samples from numerous locations throughout the site. The amount of nonradiological pollutants released to the air from A NL-E is extremely small, except for the boiler house, which is equipped with dedicated monitoring equipment for $\mathrm{SO}_{2}$ and opacity. One exceedance for opacity was noted during 1997 over a period of 3,400 hours of operation of Boiler No. 5, the coal-burning boiler. Chapter 3 provides a detailed discussion of the environmental monitoring program.

Surface water samples for nonradiological chemical analyses are collected from NPDES permitted outfalls and Sawmill Creek. A nalyses conducted on the samples from the NPDES outfalls vary, depending on the permit-mandated monitoring requirements for each outfall. The results of the analyses are compared with the permit limits for each outfall to determine whether they comply with the permit. In addition to being published in this report, the NPDES monitoring results are transmitted monthly to the IEPA in an official DM R. Table 5.1 summarizes the three exceedances of permit limits during 1997.

In addition to the permit-required monitoring, other analyses are conducted on samples collected from the combined wastewater outfall (NPDES Outfall 001) to provide a more complete evaluation of the impact of the wastewater on the environment. Water samples from Sawmill Creek are also collected and analyzed for a number of inorganic constituents. The results of these additional analyses of the main outfall and receiving streams are then compared with IEPA General Effluent Standards and Stream Quality Standards listed in IAC, Title 35, Subtitle C, Chapter I. ${ }^{25}$

\subsection{National Pollutant Discharge Elimination System Monitoring Results}

Wastewater is processed at ANL-E in two independent treatment systems, the sanitary system and the laboratory system. The sanitary wastewater collection and treatment system collects wastewater from lavatories, the cafeteria, office buildings, and other portions of the site that do not contain radioactive or hazardous materials. This wastewater is treated in a biological wastewater treatment system consisting of primary clarifiers, trickling filters, final clarifiers, and 


\section{ENVIRONMENTAL NONRADIOLOGICAL PROGRAM INFORMATION}

TABLE 5.1

\begin{tabular}{llc}
\multicolumn{2}{c}{ NPDES Permit Limit Exceedances, 1997} \\
\hline Outfall & Parameter & $\begin{array}{c}\text { Number of } \\
\text { Exceedances }\end{array}$ \\
\hline 001B & M ercury & $2^{\mathrm{a}}$ \\
004 & TSS & 1 \\
\hline
\end{tabular}

a Includes loading and concentration limit exceedances.

slow sand filters. Wastewater generated by research-related activities, such as laboratories and experimental equipment, flows to a series of retention tanks located in each building.

U se of the laboratory WTP retention tanks was discontinued with the start-up of the upgraded and expanded laboratory WTP in July 1997. Previously, laboratory wastewater below the release limits for discharge was pumped to the laboratory wastewater collection system, which directed the flow to the laboratory wastewater treatment system. The release limits are based on the DCGs of plutonium-239 $(0.03 \mathrm{pCi} / \mathrm{mL})$ for alpha activity and strontium-90 $(1.0 \mathrm{pCi} / \mathrm{mL})$ for beta activity. The system consisted of a series of concrete holding tanks that collected the wastewater prior to discharge. As with the retention tanks, once a holding tank was full, it was sampled and analyzed for radioactivity. If the level of radioactivity was below ANL-E discharge criteria, which were selected to ensure compliance with DOE Orders, it was pumped to a lined equalization basin, slowly combined with the sanitary waste stream, and discharged to Sawmill Creek. If either a retention tank or holding tank was found to contain unacceptable levels of radioactivity, the wastewater was pumped into portable tanks, treated by evaporation in Building 306, and the residue disposed of as radioactive waste.

Figure 5.1 shows the two wastewater treatment systems that are located adjacent to each other. The volume of wastewater discharged from these facilities in 1997 averaged 1.24 million L ( 0.35 million gal $) /$ day for the sanitary wastewater and 1.36 million $L(0.36$ million gal $) /$ day for the laboratory process wastewater. 


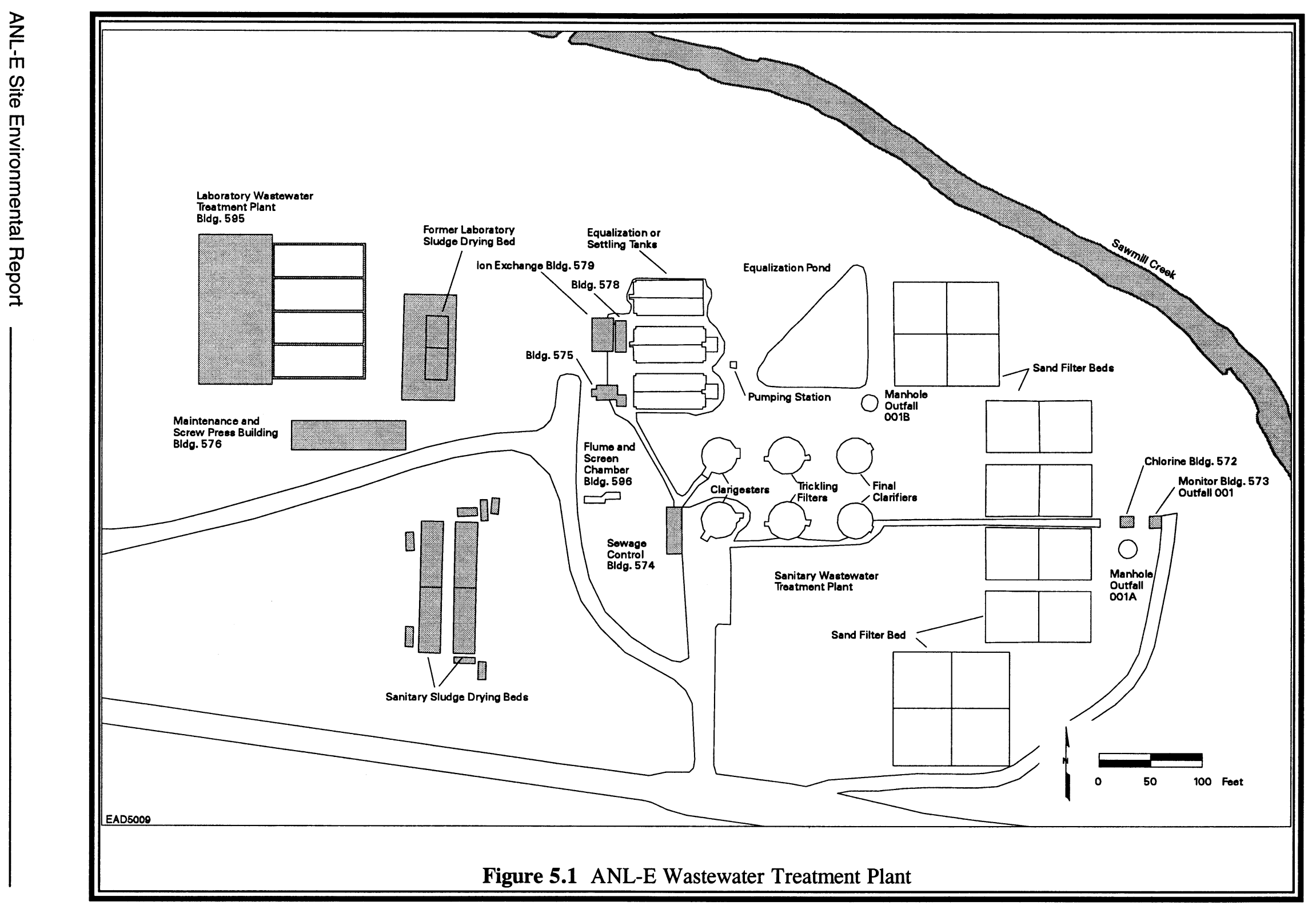




\section{ENVIRONMENTAL NONRADIOLOGICAL PROGRAM INFORMATION}

\subsubsection{Laboratory Wastewater Treatment Plant Renovations}

During 1997, the laboratory wastewater treatment facility renovation project was completed. Renovation and expansion of the existing laboratory WTP to provide additional treatment capability began in January 1996. In addition to increasing flow capacity to 3.8 million L (1.1 million gal)/day, the laboratory WTP upgrade provides additional treatment capability for metals, suspended solids, and VOCs. The upgraded laboratory WTP will provide continuous treatment through a system with numerous treatment unit operations, some of which will be selected on an as-needed basis to meet the variable nature of laboratory wastewater. Treatment capabilities of the upgraded laboratory WTP include screening and grit removal, pH adjustment, gravity separation, aeration, flow equalization, hydroxide precipitation, powdered activated-carbon adsorption, coagulation flocculation, and solids contact clarification. The NPDES compliance schedule "construction complete" milestone of July 1, 1997, was met. The facility began processing laboratory wastewater at that time, and other commissioning activities continued throughout the remainder of the year.

\subsubsection{Effluent Monitoring}

The two treatment plant systems process the vast majority of wastewater generated by ANL-E. However, a small amount of process wastewater, primarily cooling tower blowdown and cooling water, is discharged directly to a number of small streams and ditches throughout the site. This wastewater does not contain significant amounts of contaminants and does not require treatment before discharge. However, these discharge points are included in the site NPDES permit as separate regulated outfalls.

A NL-E-processed wastewater discharges are regulated by N PDES Permit N O. IL 0034592 (effective October 30, 1994, and modified A ugust 24, 1995). ${ }^{26}$ Discharge limits for 26 surface water discharge points (outfalls) and two internal monitoring points are included in this permit. The analyses required and the frequency of analysis for each point are specified in the permit. The analytical methods required for N PDES monitoring are listed in Table 1B of 40 CFR $136 .{ }^{27}$ 


\section{ENVIRONMENTAL NONRADIOLOGICAL PROGRAM INFORMATION}

Sample collection, preservation, and holding times are also mandated by requirements stipulated in Table 2 of 40 CFR $136 .{ }^{27}$

The NPDES outfall locations are shown in Figure 5.2. Outfalls 001A and 001B, the two internal monitoring points representing the effluent from the sanitary system and laboratory system, respectively, are both located at the WTP. Their flows combine to form Outfall 001, which also is located at the treatment facility. The combined stream flows through an outfall pipe that discharges into Sawmill Creek approximately $1,100 \mathrm{~m}(3,500 \mathrm{ft})$ south of the treatment plant.

\subsubsection{Sample Collection}

All samples are collected in specially cleaned and labeled bottles with appropriate preservatives added. Custody seals and chain of custody sheets also are used. All samples are analyzed within the required holding time. Samples are collected at locations 001A, 001B, and 001 on a weekly basis, consistent with permit requirements. Similarly, samples are collected at the other locations in accordance with the N PDES permit.

\subsubsection{Sample Analysis - NPDES}

NPDES sample analyses were performed in accordance with standard operating procedures (SOPs) that were issued as controlled documents. These SOPs cite protocols that can be found in 40 CFR 136, "Test Procedures for the A nalysis of Pollutants under the Clean Water Act." Six metal analyses were performed by using flame atomic absorption spectroscopy. Mercury was determined by cold vapor atomic absorption spectroscopy. Hexavalent chromium determination and chemical oxygen demand (COD) were performed by using a colorimetric technique. Five-day biochemical oxygen demand $\left(\mathrm{BOD}_{5}\right)$ was determined by using a dissolved oxygen probe. TSS; TDS; and fats, oils, and grease were determined gravimetrically. Sulfate determination was performed by using a turbidimetric technique; chloride was determined by titrimetry. A mmonia nitrogen was determined by distillation, followed by an ion-selective electrode finish. Five VOC 


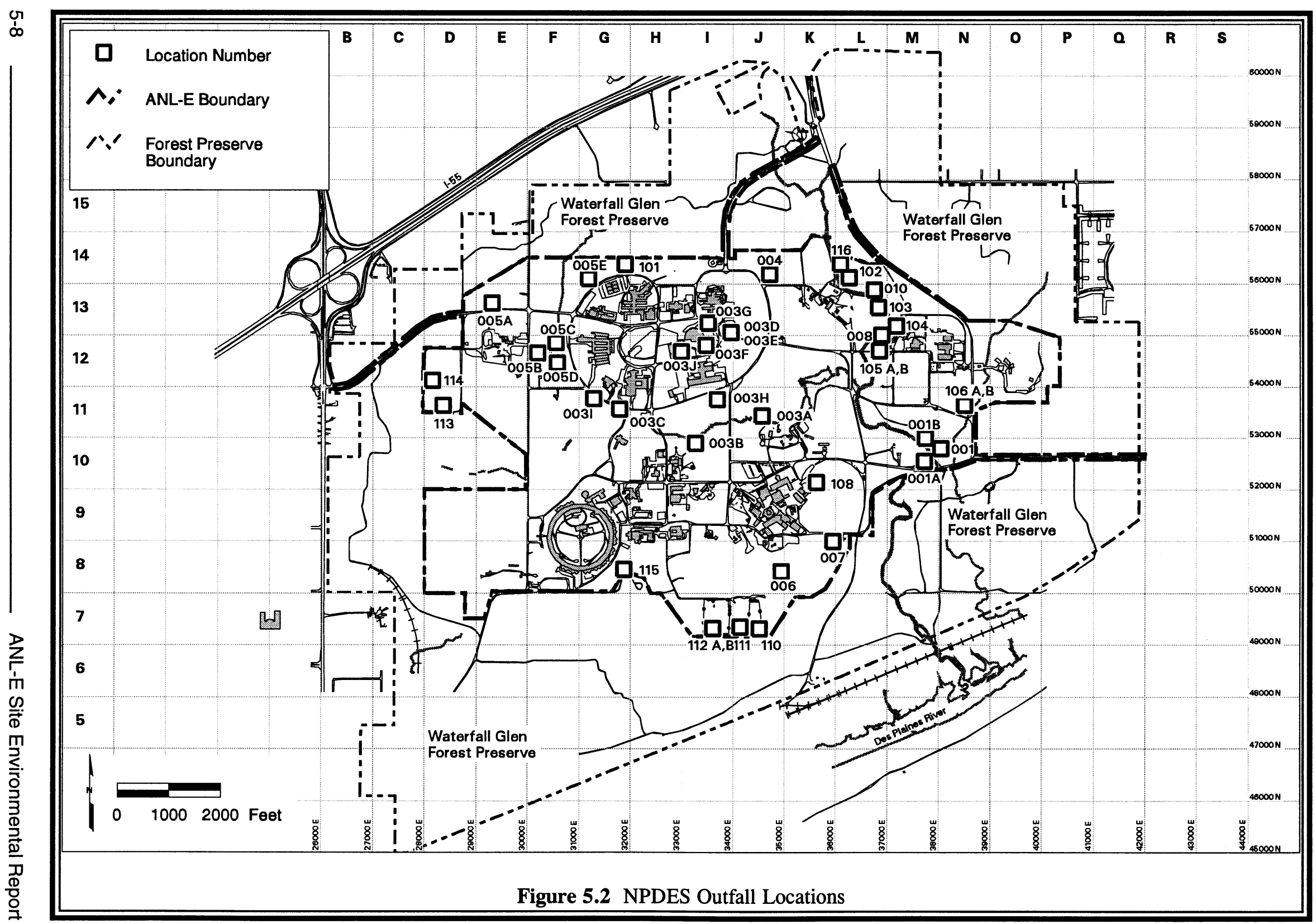




\section{ENVIRONMENTAL NONRADIOLOGICAL PROGRAM INFORMATION}

concentrations were determined by using a purge and trap sample pretreatment, followed by gas chromatography-mass spectroscopy detection. The PCB A rochlor 1260 concentrations were determined by solvent extraction, followed by gas chromatography-electron capture detection. Beta radioactivity was performed by using a gas flow proportional counting technique. Hydrogen-3 concentrations were determined by distillation, followed by a beta liquid scintillation counting technique.

Semiannually, NPDES Outfall O01B is sampled and analyzed for priority pollutant compounds. VOCs were determined by using a purge and trap sample pretreatment, followed by gas chromatography-mass spectroscopy detection. Semivolatile organic compounds (SVOCs) were determined by solvent extraction, followed by gas chromatography-mass spectroscopy detection. PCBs and pesticides were determined by solvent extraction, followed by gas chromatographyelectron capture detection. Thirteen metals were determined by graphite furnace atomic absorption and flame atomic absorption spectroscopy. Cyanide and phenol were determined by distillation, followed by a spectrophotometric finish.

NPDES Outfall 001 is sampled and analyzed annually for acute aquatic toxicity parameters. NPDES Outfalls 003H, 003I, 003), 004, 006, and 115 are tested biannually for aquatic toxicity. An off-site contractor laboratory performs both the sample collection and analyses. The testing is performed by using ANL-E effluent with Sawmill Creek receiving water, which introduces species of fish and invertebrates. Survival is measured over two to four days, and statistically significant mortality is reported as a function of effluent concentration.

\subsubsection{Results}

During 1997, approximately 99\% of all NPDES analyses were in compliance with their applicable permit limits, as compared to 1991 through 1996, when rates ranged from 96 to 98\%. Specific limit exceedances are discussed later in this section, as well as in Chapter 2. A discussion of the analytical results for each outfall follows. 


\section{ENVIRONMENTAL NONRADIOLOGICAL PROGRAM INFORMATION}

\subsubsection{Outfalls}

Outfall 001A. This outfall consists of treated sanitary wastewater and various wastewater streams from the boiler house area, including coal pile storm water runoff. The effectiveness of the sanitary wastewater treatment systems is evaluated by weekly monitoring for $\mathrm{BOD}, \mathrm{pH}$, and TSS. The limits for five-day BOD are a monthly average of $10 \mathrm{mg} / \mathrm{L}$ with a maximum value of $20 \mathrm{mg} / \mathrm{L}$. The permit limits for TSS are a maximum concentration of $24 \mathrm{mg} / \mathrm{L}$ and a monthly average of $12 \mathrm{mg} / \mathrm{L}$. The pH must range between values of 6 and 9 . All samples collected and analyzed for these parameters were within the permit limits during 1997.

The permit requires weekly monitoring for total chromium, copper, iron, lead, manganese, zinc, and oil and grease. Table 5.2 gives the effluent limits for these parameters and monitoring results. Two limits are listed; one is a maximum limit for any single sample, and the other is for the average of all samples collected during the month. The constituents in Table 5.2 are present in the coal pile runoff that may discharge to the sanitary sewage system. No limits were exceeded during 1997.

TABLE 5.2

Outfall 001A Effluent Limits and M onitoring Results, 1997

(Concentrations in $\mathrm{mg} / \mathrm{L}$ )

\begin{tabular}{lccccc}
\hline Constituent & M inimum & A verage & $\begin{array}{c}\text { A verage } \\
\text { Limit }\end{array}$ & M aximum & $\begin{array}{c}\text { M aximum } \\
\text { Limit }\end{array}$ \\
\hline Chromium & $-a$ & $<0.02$ & 1.00 & $<0.02$ & 2.00 \\
Copper & 0.018 & 0.032 & 0.50 & 0.067 & 1.00 \\
Iron & 0.074 & 0.176 & 2.00 & 0.845 & 4.00 \\
Lead & - & $<0.10$ & 0.20 & $<0.10$ & 0.40 \\
M anganese & $<0.015$ & 0.024 & 1.00 & 0.090 & 2.00 \\
Zinc & 0.045 & 0.112 & 1.00 & 0.280 & 2.00 \\
Oil and grease & - & $<5.0$ & 15.0 & $<5.0$ & 30.0 \\
\hline
\end{tabular}

a $A$ hyphen indicates no minimum values. 


\section{ENVIRONMENTAL NONRADIOLOGICAL PROGRAM INFORMATION}

Outfall 001B. This outfall consists of processed wastewater from the laboratory wastewater system. The permit requires that weekly samples be collected and analyzed for BOD, TSS, mercury, $\mathrm{pH}$, and COD.

The limits established for BOD are a daily maximum of $20 \mathrm{mg} / \mathrm{L}$ with a 30-day average of $10 \mathrm{mg} / \mathrm{L}$. The permit also contains BOD mass loading limits of $52 \mathrm{~kg}(114 \mathrm{lb}) /$ day as a daily maximum and $26 \mathrm{~kg}(57 \mathrm{lb}) /$ day as a 30-day average. The mass loading represents the weight of material discharged per day and is a function of concentration and flow. The daily maximum limit for TSS is $24 \mathrm{mg} / \mathrm{L}$ with a 30-day average of $12 \mathrm{mg} / \mathrm{L}$. The TSS mass loading limits are 62 and $31 \mathrm{~kg}$ (136 and $68 \mathrm{lb}) /$ day, respectively. No exceedances of the BOD or TSS concentration limits occurred in 1997.

The daily maximum concentration limit for mercury is $6 \mu \mathrm{g} / \mathrm{L}$; the 30-day average is $3 \mu \mathrm{g} / \mathrm{L}$. The corresponding loading values are $0.02 \mathrm{~kg}(0.034 \mathrm{lb}) /$ day and $0.01 \mathrm{~kg}(0.017 \mathrm{lb}) / \mathrm{day}$. Two exceedances of the mercury loading and concentration limits were noted during September 1997. It appears that residual mercury in the laboratory sewer system associated with the changeover to the new laboratory wastewater treatment system accounted for the elevated levels.

No concentration limits have been established for COD. The once-per-week grab samples give a rough indication of the organic and inorganic contents of this stream. The values obtained in 1997 ranged from less than 10 to $45 \mathrm{mg} / \mathrm{L}$.

A special condition at location 001B requires monitoring for the 124 priority pollutants listed in the permit during the months of J une and December. The J une sampling is to be conducted at the same time that aquatic toxicity testing of Outfall 001 is conducted. Samples were collected on June 24, 1997, and December 10, 1997, and analyzed within the required holding times.

A nalysis of these samples indicated that very small amounts of a few chemicals were present. The results for SVOCs, PCBs, and pesticides were all less than the detection limits. 


\section{ENVIRONMENTAL NONRADIOLOGICAL PROGRAM INFORMATION}

With the exception of zinc, the results for metals were similar to concentrations found in A NL-E treated drinking water. The samples contained some VOCS at very low levels. The majority of compounds detected were halomethanes. Table 5.3 lists the concentrations of volatile organics identified in these samples. Currently, no permit limits or effluent standards with which to compare these results are available for these compounds.

Prior to J uly 1997, the laboratory WTP consisted of six 259,000-L (69,000-gal) equalization or settling (holding) tanks (see Figure 5.1), the contents of which were pumped to a lined equalization pond before being discharged to Sawmill Creek. During 1989, a study was performed to determine the levels of VOCs in the influent to these tanks and to determine the variability of this concentration. A number of different volatile organics were found to be present from time to time. The concentrations varied greatly throughout the day, and maximum levels were found to occur in the late afternoon. As a follow-up to this study, each month one influent sample is obtained at about 1300 hours and analyzed for VOCs. During A ugust 1993, water began discharging from $M$ anhole $2 E$ (refer to Section 6.2.2.3.) in the 317 A rea on a regular basis. This water is known to contain volatile organics at consistent levels. A modified NPDES permit was issued by the IEPA to reflect this discharge.

The 1997 results for laboratory wastewater are quite similar to those for 1996. Table 5.4 shows the 1997 results for the most common compounds detected. Bromoform,

\section{TABLE 5.3}

Outfall 001B Priority Pollutant M onitoring Results, 1997

(Concentrations in $\mu \mathrm{g} / \mathrm{L}$ )

\begin{tabular}{lcc}
\hline \multicolumn{1}{c}{ Compound } & $\begin{array}{c}\text { Concentration in } \\
\text { June Sample }\end{array}$ & $\begin{array}{c}\text { Concentration in } \\
\text { December Sample }\end{array}$ \\
\hline Bromodichloromethane & 3 & $<1$ \\
Bromoform & 8 & $<1$ \\
Chloroform & 5 & 1 \\
Dibromochloromethane & 6 & 1 \\
M ethylene chloride & 8 & 4 \\
1,1,2-Trichloroethane & 2 & $<1$ \\
\hline
\end{tabular}




\section{ENVIRONMENTAL NONRADIOLOGICAL PROGRAM INFORMATION}

TABLE 5.4

Volatile Organic Compounds in L aboratory Wastewater, 1997

(Concentrations in $\mu \mathrm{g} / \mathrm{L}$ )

\begin{tabular}{|c|c|c|c|c|c|c|}
\hline M onth & A cetone & Chloroform & $\begin{array}{l}\text { M ethylene } \\
\text { Chloride }\end{array}$ & $\begin{array}{l}\text { Bromodi- } \\
\text { chloroethane }\end{array}$ & $\begin{array}{l}\text { Dibromo- } \\
\text { chloromethane }\end{array}$ & Bromoform \\
\hline January & $<1$ & 7 & $<1$ & 4 & 3 & $<1$ \\
\hline F ebruary & 33 & 3 & $<1$ & 2 & $<1$ & $<1$ \\
\hline M arch & 162 & 6 & 1 & 3 & 1 & $<1$ \\
\hline April & 3 & 3 & $<1$ & 2 & 2 & 3 \\
\hline May & 7 & 5 & $<1$ & 3 & 5 & 4 \\
\hline June & 7 & 3 & $<1$ & 3 & 7 & 12 \\
\hline July & 393 & 111 & $<1$ & 3 & 5 & 5 \\
\hline A ugust & 599 & 61 & 72 & 3 & 12 & $<1$ \\
\hline September & 58 & 1 & 314 & 4 & 21 & 40 \\
\hline October & 173 & 35 & $<1$ & 2 & 7 & 20 \\
\hline November & 5 & 1 & 28 & 1 & 2 & 7 \\
\hline December & 15 & 6 & 5 & 4 & 3 & $<1$ \\
\hline
\end{tabular}

bromodichloromethane, chloroform, and dibromochloromethane are halomethanes that are produced as the result of contact of the chlorinated water supply with organic chemicals. Research activity probably accounts for the presence of other volatiles. The zinc concentration was elevated $(9.6 \mathrm{mg} / \mathrm{L})$ in the June sample. The cause is unknown. The December zinc result was in the normal range $(0.3 \mathrm{mg} / \mathrm{L})$.

Similar to 1995 and 1996, the more persistent VOCs were consistently noted but at lower ranges of concentration. A cetone was detected in 11 samples, and levels ranged up to $599 \mu \mathrm{g} / \mathrm{L}$, which is substantially lower than the 1996 upper range of 9,497 $\mu \mathrm{g} / \mathrm{L}$. M ethylene chloride was detected in five samples and ranged up to $314 \mu \mathrm{g} / \mathrm{L}$. Infrequent trace levels of other chemicals, that is, acetaldehyde, 2-butanone, ethyl ether, cyclohexane, toluene, trichloroethene, and 1,1,1-trichloroethane, were al so noted.

Figures 5.3 and 5.4 present comparisons of the 1992 through 1997 laboratory wastewater results for the two more persistent VOCs. The persistent presence of acetone at elevated 


\section{ENVIRONMENTAL NONRADIOLOGICAL PROGRAM INFORMATION}

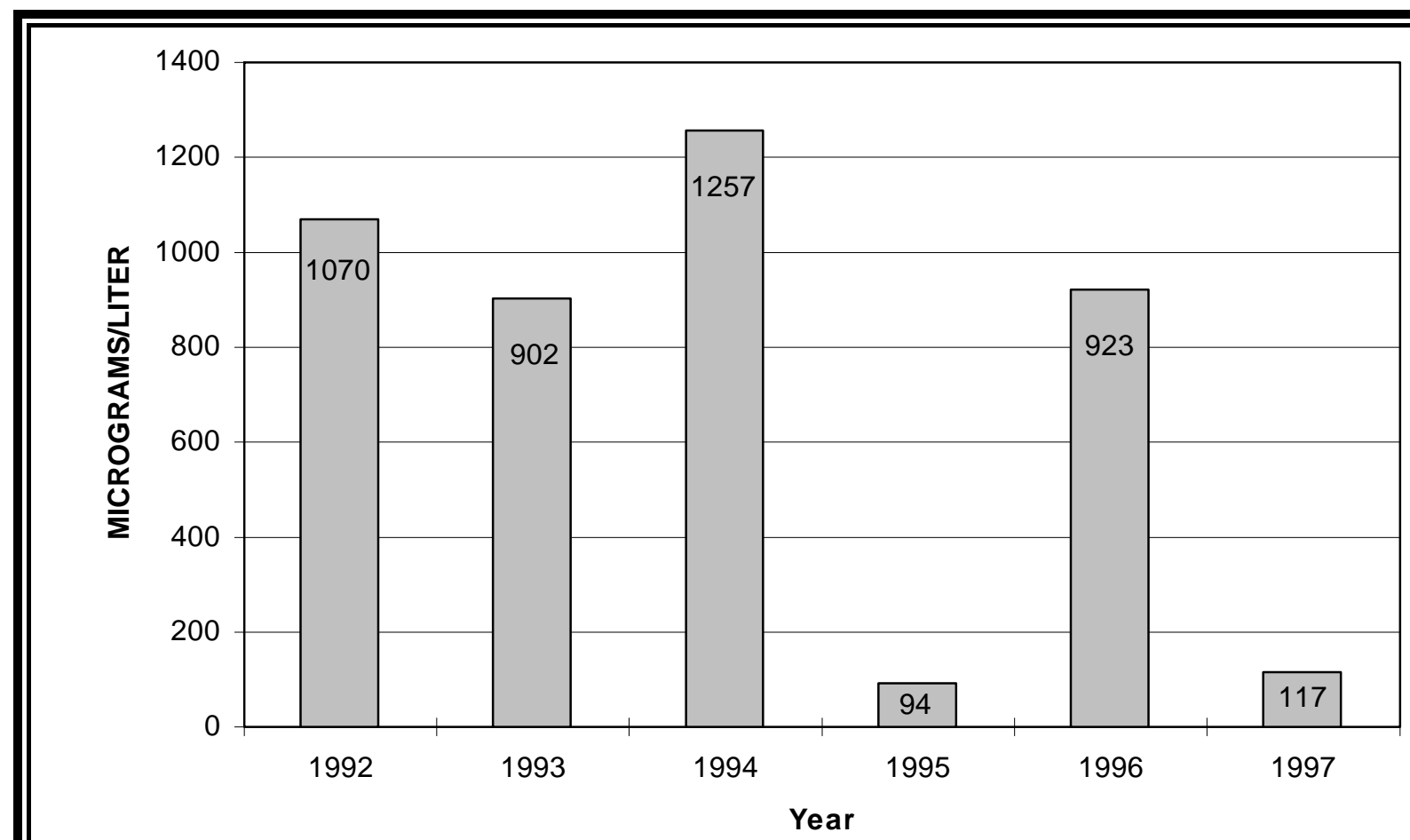

Figure 5.3 A verage A cetone L evels in L aboratory W astewater, 1992 to 1997

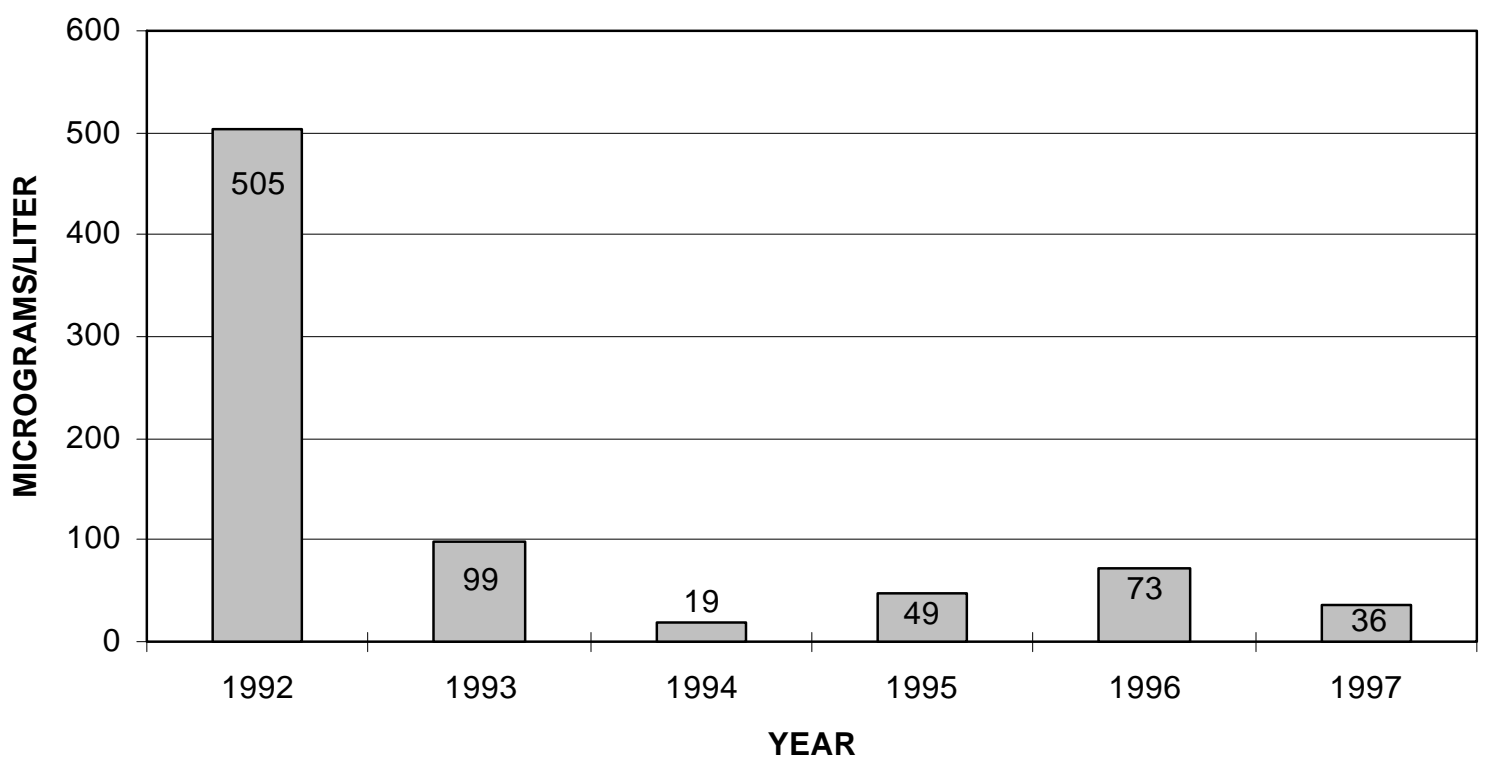

Figure 5.4 A verage M ethylene Chloride L evels in L aboratory W astewater, 1992 to 1997 


\section{ENVIRONMENTAL NONRADIOLOGICAL PROGRAM INFORMATION}

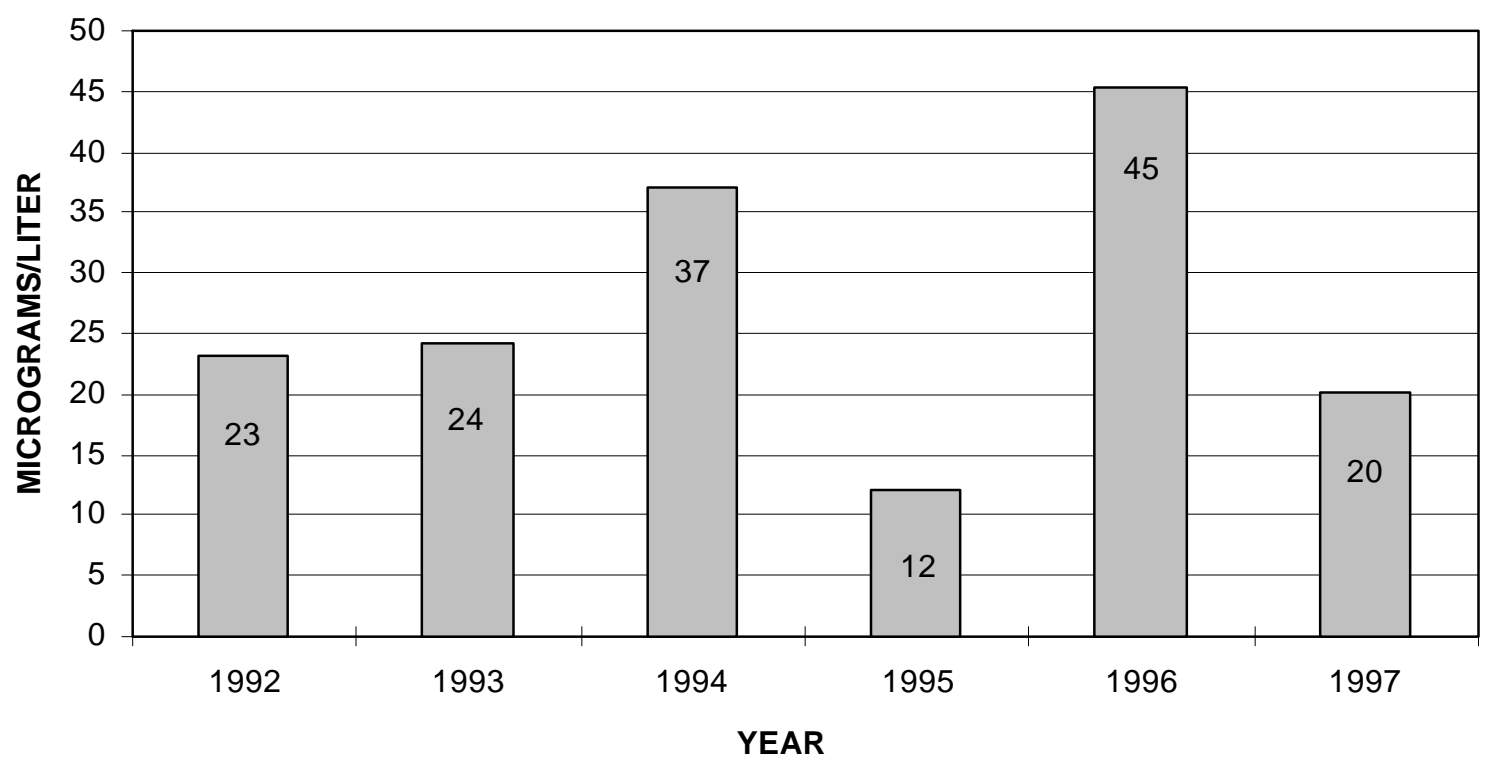

Figure 5.5 A verage Chloroform L evels in L aboratory W astewater, 1992 to 1997

concentrations is likely due to laboratory activities such as rinsing glassware. ANL-E continues to conduct a waste generator education program regarding disposal of chemicals down laboratory drains. ANL-E plans to strengthen the program for the overall reduction of volatile organics in laboratory wastewater.

Outfall 001. The treated wastewater streams from the two treatment systems are combined, and samples for analysis of most of the permit parameters are collected from a manhole downstream of the former chlorine contact chamber. This combined effluent then flows through the outfall sewer to Sawmill Creek. The effluent travels through this sewer for approximately 1, $100 \mathrm{~m}(3,500 \mathrm{ft})$ before being discharged.

The permit requires analysis of the combined effluent once a week for TDS, chloride, and sulfate. The results, limits, and number of exceedances are presented in Table 5.5. An interim limit of $1,500 \mathrm{mg} / \mathrm{L}$ for TDS became effective A ugust 24, 1995. The limit is effective up to June 30, 1998. 


\section{ENVIRONMENTAL NONRADIOLOGICAL PROGRAM INFORMATION}

TABLE 5.5

Outfall 001 M onitoring Results and Effluent Limits, 1997

(Concentrations in $\mathrm{mg} / \mathrm{L}$ )

\begin{tabular}{lccccc}
\hline \multicolumn{1}{c}{ Constituent } & M inimum & A verage & Maximum & Limit & Exceedances \\
\hline Copper & 0.020 & 0.035 & 0.056 & $1.0^{\mathrm{a}}$ & 0 \\
TDS & 401 & 714 & 1,199 & $1,500^{\mathrm{a}}$ & 0 \\
A mmonia nitrogen & 0.3 & 1.2 & 2.5 & M onitor only $^{\mathrm{a}}$ & $\mathrm{NA}^{\mathrm{b}}$ \\
\hline
\end{tabular}

a Interim limit effective A ugust 24, 1995.

b $\mathrm{NA}=$ not applicable.

Elevated TDS levels are believed to be related to discharges from boiler operations, that is, boiler blowdown, which is known to contain high levels of TDS, road salt, and cooling tower blowdown. For the past several years, chemical analysis for chloride has indicated a close relationship between TDS levels and chloride levels. Figure 5.6 shows the results of TDS and chloride analyses for 1996 through 1997. A significant decrease in TDS levels was noted during 1997. This decrease can be attributed to ANL-E's new domestic water source, Lake M ichigan, which is characterized by low TDS levels (200 to 400 ppm). Elevated levels were noted during the 1997 heating season (J anuary through M arch). Figure 5.7 shows the weekly TDS levels at Outfall 001 just prior to incorporation of Lake Michigan water during 1997. The modified NPDES permit incorporates an interim TDS limit $(1,500 \mathrm{mg} / \mathrm{L})$ and a compliance schedule for achieving final TDS effluent limits at Outfall 001. The final limits will be effective July 1, 1998. Limits for TDS, chloride, and sulfate were not exceeded during 1997.

A decrease in copper levels, compared to previous years, was noted during 1997. The changeover in the domestic water supply from groundwater to L ake M ichigan water during 1997 appears to have played a major role in reducing the amount of copper in the wastewater. A copper and lead monitoring program (see Chapter 6) determined that Lake Michigan water causes significantly less corrosion of domestic water distribution copper piping than the previously used groundwater source. During 1997, the copper levels at the ANL-E drinking water monitoring locations were below the $1.3 \mathrm{mg} / \mathrm{L}$ action level for copper. The acceptable levels for human 


\section{ENVIRONMENTAL NONRADIOLOGICAL PROGRAM INFORMATION}

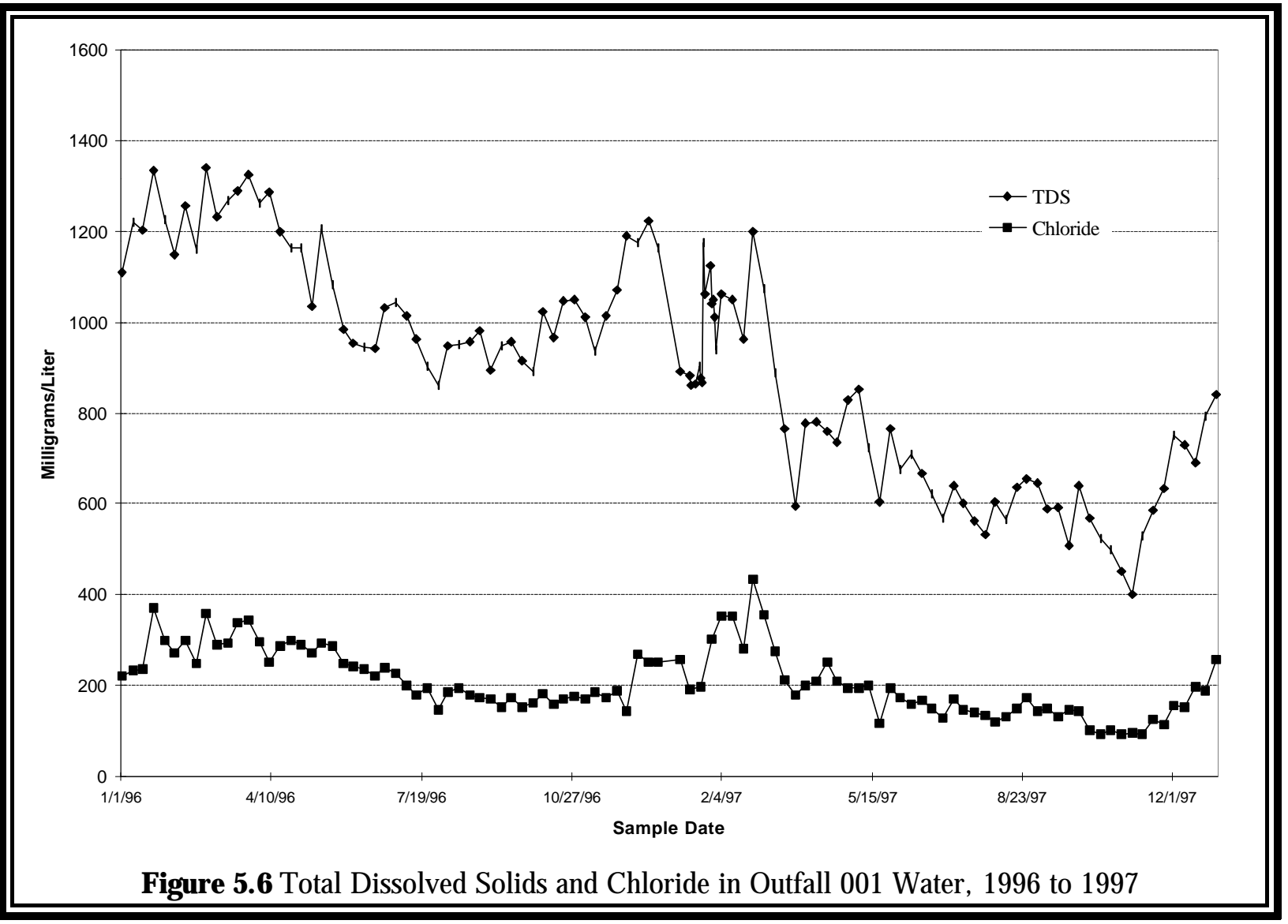

consumption are significantly above the NPDES permit limit at Outfall 001. The WTP has no process for removing copper. Past samples collected from the combined WTP effluent have been below the IEPA effluent limit of $0.5 \mathrm{mg} / \mathrm{L}$. However, concentrations measured in Saw mill Creek, below the point where the treated wastewater has been discharged, have consistently exceeded the IEPA stream standard for copper $(0.02 \mathrm{mg} / \mathrm{L})$ for several years. This is indicative of the current ambient levels of copper in surface water as a result of the increased use of copper pipe for domestic water distribution. Figure 5.8 shows the 1996 through 1997 monthly average copper levels at Outfall 001. The modified NPDES permit (effective A ugust 24, 1995) incorporates an interim upper limit ( $1.0 \mathrm{mg} / \mathrm{L}$ daily maximum) and a compliance schedule for achieving final copper effluent limits at Outfall 001. The final limits will be effective July 1, 1998. No copper exceedances occurred during 1997. 


\section{ENVIRONMENTAL NONRADIOLOGICAL PROGRAM INFORMATION}

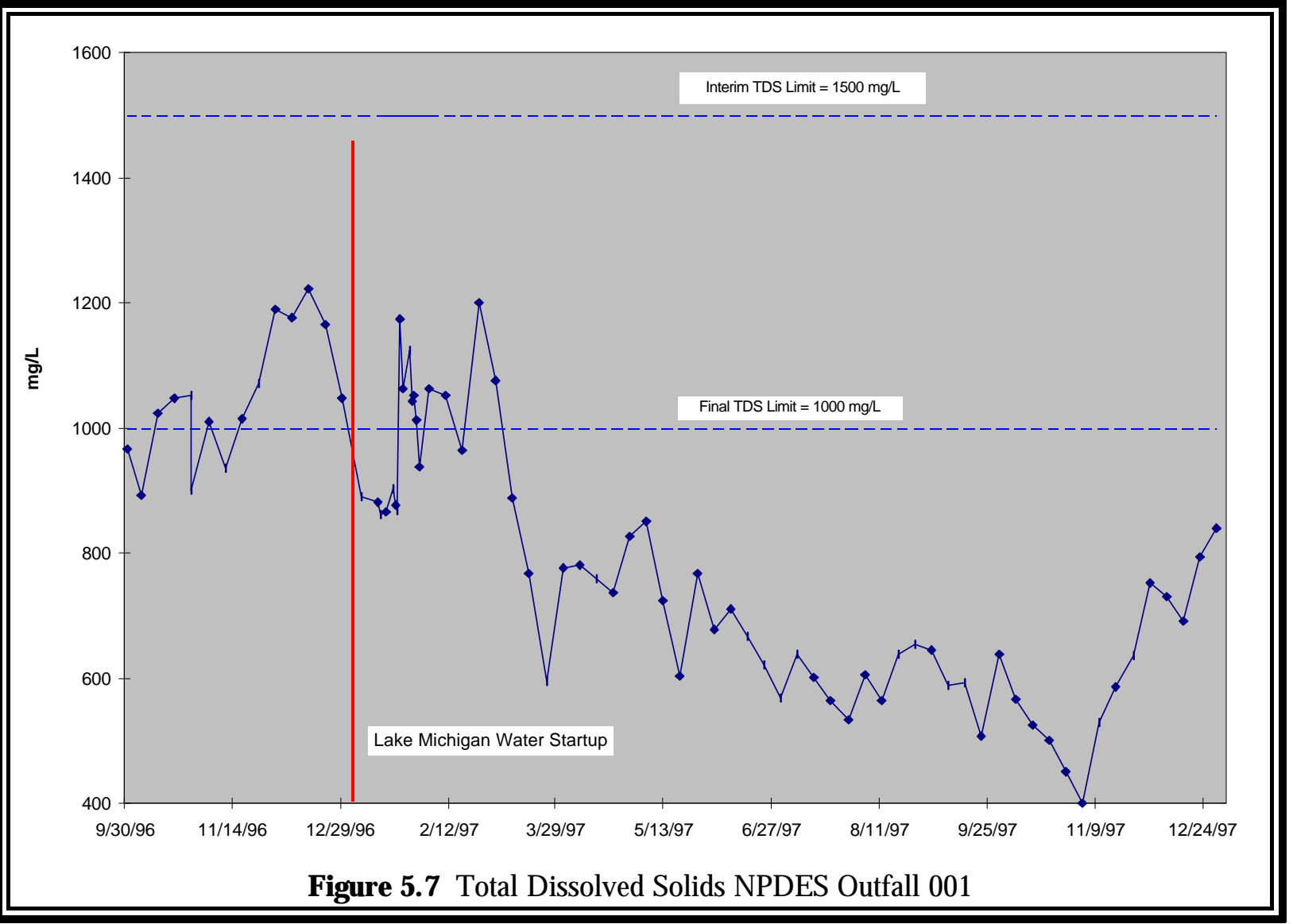

The upgrade of the sanitary wastewater treatment plant, completed in 1996, has enhanced the treatment of ammonia nitrogen. Figure 5.9 shows a decrease in the monthly average ammonia nitrogen levels prior to and after the sanitary wastewater treatment plant upgrade. Improved mechanical operation of the trickling filters results in a more even dispersion of the wastewater. Also, dome covers on the trickling filters allow the trickling filters to hold a constant temperature and aerobic conditions by providing a constant flow of air across the filter area. The modified NPDES permit (effective A ugust 24, 1995) incorporates interim ammonia nitrogen limits (monitor only) and a compliance schedule for achieving final ammonia nitrogen effluent limits at Outfall 001. Final limits will be effective July 1, 1998.

The permit requires that a biological toxicity screening test be performed on wastewater from Outfall 001 in J une of each year. The toxicity testing is run on two trophic levels of aquatic 


\section{ENVIRONMENTAL NONRADIOLOGICAL PROGRAM INFORMATION}

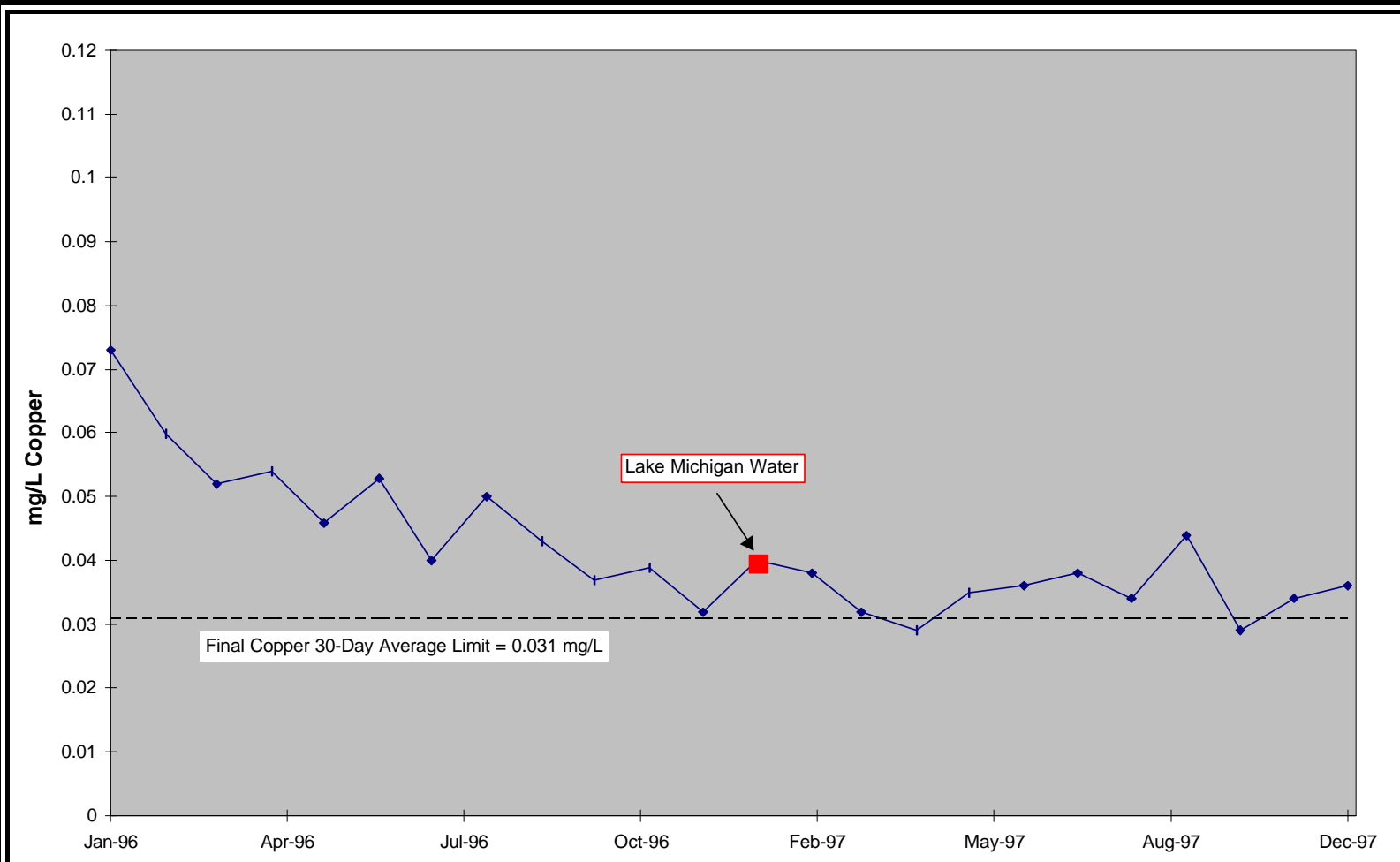

Figure 5.8 NPDES Outfall 001 30-Day Average Copper Results, 1996 to 1997

species for acute toxicity. The 1997 testing was conducted on samples collected J une 23-27; the water flea, Ceriodaphnia dubia, and fathead minnow, Pimephales promelas, were used.

No toxicity was observed to the fathead minnows or to the water flea. The concentration of wastewater that produces $50 \%$ mortality in the test population (i.e., the $\mathrm{LC}_{50}$ ) for both species is greater than 100\%; that is, concentrations higher than those found in the effluent would be required for half to be killed. Table 5.6 summarizes the results from the toxicity tests for 1997. Table 5.7 summarizes the test results from 1991 to 1997.

The permit also requires that weekly pH, ammonia nitrogen, dissolved iron, manganese, and zinc measurements be made. No exceedances of these parameters were noted in 1997. M onthly monitoring for lead, hexavalent and trivalent chromium, and beta radioactivity is required. 


\section{ENVIRONMENTAL NONRADIOLOGICAL PROGRAM INFORMATION}

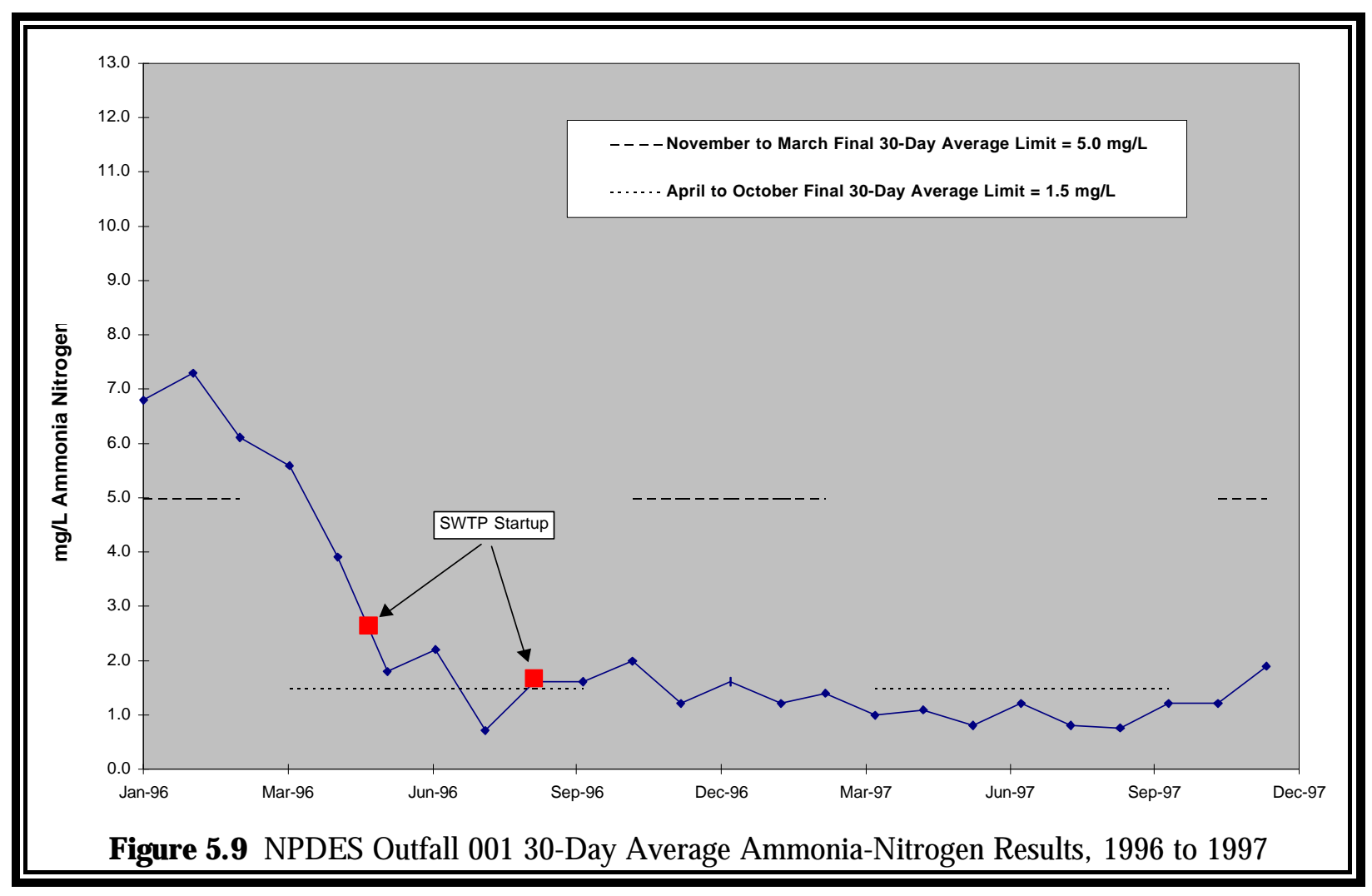

TABLE 5.6

Outfall 001 A quatic Toxicity Test Results, 1997

\begin{tabular}{ccc}
\hline Test & Endpoint & $\begin{array}{c}96 / 48-H \text { our } \\
\mathrm{LC}_{50} \\
(\%)\end{array}$ \\
\hline $\begin{array}{c}\text { 96-hour fathead minnow } \\
\text { acute toxicity }\end{array}$ & Survival & $>100.0$ \\
$\begin{array}{c}\text { 48-hour Ceriodaphnia } \\
\text { acute toxicity }\end{array}$ & Survival & $>100.0$ \\
\hline
\end{tabular}




\section{ENVIRONMENTAL NONRADIOLOGICAL PROGRAM INFORMATION}

TABLE 5.7

Outfall 001 A quatic Toxicity Test Results, 1991 to 1997

\begin{tabular}{lrrrrrrr}
\hline \multicolumn{1}{c}{ Test } & $\begin{array}{c}1991 \\
(\%)\end{array}$ & $\begin{array}{c}1992 \\
(\%)\end{array}$ & $\begin{array}{c}1993 \\
(\%)\end{array}$ & $\begin{array}{c}1994 \\
(\%)\end{array}$ & $\begin{array}{c}1995 \\
(\%)\end{array}$ & $\begin{array}{c}1996 \\
(\%)\end{array}$ & $\begin{array}{c}1997 \\
(\%)\end{array}$ \\
\hline Minnow, acute, LC 50 & 61.6 & $<6.2$ & 100.0 & 100.0 & $>100$ & $>100$ & $>100$ \\
Ceriodaphnia, acute, LC50 & 17.1 & 35.4 & 100.0 & 100.0 & $>100$ & $>100$ & $>100$ \\
Minnow, chronic, survival, NOEC ${ }^{\text {a }}$ & 50.0 & 100.0 & 50.0 & 100.0 & - b & - & - \\
Minnow, chronic, survival, LOEC & 100.0 & 100.0 & 100.0 & 100.0 & - & - & - \\
Minnow, chronic, growth, NOEC & 50.0 & 100.0 & 50.0 & 100.0 & - & - & - \\
Ceriodaphnia, chronic, survival, N OEC & 50.0 & 50.0 & 50.0 & 100.0 & - & - & - \\
Ceriodaphnia, chronic, survival, LOEC & 100.0 & 100.0 & 100.0 & 100.0 & - & - & - \\
Ceriodaphnia, chronic, reproduction, NOEC & 50.0 & 50.0 & 25.0 & 100.0 & - & - & - \\
Algal growth, LOEC & 6.2 & 6.2 & 100.0 & 100.0 & - & - & - \\
Algal growth, NOEC & 3.1 & $<6.25$ & 100.0 & 100.0 & - & - & - \\
\hline
\end{tabular}

a $\mathrm{NOEC}=$ no observable effect concentration; the highest concentration of the effluent at which no adverse effect is observed.

b A hyphen indicates that no analysis was performed because of a change in the permit.

c $\angle O E C=$ lowest observable effect concentration; the lowest concentration of the effluent at which an adverse effect is observed.

Outfall 003A. This potential discharge is located approximately $25 \mathrm{~m}(75 \mathrm{ft})$ north of the swimming pool and is a vitrified clay pipe that was originally used as the discharge point for all the swimming pool activities (filter backwash, draining, and overflow). Table 5.8 presents the sampling requirements and effluent limits.

By July 1995, discharge of chlorinated water from Outfall 003A had been completely eliminated by installation of a sump collection system that captures all the flow and discharges into the sanitary drain system.

Outfall 003B. This outfall is located approximately $150 \mathrm{~m}(500 \mathrm{ft})$ northeast of Building 308 and is composed of storm water runoff and condensate from the buildings in the watershed of the outfall. The discharge point is a 1-m (36-in.) concrete pipe to a tributary brook flowing north to the Freund Brook. Table 5.8 gives the sampling requirements and effluent limits. No exceedances occurred during 1997. 


\section{ENVIRONMENTAL NONRADIOLOGICAL PROGRAM INFORMATION}

TABLE 5.8

NPDES Effluent Summary, 1997

\begin{tabular}{|c|c|c|c|c|c|}
\hline \multirow[b]{2}{*}{$\begin{array}{l}\text { Discharge } \\
\text { Location }\end{array}$} & \multirow[b]{2}{*}{$\begin{array}{l}\text { No. of } \\
\text { Samples }\end{array}$} & \multirow[b]{2}{*}{$\begin{array}{c}\text { Permit } \\
\text { Constituent }\end{array}$} & \multicolumn{2}{|c|}{ Limit } & \multirow{2}{*}{$\begin{array}{c}\text { No. } \\
\text { Exceeding } \\
\text { Limit }\end{array}$} \\
\hline & & & $\begin{array}{l}\text { 30-D ay } \\
\text { A verage }\end{array}$ & $\begin{array}{c}\text { Daily } \\
\text { M aximum }\end{array}$ & \\
\hline \multirow[t]{4}{*}{$003 \mathrm{~A}$} & 0 & Flow & \multicolumn{2}{|c|}{ None } & 0 \\
\hline & & $\mathrm{pH}$ & \multicolumn{2}{|c|}{$6-9$} & 0 \\
\hline & & TSS & 15 & 30 & 0 \\
\hline & & $\mathrm{TRC}^{\mathrm{a}}$ & \multicolumn{2}{|c|}{0.05} & 0 \\
\hline \multirow[t]{3}{*}{ 003B } & 12 & Flow & \multicolumn{2}{|c|}{ None } & 0 \\
\hline & & $\mathrm{pH}$ & \multicolumn{2}{|c|}{ 6-9 } & 0 \\
\hline & & Temperature & \multicolumn{2}{|c|}{$<2.8^{\circ} \mathrm{C}$ rise } & 0 \\
\hline \multirow[t]{2}{*}{$003 C$} & 12 & Flow & \multicolumn{2}{|c|}{ None } & 0 \\
\hline & & $\mathrm{pH}$ & \multicolumn{2}{|c|}{$6-9$} & 0 \\
\hline \multirow[t]{3}{*}{ 003D } & 12 & Flow & \multicolumn{2}{|c|}{ None } & 0 \\
\hline & & $\mathrm{pH}$ & \multicolumn{2}{|c|}{ 6-9 } & 0 \\
\hline & & Temperature & \multicolumn{2}{|c|}{$<2.8^{\circ} \mathrm{C}$ rise } & 0 \\
\hline \multirow[t]{3}{*}{ 003E } & 12 & Flow & \multicolumn{2}{|c|}{ None } & 0 \\
\hline & & $\mathrm{pH}$ & \multicolumn{2}{|c|}{$6-9$} & 0 \\
\hline & & Temperature & \multicolumn{2}{|c|}{$<2.8^{\circ} \mathrm{C}$ rise } & 0 \\
\hline \multirow[t]{4}{*}{$003 \mathrm{~F}$} & 8 & Flow & \multicolumn{2}{|c|}{ None } & 0 \\
\hline & & $\mathrm{pH}$ & \multicolumn{2}{|c|}{$6-9$} & 0 \\
\hline & & Temperature & \multicolumn{2}{|c|}{$<2.8^{\circ} \mathrm{C}$ rise } & 0 \\
\hline & & TDS & \multicolumn{2}{|c|}{ M onitor only } & $N A^{b}$ \\
\hline \multirow[t]{3}{*}{$003 G$} & 12 & Flow & \multicolumn{2}{|c|}{ None } & 0 \\
\hline & & $\mathrm{pH}$ & \multicolumn{2}{|c|}{ 6-9 } & 0 \\
\hline & & Temperature & $<2$ & C rise & 0 \\
\hline $003 \mathrm{H}$ & 11 & Flow & & & 0 \\
\hline & & $\mathrm{pH}$ & & & 0 \\
\hline & & Temperature & $<2$ & C rise & 0 \\
\hline & & TDS & Mol & r only & NA \\
\hline
\end{tabular}




\section{ENVIRONMENTAL NONRADIOLOGICAL PROGRAM INFORMATION}

TABLE 5.8 (C ont.)

\begin{tabular}{|c|c|c|c|c|c|}
\hline \multirow[b]{2}{*}{$\begin{array}{l}\text { Discharge } \\
\text { L ocation }\end{array}$} & \multirow[b]{2}{*}{$\begin{array}{l}\text { No. of } \\
\text { Samples }\end{array}$} & \multirow[b]{2}{*}{$\begin{array}{c}\text { Permit } \\
\text { Constituent }\end{array}$} & \multicolumn{2}{|c|}{ Limit } & \multirow{2}{*}{$\begin{array}{c}\text { No. } \\
\text { Exceeding } \\
\text { Limit }\end{array}$} \\
\hline & & & $\begin{array}{l}\text { 30-D ay } \\
\text { A verage }\end{array}$ & $\begin{array}{c}\text { Daily } \\
\text { M aximum }\end{array}$ & \\
\hline \multirow[t]{5}{*}{0031} & 12 & Flow & \multicolumn{2}{|c|}{ None } & 0 \\
\hline & & $\mathrm{pH}$ & \multicolumn{2}{|c|}{$6-9$} & 0 \\
\hline & & Temperature & \multicolumn{2}{|c|}{$<2.8^{\circ} \mathrm{C}$ rise } & 0 \\
\hline & & TDS & \multicolumn{2}{|c|}{ M onitor only } & NA \\
\hline & & Oil and grease & \multicolumn{2}{|c|}{ M onitor only } & NA \\
\hline \multirow[t]{4}{*}{ 003] } & 12 & Flow & \multicolumn{2}{|c|}{ None } & 0 \\
\hline & & $\mathrm{pH}$ & \multicolumn{2}{|c|}{$6-9$} & 0 \\
\hline & & Temperature & \multicolumn{2}{|c|}{$<2.8^{\circ} \mathrm{C}$ rise } & 0 \\
\hline & & TDS & \multicolumn{2}{|c|}{ M onitor only } & NA \\
\hline \multirow[t]{3}{*}{004} & 12 & Flow & \multicolumn{2}{|c|}{ None } & 0 \\
\hline & & $\mathrm{pH}$ & \multicolumn{2}{|c|}{$6-9$} & 0 \\
\hline & & TSS & 15 & 30 & 1 \\
\hline \multirow[t]{4}{*}{$005 C$} & 12 & Flow & \multicolumn{2}{|c|}{ None } & 0 \\
\hline & & $\mathrm{pH}$ & \multicolumn{2}{|c|}{ 6-9 } & 0 \\
\hline & & Temperature & \multicolumn{2}{|c|}{$<2.8^{\circ} \mathrm{C}$ rise } & 0 \\
\hline & & Oil and grease & \multicolumn{2}{|c|}{ M onitor only } & NA \\
\hline \multirow[t]{2}{*}{ 005E } & 12 & Flow & \multicolumn{2}{|c|}{ None } & 0 \\
\hline & & $\mathrm{pH}$ & \multicolumn{2}{|c|}{$6-9$} & 0 \\
\hline \multirow[t]{5}{*}{006} & 12 & Flow & \multicolumn{2}{|c|}{ None } & 0 \\
\hline & & $\mathrm{pH}$ & \multicolumn{2}{|c|}{$6-9$} & 0 \\
\hline & & TSS & 15 & 30 & 0 \\
\hline & & TDS & Mo & r only & NA \\
\hline & & Temperature & $<2$ & $C$ rise & 0 \\
\hline 007 & 28 & Flow & & & 0 \\
\hline & & $\mathrm{pH}$ & & & 0 \\
\hline & & Temperature & $<2$ & $C$ rise & 0 \\
\hline & & TRC & & & 0 \\
\hline & & Oil and grease & Mo & r only & NA \\
\hline 008 & 12 & Flow & & & 0 \\
\hline & & $\mathrm{pH}$ & & & 0 \\
\hline & & VOC & Mo & r only & NA \\
\hline
\end{tabular}


TABLE 5.8 (Cont.)

\begin{tabular}{|c|c|c|c|c|c|}
\hline \multirow[b]{2}{*}{$\begin{array}{l}\text { Discharge } \\
\text { Location }\end{array}$} & \multirow[b]{2}{*}{$\begin{array}{l}\text { No. of } \\
\text { Samples }\end{array}$} & \multirow[b]{2}{*}{$\begin{array}{c}\text { Permit } \\
\text { Constituent }\end{array}$} & \multicolumn{2}{|c|}{ Limit } & \multirow{2}{*}{$\begin{array}{c}\text { No. } \\
\text { Exceeding } \\
\text { Limit }\end{array}$} \\
\hline & & & $\begin{array}{l}\text { 30-Day } \\
\text { A verage }\end{array}$ & $\begin{array}{c}\text { Daily } \\
\text { M aximum }\end{array}$ & \\
\hline \multirow[t]{12}{*}{010} & 0 & Flow & \multicolumn{2}{|c|}{ None } & 0 \\
\hline & & $\mathrm{pH}$ & \multicolumn{2}{|c|}{$6-9$} & 0 \\
\hline & & TSS & 15 & 30 & 0 \\
\hline & & Total iron & 2 & 4 & 0 \\
\hline & & Dissolved iron & & 1.0 & 0 \\
\hline & & L ead & & 0.1 & 0 \\
\hline & & Zinc & & 1.0 & 0 \\
\hline & & $M$ anganese & & 1.0 & 0 \\
\hline & & Hexavalent chromium & 0.011 & 0.016 & 0 \\
\hline & & Trivalent chromium & 0.519 & 2.0 & 0 \\
\hline & & Copper & 0.031 & 0.051 & 0 \\
\hline & & Oil and grease & 15 & 30 & 0 \\
\hline \multirow[t]{3}{*}{108} & 12 & Flow & \multicolumn{2}{|c|}{ None } & 0 \\
\hline & & $\mathrm{pH}$ & \multicolumn{2}{|c|}{ 6-9 } & 0 \\
\hline & & Temperature & \multicolumn{2}{|c|}{$<2.8^{\circ} \mathrm{C}$ rise } & 0 \\
\hline \multirow[t]{2}{*}{111} & 2 & Flow & \multicolumn{2}{|c|}{ None } & 0 \\
\hline & & Hydrogen-3 & \multicolumn{2}{|c|}{ M onitor only } & NA \\
\hline \multirow[t]{2}{*}{$112 \mathrm{~A}$} & 2 & Flow & \multicolumn{2}{|c|}{ None } & 0 \\
\hline & & Hydrogen-3 & \multicolumn{2}{|c|}{ M onitor only } & NA \\
\hline \multirow[t]{2}{*}{$112 B$} & 2 & Flow & \multicolumn{2}{|c|}{ None } & 0 \\
\hline & & Hydrogen-3 & \multicolumn{2}{|c|}{ Monitor only } & NA \\
\hline \multirow[t]{4}{*}{113} & 3 & Flow & \multicolumn{2}{|c|}{ None } & 0 \\
\hline & & Hydrogen-3 & \multicolumn{2}{|c|}{ M onitor only } & NA \\
\hline & & PCB 1260 & \multicolumn{2}{|c|}{ M onitor only } & NA \\
\hline & & $\begin{array}{l}\text { Lead, copper, } \\
\text { nickel, zinc }\end{array}$ & \multicolumn{2}{|c|}{ M onitor only } & NA \\
\hline \multirow[t]{4}{*}{114} & 3 & Flow & \multicolumn{2}{|c|}{ None } & 0 \\
\hline & & Hydrogen-3 & \multicolumn{2}{|c|}{ M onitor only } & NA \\
\hline & & РCB 1260 & \multicolumn{2}{|c|}{ M onitor only } & NA \\
\hline & & $\begin{array}{l}\text { Lead, copper, } \\
\text { nickel, zinc }\end{array}$ & \multicolumn{2}{|c|}{ M onitor only } & NA \\
\hline
\end{tabular}




\section{ENVIRONMENTAL NONRADIOLOGICAL PROGRAM INFORMATION}

TABLE 5.8 (Cont.)

\begin{tabular}{|c|c|c|c|c|c|}
\hline \multirow[b]{2}{*}{$\begin{array}{l}\text { Discharge } \\
\text { Location }\end{array}$} & \multirow[b]{2}{*}{$\begin{array}{c}\text { No. of } \\
\text { Samples }\end{array}$} & \multirow[b]{2}{*}{$\begin{array}{c}\text { Permit } \\
\text { Constituent }\end{array}$} & \multicolumn{2}{|c|}{ Limit } & \multirow{2}{*}{$\begin{array}{c}\text { No. } \\
\text { Exceeding } \\
\text { Limit }\end{array}$} \\
\hline & & & $\begin{array}{l}\text { 30-D ay } \\
\text { A verage }\end{array}$ & $\begin{array}{c}\text { Daily } \\
\text { M aximum }\end{array}$ & \\
\hline \multirow[t]{4}{*}{115} & 12 & Flow & \multicolumn{2}{|c|}{ None } & 0 \\
\hline & & $\mathrm{pH}$ & \multicolumn{2}{|c|}{ 6-9 } & 0 \\
\hline & & Temperature & \multicolumn{2}{|c|}{$<2.8^{\circ} \mathrm{C}$ rise } & 0 \\
\hline & & TDS & \multicolumn{2}{|c|}{ Monitor only } & NA \\
\hline \multirow[t]{3}{*}{116} & 12 & Flow & \multicolumn{2}{|c|}{ None } & 0 \\
\hline & & $\mathrm{pH}$ & \multicolumn{2}{|c|}{$6-9$} & 0 \\
\hline & & TRC & \multicolumn{2}{|c|}{0.05} & 0 \\
\hline
\end{tabular}

a NPDES Special Condition gives ANL -E two years to comply with the Total Residual Chlorine (TRC) limit.

b $N A=$ not applicable.

Outfall 003C. The discharge from this outfall is made up of footing tile drainage and storm water runoff. The discharge point is a $0.65-\mathrm{m}(2-\mathrm{ft})$ concrete pipe discharging into F reund Brook approximately $50 \mathrm{~m}$ (150 ft) upstream of the gas station, south of Building 205. The sampling requirements and effluent limits are given in Table 5.8. No exceedances occurred during 1997.

Outfalls 003D and 003E. These two discharge points are from the steam trench around Inner Circle Drive and discharge into the north fork of Freund Brook approximately $150 \mathrm{~m}$ (500 ft) east of the intersection of Inner Circle Drive and Eastwood Extension. Table 5.8 gives the sampling requirements and effluent limits. No exceedances occurred during 1997.

Outfall 003F. This outfall is intended to discharge excess water from the fire pond during storm events. The building discharges cooling tower water to the fire pond, and the rate is low enough to generally not discharge without rainwater to attain flow. The discharge is through a cement raceway to the south fork of the north branch of Freund Brook. Table 5.8 gives the sampling requirements and effluent limits. No exceedances occurred during 1997. 


\section{ENVIRONMENTAL NONRADIOLOGICAL PROGRAM INFORMATION}

Outfall 003G. Footing tile drainage from the Inner Circle steam trench is pumped to the storm sewer passing around the northeastern portion of Building 201 and discharges into the northern fork of the southern branch of Freund Brook. Condensate leaks in the steam trench produce discharge on a regular basis to the storm sewer. Table 5.8 gives the sampling requirements and effluent limits. No exceedances occurred during 1997.

Outfall $\mathbf{0 0 3 H}$. This discharge originates from the footing tile drainage around Building 212 and storm water collected from around Buildings 212 and 214 and their associated parking lots. The cooling tower located on the south roof of Building 212 discharges into the tile drainage system and is the source of the industrial discharge. Table 5.8 gives the sampling requirements and effluent limits. No exceedances occurred during 1997.

Special Condition N 0. 9 of the NPDES permit requires acute toxicity testing on the effluent from Outfalls $003 \mathrm{H}, 003 \mathrm{I}, 003 \mathrm{~J}, 004,006$, and 115 . The testing is performed on the fathead minnow (Pimephales promelas) and daphnids (Ceriodaphnia dubia). The testing is performed on a biannual basis during the months of J uly and A ugust. These outfalls were sampled during the periods of July 21-25 and A ugust 19-22, 1996. Outfall 003H was not acutely toxic to the fathead minnow or daphnids. The results are summarized in Tables 5.9 and 5.10 .

Outfall 003I. This outfall collects storm water from Buildings 200, 211, and the western portion of Building 205 areas and also accumulates cooling tower discharge from the cooling tower located behind Building 200. Table 5.8 gives the sampling requirements and effluent limits. No exceedances were noted during 1997. Results of acute toxicity tests for Outfall 003I are presented in Tables 5.9 and 5.10. Outfall 003l was not acutely toxic to the fathead minnow or daphnids.

Outfall 003J. This outfall collects storm water from the Building 213 area and parking lot. The stormwater passes through a storm sewer around Building 201. Cooling tower blowdown is the industrial discharge to this system. The sampling requirements and effluent limits are given in Table 5.8. No exceedances were noted during 1997. Results of acute toxicity tests for 


\section{ENVIRONMENTAL NONRADIOLOGICAL PROGRAM INFORMATION}

TABLE 5.9

\begin{tabular}{|c|c|c|c|}
\hline $\begin{array}{c}\text { NPDES } \\
\text { Outfall }\end{array}$ & $\begin{array}{c}\text { 96-Hour } L_{50} \\
\text { P. promelas } \\
\text { July 23-27, } 1997\end{array}$ & $\begin{array}{c}\text { 96-Hour } L C_{50} \\
\text { P. promelas } \\
\text { A ugust } 20-24,1997\end{array}$ & Comments \\
\hline 003H & $>100 \%$ & $>100 \%$ & $\mathrm{~N}$ ot acutely toxic \\
\hline 0031 & $>100 \%$ & $>100 \%$ & $\mathrm{~N}$ ot acutely toxic \\
\hline 003] & $>100 \%$ & $>100 \%$ & $\mathrm{~N}$ ot acutely toxic \\
\hline 004 & $>100 \%$ & $>100 \%$ & N ot acutely toxic \\
\hline 006 & $>100 \%$ & $>100 \%$ & $\mathrm{~N}$ ot acutely toxic \\
\hline 115 & $>100 \%$ & $>100 \%$ & N ot acutely toxic \\
\hline
\end{tabular}

TABLE 5.10

A cute Toxicity Results: Ceriodaphnia, 1997

\begin{tabular}{lccc}
\hline & $\begin{array}{c}\text { 48-Hour } L C_{50} \\
\text { C. dubia }\end{array}$ & $\begin{array}{c}\text { 48-Hour } L C_{50} \\
\text { C. dubia }\end{array}$ & \\
$\begin{array}{l}\text { N PDES } \\
\text { Outfall }\end{array}$ & $\begin{array}{c}\text { Auly 23-25, 1997 } \\
\text { August 21-23, 1997 }\end{array}$ & Comments \\
\hline $003 \mathrm{H}$ & $>100 \%$ & $>100 \%$ & Not acutely toxic \\
0031 & $>100 \%$ & $>100 \%$ & Not acutely toxic \\
$003 \mathrm{~J}$ & $>100 \%$ & $>100 \%$ & Not acutely toxic \\
004 & $>100 \%$ & $>100 \%$ & Not acutely toxic \\
006 & $>100 \%$ & $>100 \%$ & Not acutely toxic \\
115 & $>100 \%$ & $>100 \%$ & Not acutely toxic \\
\hline
\end{tabular}

Outfall 003J are presented in Tables 5.9 and 5.10. Outfall 003J was not acutely toxic to the fathead minnow or daphnids.

Outfall 004. This outfall discharges storm water from the Building 203 and Building 221 areas and cooling water from Building 221. The discharge is to a drainage ditch and sewer system that pass around the northeastern portion of Outer Circle D rive and to a ditch leading north to the fence line, east of the $V$ isitor's $C$ enter. Table 5.8 gives the sampling requirements and effluent limits. One exceedance for TSS was noted during September 1997. Flow at the outfall was 


\section{ENVIRONMENTAL NONRADIOLOGICAL PROGRAM INFORMATION}

minimal, and it appears that algae growth resulted in the elevated TSS. Results of acute toxicity tests for Outfall 004 are presented in Tables 5.9 and 5.10. Outfall 004 was not acutely toxic to the fathead minnow or daphnids.

Outfall 005A. This outfall discharges runoff from the northwestern portion of the 800 A rea. The flow passes under W estgate Road, east of the W est Gate, and flows toward the northwestern fence line. This is a storm water only outfall.

Outfall 005B. The outfall for this watershed discharges runoff collected from the major portion of the 800 A rea. The flow is collected from the parking lots and roadways and flows by storm sewers to the east, where it is discharged to the marsh located on the eastern side of Kearney Road. This is a storm water only outfall.

Outfall 005C. This outfall collects storm water from the northern side and the loading dock area of Building 200. The Building 200 once-through cooling water systems discharge to this outfall, which passes through sewers to the west of the loading dock and to the beaver pond west of Building 200. The sampling requirements and effluent limits are given in Table 5.8. No exceedances occurred during 1997.

Outfall 005D. The Building $200 \mathrm{M}$-W ing loading dock area storm water runoff is collected in a storm sewer and passes west to a beaver pond located west of Building 200. The discharge is through a 1-m (36-in.) corrugated pipe into the pond. This is a storm water only discharge.

Outfall 005E. This outfall discharges footing tile drainage from the west side of Building 203 and Building 208. It also discharges storm water collected from the same area. The industrial discharge arises from cup drains and compressors discharging into the footing tile sumps. The sampling requirements and effluent limits are given in Table 5.8. No exceedances occurred during 1997.

Outfall 006. Cooling towers at Building 350 and the 377 A rea discharge into the drainage ditch that flows south of the Canal Water Treatment Plant, bends south, and flows to the south 


\section{ENVIRONMENTAL NONRADIOLOGICAL PROGRAM INFORMATION}

fence line. The permit requires monthly sampling for $\mathrm{pH}$, TSS, and temperature. The limits are given in Table 5.8. No exceedances of NPDES limits occurred in 1996. Results of acute toxicity tests for Outfall 006 are presented in Tables 5.9 and 5.10. Unlike 1995 and 1996, Outfall 006 was not acutely toxic to daphids. It was also not acutely toxic to the fathead minnow.

Outfall 007. The watershed for Outfall 007 includes the southeastern section of the 300 A rea and extends from Building 370 east to Building 366 and north to Building 367 . W ater is collected in catchment basins and conveyed toward the southeast to a point approximately $30 \mathrm{~m}$ (100 ft) southeast of Building 366, where it is discharged into a ditch on the south side of Old

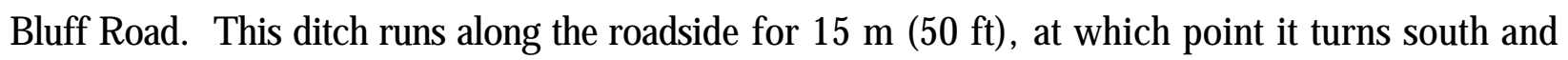
runs to the fence line where it is discharged to the forest preserve. The once-through cooling water of compressors is the industrial component of this outfall. Table 5.8 gives the sampling requirements and effluent limits. No exceedances occurred during 1997.

Outfall 008. The watershed for this outfall includes the area around the new Vehicle M aintenance and Grounds Building 46. Runoff is collected in storm water grates and catchments and conveyed through sewers to the discharge point in Sawmill Creek, which is located directly west of Building 24. Industrial activity in this small watershed involves operations associated with the maintenance of all facility vehicles; grounds, maintenance, and storage of the equipment associated with these activities; and fueling for the vehicles. Five VOCs are monitored once a month. Low levels $(0.01$ to $0.02 \mu \mathrm{g} / \mathrm{L})$ of tetrachloroethylene are consistently noted at this outfall. The only NPDES limit that applies at this point is pH. No exceedances were noted during 1997.

Outfall 010. This outfall is for the coal pile storage area runoff collection system overflow line. The collection system consists of a trench on the north and west sides of the coal pile; a sump is located at the extreme southern end of the western trench line. The overflow line comes into use only when the runoff reaches the level at which the trench system would overflow; the line was put into place to ensure against overflow conditions. During normal operations, the water is pumped to the equalization basin located in the western part of the $100 \mathrm{Area}$. The 


\section{ENVIRONMENTAL NONRADIOLOGICAL PROGRAM INFORMATION}

industrial activity associated with this outfall is solely the coal pile operation. The berm and trench system in place to collect runoff has been improved to eliminate discharge from the outfall.

This outfall is sampled once per day when flow occurs. A nalyses are performed for $\mathrm{pH}$, TSS, TDS, iron, lead, zinc, manganese, trivalent and hexavalent chromium, copper, and oil and grease. No flow occurred at this site during 1997.

Outfall 101. The drainage to this outfall is through ditches along the streets and sewer conduits from the parking lot to a marsh located between Outer Circle D rive and the fence line to the outfall; the conduits consist of a $0.65-\mathrm{m}(2-\mathrm{ft})$ corrugated metal pipe with a Palmer-Bowlus flume. The drainage then discharges on the other side of the fence line into the forest preserve. The sources of storm water runoff to the outfall are the Building 203 parking lot and loading dock and the excess equipment storage area on the north side of Outer Circle Drive. This is a storm water only discharge.

Outfall 102. This watershed includes portions of the $100 \mathrm{~A}$ rea. Large amounts of paved areas are associated with the industrial activities for the production of steam such as those areas associated with the WTP, the lime sludge pond, and the tarmac around the boiler house. The contributing runoff flows are collected from storm water inlet grates and catch basins, through storm sewers to a discharge point consisting of a $0.30-\mathrm{m}(1-\mathrm{ft})$ corrugated metal pipe extending out of the bank of Sawmill Creek. This is a storm water only discharge.

Outfall 103. The watershed for Outfall 103 includes the southern and southeastern extreme portions of the $100 \mathrm{~A}$ rea and the area south of the coal pile. These areas drain into a storm sewer that runs due east of the coal pile toward Sawmill Creek. The outfall is located at the outlet of a $0.35-\mathrm{m}(1.2 \mathrm{ft})$ corrugated metal pipe culvert located approximately $50 \mathrm{~m}(150 \mathrm{ft})$ from the creek. A ctivities that are industrial in nature take place in and around the utilities area and consist of boiler house steam generation, storage of plastic and metal, loading dock activities, a flue gas scrubber and cooling pond (no longer in use), steam condensate return storage (two tanks), and the southern access road to the coal pile storage area. This is a storm water only discharge. 


\section{ENVIRONMENTAL NONRADIOLOGICAL PROGRAM INFORMATION}

Outfall 104. This outfall includes the buildings and parking areas remaining in the East A rea, excluding Buildings 40 and 46. Buildings 4, 5, and 6 and their smaller attendant buildings are included. The area is served by a number of roadways leading to and from these buildings; contributing storm grate inlets are located on the roadways and parking areas. This is a storm water only discharge.

Outfalls 105A and 105B. Two discharge points are located within this watershed. The contributing sources of storm water for this watershed include runoff from the Building 40 area, elevated water tower tanks, and scrub vegetation areas on the west side of Tech Road. Industrial activity within this watershed includes receiving, loading, parking and storage areas, and oilcontaining transformers. These are storm water only discharges.

Outfalls 106A and 106B. The watershed for these outfalls encompasses the largest portion of the East A rea, most of which is now demolished and the buildings razed. A portion of the eastern end of the Shipping and Receiving A rea is part of this watershed, that is, Building 33, which has electrical transformers located outside of it, and a portion of A rgonne Park. Like Outfall 105 above, this watershed is served by two distinct outfalls. The industrial activities within this watershed involve the receiving and shipping areas with loading docks and the transformer area. These are storm water only discharges.

Outfall 108. This watershed encompasses a portion of the $300 \mathrm{~A}$ rea. The drainage area includes the parking areas north of Building 360, the buildings in and around Building 360, excluding Buildings 370 and 390 and the southern and western ends of the $300 \mathrm{~A}$ rea, and the paved parking and loading dock areas in and around the eastern portions of the 300 A rea (surrounding Building 363). Ongoing industrial activities in this watershed are shipping and receiving, a metals reclaim dumpster (Building 363), loading dock activities, and numerous outdoor equipment storage areas. Table 5.8 gives the sampling requirements and effluent limits. No exceedances occurred during 1997.

Outfall 110. The watershed for this outfall includes the shooting range (inactive since M arch 1993) and the area just south of the range. No other industrial activities take place within 


\section{ENVIRONMENTAL NONRADIOLOGICAL PROGRAM INFORMATION}

this watershed at present. Past industrial activity involved use of the shooting range for practice by the security force. This is a storm water only discharge.

Outfall 111. This outfall is located on the south fence line of the site due south of the old, closed 319 A rea Landfill, between the watershed for Outfall 110 and the watershed for Outfalls $112 \mathrm{~A}$ and 112B. This watershed encompasses the 319 Area Landfill, the 318 A rea (landfill area for compressed gases), and portions of the 317 A rea, primarily the paved area. In addition, the roadways for access to these areas drain to this outfall through a small ditch running along the southern extreme of the 319 A rea L andfill, turning south to the fence line, and then to the outfall location, which is a $0.65-\mathrm{m}(2-\mathrm{ft})$ corrugated metal pipe culvert that passes under the fence and discharges into the forest preserve. Industrial activities within this watershed consist of 317 A rea radioactive waste storage and remediation activities, the 319 A rea L andfill, and associated roadways for access. This outfall is sampled semiannually for flow and hydrogen-3 and has no permit limits. Hydrogen-3 results were $1.18 \times 10^{4} \mathrm{pCi} / \mathrm{L}$ during J anuary 1997 and less than $100 \mathrm{pCi} / \mathrm{L}$ during August 1997.

Outfalls 112A and 112B. The contributing sources of storm water within this watershed receive runoff from the southern and western sections of the 317 A rea radioactive waste storage. Runoff flow is generally toward the south in sheet flow from the source areas; the eastern portions consolidate at the fence line at the southeastern corner of the 317 A rea and pass under the fence through rough concrete fill. The western and central portions of the drainage area sheet flow consolidate in the same manner and pass under the fence through the same material, approximately $50 \mathrm{~m}$ (150 ft) to the west. Both flows discharge into large gullies in the forest preserve and form one flow approximately $100 \mathrm{~m}$ (328 ft) south of the ANL-E fence line. Industrial activity within this watershed consists of 317 A rea radioactive waste storage and remediation activities, loading activities at Building 350, and the associated roadways for access. These outfalls are sampled semiannually for flow and hydrogen-3 and have no permit limits. Hydrogen-3 results were less than $100 \mathrm{pCi} / \mathrm{L}$ during January and December 1997.

Outfall 113. This outfall is the discharge point for runoff from the eastern, southern, and southwestern sections of the closed $800 \mathrm{~A}$ rea L andfill. The outfall is located in a ditch on the 


\section{ENVIRONMENTAL NONRADIOLOGICAL PROGRAM INFORMATION}

extreme southern end of the landfill, approximately $50 \mathrm{~m}$ (150 ft) from the southwestern corner of the landfill fence line. This discharge flows under the fence in the ditch and empties into the creek that flows south from the wetland marsh west of the site. The marsh is the headwaters of one leg of the Freund Brook system that runs through the middle of the ANL-E site and discharges into Sawmill Creek. Industrial activity within this watershed is limited to the landfill. This outfall was sampled monthly when discharging and has no permit limits. Flow occurred during three months in 1997.

Outfall 114. This outfall is the discharge point for runoff coming from the northern and northwestern sections of the closed $800 \mathrm{~A}$ rea $\mathrm{L}$ andfill. The outfall is located in a ditch on the extreme western side of the landfill, approximately halfway between the northern and southern boundaries of the landfill. The flow proceeds along the western edge of the landfill where water is added from the marsh. The flow eventually combines with the ditch from the Outfall 113 flow and then passes into the creek that flows south from the wetland marsh west of the ANL -E site. Industrial activity within this watershed is limited to the landfill. This outfall was sampled monthly when discharging and has no permit limits. Flow occurred during three months in 1997.

Outfall 115. This watershed encompasses the APS site and the southern areas around the Building 314, 315, and 316 complex. The APS flow drains into ditches that discharge through a cement culvert into a collection pond located on the southeastern portion of the APS site. The $0.65-\mathrm{m}$ (2-ft) sewer conduit from the Building 314, 315, and 316 complex discharges into the same collection pond approximately $10 \mathrm{~m}(30 \mathrm{ft})$ east of the ditch culvert. The flow from this pond discharges south through a culvert into another pond, flows through this pond, and

discharges through a 1-m (3-ft) corrugated metal pipe culvert under the south fence line into the forest preserve. Industrial activities within the watershed involve the APS; all roadways associated with APS; loading docks in the APS buildings; and the Building 314, 315, and 316 complex storage, loading areas, and cooling water discharges. Table 5.8 gives the sampling requirements and effluent limits. No exceedances occurred during 1997. 


\section{ENVIRONMENTAL NONRADIOLOGICAL PROGRAM INFORMATION}

Results of acute toxicity tests for Outfall 115 are presented in Tables 5.9 and Table 5.10. Unlike 1996, Outfall 115 was not acutely toxic to daphnids. It also was not acutely toxic to the fathead minnow.

Outfall 116. This outfall was originally intended as a storm water discharge point only; however, it also contains non-storm-water discharges as well. The source of the discharge was traced back and found to be potable water from the domestic water treatment plant located uphill from the rest of the main utilities area. This source was investigated for corrective action and the flow stopped. The watershed for this outfall contains sections of the domestic water treatment plant, including the garage and storage area, the area around W ell No. 5, and the associated access roads for the domestic water treatment plant. Flow is conducted through storm water sewers and discharged at the outfall, which is a $0.25-\mathrm{m}(0.82-\mathrm{ft})$ vitrified clay pipe with a cement raceway into Sawmill Creek. Industrial activities for this watershed include parking, loading, and materials storage around the domestic water treatment plant; domestic water treatment plant operation, including bulk chemical storage (brine tank) and transformers (Building 129); outdoor equipment storage area and four flammable materials storage cabinets (Building 130); outdoor materials storage (Buildings 107 and 163); well operation and maintenance (Building 160); and the associated roadways for these activities. Table 5.8 gives the sampling requirements and effluent limits. No exceedances occurred during 1997.

\subsection{Additional Effluent Monitoring}

To characterize the wastewater from the ANL-E site more fully, composite samples of the combined effluent from the WTP were collected each week and analyzed for the constituents shown in Table 5.11. The results were then compared to IEPA G eneral Effluent $L$ imits found in 35 IAC, Subtitle C, Part $304 .{ }^{28}$

\subsubsection{Sample Collection}

Samples for analysis of inorganic constituents were collected daily from Outfall 001 located at the WTP by using a refrigerated time proportional sampler. A portion of the sample was 


\section{ENVIRONMENTAL NONRADIOLOGICAL PROGRAM INFORMATION}

TABLE 5.11

Chemical Constituents in Effluents from the ANL-E W astewater Treatment Plant, 1997

(Concentrations in $\mathrm{mg} / \mathrm{L}$ )

\begin{tabular}{|c|c|c|c|c|c|}
\hline \multirow[b]{2}{*}{ Constituent } & \multirow{2}{*}{$\begin{array}{c}\text { No. of } \\
\text { Samples }\end{array}$} & \multicolumn{4}{|c|}{ Concentrations } \\
\hline & & Avg. & Min. & Max. & Limit \\
\hline Arsenic & 53 & 0.0022 & $<0.0020$ & 0.0030 & 0.25 \\
\hline Barium & 53 & 0.0239 & 0.0180 & 0.0340 & 2.0 \\
\hline Beryllium & 53 & & & $<0.0002^{\mathrm{a}}$ & $-\mathrm{b}$ \\
\hline Cadmium & 53 & 0.0001 & $<0.0001$ & 0.0002 & 0.15 \\
\hline Chromium & 53 & 0.0417 & $<0.0200$ & 0.0440 & 1.0 \\
\hline Cobalt & 53 & 0.0249 & $<0.0150$ & 0.0260 & - \\
\hline Copper & 53 & 0.0305 & $<0.0170$ & 0.0450 & 0.5 \\
\hline Fluoride & 53 & 0.8209 & 0.4440 & 1.0800 & 15.0 \\
\hline Iron & 53 & 0.1893 & 0.0547 & 0.3925 & 2.0 \\
\hline Lead & 53 & 0.0012 & $<0.0010$ & 0.0021 & 0.2 \\
\hline Manganese & 53 & 0.0236 & $<0.0144$ & 0.0735 & 1.0 \\
\hline Mercury & 53 & 0.0015 & $<0.0001$ & 0.0083 & 0.5 \\
\hline Nickel & 53 & 0.0385 & 0.0250 & 0.0400 & 1.0 \\
\hline Silver & 53 & 0.0008 & $<0.0005$ & 0.0019 & 0.1 \\
\hline Thallium & 53 & & & $<0.0010$ & - \\
\hline Vanadium & 53 & 0.0236 & $<0.0200$ & 0.0240 & - \\
\hline Zinc & 53 & 0.1047 & 0.0348 & 0.2170 & 1.0 \\
\hline pH (units) & 43 & $\mathrm{NA}^{\mathrm{c}}$ & 6.53 & 7.81 & $6.0-9.0$ \\
\hline
\end{tabular}

a If all values are less than the detection limit for a constituent, only the maximum value is given.

b A hyphen indicates no effluent limit for this constituent.

c $\mathrm{NA}=$ not applicable. 


\section{ENVIRONMENTAL NONRADIOLOGICAL PROGRAM INFORMATION}

transferred to a clean bottle, a security seal was affixed, and chain of custody was maintained. Five daily samples were composited on an equal volume basis to produce a weekly sample that is then analyzed.

\subsubsection{Results}

Fifteen metals were detected by inductively coupled plasma emission spectroscopy, flame atomic absorption spectroscopy, and graphite furnace atomic absorption spectroscopy. M ercury was analyzed using cold vapor atomic absorption spectroscopy, and fluoride was determined by a specific ion electrode. Table 5.11 gives the results for 1997. None of the annual average results exceeded General Effluent L imits. ${ }^{28}$

\subsection{Sawmill Creek}

Sawmill Creek is a small natural stream that is fed primarily by storm water runoff. During periods of low precipitation, the creek above ANL-E has a very low flow. At these times, a major portion of the water in Sawmill Creek south of the site consists of ANL-E wastewater and discharges to assorted storm drains. To determine the impact ANL-E wastewaters have on Sawmill Creek, samples of the creek downstream of all ANL-E discharge points were collected and analyzed. The results were then compared to IEPA General U se W ater Quality Standards found in 35 IAC, Subtitle C, Part 302. ${ }^{29}$

\subsubsection{Sample Collection}

A proportional sampler was used to collect a daily sample at a point well downstream of the combined wastewater discharge point where thorough mixing of the A N L-E effluent and Sawmill Creek water is assured. Samples were collected in precleaned, labeled bottles and security seals were used. After pH measurement, the daily samples were acidified and then combined into equal volume weekly composites and analyzed for the same set of inorganic constituents as those in Table 5.11. 
TABLE 5.12

Chemical Constituents in Sawmill Creek, Location 7M a, 1997

(Concentrations in $\mathrm{mg} / \mathrm{L}$ )

\begin{tabular}{|c|c|c|c|c|c|}
\hline \multirow[b]{2}{*}{ Constituent } & \multirow{2}{*}{$\begin{array}{c}\text { No. of } \\
\text { Samples }\end{array}$} & \multicolumn{4}{|c|}{ Concentrations } \\
\hline & & Avg. & Min. & Max. & Limit \\
\hline A rsenic & 50 & 0.0021 & $<0.0020$ & 0.0035 & 1.0 \\
\hline Barium & 50 & 0.0454 & 0.0255 & 0.0954 & 5.0 \\
\hline Beryllium & 50 & & & $<0.0002^{b}$ & $-C$ \\
\hline Cadmium & 50 & 0.0004 & $<0.0001$ & 0.0029 & 0.05 \\
\hline Chromium & 50 & 0.0416 & $<0.0200$ & 0.0440 & 1.0 \\
\hline Cobalt & 50 & 0.0249 & $<0.0150$ & 0.0260 & - \\
\hline Copper & 50 & 0.0245 & 0.0170 & 0.0523 & 0.02 \\
\hline Flouride & 50 & 0.5135 & 0.2060 & 1.1000 & 1.4 \\
\hline Iron & 50 & 0.4918 & 0.0923 & 1.4070 & 1.0 \\
\hline Lead & 50 & 0.0036 & $<0.0010$ & 0.0115 & 0.1 \\
\hline M anganese & 50 & 0.0908 & 0.0170 & 0.4192 & 1.0 \\
\hline M ercury & 50 & 0.0002 & $<0.0001$ & 0.0061 & 0.5 \\
\hline Nickel & 50 & 0.0385 & 0.0250 & 0.0400 & 1.0 \\
\hline Silver & 50 & & & $<0.0007$ & 0.005 \\
\hline Thallium & 50 & & & $<0.0010$ & - \\
\hline V anadium & 50 & 0.0236 & $<0.0200$ & 0.0240 & - \\
\hline Zinc & 50 & 0.1199 & 0.0443 & 0.5018 & 1.0 \\
\hline $\mathrm{pH}$ (units) & 44 & $N A^{C}$ & 6.40 & 8.34 & $6.5-9.0$ \\
\hline
\end{tabular}

a L ocation $7 \mathrm{M}$ is $15 \mathrm{~m}$ (50 ft) downstream from the A NL-E wastewater outfall.

b If all values are less than the detection limit for a constituent, only the maximum value is given.

c A hyphen indicates no effluent limit for this constituent.

d $\mathrm{NA}=$ not applicable. 


\section{ENVIRONMENTAL NONRADIOLOGICAL PROGRAM INFORMATION}

Fifteen metals were determined by inductively-coupled plasma emission spectroscopy, flame atomic absorption spectroscopy, and graphite furnace atomic absorption spectroscopy. M ercury was analyzed with cold vapor atomic absorption spectroscopy. Fluoride was determined by a specific ion electrode.

\subsubsection{Results}

The results obtained are shown in Table 5.12. As in previous years, the annual average concentration for copper was above the Water Quality Standard (WQS). The maximum concentrations for copper and iron exceeded the WQS. Elevated levels of copper are probably the result of leaching of copper from the domestic water distribution system (see Section 6.1.1). The copper levels were significantly lower in 1997 when compared to 1996 results (i.e., 0.038 average, $0.25 \mathrm{mg} / \mathrm{L}$ maximum). The cause of elevated iron levels is unknown, but may be the result of inadequate retention time of high flows that are known to contain increased coal pile runoff discharges. 


\section{GROUNDWATER PROTECTION}

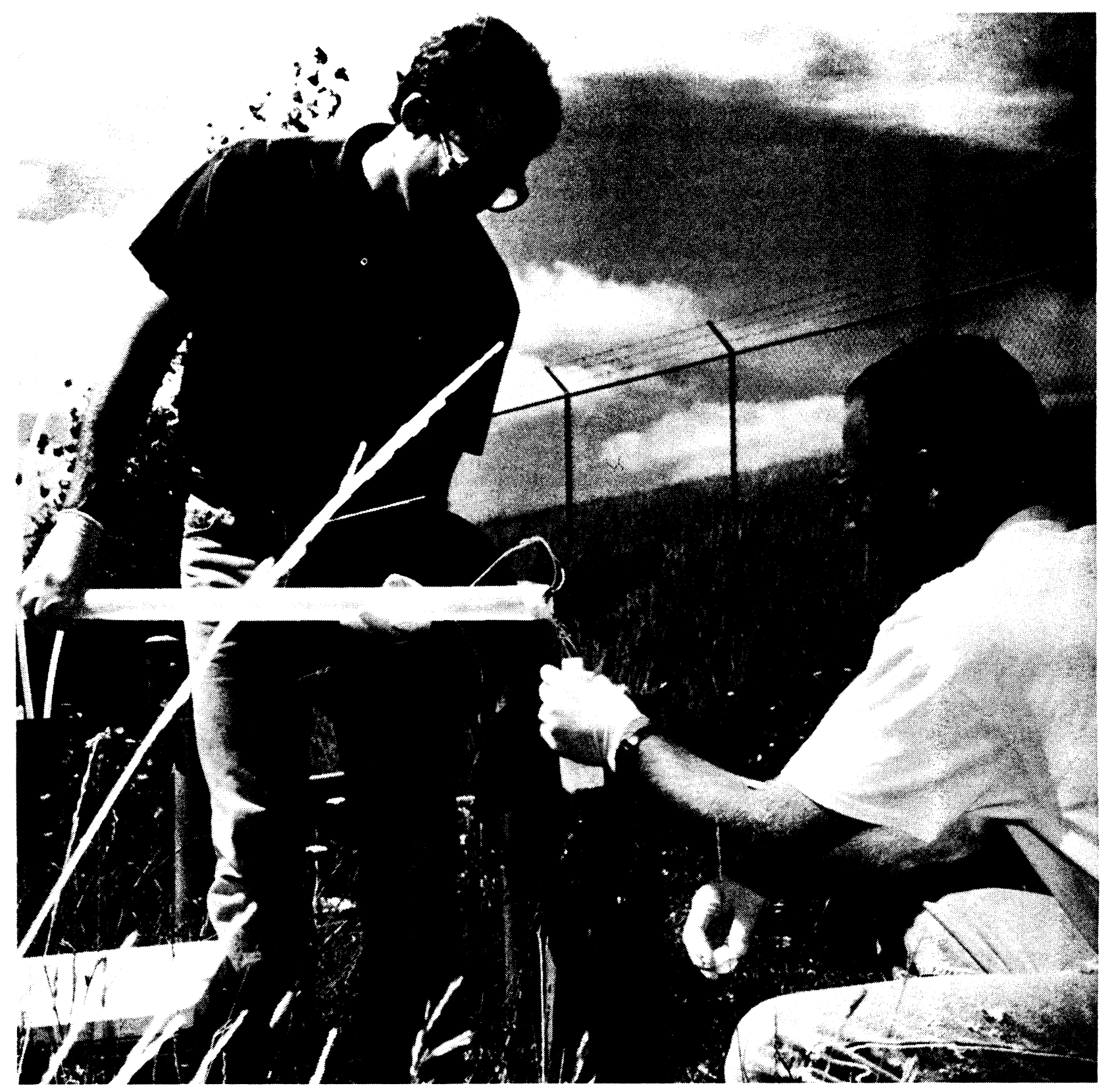




\section{GROUNDWATER PROTECTION}

The groundwater below the ANL-E site is monitored through the collection and analysis of samples obtained from the former on-site water supply wells and from a series of groundwater monitoring wells located near several sites that have the potential for affecting groundwater. Regulations establishing comprehensive water quality standards for the protection of groundwater have been enacted - IEPA Groundwater Quality Standards, 35 IAC, Subtitle F, Part $620 .{ }^{30}$ In addition, demonstration of compliance with the groundwater protection requirements in DOE Order 5400.1, as related to sitewide characterization studies and monitoring well requirements, is presented in this chapter. The permit for the $800 \mathrm{~A}$ rea Landfill requires a groundwater monitoring program; the program was initiated in July 1992.

\subsection{Potable Water System}

Domestic water for ANL-E was supplied by four wells (see Section 1.7 and Table 6.1) until December 1996, when Lake Michigan water was obtained. The well locations are shown in Figure 1.1. Lake M ichigan water was obtained to provide better quality drinking water. The dolomite water from the on-site wells had deteriorated in quality to where the TDS content of the supply water was approaching $800 \mathrm{mg} / \mathrm{L}$, which made it difficult to consistently meet the $1,000 \mathrm{mg} / \mathrm{L}$ TDS discharge limit at NPDES Outfall 001. Lake Michigan water has a TDS of approximately $200 \mathrm{mg} / \mathrm{L}$. In addition, Lake M ichigan water is lower in bicarbonate, which makes it less corrosive on the piping system.

\subsubsection{Regulatory Required Monitoring}

The responsibility for conducting any regulatory required monitoring is that of the supplier of the domestic water. Because ANL-E water is provided by the DuPage Water Commission, it is responsible for any monitoring. Therefore, ANL-E did not conduct any required monitoring in 1997. 


\section{GROUNDWATER PROTECTION}

TABLE 6.1

A NL-E Former W ater Supply Wells ${ }^{\mathrm{a}}$

\begin{tabular}{|c|c|c|c|c|c|c|}
\hline $\begin{array}{l}\text { Well } \\
\text { No. }\end{array}$ & Location & $\begin{array}{c}\text { Well } \\
\text { Elevation } \\
\text { (m AM SL) }\end{array}$ & $\begin{array}{c}\text { Bedrock } \\
\text { Elevation } \\
\text { (m AM SL) }\end{array}$ & $\begin{array}{l}\text { W ell D epth } \\
\text { (m bgs) }\end{array}$ & $\begin{array}{c}\text { Inner } \\
\text { Diameter } \\
\text { (m) }\end{array}$ & $\begin{array}{c}\text { Y ear } \\
\text { Drilled }\end{array}$ \\
\hline 1 & Building 31 & 204.5 & 184.4 & 86.6 & 0.30 & 1948 \\
\hline 2 & Building 32 & 202.4 & 183.2 & 91.4 & 0.30 & 1948 \\
\hline 3 & Building 163 & 210.0 & 182.9 & 96.9 & 0.30 & 1955 \\
\hline 4 & Building 264 & 218.2 & 181.4 & 103.6 & 0.36 & 1959 \\
\hline
\end{tabular}

a $\mathrm{AMSL}=$ above mean sea level; bgs = below ground surface.

\subsubsection{Informational Monitoring}

Samples were collected quarterly at the wellhead and analyzed to determine the presence of several types of radioactive constituents and VOCs in ANL -E groundwater. Samples from each well were tested for total alpha, total beta, hydrogen-3, and strontium-90. Samples also were analyzed annually for radium-226, radium-228, and isotopic uranium. Alpha and beta radioactivity were determined by a gas flow proportional counting technique. Hydrogen-3 was determined by distillation followed by a beta liquid scintillation counting technique. Strontium-90 was determined by ion-exchange separations followed by proportional counting. The results are presented in Table 6.2. If these wells constituted the ANL-E drinking water source, the following EPA limits established for the nuclides measured in Table 6.2 would apply:

$\begin{array}{ll}\text { Gross alpha particle activity } & =15 \mathrm{pCi} / \mathrm{L} \\ \text { Gross beta particle activity } & =50 \mathrm{pCi} / \mathrm{L} \\ \text { Hydrogen-3 } & =2 \times 10^{4} \mathrm{pCi} / \mathrm{L} \\ \text { Strontium-90 } & =8 \mathrm{pCi} / \mathrm{L}\end{array}$

A II the radiological results were in the normal range of concentrations for the various constituents except for strontium-90 in tap water. The concentration of strontium-90 in tap water was $3 \%$ of the EPA drinking water standard. 


\section{GROUNDWATER PROTECTION}

TABLE 6.2

Radioactivity in A N L -E F ormer W ater Supply W ells, 1997

(Concentrations in $\mathrm{pCi} / \mathrm{L}$ )

\begin{tabular}{|c|c|c|c|c|c|}
\hline $\begin{array}{l}\text { Type of } \\
\text { A ctivity }\end{array}$ & Location & $\begin{array}{c}\text { No. of } \\
\text { Samples }\end{array}$ & A verage & Minimum & M aximum \\
\hline Alpha & Well 1 & 4 & 4.3 & 2.4 & 6.0 \\
\hline \multirow[t]{4}{*}{ (nonvolatile) } & Well 2 & 4 & 4.4 & 2.8 & 5.8 \\
\hline & Well 3 & 4 & 3.3 & 2.6 & 4.2 \\
\hline & Well 4 & 4 & 4.2 & 2.4 & 6.1 \\
\hline & Tap & 4 & 0.5 & 0.1 & 0.8 \\
\hline Beta & Well 1 & 4 & 9.6 & 7.1 & 12.0 \\
\hline \multirow[t]{4}{*}{ (nonvolatile) } & Well 2 & 4 & 8.3 & 6.9 & 9.0 \\
\hline & Well 3 & 4 & 10.8 & 10.4 & 11.7 \\
\hline & Well 4 & 4 & 12.3 & 11.7 & 13.4 \\
\hline & Tap & 4 & 2.3 & 2.0 & 2.5 \\
\hline \multirow[t]{5}{*}{ Hydrogen-3 } & Well 1 & 4 & $<100$ & $<100$ & $<100$ \\
\hline & Well 2 & 4 & $<100$ & $<100$ & $<100$ \\
\hline & Well 3 & 4 & $<100$ & $<100$ & $<100$ \\
\hline & Well 4 & 4 & $<100$ & $<100$ & $<100$ \\
\hline & Tap & 4 & $<100$ & $<100$ & $<100$ \\
\hline \multirow[t]{5}{*}{ Strontium-90 } & Well 1 & 4 & $<0.25$ & $<0.25$ & $<0.25$ \\
\hline & Well 2 & 4 & $<0.25$ & $<0.25$ & $<0.25$ \\
\hline & Well 3 & 4 & $<0.25$ & $<0.25$ & $<0.25$ \\
\hline & Well 4 & 4 & $<0.25$ & $<0.25$ & $<0.25$ \\
\hline & Tap & 4 & 0.42 & 0.38 & 0.44 \\
\hline \multirow[t]{5}{*}{ Radium-226 } & Well 1 & 1 & $-a^{a}$ & - & 0.61 \\
\hline & Well 2 & 1 & - & - & 1.04 \\
\hline & Well 3 & 1 & - & - & 1.38 \\
\hline & Well 4 & 1 & - & - & 1.24 \\
\hline & Tap & 1 & - & - & $<0.01$ \\
\hline \multirow[t]{5}{*}{ Radium-228 } & Well 1 & 1 & - & - & 0.74 \\
\hline & Well 2 & 1 & - & - & 0.96 \\
\hline & Well 3 & 1 & - & - & 1.03 \\
\hline & Well 4 & 1 & - & - & 0.67 \\
\hline & Tap & 1 & - & - & 0.26 \\
\hline \multirow[t]{5}{*}{ Uranium-234 } & Well 1 & 1 & - & - & 1.74 \\
\hline & Well 2 & 1 & - & - & 0.39 \\
\hline & Well 3 & 1 & - & - & 0.22 \\
\hline & Well 4 & 1 & - & - & 0.23 \\
\hline & Tap & 1 & - & - & 0.09 \\
\hline \multirow[t]{5}{*}{ Uranium-235 } & Well 1 & 1 & - & - & 0.04 \\
\hline & Well 2 & 1 & - & - & $<0.01$ \\
\hline & Well 3 & 1 & - & - & $<0.01$ \\
\hline & Well 4 & 1 & - & - & $<0.01$ \\
\hline & Tap & 1 & - & - & $<0.01$ \\
\hline \multirow[t]{5}{*}{ Uranium-238 } & Well 1 & 1 & - & - & 1.23 \\
\hline & Well 2 & 1 & - & - & 0.25 \\
\hline & Well 3 & 1 & - & - & 0.13 \\
\hline & Well 4 & 1 & - & - & 0.12 \\
\hline & Tap & 1 & - & - & 0.06 \\
\hline
\end{tabular}

a A hyphen indicates that the measured value was less than the detection limit. 


\section{GROUNDWATER PROTECTION}

VOC samples were collected quarterly, and the results are presented in Tables 6.3 through 6.6. Samples were analyzed for SDWA volatile compounds and quantified by EPA M ethod 524.2. ${ }^{31}$ The detection limit reported in the tables is the Practical Quantification Limit $(P Q L)$, which is defined as 10 times the method detection limit. The tap water samples indicated the presence of three VOCs (dichlorobromomethane, chlorodibromomethane, and chloroform). These compounds are known to be associated with chlorination of drinking water, that is, trihalomethanes. The VOC results presented support the determination that no VOCs have migrated from remediation sites.

Over the past few years, ANL-E has collected the required finished water samples for conducting lead and copper analyses to determine whether the concentrations of more than $10 \%$ of the samples are above the action level of $0.015 \mathrm{mg} / \mathrm{L}$ for lead or $1.3 \mathrm{mg} / \mathrm{L}$ for copper. Although not required, samples were collected semiannually for lead and copper analyses from 40 sites in 1997. This sampling was performed in an attempt to determine the impact of Lake Michigan water on the copper pipes and to compare these data with previous data when well water was used. The same sampling protocols were used, and the results are presented in Table 6.7.

In 1996, the copper action level in well water was exceeded seven times in the spring sample set and six times in the fall set. In 1997, with Lake M ichigan water, two copper exceedances occurred in the spring set and none in the fall sample set. This provides analytical evidence that Lake M ichigan water is significantly less corrosive than well water.

\subsection{Groundwater Monitoring at Waste Management Sites}

ANL-E has occupied its current site since 1948. Since that time, waste generated by ANL -E was placed in a number of on-site disposal units, ranging from ditches filled with construction and demolition debris during the 1950s, to a modern sanitary landfill used for nonhazardous solid waste disposal until September 1992. Several of these units contain significant amounts of hazardous materials and, therefore, represent a potential threat to the environment. Groundwater below these sites is monitored routinely to assess the amount and nature of 


\section{GROUNDWATER PROTECTION}

TABLE 6.3

V olatile Organic Compounds in Former W ater Supply W ell Samples Collected M arch 11, 1997 (Concentrations in $\mathrm{mg} / \mathrm{L}$ )

\begin{tabular}{|c|c|c|c|c|c|}
\hline Constituent & Well 1 & Well 2 & Well 3 & Well 4 & Tap \\
\hline B enzene & $<0.0005$ & $<0.0005$ & $<0.0005$ & $<0.0005$ & $<0.0005$ \\
\hline V inyl chloride & $<0.0005$ & $<0.0005$ & $<0.0005$ & $<0.0005$ & $<0.0005$ \\
\hline Carbon tetrachloride & $<0.0005$ & $<0.0005$ & $<0.0005$ & $<0.0005$ & $<0.0005$ \\
\hline 1,2-D ichloroethane & $<0.0005$ & $<0.0005$ & $<0.0005$ & $<0.0005$ & $<0.0005$ \\
\hline Trichloroethylene & $<0.0005$ & $<0.0005$ & $<0.0005$ & $<0.0005$ & $<0.0005$ \\
\hline 1,1-Dichloroethylene & $<0.0005$ & $<0.0005$ & $<0.0005$ & $<0.0005$ & $<0.0005$ \\
\hline 1,1,1-Trichloroethylene & $<0.0005$ & $<0.0005$ & $<0.0005$ & $<0.0005$ & $<0.0005$ \\
\hline p-Dichlorobenzene & $<0.0005$ & $<0.0005$ & $<0.0005$ & $<0.0005$ & $<0.0005$ \\
\hline Bromobenzene & $<0.001$ & $<0.001$ & $<0.001$ & $<0.001$ & $<0.001$ \\
\hline Dichlorobromomethane & $<0.0005$ & $<0.0005$ & $<0.0005$ & $<0.0005$ & 0.0060 \\
\hline Bromoform & $<0.0005$ & $<0.0005$ & $<0.0005$ & $<0.0005$ & $<0.001$ \\
\hline Bromomethane & $<0.002$ & $<0.002$ & $<0.002$ & $<0.002$ & $<0.002$ \\
\hline Chlorobenzene & $<0.0005$ & $<0.0005$ & $<0.0005$ & $<0.0005$ & $<0.0005$ \\
\hline Chlorodibromomethane & $<0.0005$ & $<0.0005$ & $<0.0005$ & $<0.0005$ & 0.0020 \\
\hline Chloroethane & $<0.002$ & $<0.002$ & $<0.002$ & $<0.002$ & $<0.002$ \\
\hline Chloroform & $<0.0005$ & $<0.0005$ & $<0.0005$ & $<0.0005$ & 0.0150 \\
\hline Chloromethane & $<0.002$ & $<0.002$ & $<0.002$ & $<0.002$ & $<0.002$ \\
\hline o-Chlorotoluene & $<0.001$ & $<0.001$ & $<0.001$ & $<0.001$ & $<0.001$ \\
\hline $\mathrm{p}$-Chlorotoluene & $<0.001$ & $<0.001$ & $<0.001$ & $<0.001$ & $<0.001$ \\
\hline Dibromomethane & $<0.001$ & $<0.001$ & $<0.001$ & $<0.001$ & $<0.001$ \\
\hline m-Dichlorobenzene & $<0.001$ & $<0.001$ & $<0.001$ & $<0.001$ & $<0.001$ \\
\hline o-Dichlorobenzene & $<0.0005$ & $<0.0005$ & $<0.0005$ & $<0.0005$ & $<0.0005$ \\
\hline 1,1-D ichloroethane & $<0.001$ & $<0.001$ & $<0.001$ & $<0.001$ & $<0.001$ \\
\hline cis-1,2-Dichloroethylene & $<0.0005$ & $<0.0005$ & $<0.0005$ & $<0.0005$ & $<0.0005$ \\
\hline trans-1,2-Dichloroethylene & $<0.0005$ & $<0.0005$ & $<0.0005$ & $<0.0005$ & $<0.0005$ \\
\hline Dichloromethane & $<0.0005$ & $<0.0005$ & $<0.0005$ & $<0.0005$ & $<0.0005$ \\
\hline 1,2-Dichloropropane & $<0.0005$ & $<0.0005$ & $<0.0005$ & $<0.0005$ & $<0.0005$ \\
\hline 1,3-Dichloropropane & $<0.001$ & $<0.001$ & $<0.001$ & $<0.001$ & $<0.001$ \\
\hline 2,2-Dichloropropane & $<0.001$ & $<0.001$ & $<0.001$ & $<0.001$ & $<0.001$ \\
\hline 1,1-Dichloropropene & $<0.001$ & $<0.001$ & $<0.001$ & $<0.001$ & $<0.001$ \\
\hline 1,3-Dichloropropene & $<0.001$ & $<0.001$ & $<0.001$ & $<0.001$ & $<0.001$ \\
\hline E thylbenzene & $<0.0005$ & $<0.0005$ & $<0.0005$ & $<0.0005$ & $<0.0005$ \\
\hline Styrene & $<0.0005$ & $<0.0005$ & $<0.0005$ & $<0.0005$ & $<0.0005$ \\
\hline 1,1,1,2-Tetrachloroethane & $<0.001$ & $<0.001$ & $<0.001$ & $<0.001$ & $<0.001$ \\
\hline 1,1,2,2-Tetrachloroethane & $<0.001$ & $<0.001$ & $<0.001$ & $<0.001$ & $<0.001$ \\
\hline
\end{tabular}


TABLE 6.3 (Cont.)

\begin{tabular}{|c|c|c|c|c|c|}
\hline Constituent & Well 1 & Well 2 & Well 3 & Well 4 & Tap \\
\hline T etrachloroethylene & $<0.0005$ & $<0.0005$ & $<0.0005$ & $<0.0005$ & $<0.0005$ \\
\hline Toluene & $<0.0005$ & $<0.0005$ & $<0.0005$ & $<0.0005$ & $<0.0005$ \\
\hline 1,1,2-Trichloroethane & $<0.0005$ & $<0.0005$ & $<0.0005$ & $<0.0005$ & $<0.0005$ \\
\hline 1,2,3-Trichloropropane & $<0.001$ & $<0.001$ & $<0.001$ & $<0.001$ & $<0.001$ \\
\hline $\mathrm{m}$ and $\mathrm{p}-\mathrm{X}$ ylene & $<0.0005$ & $<0.0005$ & $<0.0005$ & $<0.0005$ & $<0.0005$ \\
\hline $0-\mathrm{X}$ ylene & $<0.0005$ & $<0.0005$ & $<0.0005$ & $<0.0005$ & $<0.0005$ \\
\hline 1,2-Dibromo-3-Chloropropane & $<0.010$ & $<0.010$ & $<0.010$ & $<0.010$ & $<0.010$ \\
\hline E thylenedibromide & $<0.010$ & $<0.010$ & $<0.010$ & $<0.010$ & $<0.010$ \\
\hline Bromochloromethane & $<0.001$ & $<0.001$ & $<0.001$ & $<0.001$ & $<0.001$ \\
\hline n-Butylbenzene & $<0.001$ & $<0.001$ & $<0.001$ & $<0.001$ & $<0.001$ \\
\hline sec-Butylbenzene & $<0.001$ & $<0.001$ & $<0.001$ & $<0.001$ & $<0.001$ \\
\hline tert-Butylbenzene & $<0.001$ & $<0.001$ & $<0.001$ & $<0.001$ & $<0.001$ \\
\hline Dichlorodifluoromethane & $<0.001$ & $<0.001$ & $<0.001$ & $<0.001$ & $<0.001$ \\
\hline Fluorotrichloromethane & $<0.001$ & $<0.001$ & $<0.001$ & $<0.001$ & $<0.001$ \\
\hline Hexachlorobutadiene & $<0.001$ & $<0.001$ & $<0.001$ & $<0.001$ & $<0.001$ \\
\hline Isopropylbenzene & $<0.001$ & $<0.001$ & $<0.001$ & $<0.001$ & $<0.001$ \\
\hline p-Isopropyltoluene & $<0.001$ & $<0.001$ & $<0.001$ & $<0.001$ & $<0.001$ \\
\hline Naphthalene & $<0.001$ & $<0.001$ & $<0.001$ & $<0.001$ & $<0.001$ \\
\hline n-Propylbenzene & $<0.001$ & $<0.001$ & $<0.001$ & $<0.001$ & $<0.001$ \\
\hline 1,2,3-Trichlorobenzene & $<0.001$ & $<0.001$ & $<0.001$ & $<0.001$ & $<0.001$ \\
\hline 1,2,4-Trichlorobenzene & $<0.0005$ & $<0.0005$ & $<0.0005$ & $<0.0005$ & $<0.0005$ \\
\hline 1,2,4-T rimethylbenzene & $<0.001$ & $<0.001$ & $<0.001$ & $<0.001$ & $<0.001$ \\
\hline 1,3,5-T rimethylbenzene & $<0.001$ & $<0.001$ & $<0.001$ & $<0.001$ & $<0.001$ \\
\hline
\end{tabular}


TABLE 6.4

V olatile Organic Compounds in Former W ater Supply W ell Samples Collected M ay 6, 1997

(Concentrations in $\mathrm{mg} / \mathrm{L}$ )

\begin{tabular}{|c|c|c|c|c|c|}
\hline Constituent & Well 1 & Well 2 & Well 3 & Well 4 & Tap \\
\hline B enzene & $<0.0005$ & $<0.0005$ & $<0.0005$ & $<0.0005$ & $<0.0005$ \\
\hline Vinyl chloride & $<0.0005$ & $<0.0005$ & $<0.0005$ & $<0.0005$ & $<0.0005$ \\
\hline Carbon tetrachloride & $<0.0005$ & $<0.0005$ & $<0.0005$ & $<0.0005$ & $<0.0005$ \\
\hline 1,2-D ichloroethane & $<0.0005$ & $<0.0005$ & $<0.0005$ & $<0.0005$ & $<0.0005$ \\
\hline Trichloroethylene & $<0.0005$ & $<0.0005$ & $<0.0005$ & $<0.0005$ & $<0.0005$ \\
\hline 1,1-Dichloroethylene & $<0.0005$ & $<0.0005$ & $<0.0005$ & $<0.0005$ & $<0.0005$ \\
\hline 1,1,1-Trichloroethylene & $<0.0005$ & $<0.0005$ & $<0.0005$ & $<0.0005$ & $<0.0005$ \\
\hline p-Dichlorobenzene & $<0.0005$ & $<0.0005$ & $<0.0005$ & $<0.0005$ & $<0.0005$ \\
\hline Bromobenzene & $<0.001$ & $<0.001$ & $<0.001$ & $<0.001$ & $<0.001$ \\
\hline Dichlorobromomethane & $<0.0005$ & $<0.0005$ & $<0.0005$ & $<0.0005$ & 0.0060 \\
\hline Bromoform & $<0.0005$ & $<0.0005$ & $<0.0005$ & $<0.0005$ & $<0.001$ \\
\hline Bromomethane & $<0.002$ & $<0.002$ & $<0.002$ & $<0.002$ & $<0.002$ \\
\hline Chlorobenzene & $<0.0005$ & $<0.0005$ & $<0.0005$ & $<0.0005$ & $<0.0005$ \\
\hline Chlorodibromomethane & $<0.0005$ & $<0.0005$ & $<0.0005$ & $<0.0005$ & 0.0030 \\
\hline Chloroethane & $<0.002$ & $<0.002$ & $<0.002$ & $<0.002$ & $<0.002$ \\
\hline Chloroform & $<0.0005$ & $<0.0005$ & $<0.0005$ & $<0.0005$ & 0.0120 \\
\hline Chloromethane & $<0.002$ & $<0.002$ & $<0.002$ & $<0.002$ & $<0.002$ \\
\hline o-Chlorotoluene & $<0.001$ & $<0.001$ & $<0.001$ & $<0.001$ & $<0.001$ \\
\hline $\mathrm{p}$-Chlorotoluene & $<0.001$ & $<0.001$ & $<0.001$ & $<0.001$ & $<0.001$ \\
\hline Dibromomethane & $<0.001$ & $<0.001$ & $<0.001$ & $<0.001$ & $<0.001$ \\
\hline m-Dichlorobenzene & $<0.001$ & $<0.001$ & $<0.001$ & $<0.001$ & $<0.001$ \\
\hline o-Dichlorobenzene & $<0.0005$ & $<0.0005$ & $<0.0005$ & $<0.0005$ & $<0.0005$ \\
\hline 1,1-D ichloroethane & $<0.001$ & $<0.001$ & $<0.001$ & $<0.001$ & $<0.001$ \\
\hline cis-1,2-Dichloroethylene & $<0.0005$ & $<0.0005$ & $<0.0005$ & $<0.0005$ & $<0.0005$ \\
\hline trans-1,2-Dichloroethylene & $<0.0005$ & $<0.0005$ & $<0.0005$ & $<0.0005$ & $<0.0005$ \\
\hline Dichloromethane & $<0.0005$ & $<0.0005$ & $<0.0005$ & $<0.0005$ & $<0.0005$ \\
\hline 1,2-Dichloropropane & $<0.0005$ & $<0.0005$ & $<0.0005$ & $<0.0005$ & $<0.0005$ \\
\hline 1,3-Dichloropropane & $<0.001$ & $<0.001$ & $<0.001$ & $<0.001$ & $<0.001$ \\
\hline 2,2-Dichloropropane & $<0.001$ & $<0.001$ & $<0.001$ & $<0.001$ & $<0.001$ \\
\hline 1,1-Dichloropropene & $<0.001$ & $<0.001$ & $<0.001$ & $<0.001$ & $<0.001$ \\
\hline 1,3-Dichloropropene & $<0.001$ & $<0.001$ & $<0.001$ & $<0.001$ & $<0.001$ \\
\hline Ethylbenzene & $<0.0005$ & $<0.0005$ & $<0.0005$ & $<0.0005$ & $<0.0005$ \\
\hline Styrene & $<0.0005$ & $<0.0005$ & $<0.0005$ & $<0.0005$ & $<0.0005$ \\
\hline 1,1,1,2-Tetrachloroethane & $<0.001$ & $<0.001$ & $<0.001$ & $<0.001$ & $<0.001$ \\
\hline 1,1,2,2-T etrachloroethane & $<0.001$ & $<0.001$ & $<0.001$ & $<0.001$ & $<0.001$ \\
\hline
\end{tabular}




\section{GROUNDWATER PROTECTION}

TABLE 6.4 (Cont.)

\begin{tabular}{|c|c|c|c|c|c|}
\hline Constituent & Well 1 & Well 2 & Well 3 & Well 4 & Tap \\
\hline Tetrachloroethylene & $<0.0005$ & $<0.0005$ & $<0.0005$ & $<0.0005$ & $<0.0005$ \\
\hline Toluene & $<0.0005$ & $<0.0005$ & $<0.0005$ & $<0.0005$ & $<0.0005$ \\
\hline 1,1,2-Trichloroethane & $<0.0005$ & $<0.0005$ & $<0.0005$ & $<0.0005$ & $<0.0005$ \\
\hline 1,2,3-Trichloropropane & $<0.001$ & $<0.001$ & $<0.001$ & $<0.001$ & $<0.001$ \\
\hline $\mathrm{m}$ and $\mathrm{p}$ - $\mathrm{X}$ ylene & $<0.0005$ & $<0.0005$ & $<0.0005$ & $<0.0005$ & $<0.001$ \\
\hline $0-\mathrm{X}$ ylene & $<0.0005$ & $<0.0005$ & $<0.0005$ & $<0.0005$ & $<0.0005$ \\
\hline 1,2-Dibromo-3-Chloropropane & $<0.010$ & $<0.010$ & $<0.010$ & $<0.010$ & $<0.010$ \\
\hline Ethylenedibromide & $<0.010$ & $<0.010$ & $<0.010$ & $<0.010$ & $<0.010$ \\
\hline Bromochloromethane & $<0.001$ & $<0.001$ & $<0.001$ & $<0.001$ & $<0.001$ \\
\hline n-Butylbenzene & $<0.001$ & $<0.001$ & $<0.001$ & $<0.001$ & $<0.001$ \\
\hline sec-Butylbenzene & $<0.001$ & $<0.001$ & $<0.001$ & $<0.001$ & $<0.001$ \\
\hline tert-Butylbenzene & $<0.001$ & $<0.001$ & $<0.001$ & $<0.001$ & $<0.001$ \\
\hline Dichlorodifluoromethane & $<0.001$ & $<0.001$ & $<0.001$ & $<0.001$ & $<0.001$ \\
\hline Fluorotrichloromethane & $<0.001$ & $<0.001$ & $<0.001$ & $<0.001$ & $<0.001$ \\
\hline Hexachlorobutadiene & $<0.001$ & $<0.001$ & $<0.001$ & $<0.001$ & $<0.001$ \\
\hline Isopropylbenzene & $<0.001$ & $<0.001$ & $<0.001$ & $<0.001$ & $<0.001$ \\
\hline p-Isopropyltoluene & $<0.001$ & $<0.001$ & $<0.001$ & $<0.001$ & $<0.001$ \\
\hline Naphthalene & $<0.001$ & $<0.001$ & $<0.001$ & $<0.001$ & $<0.001$ \\
\hline n-Propylbenzene & $<0.001$ & $<0.001$ & $<0.001$ & $<0.001$ & $<0.001$ \\
\hline 1,2,3-Trichlorobenzene & $<0.001$ & $<0.001$ & $<0.001$ & $<0.001$ & $<0.001$ \\
\hline 1,2,4-Trichlorobenzene & $<0.0005$ & $<0.0005$ & $<0.0005$ & $<0.0005$ & $<0.0005$ \\
\hline $1,2,4$-T rimethylbenzene & $<0.001$ & $<0.001$ & $<0.001$ & $<0.001$ & $<0.001$ \\
\hline 1,3,5-Trimethyl benzene & $<0.001$ & $<0.001$ & $<0.001$ & $<0.001$ & $<0.001$ \\
\hline
\end{tabular}




\section{GROUNDWATER PROTECTION}

\section{TABLE 6.5}

V olatile Organic Compounds in Former W ater Supply W ell Samples Collected A ugust 4, 1997 (Concentrations in $\mathrm{mg} / \mathrm{L}$ )

\begin{tabular}{|c|c|c|c|c|c|}
\hline Constituent & Well 1 & Well 2 & Well 3 & Well 4 & Tap \\
\hline B enzene & $<0.0005$ & $<0.0005$ & $<0.0005$ & $<0.0005$ & $<0.0005$ \\
\hline V inyl chloride & $<0.0005$ & $<0.0005$ & $<0.0005$ & $<0.0005$ & $<0.0005$ \\
\hline Carbon tetrachloride & $<0.0005$ & $<0.0005$ & $<0.0005$ & $<0.0005$ & $<0.0005$ \\
\hline 1,2-D ichloroethane & $<0.0005$ & $<0.0005$ & $<0.0005$ & $<0.0005$ & $<0.0005$ \\
\hline Trichloroethylene & $<0.0005$ & $<0.0005$ & $<0.0005$ & $<0.0005$ & $<0.0005$ \\
\hline 1,1-Dichloroethylene & $<0.0005$ & $<0.0005$ & $<0.0005$ & $<0.0005$ & $<0.0005$ \\
\hline 1,1,1-Trichloroethylene & $<0.0005$ & $<0.0005$ & $<0.0005$ & $<0.0005$ & $<0.0005$ \\
\hline p-Dichlorobenzene & $<0.0005$ & $<0.0005$ & $<0.0005$ & $<0.0005$ & $<0.0005$ \\
\hline Bromobenzene & $<0.001$ & $<0.001$ & $<0.001$ & $<0.001$ & $<0.001$ \\
\hline Dichlorobromomethane & $<0.0005$ & $<0.0005$ & $<0.0005$ & $<0.0005$ & 0.0100 \\
\hline Bromoform & $<0.0005$ & $<0.0005$ & $<0.0005$ & $<0.0005$ & $<0.001$ \\
\hline Bromomethane & $<0.002$ & $<0.002$ & $<0.002$ & $<0.002$ & $<0.002$ \\
\hline Chlorobenzene & $<0.0005$ & $<0.0005$ & $<0.0005$ & $<0.0005$ & $<0.0005$ \\
\hline Chlorodibromomethane & $<0.0005$ & $<0.0005$ & $<0.0005$ & $<0.0005$ & 0.0040 \\
\hline Chloroethane & $<0.002$ & $<0.002$ & $<0.002$ & $<0.002$ & $<0.002$ \\
\hline Chloroform & $<0.0005$ & $<0.0005$ & $<0.0005$ & $<0.0005$ & 0.0220 \\
\hline Chloromethane & $<0.002$ & $<0.002$ & $<0.002$ & $<0.002$ & $<0.002$ \\
\hline o-Chlorotoluene & $<0.001$ & $<0.001$ & $<0.001$ & $<0.001$ & $<0.001$ \\
\hline $\mathrm{p}$-Chlorotoluene & $<0.001$ & $<0.001$ & $<0.001$ & $<0.001$ & $<0.001$ \\
\hline Dibromomethane & $<0.001$ & $<0.001$ & $<0.001$ & $<0.001$ & $<0.001$ \\
\hline m-Dichlorobenzene & $<0.001$ & $<0.001$ & $<0.001$ & $<0.001$ & $<0.001$ \\
\hline o-Dichlorobenzene & $<0.0005$ & $<0.0005$ & $<0.0005$ & $<0.0005$ & $<0.0005$ \\
\hline 1,1-D ichloroethane & $<0.001$ & $<0.001$ & $<0.001$ & $<0.001$ & $<0.001$ \\
\hline cis-1,2-Dichloroethylene & $<0.0005$ & $<0.0005$ & $<0.0005$ & $<0.0005$ & $<0.0005$ \\
\hline trans-1,2-Dichloroethylene & $<0.0005$ & $<0.0005$ & $<0.0005$ & $<0.0005$ & $<0.0005$ \\
\hline Dichloromethane & $<0.0005$ & $<0.0005$ & $<0.0005$ & $<0.0005$ & $<0.0005$ \\
\hline 1,2-Dichloropropane & $<0.0005$ & $<0.0005$ & $<0.0005$ & $<0.0005$ & $<0.0005$ \\
\hline 1,3-Dichloropropane & $<0.001$ & $<0.001$ & $<0.001$ & $<0.001$ & $<0.001$ \\
\hline 2,2-Dichloropropane & $<0.001$ & $<0.001$ & $<0.001$ & $<0.001$ & $<0.001$ \\
\hline 1,1-Dichloropropene & $<0.001$ & $<0.001$ & $<0.001$ & $<0.001$ & $<0.001$ \\
\hline 1,3-Dichloropropene & $<0.001$ & $<0.001$ & $<0.001$ & $<0.001$ & $<0.001$ \\
\hline E thylbenzene & $<0.0005$ & $<0.0005$ & $<0.0005$ & $<0.0005$ & $<0.0005$ \\
\hline Styrene & $<0.0005$ & $<0.0005$ & $<0.0005$ & $<0.0005$ & $<0.0005$ \\
\hline 1,1,1,2-Tetrachloroethane & $<0.001$ & $<0.001$ & $<0.001$ & $<0.001$ & $<0.001$ \\
\hline 1,1,2,2-Tetrachloroethane & $<0.001$ & $<0.001$ & $<0.001$ & $<0.001$ & $<0.001$ \\
\hline
\end{tabular}




\section{GROUNDWATER PROTECTION}

TABLE 6.5 (Cont.)

\begin{tabular}{|c|c|c|c|c|c|}
\hline Constituent & Well 1 & Well 2 & Well 3 & Well 4 & Tap \\
\hline Tetrachloroethylene & $<0.0005$ & $<0.0005$ & $<0.0005$ & $<0.0005$ & $<0.0005$ \\
\hline Toluene & $<0.0005$ & $<0.0005$ & $<0.0005$ & $<0.0005$ & $<0.0005$ \\
\hline 1,1,2-Trichloroethane & $<0.0005$ & $<0.0005$ & $<0.0005$ & $<0.0005$ & $<0.0005$ \\
\hline 1,2,3-Trichloropropane & $<0.001$ & $<0.001$ & $<0.001$ & $<0.001$ & $<0.001$ \\
\hline $\mathrm{m}$ and $\mathrm{p}-\mathrm{X}$ ylene & $<0.0005$ & $<0.0005$ & $<0.0005$ & $<0.0005$ & $<0.001$ \\
\hline $0-X$ ylene & $<0.0005$ & $<0.0005$ & $<0.0005$ & $<0.0005$ & $<0.0005$ \\
\hline 1,2-Dibromo-3-Chloropropane & $<0.010$ & $<0.010$ & $<0.010$ & $<0.010$ & $<0.010$ \\
\hline Ethylenedibromide & $<0.010$ & $<0.010$ & $<0.010$ & $<0.010$ & $<0.010$ \\
\hline Bromochloromethane & $<0.001$ & $<0.001$ & $<0.001$ & $<0.001$ & $<0.001$ \\
\hline n-Butylbenzene & $<0.001$ & $<0.001$ & $<0.001$ & $<0.001$ & $<0.001$ \\
\hline sec-Butylbenzene & $<0.001$ & $<0.001$ & $<0.001$ & $<0.001$ & $<0.001$ \\
\hline tert-Butylbenzene & $<0.001$ & $<0.001$ & $<0.001$ & $<0.001$ & $<0.001$ \\
\hline Dichlorodifluoromethane & $<0.001$ & $<0.001$ & $<0.001$ & $<0.001$ & $<0.001$ \\
\hline Fluorotrichloromethane & $<0.001$ & $<0.001$ & $<0.001$ & $<0.001$ & $<0.001$ \\
\hline Hexachlorobutadiene & $<0.001$ & $<0.001$ & $<0.001$ & $<0.001$ & $<0.001$ \\
\hline Isopropylbenzene & $<0.001$ & $<0.001$ & $<0.001$ & $<0.001$ & $<0.001$ \\
\hline p-Isopropyltoluene & $<0.001$ & $<0.001$ & $<0.001$ & $<0.001$ & $<0.001$ \\
\hline Naphthalene & $<0.001$ & $<0.001$ & $<0.001$ & $<0.001$ & $<0.001$ \\
\hline n-Propylbenzene & $<0.001$ & $<0.001$ & $<0.001$ & $<0.001$ & $<0.001$ \\
\hline 1,2,3-Trichlorobenzene & $<0.001$ & $<0.001$ & $<0.001$ & $<0.001$ & $<0.001$ \\
\hline 1,2,4-Trichlorobenzene & $<0.0005$ & $<0.0005$ & $<0.0005$ & $<0.0005$ & $<0.0005$ \\
\hline 1,2,4-T rimethylbenzene & $<0.001$ & $<0.001$ & $<0.001$ & $<0.001$ & $<0.001$ \\
\hline 1,3,5-Trimethyl benzene & $<0.001$ & $<0.001$ & $<0.001$ & $<0.001$ & $<0.001$ \\
\hline
\end{tabular}


TABLE 6.6

Volatile Organic Compounds in Former Water Supply W ell Samples Collected December 1, 1997 (Concentrations in $\mathrm{mg} / \mathrm{L}$ )

\begin{tabular}{|c|c|c|c|c|c|}
\hline Constituent & Well 1 & Well 2 & Well 3 & Well 4 & Tap \\
\hline B enzene & $<0.0005$ & $<0.0005$ & $<0.0005$ & $<0.0005$ & $<0.0005$ \\
\hline V inyl chloride & $<0.0005$ & $<0.0005$ & $<0.0005$ & $<0.0005$ & $<0.0005$ \\
\hline Carbon tetrachloride & $<0.0005$ & $<0.0005$ & $<0.0005$ & $<0.0005$ & $<0.0005$ \\
\hline 1,2-D ichloroethane & $<0.0005$ & $<0.0005$ & $<0.0005$ & $<0.0005$ & $<0.0005$ \\
\hline Trichloroethylene & $<0.0005$ & $<0.0005$ & $<0.0005$ & $<0.0005$ & $<0.0005$ \\
\hline 1,1-Dichloroethylene & $<0.0005$ & $<0.0005$ & $<0.0005$ & $<0.0005$ & $<0.0005$ \\
\hline 1,1,1-Trichloroethylene & $<0.0005$ & $<0.0005$ & $<0.0005$ & $<0.0005$ & $<0.0005$ \\
\hline p-Dichlorobenzene & $<0.0005$ & $<0.0005$ & $<0.0005$ & $<0.0005$ & $<0.0005$ \\
\hline Bromobenzene & $<0.001$ & $<0.001$ & $<0.001$ & $<0.001$ & $<0.001$ \\
\hline Dichlorobromomethane & $<0.0005$ & $<0.0005$ & $<0.0005$ & $<0.0005$ & 0.0040 \\
\hline Bromoform & $<0.0005$ & $<0.0005$ & $<0.0005$ & $<0.0005$ & $<0.001$ \\
\hline Bromomethane & $<0.002$ & $<0.002$ & $<0.002$ & $<0.002$ & $<0.002$ \\
\hline Chlorobenzene & $<0.0005$ & $<0.0005$ & $<0.0005$ & $<0.0005$ & $<0.0005$ \\
\hline Chlorodibromomethane & $<0.0005$ & $<0.0005$ & $<0.0005$ & $<0.0005$ & 0.0020 \\
\hline Chloroethane & $<0.002$ & $<0.002$ & $<0.002$ & $<0.002$ & $<0.002$ \\
\hline Chloroform & $<0.0005$ & $<0.0005$ & $<0.0005$ & $<0.0005$ & 0.0050 \\
\hline Chloromethane & $<0.002$ & $<0.002$ & $<0.002$ & $<0.002$ & $<0.002$ \\
\hline o-Chlorotoluene & $<0.001$ & $<0.001$ & $<0.001$ & $<0.001$ & $<0.001$ \\
\hline $\mathrm{p}$-Chlorotoluene & $<0.001$ & $<0.001$ & $<0.001$ & $<0.001$ & $<0.001$ \\
\hline Dibromomethane & $<0.001$ & $<0.001$ & $<0.001$ & $<0.001$ & $<0.001$ \\
\hline m-Dichlorobenzene & $<0.001$ & $<0.001$ & $<0.001$ & $<0.001$ & $<0.001$ \\
\hline o-Dichlorobenzene & $<0.0005$ & $<0.0005$ & $<0.0005$ & $<0.0005$ & $<0.0005$ \\
\hline 1,1-Dichloroethane & $<0.001$ & $<0.001$ & $<0.001$ & $<0.001$ & $<0.001$ \\
\hline cis-1,2-Dichloroethylene & $<0.0005$ & $<0.0005$ & $<0.0005$ & $<0.0005$ & $<0.0005$ \\
\hline trans-1,2-Dichloroethylene & $<0.0005$ & $<0.0005$ & $<0.0005$ & $<0.0005$ & $<0.0005$ \\
\hline Dichloromethane & $<0.0005$ & $<0.0005$ & $<0.0005$ & $<0.0005$ & $<0.0005$ \\
\hline 1,2-Dichloropropane & $<0.0005$ & $<0.0005$ & $<0.0005$ & $<0.0005$ & $<0.0005$ \\
\hline 1,3-Dichloropropane & $<0.001$ & $<0.001$ & $<0.001$ & $<0.001$ & $<0.001$ \\
\hline 2,2-Dichloropropane & $<0.001$ & $<0.001$ & $<0.001$ & $<0.001$ & $<0.001$ \\
\hline 1,1-Dichloropropene & $<0.001$ & $<0.001$ & $<0.001$ & $<0.001$ & $<0.001$ \\
\hline 1,3-Dichloropropene & $<0.001$ & $<0.001$ & $<0.001$ & $<0.001$ & $<0.001$ \\
\hline E thylbenzene & $<0.0005$ & $<0.0005$ & $<0.0005$ & $<0.0005$ & $<0.0005$ \\
\hline Styrene & $<0.0005$ & $<0.0005$ & $<0.0005$ & $<0.0005$ & $<0.0005$ \\
\hline 1,1,1,2-T etrachloroethane & $<0.001$ & $<0.001$ & $<0.001$ & $<0.001$ & $<0.001$ \\
\hline
\end{tabular}


TABLE 6.6 (Cont.)

\begin{tabular}{|c|c|c|c|c|c|}
\hline Constituent & Well 1 & Well 2 & Well 3 & Well 4 & Tap \\
\hline 1,1,2,2-T etrachloroethane & $<0.001$ & $<0.001$ & $<0.001$ & $<0.001$ & $<0.001$ \\
\hline Tetrachloroethylene & $<0.0005$ & $<0.0005$ & $<0.0005$ & $<0.0005$ & $<0.0005$ \\
\hline Toluene & $<0.0005$ & $<0.0005$ & $<0.0005$ & $<0.0005$ & $<0.0005$ \\
\hline 1,1,2-Trichloroethane & $<0.0005$ & $<0.0005$ & $<0.0005$ & $<0.0005$ & $<0.0005$ \\
\hline 1,2,3-Trichloropropane & $<0.001$ & $<0.001$ & $<0.001$ & $<0.001$ & $<0.001$ \\
\hline $\mathrm{m}$ and $\mathrm{p}-\mathrm{X}$ ylene & $<0.0005$ & $<0.0005$ & $<0.0005$ & $<0.0005$ & $<0.005$ \\
\hline $0-X$ ylene & $<0.0005$ & $<0.0005$ & $<0.0005$ & $<0.0005$ & $<0.0005$ \\
\hline 1,2-Dibromo-3-Chloropropane & $<0.010$ & $<0.010$ & $<0.010$ & $<0.010$ & $<0.010$ \\
\hline E thylenedibromide & $<0.010$ & $<0.010$ & $<0.010$ & $<0.010$ & $<0.010$ \\
\hline Bromochloromethane & $<0.001$ & $<0.001$ & $<0.001$ & $<0.001$ & $<0.001$ \\
\hline n-Butylbenzene & $<0.001$ & $<0.001$ & $<0.001$ & $<0.001$ & $<0.001$ \\
\hline sec-Butylbenzene & $<0.001$ & $<0.001$ & $<0.001$ & $<0.001$ & $<0.001$ \\
\hline tert-Butylbenzene & $<0.001$ & $<0.001$ & $<0.001$ & $<0.001$ & $<0.001$ \\
\hline Dichlorodifluoromethane & $<0.001$ & $<0.001$ & $<0.001$ & $<0.001$ & $<0.001$ \\
\hline Fluorotrichloromethane & $<0.001$ & $<0.001$ & $<0.001$ & $<0.001$ & $<0.001$ \\
\hline Hexachlorobutadiene & $<0.001$ & $<0.001$ & $<0.001$ & $<0.001$ & $<0.001$ \\
\hline Isopropylbenzene & $<0.001$ & $<0.001$ & $<0.001$ & $<0.001$ & $<0.001$ \\
\hline p-Isopropyltoluene & $<0.001$ & $<0.001$ & $<0.001$ & $<0.001$ & $<0.001$ \\
\hline Naphthalene & $<0.001$ & $<0.001$ & $<0.001$ & $<0.001$ & $<0.001$ \\
\hline n-Propylbenzene & $<0.001$ & $<0.001$ & $<0.001$ & $<0.001$ & $<0.001$ \\
\hline 1,2,3-Trichlorobenzene & $<0.001$ & $<0.001$ & $<0.001$ & $<0.001$ & $<0.001$ \\
\hline 1,2,4-Trichlorobenzene & $<0.0005$ & $<0.0005$ & $<0.0005$ & $<0.0005$ & $<0.0005$ \\
\hline 1,2,4-T rimethylbenzene & $<0.001$ & $<0.001$ & $<0.001$ & $<0.001$ & $<0.001$ \\
\hline 1,3,5-Trimethylbenzene & $<0.001$ & $<0.001$ & $<0.001$ & $<0.001$ & $<0.001$ \\
\hline
\end{tabular}




\section{GROUNDWATER PROTECTION}

TABLE 6.7

Copper and L ead Samples Collected Sitewide, M ay 15 and September 25, 1997 (Concentrations in $\mathrm{mg} / \mathrm{L}$ )

\begin{tabular}{|c|c|c|c|c|}
\hline \multirow[b]{2}{*}{ Sample No. } & \multicolumn{2}{|c|}{ M ay 15} & \multicolumn{2}{|c|}{ September 25} \\
\hline & Copper & L ead & Copper & Lead \\
\hline 1 & $<0.02$ & $<0.002$ & $<0.02$ & $<0.002$ \\
\hline 2 & 0.023 & $<0.002$ & 0.022 & $<0.002$ \\
\hline 3 & 0.069 & $<0.002$ & 0.053 & $<0.002$ \\
\hline 4 & 0.081 & $<0.002$ & 0.072 & $<0.002$ \\
\hline 5 & 0.11 & $<0.002$ & 0.080 & $<0.002$ \\
\hline 6 & 0.11 & $<0.002$ & 0.087 & $<0.002$ \\
\hline 7 & 0.12 & $<0.002$ & 0.089 & $<0.002$ \\
\hline 8 & 0.14 & $<0.002$ & 0.10 & $<0.002$ \\
\hline 9 & 0.16 & $<0.002$ & 0.14 & $<0.002$ \\
\hline 10 & 0.17 & $<0.002$ & 0.17 & $<0.002$ \\
\hline 11 & 0.19 & $<0.002$ & 0.17 & $<0.002$ \\
\hline 12 & 0.20 & $<0.002$ & 0.17 & $<0.002$ \\
\hline 13 & 0.23 & $<0.002$ & 0.19 & $<0.002$ \\
\hline 14 & 0.25 & $<0.002$ & 0.20 & $<0.002$ \\
\hline 15 & 0.28 & $<0.002$ & 0.22 & $<0.002$ \\
\hline 16 & 0.30 & $<0.002$ & 0.22 & $<0.002$ \\
\hline 17 & 0.30 & $<0.002$ & 0.23 & $<0.002$ \\
\hline 18 & 0.30 & $<0.002$ & 0.24 & $<0.002$ \\
\hline 19 & 0.31 & $<0.002$ & 0.27 & $<0.002$ \\
\hline 20 & 0.34 & $<0.002$ & 0.29 & $<0.002$ \\
\hline 21 & 0.40 & $<0.002$ & 0.33 & $<0.002$ \\
\hline 22 & 0.42 & $<0.002$ & 0.37 & $<0.002$ \\
\hline 23 & 0.45 & $<0.002$ & 0.39 & $<0.002$ \\
\hline 24 & 0.45 & $<0.002$ & 0.41 & $<0.002$ \\
\hline 25 & 0.47 & $<0.002$ & 0.42 & $<0.002$ \\
\hline 26 & 0.48 & $<0.002$ & 0.44 & $<0.002$ \\
\hline 27 & 0.48 & $<0.002$ & 0.45 & $<0.002$ \\
\hline 28 & 0.49 & $<0.002$ & 0.46 & $<0.002$ \\
\hline 29 & 0.53 & $<0.002$ & 0.46 & 0.0021 \\
\hline 30 & 0.54 & $<0.002$ & 0.47 & 0.0022 \\
\hline 31 & 0.63 & 0.0034 & 0.48 & 0.0028 \\
\hline 32 & 0.68 & 0.0035 & 0.53 & 0.0034 \\
\hline 33 & 0.80 & 0.0043 & 0.53 & 0.0037 \\
\hline 34 & 0.85 & 0.0047 & 0.54 & 0.0041 \\
\hline & (90th percentile) & (90th percentile) & & \\
\hline 35 & 1.0 & 0.0047 & 0.64 & 0.0054 \\
\hline 36 & 1.2 & 0.0091 & $\begin{array}{c}0.65 \\
\text { (90th percentile) }\end{array}$ & $\begin{array}{c}0.0064 \\
\text { (90th percentile) }\end{array}$ \\
\hline 37 & 1.5 & 0.0150 & 0.70 & 0.0094 \\
\hline 38 & 3.1 & 0.2000 & 0.70 & 0.0095 \\
\hline 39 & & & 0.71 & 0.0100 \\
\hline 40 & & & 0.90 & 0.0330 \\
\hline Action level & 1.3 & 0.015 & 1.3 & 0.015 \\
\hline
\end{tabular}




\section{GROUNDWATER PROTECTION}

hazardous chemical releases from these units. Routinely monitored sites include the sanitary landfill in the $800 \mathrm{~A}$ rea and the 317/319 A rea, which consists of seven separate waste management units located within a small geographical area. The site of the CP-5 reactor is also monitored periodically to determine whether any radionuclides are being released from this unit.

\subsubsection{7 and 319 Areas}

$M$ anagement of waste has been conducted in seven separate units within the 317 and 319 A reas. The former area is currently used as for temporary storage of radioactive waste prior to off-site shipment for disposal. This area also contained two RCRA-permitted units that were formally closed during 1994 and one permitted area that is still active. The 319 A rea is an inactive landfill adjacent to the 317 A rea. In addition to these units, a second landfill site, the East-N ortheast (ENE) landfill, is located to the east-northeast of the 319 A rea. This unit was used in the late 1940s and early 1950s primarily for the disposal of construction debris from several sites, including the University of Chicago's M anhattan Project. Figure 6.1 is a sketch of the 317 and 319 A reas.

The most significant units in this area in terms of groundwater impact are an inactive $F$ rench Drain (dry well) in the 317 A rea and the landfill and French Drain in the 319 A rea. The 317 A rea F rench Drain operated in the mid-1950s and was used for disposal of unknown amounts of liquid chemical wastes. The 319 A rea L andfill was operated from the mid-1950s until 1968. The F rench Drain, similar to the one in the 317 A rea, was operated until 1968. Quantities of a wide variety of liquid wastes, including heavy metals, solvents, and waste oil (some containing $P C B s)$, were placed in the 319 A rea $L$ andfill and French Drain.

A series of interim actions have been completed or are currently underway in the 317 and 319 A reas to minimize potential releases of hazardous and radioactive materials off site. The 317 A rea contained six vaults used for temporary storage of solid radioactive waste. Water from footing drains and/or sumps was collected and discharged into a sewer system. This sewer system, which was designed to drain off site, was closed permanently in 1986 after it was 


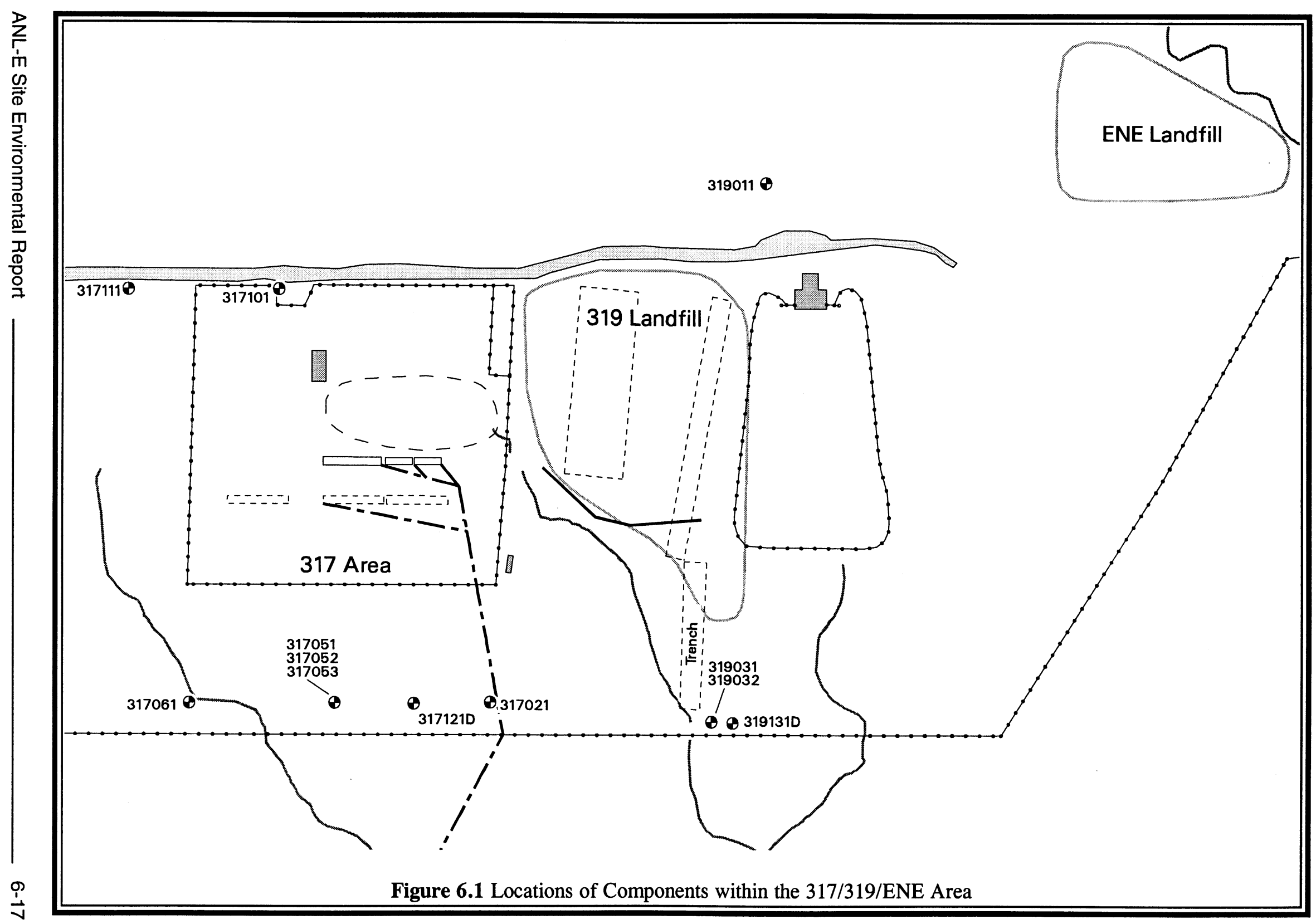




\section{GROUNDWATER PROTECTION}

discovered that the water contained very small amounts of several radionuclides. W ater collecting in the sewer system was pumped out periodically from manholes into portable tanks, transported to Building 306, and analyzed for radioactivity before release to the laboratory wastewater collection system. During 1997, a portion of this system, from M anhole E2 to the ANL-E fence line, was filled with grout; the gravel backfill outside of the pipe also was sealed with grout. The remainder of the system will be sealed in a similar manner when the $\mathrm{N}$ orth vaults are demolished. The $D \& D$ of the 317 A rea South V aults, a former radioactive waste storage area, was completed in 1996. The vaults were decontaminated to low residual radioactivity levels before they were demolished and buried in place. Also in 1997, a groundwater collection system, consisting of 13 groundwater extraction wells, was constructed south of the 317 A rea near the ANL-E fence line. The purpose of this system is to prevent contaminated groundwater from moving off site. In late 1997, a project designed to remove V OCs from the soil in the $317 \mathrm{~F}$ rench D rain area was begun. In addition, a concrete cover was placed over the 318 A rea, a small burial area used to dispose of a number of defective or damaged compressed gas cylinders.

The 319 A rea currently consists of a mound created by waste fill activities. The waste consisted of noncombustible refuse and demolition and construction debris. In addition, suspect waste (material that was not known to be contaminated but that had the potential for hidden radioactive contamination that could not be confirmed by direct measurement, such as the inside of long pipes or ductwork) was also placed in this unit. The landfill consisted of a number of trenches, 3 to $5 \mathrm{~m}$ (10 to $15 \mathrm{ft}$ ) deep, which were filled with waste material. When the trenches were filled with waste, they were covered with soil. Geophysical surveys have identified the location of these trenches. One critical action was completed in 1997 at the 319 A rea L andfill. This action consisted of construction of a leachate collection trench, an underground groundwater barrier wall, and a set of six extraction wells to prevent the off-site migration of radioactive and chemically contaminated groundwater from the 319 A rea. This system operated successfully throughout 1997.

During 1997, ANL-E proposed the construction of an impermeable composite cap (i.e., a geosynthetic clay liner covered with a clay soil layer) over the 319 A rea Landfill and French Drain. The IEPA is currently reviewing this proposal. 


\section{GROUNDWATER PROTECTION}

\subsubsection{Groundwater Monitoring at the 317 and 319 Areas}

Ten active monitoring wells (some of which are clustered or nested) are installed at the locations shown in Figure 6.2. Well data are listed in Table 6.8. The wide range in water level elevations shown in Table 6.8 is not unusual and results from some of the wells being screened at different depths in different saturated zones. This variation in water level also may be indicative of "perched" (i.e., discontinuous) groundwater conditions within the glacial till. Samples are collected quarterly following EPA sampling protocols listed in the RCRA GroundWater M onitoring Technical Enforcement Guidance D ocument. ${ }^{32}$

Groundwater monitoring in the 317 and 319 A reas has been conducted since 1986. Wells 319011, 317021, and 319031 were installed in September 1986; 317061 in A ugust 1987; 317101 and 317111 in September 1988; and Wells 319032 and 317052 were installed in J une 1989. These wells were all completed in the glacial till. In addition, W ells 317121D and 319131D were installed in November 1989 and reach the dolomite aquifer at about $25 \mathrm{~m}$ (80 ft) below the surface.

W ells 317101 and 317111 are upgradient of the 317 storage area, and Well 319011 is upgradient of the 319 A rea $L$ andfill. A sand lens present at 5 to $8 \mathrm{~m}$ ( 15 to $25 \mathrm{ft}$ ) is monitored by Wells 317052 and 319032. This layer is also intercepted by W ell 317101.

In addition to wells in this area, two manholes associated with the vault sewer system were monitored on a monthly basis. Figure 6.1 shows the locations of the manholes.

\subsubsection{Sample Collection}

The monitoring wells are sampled using the protocol listed in the RCRA Ground-Water M onitoring Technical Enforcement Guidance D ocument. ${ }^{32}$ The volume of the water in the casing is determined by measuring the water depth from the surface and the depth to the bottom of the well. This latter measurement also determines whether siltation has occurred, which might restrict water movement in the screened area. For those wells in the glacial till that do not 


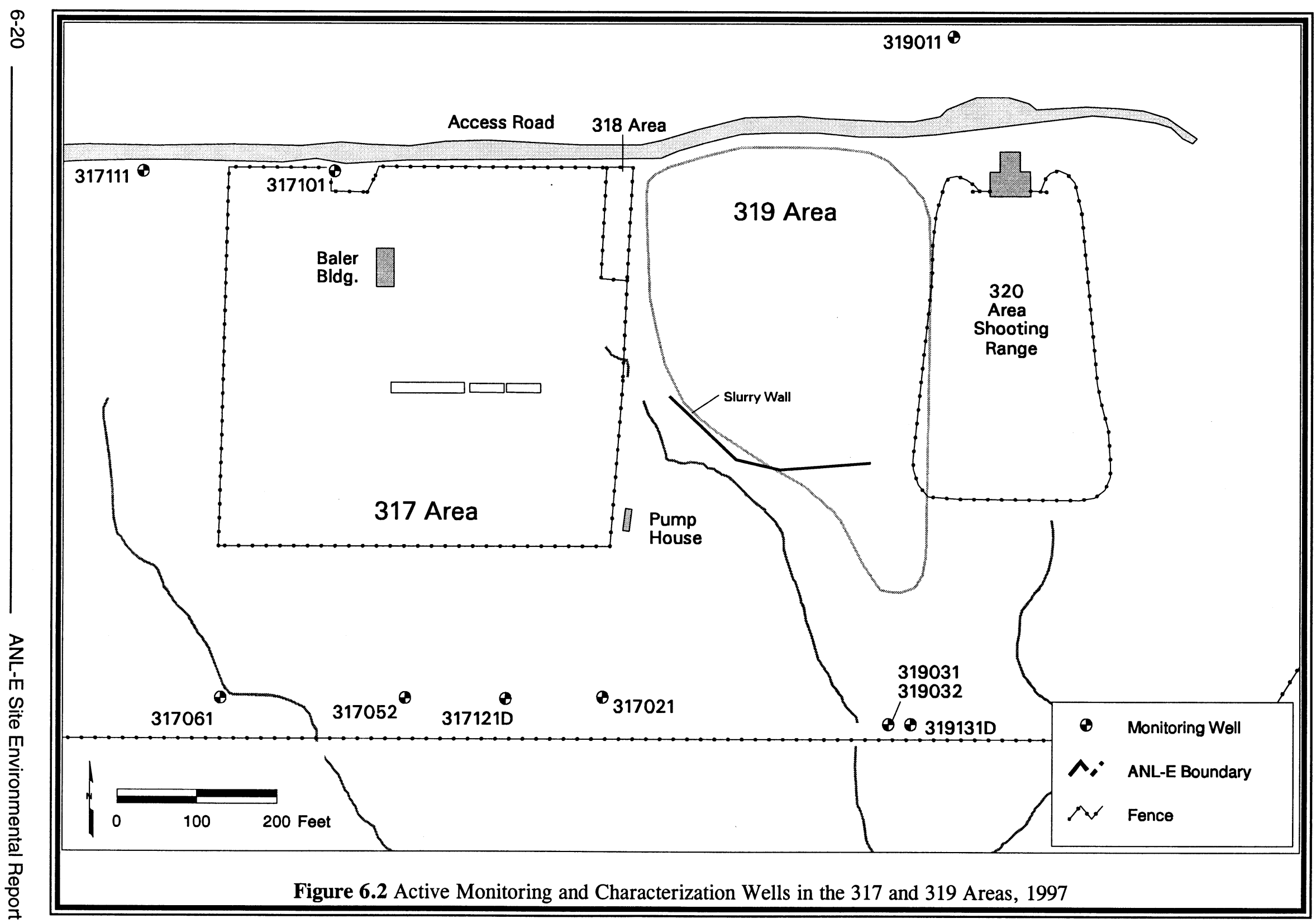




\section{GROUNDWATER PROTECTION}

TABLE 6.8

Groundwater M onitoring W ells: 317 and 319 A reas

\begin{tabular}{|c|c|c|c|c|c|}
\hline $\begin{array}{l}\text { ID } \\
\text { Number }\end{array}$ & $\begin{array}{c}\text { W ell } \\
\text { D epth } \\
\text { (m bgs) }\end{array}$ & $\begin{array}{c}\text { Ground } \\
\text { Elevation } \\
\text { (m AMSL) }\end{array}$ & $\begin{array}{l}\text { Monitoring } \\
\text { Zone } \\
\text { (m AM SL) }\end{array}$ & $\begin{array}{l}\text { Well } \\
\text { Type }^{\mathrm{a}}\end{array}$ & $\begin{array}{l}\text { Date } \\
\text { Drilled }\end{array}$ \\
\hline 319011 & 12.19 & 209.8 & $199.1-197.6$ & $0.05 / P V C$ & $9 / 86$ \\
\hline 317021 & 12.19 & 209.2 & $198.5-197.0$ & $0.05 / P V C$ & $9 / 86$ \\
\hline 319031 & 12.50 & 204.3 & $194.8-191.8$ & $0.05 / P V C$ & $9 / 86$ \\
\hline 319032 & 7.62 & 204.3 & 198.2-196. 7 & $0.05 / P V C$ & $8 / 89$ \\
\hline 317051 & 6.10 & 208.3 & $205.3-202.2$ & $0.05 / P V C$ & $7 / 87$ \\
\hline 317053 & 6.71 & 208.3 & $203.1-201.6$ & $0.05 / P V C$ & $8 / 89$ \\
\hline 317052 & 4.27 & 208.3 & $207.1-204.0$ & $0.05 / P \vee C$ & $8 / 89$ \\
\hline 317061 & 12.19 & 207.5 & 196.9-195. 3 & $0.05 / P V C$ & $7 / 87$ \\
\hline 317101 & 11.89 & 211.0 & 202.2-199. 1 & $0.05 / P \vee C$ & $8 / 89$ \\
\hline 317111 & 11.89 & 210.3 & $201.4-198.4$ & $0.05 / P V C$ & $8 / 89$ \\
\hline $317121 D^{b}$ & 24.08 & 207.6 & $185.0-183.5$ & $0.15 / C S$ & $9 / 88$ \\
\hline $319131 \mathrm{D}$ & 21.03 & 203.5 & $184.0-182.5$ & $0.15 / \mathrm{CS}$ & $9 / 88$ \\
\hline \multicolumn{6}{|c|}{$\begin{array}{l}\text { anner diameter }(\mathrm{m}) / \text { well material (PVC = polyvinyl chloride, } \mathrm{CS}=\text { carbon } \\
\text { steel). }\end{array}$} \\
\hline \multicolumn{6}{|c|}{$\begin{array}{l}\text { b ells identified by a "D" are deeper wells monitoring the dolomite } \\
\text { bedrock aquifer. }\end{array}$} \\
\hline
\end{tabular}

recharge rapidly, the well is emptied and the volume of water removed is compared to the calculated volume. In most cases, these volumes are nearly identical. The well is then sampled by bailing with a dedicated Teflon bailer. The field parameters for these samples ( $\mathrm{pH}$, specific conductance, redox potential, and temperature) are measured statically. For those samples in the porous, saturated zone that recharges rapidly, three well volumes are purged using dedicated submersible pumps, while the field parameters are measured continuously. These parameters stabilize quickly in these wells. In the case of the dolomite wells, samples are collected as soon as these readings stabilize. Samples for VOCs, SVOCS, PCBs and pesticides, metals, and radioactivity are collected in that order. The samples are placed in precleaned bottles, labeled, and preserved. 


\section{GROUNDWATER PROTECTION}

During each sampling event, one well is selected for replicate sampling. An effort is made to vary this selection so that replicates are obtained at every well over time. In addition, a field blank is also obtained.

\subsubsection{Sample Analyses - 317 and 319 Areas}

The 317 and 319 A rea groundwater chemical analyses were performed using SOPs written, reviewed, and issued as controlled documents by members of ESH-A nalytical Services, Chemistry Laboratory $(\mathrm{ASCH})$. These SOPs reference protocols are from SW-846, 3rd edition, "Test M ethods for Evaluating Solid Waste." ${ }^{9}$ Sixteen metals were routinely determined and were measured using flame atomic absorption spectroscopy, inductively-coupled plasma atomic emission spectroscopy and graphite furnace atomic absorption spectroscopy. Mercury was determined by cold vapor atomic absorption spectroscopy. Chloride was determined by titrimetry. VOCs were determined by using a purge and trap sample pretreatment followed by gas chromatography-mass spectroscopy detection. SVOCS were determined by solvent extraction followed by gas chromatography-mass spectroscopy detection. PCBs and pesticides were determined by solvent extraction followed by gas chromatography-electron capture detection. In the case of organic compound analyses, efforts were made to identify compounds that were present but not included on the method list. This was accomplished, and standard solutions of these compounds were prepared and analyzed.

The 317 and 319 Area groundwater radiological analyses were performed using SOPS written, reviewed, and issued as controlled documents by members of ESH-A nalytical Services, Radiochemistry Laboratory (ASRC). Cesium-137 was determined by gamma-ray spectrometry. Hydrogen-3 was determined by distillation followed by a beta liquid scintillation counting technique. Strontium-90 was determined by an ion-exchange separation followed by a proportional counting technique. 


\subsubsection{Results of Analyses}

Descriptions of each well, the field parameters measured during sample collection, and the results of chemical and radiological analyses of samples from the wells in the 317 and 319 A reas are contained in Tables 6.9 through 6.18. All radiological and inorganic analytical results are shown in these tables. The analytical methods used for organic compounds could identify and quantify all the compounds contained in the CLP Target Compound List. However, the vast majority of these compounds were not detected in the samples. To simplify the format of these tables, those results less than the detection limit are not included. Only those constituents that were present in amounts great enough to quantify are shown. The detection limits for the organic compounds listed were typically 1 to $5 \mu \mathrm{g} / \mathrm{L}$.

Field Results. The purging of wells to produce water representative of the groundwater being studied was followed by measuring the field parameters. For the wells reported in this study, temperature, $\mathrm{pH}$, and specific conductance remained fairly constant after two well volumes were removed. The redox potential stabilized after two well volumes were removed. On the basis of this information, sampling was conducted after the removal of three well volumes. The field parameters listed in the tables are the final readings obtained at the time of sampling. Wells 319011, 317021, 317061, 317111, and 319031 usually dry up after one well volume is removed. Therefore, field parameters were measured on one well volume. W ell 319031 was dry during the third and fourth quarters.

Inorganic Results. ANL-E chose a conservative approach for evaluating the monitoring results by selecting as the standard of comparison the Illinois Groundwater Quality Standards for Class I: Potable Resource Groundwater, 31 IA C, Section 620.410. The standards are presented in Tables 6.19 and 6.20. In 1997, all samples for metals analyses were field-filtered prior to preservation with acid (an IEPA requirement for the IEPA-approved groundwater monitoring program at the 800 A rea Landfill, Section 6.3.2.3). As noted in previous years, no elevated levels, with respect to the WQS for inorganics, were noted with the exception of $\mathrm{pH}$ at dolomite W ell 317121D and chloride at W ells 317101 and 317111. The pH changes drastically between 
TABLE 6.9

Groundwater M onitoring Results, 300 A rea W ell 317021, 1997ª

\begin{tabular}{|c|c|c|c|c|c|}
\hline \multirow[b]{2}{*}{ Parameter } & \multirow[b]{2}{*}{ Unit } & \multicolumn{4}{|c|}{ Date of Sampling } \\
\hline & & $03 / 13 / 97$ & $06 / 18 / 97$ & $09 / 09 / 97$ & $11 / 21 / 97$ \\
\hline W ater el evation & $\mathrm{m}$ & 202.96 & 202.28 & 201.47 & 199.58 \\
\hline Temperature & ${ }^{\circ} \mathrm{C}$ & 10.0 & 10.1 & 10.8 & 10.1 \\
\hline $\mathrm{pH}$ & $\mathrm{pH}$ & 7.26 & 7.3 & 7.31 & 7.21 \\
\hline Redox & $\mathrm{mV}$ & -18 & -140 & -41 & -41 \\
\hline Conductivity & $\mu \mathrm{mhos} / \mathrm{cm}$ & 538 & 812 & 775 & 639 \\
\hline Chloride - filtered & $\mathrm{mg} / \mathrm{L}$ & 24 & 26 & 23 & 36 \\
\hline A rsenic - filtered & $\mathrm{mg} / \mathrm{L}$ & $<0.002$ & $<0.002$ & $<0.002$ & $<0.002$ \\
\hline Barium - filtered & $\mathrm{mg} / \mathrm{L}$ & 0.0347 & 0.0278 & 0.0341 & 0.0365 \\
\hline Beryllium - filtered & $\mathrm{mg} / \mathrm{L}$ & $<0.0002$ & $<0.0002$ & $<0.0002$ & $<0.0002$ \\
\hline Cadmium - filtered & $\mathrm{mg} / \mathrm{L}$ & $<0.0001$ & $<0.0001$ & $<0.0001$ & $<0.0001$ \\
\hline Chromium - filtered & $\mathrm{mg} / \mathrm{L}$ & $<0.044$ & $<0.044$ & $<0.044$ & $<0.044$ \\
\hline Cobalt - filtered & $\mathrm{mg} / \mathrm{L}$ & $<0.026$ & $<0.026$ & $<0.026$ & $<0.026$ \\
\hline Copper - filtered & $\mathrm{mg} / \mathrm{L}$ & $<0.017$ & $<0.017$ & $<0.017$ & $<0.017$ \\
\hline Iron - filtered & $\mathrm{mg} / \mathrm{L}$ & $<0.037$ & $<0.037$ & $<0.037$ & $<0.037$ \\
\hline L ead - filtered & $\mathrm{mg} / \mathrm{L}$ & $<0.001$ & $<0.001$ & $<0.001$ & $<0.001$ \\
\hline M anganese - filtered & $\mathrm{mg} / \mathrm{L}$ & $<0.017$ & $<0.017$ & $<0.017$ & $<0.017$ \\
\hline M ercury - filtered & $\mathrm{mg} / \mathrm{L}$ & $<0.0001$ & $<0.0001$ & $<0.0001$ & $<0.0001$ \\
\hline Nickel - filtered & $\mathrm{mg} / \mathrm{L}$ & $<0.04$ & $<0.04$ & $<0.04$ & $<0.04$ \\
\hline Silver - filtered & $\mathrm{mg} / \mathrm{L}$ & $<0.0005$ & $<0.0005$ & $<0.0005$ & $<0.0005$ \\
\hline Thallium - filtered & $\mathrm{mg} / \mathrm{L}$ & $<0.001$ & $<0.001$ & $<0.001$ & $<0.001$ \\
\hline V anadium - filtered & $\mathrm{mg} / \mathrm{L}$ & $<0.024$ & $<0.024$ & $<0.024$ & $<0.024$ \\
\hline Zinc - filtered & $\mathrm{mg} / \mathrm{L}$ & 0.0494 & 0.0574 & 0.0492 & 0.0164 \\
\hline Cesium-137 & $\mathrm{pCi} / \mathrm{L}$ & 1.7 & $<1.0$ & $<1.0$ & $<1.0$ \\
\hline Hydrogen-3 & $\mathrm{pCi} / \mathrm{L}$ & 249 & 1,602 & 1,423 & 274 \\
\hline Strontium-90 & $\mathrm{pCi} / \mathrm{L}$ & $<0.25$ & $<0.25$ & $<0.25$ & $<0.25$ \\
\hline 1,1,1-Trichloroethane & $\mu \mathrm{g} / \mathrm{L}$ & 94 & 70 & 102 & 94 \\
\hline 1,1-Dichloroethane & $\mu \mathrm{g} / \mathrm{L}$ & 42 & 53 & 66 & 23 \\
\hline 1,1-Dichloroethene & $\mu \mathrm{g} / \mathrm{L}$ & $-b$ & 1 & 2 & - \\
\hline Carbon tetrachloride & $\mu \mathrm{g} / \mathrm{L}$ & 5 & 4 & 5 & 4 \\
\hline Chloroform & $\mu \mathrm{g} / \mathrm{L}$ & 3 & 3 & 3 & 2 \\
\hline Tetrachloroethene & $\mu \mathrm{g} / \mathrm{L}$ & 1 & 1 & 1 & 1 \\
\hline Trichloroethene & $\mu \mathrm{g} / \mathrm{L}$ & 3 & 6 & 4 & 9 \\
\hline
\end{tabular}

a Well point elevation $=197.27 \mathrm{~m}(\mathrm{MSL})$; ground surface elevation $=209.17 \mathrm{~m}(\mathrm{M} \mathrm{SL})$; casing material $=$ PVC.

b A hyphen indicates that the measured value was less than the detection limit. 


\section{GROUNDWATER PROTECTION}

TABLE 6.10

Groundwater M onitoring Results, 300 A rea W ell 317052, 1997ª

\begin{tabular}{|c|c|c|c|c|c|c|}
\hline \multirow[b]{2}{*}{ Parameter } & \multirow[b]{2}{*}{ Unit } & \multicolumn{5}{|c|}{ Date of Sampling } \\
\hline & & 03/12/97 & $06 / 17 / 97$ & 09/10/97 & $11 / 20 / 97$ & $11 / 20 / 97$ \\
\hline W ater el evation & $\mathrm{m}$ & 206.57 & 205.89 & 205.66 & 205.56 & 205.56 \\
\hline Temperature & ${ }^{\circ} \mathrm{C}$ & 6.4 & 8.6 & 12.4 & 12.3 & 12.3 \\
\hline $\mathrm{pH}$ & $\mathrm{pH}$ & 7.28 & 7.43 & 7.56 & 7.12 & 7.12 \\
\hline Redox & $\mathrm{mV}$ & -29 & -254 & -10 & -29 & -29 \\
\hline Conductivity & $\mu \mathrm{mhos} / \mathrm{cm}$ & 439 & 692 & 698 & 536 & 536 \\
\hline Chloride - filtered & $\mathrm{mg} / \mathrm{L}$ & 2 & 2 & 3 & 2 & 2 \\
\hline A rsenic - filtered & $\mathrm{mg} / \mathrm{L}$ & $<0.002$ & $<0.002$ & $<0.002$ & $<0.002$ & $<0.002$ \\
\hline Barium - filtered & $\mathrm{mg} / \mathrm{L}$ & 0.0198 & 0.0190 & 0.0250 & 0.0222 & 0.0223 \\
\hline Beryllium - filtered & $\mathrm{mg} / \mathrm{L}$ & $<0.0002$ & $<0.0002$ & $<0.0002$ & $<0.0002$ & $<0.0002$ \\
\hline Cadmium - filtered & $\mathrm{mg} / \mathrm{L}$ & $<0.0001$ & $<0.0001$ & $<0.0001$ & $<0.0001$ & $<0.0001$ \\
\hline Chromium - filtered & $\mathrm{mg} / \mathrm{L}$ & $<0.044$ & $<0.044$ & $<0.044$ & $<0.044$ & $<0.044$ \\
\hline Cobalt - filtered & $\mathrm{mg} / \mathrm{L}$ & $<0.026$ & $<0.026$ & $<0.026$ & $<0.026$ & $<0.026$ \\
\hline Copper - filtered & $\mathrm{mg} / \mathrm{L}$ & $<0.017$ & $<0.017$ & $<0.017$ & $<0.017$ & $<0.017$ \\
\hline Iron - filtered & $\mathrm{mg} / \mathrm{L}$ & $<0.037$ & $<0.037$ & $<0.037$ & $<0.037$ & $<0.037$ \\
\hline L ead - filtered & $\mathrm{mg} / \mathrm{L}$ & $<0.001$ & $<0.001$ & $<0.001$ & $<0.001$ & $<0.001$ \\
\hline M anganese - filtered & $\mathrm{mg} / \mathrm{L}$ & $<0.017$ & $<0.017$ & $<0.017$ & $<0.017$ & $<0.017$ \\
\hline M ercury - filtered & $\mathrm{mg} / \mathrm{L}$ & $<0.0001$ & $<0.0001$ & $<0.0001$ & $<0.0001$ & $<0.0001$ \\
\hline Nickel - filtered & $\mathrm{mg} / \mathrm{L}$ & $<0.04$ & $<0.04$ & $<0.04$ & $<0.04$ & $<0.04$ \\
\hline Silver - filtered & $\mathrm{mg} / \mathrm{L}$ & $<0.0005$ & $<0.0005$ & $<0.0005$ & $<0.0005$ & $<0.0005$ \\
\hline Thallium - filtered & $\mathrm{mg} / \mathrm{L}$ & $<0.001$ & $<0.001$ & $<0.001$ & $<0.001$ & $<0.001$ \\
\hline V anadium - filtered & $\mathrm{mg} / \mathrm{L}$ & $<0.024$ & $<0.024$ & $<0.024$ & $<0.024$ & $<0.024$ \\
\hline Zinc - filtered & $\mathrm{mg} / \mathrm{L}$ & 0.0551 & 0.0151 & 0.0128 & $<0.011$ & $<0.011$ \\
\hline Cesium-137 & $\mathrm{pCi} / \mathrm{L}$ & $<1.0$ & $<1.0$ & $<1.0$ & $<1.0$ & 1.2 \\
\hline Hydrogen-3 & $\mathrm{pCi} / \mathrm{L}$ & $<100$ & $<100$ & $<100$ & $<100$ & $<100$ \\
\hline Strontium-90 & $\mathrm{pCi} / \mathrm{L}$ & $<0.25$ & $<0.25$ & $<0.25$ & $<0.25$ & $<0.25$ \\
\hline 2-M ethylbutane & $\mu \mathrm{g} / \mathrm{L}$ & $-\mathrm{b}$ & - & - & 3 & 3 \\
\hline
\end{tabular}

a Well point elevation $=204.04 \mathrm{~m}(\mathrm{M} \mathrm{SL})$; ground surface elevation $=208.32 \mathrm{~m}(\mathrm{M} \mathrm{SL})$; casing material $=$ PVC.

b A hyphen indicates that the measured value was less than the detection limit. 
TABLE 6.11

Groundwater M onitoring Results, 300 A rea W ell 317061, 1997ª

\begin{tabular}{|c|c|c|c|c|c|c|}
\hline \multirow[b]{2}{*}{ Parameter } & \multirow[b]{2}{*}{ Unit } & \multicolumn{5}{|c|}{ Date of Sampling } \\
\hline & & $03 / 12 / 97$ & $06 / 17 / 97$ & $06 / 17 / 97$ & 09/10/97 & $11 / 20 / 97$ \\
\hline W ater elevation & $\mathrm{m}$ & 201.23 & 200.72 & 200.72 & 199.74 & 199.43 \\
\hline Temperature & ${ }^{\circ} \mathrm{C}$ & 10.2 & 10.6 & 10.6 & 10.4 & 10.0 \\
\hline $\mathrm{pH}$ & $\mathrm{pH}$ & 7.30 & 7.20 & 7.20 & 7.02 & 7.74 \\
\hline Redox & $\mathrm{mV}$ & -18 & -63 & -63 & -42 & -11 \\
\hline Conductivity & $\mu \mathrm{mhos} / \mathrm{cm}$ & 761 & 1,115 & 1,115 & 1,102 & 992 \\
\hline Chloride - filtered & $\mathrm{mg} / \mathrm{L}$ & 57 & 69 & 65 & 75 & 48 \\
\hline A rsenic - filtered & $\mathrm{mg} / \mathrm{L}$ & $<0.002$ & $<0.002$ & $<0.002$ & $<0.002$ & $<0.002$ \\
\hline Barium - filtered & $\mathrm{mg} / \mathrm{L}$ & 0.0533 & 0.0511 & 0.0588 & 0.0561 & 0.0564 \\
\hline Beryllium - filtered & $\mathrm{mg} / \mathrm{L}$ & $<0.0002$ & $<0.0002$ & $<0.0002$ & $<0.0002$ & $<0.0002$ \\
\hline Cadmium - filtered & $\mathrm{mg} / \mathrm{L}$ & $<0.0001$ & $<0.0001$ & $<0.0001$ & $<0.0001$ & $<0.0001$ \\
\hline Chromium - filtered & $\mathrm{mg} / \mathrm{L}$ & $<0.044$ & $<0.044$ & $<0.044$ & $<0.044$ & $<0.044$ \\
\hline Cobalt - filtered & $\mathrm{mg} / \mathrm{L}$ & $<0.026$ & $<0.026$ & $<0.026$ & $<0.026$ & $<0.026$ \\
\hline Copper - filtered & $\mathrm{mg} / \mathrm{L}$ & $<0.017$ & $<0.017$ & $<0.017$ & $<0.017$ & $<0.017$ \\
\hline Iron - filtered & $\mathrm{mg} / \mathrm{L}$ & $<0.037$ & $<0.037$ & $<0.037$ & $<0.037$ & $<0.037$ \\
\hline L ead - filtered & $\mathrm{mg} / \mathrm{L}$ & $<0.001$ & $<0.001$ & $<0.001$ & $<0.001$ & $<0.001$ \\
\hline M anganese - filtered & $\mathrm{mg} / \mathrm{L}$ & $<0.017$ & $<0.017$ & $<0.017$ & 0.0216 & $<0.017$ \\
\hline M ercury - filtered & $\mathrm{mg} / \mathrm{L}$ & $<0.0001$ & $<0.0001$ & $<0.0001$ & $<0.0001$ & $<0.0001$ \\
\hline Nickel - filtered & $\mathrm{mg} / \mathrm{L}$ & $<0.04$ & $<0.04$ & $<0.04$ & $<0.04$ & $<0.04$ \\
\hline Silver - filtered & $\mathrm{mg} / \mathrm{L}$ & $<0.0005$ & $<0.0005$ & $<0.0005$ & $<0.0005$ & $<0.0005$ \\
\hline Thallium - filtered & $\mathrm{mg} / \mathrm{L}$ & $<0.001$ & $<0.001$ & $<0.001$ & $<0.001$ & $<0.001$ \\
\hline V anadium - filtered & $\mathrm{mg} / \mathrm{L}$ & $<0.024$ & $<0.024$ & $<0.024$ & $<0.024$ & $<0.024$ \\
\hline Zinc - filtered & $\mathrm{mg} / \mathrm{L}$ & 0.0118 & $<0.011$ & 0.0164 & 0.0567 & $<0.011$ \\
\hline Cesium-137 & $\mathrm{pCi} / \mathrm{L}$ & $<1.0$ & $<1.0$ & $<1.0$ & $<1.0$ & $<1.0$ \\
\hline Hydrogen-3 & $\mathrm{pCi} / \mathrm{L}$ & $<100$ & $<100$ & $<100$ & $<100$ & $<100$ \\
\hline Strontium-90 & $\mathrm{pCi} / \mathrm{L}$ & $<0.25$ & $<0.25$ & $<0.25$ & $<0.25$ & $<0.25$ \\
\hline 2-M ethylbutane & $\mu \mathrm{g} / \mathrm{L}$ & $-b$ & - & - & - & 5 \\
\hline Butane & $\mu \mathrm{g} / \mathrm{L}$ & - & - & - & - & 1 \\
\hline Propane & $\mu \mathrm{g} / \mathrm{L}$ & - & - & - & - & 1 \\
\hline
\end{tabular}

a $\quad$ Well point elevation $=195.35 \mathrm{~m}(\mathrm{M} \mathrm{SL})$; ground surface elevation $=207.54 \mathrm{~m}(\mathrm{M} \mathrm{SL})$; casing material $=\mathrm{PVC}$.

b A hyphen indicates that the measured value was less than the detection limit. 


\section{GROUNDWATER PROTECTION}

TABLE 6.12

Groundwater M onitoring Results, 300 A rea Well 317101, 1997ª

\begin{tabular}{|c|c|c|c|c|c|}
\hline \multirow[b]{2}{*}{ Parameter } & \multirow[b]{2}{*}{ Unit } & \multicolumn{4}{|c|}{ Date of Sampling } \\
\hline & & 03/12/97 & $06 / 17 / 97$ & 09/09/97 & $11 / 19 / 97$ \\
\hline W ater elevation & $\mathrm{m}$ & 204.59 & 204.40 & 203.60 & 203.16 \\
\hline Temperature & ${ }^{\circ} \mathrm{C}$ & 11.5 & 11.0 & 11.4 & 11.2 \\
\hline $\mathrm{pH}$ & $\mathrm{pH}$ & 6.93 & 7.04 & 6.99 & 6.88 \\
\hline Redox & $\mathrm{mV}$ & 3 & -6 & -32 & -21 \\
\hline Conductivity & $\mu \mathrm{mhos} / \mathrm{cm}$ & 1,953 & 2,350 & 1,868 & 1,067 \\
\hline Chloride - filtered & $\mathrm{mg} / \mathrm{L}$ & 594 & 394 & 325 & 175 \\
\hline A rsenic - filtered & $\mathrm{mg} / \mathrm{L}$ & $<0.002$ & $<0.002$ & $<0.002$ & $<0.002$ \\
\hline Barium - filtered & $\mathrm{mg} / \mathrm{L}$ & 0.0789 & 0.0647 & 0.0548 & 0.0408 \\
\hline Beryllium - filtered & $\mathrm{mg} / \mathrm{L}$ & $<0.0002$ & $<0.0002$ & $<0.0002$ & $<0.0002$ \\
\hline Cadmium - filtered & $\mathrm{mg} / \mathrm{L}$ & $<0.0001$ & $<0.0001$ & $<0.0001$ & $<0.0001$ \\
\hline Chromium - filtered & $\mathrm{mg} / \mathrm{L}$ & $<0.044$ & $<0.044$ & $<0.044$ & $<0.044$ \\
\hline Cobalt - filtered & $\mathrm{mg} / \mathrm{L}$ & $<0.026$ & $<0.026$ & $<0.026$ & $<0.026$ \\
\hline Copper - filtered & $\mathrm{mg} / \mathrm{L}$ & $<0.017$ & $<0.017$ & $<0.017$ & $<0.017$ \\
\hline Iron - filtered & $\mathrm{mg} / \mathrm{L}$ & $<0.037$ & $<0.037$ & $<0.037$ & 0.0746 \\
\hline Lead - filtered & $\mathrm{mg} / \mathrm{L}$ & $<0.001$ & $<0.001$ & $<0.001$ & $<0.001$ \\
\hline M anganese - filtered & $\mathrm{mg} / \mathrm{L}$ & $<0.017$ & 0.0220 & 0.0302 & 0.0427 \\
\hline M ercury - filtered & $\mathrm{mg} / \mathrm{L}$ & $<0.0001$ & $<0.0001$ & $<0.0001$ & $<0.0001$ \\
\hline Nickel - filtered & $\mathrm{mg} / \mathrm{L}$ & $<0.04$ & $<0.04$ & $<0.04$ & $<0.04$ \\
\hline Silver - filtered & $\mathrm{mg} / \mathrm{L}$ & $<0.0005$ & $<0.0005$ & $<0.0005$ & $<0.0005$ \\
\hline Thallium - filtered & $\mathrm{mg} / \mathrm{L}$ & $<0.001$ & $<0.001$ & $<0.001$ & $<0.001$ \\
\hline V anadium - filtered & $\mathrm{mg} / \mathrm{L}$ & $<0.024$ & $<0.024$ & $<0.024$ & $<0.024$ \\
\hline Zinc - filtered & $\mathrm{mg} / \mathrm{L}$ & 0.0736 & $<0.011$ & 0.0155 & 0.0296 \\
\hline Cesium-137 & $\mathrm{pCi} / \mathrm{L}$ & $<1.0$ & $<1.0$ & 1.4 & $<1.0$ \\
\hline Hydrogen-3 & $\mathrm{pCi} / \mathrm{L}$ & $<100$ & $<100$ & $<100$ & $<100$ \\
\hline Strontium-90 & $\mathrm{pCi} / \mathrm{L}$ & $<0.25$ & $<0.25$ & $<0.25$ & $<0.25$ \\
\hline 2-M ethylbutane & $\mu \mathrm{g} / \mathrm{L}$ & -b & - & - & 4 \\
\hline
\end{tabular}

a Well point elevation $=198.66 \mathrm{~m}(\mathrm{M} \mathrm{SL})$; ground surface elevation $=211.04 \mathrm{~m}(\mathrm{MSL})$; casing material $=$ PVC.

b A hyphen indicates that the measured value is less than the detection limit. 
TABLE 6.13

Groundwater M onitoring Results, 300 A rea W ell 317111, 1997ª

\begin{tabular}{|c|c|c|c|c|c|}
\hline \multirow[b]{2}{*}{ Parameter } & \multirow[b]{2}{*}{ U nit } & \multicolumn{4}{|c|}{ Date of Sampling } \\
\hline & & $03 / 12 / 97$ & $06 / 17 / 97$ & $09 / 09 / 97$ & $11 / 19 / 97$ \\
\hline Water elevation & $\mathrm{m}$ & 202.52 & 202.44 & 201.27 & 200.64 \\
\hline Temperature & ${ }^{\circ} \mathrm{C}$ & 10.7 & 10.6 & 11.1 & 10.5 \\
\hline $\mathrm{pH}$ & $\mathrm{pH}$ & 7.00 & 7.13 & 7.05 & 6.91 \\
\hline Redox & $\mathrm{mV}$ & 60 & -8 & -47 & -14 \\
\hline Conductivity & $\mu \mathrm{mhos} / \mathrm{cm}$ & 982 & 1,419 & 1,421 & 1,383 \\
\hline Chloride - filtered & $\mathrm{mg} / \mathrm{L}$ & 225 & 225 & 269 & 250 \\
\hline A rsenic - filtered & $\mathrm{mg} / \mathrm{L}$ & $<0.002$ & $<0.002$ & $<0.002$ & $<0.002$ \\
\hline Barium - filtered & $\mathrm{mg} / \mathrm{L}$ & 0.0695 & 0.0744 & 0.0848 & 0.0945 \\
\hline Beryllium - filtered & $\mathrm{mg} / \mathrm{L}$ & $<0.0002$ & $<0.0002$ & $<0.0020$ & $<0.0002$ \\
\hline Cadmium - filtered & $\mathrm{mg} / \mathrm{L}$ & $<0.0001$ & $<0.0001$ & $<0.0001$ & $<0.0001$ \\
\hline Chromium - filtered & $\mathrm{mg} / \mathrm{L}$ & $<0.044$ & $<0.044$ & $<0.044$ & $<0.044$ \\
\hline Cobalt - filtered & $\mathrm{mg} / \mathrm{L}$ & $<0.026$ & $<0.026$ & $<0.026$ & $<0.026$ \\
\hline Copper - filtered & $\mathrm{mg} / \mathrm{L}$ & $<0.017$ & $<0.017$ & $<0.017$ & $<0.017$ \\
\hline Iron - filtered & $\mathrm{mg} / \mathrm{L}$ & 0.1055 & 0.0927 & $<0.037$ & $<0.037$ \\
\hline L ead - filtered & $\mathrm{mg} / \mathrm{L}$ & $<0.001$ & $<0.001$ & $<0.001$ & $<0.001$ \\
\hline M anganese - filtered & $\mathrm{mg} / \mathrm{L}$ & 0.0341 & 0.0328 & 0.0140 & 0.1737 \\
\hline M ercury - filtered & $\mathrm{mg} / \mathrm{L}$ & $<0.0001$ & $<0.0001$ & $<0.0001$ & $<0.0001$ \\
\hline Nickel - filtered & $\mathrm{mg} / \mathrm{L}$ & $<0.04$ & $<0.04$ & $<0.04$ & $<0.04$ \\
\hline Silver - filtered & $\mathrm{mg} / \mathrm{L}$ & $<0.0005$ & $<0.0005$ & $<0.0005$ & $<0.0005$ \\
\hline Thallium - filtered & $\mathrm{mg} / \mathrm{L}$ & $<0.001$ & $<0.001$ & $<0.001$ & $<0.001$ \\
\hline V anadium - filtered & $\mathrm{mg} / \mathrm{L}$ & $<0.024$ & $<0.024$ & $<0.024$ & $<0.024$ \\
\hline Zinc - filtered & $\mathrm{mg} / \mathrm{L}$ & 0.0165 & 0.0311 & 0.0237 & 0.0169 \\
\hline Cesium-137 & $\mathrm{pCi} / \mathrm{L}$ & $<1.0$ & $<1.0$ & $<1.0$ & 1.2 \\
\hline Hydrogen-3 & $\mathrm{pCi} / \mathrm{L}$ & $<100$ & $<100$ & $<100$ & $<100$ \\
\hline Strontium-90 & $\mathrm{pCi} / \mathrm{L}$ & $<0.25$ & $<0.25$ & $<0.25$ & $<0.25$ \\
\hline 2-M ethylbutane & $\mu \mathrm{g} / \mathrm{L}$ & $-b$ & - & 7 & 2 \\
\hline A cetone & $\mu \mathrm{g} / \mathrm{L}$ & - & - & 2 & - \\
\hline
\end{tabular}

a Well point elevation $=198.37 \mathrm{~m}(\mathrm{MSL})$; ground surface elevation $=210.25 \mathrm{~m}(\mathrm{MSL})$; casing material $=$ PVC.

b A hyphen indicates that the measured value was less than the detection limit. 


\section{GROUNDWATER PROTECTION}

TABLE 6.14

Groundwater M onitoring Results, 300 A rea W ell 317121D, $1997^{\mathrm{a}}$

\begin{tabular}{|c|c|c|c|c|c|}
\hline \multirow[b]{2}{*}{ Parameter } & \multirow[b]{2}{*}{ Unit } & \multicolumn{4}{|c|}{ Date of Sampling } \\
\hline & & $03 / 14 / 97$ & $06 / 18 / 97$ & 09/10/97 & $11 / 21 / 97$ \\
\hline W ater elevation & $\mathrm{m}$ & 186.87 & 186.84 & 186.81 & 186.74 \\
\hline Temperature & ${ }^{\circ} \mathrm{C}$ & 10.8 & 11.3 & 11.4 & 10.9 \\
\hline $\mathrm{pH}$ & $\mathrm{pH}$ & 11.53 & 11.33 & 10.66 & 11.63 \\
\hline Redox & $\mathrm{mV}$ & -256 & -335 & -243 & -307 \\
\hline Conductivity & $\mu \mathrm{mhos} / \mathrm{cm}$ & 722 & 574 & 546 & 1,017 \\
\hline Chloride - filtered & $\mathrm{mg} / \mathrm{L}$ & 41 & 44 & 49 & 36 \\
\hline A rsenic - filtered & $\mathrm{mg} / \mathrm{L}$ & $<0.002$ & $<0.002$ & $<0.002$ & $<0.002$ \\
\hline Barium - filtered & $\mathrm{mg} / \mathrm{L}$ & $<0.018$ & 0.0931 & 0.0701 & 0.0226 \\
\hline Beryllium - filtered & $\mathrm{mg} / \mathrm{L}$ & $<0.0002$ & $<0.0002$ & $<0.0002$ & $<0.0002$ \\
\hline Cadmium - filtered & $\mathrm{mg} / \mathrm{L}$ & $<0.0001$ & $<0.0001$ & $<0.0001$ & $<0.0001$ \\
\hline Chromium - filtered & $\mathrm{mg} / \mathrm{L}$ & $<0.044$ & $<0.044$ & $<0.044$ & $<0.044$ \\
\hline Cobalt - filtered & $\mathrm{mg} / \mathrm{L}$ & $<0.026$ & $<0.026$ & $<0.026$ & $<0.026$ \\
\hline Copper - filtered & $\mathrm{mg} / \mathrm{L}$ & $<0.017$ & $<0.017$ & $<0.017$ & $<0.017$ \\
\hline Iron - filtered & $\mathrm{mg} / \mathrm{L}$ & $<0.037$ & $<0.037$ & $<0.037$ & $<0.037$ \\
\hline Lead - filtered & $\mathrm{mg} / \mathrm{L}$ & $<0.001$ & $<0.001$ & $<0.001$ & $<0.001$ \\
\hline M anganese - filtered & $\mathrm{mg} / \mathrm{L}$ & $<0.017$ & $<0.017$ & $<0.017$ & $<0.017$ \\
\hline M ercury - filtered & $\mathrm{mg} / \mathrm{L}$ & $<0.0001$ & $<0.0001$ & $<0.0001$ & $<0.0001$ \\
\hline Nickel - filtered & $\mathrm{mg} / \mathrm{L}$ & $<0.04$ & $<0.04$ & $<0.04$ & $<0.04$ \\
\hline Silver - filtered & $\mathrm{mg} / \mathrm{L}$ & $<0.0005$ & $<0.0005$ & $<0.0005$ & $<0.0005$ \\
\hline Thallium - filtered & $\mathrm{mg} / \mathrm{L}$ & $<0.001$ & $<0.001$ & $<0.001$ & $<0.001$ \\
\hline V anadium - filtered & $\mathrm{mg} / \mathrm{L}$ & $<0.024$ & $<0.024$ & $<0.024$ & $<0.024$ \\
\hline Zinc - filtered & $\mathrm{mg} / \mathrm{L}$ & $<0.011$ & $<0.011$ & $<0.011$ & $<0.011$ \\
\hline Cesium-137 & $\mathrm{pCi} / \mathrm{L}$ & $<1.0$ & $<1.0$ & $<1.0$ & $<1.0$ \\
\hline Hydrogen-3 & $\mathrm{pCi} / \mathrm{L}$ & $<100$ & $<100$ & 103 & 134 \\
\hline Strontium-90 & $\mathrm{pCi} / \mathrm{L}$ & $<0.25$ & $<0.25$ & $<0.25$ & $<0.25$ \\
\hline
\end{tabular}

a Well point elevation $=183.49 \mathrm{~m}(\mathrm{MSL})$; ground surface elevation $=207.57 \mathrm{~m}(\mathrm{MSL})$; casing material $=$ steel. 
TABLE 6.15

Groundwater M onitoring Results, 300 A rea Well 319011, 1997ª

\begin{tabular}{|c|c|c|c|c|c|}
\hline \multirow[b]{2}{*}{ Parameter } & \multirow[b]{2}{*}{ Unit } & \multicolumn{4}{|c|}{ Date of Sampling } \\
\hline & & $03 / 12 / 97$ & $06 / 17 / 97$ & 09/09/97 & $11 / 20 / 97$ \\
\hline W ater elevation & $\mathrm{m}$ & 201.90 & 201.93 & 200.46 & 200.29 \\
\hline Temperature & ${ }^{\circ} \mathrm{C}$ & 10.4 & 10.2 & 10.3 & 10.1 \\
\hline $\mathrm{pH}$ & $\mathrm{pH}$ & 6.92 & 7.08 & 6.94 & 6.89 \\
\hline Redox & $\mathrm{mV}$ & 14 & -22 & -36 & -37 \\
\hline Conductivity & $\mu \mathrm{mhos} / \mathrm{cm}$ & 877 & 1,241 & 1,173 & 832 \\
\hline Chloride - filtered & $\mathrm{mg} / \mathrm{L}$ & 57 & 57 & 51 & 46 \\
\hline A rsenic - filtered & $\mathrm{mg} / \mathrm{L}$ & $<0.002$ & $<0.002$ & $<0.002$ & $<0.002$ \\
\hline Barium - filtered & $\mathrm{mg} / \mathrm{L}$ & 0.0397 & 0.0355 & 0.0405 & 0.0361 \\
\hline Beryllium - filtered & $\mathrm{mg} / \mathrm{L}$ & $<0.0002$ & $<0.0002$ & $<0.0002$ & $<0.0002$ \\
\hline Cadmium - filtered & $\mathrm{mg} / \mathrm{L}$ & $<0.0001$ & $<0.0001$ & $<0.0001$ & $<0.0001$ \\
\hline Chromium - filtered & $\mathrm{mg} / \mathrm{L}$ & $<0.044$ & $<0.044$ & $<0.044$ & $<0.044$ \\
\hline Cobalt - filtered & $\mathrm{mg} / \mathrm{L}$ & $<0.026$ & $<0.026$ & $<0.026$ & $<0.026$ \\
\hline Copper - filtered & $\mathrm{mg} / \mathrm{L}$ & $<0.017$ & $<0.017$ & $<0.017$ & $<0.017$ \\
\hline Iron - filtered & $\mathrm{mg} / \mathrm{L}$ & $<0.037$ & $<0.037$ & $<0.037$ & $<0.037$ \\
\hline L ead - filtered & $\mathrm{mg} / \mathrm{L}$ & $<0.001$ & $<0.001$ & $<0.001$ & $<0.001$ \\
\hline$M$ anganese - filtered & $\mathrm{mg} / \mathrm{L}$ & 0.0278 & 0.0323 & 0.0175 & $<0.017$ \\
\hline M ercury - filtered & $\mathrm{mg} / \mathrm{L}$ & $<0.0001$ & $<0.0001$ & $<0.0001$ & $<0.0001$ \\
\hline Nickel - filtered & $\mathrm{mg} / \mathrm{L}$ & $<0.04$ & $<0.04$ & $<0.04$ & $<0.04$ \\
\hline Silver - filtered & $\mathrm{mg} / \mathrm{L}$ & $<0.0005$ & $<0.0005$ & $<0.0005$ & $<0.0005$ \\
\hline Thallium - filtered & $\mathrm{mg} / \mathrm{L}$ & $<0.001$ & $<0.001$ & $<0.001$ & $<0.001$ \\
\hline V anadium - filtered & $\mathrm{mg} / \mathrm{L}$ & $<0.024$ & $<0.024$ & $<0.024$ & $<0.024$ \\
\hline Zinc - filtered & $\mathrm{mg} / \mathrm{L}$ & 0.0250 & 0.0339 & 0.0196 & 0.0209 \\
\hline Cesium-137 & $\mathrm{pCi} / \mathrm{L}$ & $<1.0$ & $<1.0$ & $<1.0$ & $<1.0$ \\
\hline Hydrogen-3 & $\mathrm{pCi} / \mathrm{L}$ & $<100$ & $<100$ & $<100$ & $<100$ \\
\hline Strontium-90 & $\mathrm{pCi} / \mathrm{L}$ & $<0.25$ & $<0.25$ & $<0.25$ & $<0.25$ \\
\hline
\end{tabular}

a $\quad$ ell point elevation $=197.60 \mathrm{~m}(\mathrm{MSL})$; ground surface elevation $=209.81 \mathrm{~m}(\mathrm{M} \mathrm{SL})$; casing material $=$ PV C. 


\section{GROUNDWATER PROTECTION}

TABLE 6.16

Groundwater M onitoring Results, 300 A rea Well 319031, 1997ª

\begin{tabular}{|c|c|c|c|c|}
\hline \multirow[b]{2}{*}{ Parameter } & \multirow[b]{2}{*}{ Unit } & \multicolumn{3}{|c|}{ Date of Sampling } \\
\hline & & 03/13/97 & $03 / 13 / 97$ & $06 / 17 / 97$ \\
\hline W ater elevation & $\mathrm{m}$ & 193.62 & 193.62 & 193.58 \\
\hline T emperature & ${ }^{\circ} \mathrm{C}$ & 10.1 & 10.1 & 10.1 \\
\hline $\mathrm{pH}$ & $\mathrm{pH}$ & 7.14 & 7.14 & 7.21 \\
\hline Redox & $\mathrm{mV}$ & -16 & -16 & 44 \\
\hline Conductivity & $\mu \mathrm{mhos} / \mathrm{cm}$ & 715 & 715 & 1,022 \\
\hline Chloride - filtered & $\mathrm{mg} / \mathrm{L}$ & 28 & 31 & 27 \\
\hline A rsenic - filtered & $\mathrm{mg} / \mathrm{L}$ & $<0.002$ & $<0.002$ & $<0.002$ \\
\hline Barium - filtered & $\mathrm{mg} / \mathrm{L}$ & 0.0541 & 0.0542 & 0.0473 \\
\hline Beryllium - filtered & $\mathrm{mg} / \mathrm{L}$ & $<0.0002$ & $<0.0002$ & $<0.0002$ \\
\hline Cadmium - filtered & $\mathrm{mg} / \mathrm{L}$ & $<0.0001$ & $<0.0001$ & $<0.0001$ \\
\hline Chromium - filtered & $\mathrm{mg} / \mathrm{L}$ & $<0.044$ & $<0.044$ & $<0.044$ \\
\hline Cobalt - filtered & $\mathrm{mg} / \mathrm{L}$ & $<0.026$ & $<0.026$ & $<0.026$ \\
\hline Copper - filtered & $\mathrm{mg} / \mathrm{L}$ & $<0.017$ & $<0.017$ & $<0.017$ \\
\hline Iron - filtered & $\mathrm{mg} / \mathrm{L}$ & $<0.037$ & $<0.037$ & $<0.037$ \\
\hline L ead - filtered & $\mathrm{mg} / \mathrm{L}$ & $<0.001$ & $<0.001$ & $<0.001$ \\
\hline$M$ anganese - filtered & $\mathrm{mg} / \mathrm{L}$ & $<0.017$ & $<0.017$ & $<0.017$ \\
\hline M ercury - filtered & $\mathrm{mg} / \mathrm{L}$ & $<0.0001$ & $<0.0001$ & $<0.0001$ \\
\hline Nickel - filtered & $\mathrm{mg} / \mathrm{L}$ & $<0.04$ & $<0.04$ & $<0.04$ \\
\hline Silver - filtered & $\mathrm{mg} / \mathrm{L}$ & $<0.0005$ & $<0.0005$ & $<0.0005$ \\
\hline Thallium - filtered & $\mathrm{mg} / \mathrm{L}$ & $<0.001$ & $<0.001$ & $<0.001$ \\
\hline V anadium - filtered & $\mathrm{mg} / \mathrm{L}$ & $<0.024$ & $<0.024$ & $<0.024$ \\
\hline Zinc - filtered & $\mathrm{mg} / \mathrm{L}$ & 0.0573 & 0.0629 & 0.0303 \\
\hline Cesium-137 & $\mathrm{pCi} / \mathrm{L}$ & $<1.0$ & 2.0 & $<1.0$ \\
\hline Hydrogen-3 & $\mathrm{pCi} / \mathrm{L}$ & 883 & 950 & 848 \\
\hline Strontium-90 & $\mathrm{pCi} / \mathrm{L}$ & 0.28 & 0.29 & 0.27 \\
\hline 1,1,1-Trichloroethane & $\mu \mathrm{g} / \mathrm{L}$ & 4 & 4 & 2 \\
\hline Trichloroethene & $\mu \mathrm{g} / \mathrm{L}$ & 5 & 5 & 5 \\
\hline
\end{tabular}

a Well point elevation $=191.78 \mathrm{~m}(\mathrm{MSL})$; ground surface elevation $=204.28 \mathrm{~m}(\mathrm{MSL})$; casing material = PV C. 
TABLE 6.17

Groundwater M onitoring Results, 300 A rea W ell 319032, 1997ª

\begin{tabular}{|c|c|c|c|c|c|}
\hline \multirow[b]{2}{*}{ Parameter } & \multirow[b]{2}{*}{ Unit } & \multicolumn{4}{|c|}{ Date of Sampling } \\
\hline & & 03/12/97 & 06/17/97 & 09/09/97 & $11 / 20 / 97$ \\
\hline Water elevation & $\mathrm{m}$ & 199.21 & 198.77 & 198.51 & 198.02 \\
\hline Temperature & ${ }^{\circ} \mathrm{C}$ & 9.7 & 9.2 & 10.4 & 10.5 \\
\hline $\mathrm{pH}$ & $\mathrm{pH}$ & 7.23 & 7.20 & 7.02 & 6.96 \\
\hline Redox & $\mathrm{mV}$ & 14 & -118 & -32 & -10 \\
\hline Conductivity & $\mu \mathrm{mhos} / \mathrm{cm}$ & 755 & 1,048 & 1,028 & 739 \\
\hline Chloride - filtered & $\mathrm{mg} / \mathrm{L}$ & 18 & 19 & 21 & 20 \\
\hline A rsenic - filtered & $\mathrm{mg} / \mathrm{L}$ & $<0.002$ & $<0.002$ & $<0.002$ & $<0.002$ \\
\hline Barium - filtered & $\mathrm{mg} / \mathrm{L}$ & 0.0625 & 0.0617 & 0.0666 & 0.0660 \\
\hline Beryllium - filtered & $\mathrm{mg} / \mathrm{L}$ & $<0.0002$ & $<0.0002$ & $<0.0002$ & $<0.0002$ \\
\hline Cadmium - filtered & $\mathrm{mg} / \mathrm{L}$ & $<0.0001$ & $<0.0001$ & $<0.0001$ & $<0.0001$ \\
\hline Chromium - filtered & $\mathrm{mg} / \mathrm{L}$ & $<0.044$ & $<0.044$ & $<0.044$ & $<0.044$ \\
\hline Cobalt - filtered & $\mathrm{mg} / \mathrm{L}$ & $<0.026$ & $<0.026$ & $<0.026$ & $<0.026$ \\
\hline Copper - filtered & $\mathrm{mg} / \mathrm{L}$ & $<0.017$ & $<0.017$ & $<0.017$ & $<0.017$ \\
\hline Iron - filtered & $\mathrm{mg} / \mathrm{L}$ & $<0.037$ & $<0.037$ & $<0.037$ & $<0.037$ \\
\hline Lead - filtered & $\mathrm{mg} / \mathrm{L}$ & $<0.001$ & $<0.001$ & $<0.001$ & $<0.001$ \\
\hline$M$ anganese - filtered & $\mathrm{mg} / \mathrm{L}$ & $<0.017$ & $<0.017$ & $<0.017$ & $<0.017$ \\
\hline M ercury - filtered & $\mathrm{mg} / \mathrm{L}$ & $<0.0001$ & $<0.0001$ & $<0.0001$ & $<0.0001$ \\
\hline Nickel - filtered & $\mathrm{mg} / \mathrm{L}$ & $<0.04$ & $<0.04$ & $<0.04$ & $<0.04$ \\
\hline Silver - filtered & $\mathrm{mg} / \mathrm{L}$ & $<0.0005$ & $<0.0005$ & $<0.0005$ & $<0.0005$ \\
\hline Thallium - filtered & $\mathrm{mg} / \mathrm{L}$ & $<0.001$ & $<0.001$ & $<0.001$ & $<0.001$ \\
\hline V anadium - filtered & $\mathrm{mg} / \mathrm{L}$ & $<0.024$ & $<0.024$ & $<0.024$ & $<0.024$ \\
\hline Zinc - filtered & $\mathrm{mg} / \mathrm{L}$ & 0.0279 & 0.0307 & 0.0412 & 0.0322 \\
\hline Cesium-137 & $\mathrm{pCi} / \mathrm{L}$ & $<1.0$ & $<1.0$ & $<1.0$ & $<1.0$ \\
\hline Hydrogen-3 & $\mathrm{pCi} / \mathrm{L}$ & 528 & 556 & 548 & 558 \\
\hline Strontium-90 & $\mathrm{pCi} / \mathrm{L}$ & $<0.25$ & $<0.25$ & $<0.25$ & $<0.25$ \\
\hline
\end{tabular}

a Well point elevation $=196.66 \mathrm{~m}(\mathrm{MSL})$; ground surface elevation $=204.28 \mathrm{~m}(\mathrm{M} \mathrm{SL})$; casing material $=$ PVC. 
TABLE 6.18

Groundwater M onitoring Results, 300 A rea W ell 319131D, 1997ª

\begin{tabular}{|c|c|c|c|c|c|}
\hline \multirow[b]{2}{*}{ Parameter } & \multirow[b]{2}{*}{ Unit } & \multicolumn{4}{|c|}{ Date of Sampling } \\
\hline & & $03 / 13 / 97$ & $06 / 18 / 97$ & 09/09/97 & $11 / 20 / 97$ \\
\hline W ater elevation & $\mathrm{m}$ & 185.56 & 185.17 & 184.94 & 184.92 \\
\hline T emperature & ${ }^{\circ} \mathrm{C}$ & 10.9 & 11.6 & 11.5 & 10.8 \\
\hline $\mathrm{pH}$ & $\mathrm{pH}$ & 7.08 & 7.49 & 7.04 & 6.94 \\
\hline Redox & $\mathrm{mV}$ & -10 & -44 & -41 & -28 \\
\hline Conductivity & $\mu \mathrm{mhos} / \mathrm{cm}$ & 817 & 812 & 1,096 & 1,007 \\
\hline Chloride - filtered & $\mathrm{mg} / \mathrm{L}$ & 53 & 50 & 53 & 48 \\
\hline A rsenic - filtered & $\mathrm{mg} / \mathrm{L}$ & $<0.002$ & $<0.002$ & $<0.002$ & $<0.002$ \\
\hline Barium - filtered & $\mathrm{mg} / \mathrm{L}$ & 0.0728 & 0.0675 & 0.0684 & 0.0668 \\
\hline Beryllium - filtered & $\mathrm{mg} / \mathrm{L}$ & $<0.0002$ & $<0.0002$ & $<0.0002$ & $<0.0002$ \\
\hline Cadmium - filtered & $\mathrm{mg} / \mathrm{L}$ & $<0.0001$ & $<0.0001$ & $<0.0001$ & $<0.0001$ \\
\hline Chromium - filtered & $\mathrm{mg} / \mathrm{L}$ & $<0.044$ & $<0.044$ & $<0.044$ & $<0.044$ \\
\hline Cobalt - filtered & $\mathrm{mg} / \mathrm{L}$ & $<0.026$ & $<0.026$ & $<0.026$ & $<0.026$ \\
\hline Copper - filtered & $\mathrm{mg} / \mathrm{L}$ & $<0.017$ & $<0.017$ & $<0.017$ & $<0.017$ \\
\hline Iron - filtered & $\mathrm{mg} / \mathrm{L}$ & $<0.037$ & $<0.037$ & $<0.037$ & $<0.037$ \\
\hline L ead - filtered & $\mathrm{mg} / \mathrm{L}$ & $<0.001$ & $<0.001$ & $<0.001$ & $<0.001$ \\
\hline M anganese - filtered & $\mathrm{mg} / \mathrm{L}$ & $<0.017$ & $<0.017$ & $<0.017$ & $<0.017$ \\
\hline M ercury - filtered & $\mathrm{mg} / \mathrm{L}$ & $<0.0001$ & $<0.0001$ & $<0.0001$ & $<0.0001$ \\
\hline Nickel - filtered & $\mathrm{mg} / \mathrm{L}$ & $<0.04$ & $<0.04$ & $<0.04$ & $<0.04$ \\
\hline Silver - filtered & $\mathrm{mg} / \mathrm{L}$ & $<0.0005$ & $<0.0005$ & $<0.0005$ & $<0.0005$ \\
\hline Thallium - filtered & $\mathrm{mg} / \mathrm{L}$ & $<0.001$ & $<0.001$ & $<0.001$ & $<0.001$ \\
\hline V anadium - filtered & $\mathrm{mg} / \mathrm{L}$ & $<0.024$ & $<0.024$ & $<0.024$ & $<0.024$ \\
\hline Zinc - filtered & $\mathrm{mg} / \mathrm{L}$ & 0.0130 & 0.0112 & $<0.011$ & $<0.011$ \\
\hline Cesium-137 & $\mathrm{pCi} / \mathrm{L}$ & $<1.0$ & $<1.0$ & $<1.0$ & 1.6 \\
\hline Hydrogen-3 & $\mathrm{pCi} / \mathrm{L}$ & 1,134 & 1,259 & 1,338 & 1,376 \\
\hline Strontium-90 & $\mathrm{pCi} / \mathrm{L}$ & $<0.25$ & 0.36 & $<0.25$ & $<0.25$ \\
\hline A cetone & $\mu \mathrm{g} / \mathrm{L}$ & $-b$ & 3 & - & - \\
\hline
\end{tabular}

a $\quad$ ell point elevation $=182.88 \mathrm{~m}(\mathrm{M} \mathrm{SL})$; ground surface elevation $=203.56 \mathrm{~m}(\mathrm{M} \mathrm{SL})$; casing material $=$ steel.

b A hyphen indicates that the measured value was less than the detection limit. 


\section{GROUNDWATER PROTECTION}

TABLE 6.19

Illinois Class I Groundwater Quality Standards: Inorganics

(Concentrations in $\mathrm{mg} / \mathrm{L}$, except radionuclides and $\mathrm{pH}$ )

\begin{tabular}{|c|c|}
\hline Constituent & Standard \\
\hline Antimony & 0.006 \\
\hline A rsenic & 0.05 \\
\hline Barium & 2 \\
\hline Beryllium & 0.004 \\
\hline Boron & 2 \\
\hline Cadmium & 0.005 \\
\hline Chloride & 200 \\
\hline Chromium & 0.1 \\
\hline Cobalt & 1 \\
\hline Copper & 0.65 \\
\hline Cyanide & 0.2 \\
\hline Fluoride & 4 \\
\hline Iron & 5 \\
\hline Lead & 0.0075 \\
\hline M anganese & 0.15 \\
\hline M ercury & 0.002 \\
\hline Nickel & 0.1 \\
\hline Nitrate, as $\mathrm{N}$ & 10 \\
\hline Radium-226 & $20 \mathrm{pCi} / \mathrm{L}$ \\
\hline Radium-228 & $20 \mathrm{pCi} / \mathrm{L}$ \\
\hline Selenium & 0.05 \\
\hline Silver & 0.05 \\
\hline Sulfate & 400 \\
\hline Thallium & 0.002 \\
\hline TDS & 1,200 \\
\hline Zinc & 5 \\
\hline $\mathrm{pH}$ & $6.5-9.0$ units \\
\hline
\end{tabular}




\section{GROUNDWATER PROTECTION}

TABLE 6.20

Illinois Class I Groundwater Quality Standards: Organics

(Concentrations in $\mathrm{mg} / \mathrm{L}$ )

\begin{tabular}{|c|c|}
\hline Constituent & Standard \\
\hline Alachlor & 0.002 \\
\hline Aldicarb & 0.003 \\
\hline A trazine & 0.003 \\
\hline Benzene & 0.005 \\
\hline Benzo(a)pyrene & 0.0002 \\
\hline Carbofuran & 0.04 \\
\hline Carbon tetrachloride & 0.005 \\
\hline Chlordane & 0.002 \\
\hline Dalapon & 0.2 \\
\hline Dichloromethane & 0.005 \\
\hline Di(2-ethyhexyl)phthalate & 0.006 \\
\hline Dinoseb & 0.007 \\
\hline Endothall & 0.1 \\
\hline Endrin & 0.002 \\
\hline Ethylene dibromide & 0.00005 \\
\hline Heptachlor & 0.0004 \\
\hline Heptachlor epoxide & 0.0002 \\
\hline Hexachlorocyclopentadiene & 0.05 \\
\hline Lindane & 0.0002 \\
\hline $2,4-D$ & 0.07 \\
\hline o-Dichlorobenzene & 0.6 \\
\hline p-Dichlorobenzene & 0.075 \\
\hline 1,2-Dibromo-3-Chloropropane & 0.0002 \\
\hline 1,2-Dichloroethane & 0.005 \\
\hline 1,1-D ichloroethene & 0.007 \\
\hline cis-1,2-Dichloroethylene & 0.07 \\
\hline trans-1,2-Dichloroethylene & 0.1 \\
\hline 1,2-Dichloropropane & 0.005 \\
\hline Ethylbenzene & 0.7 \\
\hline M ethoxychlor & 0.04 \\
\hline M onochlorobenzene & 0.1 \\
\hline Pentachlorophenol & 0.001 \\
\hline
\end{tabular}




\section{GROUNDWATER PROTECTION}

TABLE 6.20 (Cont.)

\begin{tabular}{ll}
\hline \multicolumn{1}{c}{ Constituent } & Standard \\
\hline Phenols & 0.1 \\
Picloram & 0.5 \\
PCBs (decachlorobiphenyl) & 0.0005 \\
Simazine & 0.004 \\
Styrene & 0.1 \\
2,4-5-TP (Silvex) & 0.05 \\
Tetrachloroethylene & 0.005 \\
Toluene & 1 \\
Toxaphene & 0.003 \\
1,1,1-Trichloroethane & 0.2 \\
1,1,2-Trichloroethane & 0.005 \\
1,2,4-Trichlorobenzene & 0.07 \\
Trichloroethylene & 0.005 \\
Vinyl chloride & 0.002 \\
Xylenes & 10 \\
\hline
\end{tabular}

the purging of two to five volumes of water. In each case, the last value obtained was recorded. Well 317101 exceeded the WQS for chloride for three quarters. Chloride levels ranged from 175 to $594 \mathrm{mg} / \mathrm{L}$. W ell 317111 exceeded the W QS for manganese during the fourth quarter only. $\mathrm{M}$ anganese levels ranged from 0.03 to $0.17 \mathrm{mg} / \mathrm{L}$. The W QS for chloride was exceeded each quarter and levels ranged from 225 to $269 \mathrm{mg} / \mathrm{L}$. Several wells had elevated levels of barium, but they were well below the WQS. Barium concentrations ranged from 0.02 to $0.09 \mathrm{mg} / \mathrm{L}$. The source of the elevated barium and manganese levels is unknown. Elevated levels of barium and manganese have been reported in previous annual reports. 20

Organic Results. Each well was sampled quarterly and analyzed for VOCs. The results for 1997 are similar to those reported for 1996, except that VOCs were also noted in W ell 317061. VOCs were detected in W ells 317021, 319031, 319032, 317052, 317061, 317101, 317111, 317121D, and 319131D. The detection of volatile organics in most of the wells was infrequent, and typically the concentrations were very low. The exception was Well 317021, which showed persistent volatile organic levels, as in the past, and W ell 319031, which was dry 


\section{GROUNDWATER PROTECTION}

for two quarters. No organic W QSs were exceeded. V olatile organic 2-methylbutane was noted in the control sample the third and fourth quarters; therefore, its presence in third and fourth quarter samples is suspect. Once during the year, the wells were sampled and analyzed for SVOCS, PCBs and pesticides, and herbicides. No SVOCs, PCBs, pesticides, or herbicides were found in 1997.

Figure 6.3 shows the results for Well 317021. The major components are 1,1,1-trichloroethane (TCA) and 1,1-dichloroethane; the latter can be a decomposition product of TCA. As shown in Figure 6.3, the concentrations roughly parallel each other, and the levels are remarkably constant until 1991, at which time a substantial increase is seen. The previous consistency would indicate that this well is sampling a large area of contaminated water that is unaffected by seasonal water level changes. The large increase in the summer and fall of 1991

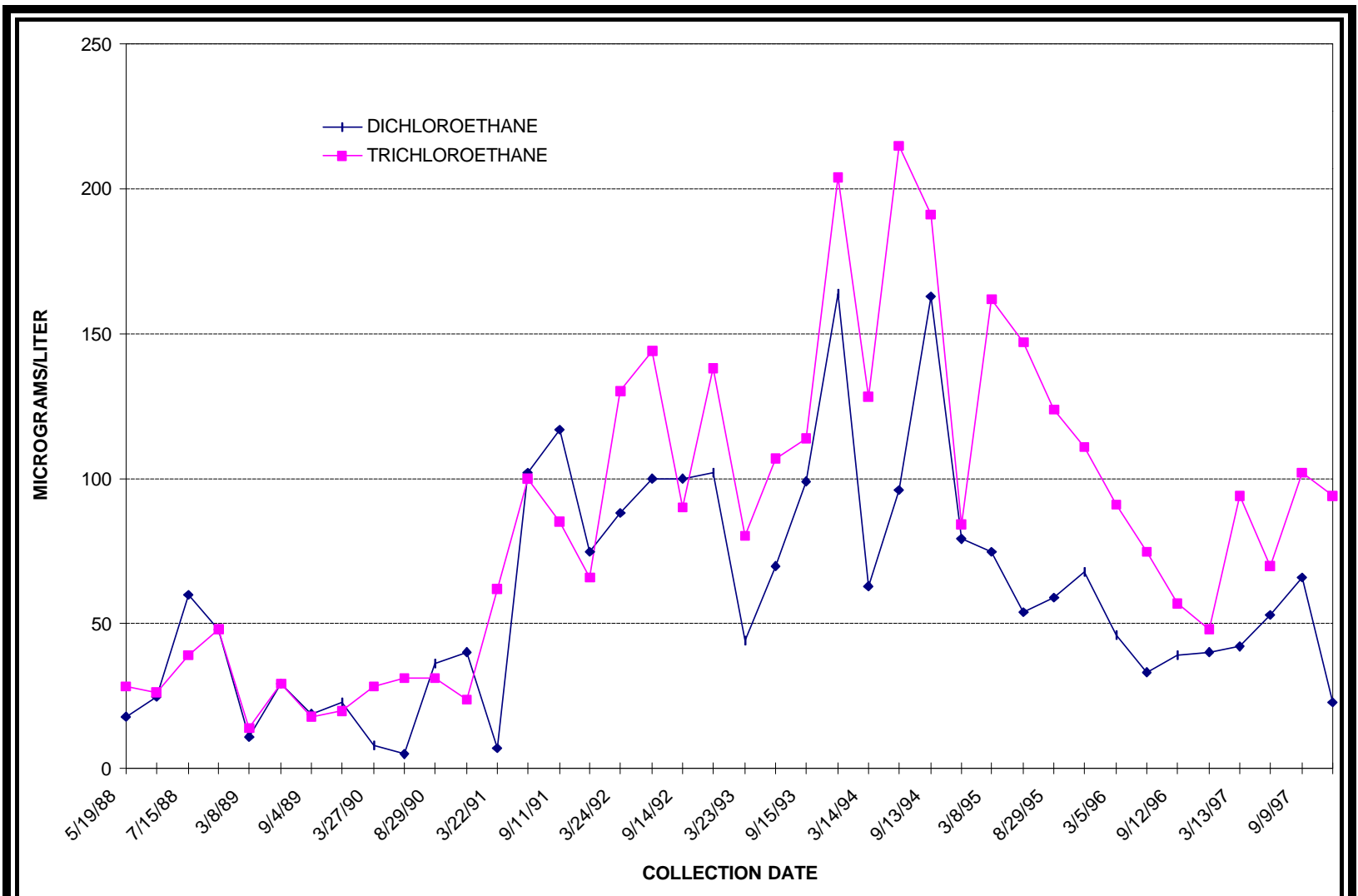

Figure 6.3 Concentration of 1,1-D ichloroethane and 1,1,1-Trichloroethane in W ell 317021 


\section{GROUNDWATER PROTECTION}

is clearly related to a period of intense drought and also could be related to restricted flow of normal dilution water. Trace levels of carbon tetrachloride, chloroform (a degradation product of carbon tetrachloride), 1,1-dichloroethene, tetrachloroethene, and trichloroethene (TCE) were also found in this well but at levels well below the WQS. The well is immediately below a former sewer line that was known to be contaminated. The sewer line was permanently closed in 1986 and sealed in 1997.

Well 319031 is frequently dry but contains organic constituents when water is present. During 1997, this well was sampled during two quarters, and levels of VOCs were well below the WQS, where appropriate. Dolomite W ell 317121D had trace levels of only 2-heptanone during two quarters, and dolomite Well 319131D showed trace levels of only acetone during just one quarter.

PCB compounds were reported in several of the wells in 1990. These wells were resampled in 1991 through 1996, and no PCBs were noted. SV OCs and pesticides and herbicides were not detected in any of the wells during 1997.

$M$ anholes $E 1$ and E2, described in Sections 6.2.1 and 6.2.2, in the 317 A rea were sampled monthly and analyzed for VOCS. The results are presented in Table 6.21. Contributors of groundwater into Manholes E1 and E2 include 757 to 1,136 L (200 to 300 gal)/day from the 319 A rea groundwater collection system, 7,571 L (2,000 gal)/day from the 317 A rea groundwater collection system (October 1997), and groundwater from existing foundation drains around storage vaults. In M ay 1997, grouting and sealing a footing drain system in the southeastern portion of the 317 A rea to prevent the migration of contaminated groundwater off site was completed. Approximately $183 \mathrm{~m}(600 \mathrm{ft})$ of underground pipe and bedding material was sealed in the 317 A rea south of the deactivated South $V$ ault system. At a future date, all underground piping immediately south of the Deep V ault, Map Tube V ault, and North V ault will be grouted and sealed.

In general, volatile constituent concentrations decreased from M anhole E1 to M anhole E2 (see Figure 6.4 and Table 6.21). This appears, in part, to be the result of dilution of $M$ anhole $E 1$ 
TABLE 6.21

V olatile Organic Compounds in the 317 A rea: M anholes E1 and E2, 1997

(Concentrations in $\mu \mathrm{g} / \mathrm{L}$ )

\begin{tabular}{|c|c|c|c|c|c|c|c|c|c|c|}
\hline \multirow[b]{2}{*}{ Date } & \multicolumn{2}{|c|}{ Chloroform } & \multicolumn{2}{|c|}{$\begin{array}{l}\text { Tetra- } \\
\text { chloroethene }\end{array}$} & \multicolumn{2}{|c|}{$\begin{array}{c}\text { Tri- } \\
\text { chloroethene }\end{array}$} & \multicolumn{2}{|c|}{$\begin{array}{c}\text { cis-1,2- } \\
\text { Dichloroethene }\end{array}$} & \multicolumn{2}{|c|}{$\begin{array}{c}\text { Carbon } \\
\text { Tetrachloride }\end{array}$} \\
\hline & $\mathrm{E} 1$ & E2 & E1 & $\mathrm{E} 2$ & $\mathrm{E} 1$ & E2 & E 1 & E2 & E1 & E2 \\
\hline $1 / 2 / 97$ & 680 & 629 & 60 & 102 & 72 & 66 & 56 & 40 & 523 & 666 \\
\hline $2 / 3 / 97$ & 284 & 4 & 40 & 20 & 24 & 7 & 37 & 28 & 281 & 52 \\
\hline $3 / 3 / 97$ & 763 & 25 & 69 & 18 & 68 & 26 & 57 & 56 & 734 & 48 \\
\hline $4 / 7 / 97$ & 226 & 5 & 78 & 10 & 37 & 38 & 27 & 87 & 291 & 10 \\
\hline $5 / 6 / 97$ & 146 & 17 & 78 & 15 & 27 & 12 & 36 & 30 & 341 & 26 \\
\hline $6 / 4 / 97$ & 74 & $<1$ & 41 & 1 & 13 & 14 & 41 & 46 & 161 & $<1$ \\
\hline $7 / 15 / 97$ & 59 & $<1$ & 28 & $<1$ & 9 & 7 & 24 & 21 & 111 & $<1$ \\
\hline $8 / 7 / 97$ & 116 & 1 & 79 & 2 & 11 & 7 & 20 & 19 & 242 & 1 \\
\hline 9/4/97 & 72 & $<1$ & 37 & $<1$ & 9 & 5 & 17 & 14 & 160 & 1 \\
\hline $10 / 16 / 97$ & 225 & 135 & 39 & 18 & 40 & 31 & 26 & 9 & 179 & 75 \\
\hline $11 / 6 / 97$ & 139 & 12 & 31 & 6 & 110 & 15 & 15 & 3 & 379 & 24 \\
\hline $12 / 11 / 97$ & 222 & 58 & 70 & 14 & 68 & 25 & 15 & 8 & 397 & 69 \\
\hline
\end{tabular}

water. Remediation activities in the 317 and 319 A reas has resulted in M anhole E2 receiving increased groundwater flows from these areas. Starting in October 1997, as part of the 317 A rea remediation project, additional 317 A rea groundwater was pumped at a rate of over 4,542 L (1,200 gal)/day to M anhole E2.

Chloroform is a degradation product of carbon tetrachloride. Cis-1,2-dichloroethene (1,2-DCE) is a degradation product of TCE. Vinyl chloride, a degradation product of 1,2-DCE, was noted at low levels in all but one monthly sample. The fact that both the original and breakdown products, such as TCE, 1,2-DCE, carbon tetrachloride, and chloroform, are present in most samples, indicates an ongoing release of these compounds into the groundwater, such as from highly contaminated soils. Trace levels of benzene, bromoform, dichlorofluoremethane, ethyl ether, methylene chloride, trans-1,2-DCE, tribromoethene, 1,1-dichloroethane, 1,2-dibromoethene, 1,1,1-trichloroethane, 1,2,4-trichlorobenzene, 1,4-dioxane, and 4-methyl-2-pentanone have been detected, but not on a consistent basis. The source of these compounds is believed to be the French drains previously described in Section 6.2.1. Extensive 


\section{GROUNDWATER PROTECTION}
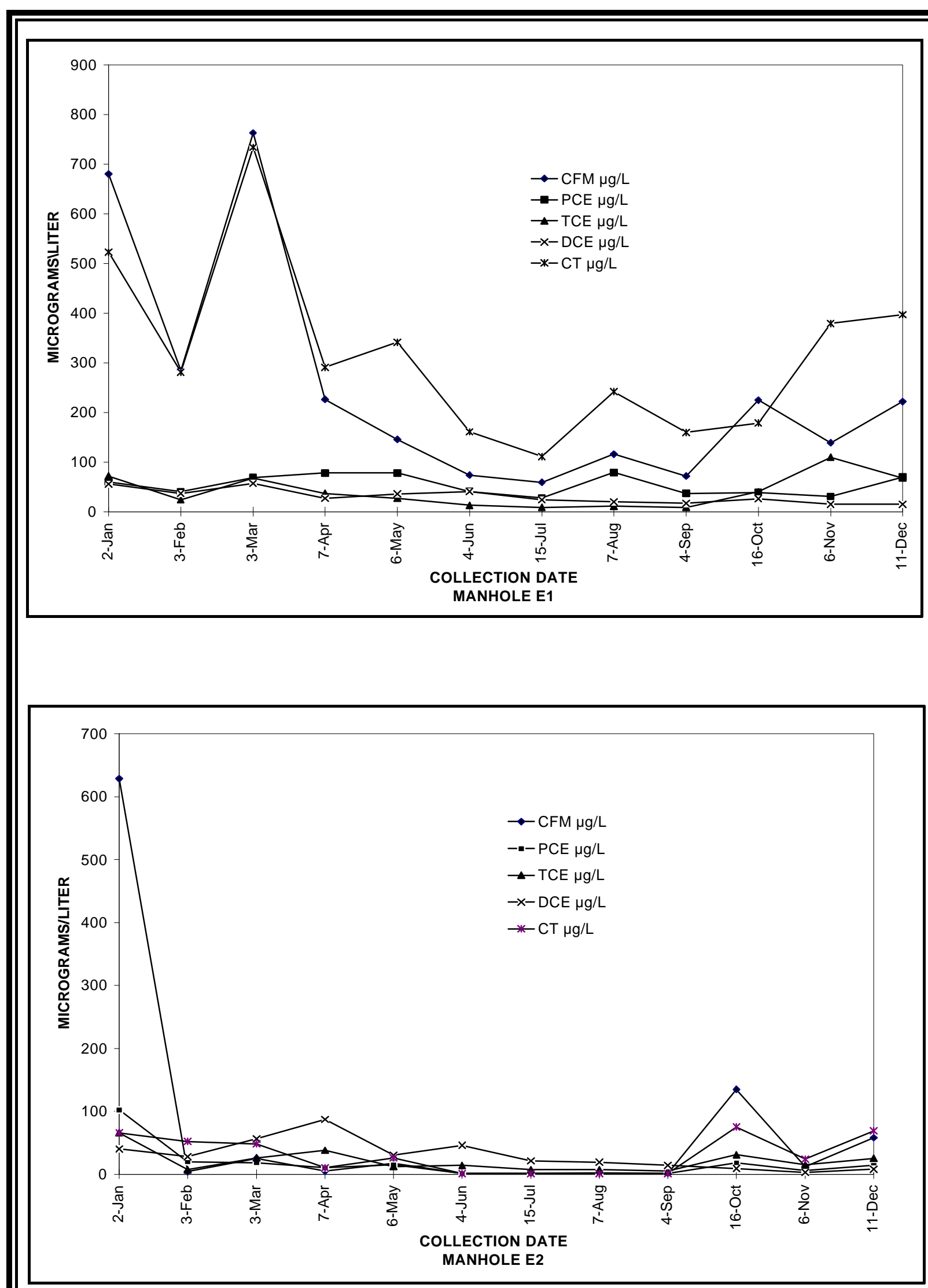

Figure 6.4 Trends of Selected Organics in 317 A rea M anholes, 1997 
characterization activities described in Section 6.5 .2 continue to better define the nature, rate, and extent of contamination at this location.

Radioactive Constituents. Samples collected quarterly from the monitoring wells in the 317 and 319 A reas were analyzed for hydrogen-3, strontium-90, and gamma-ray emitters. The results are presented in Tables 6.9 to 6.18. Evidence of possible off-site migration of radionuclides is noted by the low concentrations of hydrogen-3, cesium-137, and strontium-90 in wells located near the south perimeter fence in the 317 and 319 A reas. Similar to 1996, hydrogen-3 was detected in Wells 317021 and 317121D, located south of the 317 A rea. Hydrogen-3 was also detected in W ells 319032 and 319131D, which are located near the south perimeter fence. During one quarter, cesium-137 was detected in Wells 317021 and 317052, located south of the 317 A rea. Cesium-137 was also detected in W ells 317101 and 317111, which are upgradient of the 317 A rea. A small amount of cesium-137 was also detected in W ells 319031 and 319131D, which are south of the 319 A rea near the south perimeter fence. Strontium-90 was detected during two quarters in W ell 319031, which is near the south perimeter fence; this well was dry the other two quarters. A small amount of strontium-90 was also detected one quarter in Well 319131D, which is also located near the south perimeter fence. W ells 319031, 319032, and 319131D are directly below a small drainage swale from the 319 A rea that has contained water intermittently with measurable concentrations of hydrogen-3 and strontium-90. All concentrations are well below any applicable standards.

\subsection{Sanitary Landfill}

The 800 A rea is the site of ANL-E sanitary landfill. The 8.8-ha (21.8-acre) landfill is located on the western edge of ANL-E property (Figure 1.1). The landfill has received waste since 1966 and was operated under IEPA Permit No. 1981-29-OP, which was issued on September 18, 1981. The landfill received general refuse, construction debris, boiler house ash, and other nonradioactive solid waste until September 1992. The landfill is now being closed pursuant to Permit No. 1992-002-SP and Supplemental Permit Nos. 1994-506-SP and 1997295-P. 


\section{GROUNDWATER PROTECTION}

\subsubsection{French Drain}

The landfill area was used for the disposal of certain types of liquid wastes from 1969 to 1978. The wastes were poured into a French drain that consisted of a corrugated steel pipe placed in a gravel-filled pit dug into an area previously filled with waste. The liquid waste was poured into the drain and allowed to permeate into the gravel, and thence into the soil and fill material. A vailable documentation indicates that $109,000 \mathrm{~L}(29,000$ gal) of liquid waste was placed in this drain. Some of the wastes disposed of in this manner are now defined as hazardous wastes. The presence of volatile and other toxic organic compounds has been confirmed by soil gas surveys and leachate sampling conducted at the landfill. M easurable amounts of these materials were identified in soil vapors leachate but not groundwater near the landfill.

\subsubsection{Monitoring Studies}

During October 1992, 15 stainless-steel wells, Wells 800161 through 800203D, were installed around the landfill as part of the IEPA-approved closure plan. These wells are required to be monitored as part of the IEPA-approved groundwater monitoring program, effective January 1995. These wells are set in five clusters; each cluster consists of a shallow, medium, and deep well (see Figure 6.5 and Table 6.22). W ells 800172 and 800182 are consistently dry.

\subsubsection{Sample Collection}

The same procedure for well water sample collection previously described for the 300 A rea was used for this area. Each well is sampled annually for semivolatiles, PCBs, pesticides, and herbicides. Also, during the second quarter, in accordance with the IEPA-approved groundwater monitoring plan, both filtered and unfiltered samples for numerous parameters (e.g., metals, chloride, sulfate) are required. Volatile organics are monitored each quarter, although only required by permit during the second quarter. 


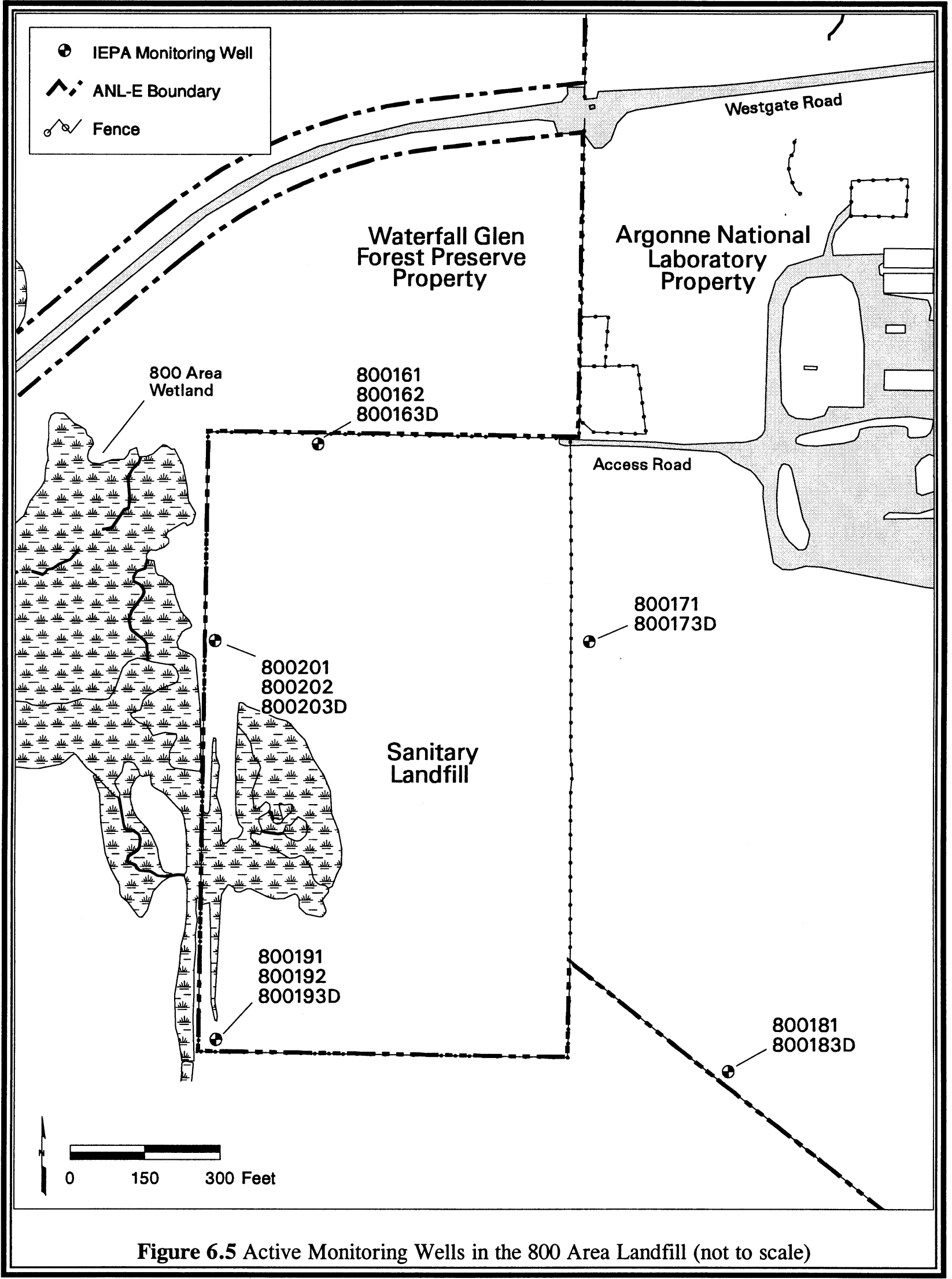




\section{GROUNDWATER PROTECTION}

TABLE 6.22

Groundwater M onitoring W ells: 800 A rea L andfill

\begin{tabular}{lrcccc}
\hline $\begin{array}{c}\text { ID } \\
\text { Number }\end{array}$ & $\begin{array}{c}\text { Well } \\
\text { Depth } \\
\text { (m bgs) }\end{array}$ & $\begin{array}{c}\text { Ground } \\
\text { Elevation } \\
\text { (m AM SL) }\end{array}$ & $\begin{array}{c}\text { M onitoring } \\
\text { Zone } \\
\text { (m A M SL) }\end{array}$ & $\begin{array}{c}\text { Well } \\
\text { Type }^{b}\end{array}$ & $\begin{array}{c}\text { Date } \\
\text { D rilled }\end{array}$ \\
\hline 800161 & 7.94 & 230.8 & $224.3-222.8$ & $0.05 / \mathrm{SS}$ & $10 / 92$ \\
800162 & 20.76 & 230.7 & $211.5-210.0$ & $0.05 / \mathrm{SS}$ & $10 / 92$ \\
$800163 \mathrm{D}$ & 47.00 & 230.8 & $186.8-183.8$ & $0.05 / \mathrm{SS}$ & $9 / 92$ \\
800171 & 7.71 & 228.4 & $222.2-220.7$ & $0.05 / \mathrm{SS}$ & $10 / 92$ \\
$800173 \mathrm{D}$ & 39.08 & 228.4 & $192.4-189.3$ & $0.05 / \mathrm{SS}$ & $10 / 92$ \\
800181 & 11.01 & 230.5 & $221.0-219.5$ & $0.05 / \mathrm{SS}$ & $10 / 92$ \\
$800183 \mathrm{D}$ & 49.68 & 230.4 & $183.7-180.7$ & $0.05 / \mathrm{SS}$ & $10 / 92$ \\
800191 & 4.62 & 227.4 & $224.3-222.8$ & $0.05 / \mathrm{SS}$ & $10 / 92$ \\
800192 & 18.67 & 227.4 & $210.2-208.7$ & $0.05 / \mathrm{SS}$ & $10 / 92$ \\
$800193 \mathrm{D}$ & 45.48 & 227.4 & $185.0-181.9$ & $0.05 / \mathrm{SS}$ & $10 / 92$ \\
800201 & 10.74 & 227.9 & $218.7-217.2$ & $0.05 / \mathrm{SS}$ & $10 / 92$ \\
800202 & 18.52 & 227.9 & $210.9-209.4$ & $0.05 / \mathrm{SS}$ & $10 / 92$ \\
$800203 \mathrm{D}$ & 38.47 & 227.9 & $192.5-189.5$ & $0.05 / \mathrm{SS}$ & $9 / 92$ \\
\hline
\end{tabular}

a Wells identified by a " $D$ " are deeper wells monitoring the dolomite bedrock aquifer.

b Inner diameter $(\mathrm{m}) /$ well material (SS = stainless steel).

\subsubsection{Sample Analyses - 800 Area}

The 800 A rea sample analyses were performed using SOPs written, reviewed, and issued as controlled documents by members of ESH-ASCH, ESH-A nalytical Services, Control Laboratory (ASCL), and ESH-ASRC. These SOP reference protocols can be found in SW-846, 3rd edition, "Test Methods for Evaluating Solid Waste." 9 Sixteen metals were routinely determined and analyzed by using flame atomic absorption spectroscopy, inductively-coupled plasma atomic emission spectroscopy, and graphite furnace atomic absorption spectroscopy. M ercury was determined by cold vapor atomic absorption spectroscopy. V OCs were determined by using a purge and trap sample pretreatment followed by gas chromatography-mass spectroscopy detection. SVOCS were determined by solvent extraction followed by gas chromatography-mass spectroscopy detection. PCBs and pesticides were determined by solvent 
extraction followed by gas chromatography-electron capture detection. In the case of organic compound analyses, efforts were made to identify compounds that were present but not included on the method list. This was accomplished, and standard solutions of these compounds were prepared and analyzed. TDS were determined gravimetrically. Sulfate determination was performed by using a turbidimetric technique, while chloride was determined by titrimetry. A mmonia-nitrogen was determined by using distillation followed by an ion-selective electrode technique.

Some analyses were performed at an off-site contractor laboratory. SW $-846^{9}$ procedures were specified and used. Cyanide and phenol were determined by distillation followed by a spectrophotometric finish. Total organic carbon (TOC) and total organic halogen (TOX) were determined by combustion techniques followed by infrared detection and coulometric titration, respectively. Chlorinated organic compounds and carbamate pesticides were analyzed by extractions followed by gas and liquid chromotography techniques, respectively.

The 800 A rea groundwater radiological analyses were performed using SOPs written, reviewed, and issued as controlled documents by members of ESH-ASRC. Hydrogen-3 was determined by distillation followed by a beta liquid scintillation counting technique.

\subsubsection{Results of Analyses}

Descriptions of each well, field parameters measured during sample collection, and the results of chemical and radiological analysis of samples from the wells in the 800 A rea are presented in Tables 6.23 to 6.35 . All radiological and inorganic analysis results are shown in these tables. The analytical methods used for organic compounds could identify and quantify all the compounds contained in the CLP Target Compound List. However, the vast majority of these compounds were not detected in the samples. Only those constituents that were present in amounts great enough to quantify are shown. The detection limits for the organic compounds listed were typically 1 to $5 \mu \mathrm{g} / \mathrm{L}$. Figures 6.6 to 6.19 show the trends for exceedances of the WQS for wells monitored as part of the IEPA-approved groundwater monitoring program for the 
TABLE 6.23

Groundwater M onitoring Results, Sanitary L andfill Well 800161, 1997a

\begin{tabular}{|c|c|c|c|c|c|c|}
\hline \multirow[b]{2}{*}{ Parameter } & \multirow[b]{2}{*}{ Unit } & \multicolumn{5}{|c|}{ Date of Sampling } \\
\hline & & $01 / 08 / 97$ & $04 / 02 / 97$ & $04 / 02 / 97$ & $07 / 09 / 97$ & $10 / 10 / 97$ \\
\hline Water elevation & $\mathrm{m}$ & 228.29 & 229.43 & 229.43 & 227.51 & 226.74 \\
\hline Temperature & ${ }^{\circ} \mathrm{C}$ & 11.0 & 9.7 & 9.7 & 10.1 & 12.8 \\
\hline $\mathrm{pH}$ & $\mathrm{pH}$ & 7.17 & 7.06 & 7.06 & 7.14 & 7.10 \\
\hline Redox & $\mathrm{mV}$ & -27 & 2 & 2 & -68 & 5 \\
\hline Conductivity & $\mu \mathrm{mhos} / \mathrm{cm}$ & 1,369 & 1,366 & 1,366 & 981 & 1,344 \\
\hline Chloride - filtered & $\mathrm{mg} / \mathrm{L}$ & 74 & 76 & 80 & 77 & 75 \\
\hline Sulfate - filtered & $\mathrm{mg} / \mathrm{L}$ & 288 & 173 & 178 & 142 & 112 \\
\hline TDS - filtered & $\mathrm{mg} / \mathrm{L}$ & 785 & 806 & 813 & 842 & 847 \\
\hline Cyanide (total) & $\mathrm{mg} / \mathrm{L}$ & $<0.005$ & $<0.010$ & $<0.010$ & $<0.010$ & $<0.010$ \\
\hline Arsenic & $\mathrm{mg} / \mathrm{L}$ & $-b$ & $<0.002$ & 0.0023 & - & - \\
\hline Barium & $\mathrm{mg} / \mathrm{L}$ & - & 0.1555 & 0.1600 & - & - \\
\hline Boron & $\mathrm{mg} / \mathrm{L}$ & - & 0.0990 & 0.1209 & - & - \\
\hline Cadmium & $\mathrm{mg} / \mathrm{L}$ & - & 0.0001 & 0.0001 & - & - \\
\hline Chromium & $\mathrm{mg} / \mathrm{L}$ & - & $<0.02$ & $<0.02$ & - & - \\
\hline Cobalt & $\mathrm{mg} / \mathrm{L}$ & - & $<0.015$ & $<0.015$ & - & - \\
\hline Copper & $\mathrm{mg} / \mathrm{L}$ & - & $<0.02$ & $<0.02$ & - & - \\
\hline Iron & $\mathrm{mg} / \mathrm{L}$ & - & 1.3750 & 2.4110 & - & - \\
\hline L ead & $\mathrm{mg} / \mathrm{L}$ & - & 0.0010 & 0.0018 & - & - \\
\hline M anganese & $\mathrm{mg} / \mathrm{L}$ & - & 0.5450 & 0.5659 & - & - \\
\hline M ercury & $\mathrm{mg} / \mathrm{L}$ & - & 0.0002 & $<0.0001$ & - & - \\
\hline Nickel & $\mathrm{mg} / \mathrm{L}$ & - & $<0.025$ & $<0.025$ & - & - \\
\hline Selenium & $\mathrm{mg} / \mathrm{L}$ & - & $<0.002$ & $<0.002$ & - & - \\
\hline Silver & $\mathrm{mg} / \mathrm{L}$ & - & $<0.0005$ & $<0.0005$ & - & - \\
\hline Zinc & $\mathrm{mg} / \mathrm{L}$ & - & 0.0439 & 0.0381 & - & - \\
\hline A mmonia nitrogen - filtered & $\mathrm{mg} / \mathrm{L}$ & 0.1000 & 0.5000 & 0.3000 & $<0.1$ & 0.20 \\
\hline A rsenic - filtered & $\mathrm{mg} / \mathrm{L}$ & $<0.002$ & $<0.002$ & $<0.002$ & $<0.002$ & $<0.002$ \\
\hline Barium - filtered & $\mathrm{mg} / \mathrm{L}$ & 0.1588 & 0.1565 & 0.1595 & 0.1554 & 0.1569 \\
\hline Beryllium - filtered & $\mathrm{mg} / \mathrm{L}$ & $<0.0002$ & $<0.0002$ & $<0.0002$ & $<0.0002$ & $<0.0002$ \\
\hline Cadmium - filtered & $\mathrm{mg} / \mathrm{L}$ & $<0.0001$ & $<0.0001$ & $<0.0001$ & $<0.0001$ & $<0.0001$ \\
\hline Chromium - filtered & $\mathrm{mg} / \mathrm{L}$ & $<0.020$ & $<0.020$ & $<0.020$ & $<0.044$ & $<0.044$ \\
\hline Cobalt - filtered & $\mathrm{mg} / \mathrm{L}$ & $<0.015$ & $<0.015$ & $<0.015$ & $<0.026$ & $<0.026$ \\
\hline Copper - filtered & $\mathrm{mg} / \mathrm{L}$ & $<0.020$ & $<0.020$ & $<0.020$ & $<0.017$ & $<0.017$ \\
\hline Iron - filtered & $\mathrm{mg} / \mathrm{L}$ & 0.1194 & $<0.0250$ & $<0.0250$ & 0.0514 & 0.1482 \\
\hline L ead - filtered & $\mathrm{mg} / \mathrm{L}$ & $<0.001$ & $<0.001$ & $<0.001$ & $<0.001$ & $<0.001$ \\
\hline$M$ anganese - filtered & $\mathrm{mg} / \mathrm{L}$ & 0.8267 & 0.6352 & 0.6281 & 0.7340 & 0.8015 \\
\hline M ercury - filtered & $\mathrm{mg} / \mathrm{L}$ & $<0.0001$ & $<0.0001$ & $<0.0001$ & $<0.0001$ & $<0.0001$ \\
\hline N ickel - filtered & $\mathrm{mg} / \mathrm{L}$ & $<0.025$ & 0.0262 & $<0.025$ & $<0.040$ & $<0.040$ \\
\hline Silver - filtered & $\mathrm{mg} / \mathrm{L}$ & $<0.0005$ & $<0.0005$ & $<0.0005$ & $<0.0005$ & $<0.0005$ \\
\hline Thallium - filtered & $\mathrm{mg} / \mathrm{L}$ & $<0.001$ & $<0.001$ & $<0.001$ & $<0.001$ & $<0.001$ \\
\hline V anadium - filtered & $\mathrm{mg} / \mathrm{L}$ & $<0.020$ & $<0.020$ & $<0.020$ & $<0.024$ & $<0.024$ \\
\hline Zinc - filtered & $\mathrm{mg} / \mathrm{L}$ & 0.0794 & 0.0143 & 0.0129 & 0.0565 & 0.0632 \\
\hline Phenols & $\mathrm{mg} / \mathrm{L}$ & $<0.005$ & $<0.005$ & $<0.005$ & $<0.005$ & $<0.005$ \\
\hline Hydrogen-3 & $\mathrm{pCi} / \mathrm{L}$ & 427 & 291 & 284 & 249 & 228 \\
\hline Chloride & $\mathrm{mg} / \mathrm{L}$ & - & 74 & 79 & - & - \\
\hline Fluoride & $\mathrm{mg} / \mathrm{L}$ & - & 0.224 & 0.220 & - & - \\
\hline Sulfate & $\mathrm{mg} / \mathrm{L}$ & - & 156 & 162 & - & - \\
\hline Total organic carbons & $\mathrm{mg} / \mathrm{L}$ & 5.6 & 4.3 & 4.5 & 3.9 & 2.2 \\
\hline Total organic carbons & $\mathrm{mg} / \mathrm{L}$ & 5.6 & 4.3 & 4.3 & 3.7 & 2.6 \\
\hline Total organic carbons & $\mathrm{mg} / \mathrm{L}$ & 5.6 & 4.4 & 4.1 & 4.2 & 3.2 \\
\hline Total organic carbons & $\mathrm{mg} / \mathrm{L}$ & 5.3 & 4.3 & 4.0 & 4.1 & 2.8 \\
\hline Total organic halogens & $\mathrm{mg} / \mathrm{L}$ & 0.012 & 0.015 & 0.013 & 0.013 & 0.013 \\
\hline Total organic halogens & $\mathrm{mg} / \mathrm{L}$ & 0.013 & 0.013 & 0.012 & 0.014 & 0.013 \\
\hline Trichlorofluoromethane & $\mu \mathrm{g} / \mathrm{L}$ & - & 4.0 & 2.0 & - & - \\
\hline
\end{tabular}

a Well point elevation $=222.83 \mathrm{~m}(\mathrm{MSL})$; ground surface elevation $=230.76 \mathrm{~m}(\mathrm{MSL})$; casing material $=$ stainless steel.

b A hyphen indicates that the sample was not analyzed for this constituent. 


\section{GROUNDWATER PROTECTION}

TABLE 6.24

Groundwater M onitoring Results, Sanitary L andfill Well 800162, 1997ª

\begin{tabular}{|c|c|c|c|c|c|}
\hline \multirow[b]{2}{*}{ Parameter } & \multirow[b]{2}{*}{ Unit } & \multicolumn{4}{|c|}{ Date of Sampling } \\
\hline & & $01 / 08 / 97$ & $04 / 01 / 97$ & 07/09/97 & $10 / 08 / 97$ \\
\hline Water elevation & $\mathrm{m}$ & 218.89 & 219.46 & 219.21 & 218.82 \\
\hline Temperature & ${ }^{\circ} \mathrm{C}$ & 10.7 & 11.9 & 10.9 & 11.8 \\
\hline $\mathrm{pH}$ & $\mathrm{pH}$ & 7.11 & 6.98 & 7.13 & 7.18 \\
\hline Redox & $\mathrm{mV}$ & -55 & 9 & -30 & -1 \\
\hline Conductivity & $\mu \mathrm{mhos} / \mathrm{cm}$ & 1015 & 1020 & 742 & 1007 \\
\hline Chloride - filtered & $\mathrm{mg} / \mathrm{L}$ & 52 & 57 & 55 & 56 \\
\hline Sulfate - filtered & $\mathrm{mg} / \mathrm{L}$ & 64 & 69 & 81 & 82 \\
\hline TDS - filtered & $\mathrm{mg} / \mathrm{L}$ & 611 & 558 & 629 & 610 \\
\hline Cyanide (total) & $\mathrm{mg} / \mathrm{L}$ & $<0.005$ & $<0.010$ & $<0.010$ & $<0.010$ \\
\hline Arsenic & $\mathrm{mg} / \mathrm{L}$ & $-b$ & 0.0035 & - & - \\
\hline Barium & $\mathrm{mg} / \mathrm{L}$ & - & 0.0637 & - & - \\
\hline Boron & $\mathrm{mg} / \mathrm{L}$ & - & 0.1236 & - & - \\
\hline Cadmium & $\mathrm{mg} / \mathrm{L}$ & - & 0.0001 & - & - \\
\hline Chromium & $\mathrm{mg} / \mathrm{L}$ & - & $<0.02$ & - & - \\
\hline Cobalt & $\mathrm{mg} / \mathrm{L}$ & - & $<0.015$ & - & - \\
\hline Copper & $\mathrm{mg} / \mathrm{L}$ & - & $<0.02$ & - & - \\
\hline Iron & $\mathrm{mg} / \mathrm{L}$ & - & 1.7740 & - & - \\
\hline L ead & $\mathrm{mg} / \mathrm{L}$ & - & $<0.001$ & - & - \\
\hline M anganese & $\mathrm{mg} / \mathrm{L}$ & - & 0.4880 & - & - \\
\hline M ercury & $\mathrm{mg} / \mathrm{L}$ & - & $<0.0001$ & - & - \\
\hline Nickel & $\mathrm{mg} / \mathrm{L}$ & - & $<0.025$ & - & - \\
\hline Selenium & $\mathrm{mg} / \mathrm{L}$ & - & $<0.002$ & - & - \\
\hline Silver & $\mathrm{mg} / \mathrm{L}$ & - & $<0.0005$ & - & - \\
\hline Zinc & $\mathrm{mg} / \mathrm{L}$ & - & $<0.01$ & - & - \\
\hline A mmonia nitrogen - filtered & $\mathrm{mg} / \mathrm{L}$ & 0.3 & 0.2 & 0.2 & $<0.1$ \\
\hline A rsenic - filtered & $\mathrm{mg} / \mathrm{L}$ & 0.0024 & 0.0029 & 0.0020 & 0.0026 \\
\hline Barium - filtered & $\mathrm{mg} / \mathrm{L}$ & 0.0657 & 0.0652 & 0.0540 & 0.0520 \\
\hline Beryllium - filtered & $\mathrm{mg} / \mathrm{L}$ & $<0.0002$ & $<0.0002$ & $<0.0002$ & $<0.0002$ \\
\hline Cadmium - filtered & $\mathrm{mg} / \mathrm{L}$ & $<0.0001$ & $<0.0001$ & $<0.0001$ & $<0.0001$ \\
\hline Chromium - filtered & $\mathrm{mg} / \mathrm{L}$ & $<0.020$ & $<0.020$ & $<0.044$ & $<0.044$ \\
\hline Cobalt - filtered & $\mathrm{mg} / \mathrm{L}$ & $<0.015$ & $<0.015$ & $<0.026$ & $<0.026$ \\
\hline Copper - filtered & $\mathrm{mg} / \mathrm{L}$ & $<0.020$ & $<0.020$ & $<0.017$ & $<0.017$ \\
\hline Iron - filtered & $\mathrm{mg} / \mathrm{L}$ & 1.8770 & 1.3990 & 1.1670 & 1.0380 \\
\hline L ead - filtered & $\mathrm{mg} / \mathrm{L}$ & $<0.001$ & $<0.001$ & $<0.001$ & $<0.001$ \\
\hline$M$ anganese - filtered & $\mathrm{mg} / \mathrm{L}$ & 0.4114 & 0.3961 & 0.3272 & 0.4126 \\
\hline M ercury - filtered & $\mathrm{mg} / \mathrm{L}$ & $<0.0001$ & $<0.0001$ & $<0.0001$ & $<0.0001$ \\
\hline Nickel - filtered & $\mathrm{mg} / \mathrm{L}$ & $<0.025$ & $<0.025$ & $<0.040$ & $<0.040$ \\
\hline Silver - filtered & $\mathrm{mg} / \mathrm{L}$ & $<0.0005$ & $<0.0005$ & $<0.0005$ & $<0.0005$ \\
\hline Thallium - filtered & $\mathrm{mg} / \mathrm{L}$ & $<0.001$ & $<0.001$ & $<0.001$ & $<0.001$ \\
\hline V anadium - filtered & $\mathrm{mg} / \mathrm{L}$ & $<0.020$ & $<0.020$ & $<0.024$ & $<0.024$ \\
\hline Zinc - filtered & $\mathrm{mg} / \mathrm{L}$ & $<0.010$ & $<0.010$ & $<0.011$ & $<0.011$ \\
\hline Phenols & $\mathrm{mg} / \mathrm{L}$ & $<0.005$ & $<0.005$ & $<0.005$ & $<0.005$ \\
\hline Hydrogen-3 & $\mathrm{pCi} / \mathrm{L}$ & $<100$ & $<100$ & $<100$ & $<100$ \\
\hline Chloride & $\mathrm{mg} / \mathrm{L}$ & - & 59 & - & - \\
\hline Fluoride & $\mathrm{mg} / \mathrm{L}$ & - & 0.242 & - & - \\
\hline Sulfate & $\mathrm{mg} / \mathrm{L}$ & - & 71 & - & - \\
\hline Total organic carbons & $\mathrm{mg} / \mathrm{L}$ & 3.8 & 3.8 & 3.1 & 1.6 \\
\hline Total organic carbons & $\mathrm{mg} / \mathrm{L}$ & 3.8 & 3.8 & 3.1 & 1.4 \\
\hline Total organic carbons & $\mathrm{mg} / \mathrm{L}$ & 4.0 & 3.8 & 3.1 & 1.5 \\
\hline Total organic carbons & $\mathrm{mg} / \mathrm{L}$ & 3.9 & 3.6 & 3.0 & 1.8 \\
\hline Total organic halogens & $\mathrm{mg} / \mathrm{L}$ & $<0.010$ & 0.067 & 0.068 & 0.049 \\
\hline Total organic halogens & $\mathrm{mg} / \mathrm{L}$ & $<0.010$ & 0.064 & 0.077 & 0.055 \\
\hline
\end{tabular}

a Well point elevation $=209.40 \mathrm{~m}(\mathrm{MSL})$; ground surface elevation $=230.73 \mathrm{~m}(\mathrm{M} \mathrm{SL})$; casing material $=$ stainless steel.

b A hyphen indicates that the sample was not analyzed for this constituent. 
TABLE 6.25

Groundwater M onitoring Results, Sanitary Landfill Well 800163D, 1997ª

\begin{tabular}{|c|c|c|c|c|c|}
\hline \multirow[b]{2}{*}{ Parameter } & \multirow[b]{2}{*}{ Unit } & \multicolumn{4}{|c|}{ Date of Sampling } \\
\hline & & $01 / 08 / 97$ & $04 / 01 / 97$ & 07/09/97 & $10 / 08 / 97$ \\
\hline W ater elevation & $\mathrm{m}$ & 192.93 & 193.30 & 193.13 & 193.08 \\
\hline Temperature & ${ }^{\circ} \mathrm{C}$ & 11.2 & 11.7 & 11.3 & 12.0 \\
\hline $\mathrm{pH}$ & $\mathrm{pH}$ & 7.02 & 6.89 & 7.05 & 7.11 \\
\hline Redox & $\mathrm{mV}$ & -123 & 25 & -23 & 3 \\
\hline Conductivity & $\mu \mathrm{mhos} / \mathrm{cm}$ & 1337 & 1330 & 974 & 1317 \\
\hline Chloride - filtered & $\mathrm{mg} / \mathrm{L}$ & 128 & 134 & 150 & 128 \\
\hline Sulfate - filtered & $\mathrm{mg} / \mathrm{L}$ & 107 & 108 & 199 & 187 \\
\hline TDS - filtered & $\mathrm{mg} / \mathrm{L}$ & 788 & 838 & 929 & 868 \\
\hline Cyanide (Total) & $\mathrm{mg} / \mathrm{L}$ & $<0.005$ & $<0.010$ & $<0.010$ & $<0.010$ \\
\hline Arsenic & $\mathrm{mg} / \mathrm{L}$ & $-b$ & 0.0058 & - & - \\
\hline Barium & $\mathrm{mg} / \mathrm{L}$ & - & 0.0584 & - & - \\
\hline Boron & $\mathrm{mg} / \mathrm{L}$ & - & 0.2143 & - & - \\
\hline Cadmium & $\mathrm{mg} / \mathrm{L}$ & - & $<0.0001$ & - & - \\
\hline Chromium & $\mathrm{mg} / \mathrm{L}$ & - & $<0.02$ & - & - \\
\hline Cobalt & $\mathrm{mg} / \mathrm{L}$ & - & $<0.015$ & - & - \\
\hline Copper & $\mathrm{mg} / \mathrm{L}$ & - & $<0.02$ & - & - \\
\hline Iron & $\mathrm{mg} / \mathrm{L}$ & - & 3.12 & - & - \\
\hline Lead & $\mathrm{mg} / \mathrm{L}$ & - & $<0.001$ & - & - \\
\hline M anganese & $\mathrm{mg} / \mathrm{L}$ & - & 0.0532 & - & - \\
\hline M ercury & $\mathrm{mg} / \mathrm{L}$ & - & $<0.0001$ & - & - \\
\hline Nickel & $\mathrm{mg} / \mathrm{L}$ & - & $<0.025$ & - & - \\
\hline Selenium & $\mathrm{mg} / \mathrm{L}$ & - & $<0.002$ & - & - \\
\hline Silver & $\mathrm{mg} / \mathrm{L}$ & - & $<0.0005$ & - & - \\
\hline Zinc & $\mathrm{mg} / \mathrm{L}$ & - & 0.0217 & - & - \\
\hline A mmonia nitrogen - filtered & $\mathrm{mg} / \mathrm{L}$ & 1.0 & 0.5 & 2.5 & 0.8 \\
\hline A rsenic - filtered & $\mathrm{mg} / \mathrm{L}$ & 0.0046 & 0.0052 & 0.0025 & 0.0045 \\
\hline Barium - filtered & $\mathrm{mg} / \mathrm{L}$ & 0.0583 & 0.0634 & 0.0536 & 0.0565 \\
\hline Beryllium - filtered & $\mathrm{mg} / \mathrm{L}$ & $<0.0002$ & $<0.0002$ & $<0.0002$ & $<0.0002$ \\
\hline Cadmium - filtered & $\mathrm{mg} / \mathrm{L}$ & $<0.0001$ & $<0.0001$ & $<0.0001$ & $<0.0001$ \\
\hline Chromium - filtered & $\mathrm{mg} / \mathrm{L}$ & $<0.020$ & $<0.020$ & $<0.044$ & $<0.044$ \\
\hline Cobalt - filtered & $\mathrm{mg} / \mathrm{L}$ & $<0.015$ & $<0.015$ & $<0.026$ & $<0.026$ \\
\hline Copper - filtered & $\mathrm{mg} / \mathrm{L}$ & $<0.020$ & $<0.020$ & $<0.017$ & $<0.017$ \\
\hline Iron - filtered & $\mathrm{mg} / \mathrm{L}$ & 2.850 & 2.693 & 1.329 & 2.004 \\
\hline Lead - filtered & $\mathrm{mg} / \mathrm{L}$ & $<0.001$ & $<0.001$ & $<0.001$ & $<0.001$ \\
\hline$M$ anganese - filtered & $\mathrm{mg} / \mathrm{L}$ & 0.0683 & 0.0582 & 0.0543 & 0.0510 \\
\hline M ercury - filtered & $\mathrm{mg} / \mathrm{L}$ & $<0.0001$ & $<0.0001$ & $<0.0001$ & $<0.0001$ \\
\hline Nickel - filtered & $\mathrm{mg} / \mathrm{L}$ & $<0.025$ & $<0.025$ & $<0.040$ & $<0.040$ \\
\hline Silver - filtered & $\mathrm{mg} / \mathrm{L}$ & $<0.0005$ & $<0.0005$ & $<0.0005$ & $<0.0005$ \\
\hline Thallium - filtered & $\mathrm{mg} / \mathrm{L}$ & $<0.001$ & $<0.001$ & $<0.001$ & $<0.001$ \\
\hline V anadium - filtered & $\mathrm{mg} / \mathrm{L}$ & $<0.020$ & $<0.020$ & $<0.024$ & $<0.024$ \\
\hline Zinc - filtered & $\mathrm{mg} / \mathrm{L}$ & $<0.010$ & $<0.010$ & $<0.011$ & $<0.011$ \\
\hline Phenols & $\mathrm{mg} / \mathrm{L}$ & $<0.005$ & $<0.005$ & $<0.005$ & $<0.005$ \\
\hline Hydrogen-3 & $\mathrm{pCi} / \mathrm{L}$ & $<100$ & $<100$ & $<100$ & $<100$ \\
\hline Chloride & $\mathrm{mg} / \mathrm{L}$ & - & 144 & - & - \\
\hline Fluoride & $\mathrm{mg} / \mathrm{L}$ & - & 0.312 & - & - \\
\hline Sulfate & $\mathrm{mg} / \mathrm{L}$ & - & 103 & - & - \\
\hline Total organic carbons & $\mathrm{mg} / \mathrm{L}$ & 3.3 & 4.0 & 2.6 & $<1.0$ \\
\hline Total organic carbons & $\mathrm{mg} / \mathrm{L}$ & 3.5 & 4.0 & 2.5 & 1.0 \\
\hline Total organic carbons & $\mathrm{mg} / \mathrm{L}$ & 3.7 & 4.0 & 2.9 & $<1.0$ \\
\hline Total organic carbons & $\mathrm{mg} / \mathrm{L}$ & 3.8 & 4.0 & 2.9 & $<1.0$ \\
\hline Total organic halogens & $\mathrm{mg} / \mathrm{L}$ & 0.025 & 0.044 & 0.065 & 0.064 \\
\hline Total organic halogens & $\mathrm{mg} / \mathrm{L}$ & 0.030 & 0.050 & 0.063 & 0.061 \\
\hline
\end{tabular}

a $\quad$ ell point elevation $=183.77 \mathrm{~m}(\mathrm{M} \mathrm{SL})$; ground surface elevation $=230.76 \mathrm{~m}(\mathrm{M} \mathrm{SL})$; casing material $=$ stainless steel.

b A hyphen indicates the sample was not analyzed for this constituent. 


\section{GROUNDWATER PROTECTION}

TABLE 6.26

Groundwater M onitoring Results, Sanitary Landfill W ell 800171, 1997ª

\begin{tabular}{|c|c|c|c|c|c|}
\hline \multirow[b]{2}{*}{ Parameter } & \multirow[b]{2}{*}{ Unit } & \multicolumn{4}{|c|}{ Date of Sampling } \\
\hline & & $01 / 07 / 97$ & $04 / 01 / 97$ & $07 / 09 / 97$ & $10 / 07 / 97$ \\
\hline Water elevation & $\mathrm{m}$ & 227.13 & 227.01 & 226.21 & 225.98 \\
\hline Temperature & ${ }^{\circ} \mathrm{C}$ & 11.5 & 10.4 & 10.8 & 12.7 \\
\hline $\mathrm{pH}$ & $\mathrm{pH}$ & 6.79 & 6.71 & 6.76 & 6.81 \\
\hline Redox & $\mathrm{mV}$ & 44 & -27 & -58 & 20 \\
\hline Conductivity & $\mu \mathrm{mhos} / \mathrm{cm}$ & 1,605 & 1,622 & 1,285 & 1,799 \\
\hline Chloride - filtered & $\mathrm{mg} / \mathrm{L}$ & 112 & 54 & 72 & 70 \\
\hline Sulfate - filtered & $\mathrm{mg} / \mathrm{L}$ & 230 & 200 & 211 & 197 \\
\hline TDS - filtered & $\mathrm{mg} / \mathrm{L}$ & 754 & 1,065 & 1,178 & 1,180 \\
\hline Cyanide (total) & $\mathrm{mg} / \mathrm{L}$ & $<0.005$ & $<0.01$ & $<0.01$ & $<0.01$ \\
\hline A rsenic & $\mathrm{mg} / \mathrm{L}$ & $-b$ & 0.0152 & - & - \\
\hline Barium & $\mathrm{mg} / \mathrm{L}$ & - & 0.2935 & - & - \\
\hline Boron & $\mathrm{mg} / \mathrm{L}$ & - & 0.2182 & - & - \\
\hline Cadmium & $\mathrm{mg} / \mathrm{L}$ & - & 0.0006 & - & - \\
\hline Chromium & $\mathrm{mg} / \mathrm{L}$ & - & 0.0387 & - & - \\
\hline Cobalt & $\mathrm{mg} / \mathrm{L}$ & - & 0.0195 & - & - \\
\hline Copper & $\mathrm{mg} / \mathrm{L}$ & - & 0.0401 & - & - \\
\hline Iron & $\mathrm{mg} / \mathrm{L}$ & - & 35.17 & - & - \\
\hline L ead & $\mathrm{mg} / \mathrm{L}$ & - & 0.0210 & - & - \\
\hline$M$ anganese & $\mathrm{mg} / \mathrm{L}$ & - & 1.0990 & - & - \\
\hline M ercury & $\mathrm{mg} / \mathrm{L}$ & - & $<0.0001$ & - & - \\
\hline Nickel & $\mathrm{mg} / \mathrm{L}$ & - & 0.0515 & - & - \\
\hline Selenium & $\mathrm{mg} / \mathrm{L}$ & - & $<0.002$ & - & - \\
\hline Silver & $\mathrm{mg} / \mathrm{L}$ & - & $<0.0005$ & - & - \\
\hline Zinc & $\mathrm{mg} / \mathrm{L}$ & - & 0.1410 & - & - \\
\hline A mmonia nitrogen - filtered & $\mathrm{mg} / \mathrm{L}$ & 0.1 & $<0.1$ & $<0.1$ & $<0.2$ \\
\hline A rsenic - filtered & $\mathrm{mg} / \mathrm{L}$ & $<0.002$ & 0.002 & $<0.002$ & $<0.002$ \\
\hline Barium - filtered & $\mathrm{mg} / \mathrm{L}$ & 0.1141 & 0.1058 & 0.0974 & 0.1882 \\
\hline Beryllium - filtered & $\mathrm{mg} / \mathrm{L}$ & $<0.0002$ & $<0.0002$ & $<0.0002$ & $<0.0002$ \\
\hline Cadmium - filtered & $\mathrm{mg} / \mathrm{L}$ & $<0.0001$ & $<0.0001$ & 0.0001 & $<0.0001$ \\
\hline Chromium - filtered & $\mathrm{mg} / \mathrm{L}$ & $<0.020$ & $<0.020$ & $<0.044$ & $<0.044$ \\
\hline Cobalt - filtered & $\mathrm{mg} / \mathrm{L}$ & $<0.015$ & $<0.015$ & $<0.026$ & $<0.026$ \\
\hline Copper - filtered & $\mathrm{mg} / \mathrm{L}$ & $<0.020$ & $<0.020$ & $<0.017$ & $<0.017$ \\
\hline Iron - filtered & $\mathrm{mg} / \mathrm{L}$ & 0.0372 & $<0.025$ & $<0.037$ & $<0.037$ \\
\hline L ead - filtered & $\mathrm{mg} / \mathrm{L}$ & $<0.001$ & $<0.001$ & $<0.001$ & $<0.001$ \\
\hline M anganese - filtered & $\mathrm{mg} / \mathrm{L}$ & 0.5171 & 0.5213 & 0.2957 & 0.3493 \\
\hline M ercury - filtered & $\mathrm{mg} / \mathrm{L}$ & $<0.0001$ & $<0.0001$ & $<0.0001$ & $<0.0001$ \\
\hline Nickel - filtered & $\mathrm{mg} / \mathrm{L}$ & $<0.025$ & $<0.025$ & $<0.040$ & 0.0509 \\
\hline Silver - filtered & $\mathrm{mg} / \mathrm{L}$ & $<0.0005$ & $<0.0005$ & $<0.0005$ & $<0.0005$ \\
\hline Thallium - filtered & $\mathrm{mg} / \mathrm{L}$ & $<0.001$ & $<0.001$ & $<0.001$ & $<0.001$ \\
\hline V anadium - filtered & $\mathrm{mg} / \mathrm{L}$ & $<0.020$ & $<0.020$ & $<0.024$ & $<0.024$ \\
\hline Zinc - filtered & $\mathrm{mg} / \mathrm{L}$ & $<0.010$ & $<0.010$ & 0.0345 & 0.0352 \\
\hline Phenols & $\mathrm{mg} / \mathrm{L}$ & $<0.005$ & $<0.005$ & $<0.005$ & $<0.005$ \\
\hline Hydrogen-3 & $\mathrm{pCi} / \mathrm{L}$ & 172 & 134 & 162 & 193 \\
\hline Chloride & $\mathrm{mg} / \mathrm{L}$ & - & 69 & - & - \\
\hline Fluoride & $\mathrm{mg} / \mathrm{L}$ & - & 0.188 & - & - \\
\hline Sulfate & $\mathrm{mg} / \mathrm{L}$ & - & 188 & - & - \\
\hline Total organic carbons & $\mathrm{mg} / \mathrm{L}$ & 4.3 & 3.5 & 2.9 & 2.0 \\
\hline Total organic carbons & $\mathrm{mg} / \mathrm{L}$ & 4.1 & 3.4 & 3.0 & 1.6 \\
\hline Total organic carbons & $\mathrm{mg} / \mathrm{L}$ & 4.1 & 3.5 & 3.2 & 1.8 \\
\hline Total organic carbons & $\mathrm{mg} / \mathrm{L}$ & 4.3 & 3.6 & 3.6 & 1.5 \\
\hline Total organic halogens & $\mathrm{mg} / \mathrm{L}$ & 0.041 & 0.065 & 0.014 & 0.100 \\
\hline Total organic halogens & $\mathrm{mg} / \mathrm{L}$ & 0.040 & 0.080 & 0.014 & 0.140 \\
\hline
\end{tabular}

a Well point elevation $=220.71 \mathrm{~m}(\mathrm{MSL})$; ground surface elevation $=228.42 \mathrm{~m}(\mathrm{M} \mathrm{SL})$; casing material $=$ stainless steel.

b A hyphen indicates that the sample was not analyzed for this constituent. 
TABLE 6.27

Groundwater M onitoring Results, Sanitary Landfill Well 800173D, 1997ª

\begin{tabular}{|c|c|c|c|c|c|}
\hline \multirow[b]{2}{*}{ Parameter } & \multirow[b]{2}{*}{ Unit } & \multicolumn{4}{|c|}{ Date of Sampling } \\
\hline & & $01 / 07 / 97$ & $04 / 01 / 97$ & 07/09/97 & $10 / 07 / 97$ \\
\hline W ater elevation & $\mathrm{m}$ & 192.88 & 193.23 & 193.07 & 192.99 \\
\hline Temperature & ${ }^{\circ} \mathrm{C}$ & 10.7 & 11.8 & 11.6 & 11.9 \\
\hline $\mathrm{pH}$ & $\mathrm{pH}$ & 7.01 & 6.89 & 7.01 & 7.11 \\
\hline Redox & $\mathrm{mV}$ & 31 & -15 & -25 & 3 \\
\hline Conductivity & $\mu \mathrm{mhos} / \mathrm{cm}$ & 1,398 & 1,392 & 1,125 & 1,465 \\
\hline Chloride - filtered & $\mathrm{mg} / \mathrm{L}$ & 175 & 159 & 216 & 197 \\
\hline Sulfate - filtered & $\mathrm{mg} / \mathrm{L}$ & 160 & 17 & 99 & 78 \\
\hline TDS - filtered & $\mathrm{mg} / \mathrm{L}$ & 861 & 810 & 999 & 926 \\
\hline Cyanide (total) & $\mathrm{mg} / \mathrm{L}$ & $<0.005$ & 0.018 & $<0.010$ & $<0.010$ \\
\hline Arsenic & $\mathrm{mg} / \mathrm{L}$ & $-b$ & 0.0057 & - & - \\
\hline Barium & $\mathrm{mg} / \mathrm{L}$ & - & 0.1019 & - & - \\
\hline Boron & $\mathrm{mg} / \mathrm{L}$ & - & 0.2186 & - & - \\
\hline Cadmium & $\mathrm{mg} / \mathrm{L}$ & - & 0.0001 & - & - \\
\hline Chromium & $\mathrm{mg} / \mathrm{L}$ & - & $<0.02$ & - & - \\
\hline Cobalt & $\mathrm{mg} / \mathrm{L}$ & - & 0.0175 & - & - \\
\hline Copper & $\mathrm{mg} / \mathrm{L}$ & - & $<0.02$ & - & - \\
\hline Iron & $\mathrm{mg} / \mathrm{L}$ & - & 5.5030 & - & - \\
\hline Lead & $\mathrm{mg} / \mathrm{L}$ & - & 0.0017 & - & - \\
\hline$M$ anganese & $\mathrm{mg} / \mathrm{L}$ & - & 0.1277 & - & - \\
\hline M ercury & $\mathrm{mg} / \mathrm{L}$ & - & $<0.0001$ & - & - \\
\hline Nickel & $\mathrm{mg} / \mathrm{L}$ & - & $<0.025$ & - & - \\
\hline Selenium & $\mathrm{mg} / \mathrm{L}$ & - & $<0.002$ & - & - \\
\hline Silver & $\mathrm{mg} / \mathrm{L}$ & - & $<0.0005$ & - & - \\
\hline Zinc & $\mathrm{mg} / \mathrm{L}$ & - & 0.0187 & - & - \\
\hline A mmonia nitrogen - filtered & $\mathrm{mg} / \mathrm{L}$ & 0.6 & 0.6 & 0.8 & 0.8 \\
\hline A rsenic - filtered & $\mathrm{mg} / \mathrm{L}$ & 0.0039 & 0.0051 & 0.0060 & 0.0026 \\
\hline Barium - filtered & $\mathrm{mg} / \mathrm{L}$ & 0.0925 & 0.0950 & 0.0854 & 0.0828 \\
\hline Beryllium - filtered & $\mathrm{mg} / \mathrm{L}$ & 0.0003 & $<0.0002$ & $<0.0002$ & $<0.0002$ \\
\hline Cadmium - filtered & $\mathrm{mg} / \mathrm{L}$ & $<0.0001$ & $<0.0001$ & $<0.0001$ & $<0.0001$ \\
\hline Chromium - filtered & $\mathrm{mg} / \mathrm{L}$ & $<0.020$ & $<0.020$ & $<0.044$ & $<0.044$ \\
\hline Cobalt - filtered & $\mathrm{mg} / \mathrm{L}$ & $<0.015$ & $<0.015$ & $<0.026$ & $<0.026$ \\
\hline Copper - filtered & $\mathrm{mg} / \mathrm{L}$ & $<0.020$ & $<0.020$ & $<0.017$ & $<0.017$ \\
\hline Iron - filtered & $\mathrm{mg} / \mathrm{L}$ & 2.8230 & 3.3670 & 2.2650 & 0.9446 \\
\hline L ead - filtered & $\mathrm{mg} / \mathrm{L}$ & $<0.001$ & $<0.001$ & $<0.001$ & $<0.001$ \\
\hline$M$ anganese - filtered & $\mathrm{mg} / \mathrm{L}$ & 0.1018 & 0.0865 & 0.0829 & 0.1067 \\
\hline M ercury - filtered & $\mathrm{mg} / \mathrm{L}$ & $<0.0001$ & $<0.0001$ & $<0.0001$ & $<0.0001$ \\
\hline Nickel - filtered & $\mathrm{mg} / \mathrm{L}$ & $<0.025$ & $<0.025$ & $<0.040$ & $<0.040$ \\
\hline Silver - filtered & $\mathrm{mg} / \mathrm{L}$ & $<0.0005$ & $<0.0005$ & $<0.0005$ & $<0.0005$ \\
\hline Thallium - filtered & $\mathrm{mg} / \mathrm{L}$ & $<0.001$ & $<0.001$ & $<0.001$ & $<0.001$ \\
\hline V anadium - filtered & $\mathrm{mg} / \mathrm{L}$ & $<0.020$ & $<0.020$ & $<0.024$ & $<0.024$ \\
\hline Zinc - filtered & $\mathrm{mg} / \mathrm{L}$ & $<0.010$ & $<0.010$ & $<0.011$ & $<0.011$ \\
\hline Phenols & $\mathrm{mg} / \mathrm{L}$ & 0.0070 & $<0.0050$ & $<0.0050$ & 0.0059 \\
\hline Hydrogen-3 & $\mathrm{pCi} / \mathrm{L}$ & $<100$ & $<100$ & $<100$ & $<100$ \\
\hline Chloride & $\mathrm{mg} / \mathrm{L}$ & - & 172 & - & - \\
\hline Fluoride & $\mathrm{mg} / \mathrm{L}$ & - & 0.3380 & - & - \\
\hline Sulfate & $\mathrm{mg} / \mathrm{L}$ & - & 16 & - & - \\
\hline Total organic carbons & $\mathrm{mg} / \mathrm{L}$ & 6.5 & 5.0 & 4.5 & 2.4 \\
\hline Total organic carbons & $\mathrm{mg} / \mathrm{L}$ & 6.7 & 4.8 & 4.5 & 2.7 \\
\hline Total organic carbons & $\mathrm{mg} / \mathrm{L}$ & 6.5 & 4.9 & 4.9 & 2.7 \\
\hline Total organic carbons & $\mathrm{mg} / \mathrm{L}$ & 6.5 & 4.7 & 4.9 & 3.0 \\
\hline Total organic halogens & $\mathrm{mg} / \mathrm{L}$ & 0.059 & 0.027 & 0.081 & 0.063 \\
\hline Total organic halogens & $\mathrm{mg} / \mathrm{L}$ & 0.073 & 0.021 & 0.061 & 0.073 \\
\hline
\end{tabular}

a $\quad$ Well point elevation $=189.34 \mathrm{~m}(\mathrm{MSL})$; ground surface elevation $=228.42 \mathrm{~m}(\mathrm{MSL})$; casing material $=$ stainless steel.

b A hyphen indicates that the sample was not analyzed for this constituent. 


\section{GROUNDWATER PROTECTION}

TABLE 6.28

Groundwater M onitoring Results, Sanitary Landfill W ell 800181, 1997ª

\begin{tabular}{|c|c|c|c|c|c|c|}
\hline \multirow[b]{2}{*}{ Parameter } & \multirow[b]{2}{*}{ Unit } & \multicolumn{5}{|c|}{ Date of Sampling } \\
\hline & & $01 / 07 / 97$ & $04 / 14 / 97$ & $07 / 15 / 97$ & $07 / 15 / 97$ & $10 / 08 / 97$ \\
\hline W ater elevation & $\mathrm{m}$ & 223.07 & 223.11 & 222.51 & 222.51 & 222.21 \\
\hline Temperature & ${ }^{\circ} \mathrm{C}$ & 9.4 & 10.3 & 9.9 & 9.9 & 10.3 \\
\hline $\mathrm{pH}$ & $\mathrm{pH}$ & 7.02 & 7.00 & 7.09 & 7.09 & 7.12 \\
\hline Redox & $\mathrm{mV}$ & -11 & -12 & -46 & -46 & 3 \\
\hline Conductivity & $\mu \mathrm{mhos} / \mathrm{cm}$ & 1,370 & 1,325 & 892 & 892 & 1,295 \\
\hline Chloride - filtered & $\mathrm{mg} / \mathrm{L}$ & 4 & 5 & 5 & 5 & 4 \\
\hline Sulfate - filtered & $\mathrm{mg} / \mathrm{L}$ & 242 & 206 & 223 & 221 & 224 \\
\hline TDS - filtered & $\mathrm{mg} / \mathrm{L}$ & 881 & 843 & 830 & 822 & 870 \\
\hline Cyanide (total) & $\mathrm{mg} / \mathrm{L}$ & $<0.005$ & $<0.010$ & $<0.010$ & $<0.010$ & $<0.010$ \\
\hline A rsenic & $\mathrm{mg} / \mathrm{L}$ & $-b$ & 0.0057 & - & - & - \\
\hline Barium & $\mathrm{mg} / \mathrm{L}$ & - & 0.2176 & - & - & - \\
\hline Boron & $\mathrm{mg} / \mathrm{L}$ & - & 0.1320 & - & - & - \\
\hline Cadmium & $\mathrm{mg} / \mathrm{L}$ & - & 0.0003 & - & - & - \\
\hline Chromium & $\mathrm{mg} / \mathrm{L}$ & - & 0.0309 & - & - & - \\
\hline Cobalt & $\mathrm{mg} / \mathrm{L}$ & - & $<0.015$ & - & - & - \\
\hline Copper & $\mathrm{mg} / \mathrm{L}$ & - & $<0.02$ & - & - & - \\
\hline Iron & $\mathrm{mg} / \mathrm{L}$ & - & 22.5 & - & - & - \\
\hline Lead & $\mathrm{mg} / \mathrm{L}$ & - & 0.0086 & - & - & - \\
\hline$M$ anganese & $\mathrm{mg} / \mathrm{L}$ & - & 0.4198 & - & - & - \\
\hline M ercury & $\mathrm{mg} / \mathrm{L}$ & - & $<0.0001$ & - & - & - \\
\hline Nickel & $\mathrm{mg} / \mathrm{L}$ & - & 0.0331 & - & - & - \\
\hline Selenium & $\mathrm{mg} / \mathrm{L}$ & - & $<0.002$ & - & - & - \\
\hline Silver & $\mathrm{mg} / \mathrm{L}$ & - & $<0.0005$ & - & - & - \\
\hline Zinc & $\mathrm{mg} / \mathrm{L}$ & - & 0.1398 & - & - & - \\
\hline A mmonia nitrogen - filtered & $\mathrm{mg} / \mathrm{L}$ & 0.1 & 0.3 & 0.3 & $<0.1$ & $<0.2$ \\
\hline A rsenic - filtered & $\mathrm{mg} / \mathrm{L}$ & $<0.002$ & 0.0023 & $<0.002$ & $<0.002$ & $<0.002$ \\
\hline Barium - filtered & $\mathrm{mg} / \mathrm{L}$ & 0.1111 & 0.1108 & 0.1146 & 0.1186 & 0.1028 \\
\hline Beryllium - filtered & $\mathrm{mg} / \mathrm{L}$ & $<0.0002$ & $<0.0002$ & $<0.0002$ & $<0.0002$ & $<0.0002$ \\
\hline Cadmium - filtered & $\mathrm{mg} / \mathrm{L}$ & $<0.0001$ & $<0.0001$ & $<0.0001$ & $<0.0001$ & $<0.0001$ \\
\hline Chromium - filtered & $\mathrm{mg} / \mathrm{L}$ & $<0.020$ & $<0.020$ & $<0.044$ & $<0.044$ & $<0.044$ \\
\hline Cobalt - filtered & $\mathrm{mg} / \mathrm{L}$ & $<0.015$ & $<0.015$ & $<0.026$ & $<0.026$ & $<0.026$ \\
\hline Copper - filtered & $\mathrm{mg} / \mathrm{L}$ & $<0.020$ & $<0.020$ & $<0.017$ & $<0.017$ & $<0.017$ \\
\hline Iron - filtered & $\mathrm{mg} / \mathrm{L}$ & $<0.025$ & $<0.025$ & $<0.037$ & $<0.037$ & $<0.037$ \\
\hline Lead - filtered & $\mathrm{mg} / \mathrm{L}$ & $<0.001$ & $<0.001$ & $<0.001$ & $<0.001$ & $<0.001$ \\
\hline$M$ anganese - filtered & $\mathrm{mg} / \mathrm{L}$ & 0.0938 & $<0.0100$ & 0.0869 & $<0.017$ & $<0.017$ \\
\hline M ercury - filtered & $\mathrm{mg} / \mathrm{L}$ & $<0.0001$ & $<0.0001$ & $<0.0001$ & $<0.0001$ & $<0.0001$ \\
\hline Nickel - filtered & $\mathrm{mg} / \mathrm{L}$ & $<0.025$ & $<0.025$ & $<0.040$ & $<0.040$ & $<0.040$ \\
\hline Silver - filtered & $\mathrm{mg} / \mathrm{L}$ & $<0.0005$ & $<0.0005$ & $<0.0005$ & $<0.0005$ & $<0.0005$ \\
\hline Thallium - filtered & $\mathrm{mg} / \mathrm{L}$ & $<0.001$ & $<0.001$ & $<0.001$ & $<0.001$ & $<0.001$ \\
\hline V anadium - filtered & $\mathrm{mg} / \mathrm{L}$ & $<0.020$ & $<0.020$ & $<0.024$ & $<0.024$ & $<0.024$ \\
\hline Zinc - filtered & $\mathrm{mg} / \mathrm{L}$ & $<0.010$ & 0.0347 & 0.0230 & 0.0379 & $<0.011$ \\
\hline Phenols & $\mathrm{mg} / \mathrm{L}$ & $<0.005$ & 0.014 & $<0.005$ & $<0.005$ & $<0.005$ \\
\hline Hydrogen-3 & $\mathrm{pCi} / \mathrm{L}$ & $<100$ & $<100$ & $<100$ & $<100$ & $<100$ \\
\hline Chloride & $\mathrm{mg} / \mathrm{L}$ & - & 4 & - & - & - \\
\hline Fluoride & $\mathrm{mg} / \mathrm{L}$ & - & 0.21 & - & - & - \\
\hline Sulfate & $\mathrm{mg} / \mathrm{L}$ & - & 216 & - & - & - \\
\hline Total organic carbons & $\mathrm{mg} / \mathrm{L}$ & 2.3 & 1.8 & 1.8 & 2.1 & $<1.0$ \\
\hline Total organic carbons & $\mathrm{mg} / \mathrm{L}$ & 2.2 & 1.7 & 2.0 & 2.1 & $<1.0$ \\
\hline Total organic carbons & $\mathrm{mg} / \mathrm{L}$ & 2.4 & 1.8 & 2.0 & 2.3 & $<1.0$ \\
\hline Total organic carbons & $\mathrm{mg} / \mathrm{L}$ & 2.4 & 1.7 & 1.7 & 1.8 & $<1.0$ \\
\hline Total organic halogens & $\mathrm{mg} / \mathrm{L}$ & 0.010 & 0.011 & 0.015 & 0.020 & 0.021 \\
\hline Total organic halogens & $\mathrm{mg} / \mathrm{L}$ & $<0.010$ & 0.014 & 0.015 & 0.028 & 0.025 \\
\hline
\end{tabular}

a Well point elevation $=219.52 \mathrm{~m}(\mathrm{MSL})$; ground surface elevation $=230.52 \mathrm{~m}(\mathrm{M} \mathrm{SL})$; casing material $=$ stainless steel.

b A hyphen indicates that the sample was not analyzed for this constituent. 
TABLE 6.29

Groundwater M onitoring Results, Sanitary L andfill W ell 800183D, 1997ª

\begin{tabular}{|c|c|c|c|c|c|c|}
\hline \multirow[b]{2}{*}{ Parameter } & \multirow[b]{2}{*}{ Unit } & \multicolumn{5}{|c|}{ Date of Sampling } \\
\hline & & $01 / 07 / 97$ & $01 / 07 / 97$ & $04 / 03 / 97$ & $07 / 09 / 97$ & $10 / 07 / 97$ \\
\hline W ater elevation & $\mathrm{m}$ & 192.88 & 192.88 & 193.22 & 193.07 & 193.00 \\
\hline Temperature & ${ }^{\circ} \mathrm{C}$ & 11.0 & 11.0 & 11.9 & 11.6 & 12.1 \\
\hline $\mathrm{pH}$ & $\mathrm{pH}$ & 7.00 & 7.00 & 6.97 & 7.04 & 7.10 \\
\hline Redox & $\mathrm{mV}$ & -12 & -12 & -13 & -53 & 4 \\
\hline Conductivity & $\mu \mathrm{mhos} / \mathrm{cm}$ & 1,303 & 1,303 & 1,288 & 954 & 1,282 \\
\hline Chloride - filtered & $\mathrm{mg} / \mathrm{L}$ & 112 & 66 & 114 & 112 & 110 \\
\hline Sulfate - filtered & $\mathrm{mg} / \mathrm{L}$ & 177 & 183 & 156 & 213 & 235 \\
\hline TDS - filtered & $\mathrm{mg} / \mathrm{L}$ & 736 & 1,076 & 765 & 895 & 820 \\
\hline Cyanide (total) & $\mathrm{mg} / \mathrm{L}$ & $<0.005$ & $<0.005$ & $<0.010$ & $<0.010$ & $<0.010$ \\
\hline Arsenic & $\mathrm{mg} / \mathrm{L}$ & $-b$ & - & 0.0043 & - & - \\
\hline Barium & $\mathrm{mg} / \mathrm{L}$ & - & - & 0.0515 & - & - \\
\hline Boron & $\mathrm{mg} / \mathrm{L}$ & - & - & 0.2098 & - & - \\
\hline Cadmium & $\mathrm{mg} / \mathrm{L}$ & - & - & $<0.0001$ & - & - \\
\hline Chromium & $\mathrm{mg} / \mathrm{L}$ & - & - & $<0.02$ & - & - \\
\hline Cobalt & $\mathrm{mg} / \mathrm{L}$ & - & - & $<0.015$ & - & - \\
\hline Copper & $\mathrm{mg} / \mathrm{L}$ & - & - & $<0.02$ & - & - \\
\hline Iron & $\mathrm{mg} / \mathrm{L}$ & - & - & 2.8650 & - & - \\
\hline Lead & $\mathrm{mg} / \mathrm{L}$ & - & - & $<0.001$ & - & - \\
\hline M anganese & $\mathrm{mg} / \mathrm{L}$ & - & - & 0.0218 & - & - \\
\hline M ercury & $\mathrm{mg} / \mathrm{L}$ & - & - & $<0.0001$ & - & - \\
\hline Nickel & $\mathrm{mg} / \mathrm{L}$ & - & - & $<0.025$ & - & - \\
\hline Selenium & $\mathrm{mg} / \mathrm{L}$ & - & - & $<0.002$ & - & - \\
\hline Silver & $\mathrm{mg} / \mathrm{L}$ & - & - & 0.0008 & - & - \\
\hline Zinc & $\mathrm{mg} / \mathrm{L}$ & - & - & $<0.01$ & - & - \\
\hline A mmonia nitrogen - filtered & $\mathrm{mg} / \mathrm{L}$ & 0.9 & 0.9 & 0.7 & 0.9 & 0.8 \\
\hline A rsenic - filtered & $\mathrm{mg} / \mathrm{L}$ & 0.0155 & 0.0146 & $<0.002$ & $<0.002$ & $<0.002$ \\
\hline Barium - filtered & $\mathrm{mg} / \mathrm{L}$ & 0.0567 & 0.0516 & 0.0477 & 0.0461 & 0.0408 \\
\hline Beryllium - filtered & $\mathrm{mg} / \mathrm{L}$ & $<0.0002$ & $<0.0002$ & $<0.0002$ & $<0.0002$ & $<0.0002$ \\
\hline Cadmium - filtered & $\mathrm{mg} / \mathrm{L}$ & $<0.0001$ & $<0.0001$ & $<0.0001$ & $<0.0001$ & $<0.0001$ \\
\hline Chromium - filtered & $\mathrm{mg} / \mathrm{L}$ & $<0.020$ & $<0.020$ & $<0.020$ & $<0.044$ & $<0.044$ \\
\hline Cobalt - filtered & $\mathrm{mg} / \mathrm{L}$ & $<0.015$ & $<0.015$ & $<0.015$ & $<0.026$ & $<0.026$ \\
\hline Copper - filtered & $\mathrm{mg} / \mathrm{L}$ & $<0.020$ & $<0.020$ & $<0.020$ & $<0.017$ & $<0.017$ \\
\hline Iron - filtered & $\mathrm{mg} / \mathrm{L}$ & 0.6801 & 0.8032 & 0.9111 & 0.7834 & 0.7186 \\
\hline Lead - filtered & $\mathrm{mg} / \mathrm{L}$ & $<0.001$ & $<0.001$ & $<0.001$ & $<0.001$ & $<0.001$ \\
\hline $\mathrm{M}$ anganese - filtered & $\mathrm{mg} / \mathrm{L}$ & 0.0145 & 0.0158 & 0.0151 & 0.0174 & $<0.017$ \\
\hline M ercury - filtered & $\mathrm{mg} / \mathrm{L}$ & $<0.0001$ & $<0.0001$ & $<0.0001$ & $<0.0001$ & 0.0001 \\
\hline Nickel - filtered & $\mathrm{mg} / \mathrm{L}$ & 0.0766 & 0.0753 & $<0.025$ & $<0.040$ & $<0.040$ \\
\hline Silver - filtered & $\mathrm{mg} / \mathrm{L}$ & $<0.0005$ & $<0.0005$ & $<0.0005$ & $<0.0005$ & $<0.0005$ \\
\hline Thallium - filtered & $\mathrm{mg} / \mathrm{L}$ & $<0.001$ & $<0.001$ & $<0.001$ & $<0.001$ & $<0.001$ \\
\hline V anadium - filtered & $\mathrm{mg} / \mathrm{L}$ & $<0.020$ & $<0.020$ & $<0.020$ & $<0.024$ & $<0.024$ \\
\hline Zinc - filtered & $\mathrm{mg} / \mathrm{L}$ & $<0.010$ & $<0.010$ & $<0.010$ & $<0.011$ & $<0.011$ \\
\hline Phenols & $\mathrm{mg} / \mathrm{L}$ & $<0.005$ & $<0.005$ & 0.009 & 0.009 & $<0.005$ \\
\hline Hydrogen-3 & $\mathrm{pCi} / \mathrm{L}$ & $<100$ & $<100$ & $<100$ & $<100$ & $<100$ \\
\hline Chloride & $\mathrm{mg} / \mathrm{L}$ & - & - & 111 & - & - \\
\hline Fluoride & $\mathrm{mg} / \mathrm{L}$ & - & - & 0.336 & - & - \\
\hline Sulfate & $\mathrm{mg} / \mathrm{L}$ & - & - & 167 & - & - \\
\hline Total organic carbons & $\mathrm{mg} / \mathrm{L}$ & 3.0 & 2.6 & 2.5 & 1.7 & $<1.0$ \\
\hline Total organic carbons & $\mathrm{mg} / \mathrm{L}$ & 2.8 & 3.1 & 2.4 & 1.7 & $<1.0$ \\
\hline Total organic carbons & $\mathrm{mg} / \mathrm{L}$ & 2.8 & 2.7 & 2.6 & 2.2 & $<1.0$ \\
\hline Total organic carbons & $\mathrm{mg} / \mathrm{L}$ & 2.8 & 2.8 & 2.4 & 2.1 & $<1.0$ \\
\hline Total organic halogens & $\mathrm{mg} / \mathrm{L}$ & 0.037 & 0.087 & 0.030 & 0.067 & 0.130 \\
\hline Total organic halogens & $\mathrm{mg} / \mathrm{L}$ & 0.032 & 0.081 & 0.026 & 0.073 & 0.150 \\
\hline
\end{tabular}

a Well point elevation $=180.69 \mathrm{~m}(\mathrm{MSL})$; ground surface elevation $=230.37 \mathrm{~m}(\mathrm{M} \mathrm{SL})$; casing material $=$ stainless steel.

b A hyphen indicates that the sample was not analyzed for this constituent. 


\section{GROUNDWATER PROTECTION}

TABLE 6.30

Groundwater M onitoring Results, Sanitary L andfill W ell 800191, 1997ª

\begin{tabular}{|c|c|c|c|c|c|}
\hline \multirow[b]{2}{*}{ Parameter } & \multirow[b]{2}{*}{ Unit } & \multicolumn{4}{|c|}{ Date of Sampling } \\
\hline & & $01 / 08 / 97$ & $04 / 02 / 97$ & $07 / 08 / 97$ & $10 / 08 / 97$ \\
\hline Water elevation & $\mathrm{m}$ & 226.49 & 226.41 & 225.86 & 225.95 \\
\hline Temperature & ${ }^{\circ} \mathrm{C}$ & 9.4 & 7.6 & 9.9 & 13.0 \\
\hline $\mathrm{pH}$ & $\mathrm{pH}$ & 6.78 & 6.92 & 6.82 & 7.09 \\
\hline Redox & $\mathrm{mV}$ & 1 & -25 & -29 & 4 \\
\hline Conductivity & $\mu \mathrm{mhos} / \mathrm{cm}$ & 1,888 & 1,960 & 1,239 & 2,100 \\
\hline Chloride - filtered & $\mathrm{mg} / \mathrm{L}$ & 216 & 178 & 159 & 390 \\
\hline Sulfate - filtered & $\mathrm{mg} / \mathrm{L}$ & 136 & 140 & 298 & 216 \\
\hline TDS - filtered & $\mathrm{mg} / \mathrm{L}$ & 1,240 & 1,546 & 1,258 & 1,308 \\
\hline Cyanide (total) & $\mathrm{mg} / \mathrm{L}$ & $<0.005$ & $<0.010$ & $<0.010$ & $<0.010$ \\
\hline A rsenic & $\mathrm{mg} / \mathrm{L}$ & $-b$ & 0.0064 & - & - \\
\hline Barium & $\mathrm{mg} / \mathrm{L}$ & - & 0.2473 & - & - \\
\hline Boron & $\mathrm{mg} / \mathrm{L}$ & - & 0.2009 & - & - \\
\hline Cadmium & $\mathrm{mg} / \mathrm{L}$ & - & 0.0007 & - & - \\
\hline Chromium & $\mathrm{mg} / \mathrm{L}$ & - & 0.0282 & - & - \\
\hline Cobalt & $\mathrm{mg} / \mathrm{L}$ & - & $<0.015$ & - & - \\
\hline Copper & $\mathrm{mg} / \mathrm{L}$ & - & 0.0473 & - & - \\
\hline Iron & $\mathrm{mg} / \mathrm{L}$ & - & 33.38 & - & - \\
\hline L ead & $\mathrm{mg} / \mathrm{L}$ & - & 0.0260 & - & - \\
\hline$M$ anganese & $\mathrm{mg} / \mathrm{L}$ & - & 2.1320 & - & - \\
\hline M ercury & $\mathrm{mg} / \mathrm{L}$ & - & $<0.0001$ & - & - \\
\hline Nickel & $\mathrm{mg} / \mathrm{L}$ & - & $<0.025$ & - & - \\
\hline Selenium & $\mathrm{mg} / \mathrm{L}$ & - & $<0.002$ & - & - \\
\hline Silver & $\mathrm{mg} / \mathrm{L}$ & - & $<0.0005$ & - & - \\
\hline Zinc & $\mathrm{mg} / \mathrm{L}$ & - & 0.1460 & - & - \\
\hline A mmonia nitrogen - filtered & $\mathrm{mg} / \mathrm{L}$ & 0.3 & 0.3 & 0.6 & 0.39 \\
\hline A rsenic - filtered & $\mathrm{mg} / \mathrm{L}$ & $<0.002$ & $<0.002$ & $<0.002$ & $<0.002$ \\
\hline Barium - filtered & $\mathrm{mg} / \mathrm{L}$ & 0.0814 & 0.0945 & 0.0653 & 0.0715 \\
\hline Beryllium - filtered & $\mathrm{mg} / \mathrm{L}$ & $<0.0002$ & $<0.0002$ & $<0.0002$ & $<0.0002$ \\
\hline Cadmium - filtered & $\mathrm{mg} / \mathrm{L}$ & $<0.0001$ & $<0.0001$ & $<0.0001$ & $<0.0001$ \\
\hline Chromium - filtered & $\mathrm{mg} / \mathrm{L}$ & $<0.020$ & $<0.020$ & $<0.044$ & $<0.044$ \\
\hline Cobalt - filtered & $\mathrm{mg} / \mathrm{L}$ & $<0.015$ & $<0.015$ & $<0.026$ & $<0.026$ \\
\hline Copper - filtered & $\mathrm{mg} / \mathrm{L}$ & $<0.020$ & $<0.020$ & $<0.017$ & $<0.017$ \\
\hline Iron - filtered & $\mathrm{mg} / \mathrm{L}$ & 1.2570 & 5.0850 & 2.3630 & 1.1720 \\
\hline L ead - filtered & $\mathrm{mg} / \mathrm{L}$ & $<0.001$ & $<0.001$ & $<0.001$ & $<0.001$ \\
\hline$M$ anganese - filtered & $\mathrm{mg} / \mathrm{L}$ & 2.0570 & 1.6810 & 1.2660 & 1.4760 \\
\hline M ercury - filtered & $\mathrm{mg} / \mathrm{L}$ & $<0.0001$ & $<0.0001$ & $<0.0001$ & $<0.0001$ \\
\hline Nickel - filtered & $\mathrm{mg} / \mathrm{L}$ & $<0.025$ & $<0.025$ & $<0.040$ & $<0.040$ \\
\hline Silver - filtered & $\mathrm{mg} / \mathrm{L}$ & $<0.0005$ & $<0.0005$ & $<0.0005$ & $<0.0005$ \\
\hline Thallium - filtered & $\mathrm{mg} / \mathrm{L}$ & $<0.001$ & $<0.001$ & $<0.001$ & $<0.001$ \\
\hline V anadium - filtered & $\mathrm{mg} / \mathrm{L}$ & $<0.020$ & $<0.020$ & $<0.024$ & $<0.024$ \\
\hline Zinc - filtered & $\mathrm{mg} / \mathrm{L}$ & 0.0358 & 0.0240 & 0.0153 & 0.0304 \\
\hline Phenols & $\mathrm{mg} / \mathrm{L}$ & $<0.005$ & $<0.005$ & $<0.005$ & 0.0140 \\
\hline Hydrogen-3 & $\mathrm{pCi} / \mathrm{L}$ & $<100$ & $<100$ & 291 & 163 \\
\hline Chloride & $\mathrm{mg} / \mathrm{L}$ & - & 166 & - & - \\
\hline Fluoride & $\mathrm{mg} / \mathrm{L}$ & - & 0.208 & - & - \\
\hline Sulfate & $\mathrm{mg} / \mathrm{L}$ & - & 134 & - & - \\
\hline Total organic carbons & $\mathrm{mg} / \mathrm{L}$ & 6.8 & 7.6 & 5.7 & 4.0 \\
\hline Total organic carbons & $\mathrm{mg} / \mathrm{L}$ & 7.1 & 7.9 & 5.7 & 4.3 \\
\hline Total organic carbons & $\mathrm{mg} / \mathrm{L}$ & 7.0 & 7.6 & 6.4 & 4.3 \\
\hline Total organic carbons & $\mathrm{mg} / \mathrm{L}$ & 7.2 & 7.7 & 6.4 & $<1.0$ \\
\hline Total organic halogens & $\mathrm{mg} / \mathrm{L}$ & 0.047 & 0.014 & 0.095 & 0.012 \\
\hline Total organic halogens & $\mathrm{mg} / \mathrm{L}$ & 0.040 & 0.020 & 0.089 & 0.012 \\
\hline
\end{tabular}

a $\quad$ ater point elevation $=222.77 \mathrm{~m}(\mathrm{MSL})$; ground surface elevation $=227.38 \mathrm{~m}(\mathrm{MSL})$; casing material $=$ stainless steel.

b A hyphen indicates that the sample was not analyzed for this constituent. 
TABLE 6.31

Groundwater M onitoring Results, Sanitary Landfill Well 800192, 1997ª

\begin{tabular}{|c|c|c|c|c|c|}
\hline \multirow[b]{2}{*}{ Parameter } & \multirow[b]{2}{*}{ Unit } & \multicolumn{4}{|c|}{ Date of Sampling } \\
\hline & & $01 / 08 / 97$ & $04 / 02 / 97$ & 07/08/97 & $10 / 08 / 97$ \\
\hline Water elevation & $\mathrm{m}$ & 223.13 & 223.03 & 222.49 & 222.32 \\
\hline Temperature & ${ }^{\circ} \mathrm{C}$ & 10.7 & 11.4 & 11.3 & 12.0 \\
\hline $\mathrm{pH}$ & $\mathrm{pH}$ & 6.83 & 6.65 & 6.74 & 6.83 \\
\hline Redox & $\mathrm{mV}$ & 4 & -81 & -16 & 18 \\
\hline Conductivity & $\mu \mathrm{mhos} / \mathrm{cm}$ & 1,442 & 1,419 & 1,063 & 1,493 \\
\hline Chloride - filtered & $\mathrm{mg} / \mathrm{L}$ & 49 & 54 & 62 & 60 \\
\hline Sulfate - filtered & $\mathrm{mg} / \mathrm{L}$ & 259 & 211 & 273 & 268 \\
\hline TDS - filtered & $\mathrm{mg} / \mathrm{L}$ & 861 & 904 & 1,016 & 982 \\
\hline Cyanide (total) & $\mathrm{mg} / \mathrm{L}$ & 0.025 & $<0.010$ & $<0.010$ & $<0.010$ \\
\hline A rsenic & $\mathrm{mg} / \mathrm{L}$ & $-b$ & 0.0256 & - & - \\
\hline Barium & $\mathrm{mg} / \mathrm{L}$ & - & 0.6902 & - & - \\
\hline Boron & $\mathrm{mg} / \mathrm{L}$ & - & 0.1761 & - & - \\
\hline Cadmium & $\mathrm{mg} / \mathrm{L}$ & - & 0.0002 & - & - \\
\hline Chromium & $\mathrm{mg} / \mathrm{L}$ & - & 0.2106 & - & - \\
\hline Cobalt & $\mathrm{mg} / \mathrm{L}$ & - & 0.0172 & - & - \\
\hline Copper & $\mathrm{mg} / \mathrm{L}$ & - & 0.0470 & - & - \\
\hline Iron & $\mathrm{mg} / \mathrm{L}$ & - & 46.95 & - & - \\
\hline L ead & $\mathrm{mg} / \mathrm{L}$ & - & 0.0108 & - & - \\
\hline M anganese & $\mathrm{mg} / \mathrm{L}$ & - & 0.6081 & - & - \\
\hline M ercury & $\mathrm{mg} / \mathrm{L}$ & - & $<0.0001$ & - & - \\
\hline Nickel & $\mathrm{mg} / \mathrm{L}$ & - & 0.1612 & - & - \\
\hline Selenium & $\mathrm{mg} / \mathrm{L}$ & - & $<0.002$ & - & - \\
\hline Silver & $\mathrm{mg} / \mathrm{L}$ & - & 0.0006 & - & - \\
\hline Zinc & $\mathrm{mg} / \mathrm{L}$ & - & 0.0579 & - & - \\
\hline A mmonia nitrogen - filtered & $\mathrm{mg} / \mathrm{L}$ & 1.7 & 0.9 & 1.0 & 1.1 \\
\hline A rsenic - filtered & $\mathrm{mg} / \mathrm{L}$ & 0.0030 & $<0.002$ & $<0.002$ & $<0.002$ \\
\hline Barium - filtered & $\mathrm{mg} / \mathrm{L}$ & 0.3515 & 0.4248 & 0.3917 & 0.3796 \\
\hline Beryllium - filtered & $\mathrm{mg} / \mathrm{L}$ & $<0.0002$ & $<0.0002$ & $<0.0002$ & $<0.0002$ \\
\hline Cadmium - filtered & $\mathrm{mg} / \mathrm{L}$ & $<0.0001$ & $<0.0001$ & $<0.0001$ & $<0.0001$ \\
\hline Chromium - filtered & $\mathrm{mg} / \mathrm{L}$ & $<0.020$ & $<0.020$ & $<0.044$ & $<0.044$ \\
\hline Cobalt - filtered & $\mathrm{mg} / \mathrm{L}$ & $<0.015$ & $<0.015$ & $<0.026$ & $<0.026$ \\
\hline Copper - filtered & $\mathrm{mg} / \mathrm{L}$ & $<0.020$ & $<0.020$ & $<0.017$ & $<0.017$ \\
\hline Iron - filtered & $\mathrm{mg} / \mathrm{L}$ & 5.388 & 7.789 & 3.500 & 11.170 \\
\hline L ead - filtered & $\mathrm{mg} / \mathrm{L}$ & $<0.001$ & $<0.001$ & $<0.001$ & $<0.001$ \\
\hline$M$ anganese - filtered & $\mathrm{mg} / \mathrm{L}$ & 0.2507 & 0.2041 & 0.1897 & 0.1884 \\
\hline M ercury - filtered & $\mathrm{mg} / \mathrm{L}$ & $<0.0001$ & $<0.0001$ & $<0.0001$ & $<0.0001$ \\
\hline Nickel - filtered & $\mathrm{mg} / \mathrm{L}$ & $<0.025$ & $<0.025$ & $<0.040$ & $<0.040$ \\
\hline Silver - filtered & $\mathrm{mg} / \mathrm{L}$ & $<0.0005$ & $<0.0005$ & $<0.0005$ & $<0.0005$ \\
\hline Thallium - filtered & $\mathrm{mg} / \mathrm{L}$ & $<0.001$ & $<0.001$ & $<0.001$ & $<0.001$ \\
\hline V anadium - filtered & $\mathrm{mg} / \mathrm{L}$ & $<0.020$ & $<0.020$ & $<0.024$ & $<0.024$ \\
\hline Zinc - filtered & $\mathrm{mg} / \mathrm{L}$ & $<0.010$ & $<0.010$ & $<0.011$ & $<0.011$ \\
\hline Phenols & $\mathrm{mg} / \mathrm{L}$ & $<0.005$ & $<0.005$ & $<0.005$ & $<0.005$ \\
\hline Hydrogen-3 & $\mathrm{pCi} / \mathrm{L}$ & 249 & 299 & 336 & 292 \\
\hline Chloride & $\mathrm{mg} / \mathrm{L}$ & - & 49 & - & - \\
\hline Fluoride & $\mathrm{mg} / \mathrm{L}$ & - & 0.228 & - & - \\
\hline Sulfate & $\mathrm{mg} / \mathrm{L}$ & - & 200 & - & - \\
\hline Total organic carbons & $\mathrm{mg} / \mathrm{L}$ & 9.3 & 13.1 & 9.9 & 11.0 \\
\hline Total organic carbons & $\mathrm{mg} / \mathrm{L}$ & 9.0 & 13.3 & 9.9 & 11.2 \\
\hline Total organic carbons & $\mathrm{mg} / \mathrm{L}$ & 9.2 & 13.5 & 9.8 & 11.2 \\
\hline Total organic carbons & $\mathrm{mg} / \mathrm{L}$ & 9.1 & 13.4 & 9.9 & 11.1 \\
\hline Total organic halogens & $\mathrm{mg} / \mathrm{L}$ & 0.049 & 0.038 & 0.074 & 0.058 \\
\hline Total organic halogens & $\mathrm{mg} / \mathrm{L}$ & 0.061 & 0.043 & 0.066 & 0.048 \\
\hline
\end{tabular}

a $\quad$ Water point elevation $=208.71 \mathrm{~m}(\mathrm{MSL})$; ground surface elevation $=227.38 \mathrm{~m}(\mathrm{M} \mathrm{SL})$; casing material $=$ stainless steel.

b A hyphen indicates that the sample was not analyzed for this constituent. 


\section{GROUNDWATER PROTECTION}

TABLE 6.32

Groundwater M onitoring Results, Sanitary Landfill Well 800193D, 1997ª

\begin{tabular}{|c|c|c|c|c|c|}
\hline \multirow[b]{2}{*}{ Parameter } & \multirow[b]{2}{*}{ Unit } & \multicolumn{4}{|c|}{ Date of Sampling } \\
\hline & & $01 / 08 / 97$ & $04 / 02 / 97$ & 07/08/97 & $10 / 08 / 97$ \\
\hline W ater elevation & $\mathrm{m}$ & 192.86 & 193.25 & 193.14 & 193.00 \\
\hline Temperature & ${ }^{\circ} \mathrm{C}$ & 11.1 & 11.9 & 12.1 & 12.1 \\
\hline $\mathrm{pH}$ & $\mathrm{pH}$ & 7.01 & 6.98 & 7.02 & 7.16 \\
\hline Redox & $\mathrm{mV}$ & -10 & -30 & -44 & 1 \\
\hline Conductivity & $\mu \mathrm{mhos} / \mathrm{cm}$ & 1,319 & 1,321 & 989 & 1,321 \\
\hline Chloride - filtered & $\mathrm{mg} / \mathrm{L}$ & 109 & 112 & 134 & 100 \\
\hline Sulfate - filtered & $\mathrm{mg} / \mathrm{L}$ & 189 & 172 & 213 & 208 \\
\hline TDS - filtered & $\mathrm{mg} / \mathrm{L}$ & 784 & 843 & 886 & 847 \\
\hline Cyanide (total) & $\mathrm{mg} / \mathrm{L}$ & $<0.005$ & $<0.010$ & $<0.010$ & $<0.010$ \\
\hline Arsenic & $\mathrm{mg} / \mathrm{L}$ & $-b$ & 0.0029 & - & - \\
\hline Barium & $\mathrm{mg} / \mathrm{L}$ & - & 0.0617 & - & - \\
\hline Boron & $\mathrm{mg} / \mathrm{L}$ & - & 0.2284 & - & - \\
\hline Cadmium & $\mathrm{mg} / \mathrm{L}$ & - & $<0.0001$ & - & - \\
\hline Chromium & $\mathrm{mg} / \mathrm{L}$ & - & $<0.02$ & - & - \\
\hline Cobalt & $\mathrm{mg} / \mathrm{L}$ & - & $<0.015$ & - & - \\
\hline Copper & $\mathrm{mg} / \mathrm{L}$ & - & $<0.02$ & - & - \\
\hline Iron & $\mathrm{mg} / \mathrm{L}$ & - & 1.916 & - & - \\
\hline Lead & $\mathrm{mg} / \mathrm{L}$ & - & $<0.001$ & - & - \\
\hline M anganese & $\mathrm{mg} / \mathrm{L}$ & - & 0.0266 & - & - \\
\hline M ercury & $\mathrm{mg} / \mathrm{L}$ & - & 0.0002 & - & - \\
\hline Nickel & $\mathrm{mg} / \mathrm{L}$ & - & $<0.025$ & - & - \\
\hline Selenium & $\mathrm{mg} / \mathrm{L}$ & - & $<0.002$ & - & - \\
\hline Silver & $\mathrm{mg} / \mathrm{L}$ & - & $<0.0005$ & - & - \\
\hline Zinc & $\mathrm{mg} / \mathrm{L}$ & - & 0.0115 & - & - \\
\hline A mmonia nitrogen - filtered & $\mathrm{mg} / \mathrm{L}$ & 0.8 & 0.6 & 1.0 & $<0.2$ \\
\hline A rsenic - filtered & $\mathrm{mg} / \mathrm{L}$ & 0.0021 & 0.0020 & $<0.002$ & $<0.002$ \\
\hline Barium - filtered & $\mathrm{mg} / \mathrm{L}$ & 0.0605 & 0.0587 & 0.0541 & 0.0475 \\
\hline Beryllium - filtered & $\mathrm{mg} / \mathrm{L}$ & $<0.0002$ & $<0.0002$ & $<0.0002$ & $<0.0002$ \\
\hline Cadmium - filtered & $\mathrm{mg} / \mathrm{L}$ & $<0.0001$ & $<0.0001$ & $<0.0001$ & $<0.0001$ \\
\hline Chromium - filtered & $\mathrm{mg} / \mathrm{L}$ & $<0.020$ & $<0.020$ & $<0.044$ & $<0.044$ \\
\hline Cobalt - filtered & $\mathrm{mg} / \mathrm{L}$ & $<0.015$ & $<0.015$ & $<0.026$ & $<0.026$ \\
\hline Copper - filtered & $\mathrm{mg} / \mathrm{L}$ & 0.0278 & $<0.020$ & $<0.017$ & $<0.017$ \\
\hline Iron - filtered & $\mathrm{mg} / \mathrm{L}$ & 1.1300 & 1.0420 & 1.0410 & 0.9154 \\
\hline Lead - filtered & $\mathrm{mg} / \mathrm{L}$ & $<0.001$ & $<0.001$ & $<0.001$ & $<0.001$ \\
\hline$M$ anganese - filtered & $\mathrm{mg} / \mathrm{L}$ & 0.0261 & 0.0244 & 0.0240 & 0.0207 \\
\hline M ercury - filtered & $\mathrm{mg} / \mathrm{L}$ & $<0.0001$ & 0.0002 & $<0.0001$ & $<0.0001$ \\
\hline Nickel - filtered & $\mathrm{mg} / \mathrm{L}$ & $<0.025$ & $<0.025$ & $<0.040$ & $<0.040$ \\
\hline Silver - filtered & $\mathrm{mg} / \mathrm{L}$ & $<0.0005$ & $<0.0005$ & $<0.0005$ & $<0.0005$ \\
\hline Thallium - filtered & $\mathrm{mg} / \mathrm{L}$ & $<0.001$ & $<0.001$ & $<0.001$ & $<0.001$ \\
\hline V anadium - filtered & $\mathrm{mg} / \mathrm{L}$ & $<0.020$ & $<0.020$ & $<0.024$ & $<0.024$ \\
\hline Zinc - filtered & $\mathrm{mg} / \mathrm{L}$ & $<0.010$ & $<0.010$ & $<0.011$ & $<0.011$ \\
\hline Phenols & $\mathrm{mg} / \mathrm{L}$ & $<0.005$ & $<0.005$ & $<0.005$ & $<0.005$ \\
\hline Hydrogen-3 & $\mathrm{pCi} / \mathrm{L}$ & $<100$ & $<100$ & $<100$ & $<100$ \\
\hline Chloride & $\mathrm{mg} / \mathrm{L}$ & - & 106 & - & - \\
\hline Fluoride & $\mathrm{mg} / \mathrm{L}$ & - & 0.310 & - & - \\
\hline Sulfate & $\mathrm{mg} / \mathrm{L}$ & - & 178 & - & - \\
\hline Total organic carbons & $\mathrm{mg} / \mathrm{L}$ & 3.0 & 2.6 & 2.6 & $<1.0$ \\
\hline Total organic carbons & $\mathrm{mg} / \mathrm{L}$ & 3.3 & 2.8 & 2.6 & $<1.0$ \\
\hline Total organic carbons & $\mathrm{mg} / \mathrm{L}$ & 2.9 & 2.9 & 3.4 & $<1.0$ \\
\hline Total organic carbons & $\mathrm{mg} / \mathrm{L}$ & 3.1 & 2.9 & 3.3 & $<1.0$ \\
\hline Total organic halogens & $\mathrm{mg} / \mathrm{L}$ & 0.035 & 0.056 & 0.011 & 0.094 \\
\hline Total organic halogens & $\mathrm{mg} / \mathrm{L}$ & 0.040 & 0.062 & 0.011 & 0.081 \\
\hline $\begin{array}{l}\text { Water point elevation = } \\
\text { steel. }\end{array}$ & 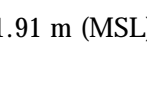 & round curfac & $1-2<1$. & 1. casing & stainless \\
\hline A hyphen indic & & alyzed for $t$ & ituent. & & \\
\hline
\end{tabular}


TABLE 6.33

Groundwater M onitoring Results, Sanitary Landfill W ell 800201, 1997ª

\begin{tabular}{|c|c|c|c|c|c|c|}
\hline \multirow[b]{2}{*}{ Parameter } & \multirow[b]{2}{*}{ U nit } & \multicolumn{5}{|c|}{ Date of Sampling } \\
\hline & & $01 / 08 / 97$ & $04 / 03 / 97$ & $07 / 09 / 97$ & $10 / 10 / 97$ & $10 / 10 / 97$ \\
\hline W ater elevation & $\mathrm{m}$ & 224.58 & 225.14 & 224.37 & 223.95 & 223.95 \\
\hline Temperature & ${ }^{\circ} \mathrm{C}$ & 10.3 & 11.1 & 10.6 & 11.3 & 11.3 \\
\hline $\mathrm{pH}$ & $\mathrm{pH}$ & 6.97 & 6.80 & 7.00 & 7.12 & 7.12 \\
\hline Redox & $\mathrm{mV}$ & -6 & -29 & -41 & 3 & 3 \\
\hline Conductivity & $\mu \mathrm{mhos} / \mathrm{cm}$ & 1,073 & 1,093 & 776 & 1,090 & 1,090 \\
\hline Chloride - filtered & $\mathrm{mg} / \mathrm{L}$ & 6 & 6 & 6 & 6 & 6 \\
\hline Sulfate - filtered & $\mathrm{mg} / \mathrm{L}$ & 62 & 47 & 64 & 63 & 65 \\
\hline TDS - filtered & $\mathrm{mg} / \mathrm{L}$ & 637 & 653 & 689 & 693 & 688 \\
\hline Cyanide (total) & $\mathrm{mg} / \mathrm{L}$ & $<0.005$ & $<0.010$ & $<0.010$ & $<0.010$ & $<0.010$ \\
\hline A rsenic & $\mathrm{mg} / \mathrm{L}$ & b & 0.0156 & - & - & - \\
\hline Barium & $\mathrm{mg} / \mathrm{L}$ & - & 0.2991 & - & - & - \\
\hline Boron & $\mathrm{mg} / \mathrm{L}$ & - & 0.1312 & - & - & - \\
\hline Cadmium & $\mathrm{mg} / \mathrm{L}$ & - & 0.0002 & - & - & - \\
\hline Chromium & $\mathrm{mg} / \mathrm{L}$ & - & $<0.02$ & - & - & - \\
\hline Cobalt & $\mathrm{mg} / \mathrm{L}$ & - & $<0.015$ & - & - & - \\
\hline Copper & $\mathrm{mg} / \mathrm{L}$ & - & 0.0204 & - & - & - \\
\hline Iron & $\mathrm{mg} / \mathrm{L}$ & - & 18.35 & - & - & - \\
\hline Lead & $\mathrm{mg} / \mathrm{L}$ & - & 0.0070 & - & - & - \\
\hline$M$ anganese & $\mathrm{mg} / \mathrm{L}$ & - & 0.7232 & - & - & - \\
\hline M ercury & $\mathrm{mg} / \mathrm{L}$ & - & 0.0001 & - & - & - \\
\hline Nickel & $\mathrm{mg} / \mathrm{L}$ & - & $<0.025$ & - & - & - \\
\hline Selenium & $\mathrm{mg} / \mathrm{L}$ & - & $<0.002$ & - & - & - \\
\hline Silver & $\mathrm{mg} / \mathrm{L}$ & - & $<0.0005$ & - & - & - \\
\hline Zinc & $\mathrm{mg} / \mathrm{L}$ & - & 0.0612 & - & - & - \\
\hline A mmonia nitrogen - filtered & $\mathrm{mg} / \mathrm{L}$ & 1.6 & 2.5 & 3.0 & 3.5 & 8.6 \\
\hline A rsenic - filtered & $\mathrm{mg} / \mathrm{L}$ & 0.0075 & 0.0072 & $<0.002$ & 0.0048 & 0.0042 \\
\hline Barium - filtered & $\mathrm{mg} / \mathrm{L}$ & 0.2550 & 0.2836 & 0.2402 & 0.2596 & 0.2655 \\
\hline Beryllium - filtered & $\mathrm{mg} / \mathrm{L}$ & $<0.0002$ & $<0.0002$ & $<0.0002$ & $<0.0002$ & $<0.0002$ \\
\hline Cadmium - filtered & $\mathrm{mg} / \mathrm{L}$ & $<0.0001$ & $<0.0001$ & $<0.0001$ & $<0.0001$ & $<0.0001$ \\
\hline Chromium - filtered & $\mathrm{mg} / \mathrm{L}$ & $<0.020$ & $<0.020$ & $<0.044$ & $<0.044$ & $<0.044$ \\
\hline Cobalt - filtered & $\mathrm{mg} / \mathrm{L}$ & $<0.015$ & $<0.015$ & $<0.026$ & $<0.026$ & $<0.026$ \\
\hline Copper - filtered & $\mathrm{mg} / \mathrm{L}$ & $<0.020$ & $<0.020$ & $<0.017$ & $<0.017$ & $<0.017$ \\
\hline Iron - filtered & $\mathrm{mg} / \mathrm{L}$ & 3.890 & 5.257 & 0.588 & 2.711 & 2.304 \\
\hline Lead - filtered & $\mathrm{mg} / \mathrm{L}$ & $<0.001$ & $<0.001$ & $<0.001$ & $<0.001$ & $<0.001$ \\
\hline$M$ anganese - filtered & $\mathrm{mg} / \mathrm{L}$ & 0.4369 & 0.4389 & 0.4070 & 0.4900 & 0.5284 \\
\hline M ercury - filtered & $\mathrm{mg} / \mathrm{L}$ & $<0.0001$ & $<0.0001$ & $<0.0001$ & $<0.0001$ & $<0.0001$ \\
\hline Nickel - filtered & $\mathrm{mg} / \mathrm{L}$ & $<0.025$ & $<0.025$ & $<0.040$ & $<0.040$ & $<0.040$ \\
\hline Silver - filtered & $\mathrm{mg} / \mathrm{L}$ & $<0.0005$ & $<0.0005$ & $<0.0005$ & $<0.0005$ & $<0.0005$ \\
\hline Thallium - filtered & $\mathrm{mg} / \mathrm{L}$ & $<0.001$ & $<0.001$ & $<0.001$ & $<0.001$ & $<0.001$ \\
\hline V anadium - filtered & $\mathrm{mg} / \mathrm{L}$ & $<0.020$ & $<0.020$ & $<0.024$ & $<0.024$ & $<0.024$ \\
\hline Zinc - filtered & $\mathrm{mg} / \mathrm{L}$ & 0.0322 & 0.0208 & 0.0416 & 0.0178 & 0.0214 \\
\hline Phenols & $\mathrm{mg} / \mathrm{L}$ & $<0.005$ & 0.0950 & $<0.005$ & $<0.005$ & $<0.005$ \\
\hline Hydrogen-3 & $\mathrm{pCi} / \mathrm{L}$ & $<100$ & $<100$ & $<100$ & $<100$ & $<100$ \\
\hline Chloride & $\mathrm{mg} / \mathrm{L}$ & - & 6 & - & - & - \\
\hline Fluoride & $\mathrm{mg} / \mathrm{L}$ & - & 0.174 & - & - & - \\
\hline Sulfate & $\mathrm{mg} / \mathrm{L}$ & - & 47 & - & - & - \\
\hline Total organic carbons & $\mathrm{mg} / \mathrm{L}$ & 32.5 & 33.4 & 26.6 & 26.5 & 28.3 \\
\hline Total organic carbons & $\mathrm{mg} / \mathrm{L}$ & 33.6 & 33.0 & 27.0 & 27.4 & 28.4 \\
\hline Total organic carbons & $\mathrm{mg} / \mathrm{L}$ & 31.8 & 34.4 & 26.6 & 28.0 & 26.6 \\
\hline Total organic carbons & $\mathrm{mg} / \mathrm{L}$ & 30.9 & 32.2 & 27.1 & 27.6 & 26.4 \\
\hline Total organic halogens & $\mathrm{mg} / \mathrm{L}$ & 0.011 & 0.059 & 0.049 & 0.044 & 0.040 \\
\hline Total organic halogens & $\mathrm{mg} / \mathrm{L}$ & 0.016 & 0.095 & 0.045 & 0.035 & 0.028 \\
\hline
\end{tabular}

a $\quad$ ater point elevation $=217.20 \mathrm{~m}(\mathrm{M} \mathrm{SL})$; ground surface elevation $=227.93 \mathrm{~m}(\mathrm{M} \mathrm{SL})$; casing material $=$ stainless steel.

b A hyphen indicates that the sample was not analyzed for this constituent. 


\section{GROUNDWATER PROTECTION}

TABLE 6.34

Groundwater M onitoring Results, Sanitary L andfill Well 800202, 1997ª

\begin{tabular}{|c|c|c|c|c|c|}
\hline \multirow[b]{2}{*}{ Parameter } & \multirow[b]{2}{*}{ Unit } & \multicolumn{4}{|c|}{ Date of Sampling } \\
\hline & & $01 / 08 / 97$ & $04 / 03 / 97$ & $07 / 09 / 97$ & $10 / 09 / 97$ \\
\hline W ater el evation & $\mathrm{m}$ & 218.21 & 218.81 & 218.50 & 218.14 \\
\hline Temperature & ${ }^{\circ} \mathrm{C}$ & 10.5 & 10.9 & 10.7 & 11.1 \\
\hline $\mathrm{pH}$ & $\mathrm{pH}$ & 7.07 & 6.94 & 7.01 & 7.16 \\
\hline Redox & $\mathrm{mV}$ & -20 & -15 & -24 & 1 \\
\hline Conductivity & $\mu \mathrm{mhos} / \mathrm{cm}$ & 1,062 & 1,055 & 766 & 1,053 \\
\hline Chloride - filtered & $\mathrm{mg} / \mathrm{L}$ & $\begin{array}{r}1,002 \\
17\end{array}$ & 16 & 20 & 19 \\
\hline Sulfate - filtered & $\mathrm{mg} / \mathrm{L}$ & 71 & 71 & 79 & 79 \\
\hline TDS - filtered & $\mathrm{mg} / \mathrm{L}$ & 625 & 612 & 648 & 647 \\
\hline Cyanide (total) & $\mathrm{mg} / \mathrm{L}$ & $<0.005$ & $<0.010$ & $<0.010$ & $<0.010$ \\
\hline Arsenic & $\mathrm{mg} / \mathrm{L}$ & $-b$ & 0.0095 & - & - \\
\hline Barium & $\mathrm{mg} / \mathrm{L}$ & - & 0.1778 & - & - \\
\hline Boron & $\mathrm{mg} / \mathrm{L}$ & - & 0.1023 & - & - \\
\hline Cadmium & $\mathrm{mg} / \mathrm{L}$ & - & $<0.0001$ & - & - \\
\hline Chromium & $\mathrm{mg} / \mathrm{L}$ & - & $<0.02$ & - & - \\
\hline Cobalt & $\mathrm{mg} / \mathrm{L}$ & - & $<0.015$ & - & - \\
\hline Copper & $\mathrm{mg} / \mathrm{L}$ & - & $<0.02$ & - & - \\
\hline Iron & $\mathrm{mg} / \mathrm{L}$ & - & 4.0490 & - & - \\
\hline L ead & $\mathrm{mg} / \mathrm{L}$ & - & $<0.001$ & - & - \\
\hline$M$ anganese & $\mathrm{mg} / \mathrm{L}$ & - & 0.2355 & - & - \\
\hline M ercury & $\mathrm{mg} / \mathrm{L}$ & - & $<0.0001$ & - & - \\
\hline Nickel & $\mathrm{mg} / \mathrm{L}$ & - & $<0.025$ & - & - \\
\hline Selenium & $\mathrm{mg} / \mathrm{L}$ & - & $<0.002$ & - & - \\
\hline Silver & $\mathrm{mg} / \mathrm{L}$ & - & $<0.0005$ & - & - \\
\hline Zinc & $\mathrm{mg} / \mathrm{L}$ & - & $<0.01$ & - & - \\
\hline A mmonia nitrogen - filtered & $\mathrm{mg} / \mathrm{L}$ & 1.1 & 1.0 & 2.0 & 1.9 \\
\hline A rsenic - filtered & $\mathrm{mg} / \mathrm{L}$ & 0.0041 & 0.0048 & 0.0035 & 0.0041 \\
\hline Barium - filtered & $\mathrm{mg} / \mathrm{L}$ & 0.1305 & 0.1505 & 0.1468 & 0.1621 \\
\hline Beryllium - filtered & $\mathrm{mg} / \mathrm{L}$ & $<0.0002$ & $<0.0002$ & $<0.0002$ & $<0.0002$ \\
\hline Cadmium - filtered & $\mathrm{mg} / \mathrm{L}$ & $<0.0001$ & $<0.0001$ & $<0.0001$ & $<0.0001$ \\
\hline Chromium - filtered & $\mathrm{mg} / \mathrm{L}$ & $<0.020$ & $<0.020$ & $<0.044$ & $<0.044$ \\
\hline Cobalt - filtered & $\mathrm{mg} / \mathrm{L}$ & $<0.015$ & $<0.015$ & $<0.026$ & $<0.026$ \\
\hline Copper - filtered & $\mathrm{mg} / \mathrm{L}$ & $<0.020$ & $<0.020$ & $<0.017$ & $<0.017$ \\
\hline Iron - filtered & $\mathrm{mg} / \mathrm{L}$ & 2.3160 & 2.2840 & 2.6970 & 3.2320 \\
\hline L ead - filtered & $\mathrm{mg} / \mathrm{L}$ & $<0.001$ & $<0.001$ & $<0.001$ & $<0.001$ \\
\hline$M$ anganese - filtered & $\mathrm{mg} / \mathrm{L}$ & 0.2621 & 0.2559 & 0.2468 & 0.2465 \\
\hline M ercury - filtered & $\mathrm{mg} / \mathrm{L}$ & $<0.0001$ & $<0.0001$ & $<0.0001$ & $<0.0001$ \\
\hline Nickel - filtered & $\mathrm{mg} / \mathrm{L}$ & $<0.025$ & $<0.025$ & $<0.040$ & $<0.040$ \\
\hline Silver - filtered & $\mathrm{mg} / \mathrm{L}$ & $<0.0005$ & $<0.0005$ & $<0.0005$ & $<0.0005$ \\
\hline Thallium - filtered & $\mathrm{mg} / \mathrm{L}$ & $<0.001$ & $<0.001$ & $<0.001$ & $<0.001$ \\
\hline V anadium - filtered & $\mathrm{mg} / \mathrm{L}$ & $<0.020$ & $<0.020$ & $<0.024$ & $<0.024$ \\
\hline Zinc - filtered & $\mathrm{mg} / \mathrm{L}$ & $<0.010$ & $<0.010$ & $<0.011$ & $<0.011$ \\
\hline Phenols & $\mathrm{mg} / \mathrm{L}$ & $<0.005$ & $<0.005$ & $<0.005$ & $<0.005$ \\
\hline Hydrogen-3 & $\mathrm{pCi} / \mathrm{L}$ & $<100$ & $<100$ & $<100$ & $<100$ \\
\hline Chloride & $\mathrm{mg} / \mathrm{L}$ & - & 17 & - & - \\
\hline Fluoride & $\mathrm{mg} / \mathrm{L}$ & - & 0.218 & - & - \\
\hline Sulfate & $\mathrm{mg} / \mathrm{L}$ & - & 65 & - & - \\
\hline Total organic carbons & $\mathrm{mg} / \mathrm{L}$ & 11.6 & 12.1 & 11.0 & 10.9 \\
\hline Total organic carbons & $\mathrm{mg} / \mathrm{L}$ & 11.3 & 11.6 & 11.0 & 11.3 \\
\hline Total organic carbons & $\mathrm{mg} / \mathrm{L}$ & 11.0 & 11.6 & 10.4 & 11.4 \\
\hline Total organic carbons & $\mathrm{mg} / \mathrm{L}$ & 11.0 & 11.6 & 10.8 & 11.0 \\
\hline Total organic halogens & $\mathrm{mg} / \mathrm{L}$ & 0.032 & 0.072 & 0.050 & 0.047 \\
\hline Total organic halogens & $\mathrm{mg} / \mathrm{L}$ & 0.026 & 0.078 & 0.049 & 0.047 \\
\hline
\end{tabular}

a $\quad$ ater point elevation $=217.20 \mathrm{~m}(\mathrm{M} \mathrm{SL})$; ground surface elevation $=227.93 \mathrm{~m}(\mathrm{M} \mathrm{SL})$; casing material $=$ stainless steel.

b A hyphen indicates that the sample was not analyzed for this constituent. 
TABLE 6.35

Groundwater M onitoring Results, Sanitary Landfill W ell 800203D, 1997ª

\begin{tabular}{|c|c|c|c|c|c|}
\hline \multirow[b]{2}{*}{ Parameter } & \multirow[b]{2}{*}{ Unit } & \multicolumn{4}{|c|}{ Date of Sampling } \\
\hline & & $01 / 08 / 97$ & $04 / 03 / 97$ & $07 / 09 / 97$ & $10 / 09 / 97$ \\
\hline W ater elevation & $\mathrm{m}$ & 192.96 & 193.38 & 193.13 & 193.05 \\
\hline Temperature & ${ }^{\circ} \mathrm{C}$ & 11.4 & 11.5 & 11.6 & 11.5 \\
\hline $\mathrm{pH}$ & pH & 7.05 & 6.98 & 7.16 & 7.19 \\
\hline Redox & $\mathrm{mV}$ & -12 & -41 & -41 & -1 \\
\hline Conductivity & $\mu \mathrm{mhos} / \mathrm{cm}$ & 1,224 & 1,181 & 859 & 1,099 \\
\hline Chloride - filtered & $\mathrm{mg} / \mathrm{L}$ & 91 & 97 & 106 & 69 \\
\hline Sulfate - filtered & $\mathrm{mg} / \mathrm{L}$ & 47 & 45 & 67 & 40 \\
\hline TDS - filtered & $\mathrm{mg} / \mathrm{L}$ & 673 & 664 & 689 & 656 \\
\hline Cyanide (total) & $\mathrm{mg} / \mathrm{L}$ & $<0.005$ & $<0.010$ & $<0.010$ & $<0.010$ \\
\hline Arsenic & $\mathrm{mg} / \mathrm{L}$ & $-b$ & 0.0052 & - & - \\
\hline Barium & $\mathrm{mg} / \mathrm{L}$ & - & 0.1171 & - & - \\
\hline Boron & $\mathrm{mg} / \mathrm{L}$ & - & 0.1929 & - & - \\
\hline Cadmium & $\mathrm{mg} / \mathrm{L}$ & - & 0.0001 & - & - \\
\hline Chromium & $\mathrm{mg} / \mathrm{L}$ & - & $<0.02$ & - & - \\
\hline Cobalt & $\mathrm{mg} / \mathrm{L}$ & - & 0.0151 & - & - \\
\hline Copper & $\mathrm{mg} / \mathrm{L}$ & - & $<0.02$ & - & - \\
\hline Iron & $\mathrm{mg} / \mathrm{L}$ & - & 2.6810 & - & - \\
\hline L ead & $\mathrm{mg} / \mathrm{L}$ & - & $<0.001$ & - & - \\
\hline M anganese & $\mathrm{mg} / \mathrm{L}$ & - & 0.0482 & - & - \\
\hline M ercury & $\mathrm{mg} / \mathrm{L}$ & - & $<0.0001$ & - & - \\
\hline Nickel & $\mathrm{mg} / \mathrm{L}$ & - & $<0.025$ & - & - \\
\hline Selenium & $\mathrm{mg} / \mathrm{L}$ & - & $<0.002$ & - & - \\
\hline Silver & $\mathrm{mg} / \mathrm{L}$ & - & $<0.0005$ & - & - \\
\hline Zinc & $\mathrm{mg} / \mathrm{L}$ & - & $<0.01$ & - & - \\
\hline A mmonia nitrogen - filtered & $\mathrm{mg} / \mathrm{L}$ & 0.3 & 1.0 & 0.5 & 1.5 \\
\hline A rsenic - filtered & $\mathrm{mg} / \mathrm{L}$ & 0.0048 & 0.0055 & 0.0074 & 0.0042 \\
\hline Barium - filtered & $\mathrm{mg} / \mathrm{L}$ & 0.1249 & 0.1202 & 0.1112 & 0.1104 \\
\hline Beryllium - filtered & $\mathrm{mg} / \mathrm{L}$ & $<0.0002$ & $<0.0002$ & $<0.0002$ & $<0.0002$ \\
\hline Cadmium - filtered & $\mathrm{mg} / \mathrm{L}$ & $<0.0001$ & $<0.0001$ & $<0.0001$ & $<0.0001$ \\
\hline Chromium - filtered & $\mathrm{mg} / \mathrm{L}$ & $<0.020$ & $<0.020$ & $<0.044$ & $<0.044$ \\
\hline Cobalt - filtered & $\mathrm{mg} / \mathrm{L}$ & 0.0377 & 0.0171 & $<0.026$ & $<0.026$ \\
\hline Copper - filtered & $\mathrm{mg} / \mathrm{L}$ & $<0.020$ & $<0.020$ & $<0.017$ & $<0.017$ \\
\hline Iron - filtered & $\mathrm{mg} / \mathrm{L}$ & 2.126 & 2.024 & 0.972 & 1.298 \\
\hline Lead - filtered & $\mathrm{mg} / \mathrm{L}$ & $<0.001$ & $<0.001$ & $<0.001$ & $<0.001$ \\
\hline$M$ anganese - filtered & $\mathrm{mg} / \mathrm{L}$ & 0.0462 & 0.0367 & 0.0508 & 0.0375 \\
\hline M ercury - filtered & $\mathrm{mg} / \mathrm{L}$ & $<0.0001$ & $<0.0001$ & $<0.0001$ & $<0.0001$ \\
\hline Nickel - filtered & $\mathrm{mg} / \mathrm{L}$ & $<0.025$ & $<0.025$ & $<0.040$ & $<0.040$ \\
\hline Silver - filtered & $\mathrm{mg} / \mathrm{L}$ & $<0.0005$ & $<0.0005$ & $<0.0005$ & $<0.0005$ \\
\hline Thallium - filtered & $\mathrm{mg} / \mathrm{L}$ & $<0.001$ & $<0.001$ & $<0.001$ & $<0.001$ \\
\hline V anadium - filtered & $\mathrm{mg} / \mathrm{L}$ & $<0.020$ & $<0.020$ & $<0.024$ & $<0.024$ \\
\hline Zinc - filtered & $\mathrm{mg} / \mathrm{L}$ & $<0.010$ & $<0.010$ & $<0.011$ & $<0.011$ \\
\hline Phenols & $\mathrm{mg} / \mathrm{L}$ & $<0.005$ & 0.011 & $<0.005$ & $<0.005$ \\
\hline Hydrogen-3 & $\mathrm{pCi} / \mathrm{L}$ & $<100$ & $<100$ & $<100$ & $<100$ \\
\hline Chloride & $\mathrm{mg} / \mathrm{L}$ & - & 97 & - & - \\
\hline Fluoride & $\mathrm{mg} / \mathrm{L}$ & - & 0.352 & - & - \\
\hline Sulfate & $\mathrm{mg} / \mathrm{L}$ & - & 41 & - & - \\
\hline Total organic carbons & $\mathrm{mg} / \mathrm{L}$ & 4.8 & 4.9 & 3.9 & 2.5 \\
\hline Total organic carbons & $\mathrm{mg} / \mathrm{L}$ & 5.0 & 4.4 & 3.9 & 2.7 \\
\hline Total organic carbons & $\mathrm{mg} / \mathrm{L}$ & 4.9 & 4.5 & 3.8 & 2.7 \\
\hline Total organic carbons & $\mathrm{mg} / \mathrm{L}$ & 4.8 & 4.4 & 4.6 & 2.7 \\
\hline Total organic halogens & $\mathrm{mg} / \mathrm{L}$ & 0.035 & 0.041 & 0.072 & 0.087 \\
\hline Total organic halogens & $\mathrm{mg} / \mathrm{L}$ & 0.024 & 0.011 & 0.067 & 0.066 \\
\hline
\end{tabular}

a $\quad$ ell point elevation $=189.47 \mathrm{~m}(\mathrm{M} \mathrm{SL})$; ground surface elevation $=227.93 \mathrm{~m}(\mathrm{M} \mathrm{SL})$; casing material $=$ stainless steel.

b A hyphen indicates that the sample was not analyzed for this constituent. 

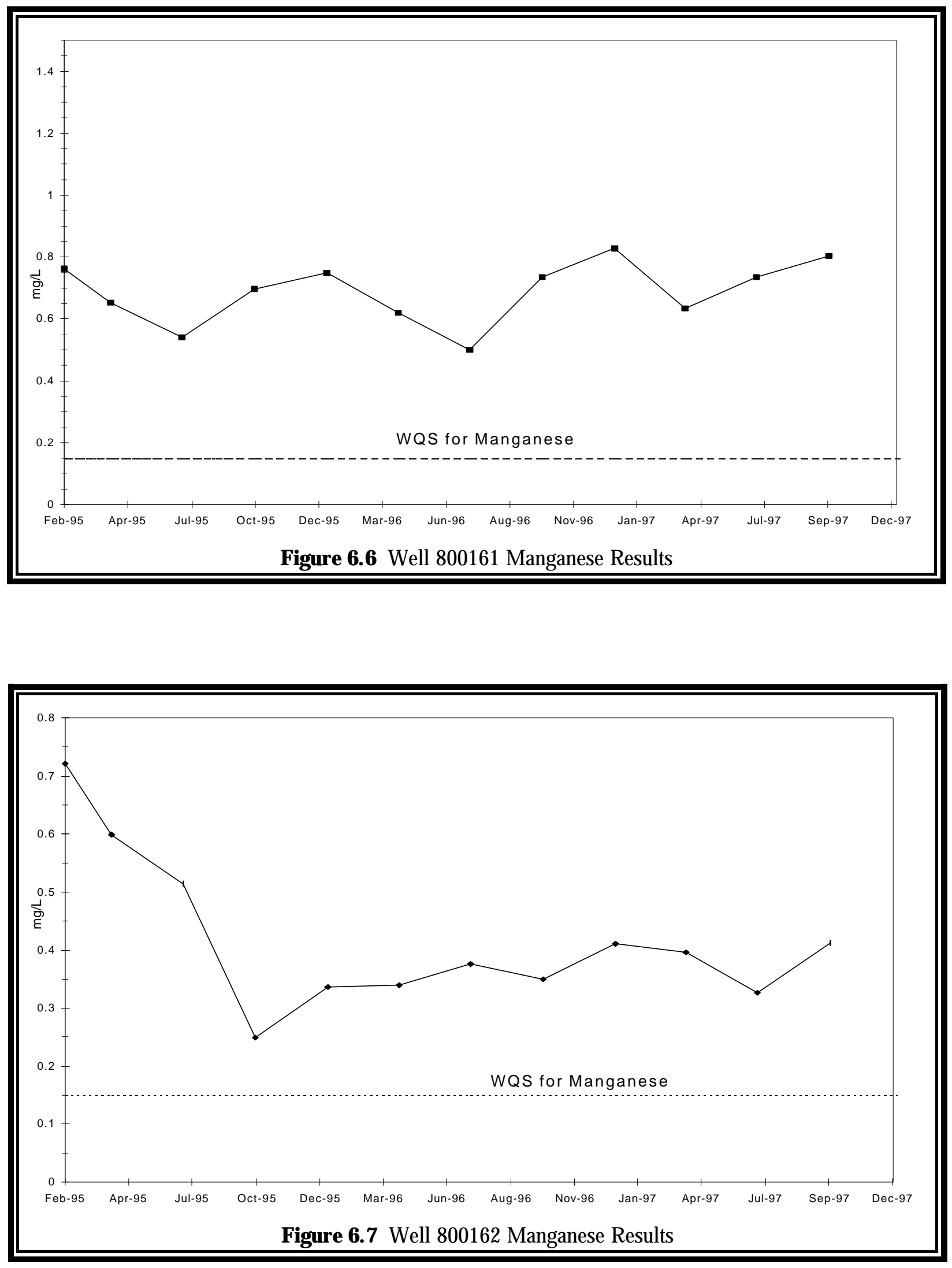


\section{GROUNDWATER PROTECTION}
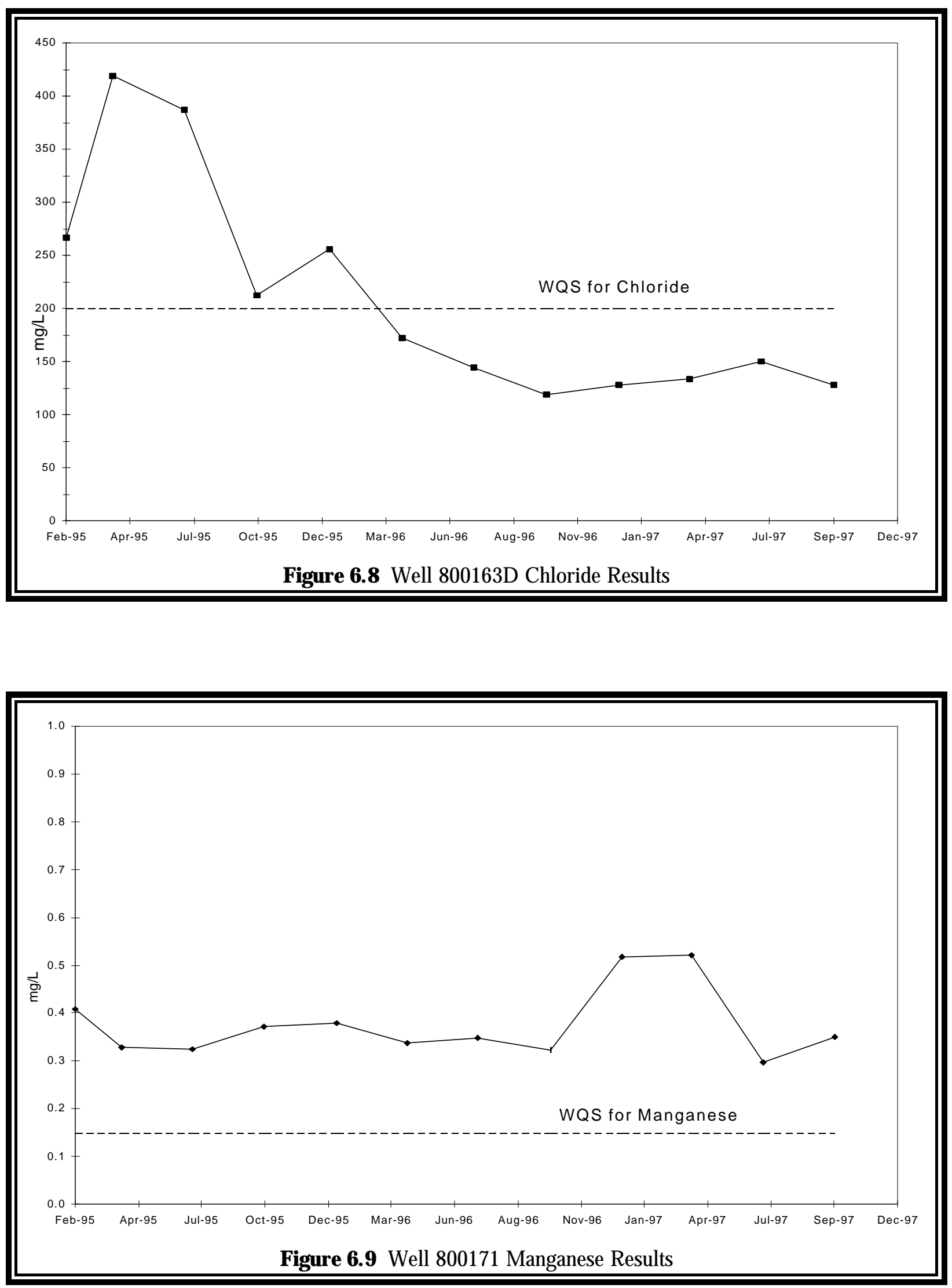

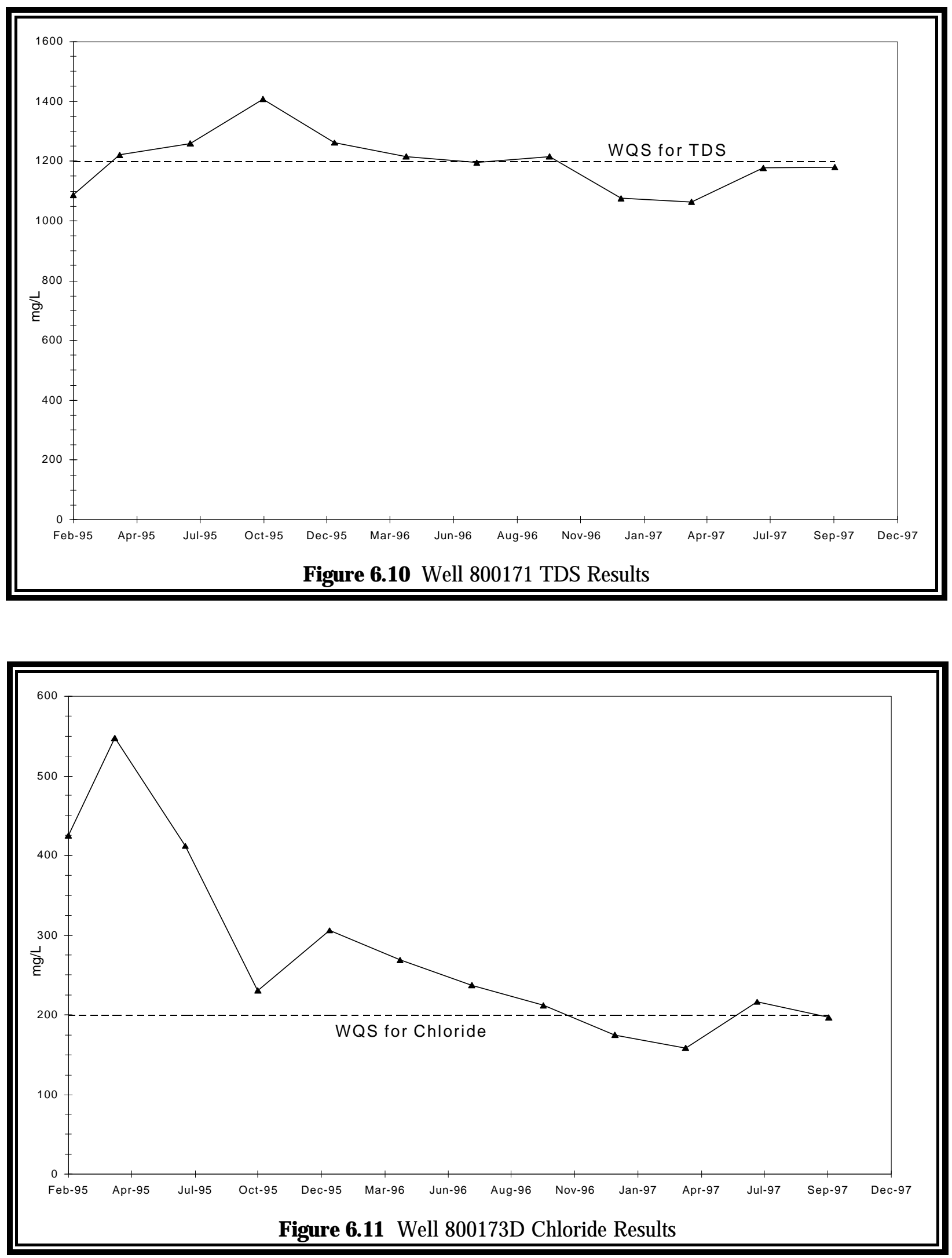


\section{GROUNDWATER PROTECTION}
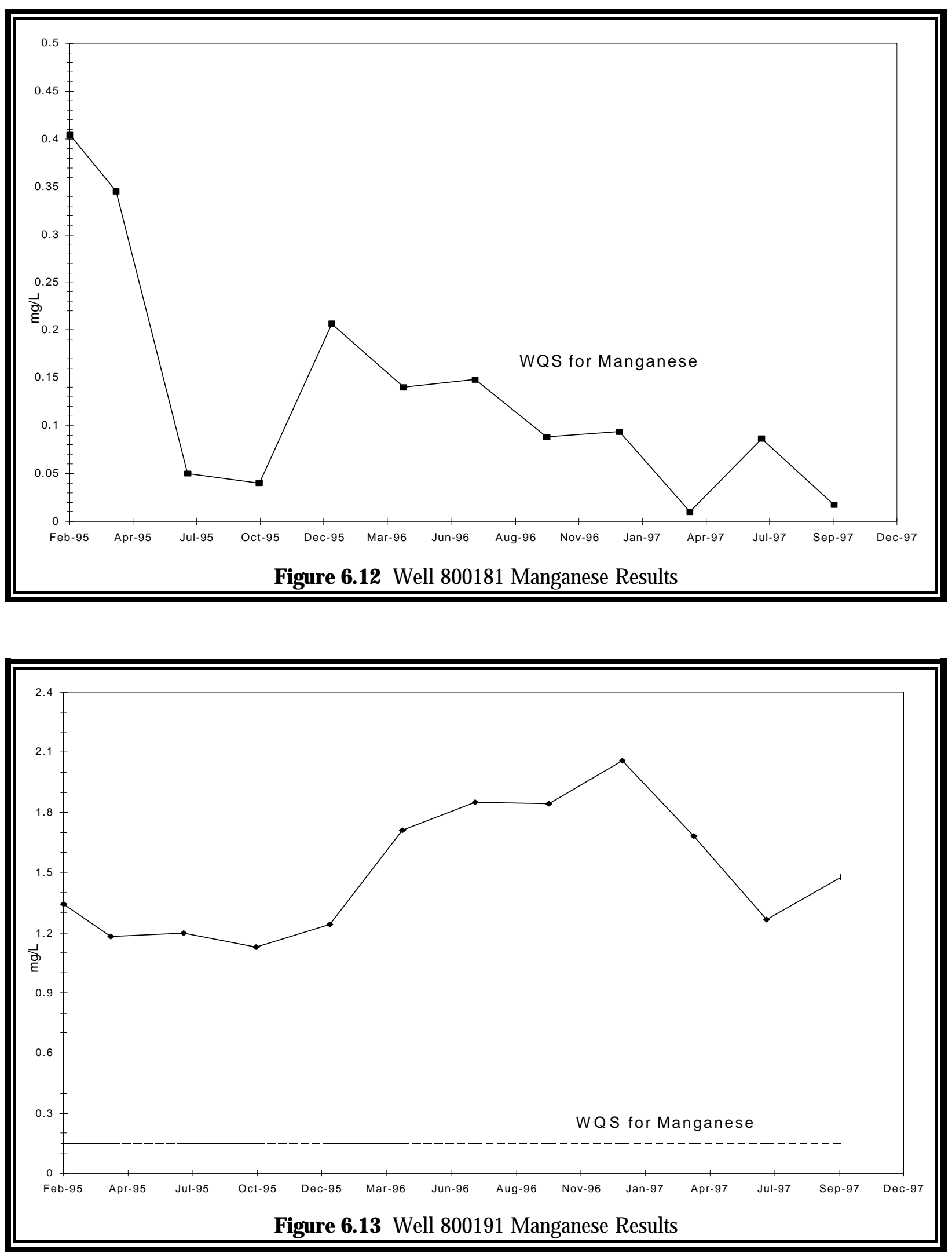

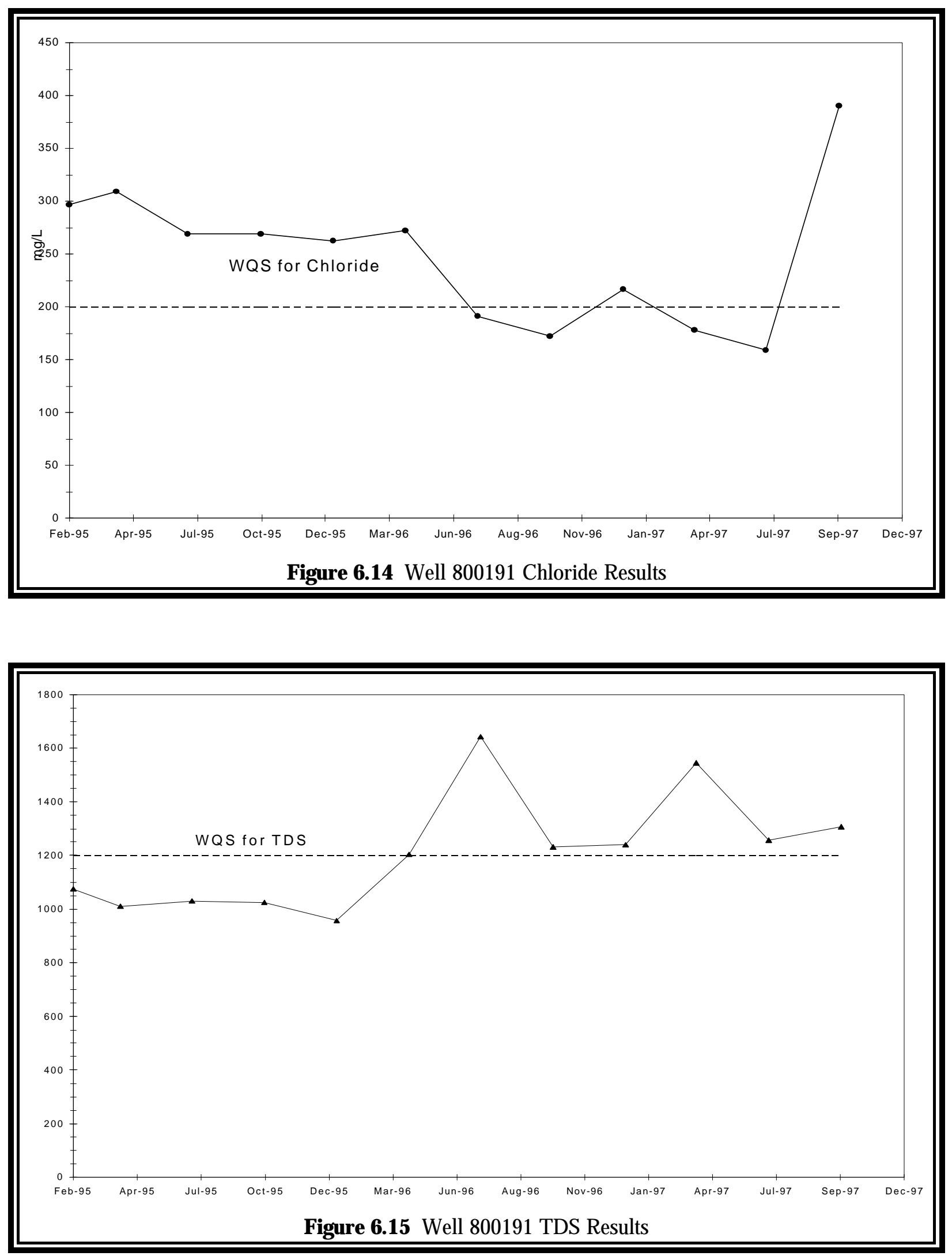


\section{GROUNDWATER PROTECTION}
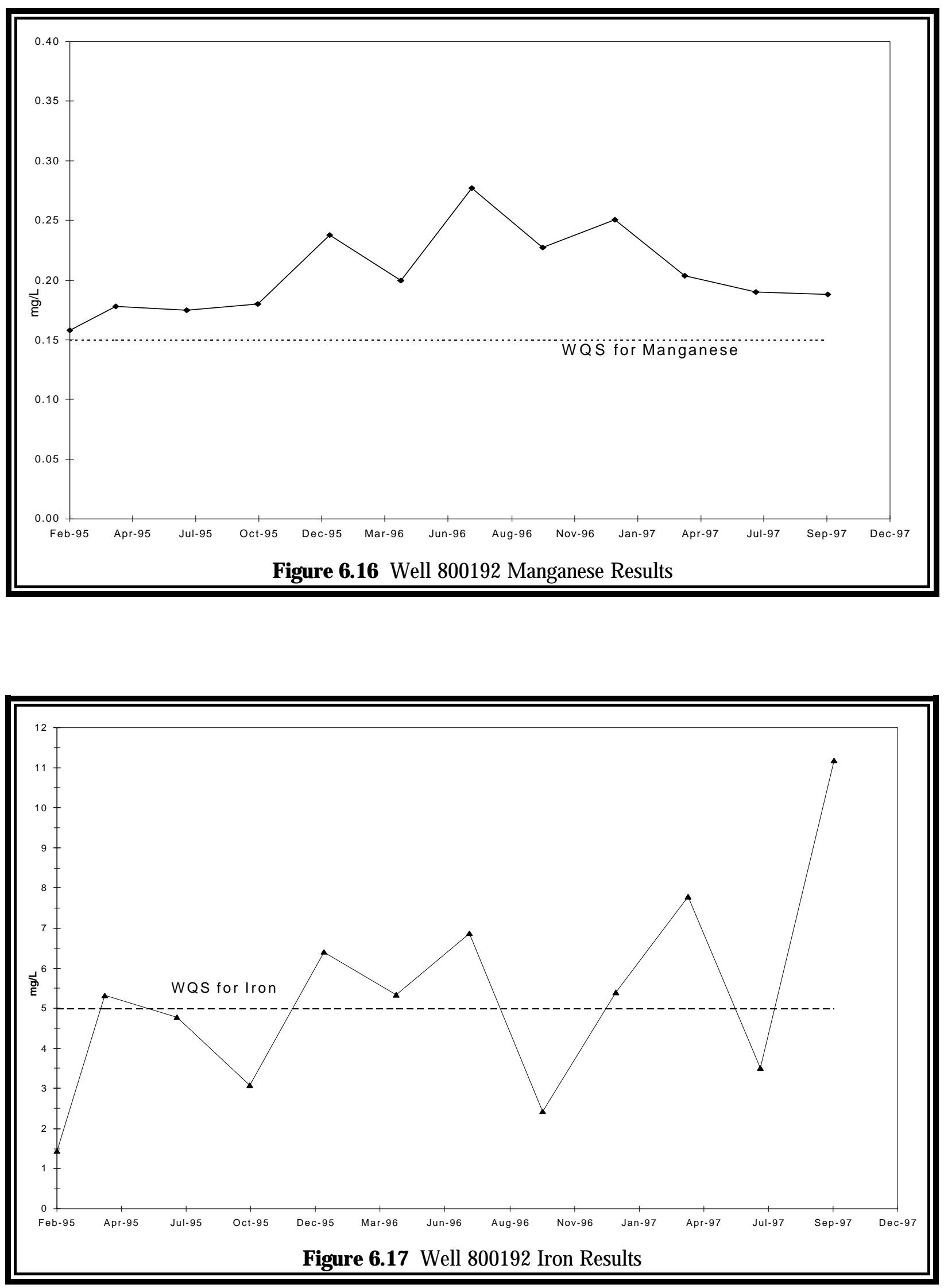

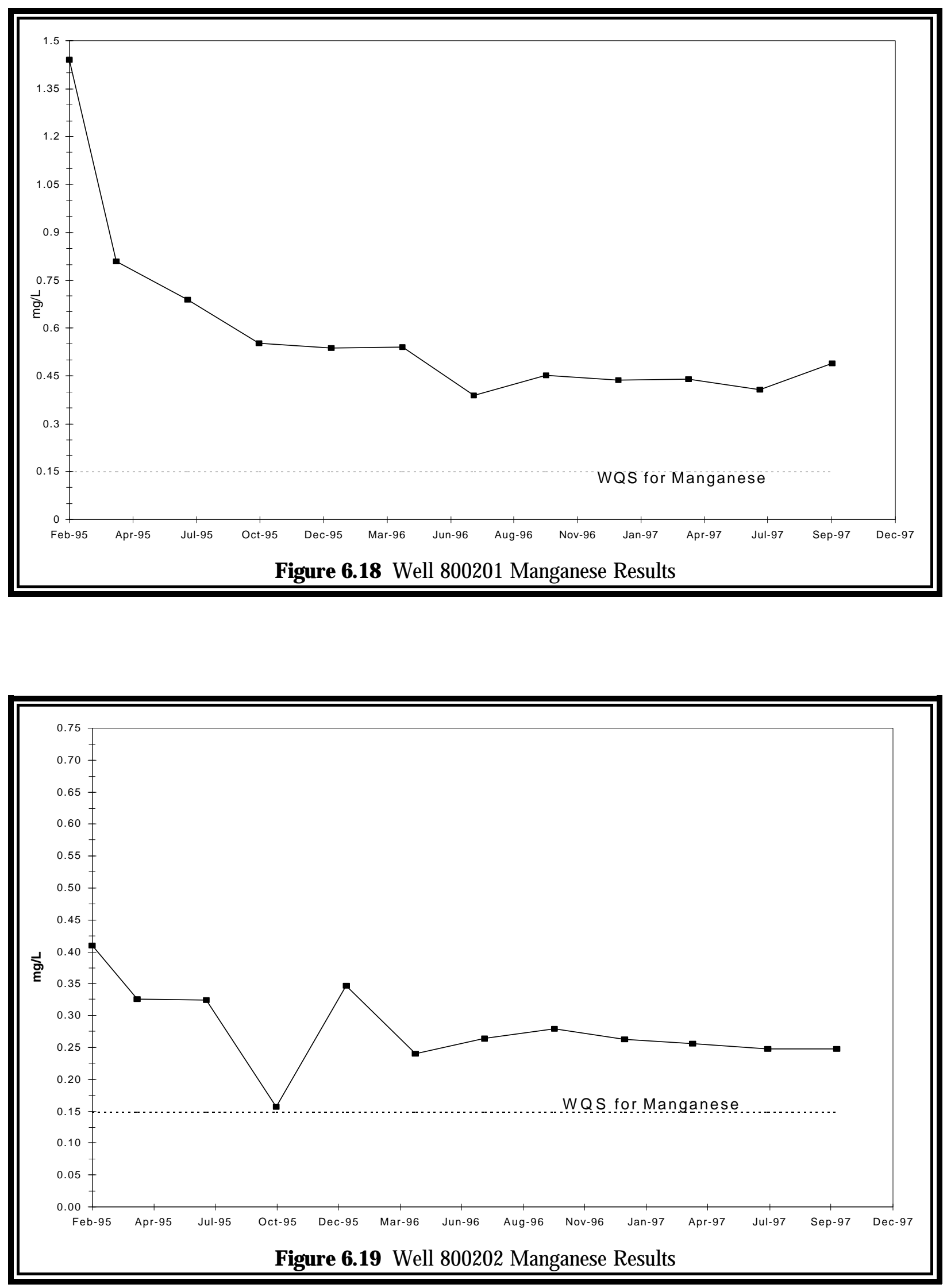


\section{GROUNDWATER PROTECTION}

sanitary landfill. Results represent filtered samples only because filtered samples are collected each quarter for the constituents presented.

On A pril 24, 1992, January 11, 1995, and November 20, 1997, the IEPA issued supplemental permits to ANL-E that, in part, approved a groundwater monitoring program for the sanitary landfill. The program should be capable of identifying any releases from the facility and demonstrating compliance with the applicable groundwater quality standards. Under the January 1995 supplemental permits, the IEPA chose 13 groundwater monitoring points (800161, 800162, 800163D, 800171, 800173D, 800181, 800183D, 800191, 800192, 800193D, 800201, 800202 , and $800203 \mathrm{D}$ ) to be sampled on a quarterly basis commencing January 1995. Parameters to be monitored include field parameters, filtered routine indicator parameters, unfiltered routine indicator parameters, unfiltered inorganic parameters, and volatile organic parameters. V olatile organic parameters are to be monitored only during the second quarter of monitoring. Routine indicator parameters are collected each quarter. Inorganic parameters are unfiltered prior to analysis and are collected only during the second quarter.

A NL-E chose a conservative approach for evaluating the inorganic monitoring results by selecting as the standard of comparison the Illinois Groundwater Quality Standards for Class I: Potable Resource Groundwater, 35 IAC Section 620.410. The most common constituents at levels above the WQS (see Table 6.22) are chloride, iron, TDS, and manganese. This is consistent with results reported in prior years using the previous well monitoring network.

Field Parameters. Field parameters include such items as well and water depth information, pH, specific conductance, and temperature of water. These parameters are measured each quarter. No standards exist for comparative purposes, with the exception of $\mathrm{pH}$. Specific conductance measurements for the third quarter were all approximately $30 \%$ lower than those of the other quarters for 1997. This was due to a malfunctioning water quality meter that was replaced before the fourth quarter measurements were taken. 
Filtered Routine Indicator Parameters. Filtered routine indicator parameters include ammonia as nitrogen, arsenic, cadmium, chloride, iron, lead, manganese, mercury, sulfate, and TDS. These parameters are measured each quarter. Ammonia, arsenic, cadmium, lead, mercury, and sulfate were all less than the WQS. Chloride exceeded the WQS $(200 \mathrm{mg} / \mathrm{L})$ in Wells 800173D and 800191 at least once during the year. Chloride levels in these wells ranged from 159 to $390 \mathrm{mg} / \mathrm{L}$.

Iron concentrations exceeded the WQS $(5 \mathrm{mg} / \mathrm{L})$ at least once during the year in Wells 800191, 800192, and 800201. Iron levels in these wells ranged from $0.6 \mathrm{mg} / \mathrm{L}$ to $11.2 \mathrm{mg} / \mathrm{L}$.

$M$ anganese concentrations exceeded the WQS $(0.15 \mathrm{mg} / \mathrm{L})$ during at least one quarter in Wells 800161, 800162,800171, 800191,800192, 800201, and 800202. M anganese levels in these wells ranged from 0.2 to $2.1 \mathrm{mg} / \mathrm{L}$. M anganese appears to be elevated over the entire $800 \mathrm{~L}$ andfill area, and similar concentrations have been measured in monitoring wells several miles from the $800 \mathrm{~A}$ rea $\mathrm{L}$ andfill.

Only Well 800191 contained concentrations of TDS above the W QS $(1,200 \mathrm{mg} / \mathrm{L})$. TDS levels in this well ranged from 1,240 to $1,546 \mathrm{mg} / \mathrm{L}$.

Unfiltered Routine Indicator Parameters. These specific parameters include cyanide, phenols (total recoverable), TOC, and TOX and are measured each quarter. All measured unfiltered routine indicator parameters were less than the appropriate WQS values, where applicable.

Unfiltered Inorganic Parameters. These parameters are measured only during the second quarter and include arsenic, barium, boron, cadmium, chloride, chromium, cobalt, copper, cyanide, fluoride, iron, lead, manganese, mercury, nickel, nitrate as nitrogen, selenium, silver, sulfate, and zinc. As in previous years, the chromium and nickel concentrations exceeded the WQS $(0.1 \mathrm{mg} / \mathrm{L})$ only in Well 800192. 


\section{GROUNDWATER PROTECTION}

Iron concentrations exceeded the WQS (5 mg/L) in Wells 800171, 800173D, 800181, 800191, 800192, and 800201. Iron levels in these wells ranged from 5.5 to $47 \mathrm{mg} / \mathrm{L}$. The iron exceedances are probably due to the requirement that these samples are unfiltered.

Lead concentrations exceeded the WQS $(0.0075 \mathrm{mg} / \mathrm{L})$ in W ells 800171, 800181, 800191, and 800192 . Lead levels in these wells ranged from 0.0086 to $0.0260 \mathrm{mg} / \mathrm{L}$.

M anganese concentrations exceeded the WQS $(0.15 \mathrm{mg} / \mathrm{L})$ in W ells 800161, 800162, $800171,800181,800191,800192,800201$, and 800202. M anganese levels in these wells ranged from 0.24 to $2.1 \mathrm{mg} / \mathrm{L}$. Elevated manganese levels appear to be normal for this area.

Organic Parameters. The unfiltered organic parameters were all below their respective detection limits except for trichlorofluoromethane in Well 800161 at $4.0 \mu \mathrm{g} / \mathrm{L}$. The PQL is $5 \mu \mathrm{g} / \mathrm{L}$.

Radioactive Constituents. Samples collected from the 800 A rea sanitary landfill monitoring wells were also analyzed for hydrogen-3. The results are shown in Tables 6.23 to 6.35. Although the disposal of radioactive materials was prohibited in the sanitary landfill, very low concentrations of hydrogen-3 were detected in W ells 800161, 800171, 800191, and 800192, probably because of inadvertent disposal of radioactivity in ANL-E trash. These results ar e consistent with 1996 results. A trace level of was also detected in W ell 800191, but only during two quarters. However, the presence of hydrogen-3 as tritiated water allows information to be obtained on the subsurface water flow pathway in the sanitary landfill area. The data indicate that the principal direction of subsurface water flow is to the south-southeast, with a small component to the northwest. This is consistent with the estimated subsurface water flow based on water level measurements and general flow patterns in the area.

\subsection{CP-5 Reactor Area}

The CP-5 reactor is an inactive research reactor located in Building 330 (see Figure 1.1). The CP-5 5-M W research reactor was used from 1954 until operations ceased in 1979. In addition 
to the reactor vessel, the CP-5 complex contained several large cooling towers and an outdoo $r$ equipment yard for storing equipment and supplies. The reactor and associated yard area are in the process of being decommissioned. A single exploratory moni toring well was installed in 1989 in the yard immediately behind the reactor building, just outside the reactor fuel storage area of the complex. Two new wells were installed as part of a full characterization study of this site, which took place during 1993. The three wells have been sampled quarterly since 1995 and analyzed for radionuclides, metals, VOCs, SVOCs, pesticides, herbicides, and PCBs. A new deep well was installed during June 1997 to determine whether there had been any vertical migration of hydrogen-3 in the groundwater from the CP-5 reactor. The results are shown in Tables 6.36 to 6.39 . Table 6.40 characterizes all wells in this area (see Figure 6.20 for locations).

Well 330011 is installed in a relatively porous, saturated region of soil and as a result, recharges quickly. Purging the well by removing several well volumes of water does not lower the water level appreciably. The water has a higher conductivity and temperature than similar wells at other locations. As in past years, the manganese W QS $(0.15 \mathrm{mg} / \mathrm{L})$ was exceeded three quarters, and levels ranged from 0.08 to $0.65 \mathrm{mg} / \mathrm{L}$. The chloride WQS $(200 \mathrm{mg} / \mathrm{L})$ was exceeded during only one quarter, and chloride levels ranged from 66 to $209 \mathrm{mg} / \mathrm{L}$. L ow levels

of barium were noted each quarter; all levels were well below the WQS of $2 \mathrm{mg} / \mathrm{L}$. As in past years, barium was detected each quarter in W ell 330021; manganese was noted two quarters, and all levels were well below the appropriate WQS.

Unlike past years, manganese and nickel exceeded the WQS $(0.15$ and $0.10 \mathrm{mg} / \mathrm{L}$, respectively) each quarter in W ell 330031 . M anganese levels ranged from 0.16 to $0.45 \mathrm{mg} / \mathrm{L}$, and nickel levels ranged from 0.30 to $1.53 \mathrm{mg} / \mathrm{L}$. The source of nickel is unknown. Similar manganese concentrations have been measured at distances from the CP-5 (see Section 6.3.2.3). Chloride concentrations exceeded the W QS $(200 \mathrm{mg} / \mathrm{L})$ two quarters, and chloride levels ranged from 141 to $359 \mathrm{mg} / \mathrm{L}$. A rsenic and barium were detected at levels well below the WQS each quarter in samples from W ell 330012D. 
TABLE 6.36

Groundwater M onitoring Results, 330 A rea W ell 330011, $1997^{\text {a }}$

\begin{tabular}{|c|c|c|c|c|c|}
\hline \multirow[b]{2}{*}{ Parameter } & \multirow[b]{2}{*}{ Unit } & \multicolumn{4}{|c|}{ Date of Sampling } \\
\hline & & $03 / 11 / 97$ & $06 / 17 / 97$ & $09 / 10 / 97$ & $11 / 24 / 97$ \\
\hline W ater elevation & $\mathrm{m}$ & 225.48 & 224.07 & 223.38 & 222.27 \\
\hline Temperature & ${ }^{\circ} \mathrm{C}$ & 13.3 & 16.0 & 18.5 & 18.1 \\
\hline $\mathrm{pH}$ & $\mathrm{pH}$ & 6.96 & 7.08 & 7.02 & 6.75 \\
\hline Redox & $\mathrm{mV}$ & 7 & -29 & 18 & -4 \\
\hline Conductivity & $\mu \mathrm{mhos} / \mathrm{cm}$ & 1,058 & 1,352 & 1,179 & 1,307 \\
\hline Chloride - filtered & $\mathrm{mg} / \mathrm{L}$ & 103 & 209 & 66 & 100 \\
\hline A rsenic - filtered & $\mathrm{mg} / \mathrm{L}$ & $<0.002$ & $<0.002$ & $<0.002$ & $<0.002$ \\
\hline Barium - filtered & $\mathrm{mg} / \mathrm{L}$ & 0.0546 & 0.0742 & 0.0561 & 0.0568 \\
\hline Beryllium - filtered & $\mathrm{mg} / \mathrm{L}$ & $<0.0002$ & $<0.0002$ & $<0.0002$ & $<0.0002$ \\
\hline Cadmium - filtered & $\mathrm{mg} / \mathrm{L}$ & $<0.0001$ & 0.0001 & $<0.0001$ & $<0.0001$ \\
\hline Chromium - filtered & $\mathrm{mg} / \mathrm{L}$ & $<0.044$ & $<0.044$ & $<0.044$ & $<0.044$ \\
\hline Cobalt - filtered & $\mathrm{mg} / \mathrm{L}$ & $<0.026$ & $<0.026$ & $<0.026$ & $<0.026$ \\
\hline Copper - filtered & $\mathrm{mg} / \mathrm{L}$ & $<0.017$ & $<0.017$ & $<0.017$ & $<0.017$ \\
\hline Iron - filtered & $\mathrm{mg} / \mathrm{L}$ & $<0.037$ & $<0.037$ & $<0.037$ & $<0.037$ \\
\hline L ead - filtered & $\mathrm{mg} / \mathrm{L}$ & $<0.001$ & $<0.001$ & $<0.001$ & $<0.001$ \\
\hline M anganese - filtered & $\mathrm{mg} / \mathrm{L}$ & 0.6461 & 0.6356 & 0.0768 & 0.3458 \\
\hline M ercury - filtered & $\mathrm{mg} / \mathrm{L}$ & $<0.0001$ & $<0.0001$ & $<0.0001$ & $<0.0001$ \\
\hline Nickel - filtered & $\mathrm{mg} / \mathrm{L}$ & $<0.040$ & $<0.040$ & $<0.040$ & $<0.040$ \\
\hline Silver - filtered & $\mathrm{mg} / \mathrm{L}$ & $<0.0005$ & $<0.0005$ & $<0.0005$ & $<0.0005$ \\
\hline Thallium - filtered & $\mathrm{mg} / \mathrm{L}$ & $<0.001$ & $<0.001$ & $<0.001$ & $<0.001$ \\
\hline V anadium - filtered & $\mathrm{mg} / \mathrm{L}$ & $<0.024$ & $<0.024$ & $<0.024$ & $<0.024$ \\
\hline Zinc - filtered & $\mathrm{mg} / \mathrm{L}$ & $<0.011$ & $<0.011$ & $<0.011$ & $<0.011$ \\
\hline Cesium-137 & $\mathrm{pCi} / \mathrm{L}$ & $<1.0$ & 1.4 & $<1.0$ & 1.0 \\
\hline Hydrogen-3 & $\mathrm{pCi} / \mathrm{L}$ & 6,314 & 7,907 & 3,082 & 5,292 \\
\hline Strontium-90 & $\mathrm{pCi} / \mathrm{L}$ & 1.64 & 2.76 & $<0.25$ & 1.27 \\
\hline 2-M ethylbutane & $\mu \mathrm{g} / \mathrm{L}$ & $-b$ & - & 3 & - \\
\hline Dichlorofluoromethane & $\mu \mathrm{g} / \mathrm{L}$ & 2 & 3 & 2 & 3 \\
\hline Trichlorofluoromethane & $\mu \mathrm{g} / \mathrm{L}$ & 4 & 4 & 2 & 5 \\
\hline
\end{tabular}

a $\quad$ ell point elevation $=221.00 \mathrm{~m}(\mathrm{MSL})$; ground surface elevation $=227.10 \mathrm{~m}(\mathrm{M} \mathrm{SL})$; casing material $=$ steel.

b A hyphen indicates that the measured value was less than the detection limit. 


\section{GROUNDWATER PROTECTION}

TABLE 6.37

Groundwater M onitoring Results, 330 A rea Well 330021, $1997^{\mathrm{a}}$

\begin{tabular}{|c|c|c|c|c|c|c|}
\hline \multirow[b]{2}{*}{ Parameter } & \multirow[b]{2}{*}{ Unit } & \multicolumn{5}{|c|}{ Date of Sampling } \\
\hline & & $03 / 12 / 97$ & $03 / 12 / 97$ & $06 / 17 / 97$ & $09 / 10 / 97$ & $11 / 24 / 97$ \\
\hline W ater elevation & $\mathrm{m}$ & 226.81 & 226.81 & 225.56 & 224.92 & 224.47 \\
\hline Temperature & ${ }^{\circ} \mathrm{C}$ & 7.8 & 7.8 & 9.4 & 12.8 & 11.9 \\
\hline $\mathrm{pH}$ & $\mathrm{pH}$ & 7.37 & 7.37 & 7.24 & 7.12 & 7.12 \\
\hline Redox & $\mathrm{mV}$ & 3 & 3 & -33 & -14 & -28 \\
\hline Conductivity & $\mu \mathrm{mhos} / \mathrm{cm}$ & 498 & 498 & 546 & 786 & 770 \\
\hline Chloride - filtered & $\mathrm{mg} / \mathrm{L}$ & 6 & 6 & 6 & 7 & 5 \\
\hline A rsenic - filtered & $\mathrm{mg} / \mathrm{L}$ & $<0.002$ & $<0.002$ & $<0.002$ & $<0.002$ & $<0.002$ \\
\hline Barium - filtered & $\mathrm{mg} / \mathrm{L}$ & 0.0218 & 0.0228 & 0.0251 & 0.0315 & 0.0251 \\
\hline Beryllium - filtered & $\mathrm{mg} / \mathrm{L}$ & $<0.0002$ & $<0.0002$ & $<0.0002$ & $<0.0002$ & $<0.0002$ \\
\hline Cadmium - filtered & $\mathrm{mg} / \mathrm{L}$ & $<0.0001$ & $<0.0001$ & $<0.0001$ & $<0.0001$ & $<0.0001$ \\
\hline Chromium - filtered & $\mathrm{mg} / \mathrm{L}$ & $<0.044$ & $<0.044$ & $<0.044$ & $<0.044$ & $<0.044$ \\
\hline Cobalt - filtered & $\mathrm{mg} / \mathrm{L}$ & $<0.026$ & $<0.026$ & $<0.026$ & $<0.026$ & $<0.026$ \\
\hline Copper - filtered & $\mathrm{mg} / \mathrm{L}$ & $<0.017$ & $<0.017$ & $<0.017$ & $<0.017$ & $<0.017$ \\
\hline Iron - filtered & $\mathrm{mg} / \mathrm{L}$ & $<0.037$ & $<0.037$ & $<0.037$ & 0.4206 & $<0.037$ \\
\hline L ead - filtered & $\mathrm{mg} / \mathrm{L}$ & $<0.001$ & $<0.001$ & $<0.001$ & $<0.001$ & $<0.001$ \\
\hline$M$ anganese - filtered & $\mathrm{mg} / \mathrm{L}$ & $<0.017$ & $<0.017$ & $<0.017$ & 0.0546 & 0.0553 \\
\hline M ercury - filtered & $\mathrm{mg} / \mathrm{L}$ & $<0.0001$ & $<0.0001$ & $<0.0001$ & $<0.0001$ & $<0.0001$ \\
\hline N ickel - filtered & $\mathrm{mg} / \mathrm{L}$ & $<0.040$ & $<0.040$ & $<0.040$ & $<0.040$ & $<0.040$ \\
\hline Silver - filtered & $\mathrm{mg} / \mathrm{L}$ & $<0.0005$ & $<0.0005$ & $<0.0005$ & $<0.0005$ & $<0.0005$ \\
\hline Thallium - filtered & $\mathrm{mg} / \mathrm{L}$ & $<0.001$ & $<0.001$ & $<0.001$ & $<0.001$ & $<0.001$ \\
\hline V anadium - filtered & $\mathrm{mg} / \mathrm{L}$ & $<0.024$ & $<0.024$ & $<0.024$ & $<0.024$ & $<0.024$ \\
\hline Zinc - filtered & $\mathrm{mg} / \mathrm{L}$ & $<0.011$ & $<0.011$ & $<0.011$ & $<0.011$ & $<0.011$ \\
\hline C esium-137 & $\mathrm{pCi} / \mathrm{L}$ & $<1.0$ & $<1.0$ & $<1.0$ & $<1.0$ & $<1.0$ \\
\hline Hydrogen-3 & $\mathrm{pCi} / \mathrm{L}$ & 117 & 133 & 164 & 173 & 256 \\
\hline Strontium-90 & $\mathrm{pCi} / \mathrm{L}$ & $<0.25$ & $<0.25$ & $<0.25$ & $<0.25$ & $<0.25$ \\
\hline 2-M ethylbutane & $\mu \mathrm{g} / \mathrm{L}$ & $-b$ & - & 3 & 4 & 3 \\
\hline A cetone & $\mu \mathrm{g} / \mathrm{L}$ & - & - & - & 2 & - \\
\hline
\end{tabular}

a $\quad$ ell point elevation $=221.95 \mathrm{~m}(\mathrm{MSL})$; ground surface elevation $=227.75 \mathrm{~m}(\mathrm{MSL})$; casing material $=$ stainless steel.

b A hyphen indicates that the measured value was less than the detection limit. 
TABLE 6.38

Groundwater M onitoring Results, 330 A rea Well 330031, $1997^{a}$

\begin{tabular}{|c|c|c|c|c|c|}
\hline \multirow[b]{2}{*}{ Parameter } & \multirow[b]{2}{*}{ Unit } & \multicolumn{4}{|c|}{ Date of Sampling } \\
\hline & & $03 / 12 / 97$ & 06/17/97 & 09/10/97 & $11 / 24 / 97$ \\
\hline Water elevation & $\mathrm{m}$ & 226.85 & 226.07 & 225.15 & 225.55 \\
\hline Temperature & ${ }^{\circ} \mathrm{C}$ & 7.3 & 9.7 & 13.6 & 12.5 \\
\hline $\mathrm{pH}$ & $\mathrm{pH}$ & 7.23 & 7.11 & 6.70 & 6.85 \\
\hline Redox & $\mathrm{mV}$ & -22 & -121 & 14 & -24 \\
\hline Conductivity & $\mu \mathrm{mhos} / \mathrm{cm}$ & 911 & 1,093 & 1,948 & 1,880 \\
\hline Chloride - filtered & $\mathrm{mg} / \mathrm{L}$ & 141 & 190 & 322 & 359 \\
\hline A rsenic - filtered & $\mathrm{mg} / \mathrm{L}$ & $<0.002$ & $<0.002$ & $<0.002$ & $<0.002$ \\
\hline Barium - filtered & $\mathrm{mg} / \mathrm{L}$ & 0.0378 & 0.0426 & 0.0709 & 0.0593 \\
\hline Beryllium - filtered & $\mathrm{mg} / \mathrm{L}$ & $<0.0002$ & $<0.0002$ & $<0.0002$ & $<0.0002$ \\
\hline Cadmium - filtered & $\mathrm{mg} / \mathrm{L}$ & $<0.0001$ & $<0.0001$ & $<0.0001$ & $<0.0001$ \\
\hline Chromium - filtered & $\mathrm{mg} / \mathrm{L}$ & $<0.044$ & $<0.044$ & $<0.044$ & $<0.044$ \\
\hline Cobalt - filtered & $\mathrm{mg} / \mathrm{L}$ & $<0.026$ & $<0.026$ & $<0.026$ & $<0.026$ \\
\hline Copper - filtered & $\mathrm{mg} / \mathrm{L}$ & $<0.017$ & $<0.017$ & $<0.017$ & $<0.017$ \\
\hline Iron - filtered & $\mathrm{mg} / \mathrm{L}$ & $<0.037$ & 3.664 & 0.0582 & 0.1966 \\
\hline Lead - filtered & $\mathrm{mg} / \mathrm{L}$ & $<0.001$ & $<0.001$ & $<0.001$ & $<0.001$ \\
\hline$M$ anganese - filtered & $\mathrm{mg} / \mathrm{L}$ & 0.1619 & 0.4502 & 0.2311 & 0.2410 \\
\hline M ercury - filtered & $\mathrm{mg} / \mathrm{L}$ & $<0.0001$ & $<0.0001$ & $<0.0001$ & $<0.0001$ \\
\hline Nickel - filtered & $\mathrm{mg} / \mathrm{L}$ & 0.3017 & 1.5290 & 0.5263 & 0.4925 \\
\hline Silver - filtered & $\mathrm{mg} / \mathrm{L}$ & $<0.0005$ & $<0.0005$ & $<0.0005$ & $<0.0005$ \\
\hline Thallium - filtered & $\mathrm{mg} / \mathrm{L}$ & $<0.001$ & $<0.001$ & $<0.001$ & $<0.001$ \\
\hline V anadium - filtered & $\mathrm{mg} / \mathrm{L}$ & $<0.024$ & $<0.024$ & $<0.024$ & $<0.024$ \\
\hline Zinc - filtered & $\mathrm{mg} / \mathrm{L}$ & 0.0206 & 0.0259 & 0.0389 & 0.0352 \\
\hline Cesium-137 & $\mathrm{pCi} / \mathrm{L}$ & $<1.0$ & $<1.0$ & $<1.0$ & $<1.0$ \\
\hline Hydrogen-3 & $\mathrm{pCi} / \mathrm{L}$ & 216 & 235 & 227 & 214 \\
\hline Strontium-90 & $\mathrm{pCi} / \mathrm{L}$ & $<0.25$ & $<0.25$ & $<0.25$ & $<0.25$ \\
\hline 2-M ethylbutane & $\mu \mathrm{g} / \mathrm{L}$ & $-b$ & 3 & - & 3 \\
\hline
\end{tabular}

a $\quad$ ell point el evation $=221.95 \mathrm{~m}(\mathrm{M} \mathrm{SL})$; ground surface elevation $=227.13 \mathrm{~m}(\mathrm{M} \mathrm{SL})$; casing material $=$ stainless steel.

b A hyphen indicates that the measured value was less than the detection limit. 


\section{GROUNDWATER PROTECTION}

TABLE 6.39

Groundwater M onitoring Results, 330 A rea W ell 330012D, $1997^{\mathrm{a}}$

\begin{tabular}{|c|c|c|c|}
\hline \multirow[b]{2}{*}{ Parameter } & \multirow[b]{2}{*}{ Unit } & \multicolumn{2}{|c|}{ Date of Sampling } \\
\hline & & $09 / 10 / 97$ & $11 / 24 / 97$ \\
\hline W ater elevation & $\mathrm{m}$ & 191.06 & 190.92 \\
\hline Temperature & ${ }^{\circ} \mathrm{C}$ & 13.3 & 13.1 \\
\hline $\mathrm{pH}$ & $\mathrm{pH}$ & 6.99 & 6.98 \\
\hline Redox & $\mathrm{mV}$ & 13 & -20 \\
\hline Conductivity & $\mu \mathrm{mhos} / \mathrm{cm}$ & 1,113 & 1,010 \\
\hline Chloride - filtered & $\mathrm{mg} / \mathrm{L}$ & 47 & 47 \\
\hline A rsenic - filtered & $\mathrm{mg} / \mathrm{L}$ & 0.002 & 0.0026 \\
\hline Barium - filtered & $\mathrm{mg} / \mathrm{L}$ & 0.0827 & 0.0718 \\
\hline Beryllium - filtered & $\mathrm{mg} / \mathrm{L}$ & $<0.0002$ & $<0.0002$ \\
\hline Cadmium - filtered & $\mathrm{mg} / \mathrm{L}$ & $<0.0001$ & $<0.0001$ \\
\hline Chromium - filtered & $\mathrm{mg} / \mathrm{L}$ & $<0.044$ & $<0.044$ \\
\hline Cobalt - filtered & $\mathrm{mg} / \mathrm{L}$ & $<0.026$ & $<0.026$ \\
\hline Copper - filtered & $\mathrm{mg} / \mathrm{L}$ & $<0.017$ & $<0.017$ \\
\hline Iron - filtered & $\mathrm{mg} / \mathrm{L}$ & $<0.037$ & 0.4431 \\
\hline L ead - filtered & $\mathrm{mg} / \mathrm{L}$ & $<0.001$ & $<0.001$ \\
\hline$M$ anganese - filtered & $\mathrm{mg} / \mathrm{L}$ & 0.0293 & 0.0204 \\
\hline M ercury - filtered & $\mathrm{mg} / \mathrm{L}$ & $<0.0001$ & $<0.0001$ \\
\hline Nickel - filtered & $\mathrm{mg} / \mathrm{L}$ & $<0.04$ & $<0.04$ \\
\hline Silver - filtered & $\mathrm{mg} / \mathrm{L}$ & $<0.0005$ & $<0.0005$ \\
\hline Thallium - filtered & $\mathrm{mg} / \mathrm{L}$ & $<0.001$ & $<0.001$ \\
\hline V anadium - filtered & $\mathrm{mg} / \mathrm{L}$ & $<0.024$ & $<0.024$ \\
\hline Zinc - filtered & $\mathrm{mg} / \mathrm{L}$ & $<0.011$ & $<0.011$ \\
\hline Hydrogen-3 & $\mathrm{pCi} / \mathrm{L}$ & 144 & 332 \\
\hline Strontium-90 & $\mathrm{pCi} / \mathrm{L}$ & $<0.25$ & $<0.25$ \\
\hline Cesium-137 & $\mathrm{pCi} / \mathrm{L}$ & $<1.0$ & $<1.0$ \\
\hline 2-M ethylbutane & $\mu \mathrm{g} / \mathrm{L}$ & 3 & $-b$ \\
\hline A cetone & $\mu \mathrm{g} / \mathrm{L}$ & 1 & - \\
\hline
\end{tabular}

a $\quad$ Well point elevation $=185.65 \mathrm{~m}(\mathrm{MSL}) ;$ ground surface elevation $=227.13 \mathrm{~m}$ $(\mathrm{M} \mathrm{SL})$; casing material $=$ stainless steel.

b A hyphen indicates that the measured value was less than the detection limit. 


\section{GROUNDWATER PROTECTION}

\section{TABLE 6.40}

Groundwater M onitoring Wells: 330 A rea/CP-5

\begin{tabular}{lccccc}
\hline $\begin{array}{c}\text { ID } \\
\text { Number }\end{array}$ & $\begin{array}{c}\text { Well } \\
\text { Depth } \\
\text { (m bgs) }\end{array}$ & $\begin{array}{c}\text { Ground } \\
\text { Elevation } \\
\text { (m AM SL) }\end{array}$ & $\begin{array}{c}\text { Monitoring } \\
\text { Zone } \\
\text { (m AM SL) }\end{array}$ & $\begin{array}{c}\text { Well } \\
\text { Type }^{\text {a }}\end{array}$ & $\begin{array}{c}\text { Date } \\
\text { Drilled }\end{array}$ \\
\hline 330011 & 6.1 & 227.2 & $224.2-221.1$ & $0.05 /$ PVC & $8 / 89$ \\
330021 & 5.8 & 227.5 & $226.3-221.7$ & $0.05 /$ SS & $9 / 93$ \\
330031 & 5.2 & 226.2 & $225.6-221.0$ & $0.05 /$ SS & $9 / 93$ \\
$330012 D$ & 41.5 & 227.1 & $191.7-185.6$ & $0.05 /$ SS & $6 / 97$ \\
\hline
\end{tabular}

a Inner diameter $(\mathrm{m}) /$ well material (PVC = polyvinyl chloride, SS = stainless steel $)$.

Each sample collected from Well 330011 in 1997 contained trichlorofluoromethane and dichlorofluoromethane concentrations ranging from 2 to $5 \mu \mathrm{g} / \mathrm{L}$, similar to results from 1991 through 1996. These levels are significantly lower than those reported in 1991 and 1992. A cetone was present at a very low level only one quarter in W ells 330021 and 330012D. The field blank showed 2-methylbutane during the third and fourth quarters; its presence in the well results for those quarters is suspect.

As in previous years, hydrogen-3 was detected in W ells 330011, 330021, and 330031 each quarter. The levels of hydrogen-3 ranged from 117 to 7,907 pCi/L. Hydrogen-3 was also detected each quarter in samples from Well 330012D at low levels of 144 and $332 \mathrm{pCi} / \mathrm{L}$. Strontium-90 was detected in only W ell 330011 during three quarters, and the levels ranged from less than 0.25 to $2.76 \mathrm{pCi} / \mathrm{L}$. Cesium-137 was detected in only W ell 330011, and the level $\mathrm{s}$ ranged from less than 1.0 to $1.40 \mathrm{pCi} / \mathrm{L}$. The CP-5 was a heavy-water-moderated reactor.

During its operational life, several incidents occurred that released small amounts of thi s heavy water containing high concentrations of hydrogen-3 to the environment. In addition, the normal operation released significant amounts of water vapor containing hydrogen-3 from the main ventilation system that may have condensed and fallen to the ground in the form of precipitation. These activities are believed to be responsible for the residual amounts of 


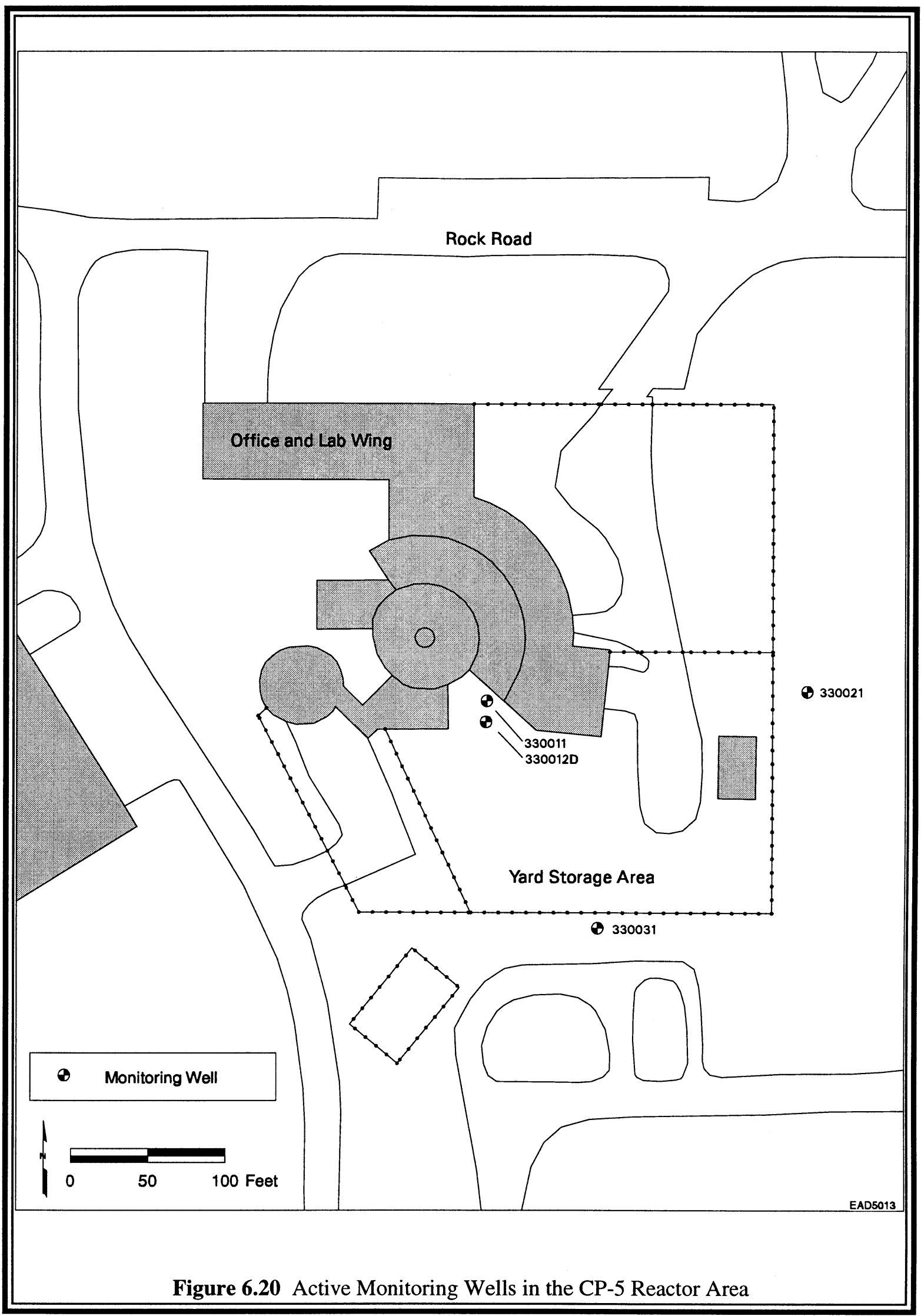




\section{GROUNDWATER PROTECTION}

hydrogen-3 now found in the groundwater. All the hydrogen-3 monitoring results for the CP-5 wells are plotted in Figure 6.21. The source of the strontium-90 and cesium-137 is not known.

\subsection{Site Remediation Activities}

Historical information about waste disposal activities on the ANL-E site, as well as groundwater monitoring results, indicate that several sites are either currently releasing smal I amounts of hazardous materials to the environment or have the potential to do so in the future. Site characterization was completed, and remediation was begun several years ago at location s where waste materials are known to have been managed or disposed of. These projects have focused on the most significant sites - the 317 and 319 A reas and the 800 A rea L andfill. The RFIs in both the 317/319/ENE A reas and the 800 A rea were completed in 1996; reports were submitted to the IEPA in 1997. ${ }^{6,7}$

\subsubsection{7/319/ENE Area Characterization}

\subsubsection{RCRA Facility Investigation}

Field activities for the RFI were begun in the 317/319/E NE A reas in December 1994 and were completed in September 1996. The purpose of this investigation was to determine the extent of known contaminated areas (e.g., 317 A rea French Drain and 319 A rea Landfill and F rench D rain) and to determine whether releases of hazardous or radioactive materials have occurred from the other units in the area. The field program resulted in the installation of a network of 33 groundwater monitoring wells and the completion of 38 soil borings. A series of soil and groundwater samples were taken and submitted for chemical analysis. In addition to the soil borings and well installation work, a sampling program for surface soil, surface water, sediment, and seep water was also completed. A program of test pit excavation and sampling was completed in the 319 and ENE A reas as well. Detailed geophysical surveys were conducted by using a variety of geophysical imaging technologies in the 318, 319, and ENE A reas. The purposes of these surveys were to detect and delineate the presence of subsurface anomalies, which likel y represent areas of disturbed earth and buried debris. 


\section{GROUNDWATER PROTECTION}

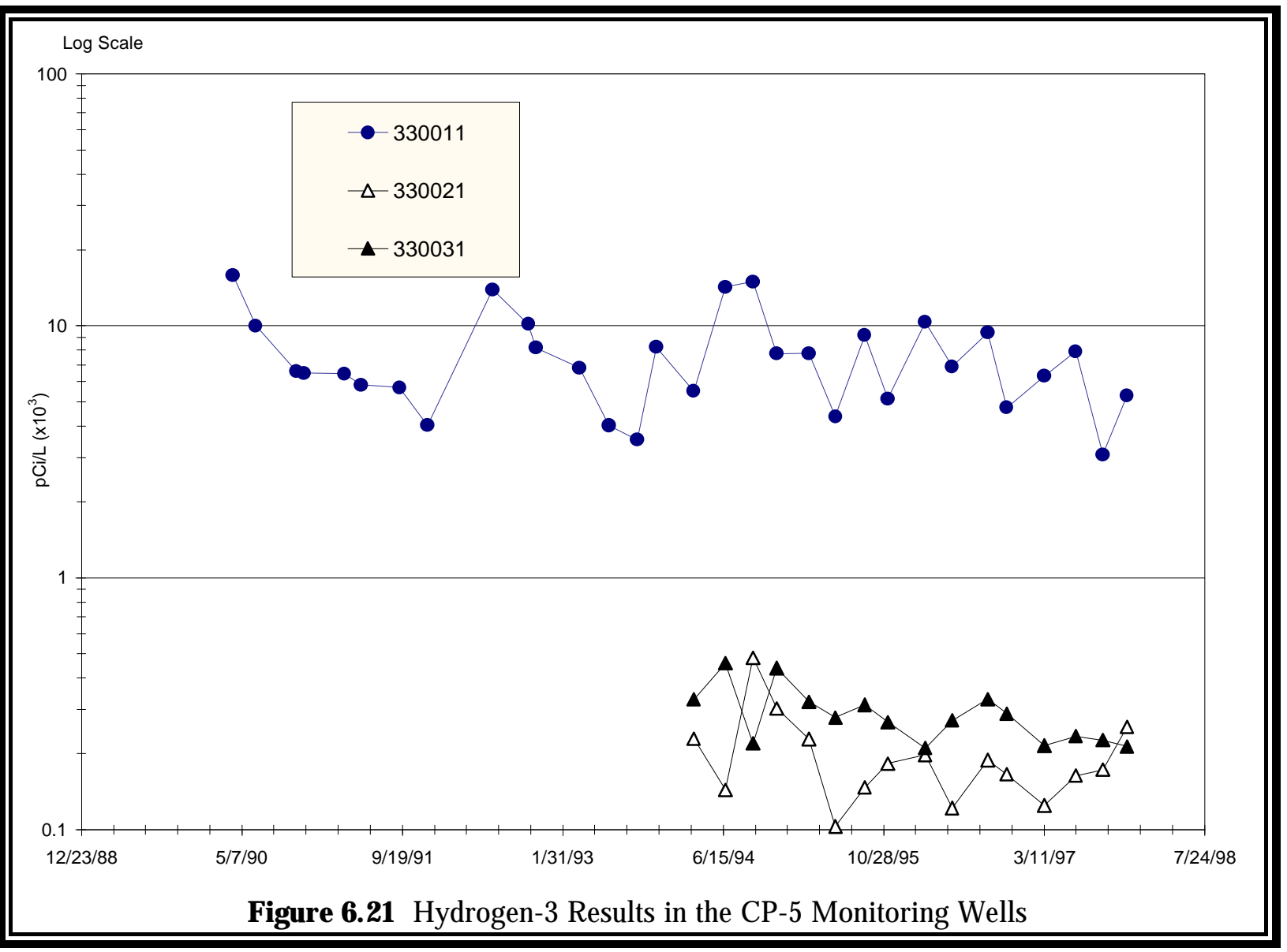

The information generated by this investigation was analyzed and summarized in the RFI Report for the 317/319/ENE A rea, which was submitted to the IEPA in A ugust 1997. ${ }^{6}$ As discussed in the RFI report, the extent of the contaminated soil zone near the 317 A rea French Drain was found to be limited to the region immediately north of the waste storage vaults. $A$ region of groundwater containing similar chemicals to those found in the French Drain area was detected south and southeast of the vaults. A region of groundwater containing hydrogen-3 and chemicals present in the 319 A rea $L$ andfill was found to extend south of the 319 Area $L$ andfill. $\mathrm{N}$ o other releases of hazardous or radioactive materials were discovered.

During the later stages of the RFI, ANL-E discovered a series of groundwater seeps in a network of steeply eroded ravines south and southeast of the 317 and 319 A reas. The seeps are located approximately $200 \mathrm{~m}$ (600 ft) south of the ANL -E fence line in the W aterfall Glen Forest Preserve. Seep samples collected during the RFI showed that two of five seeps identified in the 


\section{GROUNDWATER PROTECTION}

ravines contained detectable levels of organic contaminants. In December 1996, ANL-E began an inspection and monitoring program at these seeps. This program requires that the seeps be inspected on a weekly basis to document any human or wildlife contact with the seeps and requires that the seeps be sampled on a monthly basis to record any changes in seep water chemistry. This monitoring program continued throughout 1997. The monitoring indicated that the concentrations of the organic compounds were stable throughout the year. It also revealed the presence of very low concentrations of hydrogen-3 (well below groundwater quality standards). ANL-E also began a detailed characterization of the geology and hydrogeology of the seep area in 1997 to better understand and appropriately manage any risks associated with the seeps.

\subsubsection{Sealing of the East Vaults Footing Drain}

The RFI showed that groundwater south of the 317 A rea contained chemicals similar to those found in the 317 A rea $F$ rench D rain. The migration of those chemicals was thought to be influenced by the presence of the $E$ ast $V$ aults F ooting Drain, a partially demolished underground drainage system that is used to prevent flooding of the vaults in the $317 \mathrm{~A} \mathrm{rea}$. It was thought that groundwater may have been moving south through the now abandoned portion of the system, which extended from the former South vaults, through M anhole 2E and the A NL-E fence line. To prevent this migration of groundwater, the drainage pipe was filled with grout, and the gravel bedding outside of the pipe was sealed by pressure-injecting grout into the backfill.

\subsubsection{318 Area}

The 318 A rea consisted of a small area within the $317 \mathrm{~A}$ rea where an undetermined number of inoperative compressed gas cylinders were buried in the 1970s. The cylinders contained small amounts (typically less than one pound) of a number of toxic or corrosive gases. To prevent inadvertent disturbance of these cylinders, which could have caused a release of these materials, a concrete cover was constructed over the entire area. The area will eventually be incorporated under the 319 A rea L andfill cap. 


\section{GROUNDWATER PROTECTION}

\subsubsection{317 Area Groundwater Seep Interim Action}

The discovery of the two natural groundwater seeps containing very low concentrations of three V OCs prompted ANL -E to accelerate the planned construction of a groundwater collection system south of the 317 A rea French D rain. This system is designed to intercept groundwater moving to the south, away from the 317 A rea French Drain. The groundwater in this area contains similar chemicals to those in the off-site groundwater seeps. Construction and operation of this system was intended to prevent any further migration of this groundwater off site. It was put into operation in October 1997.

\subsubsection{317 Area French Drain Soil Treatment}

As a result of past waste disposal activities conducted in the 1950s, the soil in the 317 French Drain area contains varying concentrations of numerous VOCs. Some of these compounds have migrated to underlying groundwater and occasionally are found in storm water runoff from the 317 A rea. To prevent this ongoing release, ANL-E began a program of soil treatment. The treatment system uses an innovative soil mixing process that removes volatil e organic materials from the soil without having to excavate the ar ea. The soil treatment was begun in September 1997 and should be completed by A pril 1998.

\subsubsection{319 Area Landfill Interim Action}

In early 1996, an interim corrective action was put in place south of the 319 A rea L andfill. The interim action was designed to prevent any further release of leachate from the landfill and to capture groundwater at the source, thus preventing future releases. It consisted of a below ground barrier wall (consisting of a soil/bentonite clay mixture placed in a deep trench); a leachate collection trench that collects leachate in a shallow, gravel-filled trench; and a series of groundwater extraction wells that remove the groundwater before it migrates away from the landfill area. The system was put into operation in F ebruary 1996 and has been in continuou s operation since. Since that time, there has been no evidence of leachate release. 


\section{GROUNDWATER PROTECTION}

Final corrective actions for the landfill, which will include placing an impermeable cap over the waste mound, were designed and proposed to the IEPA in 1997.

\subsubsection{Area Characterization}

The 800 A rea RFI addressed 11 SWM U s, 2 environmental A OCs, and 1 area suspected of containing a former solid waste disposal area. The 800 A rea RFI included a field program of soil boring, installation and sampling of groundwater monitoring and leachate wells, surface water and sediment sampling, and geophysical and soil gas surveys. The report summarizing the results of this investigation was completed and transmitted to the IEPA in A pril 1997. ${ }^{7}$

A nalysis of soil samples from the Waste Oil Storage A rea detected the presence of several SVOCS. The SVOCS detected are all common constituents of fuel and waste oil. Similar SVOCS were measured in the soil samples from the Waste Oil Satellite Accumulation A rea, the area of the Waste Oil Spread on Roads, and the Scrap M etal Storage A rea. The detection of VOCS, PCBs, pesticides, and inorganics in these areas was not at levels indicating a significant source of contamination.

A nalytical data from the three leachate wells sampled in the $800 \mathrm{~A}$ rea L andfill showed the presence of VOCs in all three wells. SVOCs were detected in two of the samples. PCBs were detected in one well. Elevated levels of hydrogen-3 occurred in all the samples from the leachate wells. A nalysis of groundwater from wells installed throughout the 800 A rea did not detect significant groundwater contamination.

A landfill gas monitoring program was initiated at the ANL-E 800 A rea Landfill during J une 1997. In 1997, the EPA LandGEM model ${ }^{4}$ was used to determine levels of methane $\left(\mathrm{CH}_{4}\right)$ and NMOC. On the basis of analysis of samples from gas monitoring wells, the model calculated $\mathrm{CH}_{4}$ emissions of approximately 70 ton/yr and NMOC emissions of approximately 0.02 ton/yr for 1997. Emissions of these parameters are expected to decline, on the basis of initial refuse placement and closure of the landfill. 


\subsubsection{Sitewide Hydrogeological Characterization Project}

In 1997, a one-year project was conducted to assess the effects on groundwater levels from A NL-E's conversion to Lake M ichigan as its water source. The study involved the collection of water level measurements to determine the rate of recovery of the water table after being affected by water withdrawal for 40 years. At the cessation of pumping on the ANL-E dolomite wells, the sphere of influence caused by the cone of depression extended up to $610 \mathrm{~m}(2,000 \mathrm{ft})$ horizontally. The water levels have risen since shutoff of the supply well in late December so that by the end of 1997, the cone of depression on the groundwater surface has shrunk to where the influence is under $305 \mathrm{~m}$ (1,000 ft). This recovery of the water table could affect flow rates and the direction of contaminant movement. The data from this research project will be incorporated into the sitewide hydrogeological characterization project findings and conclusions. 


\section{QUALITY ASSURANCE}

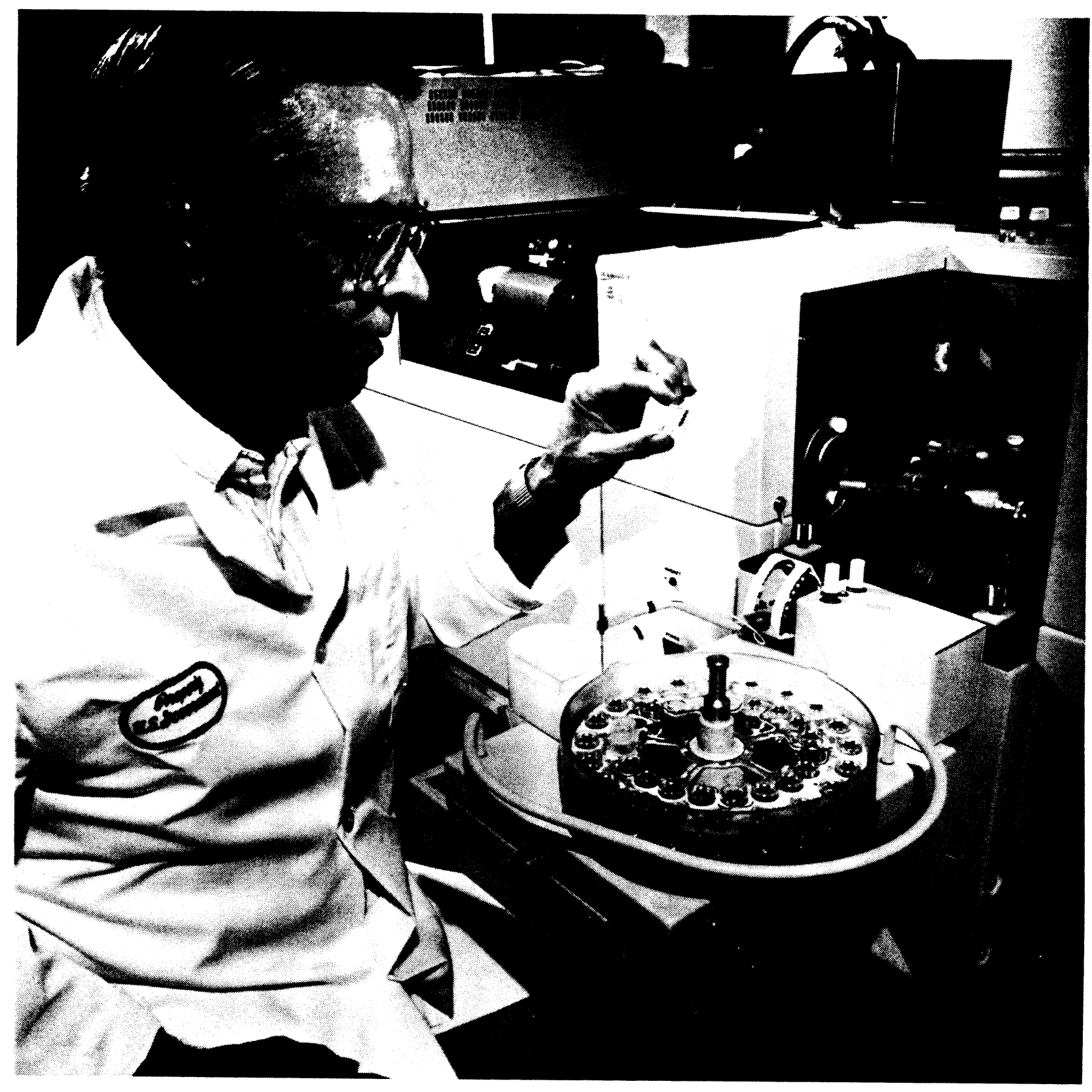




\section{QUALITY ASSURANCE}


QA plans exist for both radiological and nonradiological analyses; these Q A documents were prepared in accordance with DOE Order $5700.6 C^{33}$ and discuss who is responsible for QA and for auditing analyses. Both documents are supplemented by operating manuals.

\subsection{Sample Collection}

M any factors enter into an overall QA program other than the analytical quality control. Representative sampling is of prime importance. A ppropriate sampling protocols are followed for each type of sampling being conducted. W ater samples are pretreated in a manner designed to maintain the integrity of the analytical constituent. For example, samples for trace radionuclide analyses are acidified immediately after collection to prevent hydrolytic loss of metal ions and are filtered to reduce leaching from suspended solids.

The monitoring wells are sampled using the protocols listed in the RCRA Ground-Water Monitoring Technical Enforcement Guidance Document. ${ }^{32}$ The volume of water in the casing is determined by measuring the water depth from the surface and the depth to the bottom of the well. This latter measurement also determines whether siltation has occurred that might restrict water movement in the screened area. For those wells in the glacial till that do not recharge rapidly, the well is emptied and the volume removed is compared to the calculated volume. In most cases, these volumes are nearly identical. The well is then sampled by bailing with a Teflon bailer. If samples for parameters such as priority pollutants are collected, field parameters for these samples (pH, specific conductance, redox potential, and temperature) are measured per well volume while purging. For samples in the porous, saturated zone that recharges rapidly, three well volumes are purged by using submersible pumps. If field parameters are measured, samples are collected as soon as these readings stabilize. All samples are placed in precleaned bottles, labeled, and preserved. All field measurement and sampling equipment are cleaned by field rinsing with Type II deionized water. The samples are transferred to the analytical laboratory by using a computer floppy disk that generates a one-page list of all samples. This list acts as the chain of custody transfer document. 


\section{QUALITY ASSURANCE}

\subsection{Radiochemical Analysis and Radioactivity Measurements}

All nuclear instrumentation is calibrated with standard sources obtained from or traceable to the National Institute of Standards and Technology (NIST). The equipment is usually checked daily with secondary counting standards to ensure proper operation. Samples are periodically analyzed in duplicate or with the addition of known amounts of a radionuclide to check precision and accuracy. When a nuclide is not detected, the result is given as "less than" $(<)$ the detection limit by the analytical method used. The detection limits are chosen so that the measurement uncertainty at the $95 \%$ confidence level is equal to the measured value. The air and water detection limits for all radionuclides for which measurements were made in 1997 are given in Table 7.1. The relative error in a result decreases with increasing concentration. At a concentration equal to twice the detection limit, the error is approximately $50 \%$ of the measured value; at 10 times the detection limit, the error is approximately $10 \%$.

A verage values are usually accompanied by a plus-or-minus ( \pm ) limit value. Unless otherwise stated, this value is the standard error at the $95 \%$ confidence level calculated from the standard deviation of the average. The \pm limit value is a measure of the range in the concentrations encountered at that location; it does not represent the conventional uncertainty in the average of repeated measurements on the same or identical samples. Because many of the variations observed in environmental radioactivity are not random but occur for specific reasons (e.g., seasonal variations), samples collected from the same location at different times are not replicates. The more random the variation in activity at a particular location, the closer the confidence limits will represent the actual distribution of values at that location. The averages and confidence limits should be interpreted with this in mind. When a \pm value accompanies an individual result in this report, it represents the statistical counting error at the $95 \%$ confidence level. 
TABLE 7.1

\begin{tabular}{|c|c|c|}
\hline $\begin{array}{c}\text { Nuclide or } \\
\text { A ctivity }\end{array}$ & $\begin{array}{c}\text { Air } \\
\left(\mathrm{fCi} / \mathrm{m}^{3}\right)\end{array}$ & $\begin{array}{l}\text { Water } \\
(\mathrm{pC} \mathrm{i} / \mathrm{L})\end{array}$ \\
\hline A mericium-241 & $-a$ & 0.001 \\
\hline Beryllium-7 & 5 & - \\
\hline Californium-249 & - & 0.001 \\
\hline Californium-252 & - & 0.001 \\
\hline Cesium-137 & 0.1 & 1 \\
\hline Curium-242 & - & 0.001 \\
\hline Curium-244 & - & 0.001 \\
\hline Hydrogen-3 & - & 100 \\
\hline L ead-210 & 1 & - \\
\hline N eptunium-237 & - & 0.001 \\
\hline Plutonium-238 & 0.0001 & 0.001 \\
\hline Plutonium-239 & 0.0001 & 0.001 \\
\hline Radium-226 & - & 0.1 \\
\hline Radium-228 & - & 0.1 \\
\hline Strontium-89 & 0.1 & 2 \\
\hline Strontium-90 & 0.01 & 0.25 \\
\hline Thorium-228 & 0.001 & - \\
\hline Thorium-230 & 0.001 & - \\
\hline Thorium-232 & 0.001 & - \\
\hline U ranium-234 & 0.001 & 0.01 \\
\hline U ranium-235 & 0.001 & 0.01 \\
\hline U ranium-238 & 0.001 & 0.01 \\
\hline U ranium - natural & 0.02 & 0.2 \\
\hline Alpha & 0.2 & 0.2 \\
\hline Beta & 0.5 & 1 \\
\hline
\end{tabular}

a A hyphen indicates that a value is not required. 


\section{QUALITY ASSURANCE}

ANL-E continues to participate in the DOE Environmental Measurements Laboratory Quality A ssurance Program (DOE-EM L-QAP), which consists of semiannual distribution of four different sample matrices containing various combinations of radionuclides that are analyzed. Table 7.2 summarizes the results for 1997. In the table, the EM L value, which is the result of duplicate determinations by that laboratory, is compared with the average value obtained in the A NL-E laboratory. Information that will assist in judging the quality of the results includes the fact that typical uncertainties for ANL-E's analyses are 2 to $50 \%$, and that the uncertainties in the $E M L$ results are 1 to $30 \%$ (depending on the nuclide and the amount present). For most analyses for which the differences are large (>20\%), the concentrations were quite low and the differences were within the measurement uncertainties.

TABLE 7.2

Summary of DOE-EM L-QA P Samples, 1997

\begin{tabular}{lcccc}
\hline & \multicolumn{4}{c}{ Percent Difference From E M L V alue } \\
\cline { 2 - 5 } \multicolumn{1}{c}{ Radionuclide } & Air Filters & Soil & V egetation & W ater \\
\hline Hydrogen-3 & $-\mathrm{a}$ & - & - & $1(2)$ \\
Potassium-40 & - & $13(2)^{\mathrm{b}}$ & $11(2)$ & - \\
M anganese-54 & $10(2)$ & - & - & $10(2)$ \\
Cobalt-57 & $15(2)$ & - & - & - \\
Cobalt-60 & $10(2)$ & $12(1)$ & $11(2)$ & $8(2)$ \\
Strontium-90 & $4(2)$ & $7(2)$ & $9(2)$ & $7(2)$ \\
Ruthenium-106 & - & - & - & - \\
A ntimony-125 & $12(2)$ & - & - & - \\
Cesium-134 & $3(2)$ & - & - & $4(1)$ \\
Cesium-137 & $10(2)$ & $19(2)$ & $7(2)$ & $9(2)$ \\
Cerium-144 & $8(2)$ & - & - & - \\
Uranium-234 & $13(2)$ & $7(2)$ & - & $17(2)$ \\
Uranium-238 & $8(2)$ & $10(2)$ & - & $11(2)$ \\
Plutonium-238 & $4(2)$ & $8(1)$ & - & $2(2)$ \\
Plutonium-239 & $5(1)$ & $16(2)$ & $8(2)$ & $6(2)$ \\
A mericium-241 & $2(2)$ & $20(2)$ & $4(2)$ & $7(2)$ \\
\hline
\end{tabular}

a A hyphen indicates that a sample is not required for analysis.

$b$ The values in parentheses are the number of samples. 


\subsection{Chemical Analysis}

The documentation for nonradiological analyses is contained in the ESH-ASCL Procedure M anual. All samples for NPDES and groundwater are collected and analyzed in accordance with EPA regulations found in 40 CFR Part $136,{ }^{27}$ EPA -600/4-84-017, ${ }^{34}$ and SW $-846 .{ }^{9}$

Standard Reference M aterials (SRM), traceable to the NIST, exist for most inorganic analyses (see Table 7.3). These are replaced annually. Detection limits are determined with techniques listed in SW $-846^{9}$ and are given in Table 7.4. In general, the detection limit is the measure of the variability of a standard material measurement at 5 to 10 times the instrument detection limit as measured over an extended time period. Recovery of inorganic metals, as determined by "spiking" unknown solutions, must be within the range of 75 to $125 \%$. The precision, as determined by analysis of duplicate samples, must be within $20 \%$. These measurements must be made on at least $10 \%$ of the samples. Comparison samples for organi $\mathrm{c}$ constituents were formerly available from the EPA; they are now commercially available under the Cooperative Research and Development Agreement that exists between the EPA and commercial laboratories. In addition, standards are available that are certified by the A merican A ssociation for Laboratory Accreditation, under a memorandum of understanding with the EPA. $M$ any of these standards were used in this work. At least one standard mixture is analyzed each month; the 1997 results for VOCS and SVOCS are shown in Tables 7.5 and 7.6, respectively. The recoveries listed are those required by the respective methods.

\subsection{NPDES Analytical Quality Assurance}

ANL-E conducts the majority of the analyses required for inclusion in the DMR. These analyses are conducted in accordance with EPA-approved methods set out in 40 CFR 136. To demonstrate the capabilities of the ANL-E laboratory for these analyses, the EPA requires that ANL-E participate in the DMR Quality A ssurance program. The EPA sends a series of control 
TABLE 7.3

Reference $M$ aterials U sed for Inorganic A nalysis

\begin{tabular}{lc}
\hline Constituent & Reference M aterial $^{\text {a }}$ \\
\hline Antimony & HPS-10002-2 \\
A rsenic & HPS-10003-1 \\
Barium & HPS-10004-1 \\
Beryllium & HPS-10005-1 \\
Cadmium & HPS-10008-1 \\
Calcium & HPS-10009-1 \\
Chromium & HPS-100012-1 \\
Cobalt & HPS-100013-1 \\
Copper & HPS-100014-1 \\
Iron & HPS-100026-1 \\
Lead & HPS-100028-1 \\
M agnesium & HPS-100031-1 \\
M anganese & HPS-100032-1 \\
M ercury & HPS-100033-1 \\
Nickel & HPS-100036-1 \\
Potassium & HPS-100041-1 \\
Selenium & HPS-100049-1 \\
Silver & HPS-100051-1 \\
Sodium & HPS-100052-1 \\
Vanadium & HPS-100065-1 \\
Zinc & HPS-100068-1 \\
Chloride & NIST-SRM 3181 \\
Fluoride & NIST-SRM 3183 3182 \\
\hline & \\
\hline
\end{tabular}

a HPS = High Purity Standards, Inc.; NIST-SRM = N ational Institute of Standards and Technology - Standard Reference $M$ aterials. 
TABLE 7.4

Detection Limit for M etals A nalysis, 1997

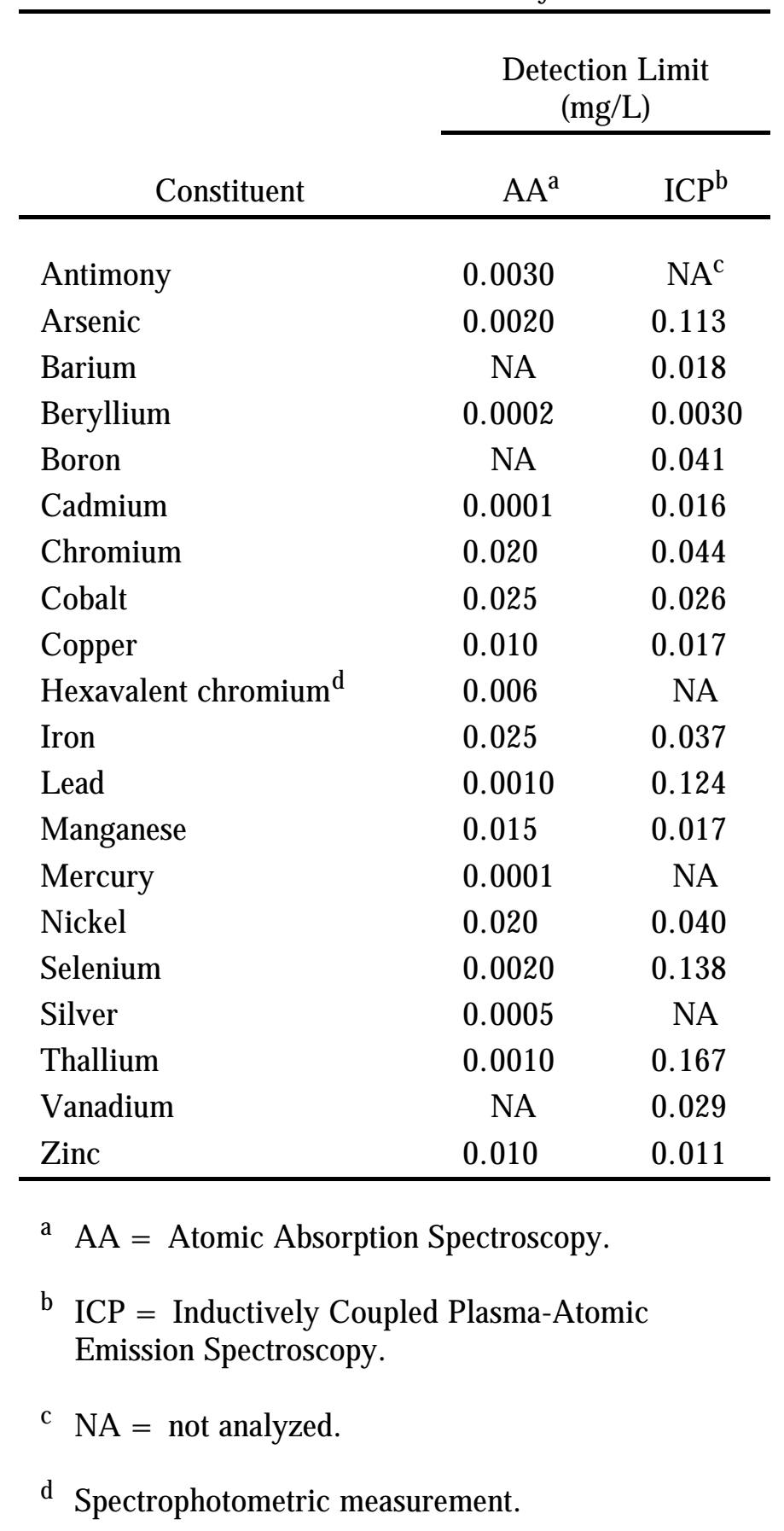


TABLE 7.5

Quality Check Sample Results: V olatile A nalyses, 1997

\begin{tabular}{|c|c|c|}
\hline Constituent & $\begin{array}{l}\text { Recovery }{ }^{a} \\
(\%)\end{array}$ & $\begin{array}{l}\text { Quality Limit } \\
(\%)\end{array}$ \\
\hline Benzene & 110 & $73-126$ \\
\hline Bromobenzene & 103 & $76-133$ \\
\hline Bromodichloromethane & 91 & $101-138$ \\
\hline Bromoform & 62 & $57-156$ \\
\hline Butylbenzene & 92 & $71-125$ \\
\hline sec-Butylbenzene & 102 & $71-145$ \\
\hline t-Butylbenzene & 113 & $69-134$ \\
\hline Carbon T etrachloride & 89 & $86-118$ \\
\hline Chlorobenzene & 117 & $80-137$ \\
\hline Chloroform & 109 & $68-120$ \\
\hline o-Chlorotoluene & 112 & $81-146$ \\
\hline p-Chlorotoluene & 99 & $73-144$ \\
\hline 1,2-Dibromo-3-chloropropane & 77 & $36-154$ \\
\hline Dibromochloromethane & 77 & $68-130$ \\
\hline 1,2-D ibromoethane & 99 & $75-149$ \\
\hline Dibromomethane & 93 & $65-143$ \\
\hline 1,2-Dichlorobenzene & 119 & $59-174$ \\
\hline 1,3-D ichlorobenzene & 115 & $84-143$ \\
\hline 1,4-D ichlorobenzene & 115 & $58-172$ \\
\hline 1,1-Dichloroethane & 105 & $71-142$ \\
\hline 1,2-Dichloroethane & 102 & $70-134$ \\
\hline 1,1-Dichloroethene & 104 & $18-209$ \\
\hline cis-1,2-D ichloroethene & 111 & $85-124$ \\
\hline trans-1,2-Dichloroethene & 107 & $67-141$ \\
\hline 1,2-Dichloropropane & 116 & $19-179$ \\
\hline 1,3-D ichloropropane & 103 & $73-145$ \\
\hline 1,1-D ichloropropene & 94 & $71-133$ \\
\hline Ethyl Benzene & 104 & 84-130 \\
\hline Isopropylbenzene & 107 & $70-144$ \\
\hline 4-Isopropyltoluene & 101 & $72-140$ \\
\hline M ethylene Chloride & 106 & $D-197^{b}$ \\
\hline n-Propylbenzene & 112 & $78-139$ \\
\hline $1,1,1,2$-T etrachloroethane & 97 & $88-133$ \\
\hline T etrachloroethene & 112 & $84-132$ \\
\hline Toluene & 118 & $81-130$ \\
\hline 1,1,1-Trichloroethane & 99 & $68-149$ \\
\hline 1,1,2-Trichloroethane & 118 & $70-133$ \\
\hline Trichloroethene & 103 & $91-135$ \\
\hline 1,2,3-T richloropropane & 109 & $50-158$ \\
\hline $1,2,4$-Trimethylbenzene & 108 & $80-144$ \\
\hline 1,3,5-Trimethylbenzene & 107 & $76-142$ \\
\hline $0-X$ ylene & 106 & $79-141$ \\
\hline $\mathrm{p}$-X ylene & 103 & $74-138$ \\
\hline
\end{tabular}




\section{TABLE 7.6}

Quality Check Sample Results:

Semivolatile A nalyses, 1997

\begin{tabular}{|c|c|c|}
\hline Constituent & $\begin{array}{l}\text { Recovery } \\
(\%)\end{array}$ & $\begin{array}{l}\text { Quality Limit } \\
\qquad(\%)\end{array}$ \\
\hline 2-Fluorophenol ${ }^{\mathrm{b}}$ & 55.7 & $21-100$ \\
\hline Phenol- $d 5^{b}$ & 45.1 & $10-94$ \\
\hline Phenol & 44.3 & $17-100$ \\
\hline 2-Chlorophenol & 85.0 & $36-120$ \\
\hline 1,4-Dichlorobenzene & 55.0 & $37-106$ \\
\hline n-N itroso-n-Propylamine & 49.4 & 24-198 \\
\hline Nitrobenzene- $d 5^{\mathrm{b}}$ & 80.3 & $35-114$ \\
\hline 1,2,4-Trichlorobenzene & 64.9 & $57-129$ \\
\hline 4-Chloro-3-M ethylphenol & 93.8 & $41-128$ \\
\hline 2-Fluorobiphenyl $\left.\right|^{b}$ & 85.0 & $43-116$ \\
\hline A cenaphthene & 89.3 & $47-145$ \\
\hline 2,4-Dinitrotoluene & 86.4 & $48-127$ \\
\hline 2,4,6-Tribromophenol ${ }^{b}$ & 76.0 & $10-123$ \\
\hline Pentachlorophenol & 110.5 & $38-152$ \\
\hline Pyrene & 88.9 & $70-100$ \\
\hline Terphenyl-d $14^{b}$ & 81.4 & $33-141$ \\
\hline
\end{tabular}

\footnotetext{
${ }^{a}$ A verage of six determinations.

${ }^{b}$ Required surrogates.
}

samples to ANL-E annually, and the ensuing analytical results are submitted to the EPA for review. The proficiency of the laboratory is determined by comparing the analytical results for the submitted samples to the actual values. The ANL-E laboratory has consistently performed very well on these tests. However, in 1997, the ANL-E analytical result for total residual chlorine was evaluated as "not acceptable." Corrective actions were implemented and documented to DOE in M arch 1998. 


\section{QUALITY ASSURANCE}




\section{APPENDIX}

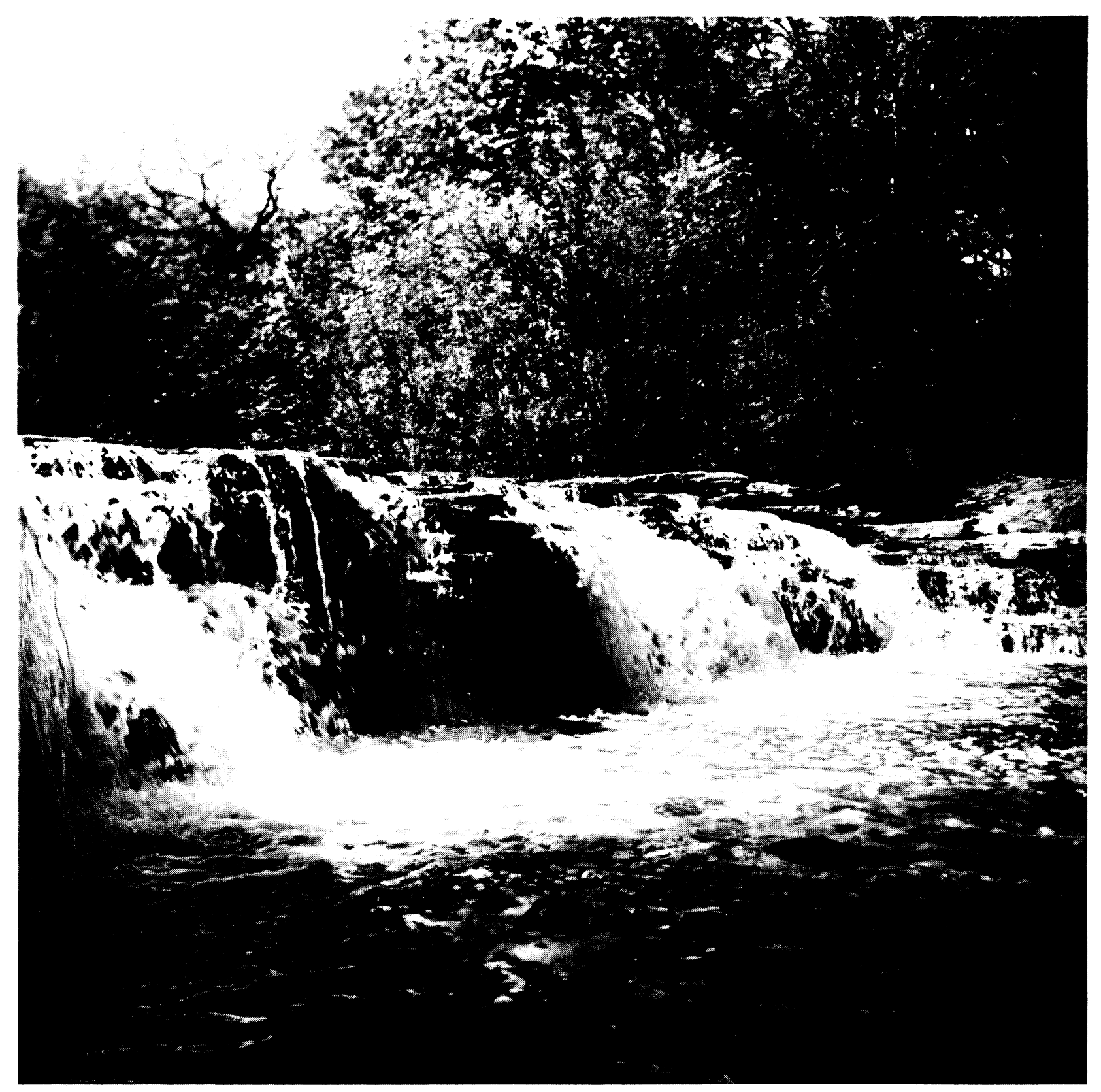




\section{APPENDIX}




\subsection{References}

1. U.S. Department of Energy, 1988, "General Environmental Protection Program," DOE Order 5400.1, Nov. 9.

2. U.S. Department of Energy, 1995, "Environment, Safety, and Health Reporting," DOE Order 231.1, Sept. 30.

3. Moses, H., and M.A. Bogner, 1967, Fifteen-Year Climatological Summary, J anuary 1, 1950 - December 31, 1964, A N -7084, A rgonne National Laboratory, IL.

4. U.S. Environmental Protection A gency, 1998, U ser's Manual Landfill Gas Emissions Model, Version 2.0, Office of Research and D evelopment, W ashington, DC, Feb.

5. U.S. A rmy Corps of Engineers, 1987, Corps of Engineers Wetlands Delineation Manual, Technical Report Y -87-1, Washington, DC.

6. A rgonne National Laboratory, 1997, Resource Conservation and Recovery Act Facility Investigation Report, 317/319 ENE Area, Revision 1, Argonne National Laboratory, Argonne, IL, July.

7. A rgonne National Laboratory, 1997, Resource Conservation and Recovery Act Facility Investigation Report, 800 Area, Argonne National Laboratory, A rgonne, IL, M arch.

8. Parks, B.S., 1992, U ser's Guide for CAP88-C, Version 1.0, EPA 402-B-92-001, Office of Radiation Programs, U.S. Environmental Protection A gency, Las V egas, NV.

9. U.S. Environmental Protection A gency, 1986, Test M ethods for Evaluating Solid Waste, 3rd ed., SW-846, W ashington, DC. 


\section{APPENDIX}

10. U.S. Department of Energy, 1988, "Radioactive Waste Management," DOE Order 5820.2A, Sept. 26 .

11. U.S. Department of Energy, 1991, Environmental Regulatory Guide for Radiological Effluent M onitoring and Environmental Surveillance, DOE/EH-0173T, Washington, DC.

12. U.S. Department of Energy, 1990, "Radiation Protection of the Public and the Environment," DOE Order 5400.5, Feb. 8.

13. International Commission on Radiological Protection, 1977, Recommendations of the International Commission on Radiological Protection, ICRP Publication 26, A nnals of the ICRP, 1(2), Pergamon Press, N ew Y ork, NY.

14. International Commission on Radiological Protection, 1979-1982, Limits for Intakes of Radionuclides by Workers, ICRP Publication 30, Part 1 (and Supplement), Part 2 (and Supplement), Part 3 (and Supplements A and B), and Index, Annals of the ICRP, Pergamon Press, N ew Y ork, NY.

15. U.S. Department of Energy, 1988, Internal D ose Conversion Factors for Calculation of Dose to the Public, DOE/EH-0071, Washington, DC.

16. Larsen, R.J., 1993, "Global Decrease of Beryllium-7 in Surface Air," Journal of Environmental Radioactivity 18:85-87.

17. A merican Society for Testing and M aterials, 1996, 1996 Annual Book of ASTM Standards, Vol. 12.01, "Sampling Surface Soil for Radionuclides, C-998-95," ASTM, West Conshohocken, PA.

18. A merican Society for Testing and M aterials, 1996, 1996 Annual Book of ASTM Standards, Vol. 12.01, "Soil Sample Preparation for the Determination of Radionuclide, C-999-95," ASTM, W est Conshohocken, PA. 


\section{APPENDIX}

19. Bennett, B.G, 1978, Environmental Aspects of Americium, DOE/EML-348, U.S. Department of Energy, Washington, DC.

20. Golchert, N.W., and R.G. Kolzow, 1997, Argonne National Laboratory-East Site Environmental Report for Calendar Year 1996, A NL 97/6, A rgonne National Laboratory, A rgonne, IL.

21. U.S. Environmental Protection A gency, 1990, "National Standards for Hazardous A ir Emissions: Standards for Radionuclides," Code of Federal Regulations, Title 40, Part 61, Subpart $\mathrm{H}$.

22. National Council on Radiation Protection and M easurements, 1987, Ionizing Radiation Exposure of the Population of the U nited States, NCRP Report N 0. 93, Washington, DC.

23. International Commission on Radiological Protection, 1975, Reference M an: Anatomical, Physiological, and M etabolic Characteristics, ICRP Publication 23, Pergamon Press, New Y ork, NY.

24. U.S. Environmental Protection Agency, 1993, "National Primary Drinking Water Regulations," Code of Federal Regulations, Title 40, Part 141.

25. State of Illinois, Rules and Regulations, 1985, Title 35, "Environmental Protection," Subtitle C, W ater Pollution, Chapter 1.

26. U.S. Environmental Protection A gency, 1984, "EPA Administered Permit Program : The National Pollutant Discharge Elimination System," Code of Federal Regulations, Title 40, Part 122.

27. U.S. Environmental Protection Agency, 1986, "Test Procedures for the A nalysis of Pollutants under the Clean Water Act," Code of Federal Regulations, Title 40, Part 136. 


\section{APPENDIX}

28. State of Illinois, Rules and Regulations, 1991, Title 35, "Environmental Protection," Subtitle C, Part 304, Jan. 22.

29. State of Illinois, Rules and Regulations, 1990, Title 35, "Environmental Protection," Subtitle C, Part 302.

30. State of Illinois, Rules and Regulations, 1991, Title 35, "Groundwater Quality Standards," Subtitle F, Part 620.

31. U.S. Environmental Protection A gency, 1992, M ethods for the Determination of Organic Compounds in Drinking Water, Supplement II, EPA-600/R-92/129, W ashington, DC.

32. U.S. Environmental Protection A gency, 1986, RCRA Ground-Water M onitoring Technical Enforcement Guidance D ocument, OSWER-9950.1, Office of Solid W aste and Emergency Response, Washington, DC.

33. U.S. Department of Energy, 1991, "Quality A ssurance," DOE Order 5700.6C, A ug. 21.

34. U.S. Environmental Protection A gency, 1984, Methods for Chemical Analysis of Water and Wastes, EPA-600/4-84-017, Washington, DC. 


\subsection{Distribution for $98 / 2$}

\section{Internal:}
S. I. Baker
W. D. Luck
G. L. Barrett
L. P. Moos
G. A. Borland
G. D. Mosho
M. C. Cole
D. M. Nelson
R. F. Coley
B. G. Pierce
A. J. Dvorak
R. E. Piorkowski
N. F eeney
D. M. Ray
N. W. Golchert (50)
M. J. Robinet
M. J. Gowdy
R. W. Rose
C. Grandy
V. C. Stamoudis
G. E. Griffin
R. E. Swale
B. A. Harvey
J. L. Tucker
W. H. Hannum
R. A. Wynveen
J. A. Heine
T. J. Yule
M. A. Kamiya
TIS File
R. G. Kolzow (5)
G. A. Kulma

\section{External:}

DOE OSTI for distribution per UC-607 (2)

ANL-E Library

ANL-W, AW-IS

DOE-HQ A ssistant Secretary for Environment, Safety and Health, EH-1 (2)

DOE-HQ, Glenn Podonsky, Deputy A ssistant Secretary of Oversight, EH-2

DOE-HQ, Richard Day, Office of Operating Experience, A nalysis and Feedback, EH-33 


\section{APPENDIX}

DOE-HQ, Ross Natoli, Office of Environmental Policy and Assistance, EH-41 (3)

DOE-HQ, Caryle M iller, Office of Energy Research, ER-7

DOE-HQ Office of Energy Research, ER-8.2 (3)

M anager, DOE-CH

P. M. Neeson, DOE-CH, STS (6)

G. Walach, DOE-CH, GLD

T. S. Crawford, DOE-ARG (8)

David A ntonacchi, Illinois Department of Public Health, Springfield, Illinois

Sandra Bron, Illinois Environmental Protection A gency, Springfield, Illinois

Tom F. Brown, W est V alley Nuclear Services, W est V alley, N ew Y ork

Daniel G. Carfagno, M ound Laboratory, M iamisburg, Ohio

Rodger Dirkes, Battelle-Pacific Northwest Laboratories, Richland, Washington

Larry Eastep, Illinois Environmental Protection A gency, Springfield, Illinois

Fred Ferate, Nevada Test Site, Las V egas, N evada

Isabel M. Fisenne, DOE-EM L, N ew Y ork, New Y ork

Robert H. Gray, Pantex Plant, A marillo, Texas

William Griffing, Fermi National A ccelerator Laboratory, Batavia, Illinois

Robert Harrach, Lawrence Livermore National Laboratory, Livermore, California

James D. H effner, Westinghouse Savannah River Company, Aiken, South Carolina

B. Sue L antz, DOE Idaho Operations Office, Idaho Falls, Idaho

Robert C. Holland, Sandia National Laboratories, Livermore, California

Hue-Su Hwang, Sandia National Laboratories, A lbuquerque, $\mathrm{N}$ ew M exico

Illinois Department of Nuclear Safety, Springfield, Illinois

William Isherwood, Lawrence Livermore N ational L aboratory, Livermore, California

Julie A. Johnston, L os A lamos N ational Laboratory, L os A lamos, N ew M exico

Dennis L uehring, DuPage County (IL) H ealth Department, W estmont, Illinois

J ohn B. M urphy, Oak Ridge National Laboratory, Oak Ridge, Tennessee

Michael M urphy, U.S. Environmental Protection A gency, Region 5, Chicago, Illinois

J. R. Naidu, Brookhaven National Laboratory, Upton, New Y ork

J. O'Connor, Illinois Department of Public Health, West Chicago, Illinois

C. Lyle Roberts, Dames and M oore, Orchard Park, N ew Y ork 
Kenneth Rogers, Water Compliance, Illinois Environmental Protection A gency, Springfield, Illinois

Gary Schroeder, Brookhaven National L aboratory, U pton, N ew Y ork

Lars Soholt, Los A lamos National Laboratory, Los Alamos, N ew M exico

Robert Stanton, DuPage County Forest Preserve District, Glen Ellyn, Illinois

David H. Stoltenberg, U. S. Environmental Protection A gency, Region 5, Chicago, Illinois

Patrick Thorson, Lawrence Berkeley Laboratory, Berkeley, California

Chris Kallis, Illinois Environmental Protection A gency, M aywood, Illinois

Chris M artin, A rgonne N ational L aboratory-West, Idaho Falls, Idaho 
